\title{
UMA CONTRIBUIÇÃO \\ PARA O ENTENDIMENTO \\ DO PAPEL DA ENSINAGEM NA \\ PRESERVAÇÃO DO CONHECIMENTO \\ EM AMBIENTES DE FÁBRICA \\ DE SOFTWARE
}

Tese apresentada à Escola Politécnica da Universidade de São Paulo para obtenção do título de Doutor em Engenharia

Área de concentração:

Engenharia da Produção.

Áreas de pesquisa:

Preservação do conhecimento;

Fábrica de software.

Orientador:

Prof. Dr. Marcelo Schneck de Paula Pessôa 
Este exemplar foi revisado e alterado em relação à versão original, sob responsabilidade única do autor e com a anuência de seu orientador.

São Paulo, 7 de novembro de 2006

\section{FICHA CATALOGRÁFICA}

Trindade, André Luiz Presende

Uma contribuição para o entendimento do papel da ensinagem na preservação do conhecimento em ambientes de fábrica de software / A.L.P. Trindade. -- Ed.Rev. -- São Paulo, 2006. $295 \mathrm{p}$.

Tese (Doutorado) - Escola Politécnica da Universidade de São Paulo. Departamento de Engenharia de Produção.

1.Gestão do conhecimento (Preservação) I.Universidade de São Paulo. Escola Politécnica. Departamento de Engenharia de Produção Il.t. 
A minha família, Rosângela $e$ Melina principalmente, pela resis tência à ausência e por não me deixar esmorecer nos momentos mais críticos; Renata, pela consul toria sobre o bom uso do portu guês; e meus pais em especial, pela luz. Ao orientador deste trabalho, Prof. Marcelo, pelos convencimen tos, pela crítica, pela competência em definir nortes e pelo entusiasmo com que me contagiou tantas vezes. Aos amigos José Augusto e Alexan dre, por tantos papos, tantas idéias, tantas caronas, tantos quilometros de estrada e alguns empurrões tão necessários em momentos tão opor tunos. A Márcio, Alba, Paulo, Ana Paula, Luis André, Heloiza, Luis, Yara e Cassius, por toda atenção e disposição em atender, discutir e responder. A Chíxaro, Vera e o pes soal da FATEC Ourinhos, por acre ditarem e apoiarem, sem falar da paciência com que me atenderam, principalmente no periodo final. A professores e funcionários da Poli técnica, pelos serviços prestados e por proporcionarem tão importante aprendizado, o qual levo para toda a vida, tanto profissional (acadêmi ca inclusive) quanto social. É imen surável a contribuição de todos pa ra o termo deste empreendimento $e$ a todos sou grato. Mesmo sob risco de parecer repetitivo, manifesto, uma vez mais, meu reconhecimento a todos enfim, parentes, amigos, colegas e participantes que tanto apoiaram e incentivaram esta aven tura pelos caminhos da ciência, porque viver é aventurar-se. 


\section{SUMÁRIO}

\section{s.1 - ÍNDICE GERAL}

Lista de figuras

Lista de tabelas

Lista de abreviaturas ...................................................................................... XI

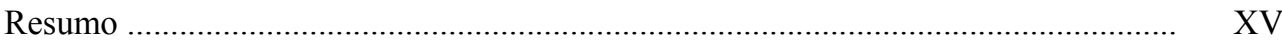

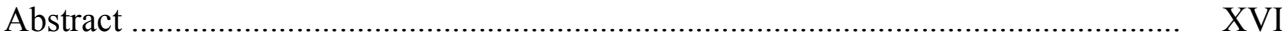

Parte 1 - Apresentação ...................................................................................... 2

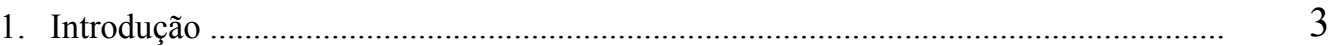

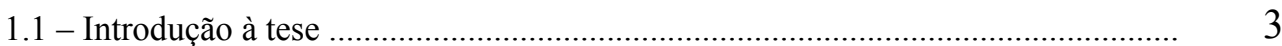

1.1 .1 - Objetivos e metas ……............................................................... 5

1.1 .2 - Justificativa .............................................................................. 6

1.1.3 - Desenvolvimento da pesquisa ………......................................... 12

1.2 - Introdução à metodologia de pesquisa ............................................................... 13

1.2.1 - Tipologia da pesquisa ................................................................. 14

1.2.2 - Método adotado …................................................................. 17

1.2.3 - Conteúdo da pesquisa da tese ......................................................... 21

1.3 - Introdução ao documento da tese ................................................................. 22

1.4 - Em suma (resumo da introdução) ................................................................. 26

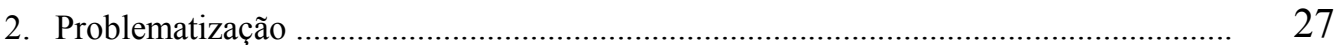

2.1 - O problema e seu equacionamento ….......................................................... 27

2.2 - Questões do estudo ............................................................................... 29

2.3 - Proposições ......................................................................................... 30

2.3.1 - Proposições de estrutura ................................................................ 30

2.3.2 - Proposições de alicerce ................................................................... 31

2.4 - Em suma (resumo da problematização) ........................................................ 34

Parte 2 - Conceitos ......................................................................................... 35

3. Modelos de negócio .............................................................................................. 36

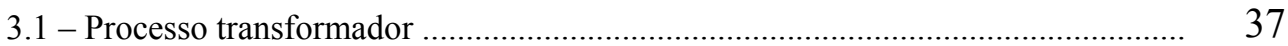

3.2 - Organização hierarquizada ........................................................................... 37

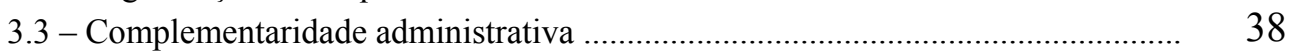

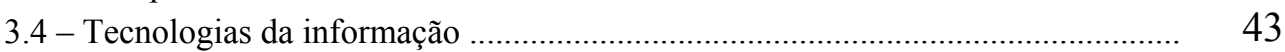

3.5 - O dinamismo da mudança .......................................................................... 45

3.6 - A organização do trabalho ............................................................................ 48

3.7 - Em suma (resumo do capítulo sobre modelos de negócio) …............................. 55

4. Fábrica de software ............................................................................................ 56

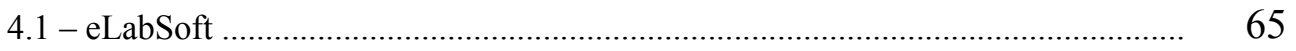

4.2 - Em suma (resumo do capítulo sobre fábrica de software) ................................... 91

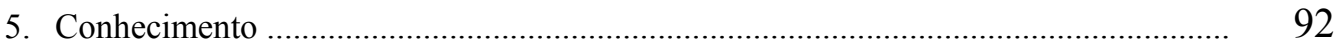

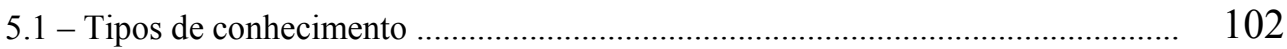

5.1 .1 - Conhecimento tácito ............................................................... 102

5.1 .2 - Conhecimento explícito ................................................................. 102

5.1 .3 - Conhecimento popular …......................................................... 103

5.1 .4 - Conhecimento teológico ............................................................... 103

5.1 .5 - Conhecimento filosófico ……..................................................... 103 
5.1.6 - Conhecimento científico

5.1.7 - Conhecimento sabido

5.1.8 - Conhecimento desconhecido

5.2 - A organização do conhecimento

5.2.1 - Abordagem de conteúdo

5.3 - Em suma (resumo do capítulo sobre conhecimento) ………………................... 120

6. Gestão do conhecimento

6.1 - O processo do conhecimento

6.2 - O mapeamento do processo do conhecimento

6.3 - O gerenciamento do processo do conhecimento

6.4 - Em suma (resumo do capítulo sobre gestão do conhecimento) ............................ 148

7. Ensinagem e aprendizagem ………........................................................................ 149

7.1 - Ensino

7.2 - Ensinagem

7.3 - Aprendizagem

7.4 - O binômio ensinagem-aprendizagem

7.5 - Em suma (resumo do capítulo sobre ensinagem e aprendizagem)

Parte 3 - Pesquisa

8. Aplicação dos conceitos

8.1 - Gestão do conhecimento em fábricas de software .......................................... 170

8.2 - Triangulação ............................................................................................. 174

8.2.1 - Conhecimento e fábrica de software ................................................ 175

8.2.2 - Conhecimento e ensinagem ........................................................... 178

8.2.3 - Ensinagem e fábrica de software ................................................... 184

8.3 - Em suma (resumo do capítulo sobre aplicação dos conceitos) .......................... 189

9. Modelo conceitual Preliminar .............................................................................. 190

9.1 - A aplicação do modelo ................................................................................ 201

9.2 - Em suma (resumo do capítulo sobre o medelo preliminar) ............................... 207

10. Aplicação da Pesquisa ................................................................................ 208

10.1 - Definição da pesquisa ....................................................................... 208

10.2 - Protocolo da pesquisa ............................................................................. 210

10.3 - A escolha dos casos ....................................................................... 214

10.4 - Relatório dos casos ........................................................................ 215

10.4.1 - Identificação das organizações ................................................... 216

10.4.1.1 - Empresa “A” ........................................................... 216

10.4.1.2 - Empresa "B" ........................................................... 217

10.4.1.3 - Empresa "C" ........................................................ 220

10.4.1.4 - Empresa "D" ............................................................ 223

10.4.2 - Culturadas organizações ........................................................ 225

10.4.2.1 - Empresa "A" ............................................................. 226

10.4.2.2 - Empresa "B" ........................................................... 226

10.4.2.3 - Empresa "C" ........................................................... 227

10.4.2.4 - Empresa "D” ........................................................... 228

10.4.3 - Conhecimento e compartilhamento ............................................... 229

10.4.3.1 - Empresa “A” ........................................................... 229

10.4.3.2 - Empresa "B" ........................................................... 230

10.4.3.3 - Empresa “C” ".................................................... 231 
10.4.3.4 - Empresa "D"

10.4.4 - Organização ambiental para a ensinagem ......

10.4.4.1 - Empresa "A"

10.4.4.2 - Empresa "B"

10.4.4.3 - Empresa "C"

238

10.4.4.4 - Empresa "D"

10.4.5 - Processo de ensinagem

10.4.5.1 - Empresa "A"

10.4.5.2 - Empresa "B"

10.4.5.3 - Empresa "C"

10.4.5.4 - Empresa "D"

246

10.4.6 - Contribuição ao ambiente produtivo

247

10.4.6.1 - Empresa "A"

10.4.6.2 - Empresa "B"

10.4.6.3 - Empresa "C"

249

10.4.6.4 - Empresa "D"

10.4.7 - Contribuição ao repositório do conhecimento ................................ 250

10.4.7.1 - Empresa "A" ................................................................... 250

10.4.7.2 - Empresa "B" .............................................................. 251

10.4.7.3 - Empresa "C" .............................................................. 252

10.4.7.4 - Empresa "D” .......................................................... 252

10.4.8 - Contribuição ao ambiente do conhecimento .................................... 253

10.4.8.1 - Empresa "A" ............................................................. 253

10.4.8.2 - Empresa "B" .............................................................. 254

10.4.8.3 - Empresa "C" ............................................................. 255

10.4.8.4 - Empresa "D" ................................................................. 255

10.4.9 - Organização de eventos de ensinagem ........................................ 256

10.4.9.1 - Empresa "A" ....................................................... 256

10.4.9.2 - Empresa "B" ............................................................ 257

10.4.9.3 - Empresa "C" ......................................................... 258

10.4.9.4 - Empresa "D” ........................................................... 258

10.5 - Em suma (resumo da pesquisa de campo) ...................................................... 259

11. Modelo de ensinagem ................................................................................... 262

11.1 - As dimensões relativas aos ambientes estudados ............................. 262

11.2 - As dimensões relativas ao modelo conceitual .................................. 264

11.2.1 - A dimensão do processo de ensinagem .............................. 264

11.2.2 - A dimensão da contribuição ao ambiente produtivo ......... 268

11.2.3 - A dimensão da contribuição ao repositório do... ............... 269

11.2.4 - A dimensão da contribuição ao ambiente do... .................. 272

11.2.5 - A dimensão da organização de eventos de ensinagem ....... 273

11.3 - Em suma (resumo do capítulo sobre o modelo de ensinagem) ........... 275

Parte 4 - Disposições Finais .................................................................................... 276

12. Considerações finais ............................................................................................... 277

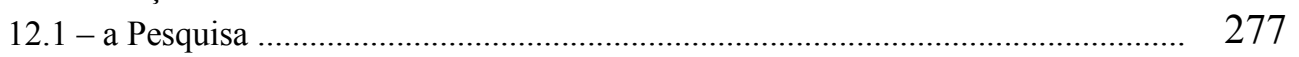

12.2 - o Modelo conceitual de ensinagem ............................................................... 281

12.3 - Em suma (resumo das considerações finais) ................................................ 282

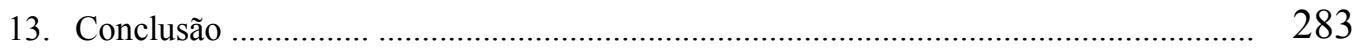

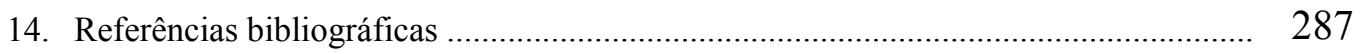




\section{s.2 - LISTA DE FIGURAS}

1. Introdução

1.01 - A relação valor $\mathrm{x}$ tempo de compartilhamento ................................................... 10

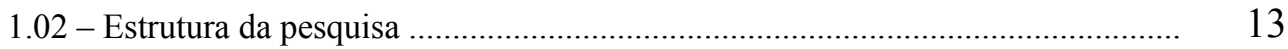

1.03 - Visão integrada dos principais elementos do processo de pesquisa ................. 14

1.04 - O método de estudo de casos múltiplos ............................................................... 19

1.05 - Estrutura parcial do documento, referente ao corpo da tese ................................ 23

2. Problematização

2.01 - O que é "core"

3. Modelo gerencial de negócio

3.01 - O sistema visto como processo

3.02 - A organização hierarquizada em suas funções decisórias

3.03 - A associação entre as visões administrativa e não administrativa do negócio ..

3.04 - O Sistema de Informações visto como um processo transformador

3.05 - O sistema de informações visto segundo as dimensões sociotécnicas

3.06 - O sistema de informações visto segundo sua categorização

3.07 - Tipos de mudança organizacional, segundo suas origens e seus efeitos

3.08 - Modelo de contingência sobre a organização do trabalho

50

3.09 - Cronologia das abordagens da organização do trabalho

4. Fábrica de software

4.01 - Processo evolucionário para fábricas de software.

4.02 - Os elementos dinâmicos e estáticos da gestão de uma fábrica de software .......

4.03 - Integração entre modelos gerenciais, de produção de software e...

4.04 - Visão embrionária, particionada, da empresa produtora de software..

4.05 - Visão detalhada da fábrica de software, explorando produção e gestão .............

4.06 - O eLabSoft segundo as visões da pesquisa e do processo

4.07 - A organização do eLabSoft em quadrantes da pesquisa e do processo

4.08 - Processo fabril modelo para fábrica de software, adotado no eLabSoft .

4.09 - A dinâmica do processo fabril em uma fábrica de software

4.10 - Processo Gestor: o gerenciamento do processo fabril

5 Conhecimento

5.01 - A expressão do conhecimento e seu processo formador

5.02 - Conhecimento como viabilizador do desenvolvimento de competências ..........

5.03 - A composição da inteligência, pela conjunção de modelos

5.04 - A dinâmica das relações entre pessoas e conhecimento

5.05 - Visão circular dinâmica do conhecimento

5.06 - Organização de conteúdo do conhecimento por meta-dados

5.07 - Ontologia do conhecimento sobre a empresa, com foco no processo...

5.08 - O modelo genérico em camadas, da memória corporativa estratégica .

5.09 - Visão ontológica do conhecimento e sua dinâmica de progresso

5.10 - Visão espacial do conhecimento e os papéis profissionais inerentes... .............. 112

5.11 - A competência expressa no processo de geração do conhecimento.................... 114

5.12 - A competência do conhecimento como um processo de produção de............... 115

5.13 - A relação entre pensamentos e saberes, na formação do conhecimento ............ 116

5.14 - Processo gestor estendido .............................................................................. 118

5.15 - O processo de condução à competitividade global através do conhecimento ... 119

6 Gestão do conhecimento 
6.01 - As dimensões da GC e da administração

6.02 - Visão evolutiva e compartimentada da competência ......................................... 128

6.03 - Visão, em camadas, dos processos sistêmicos ................................................ 131

6.04 - Meta-conhecimento, como fruto da conquista do conhecimento... .................. 132

6.05 - O contexto do Organizational Baseline ......................................................... 135

6.06 - O mapeamento do núcleo do processo de conhecimento ................................. 137

6.07 - Contextualização da Gestão do Conhecimento no ambiente da organização .... 139

6.08 - Mapeamento do processo do conhecimento organizacional. ............................ 140

6.09 - O modelo do capital intelectual, com sua matriz de gerenciamento. ................ 145

7 Ensinagem e aprendizagem

7.01 - Escada de Aprendizagem e Inovação

7.02 - O binômio ensinagem-aprendizagem

8 Aplicação de conceitos

8.01 - Informação e conhecimento: resultado da ação ampliada dos atores ................ 165

8.02 - Relação entre competências pessoais e organizacionais ................................... 166

8.03 - O processo de gestão do conhecimento e suas capacitações ............................. 168

8.04 - Componentes de gestão influenciados pela GC .............................................. 172

8.05 - Dinâmica da triangulação de desenvolvimento de relações .............................. 175

8.06 - Transformação dos ativos intangíveis ............................................................. 177

8.07 - O foco da pesquisa, sobre o meta-conhecimento .......................................... 177

8.08 - A relação da ensinagem com o conhecimento, no processo de condução à... ... 180

8.09 - Foco no binômio aprender-contribuir .......................................................... 181

8.10 - As interfaces entre processo, conteúdo e ambiente ........................................... 182

8.11 - A escada do aprendizado ............................................................................ 186

8.12 - A escada do aprendizado - vista em perspectiva ............................................ 186

8.13 - O ciclo do desenvolvimento intelectual ........................................................ 188

9 Modelo conceitual

9.01 - Modelo de ambiente de ensino à distância

9.02 - Formas de conhecimento e seus relacionamentos

9.03 - Diagrama de atividades do método SADT, na concepção de Ross ................... 195

9.04 - Diagrama de Fluxos de Dados, na concepção do método de análise essencial . 196

9.05 - Modelo conceitual preliminar do processo de ensinagem ................................ 197

9.06 - O modelo de processo de ensinagem e a escada do aprendizado ..................... 202

9.07 - O detalhamento dos conhecimentos, nas escadas do aprendizado .................... 204

9.08 - O mapeamento de conhecimentos e ferramentas, para cada curso da... .......... 206

10 Metodologia

10.01 - A relação estrutural entre o projeto e as fontes de pesquisa ........................... 209

10.02 - Os tópicos do protocolo posicionados sobre o modelo conceitual... .............. 211

10.03 - A organização da empresa "A" .................................................................. 217

10.04 - A organização da empresa "B" ...................................................................... 219

10.05 - A organização da empresa "C"

10.06 - A organização administrativa da empresa "C" "............................................. 222

10.07 - A organização da empresa "B".................................................................... 225

10.08 - Os agentes do conhecimento na empresa "A" .............................................. 230

10.09 - Os agentes do conhecimento na empresa "B" ........................................... 231

10.10 - Os agentes do conhecimento na empresa " $\mathrm{C}$ " .......................................... 232

10.11 - Os agentes do conhecimento na empresa " $\mathrm{D}$ " ............................................. 234

10.12 - A estrutura de gestão e compartilhamento do conhecimento, na empresa " $D$ " 235

10.13 - A seqüência inicial de aprendizagem prevista pela empresa "A" .................. 236 
10.14 - A dinâmica de aprendizagem e compartilhamento... na empresa " $\mathrm{D}$ "

10.15 - O modelo de gestão do ensino institucionalizado da empresa " $\mathrm{D}$ "

11 Modelo de ensinagem

11.01 - O modelo conceitual preliminar - reapresentação

11.02 - A definição de regras de contratação e preparação de instrutores e materiais . 265

11.03 - A preparação de instrutores

11.04 - A contribuição da aprendizagem e a formação de redes

11.05 - A organização do modelo conceitual de ensinagem

OBS: As figuras apresentadas nessa tese são de autoria de seu autor, exceto aquelas em que haja a declaração "Extraída de...". As idéias expressas por figuras não afeitas a essa exceção são representações das formas como o autor deste documento de tese interpreta fatos, situações ou modelos conceituais representativos de ambientes, contextos, organizações ou processos. Quando houver, na referência à fonte, a declaração "Adaptada de...", a expressão da figura resume a interpretação que o autor desta tese faz da interpretação de outrem; os níveis de implicitude ou explicitude das adaptações, nestes casos, variam circunstancialmente, objeto a objeto. 


\section{S.3 - LISTA DE TABELAS}

\section{Introdução}

1.01 - Tempo destinado a formas de absorção de conhecimento

1.02 - Fatores de entrave ao crescimento/desenvolvimento da empresa

1.03 - Grau de importância na relação de cooperação do setor

1.04 - Situações relevantes para diferentes estratégias de pesquisa

2 Problematização

2.01 - O cenário de pressuposições sustentando questões

5 Conhecimento

5.01 - Dimensões taxonômicas dos ativos de conhecimento

9 Modelo de ensinagem

9.01 - Exemplo de mapeamento de conhecimentos e ferramentas

10 Metodologia

10.01 - A composição do protocolo de pesquisa

10.02 - Características das empresas envolvidas no estudo de casos

OBS: As tabelas, assim como as figuras apresentadas nessa tese são de autoria de seu autor, exceto aquelas em que haja a declaração "Extraída de...". As idéias expressas por figuras e tabelas não afeitas a essa exceção são representações das formas como o autor deste documento de tese interpreta fatos, situações ou modelos conceituais representativos de ambientes, contextos, organizações ou processos. Quando houver, na referência à fonte, a declaração “Adaptada de...", a expressão da figura ou tabela resume a interpretação que o autor desta tese faz da interpretação de outrem; os níveis de implicitude ou explicitude das adaptações, nestes casos, variam circunstancialmente, objeto a objeto (figura ou tabela). 


\section{S.4 - LISTA DE ABREVIATURAS}

\begin{tabular}{|c|c|c|}
\hline $\mathrm{AEE}$ & $\begin{array}{l}\text { Análise Estruturada } \\
\text { Essencial }\end{array}$ & $\begin{array}{l}\text { Método de análise de sistemas, para produção de modelos de } \\
\text { sistemas de informações (SI) orientados a eventos. }\end{array}$ \\
\hline $\mathrm{BI}$ & $\begin{array}{l}\text { Business } \\
\text { Intelligence }\end{array}$ & $\begin{array}{l}\text { Inteligência de Negócio, expressão representativa da soma de } \\
\text { todas os recursos intelectuais e de TI, disponibilizados no } \\
\text { ambiente da organização. }\end{array}$ \\
\hline BRM & $\begin{array}{l}\text { Brand Relationship } \\
\text { Management }\end{array}$ & $\begin{array}{l}\text { Gestão de Relacionamento com a Marca, filosofia de negócio } \\
\text { orientada à marca, ostentada pela organização, baseada no } \\
\text { envolvimento e comprometimento do consumidor (cliente) com } \\
\text { a mesma. }\end{array}$ \\
\hline $\mathrm{CEO}$ & $\begin{array}{l}\text { Chief of Enterprise } \\
\text { Officer }\end{array}$ & $\begin{array}{l}\text { Executivo de negócios da empresa, figura do mais alto cargo } \\
\text { técnico-administrativo alcançável em uma organização, na } \\
\text { função de gestor geral de negócios. }\end{array}$ \\
\hline CHAT & Conversação remota & $\begin{array}{l}\text { Neologismo usado para definir estrutura própria ao } \\
\text { provimento de ambiente on-line de diálogo remoto entre } \\
\text { pessoas, usuárias de uma rede. }\end{array}$ \\
\hline $\mathrm{CIO}$ & $\begin{array}{l}\text { Chief of Information } \\
\text { Officer }\end{array}$ & $\begin{array}{l}\text { Executivo de SI/TI da empresa, figura do mais alto cargo } \\
\text { técnico-tecnológico alcançável em uma organização, na } \\
\text { função de gestor focado nos sistemas e nas tecnologias da } \\
\text { informação. }\end{array}$ \\
\hline $\mathrm{CKO}$ & $\begin{array}{l}\text { Chief of Knowledge } \\
\text { Officer }\end{array}$ & $\begin{array}{l}\text { Executivo do Conhecimento da empresa, figura do mais alto } \\
\text { cargo técnico-tecnológico alcançável em uma organização, na } \\
\text { função de gestor focado nos sistemas de conhecimentos e nas } \\
\text { tecnologias pertinentes a suas consagraçôes. }\end{array}$ \\
\hline CLI & $\begin{array}{l}\text { Command Line } \\
\text { Interface }\end{array}$ & $\begin{array}{l}\text { Meio (de intermediação) de Linha de Comando, designação } \\
\text { dada ao conceito de programação por linhas de comando por } \\
\text { meio não gráfico, utilizada nas definiçôes da linguagem Java. }\end{array}$ \\
\hline CMM & $\begin{array}{l}\text { Capability Maturity } \\
\text { Model }\end{array}$ & $\begin{array}{l}\text { Modelo de maturidade e capacitação técnica, destinado à } \\
\text { definição da capacidade produtiva de organizações } \\
\text { desenvolvedoras de software. }\end{array}$ \\
\hline OPEC & $\begin{array}{l}\text { Conselho de } \\
\text { Pesquisas em } \\
\text { Educação e Ciência }\end{array}$ & $\begin{array}{l}\text { Organização deliberativa, com sede em São Vicente - estado } \\
\text { de São Paulo - Brasil, formada por cientistas das mais } \\
\text { diversas áreas do conhecimento humano e por cidadãos } \\
\text { comprometidos com a educação. }\end{array}$ \\
\hline GQM & $\begin{array}{l}\text { Goal-Question } \\
\text { Metrics }\end{array}$ & $\begin{array}{l}\text { Métricas de meta-questão, denominação dada ao paradigma } \\
\text { que define a abordagem da mensuração orientado a metas, } \\
\text { proposto por Giinther Ruhe. }\end{array}$ \\
\hline CRM & $\begin{array}{l}\text { Customer } \\
\text { Relationship } \\
\text { Management }\end{array}$ & $\begin{array}{l}\text { Gestão do Relacionamento com Clientes, filosofia de negócios } \\
\text { orientada ao cliente, conforme entendem os CEOS e conceito } \\
\text { tecnológico de SI, voltado ao conhecimento sobre o cliente, } \\
\text { conforme entendem os CIOs. }\end{array}$ \\
\hline EJB & $\begin{array}{l}\text { Enterprise Java } \\
\text { Beans }\end{array}$ & $\begin{array}{l}\text { Módulo Java para Empresas, designação dada ao conjunto de } \\
\text { instruções dedicadas a desenvolvimentos profissionais, } \\
\text { utilizada nas definições da linguagem Java. }\end{array}$ \\
\hline ERP & $\begin{array}{l}\text { Enterprise Resource } \\
\text { Planning }\end{array}$ & $\begin{array}{l}\text { Planejamento de Recursos da Empresa, filosofia de negócios } \\
\text { orientada à integração de informações e sistemas de } \\
\text { informações, para visão de domínio da organização como um } \\
\text { todo, conforme entendem os CEOs e conceito tecnológico de } \\
\text { integração de outros conceitos tecnológicos, voltado ao } \\
\text { conhecimento sobre a empresa de maneira geral, conforme }\end{array}$ \\
\hline
\end{tabular}




\begin{tabular}{|c|c|}
\hline FAQ & $\begin{array}{l}\text { Frequently Asked } \\
\text { Questions }\end{array}$ \\
\hline FEMA & $\begin{array}{l}\text { Fundação } \\
\text { Educacional do } \\
\text { Município de Assis }\end{array}$ \\
\hline GTI & $\begin{array}{l}\text { Gestão de } \\
\text { Tecnologias da } \\
\text { Informação }\end{array}$ \\
\hline IDEF-0 & $\begin{array}{l}\text { Integration } \\
\text { DEFinition language } \\
0\end{array}$ \\
\hline IEEE & $\begin{array}{l}\text { Institute of } \\
\text { Electrical \& } \\
\text { Electronic Engineers }\end{array}$ \\
\hline ISO & $\begin{array}{l}\text { Organisation } \\
\text { Internationale de } \\
\text { Normalisation }\end{array}$ \\
\hline $\mathrm{J} 2 \mathrm{EE}$ & $\begin{array}{l}\text { Java to Enterprise } \\
\text { Edition }\end{array}$ \\
\hline JDBC & $\begin{array}{l}\text { Java Data Base } \\
\text { Command }\end{array}$ \\
\hline LM & $\begin{array}{l}\text { Logistic } \\
\text { Management }\end{array}$ \\
\hline $\mathrm{MC}$ & $\begin{array}{l}\text { Massa de } \\
\text { Conhecimento }\end{array}$ \\
\hline MPT & $\begin{array}{l}\text { Manutenção da } \\
\text { Produtividade Total }\end{array}$ \\
\hline MRP & $\begin{array}{l}\text { Materials } \\
\text { Requirements } \\
\text { Planning }\end{array}$ \\
\hline MRP II & $\begin{array}{l}\text { Manufacturing } \\
\text { Resource Planning }\end{array}$ \\
\hline
\end{tabular}

entendem os CIOS

Questões freqüentemente colocadas, acrônimo do temo inglês, próprio para designar a estrutura de página web destinada a compilar respostas às perguntas mais colocadas por usuários de determinado sistema, sobre determinado tema, em um sistema de rede.

Fundação municipal que mantém diversos cursos de terceiro grau, entre eles, o de ciência da computação, na cidade de Assis, estado de São Paulo.

Linha de pesquisa do Departamento de Engenharia da Produção da Escola Politécnica da Universidade de São Paulo, formada em 1996, que engloba grupos de pesquisa, inclusive o que se propõe à discussão de fábricas de software.

Linguagem (0) de definição integrada [de modelo sistêmico], normalização dos conceitos de abordagem funcional do método SADT.

Instituto de Engenharias Elétrica e Eletrônica, entidade voltada à publicações técnicas em diversos segmentos de diversas áreas cientificas, inclusos software e conhecimento. Editora de uma compilação de trabalhos direcionados à boa prática da produção de software, denominado SwEBoK.

Organização internacional de normalização, iniciativa de normalização de padrões de qualidade de processo e, mais atualmente, de produtos, para as relações comerciais internacionais, promovida por uma rede de institutos nacionais de padronização, composta por organizações não governamentais em mais de 140 países, cujos trabalhos têm coordenação centralizada na Suiça.

Edição do Java para Empresas, designação dada ao conjunto de instruções dedicadas a desenvolvimentos profissionais, utilizada nas definições da linguagem Java

Comandos para Base de Dados do Java, designação dada ao conjunto de instruções dedicadas ao tratamento de bancos de dados, utilizada nas definições da linguagem Java.

Gestão de Lógística, filosofia de negócios orientada à garantia de movimentação de materiais para a produção, pela recepção de insumos e distribuição de produtos, passando pela dinâmica interna da organização.

Representação da totalidade de conhecimento (incluindo metaconhecimento) de interesse em determinado projeto ou na gestão organizacional, composto pelos pessoais não formuláveis e pelos organizacionais já devidamente formulados e incorporados.

Programa de capacitação produtiva, que envolve treinamentos, adequação de insumos e ferramental e monitoramentos de processos.

Planejamento de requisições de materiais, processo que agrupa aplicações tecnológicas para controles de inventários de estocagem e gestão de necessidades de materiais, segundo programações de produção.

Planejamento de recursos de manufatura, processo que agrupa aplicações tecnológicas para a composição do fluxo de 


\begin{tabular}{|c|c|}
\hline NIST & $\begin{array}{l}\text { National Institute of } \\
\text { Standards and } \\
\text { Technology }\end{array}$ \\
\hline PMBoK & $\begin{array}{l}\text { Project Management } \\
\text { Body of Knowledge }\end{array}$ \\
\hline PMl & $\begin{array}{l}\text { Project Management } \\
\text { Institute }\end{array}$ \\
\hline QI & $\begin{array}{l}\text { Quociente de } \\
\text { Inteligência }\end{array}$ \\
\hline RUP & $\begin{array}{l}\text { Rational Unified } \\
\text { Process }\end{array}$ \\
\hline SADT & $\begin{array}{l}\text { Structured Analysis } \\
\text { and Design } \\
\text { Technique }\end{array}$ \\
\hline $\mathrm{SCM}$ & $\begin{array}{l}\text { Supply Chain } \\
\text { Management }\end{array}$ \\
\hline SI & $\begin{array}{l}\text { Sistema de } \\
\text { Informações }\end{array}$ \\
\hline SwEBoK & $\begin{array}{l}\text { Software } \\
\text { Engineering Body } \\
\text { of Knowledge }\end{array}$ \\
\hline $\mathrm{TI}$ & $\begin{array}{l}\text { Tecnologias da } \\
\text { Informação }\end{array}$ \\
\hline
\end{tabular}

produção e sua gestão, junto com os conceitos do MRP.

Instituto Nacional de Padrões e Tecnologias, denominação da instituição que cuida de normalizações de métodos e processos, nos Estados Unidos, detentora dos direitos sobre o IDEF-0, norma que regula o uso do método SADT.

Corpo de Conhecimento sobre Gestão de Projetos, nome dado à publicação de compilação de artigos sobre as melhores práticas para o desenvolvimento gerenciado de projetos de qualquer natureza, publicado pelo PMI.

Instituto de Administração de Projetos, órgão destinado a pesquisar formas eficazes de gerir projetos, nas mais diversas órbitas ou aplicações. Compila artigos técnicos que versem sobre as boas práticas de desenvolvimento de empreendimentos, gerando a publicação denominada PMBoK.

Denominação dada a conceito, adotado pelo psicólogo Louis Terman, que resume a razão entre as idades mensuráveis: a mental e a cronológica, com a finalidade de realizar uma medida quantitativa do grau de inteligência de uma pessoa.

Processo Unificado da Rational, modelo proponente de organização da prática da engenharia de software baseado nas prerrogativas detalhadas por Rumbaugh, Booch e Jacobson, fundadores da empresa Rational, atualmente propriedade da IBM.

Técnica estruturada de análise e projeto [de sistemas], método para modelagem de sistemas desenvolvido em 1972 (um dos primeiros metodos estruturados), por Douglas T. Ross.

Gestão da Cadeia de Suprimentos ou Gestão de Relacionamento com Fornecedores, filosofia de negócios orientada ao fornecimento de insumos, conforme entendem os CEOs e conceito tecnológico de SI, voltado ao conhecimento sobre o fornecedor, conforme entendem os CIOs.

Modelo representativo de toda dinâmica de trabalho com informações de uma organização, tanto no nivel da execução de trabalho, quanto nos niveis de gerenciamento desta, podendo assumir diversas formas, segundo a visão desejável do gestor da empresa, para entender e dominar o ambiente de negócio. Também pode assumir denominações diferentes, conforme o tipo de uso que se faz deste instrumento no dia-adia da administração da empresa, tais como sistema corporativo (SC), sistema de informações gerenciais $(S I G) e$ sistema de apoio a decisões (SAD), formando um universo de instrumentalização da gestão, também conhecido como Business Intelligence (BI).

Corpo de Conhecimento sobre Engenharia de Software, nome dado à publicação de compilação de artigos sobre as melhores práticas da aplicação da engenharia de software para viabilizar projetos de software com engenharia organizada. Publicado pelo IEEE, o SwEBoK trata da gerenciabilidade da produção, focada nas questões do software.

Conjunto de conceitos de aplicação tecnológica para atendimentos de serviços relativos ao tratamento de informações que envolve informática, telemática, multimídia e recursos aplicados ao suporte de SI. 


\begin{tabular}{l|l} 
UML & $\begin{array}{l}\text { Unified Modeling } \\
\text { Language }\end{array}$ \\
VQI & $\begin{array}{l}\text { Virtual Query } \\
\text { Interface } \\
\text { Rede } \\
\text { (de redes :: teia) }\end{array}$
\end{tabular}

Linguagem para modelagem unificada, nome dado à ferramenta de modelagem e projeto de software, composta por um conjunto de nove diagramas, os quais atendem diversas visões, nas dimensões da orientação a objetos, criada pela Rational.

Formulário para questionamento virtual, nome dado às páginas web, disponibilizadas na rede, interna ou externa, que permitam a estruturação de questionamentos remotos.

Diminutivo do termo World Wide Web, que traduz a rede de redes computacionais, formada de maneira extensiva, para a troca intensiva de informações. 


\section{RESUMO}

O encadeamento de conceitos representados por conhecimento, sua gestão e, contida nesta, sua preservação representa um tema instigante, visto que, por questões de competitividade mercadológica, tem sido transformado em recurso estratégico e, tornado corporativo, um ativo indispensável à produtividade.

Quando pensado no ramo da produção de software, com a necessária adequação de escalabilidade a um tipo diferenciado de manufatura, alicerçada em produção criativa em uma extensão maior do que o percebido por outros ramos, e que necessita da engenharia e sua padronização para romper fronteiras do amadorismo, torna-se mais instigante ainda, a ponto de ser tomado como tema para uma pesquisa.

Este trabalho procura abranger questões de importância para organizações, principalmente as que caracterizam-se como empresas voltadas à fabricação de software, trabalhando suas definições e as de seus processos produtivos e focando os papéis que desempenham o conhecimento e o duo-processo ensinagem-aprendizagem para suas administrações, visando permitir estruturação e gestão de saberes, competências e habilidades.

A pesquisa buscou a observância de um modelo conceitual, extraído de literatura formal e experiência docente, e a verificação de sua aplicabilidade e aderência em ambientes reais de produção de software sob conceito de fábrica. Foram selecionadas algumas empresas detentoras de certificações de qualidade, que lhes garante respeito a padrões e formalismos, para experimentar o modelo que propõe servir a iniciativas de preservação do conhecimento. 


\section{ABSTRACT}

The linkage of concepts represented by knowledge, its management and its preservation (preservation contained in management) represents an encouraging theme because it has been transformed in a strategic resource and an indispensable asset to productivity, by matters of market competitiveness.

When considering the branch of the software production, with the necessary scalability adaptation to a differentiated type of manufacture, based on creative production in a larger extension than noticed by other branches, and that needs the engineering and standardization to break borders of amateurism, it becomes even exciting to the point of being taken as a theme for research.

This work aims at including subjects of importance for organizations, mainly the ones that are characterized as software production companies, working with definitions and productive processes and focusing on the roles that carry out the knowledge and the teaching-learning duo-process for the improvement of their administrations, seeking to allow structuring and administration knowledge, competences and abilities.

The research looked for the observance of a conceptual model, extracted from formal literature and educational experience, and the verification of its applicability and adherence in real atmospheres of software production from a factory concept. Some qualified companies that guarantee respect to patterns and formalisms were selected to try the model that intends to serve to initiatives of preservation of knowledge. 


\section{Tudo o que é sábio já foi pensado. \\ Somente podemos tentar pensá-lo mais uma vez.}

Wolfgang Von Goethe 


\section{PARIE 1}

\section{APRESENTAÇÃO}

De início, sendo este um trabalho que procura abranger questões de ensinagem de conhecimentos a fabricantes de software, observa-se uma necessidade de preparação de temas, assuntos e tópicos, com posicionamento da temática em um contexto específico de estudo. Esta parte da tese que ora se apresenta tem como intenção apresentá-la, estrutural e conteudisticamente, discorrendo sobre seus objetivos e metas e as organizações dos desenvolvimentos, tanto da metodologia quanto da pesquisa e do documento que a descreve. Este introdutório encabeça, ainda, a externação de questões inerentes a sua problematização, do qual decorrem seus pressupostos. 


\section{INTRODUÇÃO}

As tecnologias mudam, constantemente, as formas com que se buscam, utilizam e transferem o conhecimento. Diversos autores teorizaram sobre criação, absorção, conservação, aplicação e disseminação deste que já é considerado, tanto por profissionais de áreas de sistemas quanto de administração, o principal recurso estratégico de gestão organizacional. Os estudos sobre o conhecimento introduziram inovações conceituais sobre suas importância e estrutura, no mundo dos negócios.

TAVARES (2004:2-3), baseando-se em alguns desses autores, entre eles Tidd at $\mathrm{al}^{1}$, desenvolve a idéia de que não se discute mais se as inovações devem, ou não, ser incorporadas, mas, sim, quais as melhores maneiras de fazê-lo. Parafraseando o autor, pode-se afirmar o mesmo sobre o conhecimento, pois não deve haver mais espaço para a discussão sobre sua importância ou sobre sua representatividade como valor agregado e, sim, sobre as maneiras de sua criação, sua incorporação e sua organização.

A conscientização dessa importância e sua exigência acabam por levar ao questionamento de como gerir o conhecimento na empresa, pois que sua presença é inquestionável; a consciência disso e da capacidade de repensá-lo, de dar-lhe nova forma, nova aplicação e, até, novo contexto, é um valor agregável inovador com o qual as organizações precisam preocupar-se administrativamente e os pesquisadores, cientificamente.

\section{1 - INTRODUÇÃO À TESE}

Uma vez considerado recurso estratégico, de estratégica importância, é possível equalizar as questões de geração, armazenagem, aplicação e gerenciamento do conhecimento no ambiente organizacional, envolvendo preocupações tais como: pensar como as tecnologias, incluindo a da informação, permitem a necessária gestão; quando tecnologias específicas e especialistas passam a ser necessárias para que se componha e mantenha um processo do conhecimento; se estas, assim como os conceitos que as

\footnotetext{
${ }^{1}$ TIDD, Joe; BESSANT, John; PAVITT, Keith; Managing Innovation Integrating Technological: market and organizaional change; EUA: Wiley, 1997
} 
embasam e permeiam, podem ser transferíveis; e, uma vez que se consiga identificar estes recursos e suas tecnologias, como uma organização pode garantir suas produções, manutenções e aplicabilidades.

Estas preocupações estabelecem, ainda que de maneira superficial, a linha que centraliza o ponto de partida para a pesquisa tratada por esse documento, a qual envolve e busca focar a questão da preservação, a qual envolve transmissibilidade. Tais considerações envolvem outros questionamentos, como: "o que é a gestão do conhecimento?" e "Como se realiza, na organização?". Argüições que exigem uma pergunta primordial: "É possível transformar conhecimento em recurso sob domínio?".

GIANNETTI (1997:70-87), por exemplo, argumenta a impossibilidade de sucesso total em tal transformação, à medida que conhecimento é subjetivo e envolve emoções e experiências impossíveis de serem totalmente expressas, capturadas e/ou sentidas por outrem. Segundo o autor, por mais que uma pessoa se dedique a detalhar informações sobre uma experiência vivida, não conseguirá fazer com que outra pessoa experimente exatamente o que ela vivificou. Todas as suas impressões e percepções, acerca do ocorrido, são frutos de conhecimentos e experiências anteriores - de toda sua vida -, que seu interlocutor não viveu e com as quais não pode identificar-se totalmente.

NONAKA E TAKEUCHI (1997:61-68), por sua vez, argumentam sobre a possibilidade de sucesso na transformação de conhecimento em recurso competitivo. $\mathrm{O}$ fazem sem ser diametralmente contrários à afirmação de Giannetti, pois corroboram, em boa parte, com sua opinião, ao afirmarem que há uma faceta do universo de conhecimento de uma pessoa - e de uma empresa - que, realmente, não é fácil articular, enquanto que outra é perfeitamente articulável. A articulável é denominada explícita e caracteriza-se pelo estado de formalismo que se consiga estabelecer a ponto de torná-la registrável e comunicável; a não articulável é denominada tácita e tem, na opinião destes autores, característica coincidente ao que expressa Gianetti. Ambas formam o capital intelectual que agrega valor à organização, conforme suas afirmações.

Este trabalho buscará apresentar os conceitos do conhecimento que se pode (explícito) e do que não se pode (tácito) transformar em recurso explicitamente armazenável, mesmo sendo perfeitamente utilizável pela organização, partindo dos conceitos propostos pelos autores acima, complementando-os com outros, que permitam entender o recurso e seu processo, da criação à disseminação, inclusive o sub-processo 
que transforma tácito em explícito, mecanismo de transformação dinâmico e constante, tanto para indivíduos quanto para organizações, que precisa ser observado, ter seus parâmetros funcionais percebidos a fim de se permitir qualquer forma de avaliação de suas contribuições a pessoas e organizações, precisa de políticas e regras que lhe dêem perenidade e precisa de uma estrutura que viabilize sua aprendizagem e seu domínio.

Através do estudo que ora apresenta-se, buscar-se-á entender tecnicamente o recurso do conhecimento, a ser gerido no interior dos processos administrativo e produtivo das organizações, principalmente as dedicadas à manufatura de produtos de software em larga escala, foco desta pesquisa.

Uma vez circunscrito o conhecimento ao domínio de uma fábrica de software, buscar-se-á uma triangulação destes com o processo de ensinagem (o processo do ensino sob a ótica da parte estimuladora de seu mecanismo: o docente - a ser melhor desenvolvido no capítulo 7), com o qual a empresa precisa preocupar-se, para garantir a presença do conhecimento adequado a seus processos, principalmente em ambientes com alta rotatividade, quando não de pessoas, de tipificação de problemas relativos aos produtos do negócio, caso típico do tipo de indústria aqui abordada.

A opção pela garantia do conhecimento através da dimensão do ensino intraorganizacional, que norteia o escopo desta tese, é fruto da relação de seu autor com a docência, principalmente em cursos de terceiro grau. Longa experiência trabalhando abordagens de significativa proximidade com os aspectos profissionais exigíveis para o entendimento, a decisão, a incorporação, a organização, a administração e o uso de sistemas de informações (SI) e tecnologias da informação (TI).

\subsection{1 - OBJETIVOS E METAS}

A formulação de um modelo de processo para criar, armazenar e disseminar o conhecimento, em atividades de ensino internalizadas em uma empresa produtora de software, tornando tanto o produto (conhecimento) quanto o processo (ensinagem) gerenciáveis, para que se possa garantir a gerenciabilidade do resultado (aprendizagem) e a preservação do ativo do conhecimento, define o objetivo principal deste trabalho ${ }^{2}$.

Evidente que tal objetivo não se basta; precisa aliar-se a outros, como a análise de modelos, organizacionais e processuais, que estimulem, expliquem, embasem e/ou

\footnotetext{
${ }^{2}$ Interessante observar que a visão do conhecimento como produto, na afirmação contida no parágrafo, é apenas uma interpretação circunstancial dele como resultado de um processo produtivo, cuja função é gerá-lo como recurso competitivo para a empresa.
} 
orientem o pensamento dedicado, bem como a criação de formas para avaliá-lo. Pensar o papel do conhecimento no contexto organizacional, principalmente de fábrica de software, trabalhar com as possibilidades de sua participação nos processos gestor e produtivo de uma empresa desenvolvedora de produtos computacionais intangíveis, portanto, perfaz o núcleo dessa abordagem. Precisa, ainda, de investigação para verificar se é procedente e aderente ao meio para o qual foi pensado.

Todo objetivo leva a, ao menos, uma meta. Tecer um arrazoado sobre os conceitos que permeiam a pesquisa que ora se apresenta é indispensável à construção do conhecimento relativo ao tema e à forma como ele é desenvolvido.

Nesta linha, considera-se meta a conceituação de fábrica de software e de conhecimento, como recurso e como processo, o que possibilita entender as formas de sua preservação, disseminação e gestão. A realização de tais metas permite conceber outra, ainda na dimensão das conceituações: o envolvimento da capacidade de gerir conhecimento com a de produzir software.

Estudar o que se entende sobre o processo de criação do conhecimento, sua preservação e a aprendizagem envolvida com esta, por parte daqueles que participem do contexto ao qual se aplique é considerada, aqui, a linha indicadora mestra para o cumprimento dos fatores chave, anteriormente identificados.

Também é meta a definição do modelo de pesquisa apropriado para tal análise, devidamente fundamentado em literatura técnico-científica consagrada.

\subsection{2 - JUSTIFICATIVA}

O conhecimento é dinâmico à medida que é entendido como ação sobre a informação, segundo autores como NONAKA e TAKEUCHI (1997:1-14,23-25), que o percebem como cognição, FLEURY e FLEURY (2001:28-29), que o vêem como movimento transformador e criador de saberes, e TAVARES (2004:25-27), que o entende pela fluidez de experiências e aprendizados, entre outros diversos autores que procuram estabelecer formas que contribuam com a compreensão de tal recurso.

Recurso este que, apesar da importância propalada por muitos, ainda é pouco entendido e, consequentemente, utilizado. É o que mostram FARAH JÚNIOR e SILVA (2003:3-10) ao apresentarem uma pesquisa que reflete o pensamento de uma parcela do segmento metal mecânico, o qual produz à órbita da indústria automobilística, no estado 
do Paraná, onde foram pesquisadas quatorze empresas do setor. Esta pesquisa mostra, por exemplo, que apenas 14,3\% daqueles principais dirigentes empresariais utilizam a maior parte do tempo com o planejamento estratégico, enquanto que $42,9 \%$ deles gastam esse tempo em atividades operacionais diárias. Como as atividades gerenciais, principalmente as estratégicas, fazem uso intensivo do conhecimento, é interessante perceber as correlações deste com a situação:

Inicialmente, no que se refere a uma das formas de obtenção do mesmo: a estratégia de visitas a feiras e congressos, percebe-se, por exemplo, que nenhum destes dirigentes utiliza a maior parte de seu tempo nisso e, conforme mostra a tabela 1.01, apenas a minoria o faz com uma ocupação de, no máximo, metade de seu tempo.

\begin{tabular}{||l|c|l|c||}
\hline \hline $\begin{array}{l}\text { VISITAS A FEIRAS E } \\
\text { CONGRESSOS }\end{array}$ & $\begin{array}{c}\text { FREQÜÊNCIA } \\
\%\end{array}$ & $\begin{array}{l}\text { VISITAS A CONCORRENTES E } \\
\text { EMPRESAS DO SETOR }\end{array}$ & $\begin{array}{c}\text { FREQÜÊNCIA } \\
\%\end{array}$ \\
\hline Não gasta tempo & 7,1 & Não gasta tempo & 28,6 \\
\hline Gasta pouco tempo & 78,6 & Gasta pouco tempo & 64,3 \\
\hline Gasta a metade do tempo & 14,3 & Gasta a metade do tempo & 7,1 \\
\hline Utiliza a maior parte do tempo & 0 & Utiliza a maior parte do tempo & 0 \\
\hline
\end{tabular}

TAB 1.01: Tempo destinado a formas de absorção de conhecimento.

Adaptada deFARAH JÚNIOR e SILVA (2003:5)

Ainda na mesma linha de análise das formas de absorção de conhecimento, agora utilizando estratégias de benchmarking: nenhum dos pesquisados dedica a maior parte de seu tempo em visitas a concorrentes ou outras empresas de seu setor e poucos chegam a dedicar metade do tempo a tais práticas.

Segundo os autores da pesquisa, uma vez perguntados sobre fatores que representem entraves ao desenvolvimento de suas empresas, dentre opções previamente estipuladas por eles, os pesquisadores apontaram, conforme demonstra a tabela 1.02, grande peso nas opções que envolvem, mais diretamente, a gestão empresarial.

\begin{tabular}{||l|c|c|c|c||}
\hline $\begin{array}{l}\text { FREQÜÊNCIAS } \\
(\%)\end{array}$ & $\begin{array}{c}\text { DEFASAGEM } \\
\text { TECNOLÓGICA EM } \\
\text { MÁQUINAS E } \\
\text { EQUIPAMENTOS }\end{array}$ & $\begin{array}{c}\text { RECURSOS EXIGIDOS EM } \\
\text { NOVAS TECNOLOGIAS }\end{array}$ & $\begin{array}{c}\text { AUSÊNCIA DE SISTEMA } \\
\text { DE GESTÃO VOLTADO } \\
\text { PO PLANEJAMENTO }\end{array}$ \\
\hline Sem influência & 7,1 & 14,3 & 0 & 7,1 \\
\hline Pouca influência & 28,6 & 21,4 & 21,4 & 28,6 \\
\hline Média influência & 21,4 & 28,6 & 21,4 & 28,6 \\
\hline Alta influência & 42,9 & 35,7 & 57,2 & 35,7 \\
\hline
\end{tabular}

TAB 1.02: Fatores de entrave ao crescimento/desenvolvimento da empresa. Adaptada deFARAH JÚNIOR e SILVA (2003:9)

O que se percebe, através dessa tabela de dados, é que, das quatro opções, uma tem pouca dependência da gestão empresarial direta, pois é mais afeita a mudanças nos contextos de fornecedores (se bem que planejar a absorção de matérias primas e 
insumos envolve estratégias de logística e relacionamento com fornecedores e isso é parte integrante de tal gestão) mas, as outras três, no entanto, estão total e diretamente associadas à gestão direta e às estratégias de planejamento organizacional. É, no mínimo, preocupante perceber que mais de $64 \%$ dos principais dirigentes reconhecem a significância da defasagem tecnológica sofrida por suas empresas, mais de $78 \%$ identificam médio ou alto grau de influência pela escassez de recursos tecnológicos aplicados e, ainda, e provavelmente o mais grave, que mais de $64 \%$ deles apontam significativa ausência de sistemas gestores direcionados ao planejamento estratégico.

O resultado disso, segundo os autores da pesquisa, é a não identificação do papel do conhecimento em suas administrações e a incapacidade de focar o papel participativo de suas organizações no ambiente delimitado pelo setor de sua indústria. A tabela 1.03 demonstra que, por conta da falta de uma cultura de benchmarking e pelo uso pouco extensivo da tecnologia em modelos de relacionamento participativo, os dirigentes acabam por não perceber outras importâncias, como comprar e distribuir conjuntamente ou, ainda, fomentar pesquisa e desenvolvimento de forma cooperativa. Quando percebidas tais importâncias, acabam por não implementar estratégias para que ocorram com freqüência ou, ainda, nem mesmo formalizar qualquer tentativa de implementação.

\begin{tabular}{|c|c|c|c|c|}
\hline $\begin{array}{l}\text { FREQÜÊNCIAS } \\
(\%)\end{array}$ & $\begin{array}{c}\text { COMPRAS CONJUNTAS } \\
\text { DE MATÉRIAS PRIMAS E } \\
\text { INSUMOS }\end{array}$ & $\begin{array}{l}\text { CANAIS COMUNS DE } \\
\text { DISTRIBUIÇÃO }\end{array}$ & $\begin{array}{c}\text { DESENVOLVIMENTO } \\
\text { CONJUNTO DE MOLDES } \\
\text { E FERRAMENTAS } \\
\end{array}$ & $\begin{array}{c}\text { PROJETOS CONJUNTOS } \\
\text { DE DESENVOLVIMENTO } \\
\text { DE PROCESSOS E/OU } \\
\text { PRODUTOS } \\
\end{array}$ \\
\hline Sem importante & 28,6 & 21,4 & 14,3 & 14,3 \\
\hline Pouca importante & 21,4 & 28,6 & 7,1 & 7,1 \\
\hline Média importante & 21,4 & 35,7 & 35,7 & 42,9 \\
\hline Alta importante & 28,6 & 14,3 & 42,9 & 35,7 \\
\hline
\end{tabular}

Os problemas percebidos com as questões tecnológicas interferem na capacidade de reconhecer a indispensabilidade da gestão do conhecimento, por parte das organizações, o que, consequentemente, leva à não ação e/ou percepção da necessidade de planejamentos estratégicos e participações associadas no mercado, ou, ainda, de como o conhecimento influencia em tais situações, segundo afirmam FARAH JÚNIOR e SILVA (2003:3-10).

A considerar o dinamismo do conhecimento e o quanto se exige de espírito inovador e renovador por parte dos executivos, é de se pensar que empresas que não se conscientizam de importâncias tais, passam a correr riscos até certo ponto desnecessários. O dinamismo do conhecimento, no entanto, possui, ainda, outra 
dimensão: a da obsolescência, e esta também justifica estudos sobre seu necessário gerenciamento (o que vários autores aqui citados realizam com propriedade) e sobre os processos educacionais que as organizações precisam adotar para garantir a disponibilidade de tal recurso.

Sobre a questão do aprender, BUKOWITZ e WILLIAMS (2002:24-29) discorrem com significativo teor e isso vem apoiar, em muito, o desenvolvimento da pesquisa que ora se justifica. Sobre o constante evoluir, o que leva a considerar descartável algum conhecimento (ou porque já não tem representatividade devido a alguma mudança no negócio, ou porque deve ser substituído por outro, mais moderno, completo ou tecnicamente evoluído), as autoras também discorrem e chegam a definir situações de descarte, conforme elas mesmas denominam.

SAWREY e TELFORD (1979:23-28) já discutem, desde antes de Bukowitz e Williams, as rápidas obsolescências do conhecimento e das aptidões relevantes às profissões, as quais provocam mudança no conceito de aprendizado formal. Os autores citam Coleman $^{3}$ ao exporem que os meios produtores de informações crescem em ritmo superior aos meios institucionalizados de aproveitamento dos conhecimentos. Daí a urgência por uma gestão de conhecimentos. Daí a urgência por entender os papéis do conhecimento e da ensinagem em um ambiente de fábrica de software.

A estas justaposições, podem ser somadas outras.

FELIX (2003:25-26), por exemplo, discorre sobre o fato de os valores ativos convencionais decaírem com o passar do tempo e argumenta sobre a naturalidade de tal circunstância. No entanto, declara que o valor dos ativos do conhecimento só aumenta com o decorrer do tempo de compartilhamento. A figura 1.01 expressa sua visão, a qual não contradiz as questões de obsolescência anteriormente mencionadas. Seu foco está na importância do papel do conhecimento na administração de organizações (principalmente as de ensino superior) e como estes têm consagrado os valores agregados por meio de gestões adequadas destes ativos.

Também preocupado com as questões de aprendizagem do conhecimento, tal como Sawrey, Telford e Felix, entre outros, TERRA (1999) discute a sistematização de seu processo, definindo que o investimento em sua continuidade caracteriza as 
organizações que aprendem e fazem do conhecimento um instrumento. Já os investimentos em sua expansão, caracterizam empresas que inovam e fazem do conhecimento um objetivo.

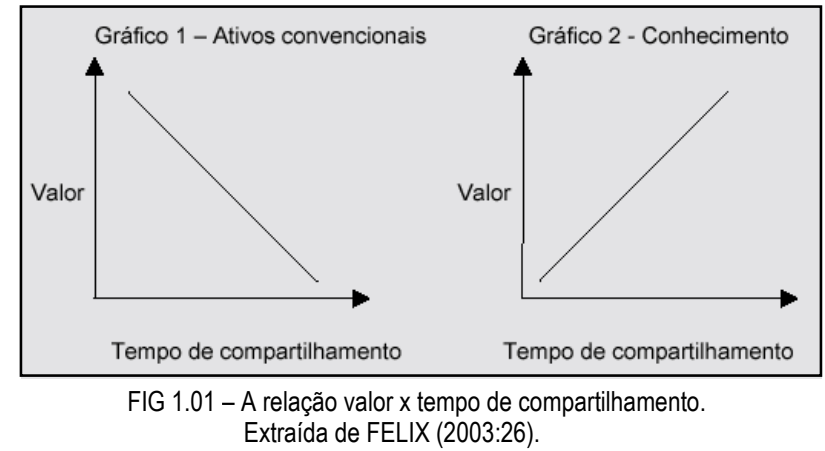

ANSOFF e MCDONNEL (1993) corroboram estas afirmações e vão além: os investimentos em continuidade denotam foco no processo, enquanto que os feitos em expansão, denotam foco no produto e na inovação como produto. Empresas que pretendam caracterizarem-se fielmente como inovadoras devem expandir a disseminação de conhecimentos até aos clientes (conquistados ou potenciais), o que sugere que os passos anteriores do processo do conhecimento devem estar sob domínio gerencial. Estes autores sugerem a definição de fatores críticos de sucesso que possibilitem a imposição clara de indicadores de desempenho - elementos essenciais para tal domínio. Alguns do fatores sugeridos são:

- investimento em pesquisa, desenvolvimento e engenharia, cujos indicadores englobam o quanto se investe em percepção e desenvolvimento de novas tecnologias e o quanto destina-se em ensino e treinamento, entre outros;

- posicionamento competitivo, cujos indicadores englobam medidas de posicionamento comparativo aos concorrentes;

- dinâmica do produto, cujos indicadores englobam a freqüência com que se consegue lançar novos produtos e o tempo de decorrência do ciclo de vida de cada produto, para sua sucessão, entre outros;

- dinâmica tecnológica, cujos indicadores englobam, por exemplo, a consciência dos ciclos de vida das tecnologias vigentes e quais são, e em que quantidades existem, as tecnologias rivais; e

- dinâmica competitiva, cujos indicadores englobam as medidas da intensidade de uso da tecnologia como elemento competitivo e da freqüência de obsolescência forçada de produtos, entre outros. 
Cada um destes fatores aponta para a necessidade do desenvolvimento da capacidade de se dominar conhecimentos (competências) para propiciar, ao processo do conhecimento, a eficiência (melhoria dinâmica para sua produção) e eficácia (melhoria qualitativa e quantitativa de sua capacidade de gerar o conhecimento como produto). Nesta visão, são perceptíveis as abordagens do conhecimento como produto do processo e, principalmente, como recurso essencial do mesmo.

Também defendendo a necessidade de entender o conhecimento como recurso essencial, DIAZ et al. (2000:3), apresentam a empresa como um empreendimento cognitivo que aprende e desenvolve conhecimento, relacionando, de forma dinâmica, seus procedimentos reflexivos e sistemáticos, o que lhe permite o entendimento de relações causais das partes e do todo organizacional, no que concordam com os autores anteriormente mencionados e outros, a revelar no desenvolver do trabalho.

Uma publicação da CNSH (2001:7-10) vem ao encontro de tais afirmações ao defender as vantagens competitivas do conhecimento e da capacidade de aprendizagem que, tornando-se um hábito, garante crescimento continuado de competências. Dentro desta linha de raciocínio, pode-se inferir, segundo a empresa, que "trabalhadores que tenham o hábito de aprender, adaptar-se-ão muito mais facilmente que os outros às mudanças e às inovações introduzidas nos negócios”.

Enfim, o que é novo em relação ao conhecimento e à sua gestão? As formas como as questões relativas ao conhecimento evoluem, apesar de inovadoras, representam o absolutamente novo em matéria de conteúdo estrutural administrativo deste bem ou, apenas, a diversificação de essências já determinadas sobre como geri-lo? A citação de Goethe, feita por MELO (1999:65), dá a impressão de que o conhecimento sobre o conhecimento já é conhecido, mesmo que ainda não aprendido.

A já mencionada experiência do autor dessa tese com a docência: somada à experiência vivida com os problemas relativos à identificação, conservação e transmissão do conhecimento, experimentados com o laboratório de fábrica de software experimental do Departamento de Engenharia de Produção da Escola Politécnica da Universidade de São Paulo, denominado eLabSoft, com o qual tem contato desde sua criação, participando, inclusive, de sua definição e formação; aliada à visão resultante de afirmações como as que acabam de ser expressas, à percepção pessoal advinda de seu contato com o ambiente profissional, externo aos limites da escola; e associada a 
uma discordância sua referente a algumas práticas no uso do termo conhecimento, em circunstâncias nas quais é tomado, em sua opinião, pelo termo informação, levou-o ao estudo de questões relativas aos saberes organizacionais (e o que, destes, caracteriza propriedade explicita da empresa ou propriedade intrínseca de pessoas, colocada a serviço da organização) e dos benefícios decorrente destes, pelas habilidades e competências que estimulam e embasam funcionalidades.

\subsection{3 - DESENVOLVIMENTO DA PESQUISA}

A estruturação processual, apresentada pela figura 1.02, define a linha de desenvolvimento da pesquisa, dividida em quatro fases de procedimento.

Cada fase do desenvolvimento é subdividida em duas etapas de progresso, as quais, uma vez cumpridas, representam a conquista de resultados parciais $\mathrm{e}$ cumulativos. Tais etapas são compostas por eventos, os quais representam os passos para o cumprimento dos objetivos anteriormente mencionados, numa sucessão de continuuns, a saber:

A fase da preparação contém uma etapa de posicionamento para a pesquisa (essa, ora em desenvolvimento) e outra, de contextualização e busca do conteúdo norteador e embasador da evolução do trabalho.

A fase de proposição de um modelo contém uma etapa de entendimento da questão central, o conhecimento como processo, e outra, voltada para a identificação do ponto de aplicação do modelo a ser definido.

A fase da aplicação contém uma etapa de organização da aplicação, na qual tanto a questão de ambientação como a de estruturação são previstas, e outra, de execução da mesma, contando com a operação do estudo de casos múltiplos e a mensuração que permita futura análise de resultados.

A última fase, de análise de resultados, contém etapas de fechamento, do modelo resultante dos estudos de caso e da pesquisa em si, voltadas à análise de como o modelo pré-concebido atende à expectativa em ambiente real. 


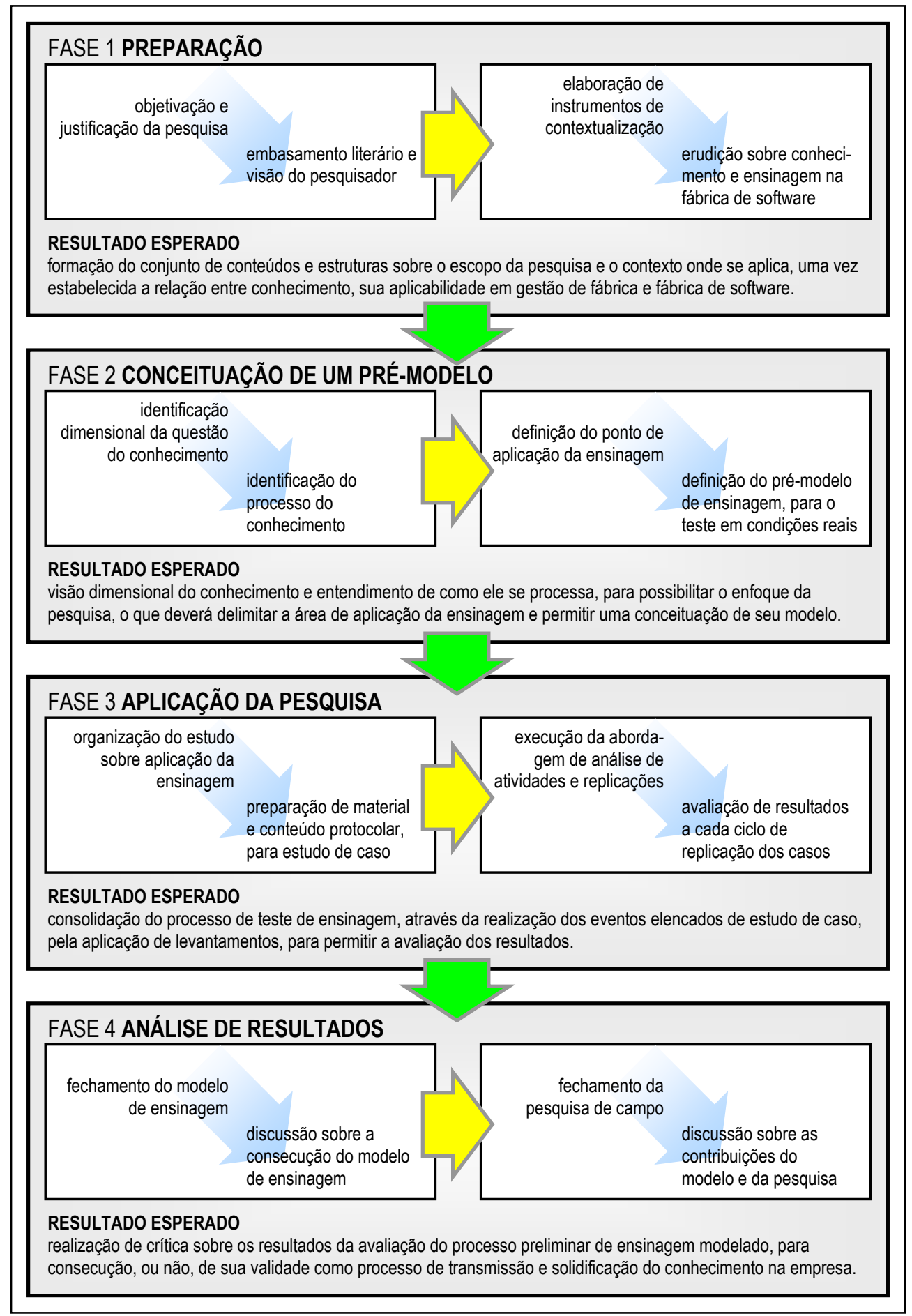

FIG 1.02 - Estrutura da pesquisa.

\section{2 - INTRODUÇÃO À METODOLOGIA DE PESQUISA}

O pré-modelo mencionado anteriormente (fig. 1.02) vai necessitar de aferição de sua adequabilidade e isso se dá por uma pesquisa complementar, observacional, de caráter científico. Pesquisar é o destino da ciência, já o disse TRINDADE (1999:7). 
Uma pesquisa pode ser definida segundo conceitos, formas e propósitos - sendo que a forma pode até vir a ser decorrente do propósito - e configura-se como uma atividade de investigação sistematizada, racional e lógica, em busca de soluções, sob a égide do método científico, conforme denotam MARCONI e LAKATOS (1996:15-21) e ANDRADE (1998:101-107).

PÁDUA (2005:31-51) posiciona tais métodos entre a epistemologia e as técnicas, na composição do cenário dinâmico do processo de pesquisa científica, contribuinte para a visão de mundo desejável de percepção, observação, formulação, discussão e entendimento, conforme mostra a figura 1.03 .

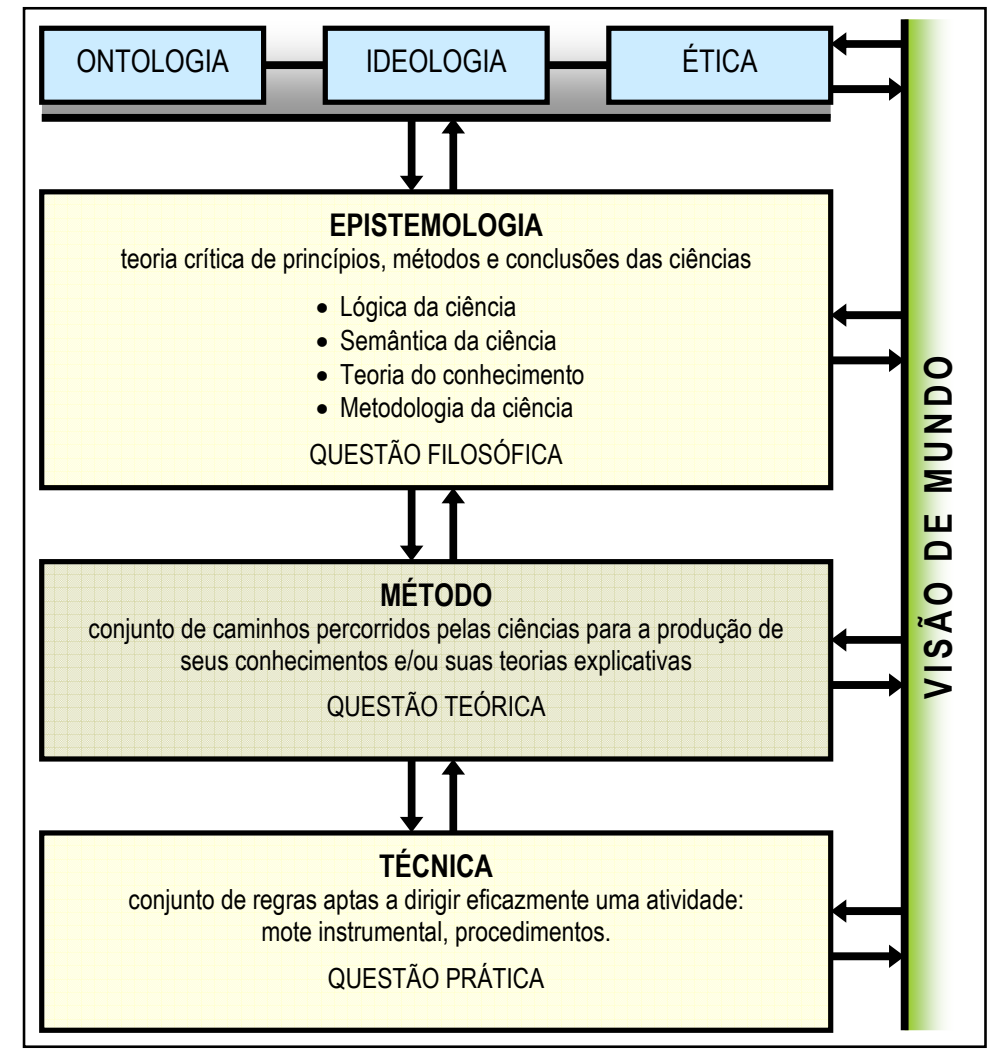

FIG 1.03: Visão integrada dos principais elementos do processo de pesquisa. Adaptada de PÁDUA (2005:35).

\subsection{1 - TIPOLOGIA DE PESQUISA:}

ANDRADE (1998:103) categoriza a pesquisa segundo quatro dimensões: sua natureza, que lhe determina essência e caráter, estabelecendo estilo de abordagem, como trabalho científico original (que retrate novas conquistas e descobertas, contribuindo para a evolução do conhecimento) ou resumo de assunto (que retrate o absolutamente fundamentado e já consagrado publicamente); seu objetivo, que lhe determina a missão e dosa a contribuição, esta, variável, desde uma avaliação pontual à 
uma revolução de paradigmas contextuais, através de abordagens exploratória (que retrate um passo preliminar para outro tipo de pesquisa, passo este expositor e limitador de temas, hipóteses e enfoques), descritiva (que retrate a exposição de observações, registros, analises, classificações e interpretações, servindo ao levantamento dos fenômenos físicos e humanos, sem interferências ou manipulações) ou explicativa (que retrate observações, análises, classificações e interpretações, abrangendo manipulação controlada de fenômenos estudados sob a ótica experimental); o procedimento de pesquisa, que lhe determina a maneira pela qual será desenvolvida, distinguindo os meios pelos quais o pesquisador pretende abordá-la, se como pesquisa de campo (que retrate observações de fatos a partir de técnicas de coleta de dados da realidade a compreender) e/ou como pesquisa em fontes literárias (que retrate as origens bibliográficas e documentais dos dados) e; o objeto da pesquisa, que lhe determina a instrumentação necessária à efetivação dos procedimentos, segundo abordagens caracterizadas por revisão bibliográfica (que retrate a apropriação, pela erudição, de informações constantes de documentos proprietários ou publicações abertas), por trabalho de laboratório (que retrate a ambientação - não necessariamente física apropriada à provocação, produção e reprodução de fenômenos, em condição de controle) ou por levantamento de campo (que retrate coletas de dados realizadas onde os fenômenos ocorrem, sem interferências).

A tipologia e a escolha dimensional, pela qual se dará o desenvolvimento de um trabalho, são decorrências naturais de um processo metodológico, em prol da essência científica da pesquisa, concordam ANDRADE (1998:104) e PÁDUA (2005:31-51). A definição do processo demanda planejamento que vise formulações, levantamentos bibliográficos, definição de recursos técnicos e metodológicos (quando não, também, econômicos), especificação cronológica, execução e análise de resultados.

O método a adotar para a realização do estudo combinará dimensões segundo proposição de ANDRADE (1998:101-107), em cuja discussão apresenta, como opções: o método indutivo, baseado na ausência de princípios pré-estabelecidos e no trabalho de coleta de dados particulares para chegar a conclusões genéricas, em formato de teorias ou leis; o método dedutivo, baseado em premissas, ou seja, em teorias ou leis aceitas, aplicáveis em situações específicas para, através da análise, gerar novas premissas; o método dialético, baseado em busca por soluções nas contradições de interpretação de um determinado problema, trabalhando a força das argumentações 
geradas pelo processo de resoluções por oposições de experimentações ou de discussões e; o método hipotético-dedutivo, baseado em testes, rigorosos e exaustivos, de teorias ou leis, na busca por respostas para novos problemas, até que falhas possam ser percebidas e, com elas, inovações possam ser propostas e incorporadas à realidade.

A autora caracteriza deterministicamente a maneira pela qual o estudo é realizado, ou seja, sua composição, estabelecendo, de forma direta, uma dualidade formada por pesquisa em fontes literárias e pesquisa de campo. A pesquisa em fontes literárias é encarregada do levantamento de conceitos, em fontes primárias e secundárias, que fundamentem proposições que levem a uma estratégia de complementação calcada em pesquisa de campo, esta encarregada da observação de fatos e situações que permitam visão de uma realidade específica, abstraída, nesse caso, do universo da produção de software com características fabris.

O trabalho de erudição, pela pesquisa em fontes literárias, é baseado em levantamento bibliográfico realizado sobre, principalmente, livros e artigos técnicos provenientes de periódico especializados e de publicações de congressos, seminários, workshops e encontros diversos.

O trabalho de observação, pela pesquisa de campo, envolve alguns métodos associáveis a uma ou mais das dimensões anteriormente comentadas. YIN (2005:21-33) denomina esta qualificação por mesclas diferenciadas de "estratégias de pesquisa", ou seja, maneiras diversas para a realização de determinado estudo, que envolvem coletas e análises de provas empíricas, tendo, cada qual, suas vantagens e desvantagens. Para este autor, uma pesquisa pode usar, como estratégia de desenvolvimento: o experimento, dedicado à busca de relações de causa e efeito com o controle de variáveis, alternativas, influências e efeitos do(s) evento(s); o levantamento, dedicado à coleta de dados quantificáveis sob determinado prisma e sobre conjuntos definidos de variáveis, a partir de amostras estatisticamente representativas; a análise de arquivos, dedicada à cuidadosa averiguação e validação semântica e de conteúdos, no que diz respeito a autenticidade, a partir de registros transacionais e de experiências em organizações; a pesquisa histórica, dedicada à busca por registros de acontecimentos nãocontemporâneos, pela análise de registros históricos sobre acontecimentos e fatos, valendo-se da possibilidade de amplitude na gama de fenômenos a serem tomados como fonte e; o estudo de caso, dedicado ao teste de teorias e, de maneira exploratória, à confirmação (ou refutação) de resultados de outros estudos, sendo útil, como tática, a 
explicações, descrições, avaliações e explorações situacionais sobre as quais o pesquisador tenha pouca ou nenhuma influência. A tabela 1.04 mostra um cenário de tais estratégias, permitindo comparações entre elas, quanto a questões envolvidas, a controles sobre eventos e a contemporaneidade dos estudos.

\begin{tabular}{|l|c|c|c|}
\hline Estratégia & Forma de questionamento & $\begin{array}{c}\text { Exigência de controle } \\
\text { sobre eventos } \\
\text { comportamentais }\end{array}$ & $\begin{array}{c}\text { Enfoque sobre } \\
\text { acontecimentos } \\
\text { contemporâneos }\end{array}$ \\
\hline EXPERIMENTO & $\begin{array}{c}\text { como, } \\
\text { por que }\end{array}$ & Sim & Sim \\
\hline LEVANTAMENTO & $\begin{array}{c}\text { quem, o que, onde, } \\
\text { quanto, quantos }\end{array}$ & Não \\
\hline ANÁLISE DE ARQUIVOS & $\begin{array}{c}\text { quem, o que, onde, } \\
\text { quanto, quantos }\end{array}$ & Não & Sim / Não \\
\hline PESQUISA HISTÓRICA & $\begin{array}{c}\text { como, } \\
\text { por que }\end{array}$ & Não & Não \\
\hline ESTUDO DE CASO & $\begin{array}{c}\text { como, } \\
\text { por que }\end{array}$ & Não & Sim \\
\hline
\end{tabular}

TAB 1.04: Situações relevantes para diferentes estratégias de pesquisa. Adaptada de YIN (2005:24).

Poder-se-ia somar, a estas estratégias, a proposta de THIOLLENT (1994:14-19), denominada pesquisa-ação, dedicada ao diagnóstico e à solução de problemas práticos de organizações, pelo envolvimento direto do pesquisador com os participantes do ambiente sob foco de estudos. Este modelo estratégico aproxima as abordagens do estudo de caso e do experimento, à medida em que oferece testes de teorias para casos específicos, onde o executor possua controle sobre variáveis e capacidade de análise de relações de causa e efeito.

\subsection{2 - MÉTODO ADOTADO:}

Analisando e ponderando as considerações feitas pelos autores citados, considera-se que esta pesquisa se classifique como um trabalho científico descritivo, com procedimentos de pesquisa em fontes bibliográficas utilizando, como instrumentação, a revisão bibliográfica e o levantamento de campo.

A revisão bibliográfica serve à erudição de conceitos e conhecimentos sobre o tema, seus periféricos e seu alicerce. Tal atividade dispõe-se a embasar cada um dos pontos de vista, cada uma das estruturas teóricas e cada uma das proposições de estímulo ao pensamento sobre negócios, fábricas, conhecimentos, ensinagens, aprendizagens e suas gestões, para permitir a solidificação de um caminho que traga à sugestão de um modelo, permeado de teoria, o qual precisa ser testado. 
Este trabalho explica-se como uma investigação original, acrescentando algo aos conceitos avançados extraídos dos livros ou de quaisquer das outras publicações científicas de que se lance mão. É descritivo, à medida que relata informações observadas, registradas, analisadas, classificadas e interpretadas, tanto a partir da erudição quanto da observação, e possui um enquadramento abrangente, tanto para a pesquisa em fontes literárias (vasta referência) quanto para a de campo (múltiplos casos), na busca pelo conhecimento de fatos, tais como acontecem na realidade. É objetivamente múltiplo, visto que se baseia em multiplicidade de meios, para sua execução, tais como o bibliográfico e o observacional, direto e indireto.

A pesquisa de campo serve à observação de realidades, fatos, situações e circunstâncias, bem como ao teste de teorias, conceitos e modelos propostos para atender tais realidades e circunstâncias. MARCONI e LAKATOS (1996:75) afirmam:

\footnotetext{
"pesquisa de campo é aquela utilizada com o objetivo de conseguir informações e/ou conhecimentos acerca de um problema, para o qual se procura uma resposta, (...) ou, ainda, descobrir novos fenômenos ou as relações entre eles".
}

Este trabalho adota, como pesquisa de campo, o estudo de caso, o qual, segundo YIN (2005:31-51), representa investigações de condições contextuais empíricas, as quais, além de investigar situações e circunstâncias de acontecimentos, em determinados momentos e locais, estabelecem limites entre o fenômeno em estudo e seu contexto, quando as fronteiras entre eles não estão bem definidas.

$\mathrm{O}$ autor considera-o uma estratégia de estudos abrangente, na medida em que, baseando-se em fontes variadas de evidências e na convergência definida dos dados, alia a capacidade de trabalhar a unicidade de algumas situações técnicas, exigentes de abordagens mais qualitativas, ao benefício da previsibilidade de proposições teóricas, norteadoras da condução das atividades de coleta e análise de dados. O método possui, sem dúvida, proximidade maior de estudos de caráter qualitativo, porém, não exime evidências quantitativas relativas ao objeto do estudo, visto que uma pesquisa quantitativa pode ser embasada em evidências qualitativas e uma qualitativa, em quantitativas. Yin apresenta, como exemplificação, um estudo de percepções psicológicas e outro, histórico. O importante, segundo ele, é não confundir o estudo de caso com pesquisa qualitativa, pura e simples, pois isso levaria seu executor a um não pré-comprometimento do núcleo temático da pesquisa com algum modelo teórico em 
proposição, ou seja, delimitaria o estudo ao conhecimento de uma situação contemporânea e geraria obstáculo a um estudo propositor de novo modelo.

A abrangência exposta pelo autor é combinada com a flexibilidade possível desta estratégia de trabalho, refletida pelo fato desta forma de inquirição não depender, exclusivamente, de etnografias e observações participantes, permitindo estudos através de contatos remotos e, mesmo, baseados em eventos anteriores, de qualidades comparáveis, devidamente publicados. Além do que, o estudo de caso pode ser exploratório ou explanatório. As explanações permitem abordagens de aproximação direta, quando não suas uniões efetivas, entre a implementação de um objeto de estudos (um programa, uma metodologia, um modelo, etc.) e seus efeitos no ambiente de sua competência. $\mathrm{O}$ estudo pode ser, ainda, de caso único, focado em um único exemplo do fenômeno em estudo ou, se muito, num esforço de replicação de observações sobre amostra única, ou de casos múltiplos, caracterizados pela diversificação da amostra e pela geração de evidências mais convincentes e robustas, conforme YIN (2005:31-75).

Destinado a testar a receptividade e a adequabilidade de um modelo conceitual de ensinagem, estabelecido em caráter preliminar, em um contexto de ambientes diversificados, o estudo de caso escolhido é múltiplo. A figura 1.04 mostra como Yin propõe a organização de um estudo de casos múltiplos.

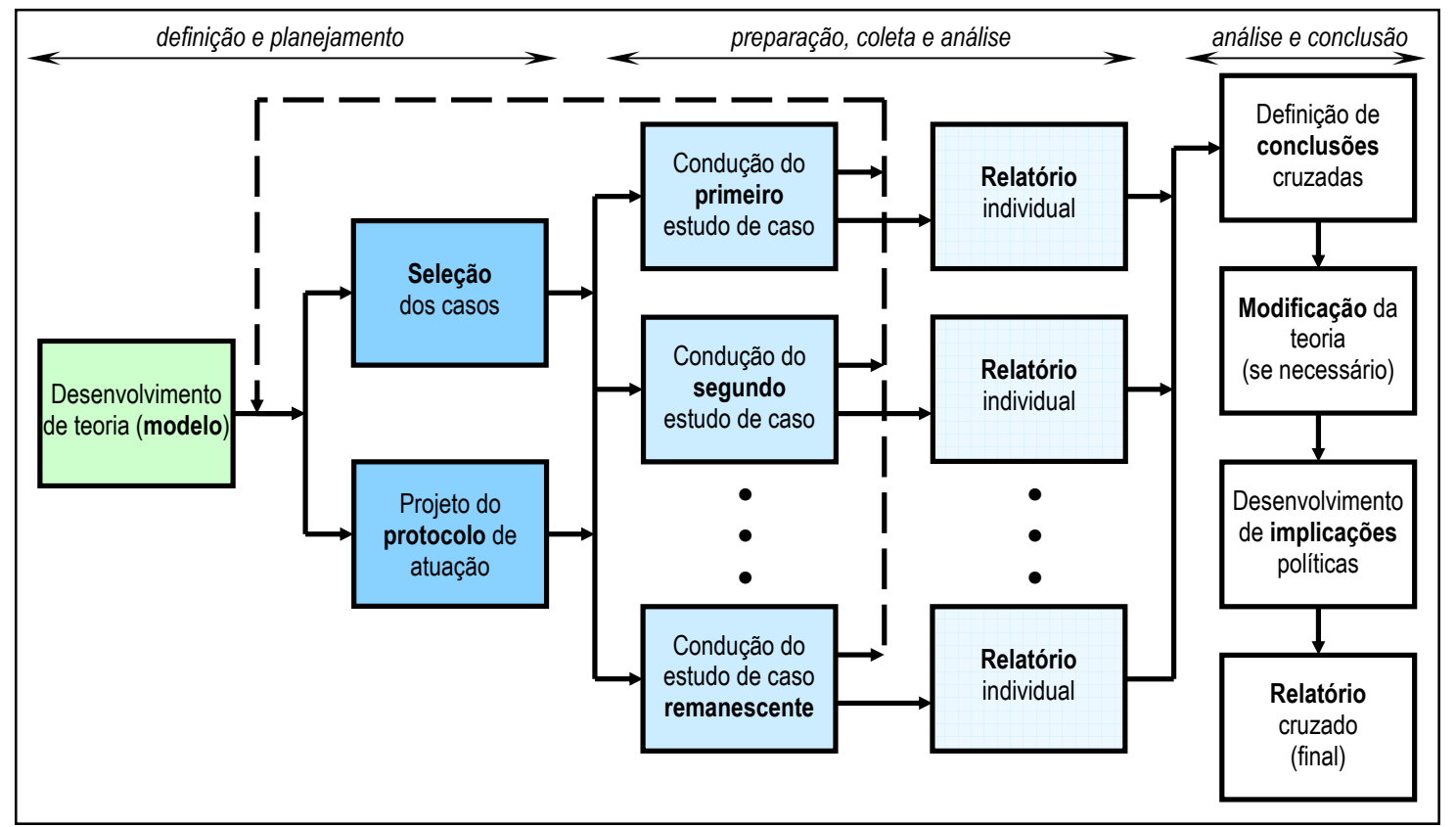

FIG 1.04: O método de estudo de casos múltiplos. Adaptada de YIN (2005:72).

O estudo de casos múltiplos é, enfim, a estratégia adotada para a pesquisa de 
campo deste trabalho e esta opção é baseada na proposta de ampliação da validação externa do modelo conceituado, pela aproximação do resultado a um estado generalizável (reservados os limites, pois que, os resultados de estudos de casos atêm-se aos casos e, se muito, aos domínios das amostras escolhidas).

Este modelo de investigação exige projeto que, por sua vez, exige um plano lógico para evoluir de uma condição inicial à outra, final, de resultados, segundo YIN (2005:41-49). O autor vai adiante e afirma, ainda, que um projeto de pesquisa é mais que um plano de trabalho, associando aspectos sinérgicos à lógica de transposição da condição anunciada, contextualizando questões e proposições e estabelecendo interagência entre problema e circunstância, de sorte que se definam os elementos de composição e o fluxo "logístico" de seus envolvimentos na evolução da análise. Para o autor, são cinco os componentes com especial importância nesta composição:

1. as questões do estudo;

2. suas proposições, ou pressuposições;

3. sua(s) unidade(s) de análise;

4. a lógica que une dados às proposições e;

5. os critérios para interpretar as constatações.

Quanto às questões do estudo, o autor discorre sobre suas importâncias como norteadoras essenciais para o entendimento das intenções da pesquisa, bem como da qualificação do teor do elemento de investigação sugerido pela forma do questionamento, conforme já o demonstrou a tabela 1.04.

Quanto às proposições do estudo, são elementos direcionadores de atenção sobre o que deve ser analisado. As proposições embasam e estruturam as questões, dando consistência de conhecimento sobre a essência do que deve ser respondido para validar o objeto de indagação em pauta. Pode-se afirmar que as proposições expressam ${ }^{4}$ um "mapa" de exploração de possibilidades e de vertentes relacionadas ao que se pretende provar ou refutar. As proposições pretendidas por Yin são pressuposições, ou seja, conjecturas circunstanciais consideradas como antecedentes necessários de outras; são juízos ou opiniões hipotéticas. Proposições são, então, hipóteses, conforme pode confirmar PÁDUA (2005:44), com sua explanação da etimologia da palavra, a qual vem afirmar que hipótese é o que está sob tese, é afirmação provisória e em suspeição, ou

\footnotetext{
${ }^{4} \mathrm{O}$ termo "expressam" deve ser tomado no sentido do condicionamento básico que representam, como elementos
} afeitos ao alicerçamento de condições que garantam a expressividade das possíveis respostas às questões do estudo. 
seja, é proposição a ser (ou não) confirmada’ pela pesquisa.

Quanto à unidade de análise, YIN (2005:41-49) afirma ser parâmetro que serve à definição do que pode vir a ser um caso de estudo, ou seja, sobre o quê (ou quem) uma investigação científica pode concentrar esforços na finalidade de compreender uma situação contextual contemporânea. Uma unidade de análise pode se configurar como:

- uma pessoa (o indivíduo como unidade primária de análise) ou um conjunto de pessoas com certa especificidade;

- uma entidade, grande ou pequena, pública ou privada, classificada em qualquer dos tipos de negócio, da qual pretenda-se compreender a organização e os métodos, analisando políticas, processos, recursos, participações mercadológicas e programas, por exemplo e;

- um evento, individual ou coletivo, tal qual ações políticas, tomadas de decisões, implantações organizacionais e mudanças, entre outras.

Através da unidade de análise procura-se definir os parâmetros que servirão à análise de agentes ambientais, ou seja, à procura de identificação de agentes que se alinhem ao fenômeno investigado. Procura-se, também, determinar se, para cada tipo de estudo possível, é possível encontrar o tipo certo de unidade, passível de encaixe nas prerrogativas exigíveis pelo teor da pesquisa.

Quanto à lógica que une os dados às proposições, o autor declara ser um componente de pesquisa ainda pouco discutido e desenvolvido, porém sugere, como prática promissora, estruturação da exposição dos dados dentro de um padrão de adequação tópica que facilite suas análises pontuais e contribua com a visão global do fenômeno.

Quanto aos critérios para interpretar as constatações, a insuficiência de definição é tão crítica quanto a apontada para o componente anterior, reclama o autor, pois ambas envolvem a subjetividade da análise dos casos. Não há maneiras devidamente formuladas que embasem o estabelecimento de tais critérios (até mesmo pelo caráter de particularidade que cada investigação contém) e a cada projeto de pesquisa, os pesquisadores devem procurar a personalização adequada do método, o que conferirá originalidade ao trabalho.

\subsection{3 - CONTEÚDO DA PESQUISA DA TESE:}

A figura 1.02 dá uma idéia do conteúdo pretendido: um estudo sobre 
conhecimento e a gestão que lhe garanta preservação, através de processos de ensinagem. Para que estes produtos se configurem como conteúdo de pesquisa, necessitam outros, como o de possíveis modelos gerenciais de negócios, o de organização de trabalho e o de ensino. Este último, por sinal, configura-se tão central como as questões referentes ao conhecimento, já que o foco da pesquisa é uma estrutura de processo de ensinagem. Conteúdo conceitual sobre fábrica de software também se faz presente, pois que a aplicação do corpo de pesquisa dar-se-á nesse tipo de organização.

Para a consecução do estudo de caso múltiplo, algumas fábricas de software, independentes do meio acadêmico, qualificáveis como fornecedoras de tecnologias e aplicativos, estão envolvidas no estudo ambiental.

\section{3 - INTRODUÇÃO AO DOCUMENTO DA TESE}

O documento que ora se apresenta está estruturado em segmentos e partes. Os segmentos são: pré-texto, texto e pós-texto.

No primeiro deles, o pré-texto, estão contidos itens de formatação e mapeamento de informações, tal qual capa, folha de rosto, dedicatórias e agradecimentos, sumário (este apresentando as diversas formas de índice, como capítulos, figuras, tabelas, etc.) e resumo, acompanhado do respectivo abstract.

No segmento do texto estão contidas partes do desenvolvimento do corpo da tese. Uma, própria para as apresentações devidas (na qual esta página encontra-se posicionada); outra, para a exposição dos conceitos que permeiam o assunto da tese; uma terceira, para a explanação da pesquisa, na qual está inclusa uma triangulação entre os conceitos centrais mostrados na parte anterior; e uma última parte, dedicada às disposições finais, conforme demonstra a figura 1.05, a qual apresenta, ainda, os fracionamentos internos destas partes, compostos por capítulos.

O último dos segmento, o pós-texto, é caracterizado pela contra-capa.

O corpo do texto, compõe-se de um conjunto de capítulos, dos quais o primeiro é o que ora se desenvolve, dedicado a apresentar o trabalho em si. Quanto aos demais:

O capítulo 2, da problematização, contém a definição do problema abordado pela tese e, consequentemente, alguns pressupostos que tal situação acaba por exigir 
para o caráter de experimentação através de casos.

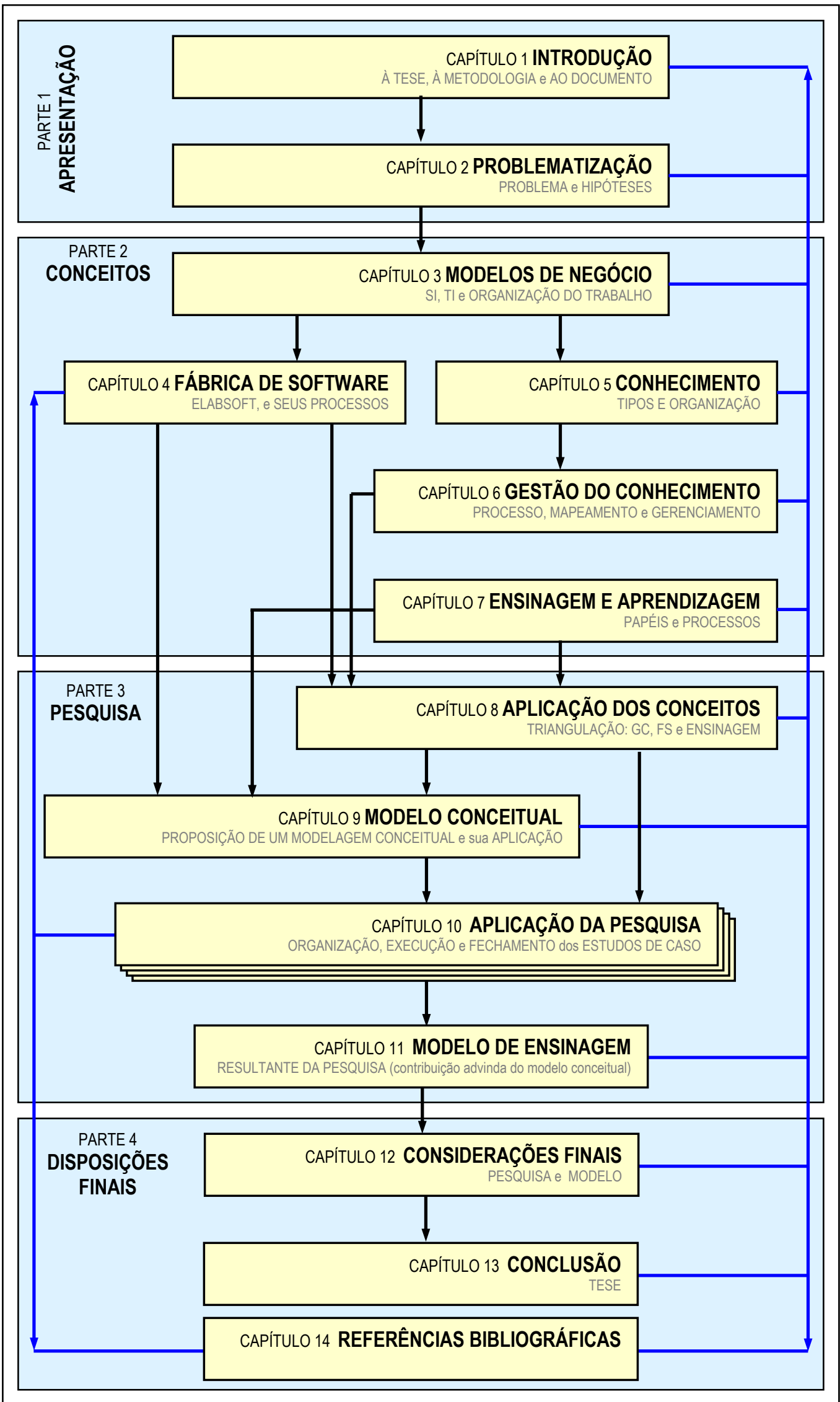

FIG 1.05 - Estrutura parcial do documento, referente ao corpo da tese (segmento do texto). 
O capítulo 3, dos modelos de negócios, contém um arrazoado sobre as questões de gerenciabilidade das organizações e como precisa organizar-se, instrumentalizar-se e aparelhar-se a administração, para garantir a operacionalidade empresarial. A instrumentalização caracteriza-se pelo sistema de informações e suas possíveis abordagens, cada qual permitindo visão de negócio adequada a uma abordagem organizacional específica. $\mathrm{O}$ aparelhamento caracteriza-se pelas tecnologias da informação possíveis de instalar-se em uma organização, focadas nas mais diversas visões especializadas de conceituação e atuação tecnológica, com abrangência minimamente suficiente do universo administrativo de um negócio.

O capítulo 4, da fábrica de software, contém a conceituação deste tipo de negócio, baseado na manufatura de produtos de software e caracterizado pela busca de escalabilidade e padronização produtiva. Uma definição do eLabSoft, fábrica experimental da PoliUSP é apresentada, também, neste capítulo, discorrendo sobre os conceitos técnicos que embasaram sua estrutura organizacional e sobre seus processos, tanto de produção quanto de gestão.

O capítulo 5, do conhecimento, contém a conceituação apoiada em literatura do que se entende como conhecimento e seus tipos, principalmente os que o qualificam como possível, ou não, de formulação e conseqüente aprendizagem, pois este é o núcleo da pesquisa. Traz, também, opiniões de diversos autores, sobre a aplicabilidade do conhecimento, como recurso de domínio de negócios.

O capítulo 6, da gestão do conhecimento, contém o agrupamento de conceitos anteriormente determinados, apoiados nas formas como evoluem e progridem as aplicações de conceitos tecnológicos nos mais diversos modelos de negócio (entre eles os de fábrica de software). Discute a dinâmica do gerenciamento dos conhecimentos sobre tais conceitos, tecendo considerações sobre como estes modelos e conceitos apoiam-se e exigem formas complexas de utilizar informações. Este capítulo procura o entendimento sobre o objeto de gerência, descortinando, tanto quanto possível, seu processo, através do mapeamento do mesmo.

O capítulo 7, de ensinagem e aprendizagem, contém um levantamento do que se emprega na conceituação e na aplicação das práticas docentes e discentes do ensino, tornáveis corporativas, aplicáveis às proposições de preservação do conhecimento, sobre a qual baseia-se a definição primordial do problema, adiante. Com base nas visões 
de vários autores, a proposição da idéia de ensinagem representa o foco maior desta parcela do documento.

O capítulo 8, da aplicação dos conceitos, contém uma triangulação entre os elementos principais: a fábrica de software, o conhecimento e o processo de ensinagem. Inicialmente, há uma análise de como o conhecimento (e, consequentemente, sua gestão) aplica-se em fábricas de software. Esta análise é seguida de outra, que trata da relação do conhecimento com sua conservação e disseminação, mais especificamente, através de processos de ensino, pelo aculturamento, pela formação, pelo treinamento ou outras formas de difusão do mesmo em processos de ensinagem, que garantam a preservação do conhecimento como recurso produtivo. Uma terceira análise é realizada e dá conta de como este processo de ensinagem pode desenvolver-se em organizações que fabricam software, o que caracteriza a ação de ensinagem orientada a desenvolvedores de um produto específico.

O capítulo 9, do modelo conceitual, contém uma proposição de como pode ser resolvido, com adequação necessária, a questão do processo de capacitação tomado internamente, nas organizações, para suportar base e estrutura do conhecimento necessário ao negócio, através de um processo conceitual de trabalho, com proposta preliminar, a ser testado por estudos de casos vindouros.

O capítulo 10, da aplicação da pesquisa, contém determinações estruturais, através de protocolo e definições de entrevistas, e relatos de acontecimentos sobre sua aplicação, bem como o fechamento da questão, pela análise de resultados.

O capítulo 11, do modelo de ensinagem, contém a contribuição da tese, com os ajustes necessários ao modelo conceitual preliminar, proposto no capítulo 9, caso confirme-se sua consecução.

O capitulo 12, das considerações finais, contém os arrazoados finais do trabalho, permeado pelas discussões sobre os resultados conquistados (ou não) com a execução da pesquisa e como esta corrobora para o atendimento do modelo (e este, para o atendimento das situações em que foi estudado) e das hipóteses levantadas.

O capitulo 13, da conclusão, contém o fechamento da questão e da tese em si.

O capítulo 14, das referências bibliográficas encerra, com a relação das fontes utilizadas para a erudição, o corpo do trabalho. 


\section{4 - EM SUMA...}

Este primeiro capítulo dedicou-se a iniciar a apresentação do trabalho e seu documento, introduzindo a temática e suas justificativas, bem como a metodologia adotada e as estruturas planejadas, de desenvolvimento da pesquisa e de composições do documento da tese.

Resumidamente, apresentou-se um trabalho de pesquisa sob o tema da gestão do conhecimento em fábrica de software, a ser analisado através de estudo múltiplo de casos, cujo foco aborda questões de ensino corporativo, necessárias à solução de problema, ainda por configurar-se, no capítulo a seguir. 


\section{2 \\ PROBLEMATIZAÇÃO}

Pode-se pensar, por um instante que seja, que as organizações tomariam para si o papel de disseminadoras do conhecimento, responsabilizando-se por processos de aprendizagem anteriormente delegados ao estado e, antes dele, à igreja?

Esta é a conjectura lançada por DAVIS e BOTKIN (1996:25-42) para denotar o problema que percebem, relativo ao conhecimento e à revolução que a percepção de sua importância gera, e que tem sido trabalhado por organizações preocupadas em transformar conhecimento em recurso estratégico, seja fazendo-o parte do instrumento produtivo e/ou administrativo, seja embarcando-o em produtos ou fazendo dele seu produto. Os autores consideram que o conhecimento é o recurso que mais agrega valor aos negócios e à economia e denominam "empresa do conhecimento" àquelas que têm transformado a maneira de aprender das pessoas.

O problema motivador desta tese coincide com a preocupação aventada pelos autores e corrobora outras, de outros autores: as questões relativas ao conhecimento, efetivo (como preservar) e potencial (como aprender), em desenvolvimento e em aplicação na organização e, mais propriamente, nas produtoras de software dentro de padrões fabris. Este capítulo busca a definição de questões e pressupostos que norteiem a pesquisa como um todo.

\section{1 - O PROBLEMA E SEU EQUACIONAMENTO:}

No que diz respeito ao conhecimento, alguns problemas podem ser relacionados, tais como a própria definição do termo que, mesmo antigo, mesmo presente desde tempos imemoriais, representa um mistério quando sua conotação é empresarial. Às corporações, parece haver, para dizer o mínimo, um hiato no que diz respeito às questões do conhecimento: $\mathrm{O}$ que é e como se diferencia das informações, como pode ser utilizado como recurso, qual é proprietário e qual não é, qual serve a cada situação, com qual se pode contar nas garantias de domínio sobre as situações nas quais as tomadas de decisão, táticas e estratégicas, se fazem imprescindíveis e, mais recentemente, como se conserva o conhecimento como um ativo organizacional. 
O primeiro problema, então, está na definição do conhecimento e em sua categorização como recurso de trabalho, bem como em seu posicionamento no contexto ambiental, administrativo ou produtivo, da organização. Isso dificulta (quando não inviabiliza) entender como se processa o conhecimento e, portanto, como se pode extrair dele o melhor da potencialidade agregadora de valores que possua.

A considerar a organização sendo uma fábrica de software e, com isso, considerar que os produtos não contenham qualquer porção produtiva totalmente mecanizável (ou seja, são frutos de constante produção intelectual, mesmo que o exigível seja apenas o cumprimento de especificações claras e devidamente detalhadas), a prática do uso do conhecimento se potencializa e, com ela, a necessidade de desenvolver, estocar, preservar e reutilizar volumes maiores deste recurso na produção.

Tais situações produtivas exigem, ainda, administração, a qual se pratica com o exercício do conhecimento sobre como tratar e operar informações sob as mais diversas formas, em diferentes níveis de decisão. A tal administração cabe, por exemplo, a responsabilidade de conservar o conhecimento necessário à eficiência produtiva e à eficácia mercadológica, resolvendo problemas como a perda de conhecimentos cruciais pela perda de funcionários estratégicos ou executivos chave para o negócio; como a necessidade de saber qual é seu legado de conhecimento e saber onde buscar conhecimento extra para atender exigências maiores ante cada novo projeto e; como garantir o aprendizado de seus partícipes e, ainda, garantir que seus aprendizados contribuam para o conhecimento corporativo.

A rotatividade de pessoal, a não ciência do legado e o desconhecimento sobre onde buscar tal recurso representam ameaças à competitividade, visto que desaceleram a produtividade e ampliam custos pela constante necessidade de reaprender do corpo funcional, o que acarreta incapacidade de atendimento da demanda de projetos e, conseqüentemente, perdas econômicas.

No caso mais localizado de laboratórios de fábrica de software, como o eLabSoft, agrava-se o problema do reaprender pelo fato de se trabalhar com uma massa crítica funcional bastante volátil. A rotatividade de participantes dos projetos, dos estágios e dos eventos é significativa e isso gera perda de capacidade de agregação em ambos os sentidos, tanto do legado para os participantes, quanto deles para a instituição.

No caso da função didática e de pesquisa que estes laboratórios possuem, 
sobressai a preocupação com o desenvolvimento de uma capacidade específica de transferência do conhecimento pelo processo de ensino. Processo este que sirva aos propósitos diretos dos teores experimentais do mesmo junto aos alunos das escolas às quais estão ligados e da capacitação da entidade para transferir tal habilidade às empresas que, porventura, possam aplicar tal conhecimento.

De imediato, pode-se pensar que tais prerrogativas, baseadas em um processo de ensinagem, apliquem-se na administração voltada à preservação e acessibilidade do conhecimento como forma de garantir a disponibilidade de um recurso absolutamente estratégico. O problema central deste trabalho relaciona-se, diretamente, com a proposição de tal processo.

Seu equacionamento depende da identificação de questões e pressupostos primordiais, que levem ao centro do problema e, uma vez identificado seu teor, definam interpretações provisórias de condições para o sucesso da compreensão do fenômeno, segundo comenta YIN (2005:41-49).

Como a investigação tem o estudo de caso múltiplo como método adotado, com base nos postulados de Yin, a estruturação da pesquisa dar-se-á nos moldes e cronologia dos cinco componentes de projeto, por ele sugeridos: as questões do estudo; suas proposições; as unidades de análise; a lógica que une dados e proposições; e os critérios para interpretar as constatações. Este capítulo aborda, apenas, os dois primeiros componentes. Os demais serão devidamente identificados em capítulos vindouros.

\section{2 - QUESTÕES DO ESTUDO:}

A considerar o olhar sobre a gestão do conhecimento aplicada à conservação e acessibilidade, conforme mencionado anteriormente, define-se, na forma de uma questão primordial, em acordo com a proposição de Yin, a principal preocupação desta pesquisa: “Como fábricas de software preservam o conhecimento?”.

Esta pergunta retrata o cerne dos estudos em desenvolvimento, tanto nos levantamentos bibliográficos, quanto nos casos em estudo, para os quais se busca embasamento em literatura consagrada e em experiências vivenciadas.

Preservar, no escopo desta pesquisa, não significa apenas organizar, armazenar e garantir a integridade de conhecimentos depositados em bancos ou repositórios que os 
possam conter. Preservar possui um significado maior, que engloba a capacidade de têlos disponíveis quando necessário for, mesmo havendo um dinamismo acentuado nas rotatividades de projetos e/ou funcionários envolvidos com a produção de software. $\mathrm{O}$ processo de ensino, institucionalizável, inclui-se nesta prerrogativa de preservação, e isto leva a outra questão, também digna de ser reputada como essencial: "Como se realizam os processos de transmissão do conhecimento, no corpo funcional, e como estes garantem o sucesso da ensinagem em eventos como cursos e treinamentos?".

\section{3 - PROPOSIÇÕES:}

Segundo a definição de YIN (2005:41-49), proposições (ou pressupostos) são direcionadoras para considerações preliminares a serem testadas, a fim de embasarem a investigação pela busca de respostas às questões do estudo. Neste trabalho, dois níveis de proposições serão utilizados: inicialmente, um nível mais genérico, denominado "de estrutura" e, logo após, um nível mais básico, denominado "de alicerce".

\subsection{1 - PROPOSIÇÕES DE ESTRUTURA:}

São três as pressuposições que pretendem dar sustentabilidade às questões formuladas anteriormente, através de afirmações, ainda que conjecturas, sobre o conhecimento, a necessidade de seu embarque na organização e o processo de ensino institucionalizado que se pode estabelecer para provocar evolução de habilidades e competências. Como proposição e hipótese são tomadas como sinônimos, segundo o que se explanou no capítulo anterior, as numerações do proposto nesse nível, para fins de diferenciação da que se utilizará adiante, receberão a letra " $H$ " ao invés de "P":

H1 - Conhecimento é recurso armazenável, transferível e reutilizável. Essa proposição parte do princípio que a organização do conhecimento permite, à corporação, saber o que se sabe e está institucionalizado, saber o que se sabe mas ainda é propriedade exclusiva de pessoas do corpo funcional e saber o que não se sabe mas que existe e que se sabe necessário à realização de projetos e, portanto, o saber corporativo possui mapeamento de tais saberes, o que permite, à empresa, o acesso a eles, quanto necessário, junto a pessoas e empresas que não fazem parte de seu corpo funcional.

H2 - É possível pensar um processo definido para reger a internalização do ativo 
de conhecimento na base corporativa, o que demanda organização do conhecimento e, consequentemente, domínio sobre conhecimentos sobre o conhecimento. Essa proposição considera a importância da regência administrativa, via alinhamento estratégico entre negócio e TI, para a potencialização da capacidade intelectual e produtiva da empresa através de seu corpo funcional, apontando-a para a diversidade de novos saberes e, principalmente, domínio sobre eles. Apoiado em literatura, pode-se dizer que há conhecimentos essenciais inerentes a cada tipo de negócio (core business), os quais precisam ser internalizados.

\section{H3 - É possível criar um modelo de ensinagem que sirva à internalização de novos} conhecimentos e à disseminação otimizada do conhecimento já apropriado, como forma de preservá-lo. Essa proposição possui uma relação direta com a questão primordial da tese, sobre a preservação do conhecimento, e a questões ligadas ao sucesso desejável da aprendizagem. Expressa a possibilidade de contribuição, principalmente por representar o cerne da pesquisa: um modelo de ensinagem que, diferenciado do modelo de ensino, praticado em escolas, represente processo de melhor eficiência. Isso, afirmado com base em que, no ambiente profissional das organizações, o tempo esperado de resposta advinda de uma aprendizagem é menor do que se pode considerar na abordagem escolar. Sem falar no diferencial esperado da eficácia, pois que o autor dessa tese considera o índice de perdas na absorção do conhecimento possível em ambientes escolares como algo próximo do inaceitável em ambientes empresariais.

Cada uma destas proposições pode ser vista como um bloco estrutural, alicerçado por proposições de nível mais básico.

\subsection{2 - PROPOSIÇÕES DE ALICERCE:}

São nove as proposições fundamentadoras, divididas em três blocos, um para cada pressuposição " $\mathrm{H}$ " apresentada no item anterior. Agora, as identificações numéricas serão precedidas pela letra "P".

As primeiras delas são as que dizem respeito ao conhecimento como recurso, conforme proposto em $\mathrm{H} 1$ :

P1 - Conhecimento é recurso tornado organizacional e categorizado operacional, tática ou estrategicamente. 
P2 - O conhecimento corporativo pode ser organizado de forma que, com a devida tecnologia, a otimização de seu uso seja uma realidade na melhoria dos processos organizacionais.

P3 - Essa organização do conhecimento tem que ser abrangente o suficiente para permitir e otimizar o uso de conhecimentos que a empresa não possua, mas saibaos necessários a seus propósitos.

A terceira proposição parte das idéias de que as empresas utilizam conhecimentos próprios e que não lhes são próprios e de que, independente de conseguirem, ou não, gerir tais saberes, estabelece-se a premissa de que existem conhecimentos sobre os conhecimentos: se os recursos de conhecimento são próprios e gerenciáveis, a organização conhece o que conhece e, para tal, precisa de conhecimentos sobre o conhecimento; se os recursos são de outrem e a organização deles precisa, conhece o que não conhece e sabe onde encontrá-los, portanto, possui, uma vez mais, conhecimentos sobre o conhecimento.

Contribuindo com esta premissa, as próximas afirmações versam, justamente, sobre os conhecimentos relativos ao conhecimento (pessoal ou corporativo), fundamentando $\mathrm{H} 2$ :

P4 - A base de dados corporativa deve conter informações pertinentes a conhecimentos não próprios da organização (institucionalizados ou não) de sorte que possam ser absorvidos ou comercializados, por aquisição e/ou adoção.

P5 - É necessário internalizar o conhecimento, seja recurso ou meta-recurso, considerando que este seja primordial para o core business da empresa ou do negócio ora ativo.

A pressuposição P4 considera, em prol de sua consecução, conceitos e formas de como buscar e conservar os conhecimentos sobre os conhecimentos. Na busca, como descobri-los e àqueles que os possuem (ou às habilidades e competências decorrentes do mesmo), relativos aos interesses de negócios específicos.

A pressuposição P5 já possui comprovação positiva em TAVARES (2004:4-6), no que tange a conhecimentos essenciais de negócio, conforme demonstra a figura 2.01, a qual demonstra o que é e o que não é considerado core busines.

Evidente que o demonstrado pelo autor não pode ser generalizado para todo o 
conhecimento, pois foi demonstrado para uma situação específica, relativa ao setor bancário e seus fornecedores. O próprio Tavares, no entanto, fortaleceu sua resposta ao associá-la a exposições de outros autores, como Quinn', do qual se originou a figura apresentada em 2.01, e Prahalad ${ }^{6}$, tor-

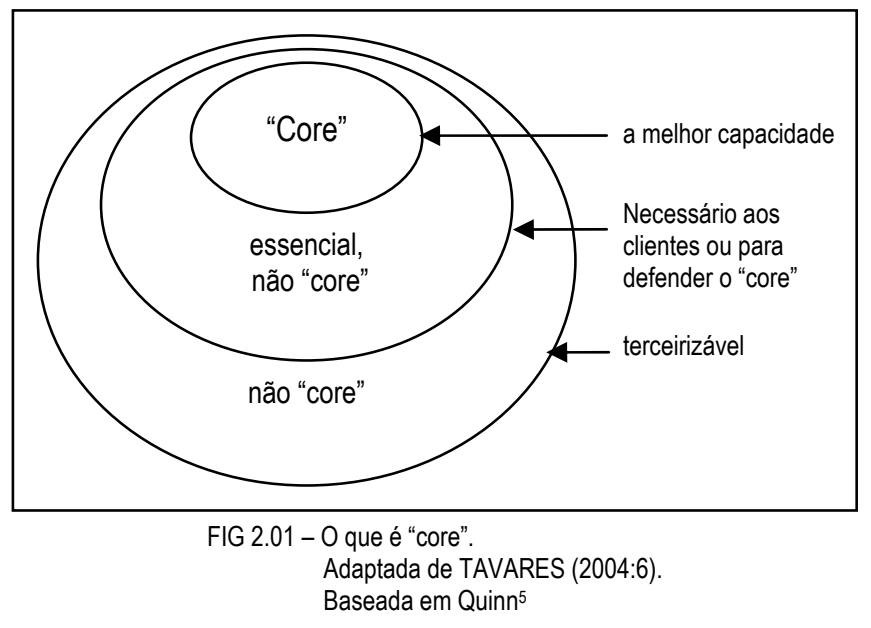
nando-a extensiva a fronteiras mais abrangentes.

A premissa foi incluída neste bloco de proposições para permitir a observação de sua abrangência e verificar se pode ser tomada como verdade para os conhecimentos sobre os conhecimentos em um ambiente de fábrica de software e, de alguma forma, as informações sobre seus processos e produções, como parte do conhecimento desejavelmente sob domínio que estas organizações precisam.

Além do que, esta pressuposição leva a outras, sobre o aprendizado necessário para a incorporação do conhecimento, tema sobre o qual versam os fundamentos de H3:

P6 - Uma vez entendido o que é "core", deve-se pensar um modelo de ensino que se encarregue de incorporar o conhecimento à organização.

P7 - O recurso do conhecimento deve ser absorvido, seja ele referente a saberes de aplicação direta ou saberes sobre saberes necessários, mas não apropriáveis.

P8 - O recurso do conhecimento deve ser disseminado entre os partícipes do corpo funcional da empresa e, para tanto, é necessário investir na busca que a gestão do conhecimento faz pela otimização da difusão desse recurso de trabalho.

P9 - A ensinagem precisa ter presença e modelo estabelecidos na organização, pois dela decorrem importantes contribuições para com o volume de conhecimentos armazenáveis (viabilidade de melhoria do próprio processo para ciclos vindouros), para com o ensino de saberes incorporados e armazenados de experiências anteriores (viabilidade de otimização e inovação de processos produtivos) e para

${ }^{5}$ QUINN, James B. Strategic Outsourcing: leveraging knowledge capabilities; in: Sloan management Review vol.40, no 4; EUA: MIT, summer 1999.

${ }^{6}$ PRAHALAD, C.K.; Managing Discontinuities: the emerging challenges; in Research Technology Management Journal - vol.41, nº 3; EUA: IRI - Industrial Research Institute, maio e junho de 1998. 
com os saberes que, apesar de não armazenáveis em bancos corporativos, são importantes para os processos de negócio (viabilidade de incorporação de novos padrões de projetos).

Este conjunto de pressuposições considera alguns pontos como a importância em se reconhecer o que é "core" para empresas produtoras de software e como é vital a internalização de conhecimentos relativos a ele. A partir daí, outros pontos são considerados, como as viabilizações de aquisição e disseminação de saberes e o reconhecimento do papel da ensinagem e da aprendizagem neste cenário. Todas as pressuposições, de níveis "P” e "H”, estão sob investigação. A tabela 2.01 demonstra um cenário de relações entre questões e pressupostos.

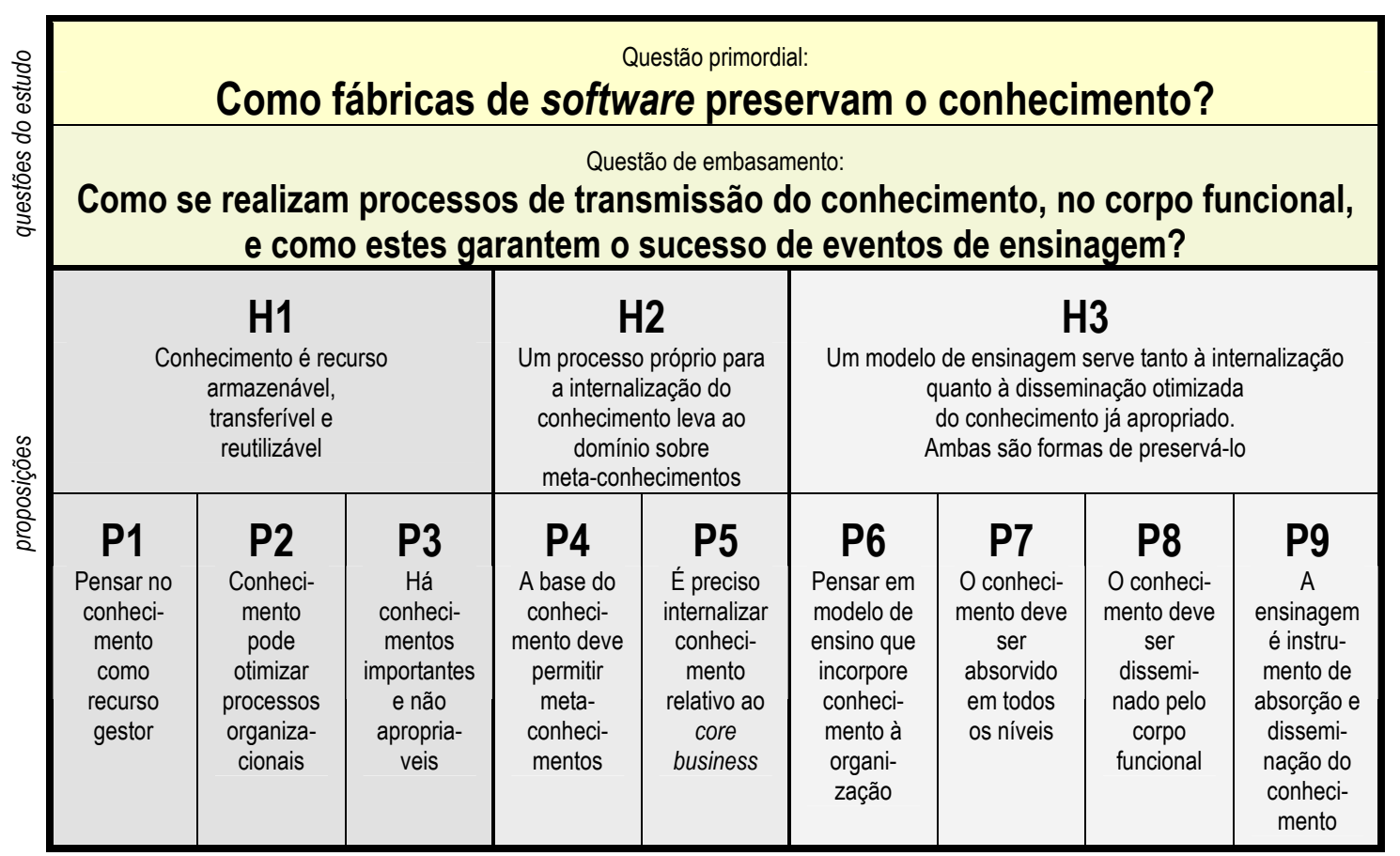

TAB. 2.01 - 0 cenário de pressuposições sustentando questões.

\section{4 - EM SUMA...}

Este capítulo dedicou-se a apresentar o problema que se espera compreender e responder, através de uma questão primordial, seguida, diretamente, de uma indagação de embasamento e, indiretamente, de algumas proposições alicerçantes do problema principal sob investigação: Como fábricas de software preservam o conhecimento.

Os próximos capítulos cuidarão de outra forma de apresentação: a de conceitos fundamentais para a pesquisa. 


\section{PARTE 2}

\section{CONCEITOS}

Faz-se necessário estabelecer uma base conceitual que permita e induza a compreensão de termos e este é o princípio que embasa este segmento do documento. Os conceitos principais a desenvolver são o de fábrica de software, o de conhecimento e sua gestão e o de ensinagem. A triangulação entre estes conceitos exige outros, como a criação e o processo de disseminação de conhecimentos, a aprendizagem no contexto corporativo e a organização do trabalho inerente do modelo gerencial de negócio. 


\section{亿 MODELOS DE NEGÓCIO}

Manufaturar ou executar serviço com excelência tem sido o norte adiministrativo a orientar o comportamento da governança empresarial, quando o pensamento volta-se à função produção, a qual, exigivelmente, abrange escalabilidade produtiva e garantias de efetividade, qualidade e manutenibilidade.

A conquista dessa abrangência decorre da competência essencial, conforme teorizam LEI et al (2001:157-180). Competências estas que cada membro da organização deve dispor, segundo as habilidades componentes de suas capacitações, principalmente na formação do corpo gerencial das organizações, cujas responsabilidades de comprometimento envolvem competência de vislumbrar oportunidades e estratégias contextuais de planejar, de sociabilizar ambientes e envolvidos no negócio, de conhecer e dominar áreas de atuação e, principalmente, de perceber e entender as estruturas conceituais e físicas, administrativas e executivas, da empresa, conforme se pode perceber também em FLEURY e FLEURY (2001:18-33).

$\mathrm{Na}$ administração de empresas, existem alguns modelos clássicos, que permeiam tais estruturas organizacionais e permitem visões conceituais sobre processos operacionais e composições administrativas. Modelos aos quais a gestão de fábricas de software não pode deixar de observar, considerando-se sua característica partícipe em um mercado que, mesmo ainda novo é e torna-se cada vez mais expressivo. O conceito de novo aplicado aqui é baseado no fato da produção de software, dentro dos padrões estabelecidos por John Von Newman, ter seu princípio na década de 1940, segundo TRINDADE (1999:3).

Por tais razões, este capítulo procura estabelecer uma visão ampla e genérica da organização, no que diz respeito à seus processos, seus conceitos dinâmicos e sistêmicos e sua estruturabilidade, a fim de tornar perceptível a influência do conhecimento e a importância de sua preservação, tanto para a administração quanto para a produção.

Os modelos em evidência incorporam os conceitos de processo transformador e o de organização hierarquizada, os quais, unidos em um segundo momento, traduzem a organização de uma organização. 


\section{1 - PROCESSO TRANSFORMADOR:}

O modelo de processo, capaz de transformar insumos (estímulo) em produtos (resposta), demonstrado pela figura 3.01, origina-se das proposições da teoria sistêmica de BERTALANFFY (1975:52-81), através do desenvolvimento de seus estudos na área da biologia. Estudos que o levaram à moderna teoria do desenvolvimento, publicada em artigo de 1928, que evoluiu para teorias como a de sistemas biológicos abertos, publicada em 1950, e a geral de sistemas, publicada em 1955. Estas publicações, junto com outros tantos artigos do mesmo autor, culminaram na edição, em livro, da teoria geral dos sistemas, em 1968, conforme descreve o próprio autor. Tal modelo é replicado, de formas diversas, por vários autores, em representações de serviços, tanto na administração como na produção.

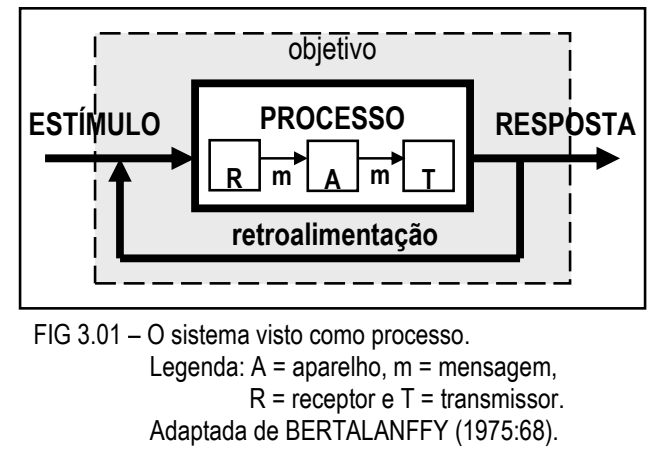

\section{2 - ORGANIZAÇÃO HIERARQUIZADA:}

A visão de organização categorizada em níveis tem sua consagrada essência estrutural proposta por ANTHONY (1965:17), e representada pela figura 3.02, a partir de uma derivação do conceito de hierarquia de Fayol. O autor estabeleceu limites claros

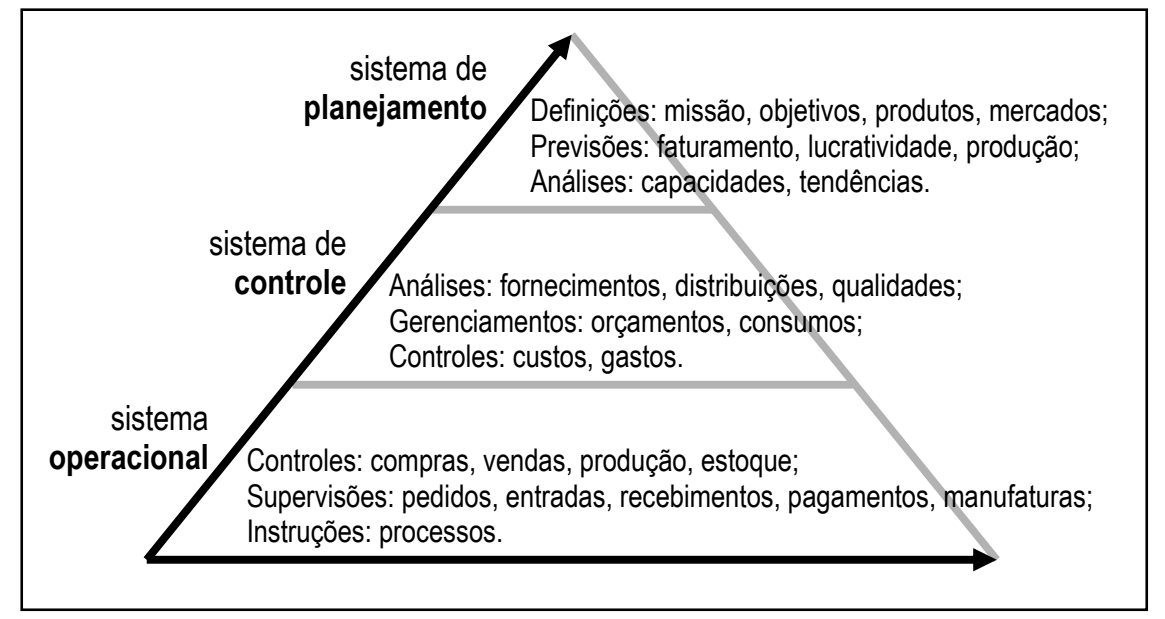

FIG 3.02 - A organização hierarquizada em suas funções decisórias. Adaptada de ANTHONY (1965:17). 
entre o planejamento estratégico, o controle administrativo do negócio e o controle operacional do processo. Tomou por base a concepção de que atividades de gestão de uma organização consistem de sistemas de planejamento e controle e que o planejamento estratégico necessita de um elemento sistêmico intermediando suas decisões com o gerenciamento executivo, numa visão funcional dos sistemas de informações e de administração.

\section{3 - COMPLEMENTARIDADE ADMINISTRATIVA:}

Ambos os modelos citados, são complementares na visão de diversos autores, na forma como podem expressar a organização de empresas, em visões administrativas, conforme representa a figura 3.03 :

- KWASNICKA (1989:21-25 e 1995:83-91), que a intitula "pirâmide organizacional" e a observa como uma combinação da proposta original de Anthony (figura 3.02) com o conceito weberiano de estrutura burocrática e, ainda, a estuda sob o ponto de vista dos processos decisórios em cada uma das camadas, atendendo a cada uma das áreas funcionais: produção, recursos humanos, finanças e marketing;

- HAMPTON (1990:13-25), que define, no que denomina "níveis de administração", atividades exclusivamente gerenciais, relativas à supervisão de processos (base da pirâmide), média gestão (região intermediária) e alta administração (alto da pirâmide);

- CHIAVENATO (1999:11-19), que analisa a empresa sob o ponto de vista dos problemas a serem resolvidos nos "níveis administrativos", no que tange a decisões institucionais (alto), intermediárias e operacionais (base);

- FELICIANO NETO e SHIMIZU (1996:41,49-54), que aplicam o conceito piramidal como forma de explicar tanto o processo que integra objetivos e políticas empresariais no planejamento estratégico da mesma, quanto no processo integrado de controle organizacional;

- POLLONI (2000:28), que considera a pirâmide organizacional a própria organização de sistemas de informações para demonstrar um modelo de sistemas de informações gerenciais (SIG), aplicado na administração, e como 
gerenciá-lo na organização;

- ROSINI e PALMISANO (2003:13-29), que também interpretam a divisão hierárquica como forma de organizar o sistema de informações, instrumento necessário à gestão, visto que os executivos necessitam de informações de cunho estratégico, tático e operacional para bem administrar o negócio;

- MINTZBERG e HUY (2003:64-72), que aplicam aos níveis hierárquicos seus conceitos de mudança sistêmica e denominam "o triângulo da mudança" a forma piramidal da organização, sobre a qual combinam, de forma equilibrada, três tipos de mudança: radical, sistemática e orgânica.

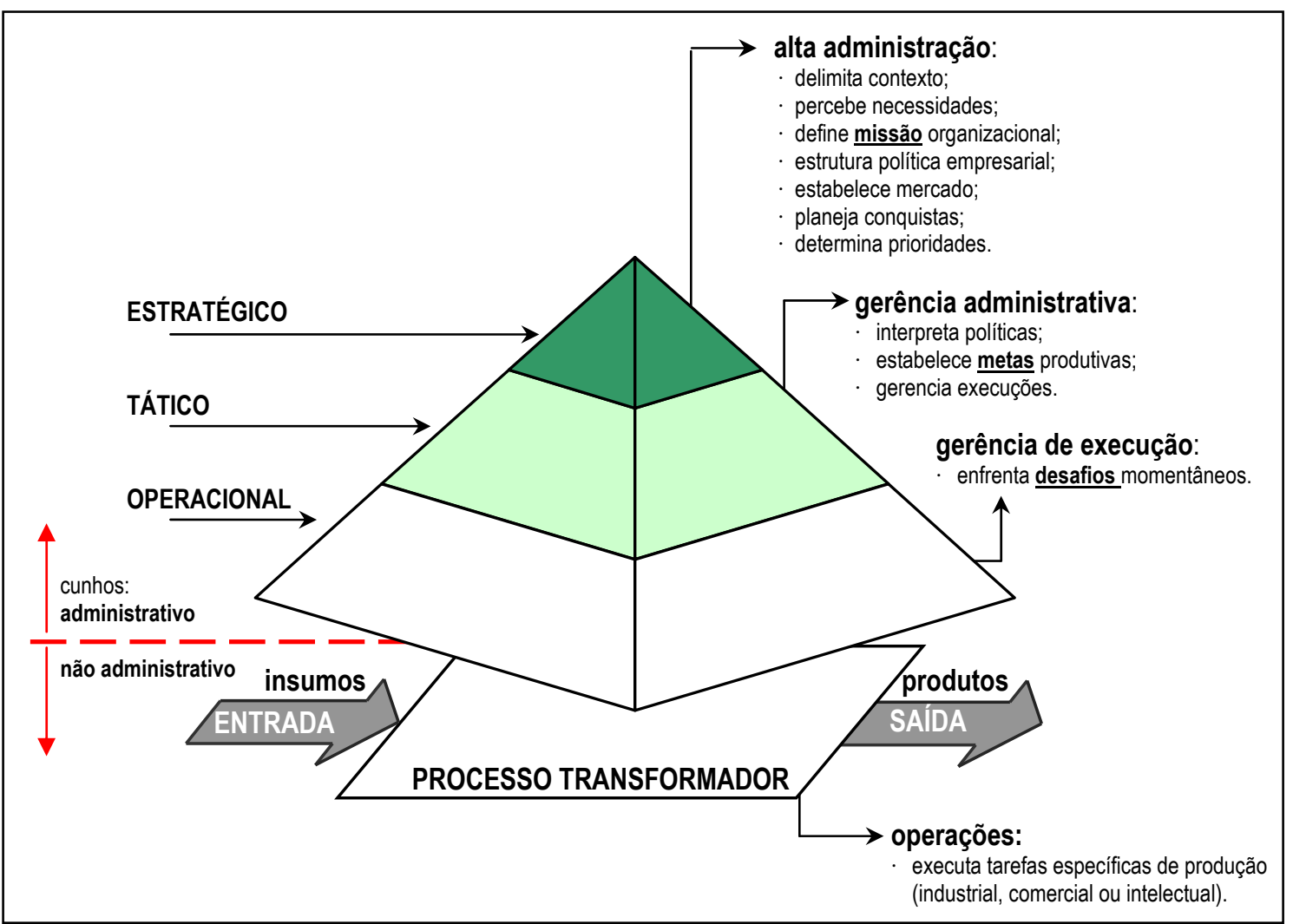

FIG 3.03 - A associação entre as visões administrativa (organização) e não administrativa (processo) do negócio. Composta das teorias de diversos autores.

O modelo que retrata a visão gerencial que se pretenda ter da empresa, retrata, também, seu sistema de informações (SI), ou seja, seu conjunto de processos dedicados a trabalhar toda espécie de informações sobre o negócio. SI tem, como missão, prover o administrador (tomador de decisões) de informações, em volume e precisão adequados, sobre cada um dos elementos componentes do sistema da empresa. É, portanto, necessário à atuação dos administradores na gestão da organização e precisa ser amoldável e aderente, na condição de instrumento de trabalho: 
- para a visão de processo, cabe um modelo representativo de processo e este pode ser imaginado como uma camada distinta do processo transformador operacional, conforme demonstra a figura 3.04;

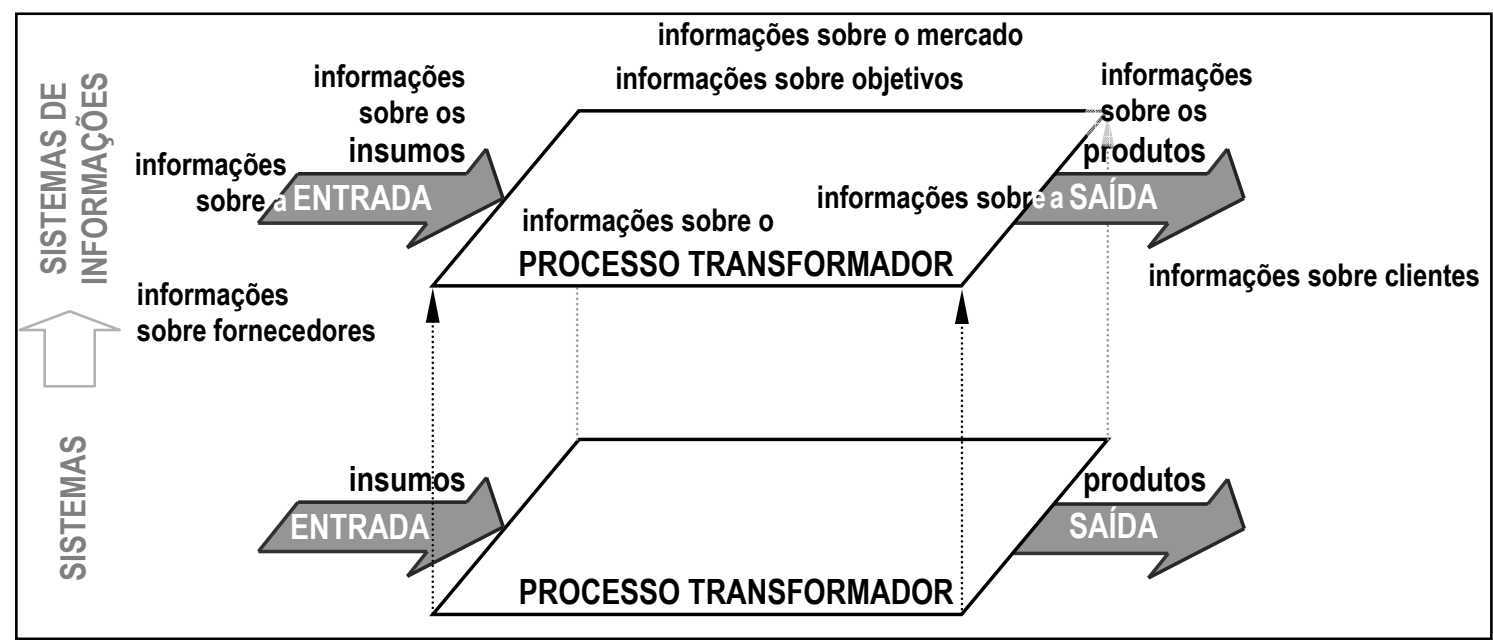

FIG 3.04 - O Sistema de Informações visto como um processo transformador.

- para a visão hierárquica, cabe um modelo representativo de composição hierárquica, conforme demonstra a figura 3.03, expresso na forma de uma pirâmide de três níveis. A diferença para o expresso pela figura aludida é que, ao SI, importa o tipo de informação estratégica que aos membros do nível estratégico possa interessar, ao invés de quem forma o corpo estratégico da organização. $\mathrm{O}$ mesmo pode-se afirmar dos outros níveis;

- se for uma visão sociotécnica a desejável, caberá um modelo sociotécnico de SI figura 3.05 - permitindo, aos gestores, uma visão das dimensões da organização.

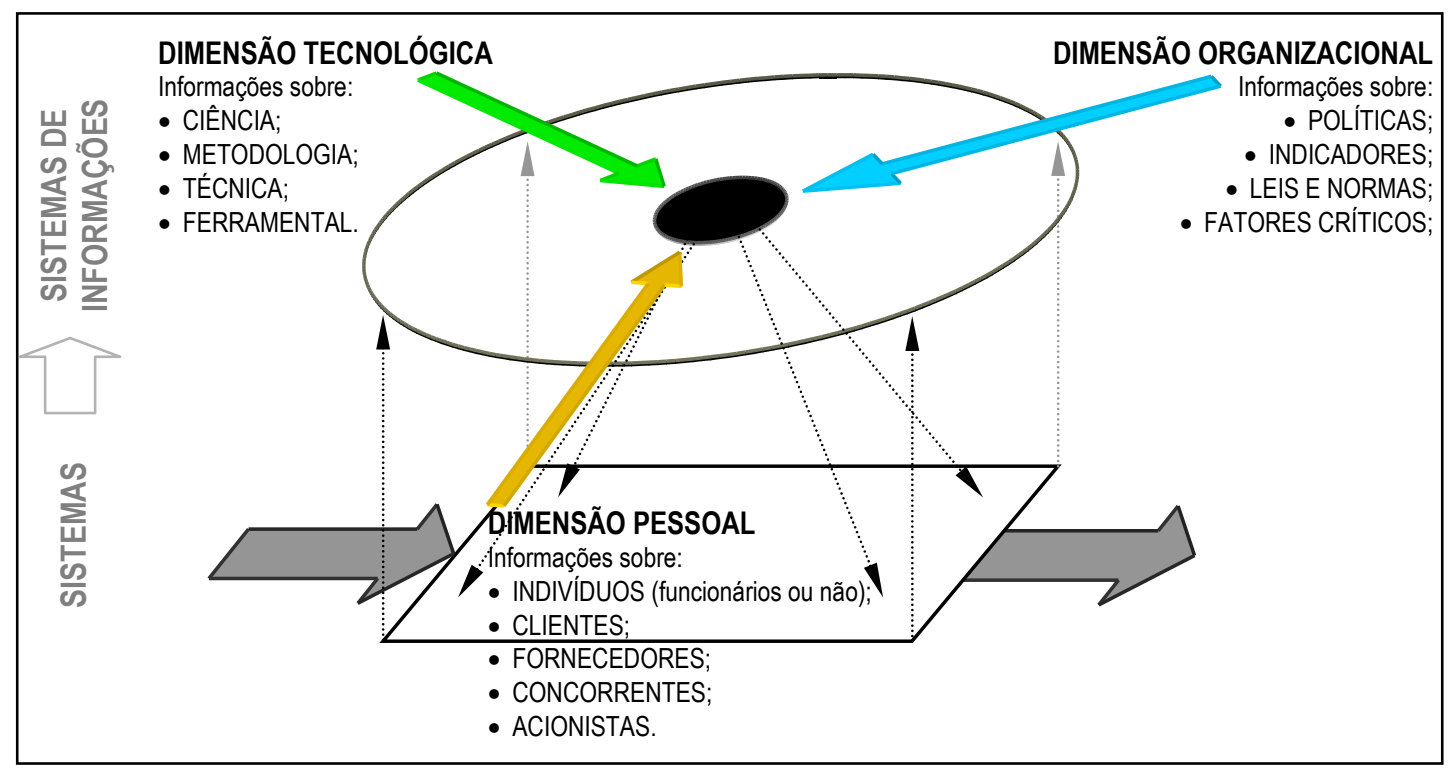

FIG 3.05 - 0 sistema de informações visto segundo as dimensões sociotécnicas, baseado em LAUDON e LAUDON (1999:6) e adaptada ao modelo de camadas. 
Nesta forma de visualização, a preocupação não é o processo ou a hierarquia administrativa do SI e, sim, a tipificação das informações a serem sistematizadas conforme suas "classes": a organizacional (tudo sobre política e gerenciablilidade da empresa), a tecnológica (tudo sobre aplicação da ciência envolvida com o negócio) e a pessoal (tudo sobre os envolvidos com a organização). A dimensão sociotécnica possui várias formas de retratação, dependentes da autoria. A utilizada na figura 3.05 é uma adaptação da visão de LAUDON e LAUDON (1999:4-11).

Interessante ressaltar que uma visão não surge, simplesmente, para substituir outras e, sim, para integrar-se a elas, no intuito de agregar capacidades de entender a organização de uma organização.

Neste trabalho, a visão mais comum a ser utilizada será a organizacional hierárquica (pirâmide). Em alguns momentos, usar-se-á, também, a visão de processo. Independente da visão, interessa a percepção de que o SI complementa o processo transformador operacional instituído na empresa, ou em cada um dos negócios dela, da mesma forma que a gestão administrativa complementa a execução operativa do trabalho. Oferecer mais de uma forma de visualizar o instrumento de trabalho denominado SI é oferecer mais de uma forma de enxergar a própria organização, para aqueles que precisam administrá-la.

Os sistemas de informações possuem, ainda, designações diversificadas, como categorizações, dependentes da forma e do grau de usabilidade nos domínios administrativos da organização ou do negócio, segundo POLLONI (2000:25-85) e ROSINI e PALMISANO (2003:13-29). É o que demonstra a figura 3.06, na qual

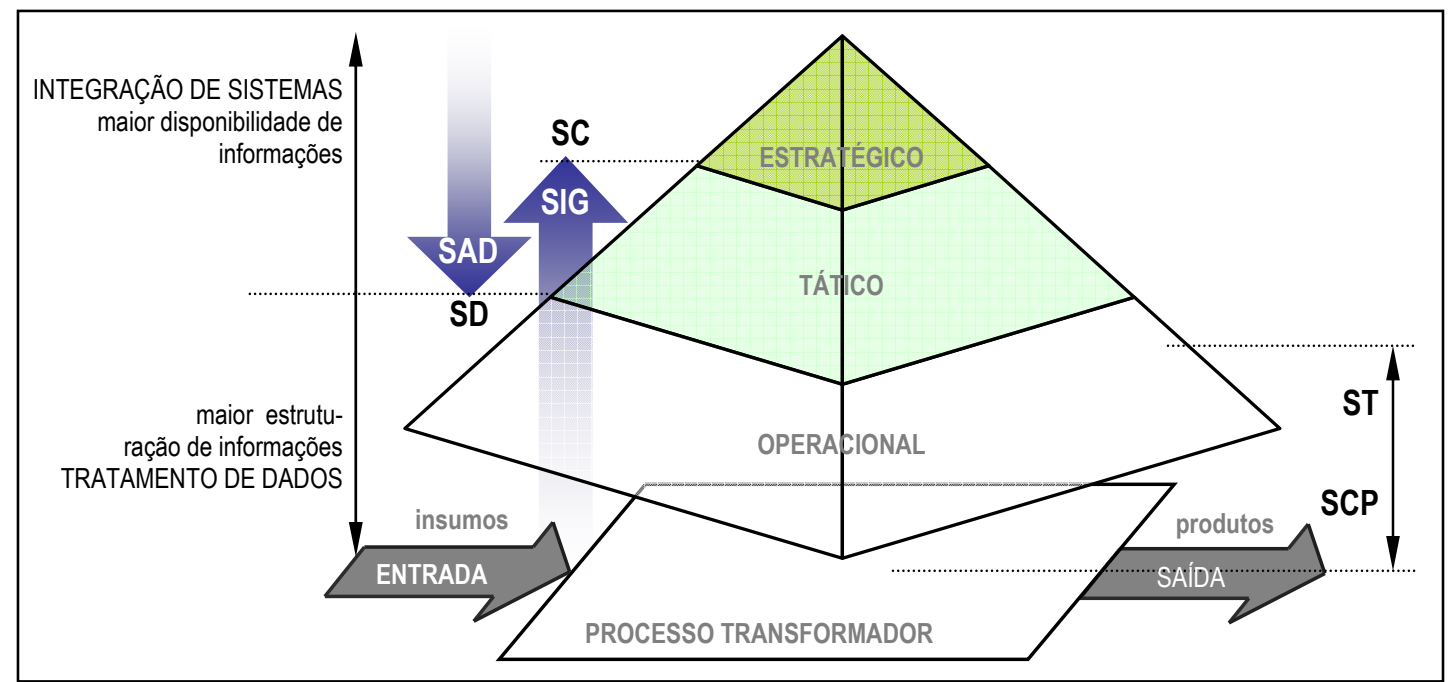

FIG 3.06 - O sistema de informações visto segundo sua categorização. 
percebe-se que:

- SC - Sistema Corporativo, representa a denominação dada ao SI, quando utilizado como recurso destinado aos executivos da organização, para acesso às bases de dados de forma livre e flexível, através de ferramentas poderosas de produção de relatórios, inclusive gráficos, que permitam visão abrangente do cenário empresarial;

- SIG - Sistema de Informações Gerenciais, representa o SI utilizado como recurso dedicado à geração de informações para o processo de gestão organizacional, de forma bem estruturada, com capacidade otimizada de síntese de situações de todos os segmentos empresariais;

- SAD - Sistema de Apoio à Decisão, representa o SI utilizado como recurso de instrumentalização no processo de tomada de decisões organizacionais, em níveis estratégicos e táticos, envolvendo projeções estatísticas e simulações a partir de dados devidamente compilados e planilhados;

- SD - Sistema Departamental, representa o SI utilizado como recurso gerencial executivo, básicos, para interpretação imediata de ocorrências e situações produtivas em todos os segmentos da empresa;

- ST - Sistema Transacional, representa o SI utilizado como são recurso operacional executivo, para registro e recuperação de ocorrências e tratamento imediato de processos fundamentais, relativos à dinâmica empresarial em todos os seus segmentos;

- SCP - Sistema de Computação Pessoal, representa o SI utilizado como recurso de tratamento individualizado de dados e informações, de aplicação imediata, nas atividades funcionais, permitindo execução e gerenciamento executivo de ações.

POLLONI (2000:25-85) preconiza, ainda, que os sistemas de informações devem evoluir para tornarem-se corporativos, gerenciais e apoiadores de decisões, à medida que amadureça o pensamento administrativo da organização, relativo ao uso das informações e ao emprego de tecnologias departamentais e transacionais adequadas. Já ROSINI e PALMISANO (2003:13-29) definem tais categorias como forma de posicionar as filosofias de gestão e as tecnologias da informação que os administradores devem conhecer e reconhecer, no contexto do negócio.

Oferecer mais de uma forma de visualizar o instrumento de trabalho denominado 
SI, tanto pela ótica de sua forma, quanto pela da categorização de sua aplicabilidade, é, então, oferecer mais de uma forma de visualizar aplicações de tecnologias da informação (TI) apropriadas a gerir, entre outras coisas, planejamentos estratégicos e relacionamentos com clientes e fornecedores. É através das TI que otimiza-se o uso de SI (alguns deles, só se viabilizam pela TI).

\section{4 - TECNOLOGIAS DA INFORMAÇÃO:}

Conjunto de recursos tecnológicos dedicados ao tratamento de informações, em atividades de captura, apropriação, interpretação, confecção, armazenamento, disponibilização, divulgação, comunicação e gestão de dados, puros ou tratados, conforme entendem LAUDON e LAUDON (1999:10-37), ROSINI e PALMISANO (2003:34-55) e POLLONI (2000:32).

LÉVY (1993:3-27) tem uma visão bem particularizada das TI: são as tecnologias da inteligência, em razão da evolução e da ampliação da capacidade de operação dos dados e das informações, com o avanço de equipamentos e formas. Segundo o autor, são instrumentos de potencialização do conhecimento.

LAURINDO (2002:19-23), com base em diversos autores, entre eles Keen ${ }^{7}$, entende TI como um termo abrangente, que envolve não só hardware e software, mas todo o conceito, em constante mudança, de telecomunicações, ferramentas e a influência de suas aplicações nos aspectos humanos, administrativos e organizacionais. É, enfim, o conjunto de técnicas que proporcionam competitividade pela aplicação intensa de computadores, redes de comunicação, elementos de automação produtiva e métodos de uso tático e estratégico de informações em prol da competitividade, provendo eficiência e eficácia nos organismos empresariais.

A abrangência é tal que o termo pode representar desde um aplicativo de computador ou um simples equipamento dedicado ao tratamento de informações, até um conceito tecnológico aplicável em nível estratégico; o que, sob a ótica de administradores, configura-se como uma filosofia de gestão, conforme explica GRABNER-KRAEUTER (2002:1-13), em trabalho sobre a gestão do relacionamento com clientes (CRM), no qual procura discutir meios de avaliar o que executivos de

\footnotetext{
${ }^{7}$ KEEN, Paul G.W.; Information Technology and the Management Theory: the fusion map; in: IBM System Journal - vol.32, nº 1; EUA: IBM, 1993
} 
negócio (CEO) consideram uma filosofia estratégica de trabalho e executivos de informações (CIO), um instrumento sistêmico focado no uso tático-estratégico de informações. Suas ponderações consideram, inclusive, a necessidade de alinhamento estratégico entre TI e negócios, para viabilizar a otimização do uso de tal tecnologia e tornar possível medir adequadamente seus resultados, em valor agregado, para a organização.

O exemplo utilizado por GRABNER-KRAEUTER (2002) pode ser estendido a outros: como os da própria gestão de relacionamentos com clientes, comentados por GREENBERG (2001:26-65) e BRETZKE (2002:5-15); como os da gestão da cadeia de suprimentos (SCM), também chamada gestão de relacionamentos com fornecedores, comentados por OAKS et al. (2004:128-136) e SLACK et al. (2002:316-319); como os do planejamento de recursos das empresas (ERP), comentados por BARBARÁ (2002:10-13) e HABERKORN (1999:145,181-185); e como os da gestão de relacionamento com a marca (BRM), comentados por NEBEL e BLATTBERG (2005:1-7) e SCHULTZ e HATCH (2004:96-104).

Agrupando todos estes conceitos filosóficos (categorizações pelas quais se pode reconhecer as aplicabilidades dos SI) e somadas as tecnologias da informação que lhes são próprias, compõe-se a inteligência de negócio (BI) da empresa, ou seja, um patrimônio intelectual e tecnológico que permite visão e domínio de negócio e agrega valor informacional aos planejamentos e às decisões estratégicas, táticas e operacionais, conforme discorre ERBUG (2005).

Este trabalho não pretende desenvolver com mais profundidade estes conceitos que tanto são visualizados como filosofias de trabalho, por CEOs, quanto como tecnologias da informação, por CIOs. Suas exposições associadas, ainda, ao conceito de gestão do conhecimento, têm o intuito de mostrar como se avolumou e o quão complexo tornou-se trabalhar o conjunto de dados, informações e conhecimentos relativos e necessários à manutenção de uma empresa no mercado, com excelência de produto e processo, primando pela eficiência, pela eficácia, pela efetividade e pela qualidade.

Trabalhar o conhecimento torna-se, diante de tal cenário, imprescindível para o corpo da organização, tanto administrativo quanto não administrativo, exigindo evolução de habilidades, acumulo de saberes e desenvolvimento de competências, tal qual definem LEI et al. (2001:157-180) sobre as competências essenciais. A definição 
destes autores é baseada em intuição e perspicácia na definição e na solução de problemas, que levam à aprendizagem de táticas e estratégias. Quando definem a anatomia da competência essencial, eles discorrem sobre a aprendizagem organizacional e a positividade de seus resultados, construindo as competências e experimentando-as e redefinindo, tanto quanto necessário e possível seja, o conjunto de regras metodológicas que conduzam à resolução de problemas e à pesquisa necessária para tal.

Mas, por que tornou-se tão complexo administrar? Por que os volumes de informações cresceram, e ainda crescem, tanto? Por que filosofias diferenciadas, aliadas a recursos complexos, são constantemente pensadas para compor o ambiente empresarial?

\section{5 - O DINAMISMO DA MUDANÇA:}

ROSINI e PALMISANO (2003:94-102), concordando com diversos outros autores, apoiam suas alternativas de resposta a estas questões na mudança. A mudança é um processo constante no contexto ambiental do mercado onde a empresa está inserida. A empresa necessita, também, mudar constantemente, para acompanhar os movimentos que este ambiente impõe e que têm demonstrado seguir o caminho do aumento da competitividade, do nível de informação de clientes, fornecedores e outros envolvidos com cada processo de negócio e da necessidade de qualidade, tanto no produto, como na produção e nos relacionamentos que a permeiam. Estes autores partem do princípio de que toda mudança deve representar uma evolução de conceitos, de postura e de produtividade, ou seja, cada passo do processo de mudança é um passo a favor do amadurecimento técnico, profissional e social da organização e de seus membros.

Considerando a importância de se perceber e entender as questões de mudança, MINTZBERG e HUY (2003:64-72) desenvolveram um estudo sobre seus tipos, suas amplitudes no organismo da empresa e suas qualificações, dependendo do que as originam e dos tipos de resultado que provocam. A mudança pode ser um fenômeno estratégico, tático ou operacional. Quando estratégica, é radical e representa atos de nível estratégicos e táticos que podem ser corretivos, em estados críticos, ou evolutivos, em momentos de grande oportunidade mercadológica. Quando tática, representa ações sistemáticas, dirigidas a processos encadeados, e são executadas internamente, em setores ou grupos de trabalho responsáveis por organizações e planejamentos do 
conjunto administrativo e executivo. Quando operacional, a mudança representa ações orgânicas, de adaptações a situações de cunho básico, no nível executivo ou gerencial direto dos processos, visando correções de procedimentos ou adequações de pouca monta. A figura 3.07 demonstra tais proposições.

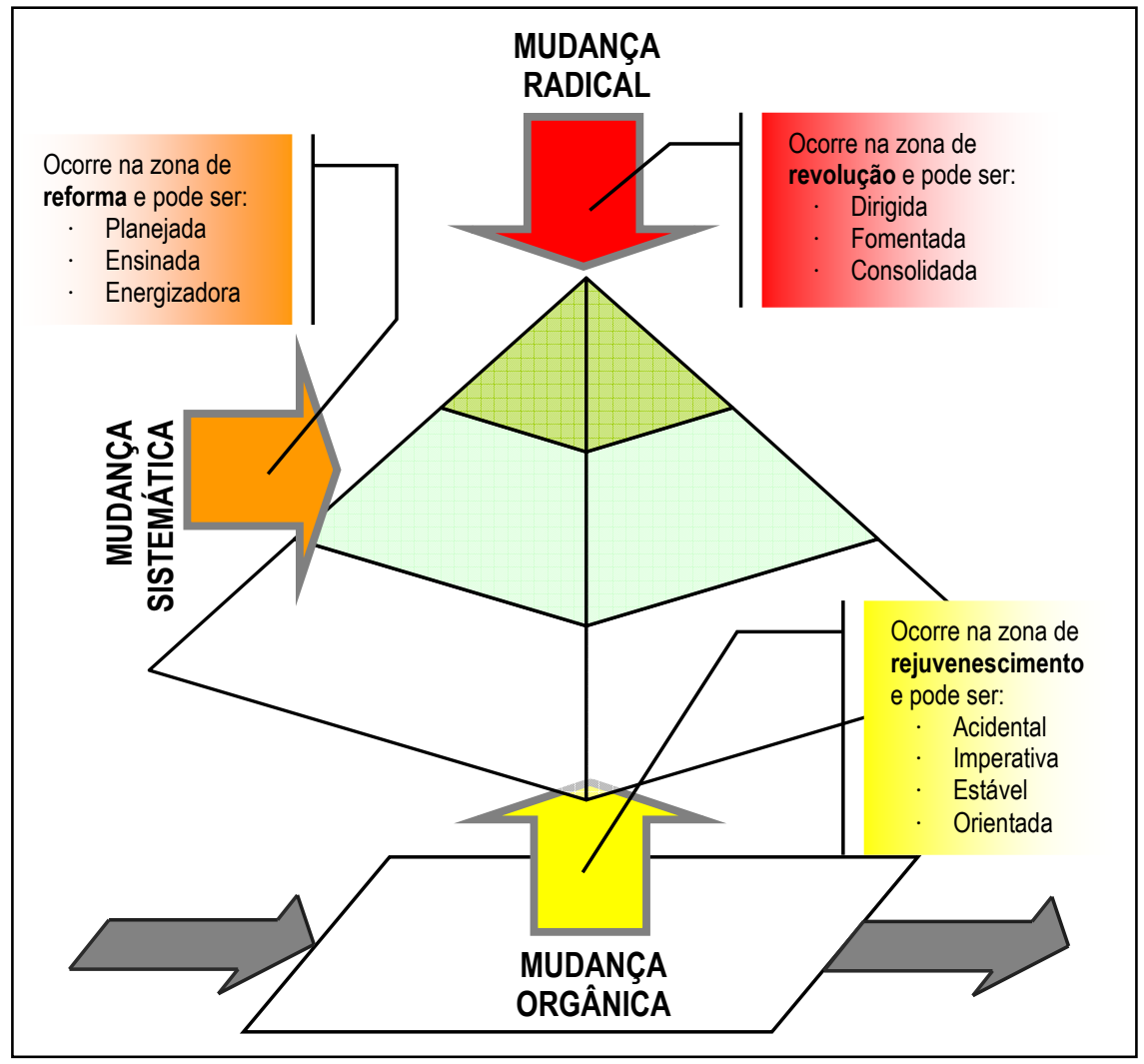

FIG 3.07 - Tipos de mudança organizacional, segundo suas origens e seus efeitos. Adaptada de MINTZBERG e HUY (2003:67).

A mudança radical é de atuação estratégica e revoluciona a organização, segundo as mudanças ambientais externas, ou ajusta-a ao contexto, pré-acontecimento, provocando estratégias relacionais e comerciais inovadoras, devendo ser:

- dirigida - só um fragmento da organização, um piloto, em momento determinado, será influenciado, pois o risco de revolucionar a empresa como um todo é impensável;

- fomentada - originada em experimentos e implantada pela força de liderança e com apoio político;

- consolidada - que conquiste consagração pela eficácia demonstrada.

A mudança sistemática é de atuação tática e reforma a organização segundo as necessárias adequações gerenciais às novas realidades do negócio, devendo ser:

- planejada - pensada de maneira orgânica para afetar planejamentos gerenciais e 
operacionais da melhor forma possível, ou sejam;

- ensinada - ocorre a partir de treinamentos sistemáticos e constantes em programas de mudança;

- energizadora - que promove a condução direta da mudança orgânica, para que seja motivadora e leve o corpo administrativo e executor ao comprometimento com a evolução.

A mudança orgânica é de atuação operacional e rejuvenesce a organização pela capacitação ao ajuste segundo os desafios cotidianos da produção, podendo ser:

- acidental - as lições do dia a dia e as experiências inventariadas induzem a modificações procedimentais de um ou alguns poucos processos ou modelos de uso básico no trabalho;

- imperativa - originada na média gerência executiva, altera formas de trabalho e tecnologias, sem afetar o sistema;

- estável - que baseia-se em resultados já conferidos e absorvidos de mudanças em processos cotidianos, as quais podem ter sido geradas a partir de experiências anteriores ou a partir de situações inesperadas;

- orientada - originada em exemplos pessoais e culturais discutidos e desenvolvidos por iniciativas dos grupos de trabalho ou da organização.

Enfim, as mudanças, conforme se pode perceber pelas exposições apresentadas, desencadeiam a agregação de sistemas e tecnologias de informações, diferenciados e complexos, associados a filosofias administrativas novas, que exigem o saber sobre a informação e sua aplicabilidade no cenário da organização. MORON (1998:13-19), ao analisar o risco na tomada de decisão, na administração, comenta que "certeza" é uma razão direta do domínio sobre possibilidades bem definidas, resultante do quanto se conhece sobre determinado assunto, enquanto "risco" é uma razão direta da diversificação de possibilidades, resultante da escassez de saber, ou seja, o aumento do conhecimento e o aumento do domínio que se tem dele, diminui riscos nas tomadas de decisão gerencial. Conhecer e gerenciar estes conhecimentos, sob as mais diversas abordagens, na plenitude de seus volumes, torna-se uma necessidade para as organizações e, nestas, incluem-se as fábricas de software, e é sobre esses pontos: o conhecimento e a fábrica de software, que o trabalho terá focado $\mathrm{o}$ seu desenvolvimento. 
ROSINI e PALMISANO (2003:94-102), a respeito da mudança, afirmam-na, ainda, como uma espécie de vocação compulsória, ou seja, uma realidade da qual a organização não tem como escapar, pois não é originada nela e, sim, no contexto do ambiente que a contém. A empresa precisa desenvolver vocação para a mudança, inclusive para provocá-la internamente e não deixar que o meio (dinâmico) provoque pressões que esmaguem a estrutura organizacional. A mudança é, portanto, uma função natural decorrente da necessidade de ampliação de conquistas em produtividade e qualidade, segundo estes autores, os quais afirmam, ainda, que as principais evoluções na história das organizações, basearam-se em questões culturais - tal como a ênfase à coletividade e ao profissionalismo tomando lugar antes dominado pelo trabalho individualizado e artesanal - e na organização do trabalho - paradigmas da produção empírica dando lugar aos da profissionalizada, edificados sobre fundamentos científicos, e, entre estes, os da produção linear cedendo espaço às células de autogerenciamento, em diferentes arranjos que mudaram a visão que a organização deve fazer do trabalhador, elevando-o da condição de mero apêndice do sistema à de colaboradores de máxima importância.

\section{6 - A ORGANIZAÇÃO DO TRABALHO:}

O processo contínuo de mudança traz a necessidade do progresso nas formas de visualizar sistemas e tecnologias e, com estes, redefinir os arranjos relativos à capacidade de realizar trabalho, no ambiente de trabalho, do que decorrem necessidades de percepção e domínio do conhecimento: o que representa, para a organização, o saber que ela "possui" e o que possuem seus integrantes.

Pode-se afirmar, com base no que postulam FLEURY e VARGAS (1994:17-37), que o conhecimento - e, consequentemente, a necessidade de sua gestão - passou a ter o foco organizacional que tem hoje com a proposição da administração científica, por Taylor, em 1911, visto que os princípios que a regem denotam a necessidade (hoje considerada básica) de organizar, padronizar e disseminar os saberes sobre métodos, técnicas e ferramentas apropriadas à otimização dos processos: o primeiro princípio diz respeito à necessária disciplina da interferência do conhecimento operário na execução dos afazeres, disciplina esta a ser estabelecida pela gerência; o segundo, trata as questões de identificação, seleção e preparação do trabalhador adequado a cada função, 
uma vez que o trabalho já tenha sido dominado (estudado, analisado, simplificado e particionado) pela gerência; o terceiro, enfim, considera a importância do planejamento do trabalho e da especialização de responsabilidades gestoras, o que levou à mudança do paradigma do controle ao da gerência e, deste, ao da administração estratégica da produção e, por evolução natural e posterior, à gestão do negócio de forma mais abrangente.

Esta trajetória evolutiva, dita natural, ocorreu pela conjugação das contribuições de Taylor e Fayol, segundo comenta ARBAGE (2000), para quem o fayolismo e sua preocupação com a definição das funções administrativas e dos processos organizacionais, na previsão, na estruturação, no comando, na coordenação e no controle das ações de trabalho, acabou por proporcionar um novo paradigma na forma de entender a função administração, complementar ao postulado por Taylor, por representar uma perspectiva diferente do mesmo rigor científico que veste o taylorismo.

A abrangência desta evolução produziu visões holísticas sobre organizações e negócios, agregando formas diferenciadas de entender o sistema de informações e abordagens cada vez mais especializadas de filosofias administrativas e aplicabilidades dos conceitos tecnológicos correspondentes.

FLEURY e VARGAS (1994:23), ao explanarem:

"Estes princípios [comentados há 3 parágrafos] mostram como serviriam de base para a organização do trabalho fabril. O taylorismo não deve ser visto como um simples estudo de tempos e movimentos, isto porque é orientador de muitas outras técnicas de gestão da produção. Além disso, não se limita somente ao campo de atuação do engenheiro, mas, também, incursiona nas demais profissões que cuidam da atividade fabril como, por exemplo, o selecionador e treinador de pessoal, o ergônomo, o médico do trabalho, etc.",

apregoam conceitos concordantes entre os autores clássicos citados e são corroborados por ARBAGE (2000), sobre o paralelismo de pensamentos entre os engenheiros Taylor e Fayol, ambos empenhados em discutir como deveriam ser administradas as empresas.

No que diz respeito à presença da tecnologia na produção e sua influência na organização do trabalho, FLEURY (1994:84-106) propõe um modelo de contingência, através do qual visualizam-se duas dimensões principais, conforme demonstra a figura 
3.08: uma do dinamismo ambiental do trabalho humano e outra, do aporte tecnológico.

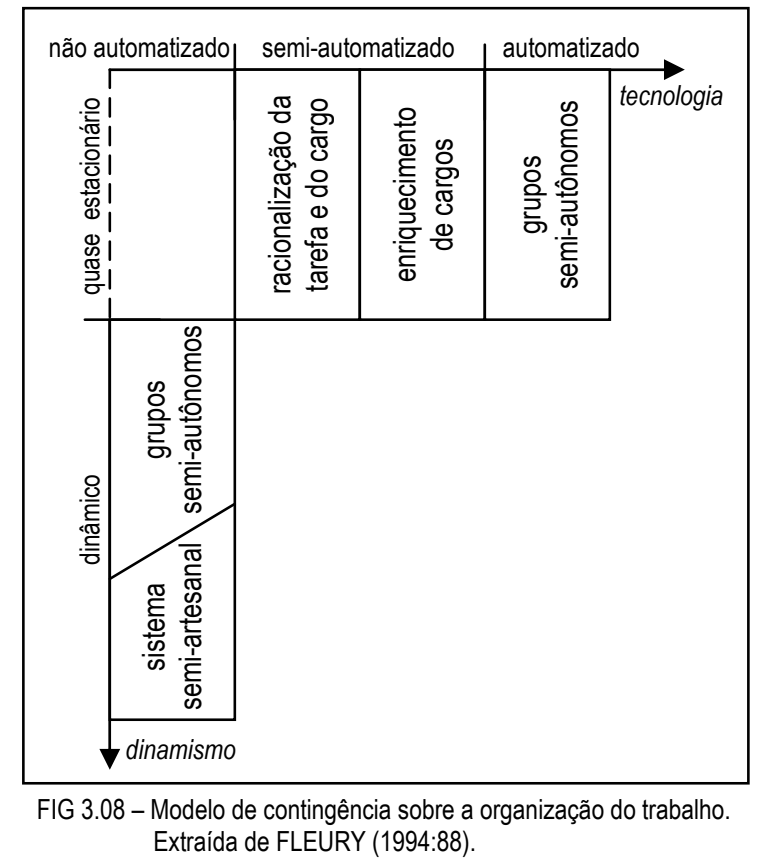

Os quadrantes de composição mostram que quanto maior o aporte tecnológico, ou seja, quanto maior o índice de automação do processo produtivo, maiores e melhores tornam-se os mecanismos de controle, modificando o papel desempenhado pelos trabalhadores na relação homem-máquina-produto: a racionalização da tarefa do cargo é conseqüência direta da divisão de trabalho, um dos parâmetros alicerçadores da administração científica e base para a organização pretendida pelos três princípios desta; o enriquecimento de cargos é conseqüência direta da racionalização da tarefa, somando ao seu aspecto mecanicista a motivação para o trabalho pela ampliação do mesmo, de forma a avolumar oportunidades de sua execução com a satisfação decorrente da conquista e; os grupos semi-autônomos são a conseqüência natural da união do tecnicismo proeminente da racionalização da tarefa com o aspecto social do enriquecimento de cargos, produzindo uma concepção sociotécnica para a análise das organizações, buscando a melhor conjugação entre a visão mecanicista e a não destituição social do indivíduo, para otimizar o processo produtivo. Por outro lado, a figura sugere que a não automação exige características para o desenvolvimento de tarefas com traços artesanais em qualquer que seja o papel desempenhado pelos trabalhadores.

A distribuição dos quadrantes é uma função da evolução provocada por uma combinação de progressos, do dinamismo do trabalho e da tecnologia de produção que, 
posteriormente, otimizada pela introdução da TI, produziu evolução mais abrangente, conforme demonstrou o item anterior desse capítulo e com o que concordam autores como FLEURY e FLEURY (2001) LAURINDO (2002) e SLACK et al. (2002).

FLEURY e FLEURY (2001:58-64), olhando o assunto sob a ótica da gestão de pessoas, para a formação de competências, apresentam uma cronologia que parte da introdução do taylorismo-fordismo (início do século XX) e chega à abordagem sociotécnica (década de 1960), sobre a qual a organização da produção observa a combinação de conhecimentos e habilidades técnicas e sociais como a semente da competência desejada e, nesse sentido, estendem-se até a análise do modelo japonês (década de 1980), mostrando particularidades desta transformação que, baseada nos verbos mobilizar, participar, aprender e comprometer, produzem uma visão estratégica da empresa muito mais presente (abrangente) do que no modelo sociotécnico. Para estes autores, a gestão estratégica dos recursos humanos permite à organização planejar e dominar a formação de competências.

LAURINDO (2002:32-38) analisa a relação da TI com a evolução da estratégia de gestão da empresa pelo aspecto da promoção de eficiência e eficácia (principalmente esta última) nas competências relativas, funcional e operacional. $\mathrm{O}$ autor diferencia conceitos de função (aspecto mais geral, com fixação de padrões, arquitetura e diretrizes) e operação (aspecto mais restrito à implementação e utilização).

SLACK et al. (2002:294-297) vão além destas análises de níveis de automação e de dinamismo (figura anterior), para apresentar, também sobre o eixo cartesiano, conceitos de alargamento e enriquecimento do trabalho. Para estes autores, o enriquecimento do trabalho é uma evolução sobre o enriquecimento de cargos, pois acrescenta ao seu caráter de racionalização em prol da minimização de pressões, maior domínio e crescente autonomia para a tomada de decisão, mesmo que isso acarrete maior responsabilidade. $\mathrm{O}$ alargamento do trabalho traduz aumento de tarefas de mesmo tipo, pelo aumento do volume de serviços relativos aos afazeres englobados. O fato é que os autores concordam com dois aspectos percebidos nas disposições anteriores, tanto sobre a organização do trabalho, quanto sobre o desenvolvimento de filosofias e tecnologias altamente especialistas para potencializar a gestão dos negócios:

O primeiro deles é o que diz respeito à influência das tecnologias, inclusa a TI, na ampliação da capacidade de domínio sobre o negócio, conforme retratam as 
disposições, já comentadas por outros autores, da organização do trabalho. SLACK et al. (2002:277-303) também são partícipes do conceito evolucionário, iniciado antes de 1900, com a divisão do trabalho, que vem definindo rearranjos na forma como realizar trabalho e estruturar negócios. A figura 3.09 expressa a cronologia das abordagens de tal evolução, a qual difere um pouco do postulado por Fleury, Fleury e Vargas, sem necessariamente divergir dicotomicamente destes. A evolução do projeto de trabalho mostra a administração científica (estudo sobre meios de desenvolver e aplicar métodos mais fáceis e mais eficazes de reduzir custos e a aplicação de técnicas apropriadas para estabelecer e medir o tempo ótimo de desempenho de tarefas) como resultado da divisão de grupos e, desta, desenvolveram-se a ergonomia (estudo dos aspectos fisiológicos do projeto do trabalho que confronta os aspectos físicos do local de trabalho e os aspectos ambientais deste, como iluminação, temperatura e barulho, entre outros), a abordagem comportamental (estudo sobre como proporcionar o aumento da qualidade de vida no trabalho e a conquista de altos níveis de motivação, como instrumentos de melhoria de desempenhos relativos a qualidade e volume, levando em conta as necessidades de autoestima e desenvolvimento pessoal dos envolvidos. Dentro deste contexto é que se trabalha os conceitos de alargamento e enriquecimento do trabalho), o empowerment (estudo sobre como estender a característica de autonomia do trabalho, dando autoridade para mudanças de forma e conteúdo, no trabalho, e criando diferenciados níveis de envolvimento, importantes ao desenvolvimento) e os conceitos de trabalho em equipe (estudo sobre equipes de trabalho autogeridas ou semi-autônomas, associado ao conceito de empowerment, nas quais funcionários com habilidades justapostas controlam alocações de tarefas, medições de qualidade e melhorias e contratações) e flexível (estudo da mudança da natureza dos empregos, visando novas tecnologias, entendimento das cada vez mais diferenciadas dinâmicas do mercado e compreensão de como deve ser equilibrada a vida social-familiar com a profissional, buscando formas alternativas tanto de organização quanto de atitudes que permitam e encorajem flexibilidade na prática do trabalho. Sob a perspectiva das estratégias de administração, as flexibilidades de habilidades, de tempo e de localização são consideradas aspectos significativos do trabalho, sob a ótica dos autores). Com estas prerrogativas, paradigmas têm sido mudados no decorrer do tempo, fazendo com que os trabalhadores deixassem de ser vistos como custo, para tornarem-se recurso e, daí, aliados, pois a ênfase, que no início, na divisão do trabalho, era exclusivamente no controle gerencial, muda o foco 
para o comprometimento e engajamento de pessoal.

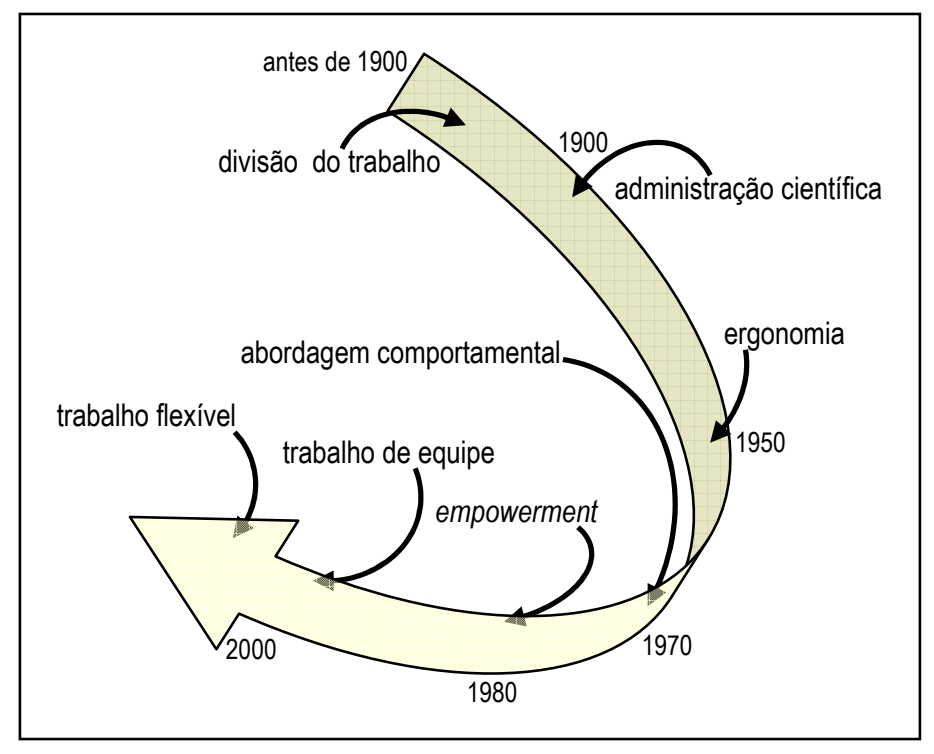

FIG 3.09 - Cronologia das abordagens da organização do trabalho. Adaptada de SLACK et al. (2002:278).

O segundo aspecto é o que diz respeito à proporção direta com que cresce a necessidade de conhecimento aplicado, com o crescimento da especialização dos sistemas e tecnologias da informação referentes aos negócios ou à filosofia gestora de uma organização. As promoções de cientificismo, metodologia, sistematização e, principalmente, de integração da organização com comunidades, interna e externa, que levam às preocupações com a aprendizagem sobre os conhecimentos necessários, sobre os modelos sistêmicos de trabalho e sobre as tecnologias aplicadas, baseiam-se em questões de organização do trabalho, ou seja, a necessidade de repensar e redefinir, com constância, as estruturas de trabalhabilidade no ambiente produtivo, devido às evoluções naturais que a ciência promove no campo do conhecimento humano e mercadológico e no campo de suas relações sociais, profissionais e comerciais.

SANT'ANNA (2004:8-10) concorda com as idéias de repensar e redefinir, quando afirma que o conceito de competência, não sendo novo, tem sido reconceituado e revalorizado, em face às mudanças que o mercado tem promovido no ambiente ao qual as organizações estão contidas. Mudanças que exigem que o pensar nos conhecimentos e nos saberes relativos, estes associados às capacidades de fazer, evoluam para uma modernidade organizacional, que reposiciona a questão do conhecimento e sua necessária gestão pela evolução da organização do trabalho. Sua discussão sobre o sentido da modernidade abrange ocorrências de inovações circunstanciais promovidas, por algum tempo, apenas por tecnologias, domínios da 
razão científica e a idéia de progresso e que, mais recentemente, busca transcender os limites da racionalidade instrumental para englobar a ênfase no elemento humano, com preocupações relativas a crescimento, liberdade e criatividade, configurando tais limites como uma redução que leva a crises de participação e competitividade, pelo não redirecionamento do homem (e uma organização é formada por pessoas) ao centro da sociedade, combinando racionalização e subjetivação, na dimensão tecnológica, viabilizando a subjetivação por meio de um movimento sociabilizante, na dimensão social, permitindo as expressões doutrinária e ideológica do indivíduo, na dimensão política, e promovendo valores de liberdade e eficácia, na dimensão cultural. As questões de satisfação no trabalho, aliadas às de produtividade, associam-se à capacidade da organização promover crescimento e evolução profissional.

O autor, através de uma pesquisa que buscou identificar competências requeridas ao trabalho junto a trabalhadores, mostra que a evolução da organização do trabalho acaba por estabelecer níveis diferenciados de modernidade às dimensões estudadas e de requisição de competências junto ao indivíduo, sendo que qualidades pessoais e relacionais acabam apresentando peso maior que habilidades manuais e conhecimentos técnicos, ou seja, capacidades de aplicação de conhecimentos tácitos e domínio situacional mostram-se elementos de diferenciação mais incisivos que os conhecimentos explícitos técnicos (em momento algum o autor prestigia alguma destas características em detrimento de outras). Consequentemente, a modernidade organizacional apresentou maior grau de efetividade para a dimensão cultural, que foi seguida da social, deixando, por último, a política. Considerando que os estudos foram relativizados ao organismo empresarial, concluiu o autor que as dimensões organizacionais devam ser alinhadas na seguinte seqüência: cultural, administrativa, gestora técnica e política. A pesquisa mostrou, ainda, que este cenário de modernização deve-se ao favorecimento de ambientes internos de trabalho pelo estímulo a processos de aprendizagem contínua e suas decorrências, tais como entendimentos, por parte do trabalhador: do papel da organização no mercado e de seu papel na organização; de seu valor como partícipe; de sua capacidade de conquistar autonomia de produção e decisão e; de sua possibilidade de envolvimento por conta da ampliação de seu domínio de conhecimento.

Independente de classificações posicionadoras dos elementos, que mostram, por exemplo, que a dimensão com menor grau de modernidade desenvolvida pelas 
organizações é a política, o que pode sugerir a prevalescência de modelos autoritários, centralizadores e conservadores, conforme mostra SANT'ANNA (2004:18-19), é importante que se possa observar o papel da organização do trabalho no estímulo e na evolução dos processos de educação e aculturamento, praticados pelas organizações, bem como de toda a gestão do conhecimento gerado, acumulado e solidificado nos processos gestor e transformador das empresas.

\section{7 - EM SUMA...}

Este capítulo dedicou-se a definir a organização sob a ótica do sistema de informações, definidor que é da usabilidade das informações pertinentes ao negócio e sobre o qual aplicam-se as tecnologias da informação. Seu intuito é permitir visualização da estrutura e da dinâmica organizacional, sobre as quais se exige conhecimento necessário à produção e sua administração.

O modelo de negócios aqui sugerido procurou abranger possibilidades diversas de aplicação do conhecimento, inclusive sua gestão, necessário ao entendimento tanto da composição quanto do dinamismo que envolve uma empresa em sua interagência com o ambiente que a envolve. Dinamismo este provocado por mudanças que, constantes, exigem o exercício contínuo da administração e da (re)organização do trabalho. Tanto a idéia da mudança quanto a da organização compuseram os conceitos apresentados por este capítulo.

Esta visão amplificada e genérica da organização como processo, de seu SI e da TI aplicada, é decorrente da necessidade de vislumbrar onde e como o conhecimento se faz presente na empresa, bem como a influência de sua gestão.

O próximo capítulo, seguindo esta mesma linha, discorre sobre o tipo específico de organização sobre o qual esta pesquisa se desenvolve. 


\section{FÁBRICA DE SOFTWARE}

O esforço pelo desenvolvimento de produtos de software com escalabilidade e garantias de qualidade é uma preocupação que acompanha administradores, arquitetos e desenvolvedores, desde o início da comercialização dos computadores. Preocupação esta condizente com os preceitos administrativos considerados, sobre as questões de produtividade, por diversos autores; entre eles, os citados no capitulo anterior.

Pensar uma estrutura profissionalizada de produção de software, assim como se faz no segmento do hardware, com aplicação adequada de conceitos de engenharia, suplantando índices e problemas do trabalho amadorístico e, muitas vezes, informal, é realidade desde a década de 1950. Segundo CUSUMANO (1989:161), o resultado disso foi o forjamento, no Japão, do termo fábrica de software, o qual foi utilizado, em publicação, pela primeira vez, em 1960.

Este capítulo tem por finalidade, definir este tipo específico de organização produtora, bem como focar um exemplo específico, para solidificar conceitos sobre o modelo organizacional sobre o qual desenvolve-se a pesquisa.

A distinção feita pelos japoneses já levava em conta características que, hoje, ainda são desapercebidas por várias empresas que associam o termo "fábrica" ao mero desenvolvimento de software, sem preocuparem-se com padronizações que vão além do algoritmo exigido pela linguagem de programação ou com os aspectos associados a produção em massa e em larga escala, tais como: padronizações de tarefas e de controles; divisão do trabalho; mecanização e automatização. O autor supra citado afirma não se poder considerar uma fábrica de software, empresas que não se preocupem com as boas práticas da engenharia de software, aplicadas sistematicamente.

Uma fábrica de software deve ser um ambiente adequado à construção de programas, defende BEMER (1969:1626-1627), no qual se fazem necessários o processo que leva à manufatura e aos testes e o ferramental apropriado que garanta medidas de produtividade e qualidade, registros financeiros e estimativas gerenciais, que permitam gestão de projetos ativos e previsibilidade de projetos futuros.

Na opinião de CANTONE (1992:27-29,124-129), uma fábrica de software deve 
ter flexibilidade para produzir produtos diversificados, implementando, a cada novo projeto, todos os conceitos envolvidos com a engenharia de software - metodologia, ferramental, ambientação e direcionamento para a construção de fábricas de software avançadas - e sendo capaz de estudar, projetar, implementar, evoluir e melhorar seus sistemas. $\mathrm{O}$ autor propõe, ainda, um conceito evolucionário que deve ser observado na composição das avançadas fábricas de software (ASF - nomenclatura dele próprio), para garantir agregação de valor produtivo e qualitativo, representado pela figura 4.01. Tal garantia é baseada no fato das ASF realizarem suas produções associando e integrando a capacidade de criar e aplicar modelos (engenharia descritiva) à capacidade de executar com qualidade (engenharia aplicada).

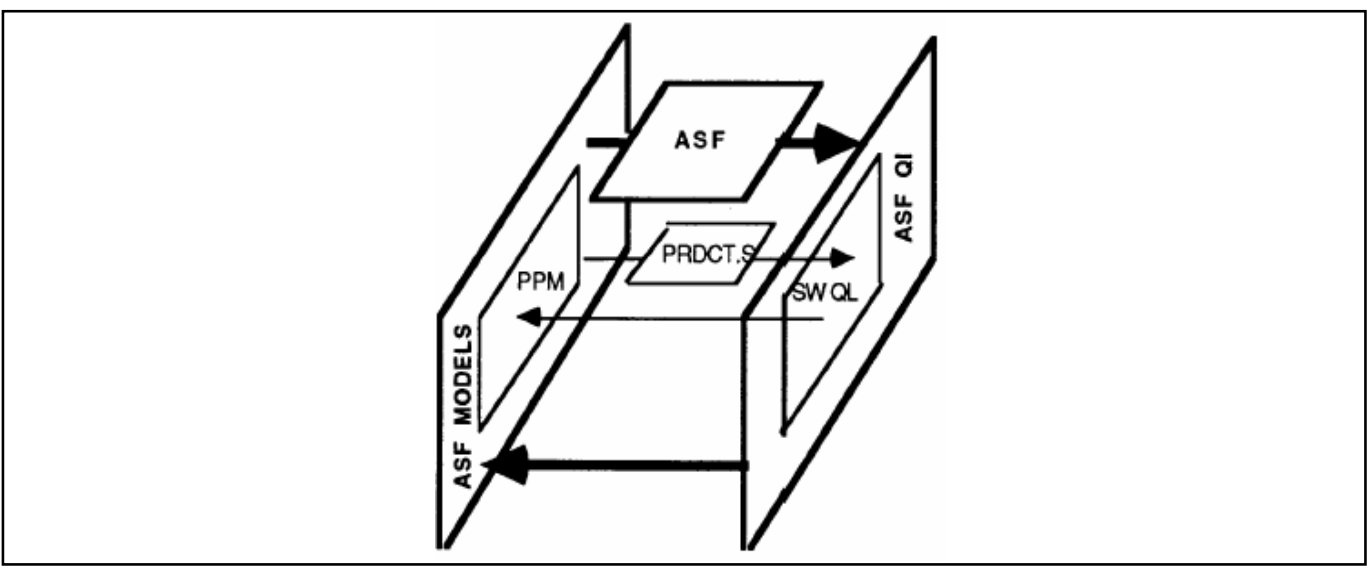

FIG 4.01 - Processo evolucionário para fábricas de software.

Legenda: ASF = fábrica de software avançada (advanced software factory); PPM = modelos de produtos e de processos (product and process models); PRDCT.S = produtos (projetos); $\mathrm{QI}=$ melhoria da qualidade (quality improvement); SW QL = qualidade de software (software quality). Extraída de CANTONE (1992:125).

Estes conceitos, de Bemer, Cantoni e Cusumano, são corroborados com os de LUCHETTI e PESSÔA (2001:5) no que diz respeito à necessidade de planejamentos, gestões e garantias de qualidade, na produção de software, tanto que apontam para instrumentos de manutenção da produtividade total (MPT) e de avaliação, dentro do modelo de maturidade e capacitação técnica conhecido pela sigla CMM.

Para os propósitos deste trabalho, a visão de organização e gerenciabilidade da fábrica de software será o foco, pois mantém relação direta com as aplicabilidades da gestão de conhecimentos neste tipo de empresa.

Um modelo de fábrica de software baseado em disposições de qualidade, e fortemente focado nelas, proposto por LI et al. (2001:2-12), demonstrado pela figura 4.02, propõe a agregação de ISO (9000) e CMM à organização do processo e analisa, 
em caráter de associação, os elementos estáticos e dinâmicos de um sistema de produção de software, observando as forças que definem participações, controles, suportes e gestões dos processos. As determinações de tais elementos são embasadas na plataforma de suporte à gestão, que pode não ser única, mas deve ter perenidade significativa no ciclo de vida do negócio em questão.

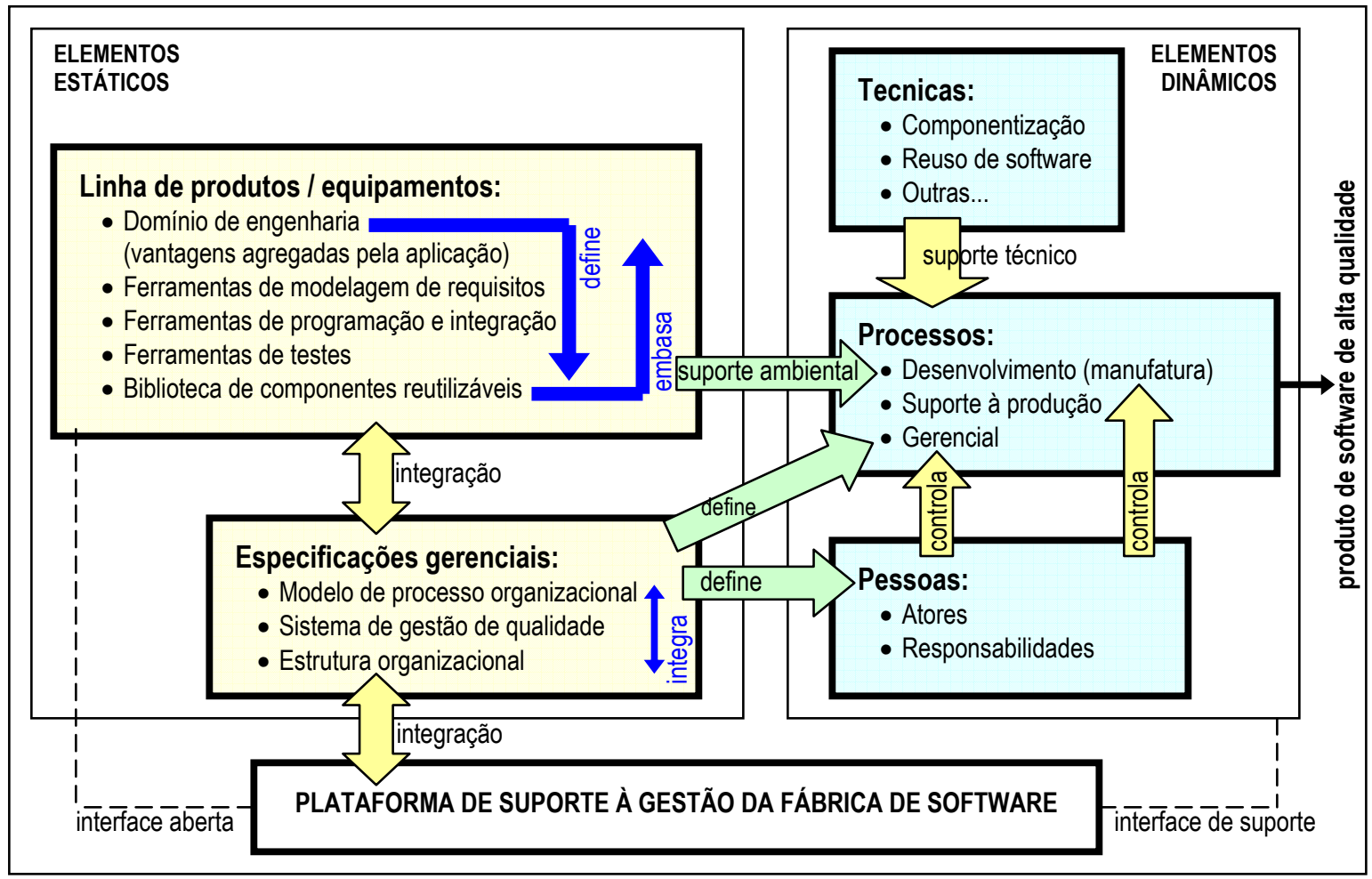

FIG 4.02 - Os elementos dinâmicos e estáticos da gestão de uma fábrica de software.

Adaptada de LI et al. (2001:4).

Os elementos estáticos representam as definições de maior perenidade na organização de um negócio, especificadas segundo missão e estratégia do mesmo. No caso de uma fábrica de software, deve-se pensar em:

- Linha de produtos e/ou equipamentos envolvidos: agrega desde a engenharia específica ao tipo de produção até a biblioteca de produtos. A engenharia sob domínio promove a agregação de vantagens pela cientificidade aplicada que lhe é intrínseca pela definição que estabelece do ferramental necessário para a modelagem dos requisistos de produto e de processos envolvidos e do ferramental operacional de manufatura e de testes do produto. Toda especificação de uso desse ferramental, bem como os produtos - ou parte deles - permanece devidamente armazenado em biblioteca;

- Especificações gerenciais: agregam as determinações de cunho administrativo do 
negócio, que responsabilizam-se pela integração dos modelos de processo organizacional e da estrutura organizacional, com toda informação condicionante dos fatores críticos e indicadores, e o sistema adotado para a gestão da qualidade, tanto dos processos quanto dos produtos;

- As integrações necessárias entre linhas de produtos e/ou equipamentos e as especificações gerenciais e, ainda, entre estas e os parâmetros de gerenciabilidade, definidos pela plataforma adotada para tal gestão. Inclui-se, também, as formas de integração entre estes elementos, estáticos, e os dinâmicos, oferecendo definição e suporte ambiental aos processos de produção e definição de pessoal.

Os elementos dinâmicos representam determinações ou objetos de menor perenidade tanto por suas naturezas quanto pela natureza dos projetos contratados para a fábrica de software. Nesse caso, deve-se pensar em:

- Técnicas: agregam as formas como aplicar-se-á a tecnologia envolvida com a organização produtora em cada ciclo de desenvolvimento e as políticas de absorção, armazenamento, aplicação e divulgação/distribuição de itens estruturais como a componentização praticada na produção, ou as regras para reuso de software, entre outras. As técnicas oferecem o devido suporte gerencial e operacional aos processos;

- Pessoas: agregam todos os envolvidos com a organização, tanto em sua gerenciabilidade quanto em sua operacionalidade, envolvendo não apenas a determinação dos atores, como também suas responsabilidades participativas. Tais definições são vitais ao controle da capacidade de gestão e de manufatura;

- Processos: agregam conhecimentos específicos do ambiente produtivo e dos projetos ora em curso, necessários às capacitações exigíveis para o desenvolvimento dos produtos, o suporte à produção e o gerenciamento de atividades.

A função produção é decorrente de toda capacitação regida por tais elementos. A presença de ISO e CMM, na proposição dos autores, dá-se nos sistemas de gestão da qualidade e na forma como o domínio de engenharia define e agrega valor no ferramental e na organização da biblioteca e, por conseguinte, influenciam a melhoria da aplicação de técnicas, de processos, de profissionais e das interagências entre os elementos, através de controles, definições, suportes e integrações. Este trabalho não pretende uma aproximação maior de tais normas e modelos, outrossim, apenas, 
considerar o modelo de fábrica proposto por eles, fruto de considerações de como produzir, com a devida qualidade, os produtos de software de necessária qualidade. Este modelo de fábrica aproxima-se do modelo administrativo, anteriormente apresentado, na medida em que necessita de gestão, como qualquer outro tipo de negócio ou organização.

Uma associação do modelo proposto por Li et al. (figura 4.02) com o modelo composto (figura 3.03) de categorização por níveis, foi pensada como forma de demonstrar como a gestão de uma fábrica de software pode ser sobreposta à gestão de negócio, pois, sobre a concepção do sistema de informações possível, é que se apoiará qualquer conceito de gestão de conhecimentos relacionados a esta espécie de empresa. A figura 4.03 permite visualizar tal associação.

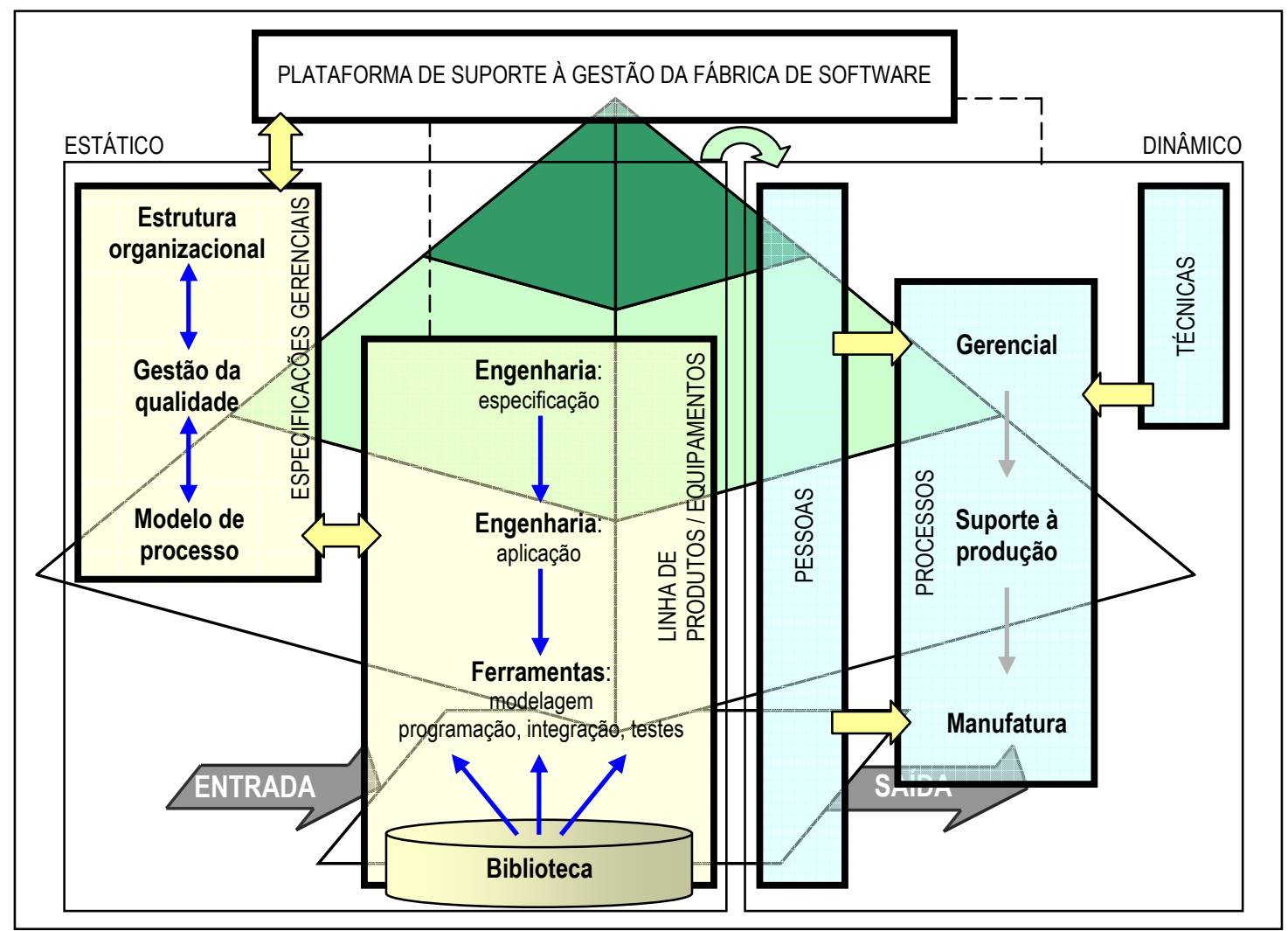

FIG 4.03 - Integração entre modelos gerenciais, de produção de software e de administração.

A associação, mencionada e representada, posiciona as definições sobre plataformas, de suporte e gestão, como definições de nível estratégico. No que tange a elementos estáticos, percebe-se que as especificações gerenciais posicionam a estrutura organizacional no nível estratégico, a gestão de qualidade no nível tático e as resoluções de modelo de processo no nível gerencial executivo (operacional administrativo), 
enquanto que as definições de linha de produtos e equipamentos posicionam especificações da engenharia em nível tático e suas aplicabilidades em nível operacional (administrativo), o ferramental transita entre os níveis operacionais (administrativo e não administrativo) e a biblioteca em nível de processamento operacional (não administrativo). No que tange aos elementos dinâmicos, as definições técnicas são atribuições de nível gerencial tático-estratégico, enquanto que as definições de processos abrangem a gerência administrativa (nível tático) quando trata dos gerenciais, a gerência executiva (operacional administrativo) quando trata do suporte à produção e o processo operacional (não administrativo) quando trata da manufatura. Ainda sob o aspecto dos elementos dinâmicos, há toda a referência ao pessoal, que abrange todos os níveis da organização.

HUMPHREY (1991:370-376) preocupou-se, também, com a proximidade da gestão de fábricas de software com as formas clássicas de gestão de negócios. Em artigo no qual delineia o conceito de software e seu paradigma da produção em escala, configurando-a como exercício industrial, conclui que as motivações para a evolução do conceito de "softwarehouse" para "fábrica de software" estão firmemente alicerçadas nas necessidades de aumento da produtividade deste tipo de produto, pela implementação de práticas de reuso de componentes, de modelos processuais e, até, de métodos apropriados à contiguidade administrativa. Sua analise parte das quatorze diretrizes apontadas por Deming (William E. Deming) e as utiliza para nortear os negócios da produção de software, segundo uma divisão por áreas de gerenciabilidade, que ele denomina "princípios da gestão do processo de software", a saber:

- Administração de pessoal, pois os profissionais são fatores críticos no processo produtivo e devem ser intimamente envolvidos em seu desenvolvimento e em sua melhoria. A gestão deve focar os defeitos de produção, não como uma forma de caracterizar erros pessoais, mas como oportunidades para a evolução do processo;

- Metodologia de processo, pois esses precisam ser formalmente definidos e ter metas e elementos de mensuração estabelecidos, para que dados estatísticos possam ser colhidos e, analisados, permitam identificar problemas e determinar-lhes as causas;

- Suporte ao processo, pois grupos especiais destes precisam ser estabelecidos para que especializações e treinamentos necessários, tanto dos profissionais de produção como de administração, sejam providenciados, visando a obtenção e o bom uso do 
melhor ferramental em suas especificidades;

- Controle do processo, pois práticas de gerenciamento são necessárias ao controle das mudanças, considerando que a avaliação dos períodos produtivos é conduzida para o monitoramento de efetividades e identificação de necessidades de melhoria, o que leva a procedimentos certificadores da implementação de ações corretivas, quando necessárias, e, consequentemente, da qualidade do processo.

RUHE (1999:63,68-70) discorre, também, sobre a necessidade de aproximação da produção de software de práticas administrativas acusando, ainda, uma característica atípica inerente do tipo de produção: software é um produto incomum em sua conceituação e de gerenciamento não trivial em sua produção, pois exige organização de trabalho capaz de combinar a dimensionalidade múltipla de um trabalho quase todo intelectual com a linearidade de uma produção escalar de fábrica. Em sua proposta de um modelo de mensuração orientado a metas - o paradigma GQM (Goal-Question Metrics), conforme sua própria nomeação - comenta sobre o diferencial entre a demanda inflada por uma engenharia de software ainda dramaticamente defasada quanto a qualificação dos desenvolvedores.

Esta proximidade organizacional entre a produção de software e a administração é compartilhada, ainda por vários outros autores, preocupados em definir modelos capazes de promover domínio sobre o negócio de fabricar software a quem há de gerir negócios nessa indústria. Pode-se citar, por exemplo, BASILI et. al. (1992a:53-80) e o modelo por eles proposto, fundamentado na idéia de dividir o modelo produtivo do desenvolvimento, intitulado "fabril" em dois segmentos de processo: a um, eles deram o nome de "organização por projetos" e, ao outro, "fábrica de componentes". A idéia de produtos de software futuros (a construir) vem de agentes encarregados de sua arquitetura, enfileira-se num agendamento de processos de produção por projetos, são produzidos, módulo a módulo (chamados componentes), e entregues a agentes implementadores que "constróem" o produto final (montagem). Os autores, cujo modelo encontra-se ilustrado na figura 4.04, defendem que uma organização com características de fábrica de software deve possuir uma estrutura de desenvolvimento baseada em componentes e que os componentes utilizados na construção do produto podem ser desenvolvidos por uma unidade manufaturadora de componentes. A partir de tal consideração, pode-se deduzir que uma fábrica de componentes é a base para a 
implementação de uma fábrica de software.

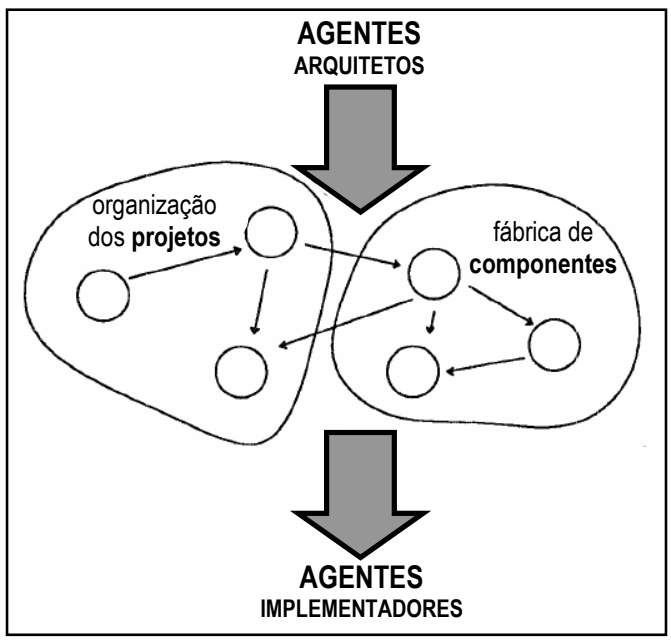

FIG 4.04 - Visão embrionária, particionada, da empresa produtora de software desenvolvida como fábrica experimental de software.

Adaptada de BASILI et al. (1992a:63).

A evolução desta visão embrionária de divisão de modelo fabril, organização e fabricação foi desenvolvida pelos próprios autores, segundo um modelo de experimentação advindo de uma pesquisa laboratorial, realizada na Universidade de Maryland e que apontou-lhes a importância da experiência (profissional, com o processo) para a amplificação da produtividade na fabricação de software. Enquanto a organização por projetos é tratada como uma questão organizacional administrativa do negócio, a produção do software é vista sob o foco organizacional técnico, na estruturação de uma fábrica de experiências, ou seja, a agregação do aprendizado com a fabricação do produto torna-se tão importante quanto o produto em si.

No desenvolvimento descrito pelos autores, da experimentação surge o conceito dinâmico da fábrica de experiências aplicado sobre o de fabrica de componentes. A figura 4.05 demonstra tal dinâmica.

A organização por projetos sugere uma fábrica de projetos que exige planejamento, construção (execução do projeto) e análise (do produto), gerando planos, dados e especificações para a produção. A fábrica de experiências abrange o domínio de fabricação propriamente dita e sua produção de experiências (conhecimentos) devidamente indexados e sintetizados para que possam ser armazenadas. Tais aprendizados ocorrem tanto na confecção do projeto quanto na do produto (implementação) e oferecem modelos e componentes para novos projetos.

Entre as solicitações, é perceptível a idéia dos autores: de que "produtos" 
referem-se aos componentes para construção de software; de que "dados" representam estatísticas para controle de custo, prazo e qualidade e, ainda; de que "planos" determinam modelos e métodos para analise e projeto de software. Após a solicitação, a organização baseada em projetos recebe os modelos e os componentes para construção do software e, ao final do processo, o produto para implantação.

O processo torna-se cíclico na integração entre a organização de processos de desenvolvimento dos projetos e o domínio da fábrica, de forma a tornar possível armazenar os dados gerados - considere-se informações e componentes como dados - e experiências adquiridas com o desenvolvimento do trabalho, em cada iteração do processo, conforme desenvolvem os próprios autores, em BASILI et al. (1992b:370381), quando apresentam o ciclo de iteração gerencial associado ao de iteração de desenvolvimento de produto.

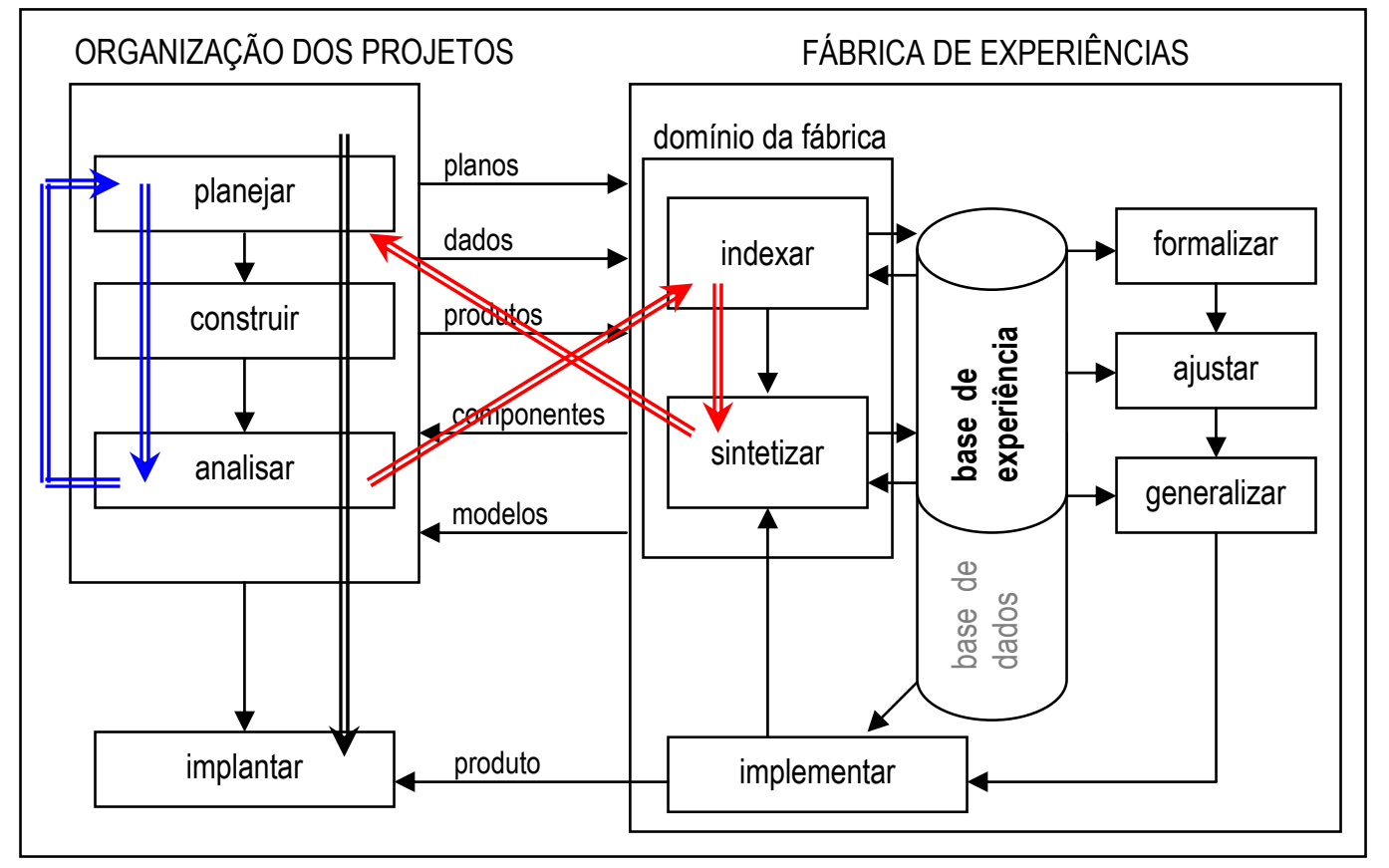

FIG 4.05 - Visão detalhada da fábrica de software, explorando os ciclos de produção e de gestão. Adaptada de BASILI et al. (1992a:57 e 1992b:371).

A questão de armazenamento de experiências destina todo o conhecimento relativo à organização fabril, a ponto de fazer com que a fábrica em si (produção) seja totalmente abarcada pela "fábrica de experiências", a qual interage com a produção e administração de projetos. O conhecimento passa a ocupar foco centralizado, junto com processos e organizações.

$\mathrm{Na}$ figura (4.05), os ciclos determinados pelas setas simples, em preto, representam o processo de trabalho movimentando componentes e informações, tanto 
sobre estes quanto sobre as práticas de seus desenvolvimentos e o que isso pode vir a agregar como experiência, via capacidade de síntese do sistema. A seta de traço duplo maior, em preto, representa o caminhamento natural esperado pelo projeto - o desenvolvimento que deve ser garantido pelos administradores - e suas iterações são demonstradas pelas setas de traço duplo em cor azul, ciclo esse que se repetirá tantas vezes quanto necessário para que se realize cada um dos projetos contratados. $\mathrm{Na}$ composição concebida pelos autores, a análise, após cada passo construtivo serve tanto às definições técnicas quanto às avaliações técnicas necessárias e a cada passo de desenvolvimento, tal análise iniciará o fluxo anotado por setas de traço duplo, em vermelho, na figura, ou seja: a análise leva à indexação da experiência relativa, suas informações são sintetizadas e isso leva ao planejar de um novo passo ou de um retrabalho do passo atual, caso necessário.

O que a proposição de Basili e seus co-autores, mencionados anteriormente, oferece, além das visões dinâmicas de processo e organização, é uma visão das competências inerentes ao negócio de fabricar software. Neste sentido, FERNANDES e TEIXEIRA (2004:115-118) contribuem com a formulação estrutural da organização de uma fábrica de software, a qual eles dividem em:

- Fábrica de programa, responsável pela construção e testes unitários dos códigos de software;

- Fábrica de projetos físicos, responsável pelo detalhamento do projeto e realização dos testes complementares, de integração e aceitação, além das atividades da fábrica de programas, a qual contém;

- Fábrica de projetos de software, responsável pela confecção do projeto conceitual do software e sua especificação lógica, além das atividades da fábrica de projetos físicos, a qual contém;

- Fábrica de projetos ampliada, responsável pela confecção da análise e arquitetura da solução, além das atividades da fábrica de projetos de software, a qual contém.

\section{1 - ELABSOFT:}

O Departamento de Produção da Escola Politécnica da Universidade de São Paulo mantém, ligado aos programas de mestrado e doutorado, uma linha de pesquisa sobre gestão de tecnologia da informação, denominada GTI. Dentre as pesquisas e seus 
diversos enfoques, um versa sobre fábricas de software e, a partir dele, desenvolve-se uma "fábrica modelo", como laboratório de pesquisas sobre temas, organizações, métodos, técnicas e ferramentas relativas ao modelo de fábrica, na forma mais ampla possível. Tal experimento contínuo é denominado eLabSoft.

A razão primeira do laboratório é levantar, discutir, experimentar e gerir conhecimentos, direta e indiretamente ligados à aplicabilidade da engenharia de software, mais especificamente sobre como potencializar a produtividade no desenvolvimento de software através de processos otimizados, tanto de manufatura, como de organização e gerenciamento da produção.

O modelo organizacional, até por questões de gestão das pesquisas, segue as prerrogativas conseqüentes das já mencionadas discussões de BASILI et al. (1992a e 1992b), combinadas com outras premissas, tais como:

- as de THORESON (1989:1576-1580), que apresenta a organização da fábrica de software como um espaço funcional entre a interface do usuário e a base de dados de projetos, deixando bem definidos os procedimentos de produção (proximidade com interface) e os de administração (proximidade com projetos);

- as de VERRALL (1991:1-4), que comenta a organização de fábrica proposta pelo projeto Eureka, o qual se preocupa com o desenvolvimento da capacidade produtiva e promove o conceito de software bus, um canal de comunicação definindo o processo de produção de software que recebe, com o desenvolvimento cronológico do projeto, componentes que vão sendo desenvolvidos segundo um planejamento gerencial bem definido;

- as de ROCKWELL e GERA (1993:80-92), que também desenvolvem suas proposições a partir das experiências com o projeto Eureka e apresentam, como forma de visualizar a gestão do software bus, uma delineação mais explícita das presenças da administração, dos projetos em andamento e das atividades produtivas de larga escala;

- até mesmo outras de BASILI et ali. (1998:3-11), que organizam o ambiente de fabricação de software para o conhecimento cuja agregação seja necessária, tanto para provocar evolução dos processos produtivos, quanto para desenvolver a capacidade administrativa. Os autores procuram, em seus estudos, soluções para as dificuldades de absorção e difusão dos resultados das experimentações com 
engenharia de software, face à complexidade inerente da diversificação de contextos para os quais as aplicações destinam-se, o que torna difícil a coesão dos entendimentos aplicados e conquistados;

- as do grupo de pesquisa do GTI que, desde 2001, vem se reunindo para discutir a formação do laboratório de desenvolvimento de fábrica de software da Escola Politécnica, que culminou no eLabSoft e determinou como seria sua organização.

Tal organização aborda duas coisas distintas: o planejamento de uma fábrica de software e o do laboratório que pesquisa modelo para tal fábrica. A conformação do laboratório não será aprofundada neste trabalho, pois não é pertinente com sua proposta. A organização da fábrica em si é o foco de interesse e nela limitar-se-ão as atenções.

O modelo que frutificou das discussões precisa de duas visões. A primeira delas é voltada para questões de processo, a qual concorda com os diversos autores mencionados no que diz respeito à organização da fábrica segundo abordagens: dos negócios, à medida que os projetos de produtos de software forem sendo contratados, e; da produção de seus componentes, à medida que as solicitações internas forem ocorrendo. A segunda é voltada para questões de pesquisa e desenvolvimento e aborda: as metodologias envolvidas com o negócio de fabricar software e; as tecnologias envolvidas com tal produção, atentando para o conjunto de técnicas e ferramentas possíveis e disponíveis. A figura 4.06 demonstra as visões dispondo, na horizontal, a de pesquisa e, na vertical, a de processo.

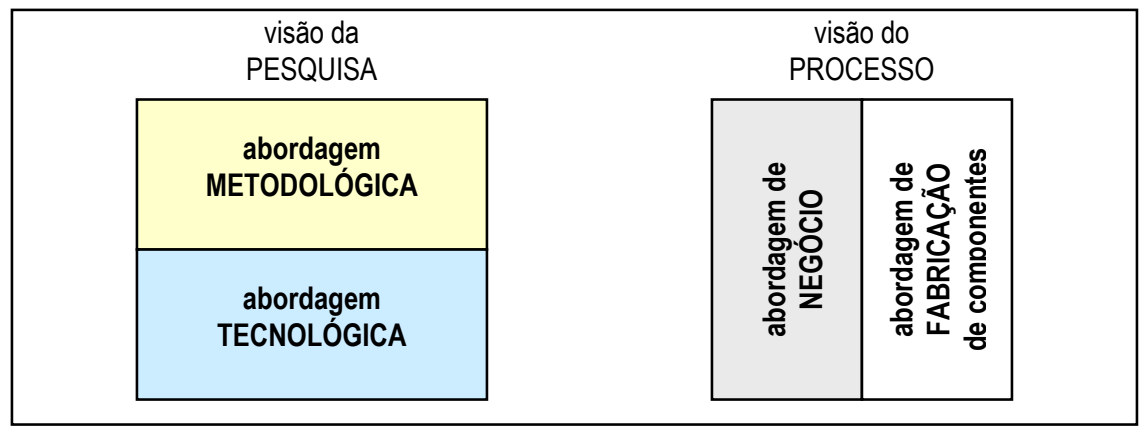

FIG 4.06 - O eLabSoft segundo as visões da pesquisa e do processo.

A abordagem metodológica compreende toda questão de definição de modelos conceituais para análise e representação do sistema de informações correspondente ao (futuro) produto e para a expressão do processo de criação e fabricação do software. A abordagem tecnológica dispõe de técnicas e ferramentas aplicáveis ao desenvolvimento do software, tanto as de manufatura de componentes, quanto as de projeto, montagem e 
manutenção do produto final. A abordagem de negócio visa definir a atividade de negociadores, analistas, engenheiros e codificadores, desde a contratação de um projeto até a manutenção do produto implantado no cliente. A abordagem de processo cuida da confecção de modelos de trabalhos, tais como padrões de produção, projetos e domínios, e da manufatura dos componentes do produto sob contrato, agregando projetistas aos profissionais antes mencionados.

As visões propostas (e apresentadas pela figura 4.06) se sobrepõem para formar quadrantes representativos da organização do eLabSoft, mostrados pela figura 4.07, em plena interagência e certa cronologia lógica. A figura procura representar as presenças de atividades, profissionais (cujos perfis serão comentados adiante) e fluxos de

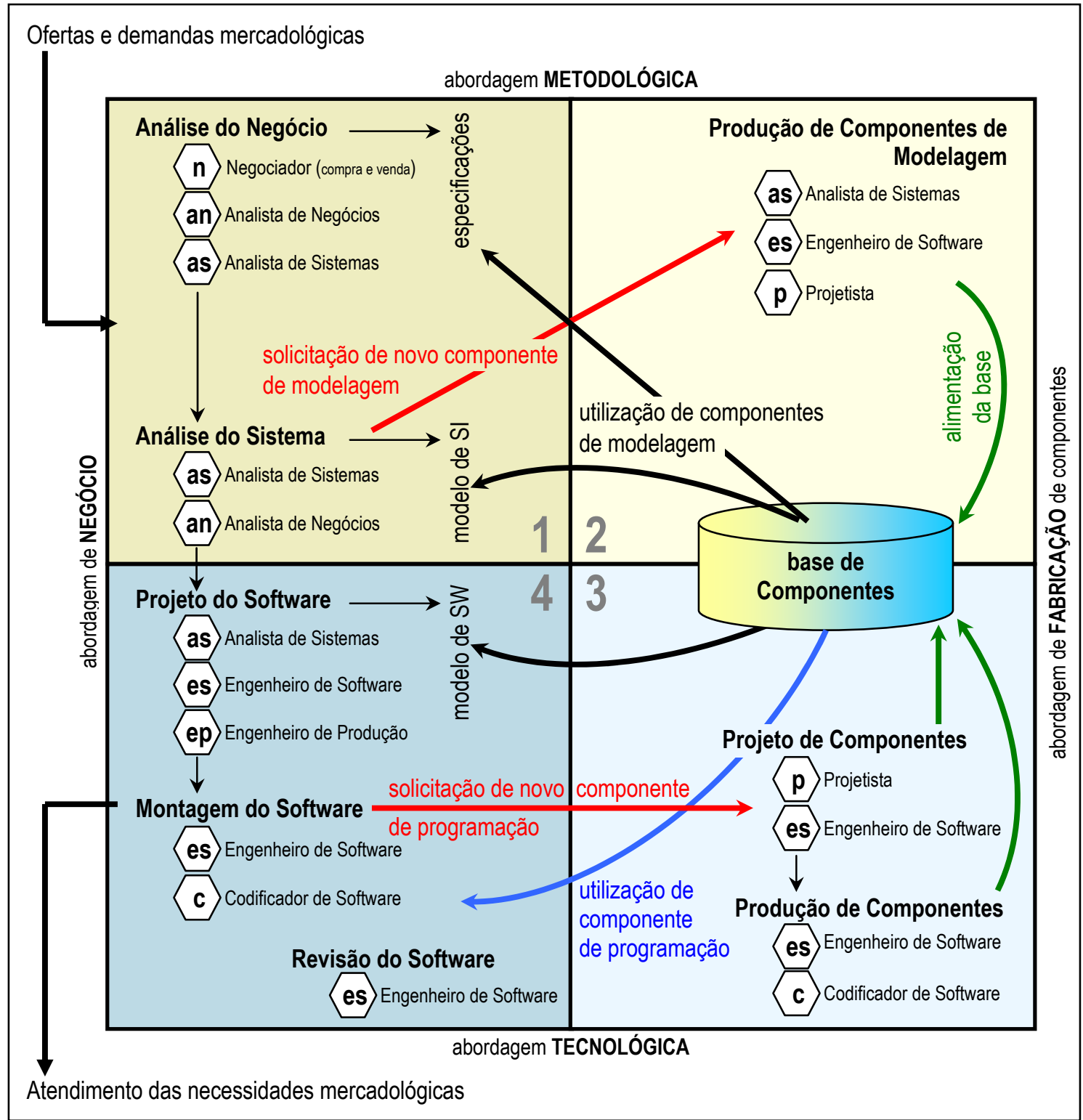

FIG 4.07 - A organização do eLabSoft em quadrantes da pesquisa e do processo. 
solicitações e respostas (estas tomadas, ainda, sem aprofundamento de detalhes), todos correspondentes à dinâmica do negócio.

O primeiro quadrante representado pela figura (4.07), dispõe as negociações para um novo software, as quais definem as especificações devidas ao novo projeto, que servirão à modelagem do sistema de informações (SI) percebido, necessário ao desenvolvimento do software. Se for desejável olhar este quadrante sob o paradigma da orientação a objetos, como o proposto pelo processo unificado (apresentado pelo RUP, como meio de organizar a aplicação da engenharia de software), estas atividades assemelham-se à produção de casos de uso de computador na dinâmica da empresa consumidora do software. Se o desejável for olhar sob o paradigma da orientação a processos, pode-se aplicar a abordagem da análise estruturada essencial (AEE), obtendo-se atividades resultantes da conjugação do diagrama de contexto com a lista de eventos. Tanto o levantamento dos requisitos (especificações) quanto a modelagem sistêmica utilizam componentes de modelagem existentes na base de componentes e, quando da definição do modelo de trabalho, novos componentes de modelagem podem ser solicitados ao elemento devido, no segundo quadrante. Quando a formatação do modelo de SI estiver adequada, segue para a formulação técnica do projeto de software, no quarto quadrante. A presença de profissionais foi discutida pelo grupo de pesquisa e perfis como o do negociador de software e dos analistas de negócios e de sistemas foram considerados necessários ao foco relativo ao quadrante em discussão.

O segundo quadrante comporta a produção de componentes de modelagem, atividade encarregada da criação de padronizações e expressões de métodos, técnicas, ferramentas, processos, domínios e determinações sobre arquitetura e gerenciamento, inclusive na historiação das experiências (dados, fatos, formas e conhecimentos) de produção. Tal atividade de produção é estimulada pela solicitação de analistas, quando da modelagem do SI e, uma vez efetivada, alimenta a base de componentes com os resultados do trabalho realizado por profissionais com perfis de analista de sistemas, engenheiros de software e projetistas, necessariamente envolvidos com a tarefa.

O terceiro quadrante traz o foco na fabricação de componentes de programação, englobando projetos e produtos dos módulos (fragmentos) de produtos de software. Há de se observar que um componente de código, simples ou complexo, pode, também, ser observado como um produto comercializável pela organização produtora de software. 
Os projetos de componentes de programação são iniciados pela solicitação do grupo de montagem ou, eventualmente, de revisão de produtos de software e suas confecções, geram componentes (códigos ou infra-estrutura de software) que alimentam a base de componentes, ao findar as tarefas de projetistas, engenheiros e codificadores de software.

O quarto quadrante agrega o projeto do software, sua construção (montagem) e uma atividade de pós-venda: a revisão de produtos, atividades estas desenvolvidas por analistas de sistemas, engenheiros de software e de produção e codificadores. A modelagem do software utilizar-se-á de toda sorte de componentes de modelagem disponíveis na base. A montagem do mesmo, assim como sua revisão, aplicará os componentes de software (códigos) armazenados e, se necessário, pode solicitar a confecção de novos componentes. No atendimento das necessidades mercadológicas, entenda-se toda atividade de implantação de produtos no ambiente do consumidor.

Funcionando como um repositório, o local denominado "base de componentes" é destinado a armazenar os mais diversos tipos de elementos envolvidos com o negócio da produção de software, inclusive novos recursos processuais e comportamentais, como experiências, caracterizados pela preocupação com aprendizagem constante e agregação de conhecimentos. Tal definição de amplitude harmoniza com a linha de pensamento de BASILI et al. (1992a:53-80, 1992b:370-381 e 1998:3-11), para quem componente é um conceito amplo que envolve uma coleção de elementos, desde os módulos coesos e pontualmente focados do software até as experiências vividas em processos de gerenciamento e produção desta espécie de produto.

Destas definições de escopo, função e funcionalidade da fábrica-laboratório, visando atender às prerrogativas do GTI como grupo de pesquisa, cujo objetivo é o planejamento, o desenvolvimento e a implantação de sistemas ativos relacionados à tecnologia da informação (TI), derivou-se um modelo de processo que atende critérios de organização da engenharia aplicada ao empreendimento de construção de software, tais como o RUP, de JACOBSON et al. (1998), e o SwEBoK, do IEEE (2002).

A este processo denominou-se "processo fabril": um modelo fabril que tem sua organização baseada em projetos de software (intitulada unidade de produção de software) e fábrica de componentes (intitulada unidade de produção de componentes), conforme apresentam FABRI et al. (2004a e 2004b : 1-98). Esta divisão corrobora com 
conceitos divulgados por BASILI et al. (1992b e 1998) e ROCKWELL e GERA (1993), trazendo uma linha de desenvolvimento do software e outra dedicada aos componentes de software, de sua modelagem e do gerenciamento de sua produção.

As linhas evolutivas do desenvolvimento apresentam, na produção de software, as etapas de análise (requisitos do produto), projeto (do produto final), implementação (montagem e integração), testes (de produto), implantação e revisão de software e, na produção de componentes, as etapas de projeto (do componente), implementação (codificação ou padronização), teste (unitário e de integração parcial), armazenamento e distribuição destes, em suas mais diversas naturezas, relativas ao produto de software e sua fabricação.

O processo de FABRI et al. (2004a e 2004b) não percebe, no entanto, alguns pontos importantes para a fábrica de software, pois fora desenvolvido com foco na organização de manufatura e entrega, sem abrangência anterior, quando ocorre o contato de contratação de um projeto e a análise deste como negócio e como produto categorizável em ferramenta de suporte a um SI. Tais pontos agregam, ao processo fabril, fases de negociação e modelagem, anteriores à análise que contextualiza o produto de software e, ainda, observa a etapa de revisão como sendo parte da negociação, num procedimento pós-venda e pós-implantação, esta última, inclusive, tem parte de seu desenvolvimento na abordagem da negociação, no que diz respeito à entrega em curso do produto. Além do que, há uma necessidade premente de ampliação das derivações do conceito de componente, pois o processo dos citados autores só percebe os de software (todo fragmento de código) e três de infra-estrutura (projetos, padronizações de processos e formulários) e a estes é preciso somar outros, como dados históricos e registros de experiências.

O modelo de fábrica de software de FERNANDES e TEIXEIRA (2004:115118), por sua vez, percebe a fase inicial de análise, comentada como ausente no modelo de Fabri et al, a que eles denominam "arquitetura de solução", mas não demonstram os cuidados finais com implantação (conclusão) e manutenção extensiva (revisão).

A figura 4.08 demonstra o processo fabril já acrescido de tais abordagens, ou seja, já agregada a análise de negócios em ambas as linhas: da produção de software e da produção de componentes, e já agregada a modelagem sistêmica na unidade de construção do sistema de software. As linhas citadas são representadas por duas 
unidades nítidas que podem ser apresentadas como:

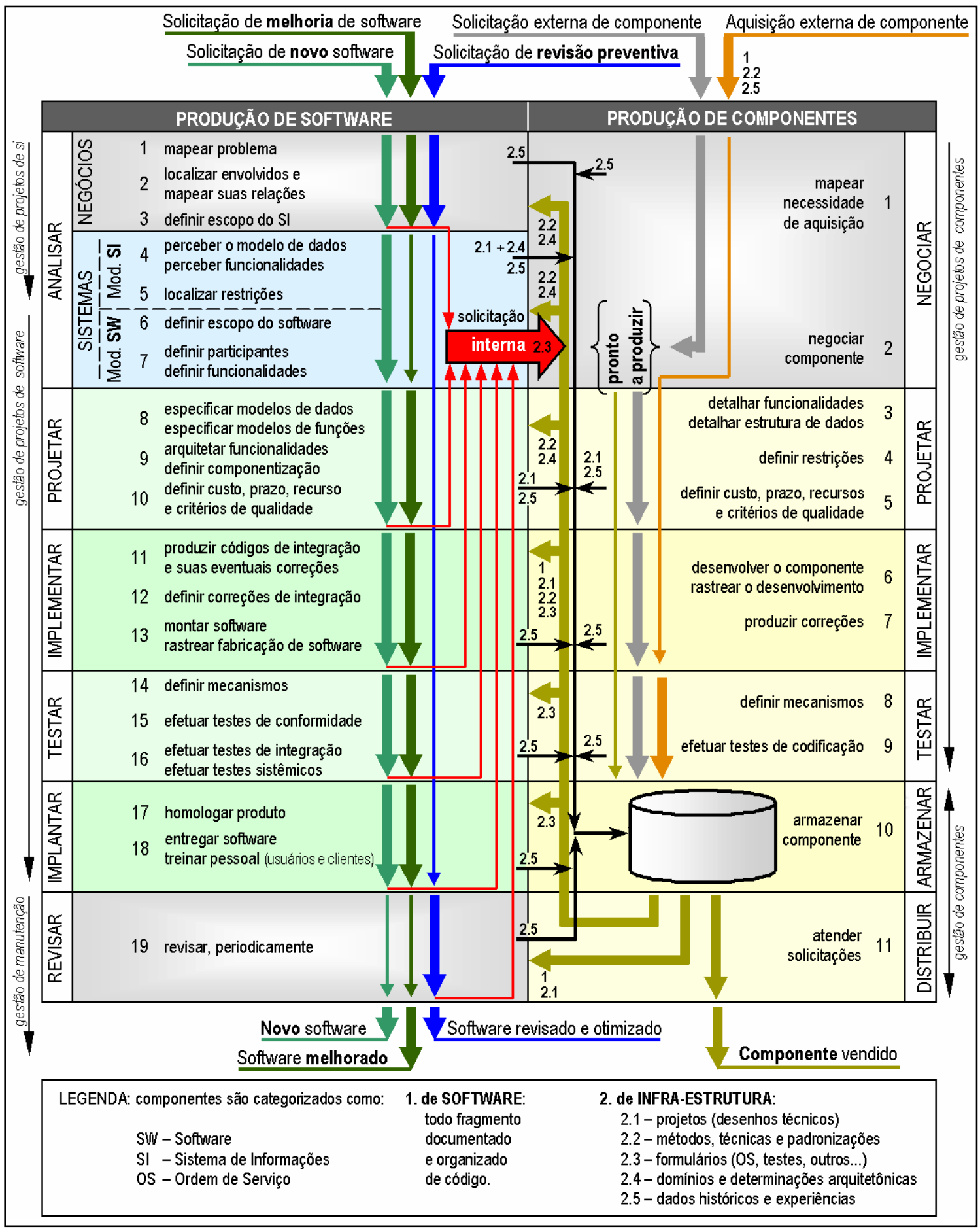

FIG 4.08 - Processo fabril modelo para fábrica de software, adotado no eLabSoft.

Evolução desenvolvida a partir de modelo de FABRI et al. (2004a e 2004b).

- a de produção de software, à esquerda, através da qual desenvolve-se a negociação de novos projetos, suas sistematizações e contextualizações, seus projetos, suas montagens (implementações e testes), suas implantações e, até mesmo, suas manutenções posteriores ao advento da produção; 
- a de produção de componentes de software, à direita, através da qual desenvolve-se a negociação de novos componentes, tanto para atender demandas externas quanto internas, seus projetos, suas confecções (implementações e testes), seus armazenamentos e suas distribuições, tanto externas quanto internas.

O modelo engloba atendimentos de solicitações externas inclusive no nível da compra e da venda (papéis dos negociadores apresentados na figura 4.07), modelagens dos sistemas de informações relativos à dinâmica processual à qual o software (a ser desenvolvido) vai dar suporte, projetos de produtos, sua produção, implantação e, no pós-venda, sua manutenção. Administrativamente, gestões de modelagens, de projetos de produtos de software e de seus componentes, do produto representado pelo componente armazenado e da manutenção pós-implantação formam o plano do gerenciamento da fábrica, responsável estratégica, tática e operacionalmente pela eficiência e pela eficácia do negócio.

Esta gestão orienta-se a um negócio baseado na montagem de componentes plenamente reutilizáveis ou, no mínimo, orientados ao reuso, na qual supõe-se que partes do produto de software desejável já existam, armazenadas em base interna da fábrica ou, eventualmente, disponíveis em ambiente externo e passíveis de aquisição. $\mathrm{O}$ processo de desenvolvimento fica concentrado na integração destas partes, o que promove otimizações de tempo, consumo e esforços, com o que encontra-se concordância em SOMMERVILLE (2004:259-275).

Em sua opinião, o processo de montagem acontece em uma estrutura de objetos distribuídos, conectados através do sistema de intermediação denominado software bus, anteriormente citado neste trabalho, que deve ser entendido não como um barramento físico mas, sim, conceitual, ou seja: uma representação que permita a visualização da comunicabilidade entre objetos que provêem serviços a outros objetos e destes também os receba, num processo de desenvolvimento dos elementos e acoplamentos destes através de suas interfaces padronizadas. Ao que ele denomina "objetos" e "elementos", entenda-se os componentes, segundo nomenclatura que vem sendo utilizada neste trabalho e observe-se que a denominação de objetos é fruto da orientação a objetos, da qual deriva a proposição do autor.

Para o modelo de processo fabril e para a abordagem de pesquisa pretendida pelo eLabSoft, nenhuma orientação de desenvolvimento deve sobrepor-se sobre outras, 
o que leva a organização da dinâmica de fabricação, mostrada pela figura 4.08, aplicarse tanto à orientação a processos quanto a objetos. Em nome de tal imparcialidade técnica, o modelo foi baseado somente nas divisões de procedimento sob a visão da gerenciabilidade do trabalho, seja aplicando desenvolvimento evolucionário ou incremental, bastando a possibilidade de organização das atividades envolvidas nos diversos pontos de vista.

Do ponto de vista da negociação, por exemplo, o modelo abrange: análise de oportunidades e demandas, para contratar novos projetos ou adquirir elementos de composição de produtos e de processos e; revisão periodicamente prevista para garantir a perenidade dos produtos entregues às necessidades mercadológicas.

A negociação relativa aos softwares envolve o mapeamento de problemas apresentados pelos clientes da fábrica, localizando os agentes envolvidos com sua contextualização, dos quais se possa extrair informações suficientes para entender suas relações de trabalho e necessidades, tanto procedimentais como informacionais, a ponto de inserir o problema numa determinada fronteira de entendimento que revele o escopo do sistema de informações necessário, como solução.

O conceito de negócio relativo aos componentes é mais amplo que o do software, pois, uma vez desvendadas as necessidades da fábrica, não se limita ao atendimento de demanda externa por novos produtos - cuja responsabilidade de manufatura seja da própria fábrica de software - mas, também, de aquisição de elementos de software - tais como código disponibilizado no mercado, por outro produtor - e outros elementos distintos, adquiridos por processos não comuns de comercialização, como, por exemplo: a agregação de um novo padrão de produção; a adoção de uma nova técnica que venha implementar ou evoluir alguma já em uso; a perfilhação de um método administrativo, produtivo ou de aplicação tecnológica; a compilação de dados históricos que, eventualmente, possam ser percebidos externamente, por estudos de casos publicados ou por observação de registros de parceiros de negócio; e, até mesmo, pelas experiências relativas ao negócio com que integrantes de equipes de produção de software possam contribuir.

A revisão periódica, ao final da linha de desenvolvimento do processo, representa toda atividade de manutenção de produto, uma vez instalado e operacional, estimulada por evoluções, inserções de novos elementos de processo ou, mesmo, 
correções de problemas detectados em componentes ou em suas integrações. A solicitação, no modelo, caracteriza-se como estímulo externo, já que sempre ocorrerá por iniciativa do cliente da fábrica de software, mesmo que a informação que lhe seja causa tenha partido do desenvolvedor do produto. Mesmo estando este segmento ao final do processo, faz parte da negociação (áreas de cor cinza, na figura).

Do ponto de vista das modelagens sistêmicas, ainda na fase de análise, desenvolvem-se dois modelos: o de sistema de informações (SI) e o de software (ambos grafados em segmentos de cor azul, na figura).

A modelagem do SI cuida da percepção dos modelos de dados e de funções que correspondam ao escopo determinado pelo terceiro passo da fase imediatamente anterior. Tal percepção pode ser feita separadamente, se adotada uma orientação a eventos essenciais (processos) ou em conjunto (no caso de adoção de uma orientação a objetos). Uma vez colecionados, dados e funções, uma análise de restrições deve ser levada a efeito, para prover o domínio sobre a efetivação do produto futuro no ambiente ao qual ele seja pretendido.

A modelagem do software, por sua vez, busca determinar seu escopo, analisando o que é necessário e o que é possível, no atendimento da amplitude de trabalho com as informações, expressa pelo SI. É uma etapa na qual se procura "encaixar" o software adequado à realização do trabalho definido pelo sistema de informações, que vem acompanhada pela definição de participantes - aqui determinada por agentes e personagens - e de suas responsabilidades funcionais no binômio sistêmico SI/TI.

Do ponto de vista da confecção do projeto, no sentido dos desenhos e especificações técnicas do software, completo ou não, o modelo busca o detalhamento de requisito de produtos e de seus componentes - tanto os que se aplicarão por reuso como os que deverão ser confeccionados - para que o empreendimento se concretize. Tal confecção envolve o projetar, o implementar e o testar, tanto software (produto) quanto seus componentes (infra-estrutura e partes do produto), além do armazenar e distribuir componentes e do implantar software. Estas fases produtivas relativas ao software (representados, na figura, por áreas de cor verde) e aos componentes (áreas de cor amarela) são comentadas em seqüência.

Projetar o software significa especificar, com nível maior de detalhes, seus dados e suas funcionalidades - mais uma vez, juntos (orientação a objetos) ou separados 
(orientação a processos) - para que se tornem explícitas as suas capacidades de trabalho, divulgáveis através de um documento de arquitetura que já determine, também, todos os componentes que formarão o produto final. Esta componentização do software permite à gestão do projeto (empreendimento), a distribuição da produção pela distribuição dos elementos fragmentares aos desenvolvedores (que podem, inclusive, ser terceiros, dependendo de como se estruture o negócio de fabricação; é bom recordar que componentes podem ser solicitados internamente ou adquiridos externamente), quando da solicitação de produção de componentes. Detalhamento e componentização beneficiam, ainda, a metrificação do produto e de seu processo construtivo, permitindo definir, com certitude, custos, prazos, recursos e parâmetros qualitativos.

Projetar um componente significa especificar em detalhes a função e os dados relativos a um fragmento de software a ser codificado ou os detalhes necessários à definição e estruturação de outros elementos, voltados à funcionalidade ou à gestão do processo produtivo. Em ambos os casos, restrições de caracterização da função do componente ou de seu processo de desenvolvimento devem ser estabelecidas, para orientar os próximos passos, nos quais inclui-se a devida metrificação de custo, prazo, recursos e qualidade.

Do ponto de vista da implementação, de produto ou de seus componentes, o modelo expressa a etapa de construção literal dos códigos, de função e de integração, e dos artefatos de operacionalização e gerenciamento do processo de manufatura.

Implementar software representa etapa com pouco exercício de codificação, apenas o necessário às integrações de códigos, e uma quantificação significativa de programações, necessárias à preparação das correções, pelas definições dos testes indispensáveis do próprios códigos de integração e da integração em si. Nesta fase, monta-se o software e rastrea-se esta composição, o que permite sua gestão.

Implementar componentes representa etapa com muito exercício de codificação, pois o grosso da manufatura dos elementos fragmentares do software é, aí, desenvolvido. A quantificação de programação é diretamente proporcional, pois intensifica-se a necessidade de testes unitários destas unidades e tanto a codificação quanto a preparação das correções precisam ser devidamente rastreadas para que se conquiste capacidade de administração do processo.

Do ponto de vista dos testes essenciais, o modelo sugere alguns passos para 
determinar a infra-estrutura das baterias de testes e para realizá-las, também considerando duas abordagens: a do software e a dos componentes.

Testar o software é uma atividade que envolve procedimentos para definir os mecanismos necessários para que a operação se realize, considerando o processo propriamente dito e a aplicação gerencial dos dados resultantes, inclusive a análise de conformidade dos testes ao produto e do produto ao projeto. Os testes realizados têm foco nas relações entre os componentes e no atendimento de requisitos do produto como um todo, considerando os acoplamentos e a sinergia entre os elementos.

Testar o componente é uma atividade que envolve procedimentos para determinar como a operação deve ser realizada com eficiência de resultados voltados à aplicabilidade do teste em si e da aplicação administrativa de dados resultantes. São testes unitários (dos códigos) que verifiquem a coesão dos elementos distintos.

Do ponto de vista da implementação, o modelo considera toda atividade de operacionalização do produto final, que envolve a entrega do software ao cliente entrega de forma definitiva, já que partes do mesmo vão sendo implantadas no decorrer da produção - e sua homologação, pela aceitação dos resultados dos testes, por parte do desenvolvedor e pela anuência do cliente. Aculturamentos e treinamentos são considerados parte do procedimento de implantação.

Do ponto de vista do armazenamento de componentes, o modelo sugere a formação de um repositório, ou seja, uma base com amplitude e organização suficientes para guardar um conjunto diverso de elementos envolvidos com o negócio da produção de software, tais como:

- os componentes, hermeticamente fechados, contentores de um processo codificado de trabalho (visão orientada a processos) ou de um código associado a um conjunto de dados, caracterizadores de um elemento sistêmico (visão orientada a objetos);

- toda a documentação técnica, composta por desenhos e memoriais, sobre os projetos realizados pela empresa;

- todas as definições, do conceitual ao analiticamente detalhado, que determinem métodos, técnicas, ferramentas e suas padronizações de uso, adotados pela organização, que instrumentalizam o negócio; 
- o conjunto de formulários que documentem ordens de produção e execuções de tarefas e explicitem efetivações dos processos e informações resultantes dos mesmos;

- todas as definições limítrofes que estabeleçam os domínios de aplicação dos elementos descritos nos itens anteriores, estabelecendo o foco de negócio (core business) ao qual a fábrica de software restringe-se. Também os domínios e processo por meio dos quais a empresa pode realizar seu trabalho (processos, objetos, aspectos e outros, possivelmente vindouros - o laboratório de pesquisa precisa considerar a certeza de evolução, a empresa produtora precisa estar estruturada para a evolutibilidade certa) e todas as determinações arquitetônicas que cada um destes meios estabelece na especificidade de seus contextos;

- o conjunto dos dados sobre projetos e tarefas já realizados na história da empresa, bem como o registro das experiências vividas, aprendidas e formuladas pelos desenvolvedores, nos mais diversos papéis profissionais envolvidos com o negócio. Este item, assim como o anterior, têm forte embasamento na capacidade de criar e gerir conhecimentos.

Do ponto de vista da distribuição de elementos de trabalho, o modelo procura demonstrar os fluxos de todos estes tipos de componentes e como fluem pelo modelo, em função do provimento de recursos necessários a cada uma das etapas da fabricação. Tais fluxos, no entanto, não ocorrem apenas no sentido base $\rightarrow$ ambiente. $\mathrm{O}$ inverso também é uma constante e ocorre com intensidade significativa, já que cada movimento, em cada procedimento, pode gerar informação armazenável.

A dinâmica do processo é expressa de duas formas: por setas internas (coloridas), que representam fluxos diversos do processo em si, e por setas externas (somente em preto), que representam gestões focadas às diversas fases fabris.

No processo em si, as setas mais largas representam fases a serem realizadas em cada um dos possíveis desenvolvimentos e as estreitas, fases a não serem realizadas. Por exemplo, a solicitação de um novo software (fluxo representado em verde mais claro) executa tarefas em todas as fases, exceto revisão. Já a solicitação de uma revisão preventiva (fluxo em roxo), executa tarefas apenas de negociação e de revisão, não envolvendo tarefas em outras fases. Cada fase da produção do software faz um tipo de requisição por componentes (solicitação interna - fluxos vermelhos) que, se já existir 
(pronto e disponível), vai direto à armazenagem, para distribuição (fluxos em amarelo escuro) e, se ainda não existir na biblioteca (base de componentes), terá que ser produzido (fluxo cinza) antes de sua distribuição.

Os responsáveis por toda esta dinâmica são profissionais com papéis sugeridos segundo perfis de trabalho, julgados necessários pela equipe de pesquisadores do eLabSoft e - em parte por erudição direta, em parte por coincidência baseada em conhecimentos outros - corroborados por tratados de organização da engenharia de software, tais como o processo unificado proposto pelos fundadores da empresa Rational (RUP) e o corpo de conhecimentos sobre a engenharia de software (SwEBoK) proposto, na forma de uma compilação, pelo pessoal do Instituto de Engenharias Elétrica e Eletrônica (IEEE). Analistas, engenheiros, negociadores, projetistas e codificadores fazem parte deste cenário com papéis determinados e diversificados, conforme demonstra a figura 4.09, que também demonstra, sob outra ótica, o desenvolvimento do processo descrito pelas duas figuras imediatamente anteriores. Os profissionais locam-se em diversas funções, hora atuando como personagens principais, ora como secundários, fornecendo apoio técnico ou tático a outros, para a composição de análises, projetos ou administrações de atividades.

A figura 4.09 também busca explicitar, ainda que de forma genérica, a participação e a movimentação dos principais documentos gerados pelo sistema, tais como "ordens de serviços", identificados pela sigla "OS", e "formulários" de registro e de divulgação de dados, estes identificados pela inicial “i”, relativa à informação em movimento, genérica ou detalhada, que tais formulários circulam.

A base de componentes, dado sua amplitude já descrita, acabou por receber a denominação de "biblioteca" por adoção de consenso, com sua estruturação em projetopiloto sendo desenvolvimento à época da composição deste trabalho. Sua orientação temática é fruto desta iniciativa de gestão de conhecimentos relativos ao caso.

O modelo da figura 4.09 sintetiza a dinâmica apresentada pela figura 4.08, procurando evidencia-la segundo as etapas do desenvolvimento do processo envolvido com o negócio de fábrica, a partir das áreas funcionais determinadas (negócio, modelagem, projetos do produto e dos componentes e revisão). 


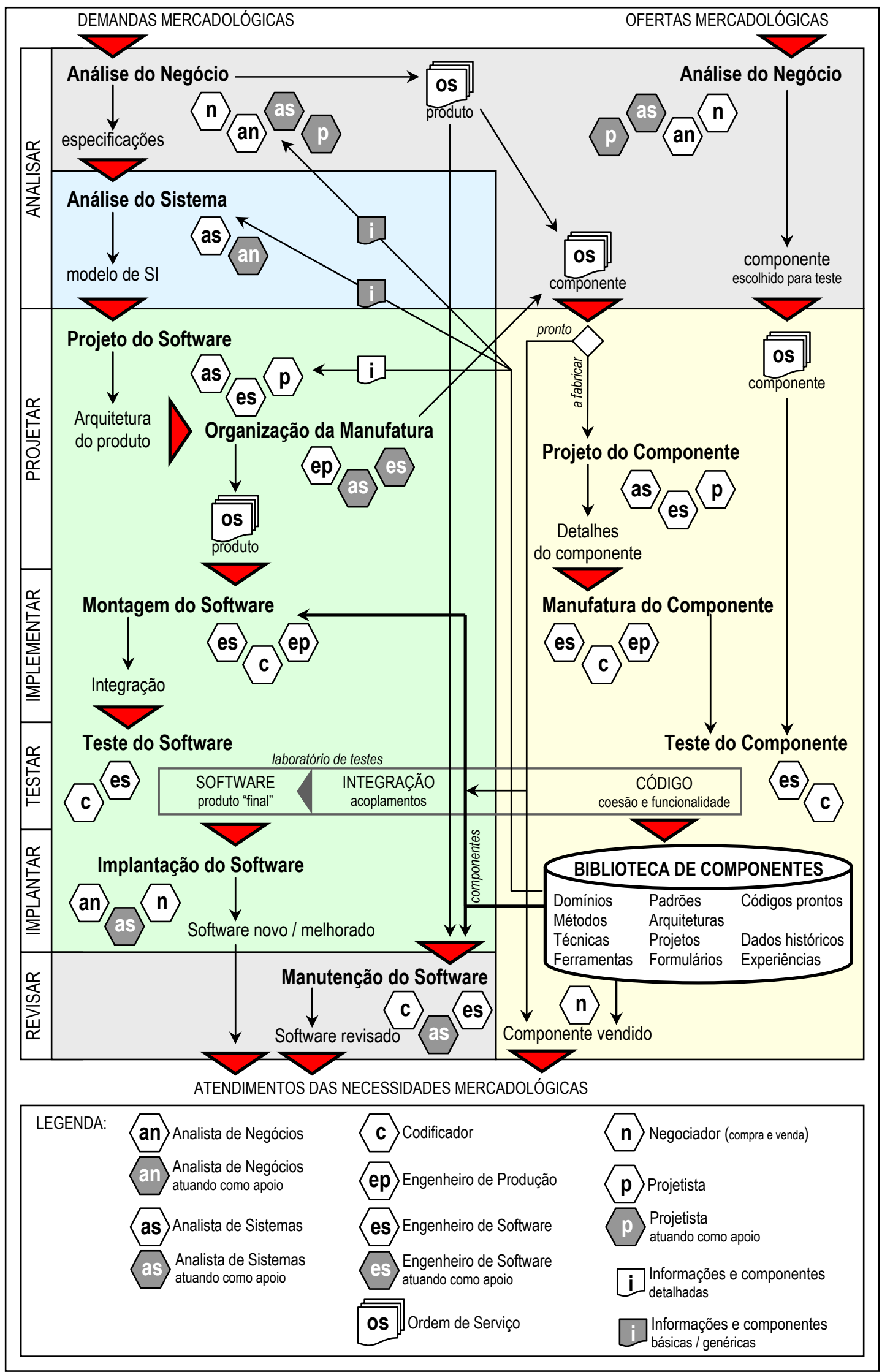

FIG 4.09 - A dinâmica do processo fabril em uma fábrica de software (padrão definido no eLabSoft). 
A organização da manufatura é a única fase ainda não explorada. Tem, como função, gerar a documentação de fabricação, na forma de ordens de serviço, para a montagem do software, com todas as atividades subsequentes relativas a ela, e a manufatura dos componentes deste software, se for o caso de novos componentes, ou a solicitação para a montagem, se for o caso de componentes já prontos, armazenados no repositório representado pela biblioteca de componentes.

Sobre este repositório, e sobre a tipificação de seu conteúdo, também já houve comentários, mas ainda cabe uma explicação: as ferramentas armazenadas não serão, necessariamente, os elementos físicos de trabalho, mas, sim, as informações sobre estes, necessárias ao trabalho (se bem que, sob certo ponto de vista, o ferramental físico também é considerado "dado" e o conceito de repositório não precisaria limitar-se às informações sobre tal dado. Envolveria-o também, como conteúdo; mas tal discussão não deve ser envolvida nos propósitos deste trabalho).

Quanto aos perfis profissionais dos envolvidos no processo, seguem algumas explicações sobre suas definições, segundo os papéis que desempenham no processo. Cabe observar que o conceito de papéis, no qual se refenciou este trabalho e do qual originou-se as definições a seguir, é baseado, em princípio, ao proposto por JACOBSON et al. (1998:3-32) e constante das disposições do RUP. Papel é um conceito abstrato que engloba um conjunto de atividades e responsabilidades, despenhado por uma ou mais pessoas, juntos ou em separado, ao mesmo tempo ou em momentos distintos. Portanto, papéis não devem ser confundidos com pessoas (profissionais), pois encarregam-se da descrição de comportamento destas quando envolvidas (ou, mais: comprometidas) em projetos. São os seguintes, os papéis a serem desempenhados:

- O analista de negócios, representado pela sigla "an", responsabiliza-se pela liderança e pela coordenação da modelagem de negócios, definindo e delimitando a organização e seu problema (para o qual, uma solução será contratada), percebendo atores e agentes de negócios e como eles interagem, entre si e com o ambiente. É o profissional responsável pela arquitetura do negócio, com seus fluxos de trabalho, de informações e suas entidades. Responsabiliza-se, também, pela percepção da necessidade e execução das revisões relativas a um negócio já efetivado. Deve possuir considerável conhecimento do domínio do negócio e da tecnologia possível 
para sua automação, ser capaz de estabelecer relações bem definidas de comunicação e abstração. No processo descrito na figura 4.09, atua na análise do negócio, tanto de software quanto de componente, e na implementação do software, por serem os dois pontos evidentes de contato com o cliente da fábrica, além de oferecer apoio às atividades de analise do sistema;

- O analista de sistemas, representado pela sigla "as", responsabiliza-se pela liderança e pela coordenação da identificação de requisitos e da modelagem do SI relativo ao problema percebido, delimitando-o e definindo suas funcionalidades, seus dados e sua interação com agentes e com o negócio. Apoia o planejamento e a condução da revisão formal do modelo de sistema e do software, determinando os envolvimentos funcionais de sua manutenção. Participa ativamente dos projetos de software e de componentes, especificando o produto de software adequado para atender as demandas do SI modelado, estabelecendo suas fronteiras e orientando as atividades de engenheiros e projetistas. Deve possuir considerável habilidade de comunicação e abstração, além de conhecimento dos domínios do negócio e da tecnologia. No processo, atua na análise do sistema e nos projetos do software e do componente, colaborando com a estruturação de todo o processo, até os testes. Apoia diversas outras etapas, como a análise do negócio, a implantação do software e a manutenção do software;

- O engenheiro de software, representado pela sigla “es", é o responsável pela aplicação da engenharia de software ao processo de fabricação, estabelecendo seu desenvolvimento organizado, pela introdução e avaliação de recursos técnicos de planejamento, validação e avaliação dos projetos e de seus ciclos de vida. Responde, ainda, pela liderança e coordenação de atividades e recursos técnicos, estabelecendo a arquitetura estrutural de projetos e de produtos, seus agrupamentos de elementos e as suas interfaces. Tem visão ampla do negócio, do problema, da solução e da solução criada para ele (que nem sempre são a mesma coisa). Precisa de atributos como: experiência no domínio do problema e domínio, pelo conhecimento de seus requisitos, da solução e da engenharia de software; liderança para conduzir o esforço técnico e tomar decisões técnicas, no desenvolvimento do processo; orientação às metas produtivas; enfoque nos resultados e; profundo conhecimento sobre desenvolvimento de software. Divide com o analista de sistema, a autoria da 
arquitetura do software e atua no processo, no projeto, na montagem e no teste do software e/ou componente, além de apoiar a atividade de organização da manufatura;

- O engenheiro de produção, representado pela sigla "ep", é responsável pela organização da manufatura e pelo controle, tanto da fabricação dos componentes, quanto da montagem do software. Gerencialmente, este profissional encarregar-se-á do processo como um todo, no que disser respeito à sua produtividade, e dos projetos em andamento, alocando recursos, ajustando prioridades, coordenando interações e gerindo mudanças. Deve possuir experiência no desenvolvimento de software e habilidades para analisar e gerenciar configurações, riscos, estimativas e planejamentos, necessárias às tomadas de decisões. No processo, atual organização da manufatura, na manufatura do componente e na montagem do software;

- O projetista, representado pela letra “p”, é responsável pela liderança e coordenação da transformação gráfica do modelo de SI em modelo de TI (mais precisamente, modelo de software), assegurando que o produto responda a eventos com imediatismo, de acordo com seus requisitos de tratamento de dados, definidos por tabelas, índices, visões, restrições, e parâmetros do banco de dados adequado. É função do projetista criar os pacotes de design essenciais ao desenho técnico do produto de software e criar tais desenhos, com seus memoriais de especificações detalhadas, inclusive para dar condições de teste aos componentes manufaturados e ao software montado. Deve conhecer técnicas de análise e projetos de processos e bancos de dados (ou classes, se trabalhar sob orientação a objetos), arquitetura de sistemas e do ambiente onde será inserido o produto e a linguagem com a qual este será implementado. Tal atividade requer experiência no tratamento de problemas de simultaneidade e conhecimento solidificado sobre e como tratar os tipos de problemas possíveis em sistemas reativos de alta simultaneidade. Conhecimento dos problemas de recursos de criação, das limitações tecnológicas impostas e de estados de comportamento eventuais dos produtos de software também são requeridos. No processo apresentado pela figura 4.09, os projetistas atuam no projeto de software e no projeto de componentes, além de apoiar a análise de negócios (apenas fornecendo informações básicas);

- O codificador, representado pela letra "c", é responsável pelo desenvolvimento e pelos testes de componentes de produto e de teste de produto, além de desenvolver e 
testar os componentes de integração necessários à montagem e teste do produto de software, de cujas atividades também participa, de acordo com o estabelecido pelo projeto. Este profissional, também denominado “implementador" pela RUP, deve possuir conhecimento do aplicativo que está em desenvolvimento, além de familiaridade com ferramentas próprias para criação, testes e automatização de testes de códigos e habilidades de programador. No processo, atua na manufatura e no teste do componente, na montagem, no teste e na manutenção do software;

- O negociador, representado pela letra "n", é responsável pelo contato direto com os clientes da fábrica de software, na negociação e na entrega do produto. Os processos de compra e venda têm suas possibilidades identificadas por ele e são, em primeira instância, por ele realizados. Atua como captor de clientes e potencializador de negociações. Deve ser perito na arte da venda, perícia esta necessariamente aliada a bom conhecimento das características diferenciadas do produto de software e suas aplicabilidades nas mais diversas áreas empresariais.

Além destas funções desempenhadas muito à proximidade do processo transformador, totalmente operacional (não administrativo), conforme demonstrado pela figura 3.03, há outras, afeitas ao processo gestor, atuante sobre o nível das operações apresentado, na camada administrativa da fábrica de software.

Mesmo que grande parte deste trabalho de gestão seja característica de profissionais de administração, há atuações relativas a engenheiros e analistas, pois que exigem trabalho com perfil técnico aplicado às estratégias e táticas da empresa que desenvolve software, conforme demonstrou a figura 4.03, que serve de elemento de origem para estabelecer outros papéis, demonstrados pela figura 4.10, desta feita relativos ao gerenciamento do processo fabril. Importante observar que, na aludida próxima figura, o processo fabril não se apresenta mais de forma detalhada, no sentido vertical e, sim, no sentido horizontal, de forma simplificada, expondo, de forma generalizada, as áreas de processo. A idéia é destacar, com detalhes, a pirâmide organizacional, com que o nível administrativo das organizações vem sendo demonstrado, desde o capítulo terceiro. 


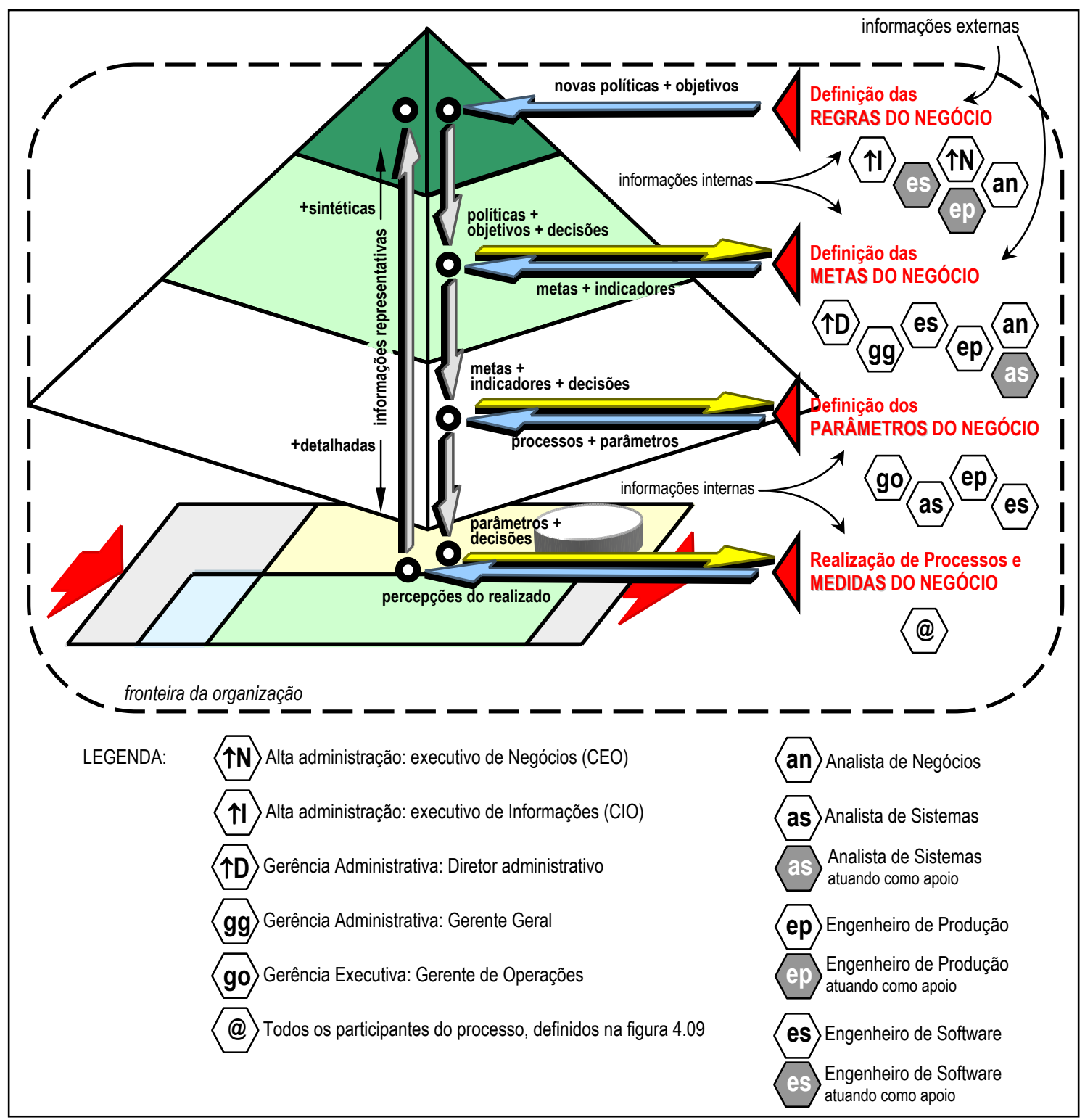

FIG 4.10 - Processo Gestor: o gerenciamento do processo fabril.

Do ponto de vista da gestão, o nível estratégico encarrega-sede definir regras de negócio, baseando-se muito em informações ambientais externas e internas, o nível tático preocupa-se com as definições de metas do negócio, baseando-se muito em informações internas e algumas externas, e o nível operacional dedica-se a definir os parâmetros do negócio, necessários à sua efetivação. Cada um destes níveis produz decisões, pertinentes a suas competências, endereçada aos níveis inferiores.

A efetivação do processo realiza o trabalho (segundo o modelo descrito anteriormente) e gera medições de sua produtividade, as quais são apresentadas, na forma de resultados, aos níveis superiores, de gestão.

Sob esta dimensão do negócio de produção de software, também cabem algumas 
explicações sobre os perfis profissionais dos envolvidos, de acordo com os papéis previstos para seus desempenhos no processo de gerenciamento da fábrica de software. Cabe observar que, ao contrário das atribuições descritas anteriormente, quando os papéis representavam, diretamente, profissionais ligados ao processo produtivo do software, as atribuições de agora serão mais genéricas, mais próximas da administração em si de um negócio ou de uma empresa. Importante lembrar que papéis são conceitos abstratos que englobam responsabilidades e não devem ser confundidos com profissionais individualizados. Importante salientar que as disposições sobre a gestão da empresa produtora de software em foco, no que diz respeito a sua gerenciabilidade, aproxima-se mais de conceitos de administração que de engenharia (de software, no caso), o que leva a considerar, na definição de atribuições dos diversos papéis, preceitos dispostos por ANTHONY (1965:17), KWASNICKA (1989:67-73 e 1995:83-91), CASSARO (1998:11-17), MELO (1999:67-73) e NATSUI (2002:15-26). Cabe lembrar, ainda, que uma parte das definições a seguir procuram atender requisitos definidos pelo RUP, no que diz respeito ao processo direto do software. São os seguintes, os papéis a serem desempenhados:

- O executivo de negócios, representado pela sigla “个N”, responsabiliza-se pela visão estratégica da organização e como ela se relaciona com o mercado, no que diz respeito à delimitação de contexto externo e missão, à estruturação política empresarial do organismo e às capacidades de comercialização, participação e comprometimentos sociais. Encarrega-se, também, das definições e estratégias participativas inerentes a: recursos e talentos humanos; recursos contábeis e financeiros e; abordagens comerciais e mercadológicas, necessários à contextualização do negócio. Na ambientação e disponibilização operacional dos negócios, cuida da determinação de fatores críticos de sucessos e seus indicadores de desempenho direcionados à mensuração de eficácia. Este papel exige, do profissional, profundo domínio administrativo nas áreas funcionais do marketing, do financeiro e dos recursos humanos (normalmente, exigir-se-ia, também, domínio sobre a produção, mas, no caso de fábricas de software, esta atribuição condiz mais com o executivo de informações, pela combinação do tipo de negócio com sua formação em SI e TI) e características próprias de empreendedorismo, de valorização dos ativos intelectuais da comunidade interna da organização, de perceber e fazer convergir competências e qualificações, de incentivar capacidades de inovação, tanto 
organizacional quanto individual, de contextualizar empreendimentos, situações e circunstâncias de interesse do negócio, de estabelecer relações de mercado e de desenvolver os vetores estratégicos e táticos necessários à organização;

- O executivo de informações, representado pela sigla “个I”, responsabiliza-se pela visão de negócio relativa aos sistemas e tecnologias de informações, tanto para modelar soluções para clientes quanto para estruturar soluções internas de tratamento de informações e uso de aplicativos; estruturar, também, logísticas e estocagem de toda forma de componentes, atribuição esta que, em fábricas de software, têm complexidade atípica em função da natureza intangível do produto. Encarrega-se, ainda, da detecção de sinais de inovações metodológicas, tecnológicas ou de produtos; de promover suporte analítico e crítico para o desenvolvimento de negócios associados a estratégias de informações e embarque/desenvolvimento de novas tecnologias e; de prospecção de clientes e mercados de software, dentre os identificados, pelo executivo de negócios, como potenciais. Cuida das definições estratégicas relativas às tecnologias envolvidas com a manufatura de software, tais como a plataforma de suporte à gestão do negócio, com as técnicas adotáveis e adotadas para o desenvolvimento do negócio e com a estruturação organizacional no que diz respeito ao lado técnico-tecnológico do negócio (o lado administrativo fica por conta do executivo de negócios). No desempenho deste papel, é exigível amplos conhecimento sobre a empresa de software e sobre tecnologias da informação, as quais envolvem ferramentas, métodos e soluções tecnológicas de infra-estrutura, além de habilidade de percepção e síntese de informações, sistemas, processos e soluções tecnológicas.

- O diretor administrativo, representado pela sigla “ $\uparrow$ ”, responsabiliza-se pelo fomento de recursos necessários aos projetos e pelos seus ajustes de prioridades, além da determinação dos indicadores de desempenho específicos à mensuração da eficiência, tanto de produção como financeiros, necessários à administração dos mesmos. Encarrega-se, também, das organizações inerentes a recursos humanos, contábeis e logísticos, necessários ao processo do negócio. Espera-se que, para o cumprimento deste papel, o profissional apresente capacidades de análise de riscos, de planejamento de projetos e suas produções, de objetividade em definições e avaliações de equipes e de trabalhos, de compartilhar arquiteturas e de agregar 
valores à organização e à sua comunidade, tanto interna quanto externa;

- O gerente geral, representado pela sigla "gg", responsabiliza-se pela alocação de recursos, pela coordenação das relações entre clientes (interessados e usuários) com o projeto e pela manutenção de equipes focadas de projeto. É, também, função deste profissional a garantia da integridade e a qualidade dos produtos resultantes dos projetos em andamento, além da gestão de indicadores de desempenho, tanto os de eficácia quanto os de eficiência (gerais ou de projetos). Neste papel, exige-se conhecimento e experiência em domínios de projetos e em desenvolvimento de software, além de conceitos sólidos da administração de recursos, equipes, estimativas e riscos. Liderança, bom relacionamento interpessoal e gerenciabilidade de tempos e métodos são características exigíveis também. Conhecer e dominar as atribuições da gerência executiva são imprescindíveis, principalmente no que tange ao conjunto das características da gerenciabilidade operacional de desenvolvedores de software, que envolvem configurações, implementações, testes, mudanças e implantações, entre outras;

- O gerente de operações, representado pela sigla "go", responsabiliza-se por toda parte operacional do processo, controlando a execução e gerenciando o desenvolvimento como um todo, inclusive de equipes de trabalho. Há diversos subpapéis derivados, tais como:

- o de gerente de sistema computacional, preocupado em manter o ambiente de desenvolvimento ativo, cuidando de hardware, de software e de todos os elementos operativos relacionados, como backup, por exemplo. Para tal papel, exige-se bons conhecimentos de componentes, de hardware e software, e de suas possíveis dependências, além de sistemas operacionais e de plataformas de desenvolvimento;

- o de gerente de configurações, preocupado em disponibilizar e manter a infra-estrutura geral, tecnológica e de ambientação, necessária ao desenvolvimento de projetos, oferecendo todo o suporte necessário à fabricação de produtos, garantindo espaços adequados de trabalho para implementações, testes e manutenções e assegurando a facilitação de revisões e conseqüentes controles de mudanças e 
correções de defeitos. Para tanto, é exigível que conheça princípios de gerenciamento de configurações e seja experiente em ferramentas de gestão de configurações. Atenção a detalhes e assertividade são necessários para assegurar a não ignorância a políticas produtivas;

- o de gerente de mudanças, preocupado em manter a organização, a documentação e a gerenciabilidade das configurações e seus processos de modificação. Precisa ser devidamente qualificado para executar estimativas de impactos, tanto em custos quanto em cronogramas, quanto solicitações de mudança ocorrem;

- o de gerente de processos, preocupado com o processo de desenvolvimento, desde sua configuração pré, até sua crítica pós, envolvendo as equipes de desenvolvimento, a dinâmica de suas composições, e os esforços, de avaliação e aprimoramento, constantes e ininterruptos de todo o aspecto produtivo e técnico-tecnológico do processo. Exige-se conhecimento significativo de desenvolvimento de software e habilidades de comunicação para o bom desempenho deste papel;

- o de gerente de testes, preocupado com a responsabilidade pelos esforços de teste e seus resultados positivos, decorrentes da capacidade de se garantir a qualidade da atividade, o que exige, fundamentalmente, domínio geral sobre os aspectos da engenharia de software, experiência em diversificados esforços, técnicas e ferramentas de teste, habilidades interpessoais, de planejamento e de gerenciamento e conhecimento sobre domínio, sistema ou aplicativo em teste, além de experiência em programação;

- o de gerente de implantação, preocupado com a transição de produtos para a comunidade de usuários, o que lhe exige experiência com implantações de sistemas, proatividade, comunicabilidade, coordenação de trabalhos e respeito a orientações administrativas por metas;

- O analista de negócios, representado pela sigla "an", possui todas as responsabilidades anteriormente descritas, somadas a atuações gerenciais: 
- No nível estratégico, compondo com o executivo de negócios, para as discussões e determinações relativas ao negócio de software no mercado e nas prospecções deste e;

- No nível tático, compondo com o diretor administrativo nas discussões e definições de modelos gerenciais para projetos, segundo perspectivas de atendimento a clientes e de atendimento aos quesitos de qualidade;

- O analista de sistemas, representado pela sigla "as", possui todas as responsabilidades anteriormente descritas, somadas a atuações gerenciais:

- No nível tático, oferecendo suporte para a definição das metas de negócio, no que diz respeito aos modelos e planejamentos com os quais os processos serão implantados na fábrica;

- No nível operacional, compondo com engenheiros e gerentes na consecução dos processos e nas análises dos resultados obtidos por suas atividades operacionais;

- O engenheiro de produção, representado pela sigla "ep", possui todas as responsabilidades anteriormente descritas, somadas a atuações gerenciais:

- No nível estratégico, oferecendo suporte ao executivo de negócios, na concepção do modelo estratégico de produção de software a ser organizado para a fábrica;

- No nível tático, compondo com engenheiros e gerentes na definição do modelo de engenharia (de produção) a ser adotado pela organização, além de contribuir com os modelos gerenciais diversos e com a gestão de qualidade a serem implantados;

- No nível operacional, compondo com engenheiro de software e gerentes na definição dos modelos de processos de manufatura e nos esquemas de avaliação e validação dos mesmos, além de oferecer suporte à produção;

- O engenheiro de software, representado pela sigla "es", possui todas as responsabilidades anteriormente descritas, somadas a atuações gerenciais:

- No nível estratégico, oferecendo suporte ao executivo de informações 
para a concepção das estratégias de desenvolvimento a serem adotadas, para a estruturação organizacional tecnológica, para as decisões sobre plataformas gestoras e para as escolhas das técnicas de trabalho relativas ao tipo de fábrica desejável;

- No nível tático, compondo com engenheiro de produção e com a gerência na determinação do modelo de engenharia (de software) a ser adotado para a fábrica e na discussão da aplicabilidade das técnicas escolhidas, a serem implantadas para o trabalho, além de dar suporte ao recursos humanos, no que tange a pessoal especializado para esse tipo de empresa;

- No nível operacional, compondo com os demais elementos da gerência executiva para garantir a aplicação da engenharia determinada e participar da modelagem e da aplicação dos processos de desenvolvimento, além de contribuir com definições relativas a ferramental e suporte à produção (sob aspecto tecnológico).

\section{2 - EM SUMA...}

Este capítulo foi dedicado a definir o conceito de fábrica de software e a estrutura organizacional que a permeia, de forma a entendê-la tanto técnica quanto administrativamente.

Apresentou-se, também, o eLabSoft, tomando seu modelo com um modelo perceptível e exemplificável de como uma fábrica de sotware pode ser, entendendo-a sob a ótica de diversos autores e, indo adiante, sob as óticas dos processos produtivo e gestor, no que tange a suas organizações e dinâmicas processuais.

A visualização da empresa sob estas óticas foi utilizada, aqui, como estratégia para formular uma estrutura sobre a qual aplicam-se técnicas de produção e papéis profissionais, procurando estabelecer o contexto dos estudos do conhecimento e sua gestão e preservação. 


\section{CONHECIMENTO}

Há várias definições para o termo conhecimento que acabam por resumi-lo à simplicidade objetiva e eficaz da informação tratada, compreendida e armazenada, aplicável e em plena aplicação, em finalidades diversas, segundo objetivos específicos e especificidades circunstanciais.

Este capítulo procura formular conceito sobre as substâncias explícitas e tácitas desse termo, a fim de formar-lhe o corpo sobre o qual se dá o estudo das formas de sua gestão e, nesta, de sua preservação.

NONAKA e TAKEUCHI (1997:1-14), por exemplo, definem este corpo segundo crenças compromissadas que agregam e exigem que informações sejam capturadas, produzidas, guardadas e distribuídas, para a formação de um conceito único de conteúdo baseado na associação entre informação e ação. Conhecimento, segundo eles, é cognição determinada por modelos mentais, esquemas estruturais e percepções contextuais e integradas (como fonte e resultado) a habilidades e competências.

Os autores enfatizam a diferença conceitual entre os pensamentos ocidental e oriental e como esta diversificação influencia a formação do conhecimento. O pensamento ocidental é baseado na dualidade cartesiana, enquanto que o oriental, baseia-se na filosofia da unidade primordial. O primeiro separa o indivíduo (conhecedor) do objeto (conhecido) e de sua natureza ambiental; já o segundo unifica homem e natureza, indivíduo e objeto, compondo um só elemento pluralizado. Apesar de apontar tal diferença, não o fazem de maneira binária e excludente e, sim, buscando solidez metodológica na complementaridade analógica entre ambas as formas: uma composição da natureza do agregado "corpo-mente-sociabilidade-ambientação" com a apistemologia do conjunto formado por racionalismo dedutivo e empirismo indutivo.

TAVARES (2004:25-27), por sua vez, define conhecimento como o acumulado de experiências e aprendizados, cujo conceito é de difícil determinação, haja visto a fluidez e a subjetividade intrínsecas a ele. Citando diversos autores (o que lhe confere pertinência à característica de acumulação), completa sua proposição explicando sua abrangência de escopo, suas fronteiras não bem delimitadas, seu embasamento nas 
informações, seu alicerçamento em habilidades e competências, seu princípio humano e sua composição baseada em objetivo, ação e significado.

RAMASUBRAMANIAN e JAGADEESAN (2002:53-55) procuram estruturar a definição de conhecimento no conjunto de informações, experiências e especialidades coletado em vivências. Tal conjunto deve ser organizado, mantido e compartilhado. Apesar de este conceito aplicar-se de maneira genérica às mais diversas circunstâncias, os autores trabalham-no com o foco na pessoa dos profissionais, nos agrupamentos destas para a formação de equipes de trabalho e na corporatividade das organizações, formadas pela composição de pessoas e equipes, apontando para questões relativas ao conhecimento e à sua gestão, dedicadas ao negócio.

TERRA (1999) acredita que o conhecimento seja a capacidade individual de selecionar e interpretar informações, adquirida por processos de aprendizagem originados em conceitos behavioristas, cognitivistas e experiencialistas ${ }^{8}$. Conceitos estes que combinam ênfases - em experiências concretas, observações reflexivas, conceituações abstratas e experimentações ativas - na necessária interação social, que cria e recria a organização contextual perceptível.

Conhecimento é processo de composição e aplicação de informações, como resultado da contextualização de dados, representativo de uma evolução que parte de elementos básicos (os dados) para constituir elementos complexos de relação entre cognições (capacidade de perceber e absorver coisas e fatos através dos dados que as caracterizam) e habilidades para resolver problemas.

Este conceito evolucionário que leva dos dados às informações e destas aos conhecimentos, apóia-se, além dos já citados, em autores como SOUZA (2003), MARÇULA (2001) e STEWART (1998).

SOUZA (2003:3-16) argumenta ser o conhecimento um conjunto de informações capaz de caracterizar um saber específico sobre algo e que há uma relação profunda entre conhecimento e informação, a ponto de tornar confusa a distinção entre ambos. Sua abordagem é focada em Ensino à Distância e, atendo-se aos limites da mesma, a autora procura definir, sólida e distintamente, elementos importantes a ela e

\footnotetext{
${ }^{8}$ Por behaviorista, o autor entende condicionamentos e estímulos-respostas mudando comportamentos humanos. Por cognitivistas, discernimentos e compreensões de relações lógicas entre meios e fins e entre causas e efeitos, estabelecendo os saberes. Por experiencialistas, tensões e conflitos, estabelecidos pelas interações entre indivíduo e ambiente, gerando processos permanentes de revisão de conceitos.
} 
estabelece que informação é um conjunto finito de dados que possuem determinada semântica e cuja significação difere segundo a interpretação dos agentes que a utilizam, a influência de fatores temporais, a forma de transmissão escolhida e o suporte adotado para seu tratamento. O conhecimento, por sua vez, resume todo saber sobre como perceber, distinguir, absorver, guardar, aplicar e disseminar as informações relativas a um determinado tema, pelo domínio de técnicas para seus processos e linguagens para suas caracterizações. A autora apresenta informação e conhecimento como correlatos, mas não sinônimos, e caracteriza a informação como matéria-prima e conhecimento como a ciência do saber produtivo necessário para usá-la e transformá-la em produto.

MARÇULA (2001:8-16) considera o conhecimento como o resultado natural do aprendizado de alguém que adquire capacidade de criar novas informações e idéias a partir de interpretação e aplicação de informações em processos de tomada de decisão. Essas informações, insumos para aquelas, são o fruto de formatações e filtragens de dados, em busca de seus significados, de acordo com os contextos nos quais os recebem. Os dados, por sua vez, representam toda sorte de sinais entrantes e estimulantes, fornecidos pelo ambiente com constância e abundância. Novos conhecimentos aprendidos são guardados junto aos já anteriormente adquiridos, denominados "acumulados", conforme demonstra a figura 5.01, que busca explicitar os processos e os estágios da composição.

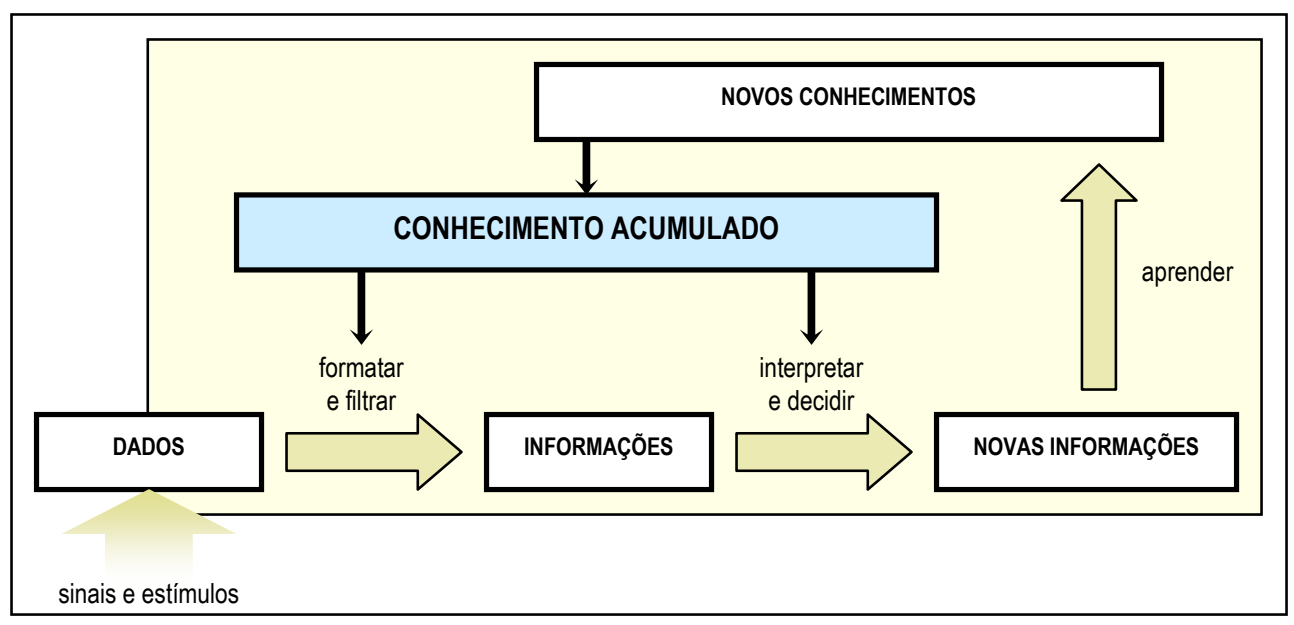

FIG 5.01 - A expressão do conhecimento e seu processo formador. Adaptada de MARÇULA (2001:15).

STEWART (1998:4-17) aponta o conhecimento como sendo mais que a soma de dados e que suas agregações, interações e acumulações são frutos de conexões destes dados, tal e qual peças em um mosaico, só possíveis com o aprendizado da experiência. Conhecer é dominar um determinado assunto, o que representa mais que o mero saber 
de um fato ou a simples posse de informações sobre determinada coisa. Este autor concorda com a dificuldade potencializada de distinção, pois qualquer definição limítrofe entre dado, informação e conhecimento é relativa ao contexto ora em evidência, ou seja, o que é dado em determinada situação, torna-se informação em outra; o que é informação sob determinado enfoque, torna-se conhecimento em outro.

Outros autores estendem o conceito evolucionário, apresentado pelos anteriores, colocando o conhecimento não como um fim, mas como um meio para a conquista de competências, excelências e sabedorias. Como exemplo: DAVIS e BOTKIN (1996), FLEURY e FLEURY (2001) e SETZER (2004).

DAVIS e BOTKIN (1996:43-62) definem conhecimento como informação posta em uso produtivo, num processo de aprendizagem evolutiva que transcende o conhecimento para conquistar sabedoria. A passagem de um estágio para outro (eles denominam estágio aos elementos de composição) é vista como um passo em função do desenvolvimento da inteligência. $\mathrm{Na}$ escalada proposta pelos autores, constam os estágios dos dados, das informações, do conhecimento e do domínio da aplicabilidade do conhecimento, o que eles intitulam sabedoria. Como resultado, conquista-se o saber de como aplicar os conhecimentos adequados a cada situação ou circunstância.

Estes autores criticam a forma indiscriminada como os termos conhecimento e gestão de conhecimento vêm sendo usados por empresas que não agregam valores ao seu capital intelectual pelo atendimento mínimo do processo de aprendizagem, usando, de forma despreocupada, conhecimento como sinônimo de informação e gestão de conhecimento como sinônimo de sistema de informações.

SETZER (2004:6-7) compõe o conceito evolucionário destacando a competência como fim e definindo-a como capacidade de produzir algo com uma preocupação focada, principalmente, na utilidade social da ação física envolvida - evidentemente maior que sintaxes, semânticas e pragmatismos - e envolvedora de habilidades relativas à sua área de conhecimento específica. A competência é subjetiva, visto que existe no universo interior de alguém, e objetiva, visto que o que quer que seja produzido a partir dela poderá ser visto por qualquer um. A competência é resultado da aplicação de conhecimento que, por sua vez, é descrito como o acúmulo de saberes resultante de associações subjetivas e pragmáticas de conceitos, baseadas em uma vivência pessoal. A subjetividade é razão da particularidade das vivências diferenciadas de cada um e o 
pragmatismo, da aplicabilidade do aprendizado resultante das experiências vividas, traduzidas por informações que, a seu tempo, são conceituadas como mensagens compostas de dados que o receptor consegue compreender e associar-lhes um significado. "Compreensão e significado dependem da capacidade de pensar, isto é, de associar percepções e certos conceitos a outros conceitos", descreve o autor, ao discorrer sobre a semântica e sobre recepção e interpretação, como capacidades humanas necessárias ao processamento dos dados, estes, enfim, definidos como uma representação simbólica quantificável, organizada segundo um objetivo e a sintaxe do protocolo especifico da linguagem em uso.

Setzer, entretanto, afirma ser impossível transmitir conhecimentos, o que, aparentemente, confronta a idéia de disseminação do mesmo, como parte de sua gestão, defendida por esse trabalho. O que o autor busca, no entanto, é um entendimento mais objetivo da essência da ação humana relativa ao conhecimento que, em sua opinião, restringe a capacidade transmissora das pessoas apenas aos dados, que podem ser recebidos como informações pelo seu receptor, para, posteriormente, ser incorporado a seu conhecimento, num processo independente da vontade ou da participação interna do transmissor.

FLEURY e FLEURY (2001:18-33) concordam com o conceito de que transferir conhecimento é uma das facetas da competência que indivíduos e empresas devem desenvolver e denominam, a essa competência, "agregação de valor", conforme demonstra a figura 5.02. O conceito evolucionário exposto pelos autores conta com três partes que, apesar de funcionalmente distintas, integram-se em interagência no processo do conhecimento: no primeiro momento, um processo de memorização e disseminação de informações garante a aquisição e o desenvolvimento de fragmentos potenciais de conhecimento. Estes elementos, num segundo momento, provocam a aprendizagem de alguns componentes de conhecimento, tais como o agir, o mobilizar, o transferir, o aprender, o engajar-se, o vislumbrar de estratégias e o assumir responsabilidades. Tais saberes são elementos importantes que, num terceiro momento, devidamente compostos, representam a competência desejável, tanto para a sociabilização do indivíduo, quanto à realização econômica da empresa.

A transferência de recursos de conhecimento e habilidades deve vir das capacitações provenientes da aprendizagem e gerar, para os indivíduos, dentro ou fora das organizações, mais conhecimento, novas habilidades e exigências de atitude. A 
considerar as necessidades das organizações, pode-se afirmar que todos estes elementos, no indivíduo, são componentes do conhecimento que ele, de alguma forma, precisa externar para que a agregação de valor não seja apenas pessoal.

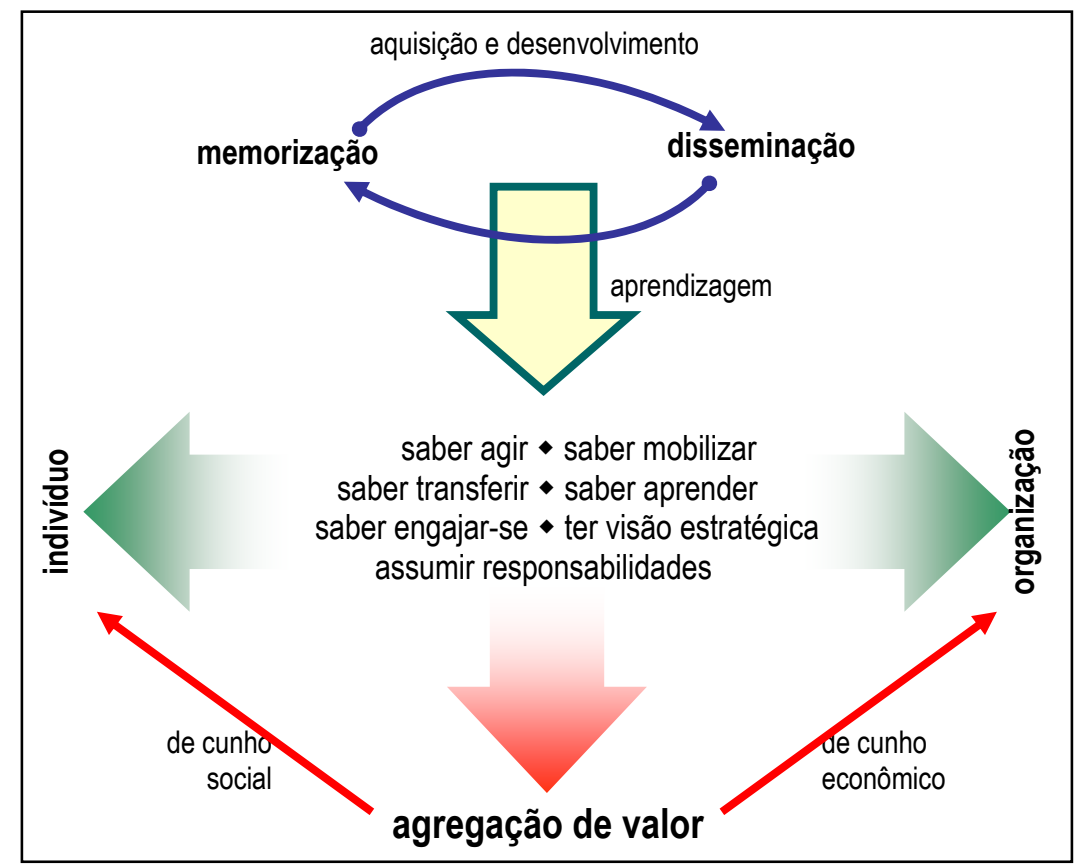

FIG 5.02: Conhecimento como viabilizador do desenvolvimento de competências. Adaptada de FLEURY e FLEURY (2001:21,31).

Além destes, outros autores podem, também, ser citados por proverem idéias diversas destas, sobre o conhecimento, seja para estudar sua estrutura e componentização, seja para discutir sua aplicabilidade, como instrumento. Entre eles, LÉVY (1996), SMALL e TATALIAS (2000) e NEUBAUER (2004).

NEUBAUER (2004:52-57) compara modelos de avaliação de inteligência no questionamento sobre sua essência, estudando as possibilidades de defini-la como característica homogênea, fechada em si mesma, ou como uma série de capacidades específicas independentes, reunidas sob alguma aleatoriedade, dadas as suas especificidades distintas e afinidades nem sempre determinadas entre si. Segundo o autor, inteligência é a ação do conhecimento, na acepção da palavra (pois origina-se do latin intelligere: entender, compreender, conhecer). Tal ação promove: a capacidade de orientação em meio às situações que exigem tomadas de decisão; e, valendo-se do que postula Cattell ${ }^{9}$ (Neubauer é quem o afirma), a promoção da conjunção da mobilidade cognitiva (denominada "fluída") com a solidificação das experiências aprendidas (denominada "cristalizada").

\footnotetext{
${ }^{9}$ CATTELL, Raymond B.; Intelligence: Its structure, growth, and action; EUA: Elsevier, 1987.
} 
Sua pesquisa, realizada na Universidade Karl-Franzens (Áustria), define uma estrutura que associa e contemporiza os modelos da Avaliação do Quociente de Inteligência (de Alfred Binet), do Fator G (de Charles Spearman) e da Pirâmide Hierárquica de Funções (de John Carroll), com o Berlinense (de Adolf Jäger), sem desprezar conceitos de vinculação direta entre saberes, emoções, especializações e desempenhos, como o proposto pelo Paradígma Especialista-Novato (de William Chase e Herbert Simon) e o proposto pela Inteligência Emocional (de Peter Salovey e John Mayer). A proposição de Neubauer contempla as contribuições de todos estes estudos através de gráficos representativos, cuja síntese é apresentada pela figura 5.03, na qual as capacidades parciais dos diversos modelos se fundem para a formação e solidificação do conhecimento.

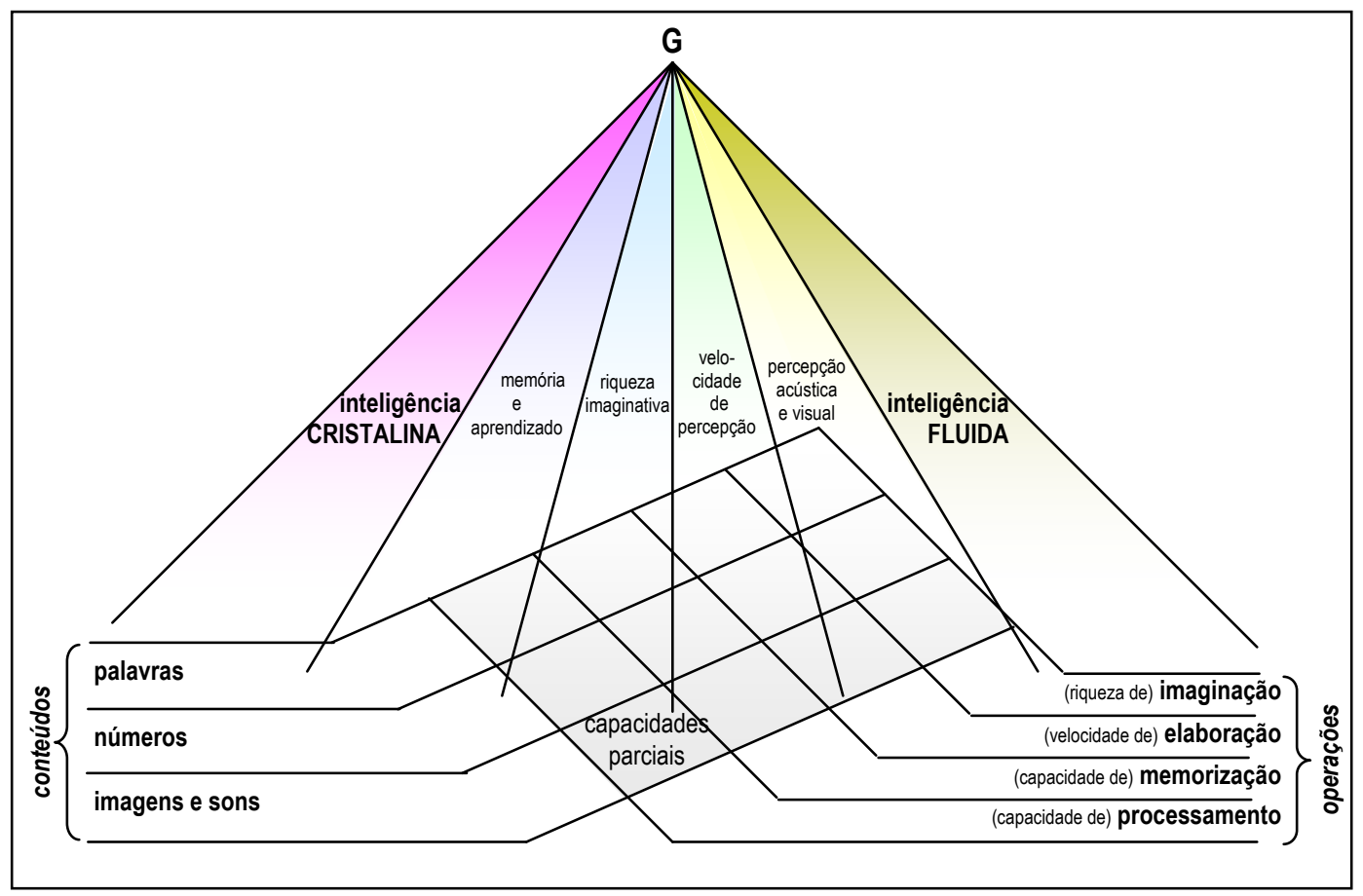

FIG 5.03: A composição da inteligência, pela conjunção de modelos Adaptada de NEUBAUER (2004:55).

A base do modelo representado pela figura 5.03 envolve, de maneira mais explícita, os postulados dos modelos Piramidal e Berlinense. A ambos, o autor associou o Fator G, o qual aparece no topo da pirâmide, em um, e na concavidade de operações e conteúdos, em outro. Os conteúdos têm uma identidade estabelecida com a inteligência cristalina, visto que representam o conhecimento acumulado, formado por insumos (palavras, número, imagens e sons conhecidos) que serão aplicados nas operações que resultarão em novos conhecimentos, formados por dados de mesmas espécies dos insumos, a serem acumulados. As operações, por sua vez, têm identidade estabelecida 
com a inteligência fluida, visto que representam a dinâmica do processo de composição da inteligência na formação dos conteúdos (conhecimentos). As relações entre as operações e os conteúdos identificam capacidades parciais de funções intelectuais que, somadas a elementos de composição das inteligências, tais como memória, aprendizado, imaginação e percepção, formam uma inteligência geral (General Intelligence $\rightarrow$ G factor) e compõem as habilidades e os saberes mensuráveis em diversos testes de inteligência, entre eles: o de QI e o do Paradigma Especialista-Novato.

SMALL e TATALIAS (2000) pensam as questões do conhecimento sob a ótica das relações deste ativo com as pessoas e como elas o produzem e o utilizam como recurso, olhando-o sob uma abordagem holística, que envolve diversas abordagens, e que provoca a divisão do contexto de estudo em duas dimensões, apresentadas pela figura 5.04: uma do próprio conhecimento e outra de sua dinâmica relacional.

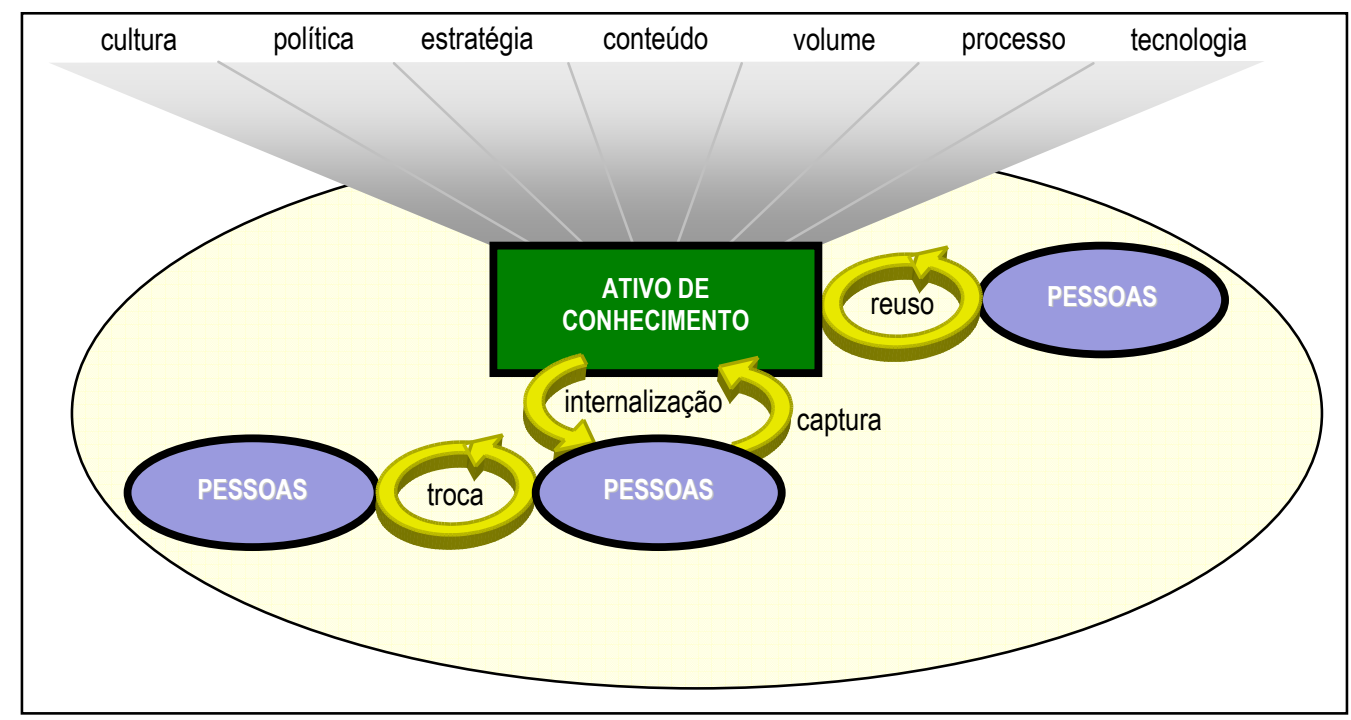

FIG 5.04: A dinâmica das relações entre pessoas e conhecimento Adaptada de SMALL e TATALIAS (2000).

A dimensão do conhecimento como objeto (chamado de ativo de conhecimento, pelos autores), discute a composição do mesmo sob uma abordagem de elementos diversos que provêem e influenciam sua criação, colocando, ao centro, o aspecto relativo ao conteúdo, ou seja, a informação propriamente dita como elemento de caracterização e reconhecimento existencial, e juntando outros aspectos, como o da estratégia, que exige alinhamento entre a corporação e seus elementos de sustentação; o do volume (denominado como dimensão mensurável pelos autores e, aqui, chamado volume para não confundir a dimensão "quantificação" com a dimensão “abordagem”), que se preocupa com definição e uso de métricas que quantifiquem o conhecimento, 
seus benefícios e sua evolução; o da política, que delineia sua razão e norteia sua aplicação; o do processo, que procura definir as formas com que o conhecimento deva ser percebido e aplicado na determinação de missões, metas e operações empresariais; o da tecnologia, que busca os meios para viabilizar criação, armazenamento e difusão do conhecimento pela e para a organização e, por fim, o da cultura, que define ambientação e contextualização do mesmo aos quesitos organizacionais e mercadológicos do negócio e os discute sob a égide de valores, normas e práticas

A dimensão dinâmica da relação propõe as atividades consideradas críticas (por eles) à criação, aplicação e renovação do ativo do conhecimento, bem como as relações deste com pessoas que capturam o conhecimento e o armazenam de alguma forma, que buscam em ativos consolidados a internalização de algum conhecimento ou que apenas acessam o ativo para reutilizar algum conhecimento anteriormente internalizado. Os autores apontam, ainda, uma relação de conhecimento entre pessoas, a que chamam troca de conhecimento, que podem provocar contribuição com o ativo estabelecido. As três atividades básicas (troca, captura-internalização e reuso) são naturalmente cíclicas.

O conceito de Small e Tatalias concorda com o de LÉVY (1993:3-27), que também imagina o conhecimento como processo cíclico e contínuo, só que apresentando-o como uma dinâmica central que correlaciona ciência, sociedade, economia, ideologia, produção e tecnologia, envolvendo formas de perceber, pensar e sentir, estruturado nas experiências dos membros de coletividades especificas (considerando que cada coletividade guarda seus próprios conhecimentos originais culturas, por exemplo), no decorrer do tempo; o que é denominado por ele de transcendental histórico. Para o autor, a dinâmica transcende qualquer limite possível e imaginável dos elementos, os quais não passam de abstrações do contexto em que os indivíduos vivem. Em sua obra, Lévy discorre sobre as relações disciplinares entre os elementos dimensionais, conforme demonstra a figura 5.05, na busca de formas de retratar a organizicidade e a representatividade de tal organização, como meios de dominar processos aparentemente informais de captura, estruturação, absorção e disseminação de co-

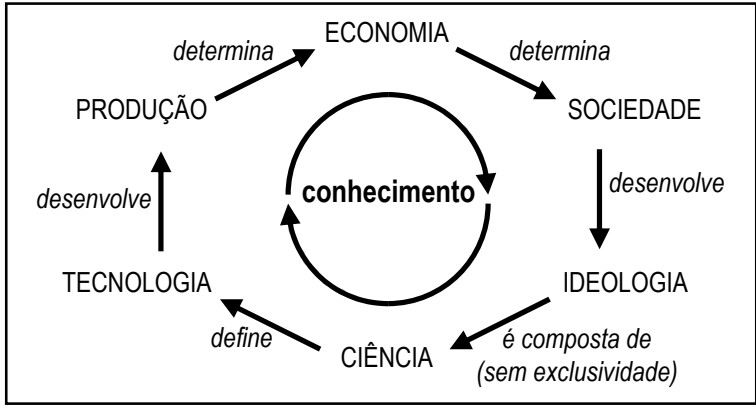

FIG 5.05: Visão circular dinâmica do conhecimento. nhecimentos, tais como o hipertexto (em 1993, ainda uma novidade). 
A Lévy não agrada a idéia de representação diagramada de seu conceito, pois, ainda que houvessem retroações nos fluxos percebidos, ou outros fluxos compondo ligações intermediárias entre os elementos todos, o gráfico, em sua opinião, seria uma expressão mistificadora, conforme seus elementos passem a representar meras dimensões de análise, como se pontos de vista pudessem ser congelados em disciplinas. Neste trabalho, porém, a diagramação faz-se necessária para representar tal relacionamento dinâmico entre disciplinas dimensionais, para que se visualize, mesmo que de forma incompleta, a relação dos elementos com o conhecimento. Para os propósitos deste trabalho, basta percebe-los e às suas relações, de forma sistematizada, sem detalhes de transcendências.

As interpretações de Neubauer, de Lévy e de Small e Tatalias representam, aprofundadas suas análises, discussões sobre dimensões da composição e da dinâmica relativas ao conhecimento em sua essência. Isto estabelece aspectos, focos e profundidade que este trabalho não pretende discutir, por envolver áreas não contextualizadas, como a psicologia, a biologia e a educação pura. Serviram, então, apenas como mapeadoras, ou norteadoras, e complementares, pela forma ilustrativa como puderam ser apreciadas.

Apesar da diversificação de formas, ângulos e pontos de vista com que os autores citados apresentam suas derivações sobre o conhecimento, há uma essencialidade comum, uma concordância percebida como objetividade, necessária ao embasamento de suas idéias em torno da ação do conhecimento, pois que o termo, em nenhum deles, foi apresentado como objeto estático e, sim, como elemento dinâmico. As derivações são necessárias, pois necessário é o entendimento do assunto sob aspectos diversificados e necessária é a amplificação das formas que levem ao conhecimento sobre o conhecimento.

Não é novo o conceito do conhecimento, tanto o essencial comum como as especificidades individualizadas de cada autoria, alegam BOFF et al. (2001:1-2), ao afirmarem que o foco da necessária gestão do conhecimento, de agora, apenas vem iluminar idéias até então obscuras no ambiente de trabalho das organizações, ou seja: todos sabiam que o conhecimento existia, todos entendiam sua importância para o ser humano e para as empresas, mas ele mantinha-se como uma "caixa-preta" no que diz respeito a seus mecanismos, sua geração e sua gerenciabilidade, como conjunto sistematizado de informações tratadas, compreendidas, estocadas e difundidas, em prol 
da agregação de valores e da evolução organizacional. Abrir tal "caixa" e entender seus mecanismos começa pela identificação dos tipos de conteúdo que se possa produzir através dela.

\section{1 - TIPOS DE CONHECIMENTO:}

Há tipos diferentes e diferenciados de conhecimentos que devem ser percebidos, pois alguns só terão interesse em níveis pessoais de trabalho, enquanto outros adquirem importância organizacional. Além do que, não se pode negligenciar a possibilidade de um certo conhecimento, tipicamente pessoal em determinado instante, vir a ser incluído no rol dos organizacionalmente importantes, quando uma situação qualquer mudar.

A tipificação aqui pretendida começa com a apresentada por NONAKA E TAKEUCHI (1997:61-68), e já comentada no início deste trabalho, que classificaram o conhecimento segundo duas qualificações: tácito e explícito. Para as pretensões deste trabalho, esta tipificação é a mais importante.

\subsection{1 - CONHECIMENTO TÁCITO:}

O tácito é o difícil de ser articulado, pois envolve e se estrutura em conhecimento pessoal incorporado, envolvendo fatores intangíveis, como crenças, perspectivas e valores pessoais. Os autores classificam-no como o tipo mais importante e o modo dominante na cultura oriental, permeado por elementos cognitivos e técnicos: cognitivos são esquemas, paradigmas, perspectivas, crenças e pontos de vista, entre tantos elementos que permitam a formação dos modelos mentais necessários ao entendimento que os indivíduos teçam de seus mundos; técnicos são o que estes indivíduos acumulem de saber concreto, de técnicas e de habilidades.

\subsection{2 - CONHECIMENTO EXPLÍCITO:}

O explícito é o articulável em linguagem formal e pode ser formulado e expresso com afirmações gramaticais, especificações e expressões matemáticas. Os autores o classificam como o modo dominante de conhecimento na tradição ocidental. É o modo desejável de conhecimento, em questões organizacionais, por ser disseminável e os estudos de Nonaka e Takeuchi baseiam-se na relação entre tácito e explícito e na competência que se deve desenvolver para transformar o tácito em explícito.

Na visão de CHERUBINI NETO (2002:15-18), o conhecimento possui outras 
categorizações, como popular, teológico, filosófico e científico, por exemplo, que o autor desenvolve com base em citações de outrem.

\subsection{3 - CONHECIMENTO POPULAR:}

O popular é o empírico, formado pelo senso comum, que é provido pelas experiências de dia-a-dia das pessoas, com suas situações, circadianas ou não, seus acasos e de suas investigações mais ou menos formais sobre os mais diversos assuntos. É um conhecimento vulgar e, por isso, a forma mais comum de ser encontrado, nas coletividades sociais.

\subsection{4 - CONHECIMENTO TEOLÓGICO:}

O teológico é o revelado e aceito como revelação, por fé teológica, como conjunto de verdades a que os homens podem chegar mediante aceitação de revelações divinas, valendo-se de argumentação advinda de autoridades e aceita de modo especial. Os autores chegam a citar elementos originários de livros sagrados, aceitos, racionalmente, pelos homens, após serem submetidos à crítica histórica exigente.

\subsection{5 - CONHECIMENTO FILOSÓFICO:}

O filosófico é o objeto de investigação e método, no limiar da explanação científica, que estabelece, pela discussão, a realidade mediata e, pela correlação, a física e a metafísica caracterizantes dos elementos de uma realidade. É o conhecimento que busca deterministicamente, estabelecer os conceitos necessários ao entendimento contextual. Pode-se afirmar que o conhecimento teológico seja, também, filosófico, mas, neste caso, a informação revelada não é, necessariamente, tomada como dogma e sim, aproximando-se do aspecto científico, investigada em nome do entendimento da realidade.

\subsection{6 - CONHECIMENTO CIENTÍFICO:}

O científico é o aplicado quando preocupa-se com a expressão e a ciência sobre os fenômenos e sobre suas relações de causa e efeito, dentro de contextos definidos e com objetivos e finalidades bem caracterizados. Transpõe os limites do empírico e resulta da aplicação de metodologia na busca de evolução de domínio sobre situações e circunstâncias (negócios inclusos). Esta categoria de conhecimento tem, em suas fundamentações, concordâncias de MARCONI e LAKATOS (1996:15-21) e de 
ANDRADE (1998:101-107), conforme pode-se perceber pelo mencionado no capítulo um, pois estas autoras também preocupam-se e focam as questões da metodologia científica para estabelecimento de conhecimentos.

Na visão de BUKOWITZ e WILLIAMS (2002:19), há uma classificação mais simples, porém não menos abrangente, composta de, somente, duas categorias:

\subsection{7 - CONHECIMENTO SABIDO:}

Aquele que o indivíduo sabe que sabe. Não se extingue, na opinião das autoras, nenhuma das categorizações vistas anteriormente; ou seja, apesar delas não desenvolverem maiores detalhes, percebe-se que trabalham com as possibilidades propostas, inclusive com a idéia que do sabido, uma porção é tática, outra, explícita.

\subsection{8 - CONHECIMENTO DESCONHECIDO:}

Aquele que o indivíduo não sabe que sabe. Naturalmente qualificável como tático, compõe todo um conjunto de saberes integrados ao jeito como o indivíduo executa formas de trabalho que se tornaram hábitos e se mecanizaram e, sobre as quais, ele nunca equacionou ou, sequer, pensou com intenção de detalhamento de processo.

\section{2 - A ORGANIZAÇÃO DO CONHECIMENTO:}

Para que a empresa capacite-se a gerenciar o conhecimento, é necessário que haja estruturas de organização deste ativo. Apesar desta estrutura não ser o foco deste trabalho, alguns autores foram pesquisados e suas proposições merecem ser vistas, pois entender o objeto do conhecimento é necessário ao entendimento de sua gestão e levou a definições de como atuar em prol de sua preservação. Uma das formas de organizar o conhecimento é segundo dois aspectos: conteúdo (estrutura, antologias e dimensões) e geração/aplicação (processo e dinâmica):

\subsection{1 - ABORDAGEM DE CONTEÚDO:}

ANGELONI (2002:xv-xxiii), em busca de um modelo teórico para a organização do conhecimento, utiliza-se de um modelo atômico (de Donald Schon) em sua estruturação tridimensional para o conteúdo do mesmo, no qual percebe-se: uma preocupação com a estrutura de conhecimentos, sistemas e suas relações, formais e informais, estabelecidas entre indivíduos e atributos, com suas organizações e papéis. 
Sobre tal estrutura, a autora desenvolve sua interpretação das dimensões da organização, da tecnologia e da pessoa, baseando-se, ainda, na abordagem sociotécnica de organização e visualizando o conhecimento segundo sua abrangência ambiental, apoiado sobre o sistema de informações da organização.

Com a proximidade do modelo sociotécnico de Laudon e Laudon, apresentado pela figura 3.05, a autora propõe uma dimensão de infra-estrutura organizacional, pela qual se pretende transcender a visão newtoniana-cartesiana da organização, como conjunto de fragmentos, e alcançar uma visão holística, da mesma, como um todo dinâmico (aí com certa proximidade do que apregoam Nonaka e Takeuchi), o que exige trabalhar sobre a cultura organizacional e o estilo gerencial, buscando gestão participativa e estrutura flexível. Outra dimensão proposta é a da tecnologia, a qual envolve computadores, softwares e redes e todo o recurso tecnológico com eles envolvidos ou deles decorrentes (alguns dispostos no modelo, como de processos definidos, de bancos de dados, de edição e gestão eletrônicas de dados e de tratamentos complexos de dados). A terceira dimensão é a de pessoas, ou seja, das características pessoais associadas ao conhecimento e de como este se integra, em diferentes níveis, às ações, habilidades e competências dos indivíduos, através da ação de seus modelos mental e de aprendizagem, da oportunidade de suas intuições, criatividades e sensos inovadores e da providência de seus perfis de compartilhamento.

OLIVEIRA JÚNIOR (2001:138-141), por sua vez, percebe, no aspecto conteudista do conhecimento, necessária taxonomia para sua organização, a qual permite gerenciabilidade, ao menos inicial, dos elementos, pela observação de seus posicionamentos como mais ou menos tácitos, mais ou menos difíceis de transferir, conforme mostra a tabela 5.01, que determina as dimensões taxonômicas.

A taxonomia proposta compõe-se de dimensões de continuidade: a primeira delas define o que é tácito e o que é explícito e dinamiza a classificação entre o completamente intransferível (vermelho) e o completamente transferível (verde), decompondo-se em duas sub-dimensões: um continuum entre o não ensinável e o ensinável e outro do não articulável ao articulável, observando que o ensinável acontece antes de ser definitivamente explícito e o não articulável já pode ser ensinado, por não ser totalmente tácito; a segunda dimensão de continuidade é o da observabilidade em uso, uma função da extensão do conhecimento em exposição que influencia sua transferibilidade (grande ou toda extensão observável) ou intransferibilidade (pouca ou 
nenhuma extensão observável); a terceira é expressa pelo continuum da quantidade de informação requerida para a caracterização do conhecimento, ou seja, quanto maior o número de elementos envolvidos, maior a complexidade e menor a transferibilidade; a quarta dimensão de continuidade é da dependência do conhecimento e mede o quão disponível ele encontra-se para uso isolado, o que o torna mais transferível, e o quão comprometido ele encontra-se a conjuntos mais complexos e mais difíceis de transferir.

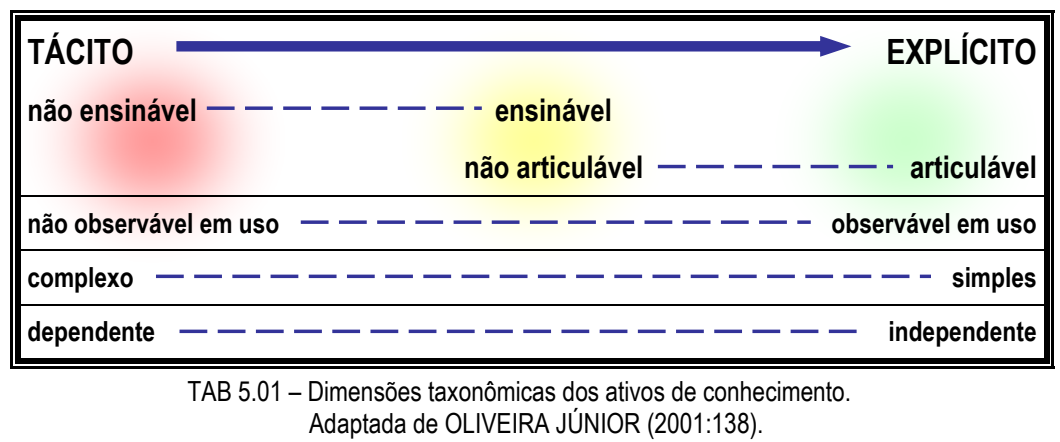

MIRANDA (1999:286-292) também preocupa-se com a taxonomia, porém com outra abordagem, por entender o conhecimento sob forma estruturada, como a combinação dos aspectos estratégico e tático de conjuntos de informações. Ele propõe que sua organização deva abranger uma classificação segundo a taxonomia das ações estratégicas às quais o conhecimento será empregado e, ainda, que uma esquematização das informações que o estruturam formem seu conteúdo.

A taxonomia, proposta pelo autor, combina, na base da organização do conhecimento, os dados ambientais referentes ao negócio, tanto os internos quanto os externos à empresa, devidamente distinguidos uns dos outros. Sobre eles, propõe uma camada de informações, sendo que as de cunho tático (que agregam as operacionais) apoiam-se sobre os dados internos e as de cunho estratégico, sobre os externos. Sobre estas, por sua vez, visualiza o entendimento do conhecimento em si, agregando e combinando as informações (o autor denomina "conhecimento estratégico" a esse produto da composição do que é tático com o que é estratégico). Este conhecimento, documentado segundo algumas dimensões (as quais representam parâmetros de caracterização do mesmo e lhe permitem identificação de situações e circunstâncias em que possa ser aplicado), é base de sustentação para a inteligência estratégica da empresa, que, por sua vez, vai servir à elaboração da estratégia de negócio, que embasa suas ações estratégicas.

PFLEEGER (1999:32-38) faz algo próximo da proposição de Miranda, sem ater- 
se ao detalhamento dimensional. O que ela propõe para a elaboração estrutural de um conselho técnico de engenharia de software pode, por analogia, ser a composição organizacional do objeto do conhecimento de qualquer negócio, inclusive o do conselho técnico de engenharia de software. A autora traz um conceito de organização que vai ao estrutural físico, a partir do contextual abstrato; uma ontologia que conduz da organização ambiental e contextual do conhecimento na organização do negócio ao detalhamento "atômico" do meta-dado sobre a informação que caracteriza o conhecimento relativo ao negócio, conforme a figura 5.06 demonstra: o conhecimento, uma vez descrito, possui três níveis de informações organizacionais: sua classificação (as opções de classificação apresentadas pela figura representam, apenas, alguns exemplos, os quais devem ser configurados conforme o negócio ou a empresa), sua área de aplicação (com possíveis sub-classificações de áreas necessárias) e sua composição (também reconfigurável segundo a aplicação).

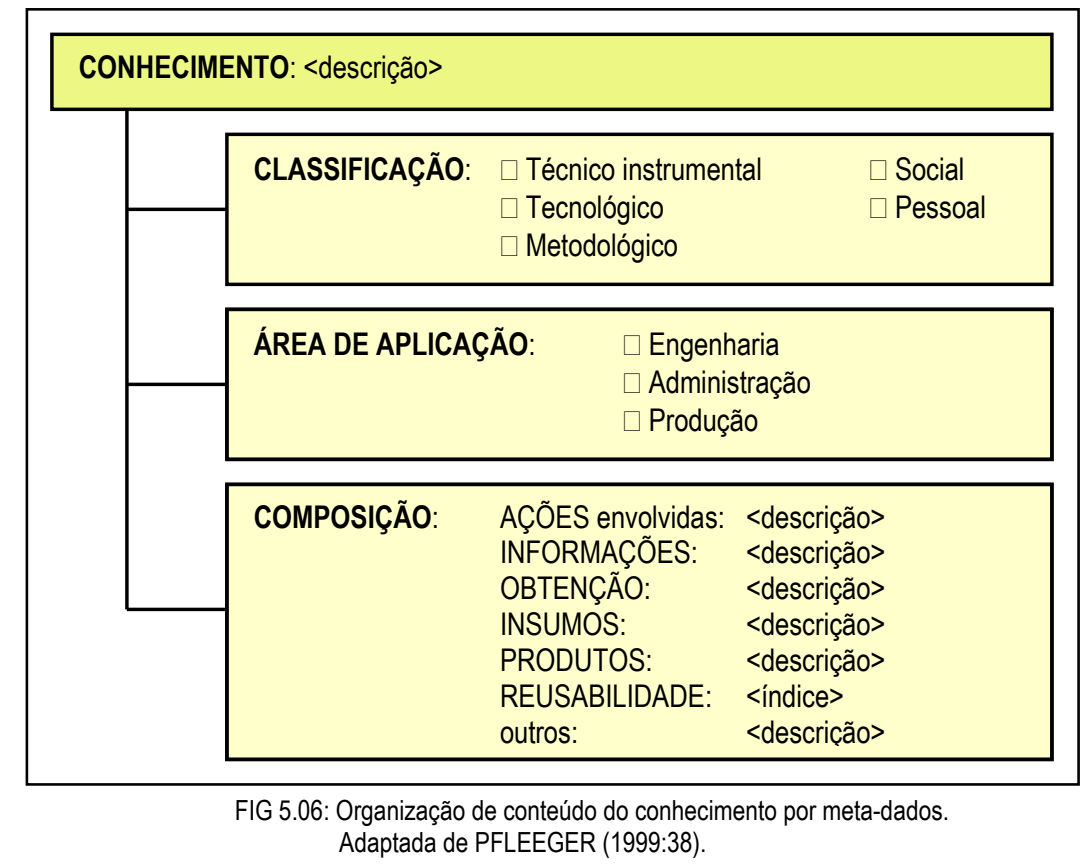

O conceito de ontologia é explicado por diversos autores, dos quais três foram destacados: MACEDO (2003), OLIVEIRA et al. (2004) e FELIX (2003).

MACEDO (2003:86-107) apresenta tese alicerçada em estudo para definição de uma memória corporativa focada em questões estratégicas (strategic corporate memory). Considera, em face das características de competitividade do mercado, argumentos defensores de avanços, nas engenharias de software e de requisitos, tais que suportem a proposta de uma arquitetura de memória estruturada em especificidades 
estratégicas e táticas que permeiem a competência competitiva das organizações, através dos conhecimentos de seus partícipes. Daí a necessidade de uma organização explícita do conhecimento. O que ele propõe através da ontologia.

Para o autor, ontologia é uma abordagem de definição de um conhecimento de domínio de uma maneira genérica, tal que o entendimento do mesmo seja aceito pela comunidade desse domínio. Uma ontologia especifica um conhecimento de maneira conceitual, para uma determinada área do conhecimento, sendo que a essência do objeto do conhecimento pertence a esse domínio. Para ele, é abordagem adequada para expressar a aquisição, a conceituação e a formalização de um conhecimento e pode ser classificada, do pondo de vista da apresentação, como: altamente informal (quando utiliza linguagem natural, como em glossários); semi-informal (quando apresenta-se em forma restrita e estruturada de linguagem natural, como em glossários estruturados pela inclusão de atributos); semi-formal (quando utiliza linguagem formalmente definida e artificial. O autor sugere "Ontolingua", numa referência a Fikes et al. ${ }^{10}$ ) e; rigorosamente formal (quando utiliza linguagem com semântica formal, teoremas e suas comprovações).

O autor explica, também, que uma ontologia é composta de: conceitos (suas unidades básicas, vinculados entre si através de uma rede de relacionamentos, formando grupos estruturais, nos quais cada conceito possui um conjunto de propriedades, denominadas atributos, num sistema próximo ao apresentado pela figura 5.06); relacionamentos (seus vínculos estabelecidos entre conceitos e grupos de conceitos, formando uma rede de caracterização ou, mesmo uma rede de conjuntos e subconjuntos) e; axiomas (suas regras de prevalência em uma dada ontologia, regidas por sentenças sempre verdadeiras). Os relacionamentos podem ser dos tipos: taxonômico (que especializa conceitos e usa noções de classe e sub-classe em uma hierarquia "is-a"); mereológico (que se compõem com conceitos "part-of", ou seja, um conceito sendo parte de outro conceito); cronológico (que possui precedência sobre os conceitos relacionados e associados, permissivamente temporais) e; topológico (caracterizado pela propriedade da conexão, através do conceito "connect-to", a outros conceitos, gerando e sofrendo influências).

\footnotetext{
${ }^{10}$ FIKES, Ricahrd; FARQUHAR, Adam; RICE, James; Tools for Assembling Modular Ontologies in Ontolingua. Knowledge Systems Laboratory; in: Proceedings of the $14^{\text {th }}$ National Conference on Artificial Intelligence (AAAI '97); EUA: AAAI - the American Association for Artificial Intelligence, julho de 1997.
} 
Tipologias podem, ainda, caracterizar as ontologias de domínio, de tarefa, de uso geral, de representação, de generalização e de aplicação, segundo Macedo, porém, transitam uma modalidade da organização do conhecimento que não constitui o principal foco deste trabalho e, por isso, não serão melhor detalhadas aqui, apenas citadas, bem como as aplicabilidades e os métodos de descrição.

O autor reproduz um exemplo de uso de conhecimento organizado na produção de uma arquitetura de software, utilizando os princípios da inteligência artificial, e trabalhando com agentes de software (que muito se assemelham ao conceito de personagem interno do RUP/UML). O exemplo leva à arquitetura da memória corporativa estratégica (strategic corporate memory) de uma organização e contém uma estrutura hierárquica de organização dos elementos de conhecimento que formam o ativo intelectual da empresa. O exemplo representa o uso da ontologia, conforme demonstra a figura 5.07, utilizando relacionamentos mereológicos (primeiro para o segundo e segundo para o terceiro níveis) e taxonômicos (terceiro para o quarto níveis, na subordinação do processo). O que o exemplo procura é a demonstração do organograma de uma empresa visto através de ontologias expressivas da estrutura do conhecimento relativo a ela e a seus negócios.

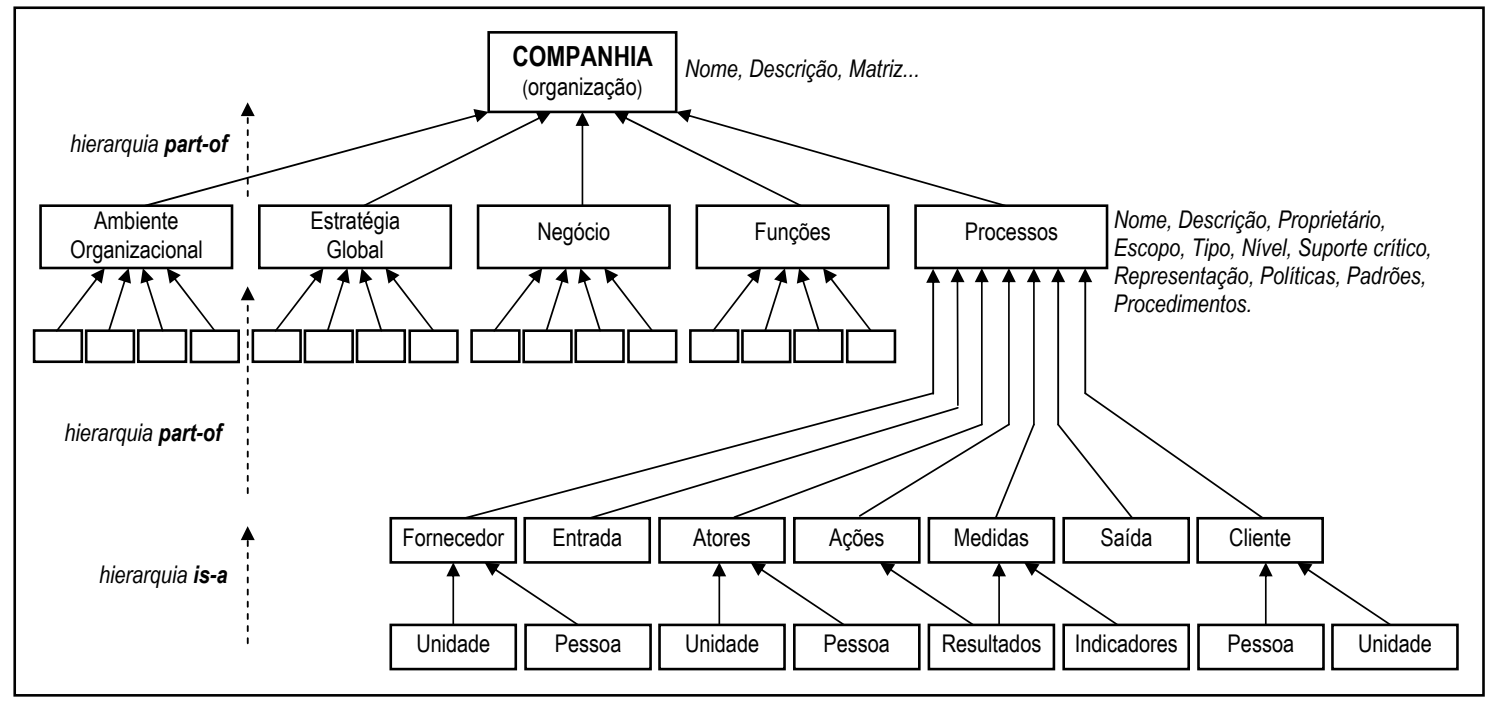

FIG 5.07: Ontologia do conhecimento sobre a empresa (organização), com foco no processo. Adaptada de MACEDO $(2003: 89,93)$

Cada um dos itens organizacionais do primeiro nível possui suas decomposições em elementos de nível subordinado, porém, a figura detalha apenas um deles: propositadamente, o processo. O negócio desvenda-se por ontologias de relacionamentos "part-of", ou seja, cada nível que se abre, subordinado ao elemento superior, é "parte de" este elemento, formando um conceito encadeado de como está 
composto o conjunto de conhecimentos sobre a empresa e sobre seus negócios. Nos níveis mais abaixo, representados na figura (5.07), há relacionamentos "is-a", ou seja, cada nível aberto por subordinação ao elemento superior é um representante (ou, uma representação) do elemento acima.

O autor, dado o resultado da aplicação da ontologia, ou seja, dada a viabilização de domínio da organização do conhecimento, deriva um modelo de informações e define a arquitetura genérica da memória corporativa estratégica, objetivo de toda a aplicação dos conceitos ontológicos. A figura 5.08 representa um exemplo de modelo definido por ele, projetado em camadas de aplicação. Os agentes de intermediação estabelecem as relações (interfaces) entre as pessoas encarregadas da gestão de negócio, os repositórios (organizados segundo o modelo de informações) e os aplicativos (programas). Esta concepção ambiental leva ao projeto, configurado em camadas de componentes, de intermediação, de repositórios e de fontes.

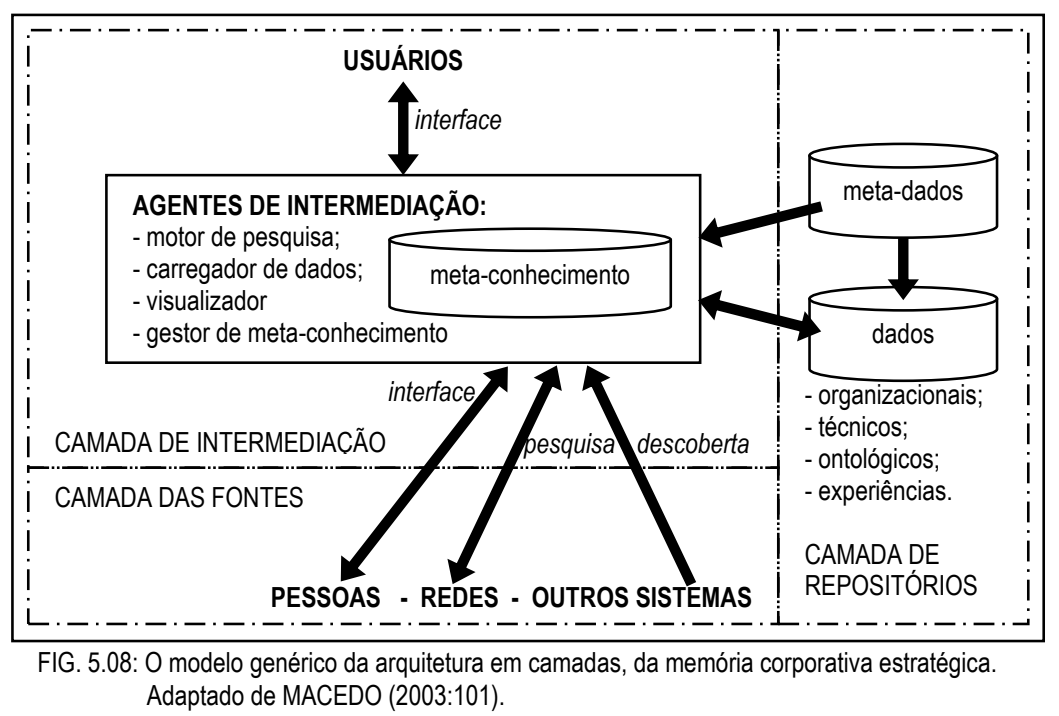

OLIVEIRA et al. (2004:1-10) afirmam que uma ontologia é um conjunto de informações que resume o meta-conhecimento, ou seja, que tem capacidade para especificar, de forma explícita, objetos, conceitos e outras entidades representativas de um contexto de conhecimento, existentes em uma determinada área de interesse. A ontologia exige formalismo para garantir definição prévia de conceitos e restrições e assegurar seu compartilhamento. Os autores utilizam-na para definir a infra-estrutura necessária à integração de sistemas inteligentes e, com isso, conquistar: compartilhamento do conhecimento intra-equipes de forma interdisciplinar; interoperacionalidade pela integração de informações em aplicações distribuídas; 
referencial sobre domínios de desenvolvimento; reusabilidade de modelos sistêmicos no nível do conhecimento; e agilização e flexibilização da recuperação de recursos em bases de informações.

Tais conquistas, segundo os autores, são exemplificadas pela aplicação de uma proposta tecnológica de padronização e de sistematização de padrões, pela organização de descrições e representações, assim como de restrições de sistemas de padrões, promovendo um vocabulário comum entre profissionais - de padrões, de aplicações, etc. - envolvidos com determinado empreendimento. Tal proposição corrobora a de Macedo à medida em que também preocupa-se com o domínio sobre o conhecimento através de sua organização.

Outra autora, FELIX (2003:37-44), resume o conhecimento segundo duas dimensões organizacionais: a epistemológica e a ontológica. A dimensão ontológica, em sua opinião, expressa teoria advinda de estudos do ser, ou seja, dos conhecimentos individuais que, naturalmente, são potencializados, amplificados e desenvolvidos pela interação do indivíduo com seu meio e com as pessoas que o compõem. Sendo esta dimensão a da especificação de uma conceituação, pelos conjuntos de palavras e símbolos, ligados sintática e semanticamente, com o objetivo de descrever um dado domínio de conhecimento, ela enfatiza que a criação deste acontece continuamente em todos os níveis da organização, como um processo de ampliação do conhecimento, que transita por fases, da individual à organizacional, passando pela grupal. Os conhecimentos individuais ampliam-se e desenvolvem-se a partir da pessoa, disseminando-se para outras pessoas e para as instituições organizacionais. A organização tem um papel fundamental nesse processo de criação de seu conhecimento próprio: facilitar a realização de atividades em grupo, de forma a permitir reciclos, recriações, armazena-mento e disseminação do conhecimento individual.

Segundo Felix, a dimensão ontológica desta dinâmica de garantia dos saberes é representada pela figura 5.19, que reúne elementos de conhecimento, por relação e associação, a fim de prover uma organização de saberes e habilidades. Organização esta que vai do pessoal ao empresarial, efetivando um ativo intelectual, fruto da organização dos conhecimentos

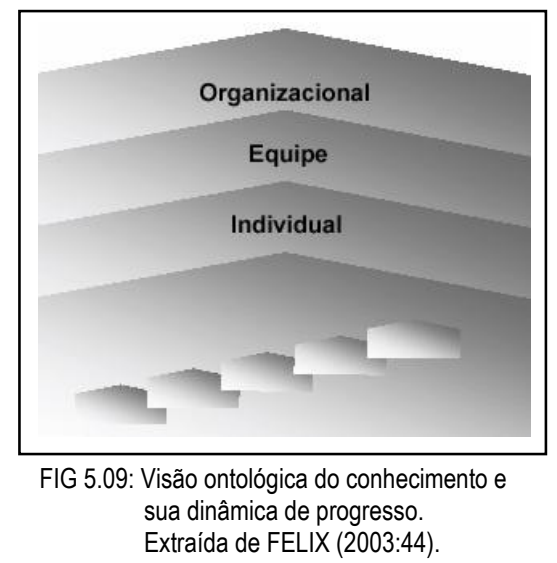


compartilhados de cada um, tácitos ou explícitos e, esses, registrados ou não em bases de conhecimentos (dados + experiências).

BUKOWITZ e WILLIAMS (2002:73-85,97-105) também se preocupam com esta dinâmica de crescimento do conhecimento organizado, buscando determinar, inclusive, fenômenos de criação de papéis funcionais e profissionais voltados à guarda, à coordenação e à gestão dos trabalhos de evolução do ativo de conhecimento. Elas transcendem, portanto, a visão evolucionária que leva do indivíduo à equipe e, desta, à organização e procuram caracterizar a tridimensionalidade do conhecimento, na qual tal evolução encaixa-se. O conhecimento, no entender das autoras, compõe-se em um espaço tridimensional, representado pela figura 5.10, em cujo eixo horizontal pode-se imaginar todas as prerrogativas inerentes ao seu conteúdo, com as devidas especificações e parametrizações vitais - algo como a proposta de MIRANDA (1999).

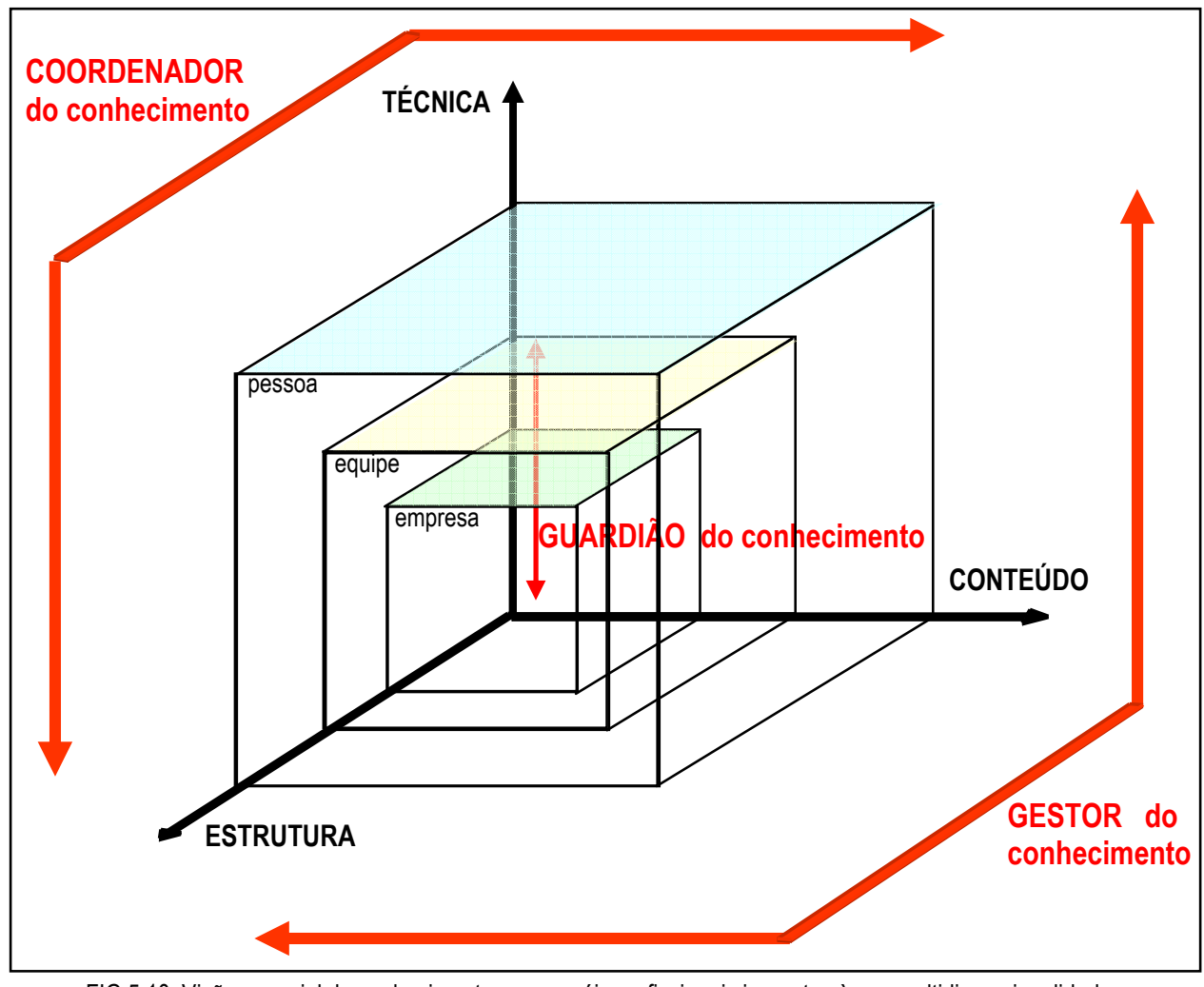

FIG 5.10: Visão espacial do conhecimento e os papéis profissionais inerentes à sua multidimensionalidade.

O eixo transversal permite imaginar todas as prerrogativas inerentes à estrutura de composição do conhecimento, seus elementos de constituição, seus relacionamentos e associações e, até, as restrições impostas pela aplicabilidade contextual do mesmo (algo que reuna as propostas de Pfleeger, Felix e Macedo, figuras. 5.06 a 5.09, por exemplo). O eixo vertical, por fim, permite imaginar todas as prerrogativas inerentes à técnica necessária para concretizar a organização pretendida e implantar um sistema de 
conhecimento adequado, decidindo pela escolha de métodos arquitetônicos, técnicas de representação e tecnologias de implementação e suporte que componham a infraestrutura necessária. As autoras não determinam qual eixo contém qual dimensão; a definição pretendida nesse trabalho tem, como único motivo, a representatividade desta visão pela construção de uma figura (a 5.10) que agregue e torne mais clara a composição teórica.

Bukowitz e Williams propõem, assim, que todo e qualquer fragmento, elemento ou porção de conhecimento possui identificação em cada uma destas dimensões, o que corrobora com os conceitos de organizações, taxonomias e ontologias tratados por outros autores, entre eles, os anteriormente citados. Ao centro de convergência do eixo, tendem o conhecimento institucionalizado, o qual forma o capital organizacional. Já a tendência do conhecimento pessoal, que envolve tanto o capital humano participante do processo de negócio, quanto o que se pode absorver de seus clientes, é inversa àquele, pois representa volumes maiores de expressão tácita que a deles, ou seja, quanto mais ao centro, mais explícito e minimamente tácito; quanto mais distante do centro, maior volume de tácito convive com o explícito sem, necessariamente, haver parâmetros de comparação. Entre o capital da empresa e da pessoa, encontra-se o da equipe de trabalho, representada por pessoas integrantes do processo de negócio potencializando suas habilidades e competência em favor deste ao agruparem-se com a finalidade específica de compartilhar, socializar e internalizar saberes, em que as autoras concordam com o que conceituam NONAKA e TAKEUCHI (1997:26-68).

As autoras (Bukowitz e Williams) discorrem, ainda, sobre perfis profissionais envolvidos com a questão do conhecimento na organização, apresentando o gestor, o coordenador e o guardião. O gestor do conhecimento é a representação do executivo do conhecimento ou profissional com competência para entender estratégica e taticamente o conhecimento do ponto de vista de conteúdo e estrutura, com idéia da técnica necessária para garanti-lo à organização. O coordenador do conhecimento é a representação do executivo da informação, com competência para entender tática e operacionalmente o conhecimento do ponto de vista de estrutura e técnica, com alguma idéia do conteúdo e sua funcionalidade (até para poder definir modelos estruturais convenientes). O guardião do conhecimento é a representação do profissional de TI, com competência para entender, operacionalmente, toda tecnologia necessária à geração e gestão do conhecimento em repositórios da empresa, bem como sua disseminação, 
quando necessária; podem representar tal profissional.

\subsection{2 - ABORDAGEM DE GERAÇÃO/APLICAÇÃO:}

Sendo o conhecimento um fenômeno dinâmico de aplicação de informações com interagência, seu entendimento acaba por exigir visualização de sua geração e esta, de alguma forma, tem sido comentada, desde o início deste capítulo, com apresentações de processos como os de Marçula (figura 5.01) e Fleury e Fleury (figura 5.02).

NONAKA e TAKEUCHI (1997:61-79), concordando com estes e outros autores, têm uma abordagem sólida para a questão da criação do conhecimento, alicerçada em suas convicções de que o domínio sobre essa criação agrega significativo valor à gestão do negócio. Agregação pela produção de uma riqueza organizacional indispensável (opinião deles), revelada como capital intelectual em um mecanismo de transformação de saberes, que define condições de liderança, na forma de um processo dinâmico, representado pela figura 5.11, de receber conhecimentos tácitos e transformálos em explícitos.

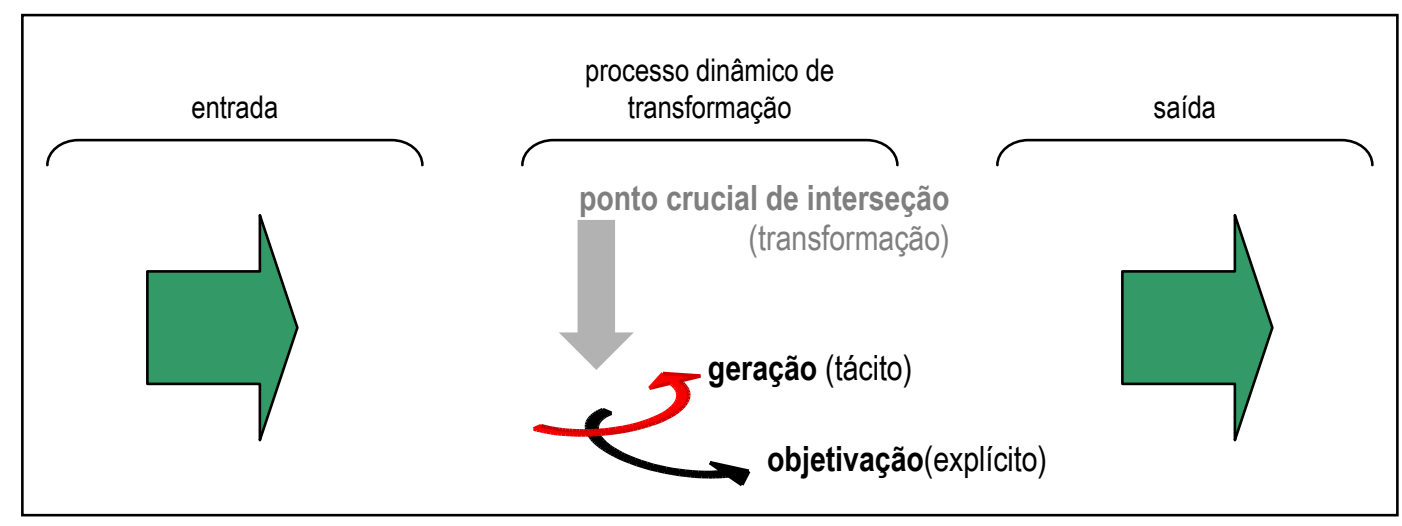

FIG 5.11: A competência expressa no processo de geração do conhecimento

Para os autores, a criação do conhecimento associa duas dimensões: uma epistemológica, que o define como tácito (resultado direto da geração - todo conhecimento é tácito em seu primeiro instante) ou como explícito (resultado direto da objetivação - nem todos os conhecimentos chegam a esta condição), e uma ontológica, que encarrega-se de organizar conteúdo e estrutura segundo sua "esfera" de aplicação, pessoal, interpessoal (grupos e equipes), organizacional ou interorganizacional. $\mathrm{O}$ insumo (entrada) do processo é toda e qualquer informação observada e absorvida, fruto de vivência ou experiência, associada por interagência com o meio, enquanto que o produto (saída) é o próprio conhecimento, tácito ou explícito.

Esta visão processual sistêmica é compartilhada por LE BOTERF (1994:16-21), 
para quem a competência é um processo dinâmico, de constante transformação de situações de influências sobre a capacidade de desempenhar trabalho, individual ou coletiva, pessoal ou corporativa. Nesse processo, demonstrado pela figura 5.12 e construído sobre as premissas básicas do autor (saber, saber fazer e saber aprender ${ }^{11}$ ), a ativação de saberes disponíveis, o uso do saber-fazer e a aplicação do conhecimento, gera, como produto, influências sobre desempenho, encarregando-se da transformação de uma condição inicial de conhecimento para uma condição de conquista de conhecimento.

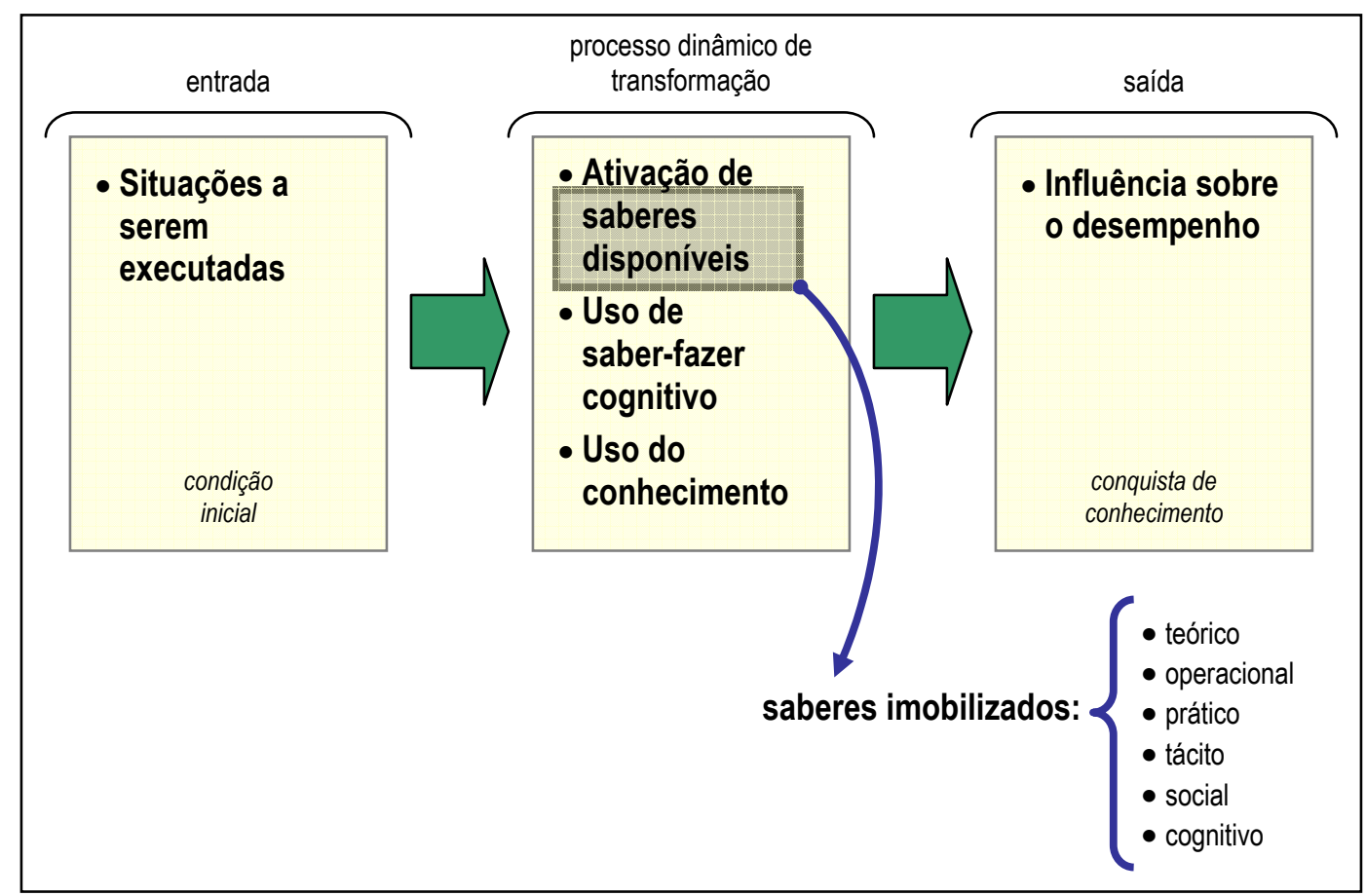

FIG 5.12: A competência do conhecimento como um processo de produção de influências.

No processo de transformação visto sob a ótica tanto de Nonaka e Takeuchi quanto de Le Boterf, deve-se considerar que o conhecimento pode ser entendido conforme a definição de essência do ser, proposta por CÍCERO (1995:20-23): um conjunto de "determinidades empíricas, positivas e particulares", capazes de caracterizar e provar existências, através dos pensamentos pensados e pensantes. A idéia de empirismo e particularidade em suas palavras aproxima-se da intangibilidade do tácito, pois apoiam-se no que é pessoal de cada indivíduo executando o processo, enquanto que o concretismo positivista do que já foi pensado, portanto está composto e consegue ser insumo, aproxima-o da objetividade do explícito, sem obrigatoriamente limitar ao que já se conseguiu formular. A figura 5.13 procura posicionar tais

\footnotetext{
${ }^{11}$ O saber expressa o legado de conhecimento e sua disponibilidade. O saber fazer expressa a habilidade para aplicar o legado. O saber aprender expressa a atitude de aplicação.
} 
pensamentos, ditos pensado e pensante.

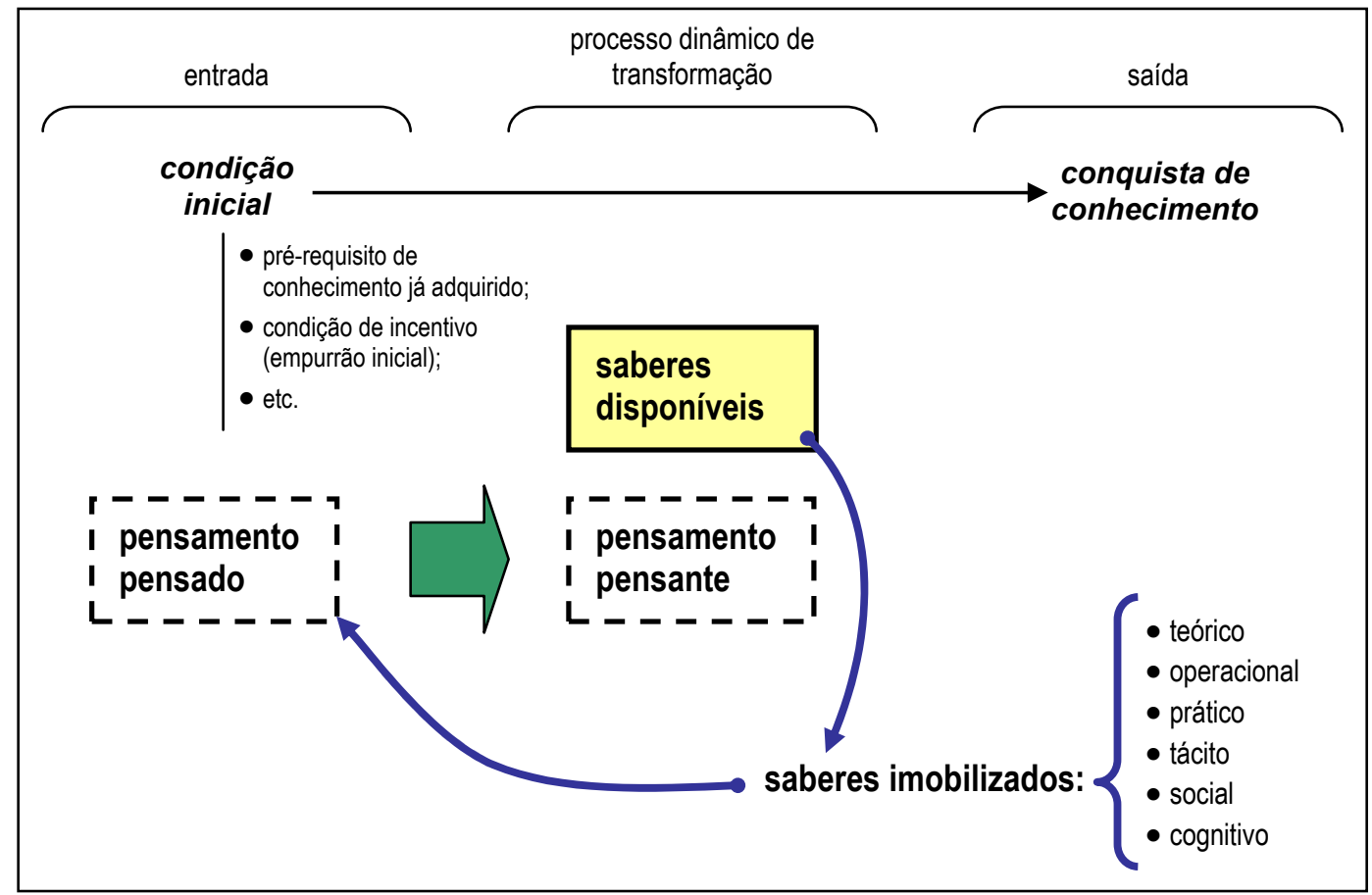

FIG 5.13: A relação entre pensamentos e saberes, na formação do conhecimento.

Pensamento pensado, segundo o autor, é aquilo que já está composto, que já tem conteúdo, já foi formulado e existe para o uso. Pode, portanto, ser aplicado em situações futuras para o entendimento das coisas. Se isso for visto do ponto de vista pessoal, apenas, é tácito e caracteriza-se como experiência dificilmente comunicável. Se for visto como algo comunicável, é explícito.

O pensamento pensante, ainda conforme o autor, é aquilo que está acontecendo, sendo composto a cada instante, cuja formulação ainda não se completou. Isso pode ser visto como a geração de conhecimento, não importa se tácito ou não, ou o próprio processo de externação de conhecimento, num evento de transformação para o explícito. Ao tomar como base ferramentas, técnicas, regras, métodos e filosofias, nessa construção, faz-se uso de tudo o que é pensamento pensado.

A habilidade do pensar, então, é a capacidade de aplicar os saberes disponíveis para sair de um estágio inicial de conhecimento e conquistar novos conhecimentos, o que influencia a forma como se percebe e entende as coisas e a forma como se executa trabalho. Esta é a agregação de valor que capacita, enriquece o saber-fazer e estabelece diferencial, tanto individual como organizacional e é isto o que se pretende gerenciar na organização: quais destas habilidades são necessárias aos diversos projetos e como têm 
sido desenvolvidas, armazenadas e difundidas e, ainda, sobre as não desenvolvidas, mas necessárias, se há informações adequadas suficientes.

FELIX (2003:37-52) também apresenta, além da dimensão ontológica, na organização do conhecimento, uma dimensão epistemológica, ou seja, aquela ligada ao estudo do conhecimento com base na diferenciação do que é tácito e do que é explícito, considerando o aspecto processual da criação do conhecimento organizacional, alicerçando-se na espiral do conhecimento, de Nonaka e Takeuchi. A autora explica que, na prática, o processo em espiral começa no nível individual e amplia-se por outros indivíduos, agrupando-os em comunidades de interação, ultrapassando as fronteiras das seções, dos departamentos, das divisões e até mesmo da organização.

BUKOWITZ e WILLIAMS (2002:24-27) também ocupam-se de uma dinâmica capaz de realizar as operações relativas a manutenibilidade do conhecimento como ativo da empresa, criando conceitos que vão da captura à disseminação de conhecimentos, passando pelo armazenamento e pelo reuso destes bens intangíveis.

Estas dinâmicas de criação e uso, assim como outras, serão novamente abordadas, com mais detalhes inclusive, no decorrer dos capítulos sétimo e nono: gestão do conhecimento e aplicação, respectivamente.

Quanto à aplicabilidade do conhecimento (segunda das abordagens tratadas por esse item do trabalho) as autoras também contribuem, com sua definição de perfis profissionais envolvidos com a questão do conhecimento. A figura 5.14 (uma releitura da 4.10, estendendo-a) soma os novos profissionais: o gestor, como executivo do conhecimento $(\mathrm{CKO})$, conhecedor de estratégias próprias para tal recurso; o coordenador, como executivo da informação (CIO), portador de saberes que transcendem os relativos ao SI; e o guardião, sabedor de técnicas próprias de engenharia e gerência de operações.

Tanto as proposições dessas autoras, quanto as dos demais, anteriormente citados, são desenvolvidos em seus trabalhos de maneira muito mais rica que aqui, pois este trabalho pretende, apenas, informar sobre esta modalidade de organização do conhecimento, a qual não representa seu foco. A focalização pretendida é a da dinâmica e do processo necessários à gestão do conhecimento. 


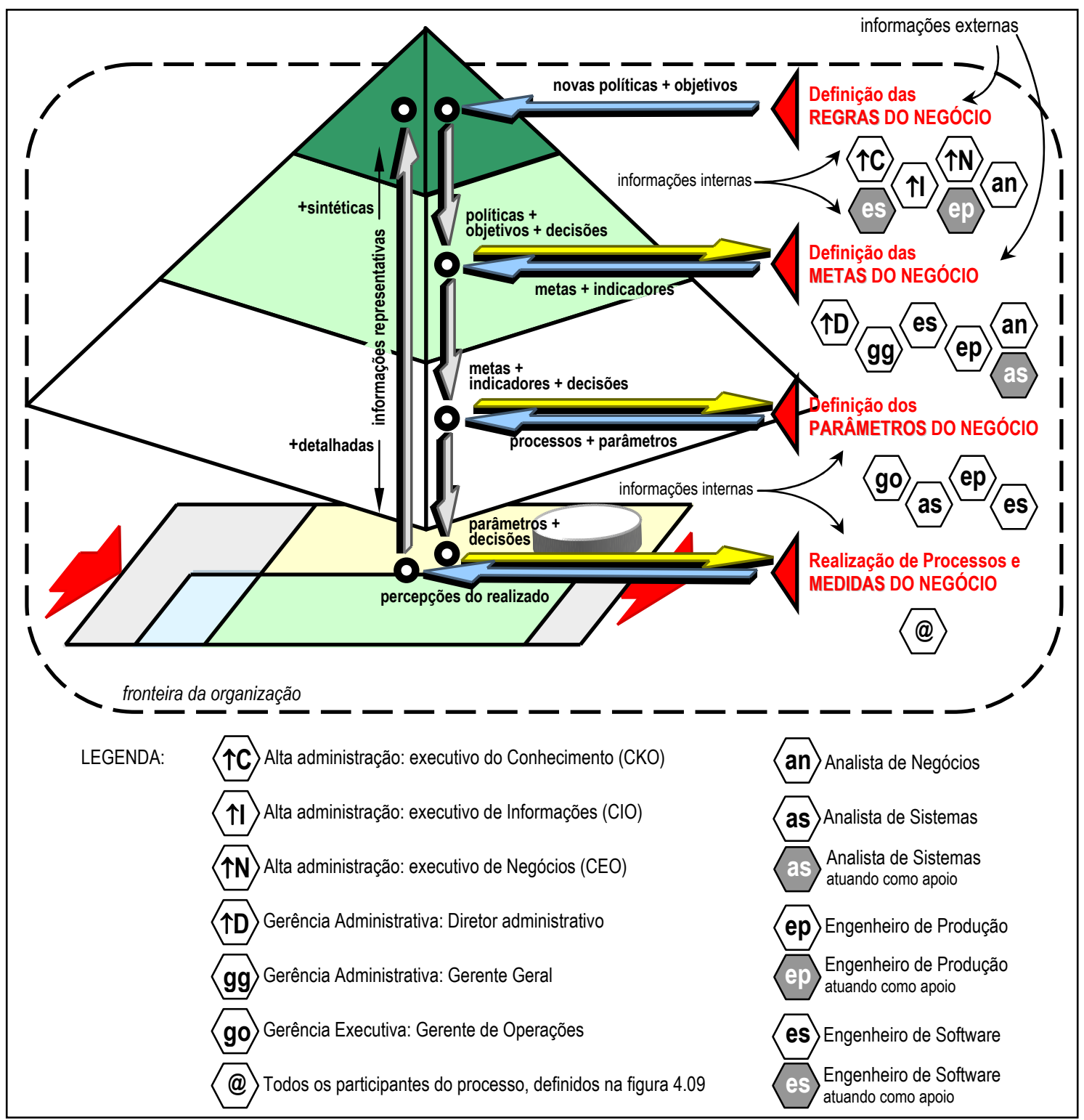

FIG 5.14 - Processo gestor estendido (releitura da figura 4.10).

A visão advinda da proposição de Bukowitz e Williams é, em verdade, a de uso do conhecimento visto não como um fim, mas como um meio de conquista de algo posterior - a competência. Outro autor concorda com as visões de Davis e Botkin, Fleury e Fleury e Setzer, mencionados anteriormente, à respeito da competência: CHATTERJEE (2002:1-4), desenvolvedor de conceito sobre o processo gerador e aplicador do conhecimento, mostrando outra forma de perceber e visualizar a criação do mesmo e seu avanço, até atingir um grau da competência tal que provoque competitividades globais no âmbito do negócio.

Para Chatterjee, a conquista da competitividade global é uma questão de competência e esta, fruto da capacidade inovadora da organização, associada ao 
empreendedorismo e à visão de negócios (estratégica) que seus dirigentes possuam (ou que já tenha sido incorporada ao sistema de conhecimento instalado). A característica inovadora desejável é fruto de conhecimentos (pessoais ou já corporativos) aplicados, associados à capacidade gerencial aprendida por experiências vividas, estudos e pesquisas e à disposição pela ação daqueles comprometidos com o negócio. Recursos humanos e tecnológicos são especialmente necessários à aplicação de processos específicos, nesta fase. O conhecimento, tido tanto como recurso (conteúdo) quanto como instrumento (funcionalidade) é fruto da intuição de seus operadores (executivos, funcionários e envolvidos) aplicada em processos de interagência entre eles e deles com o ambiente, na coleta, seleção e tratamento de informações. Esta intuição, por sua vez, é o produto da capacidade de análise contextual que cada indivíduo possui, para acumular os frutos de experiências vividas e de experimentações realizadas. A figura 5.15 mostra o processo visualizado pelo autor, de geração e aplicação do conhecimento.

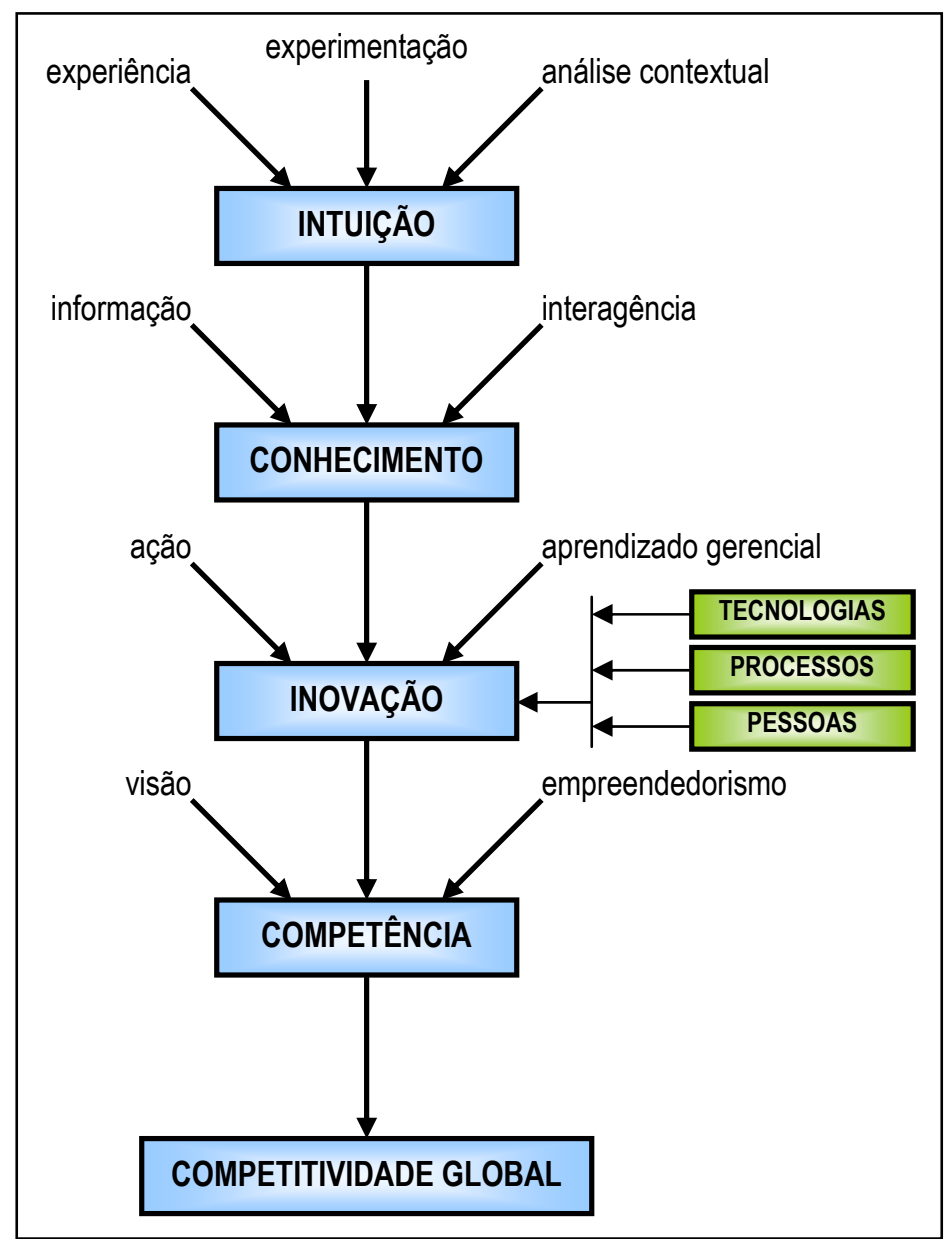

FIG 5.15: O processo de condução à competitividade global através do conhecimento. Adaptada de CHATTERJEE (2002:4). 
Chaterjee não foca sua proposição na definição do conhecimento ou em seu processo estrutural e, sim, em sua função, como instrumento. Assim como as dinâmicas de criação e uso, a aplicabilidade do conhecimento é artigo de necessidade para a obtenção de gerenciabilidade sobre o mesmo. Assim como as dinâmicas, esta aplicabilidade será alvo de maiores detalhes no decorrer de capítulos próximos, especialmente 6 e 8 .

\section{3 - EM SUMA...}

O que este capítulo procurou mostrar, inicialmente, foi uma coleção de pensamentos sobre o conceito de conhecimento e suas organização e classificação. Acabou-se por denotá-lo como um processo dinâmico ou, ainda, melhor seria entendêlo como o dinamismo do processo de formação e aplicação da informação.

A abordagem de aplicação do conhecimento, de forma particular, aproximou-se bastante do conceito de gerenciabilidade, aproximação essa necessária ao entendimento da dinâmica do conhecimento para o entendimento de sua gestão, assunto do próximo capitulo, o qual, por certo, aproximará seu conteúdo da visão de processo tratada aqui. 


\section{1 \\ GESTÃO DO CONHECIMENTO}

Assim como o termo conhecimento possui várias formas de conceituação, sua gestão tem sido alvo de vários estudos e, consequentemente, sua conceituação tem sido formulada por vários autores. $\mathrm{O}$ que estes autores e suas conceituações apresentam, por resumo, é a idéia de domínio sobre o conhecimento, através de uma capacitação específica que lhe confira competência gerencial e administrativa sobre o conjunto de informações e saberes relativos a um determinado assunto.

Se o conhecimento é dinâmico, como visto no capítulos 5, sua gestão é tão ou mais dinâmica que ele e exige trabalho constante sobre estruturas e processos de conquista e armazenamento de todo conhecimento que se tem e sobre o que não se tem, mas sabe-se necessário à realização de trabalho e, em caso de não possuí-lo, onde encontrá-lo e como agregá-lo, individual ou corporativamente.

Se o conhecimento é configurado segundo visões diferentes, a gestão do conhecimento deve ser vista sobre óticas diferenciadas, para que seu entendimento some possibilidades de agregação de valor sobre dimensões diversificadas dentro de projetos, negócios e empresas.

Este capítulo traz um arrazoado de diversos autores sobre a gestão de conhecimento e procura oferecer algumas formas de visualizar como se realiza o processo do conhecimento, inclusive propondo um mapeamento sobre tal dinâmica gestora.

DAVENPORT (1996:3-5), relatando um estudo de caso levado a efeito em uma grande empresa, discute papeis e responsabilidades do conhecimento e de sua gestão para a organização e como estes influenciam os processos produtivos. Para o autor, a gestão do conhecimento aplica-se nas formações de conteúdos, na composição de uma base de talentos, tanto pela educação internalizada de seus funcionários quanto pela formação de uma rede de conhecimento sobre onde encontram-se competências do interesse do negócio, e na melhoria de estruturas e gerenciabilidades dos processos de produção.

A necessidade de gestão do conhecimento não é nova. A considerar que esta 
gerenciabilidade diz respeito a toda forma de conscientização sobre o que se aprende e o que se sabe e, ainda, sobre a capacidade de solucionar problemas pelo uso desse saber, ela é algo que se pratica por toda a história da humanidade.

FELIX (2003:24-35) afirma que este é um processo que sempre existiu em todos os tipos de empresas e, ainda, que, desde há muito, a sabedoria sobre os negócios de família passam de pais para filhos e de artesãos para aprendizes, geralmente através de experiências entre trabalhadores. O novo resume-se à abordagem que ora se dá à questão e esta nova abordagem retrata a gestão do conhecimento como um objetivo organizacional explícito, no enfoque contemporâneo da gestão de empresas.

Para a autora, a gestão do conhecimento é caracterizada por uma contínua redefinição da proposta organizacional e de sua aplicabilidade funcional, tal que se conquiste formas de minimização dos tempos de resposta aos participantes de negócio, pela aplicação de saberes anteriores ou criados em tempo de execução das ações de negócio. É ação estratégica de criação de processos práticos para identificação, captura e alavancagem do conhecimento, bem como de processos gerenciais para administrar o uso tanto de tal conhecimento quanto do processo prático. Esta gestão:

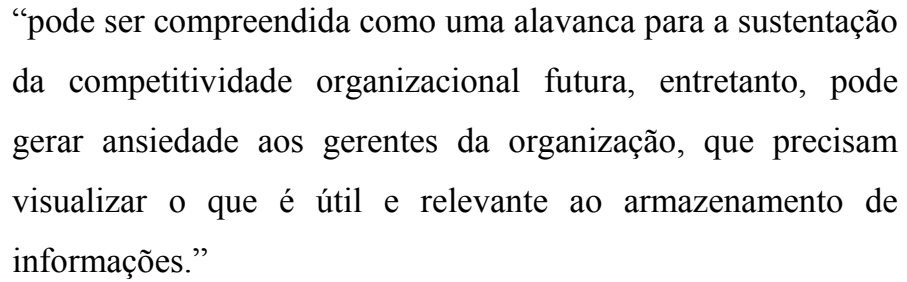

A autora foca a gestão do conhecimento sob óticas como TI, capital intelectual e aplicação prática, considerando que: sob a da TI, é um processo da organização (sem deixar de ser do indivíduo, também) capaz de combinar dados e informações de maneira sinérgica, com criatividade e inovação (sob aspecto organizacional, este processo é realizado por sistemas informacionais); sob a ótica do capital humano, é exercício de exploração desse recurso de inteligência individual, inclusive e principalmente sua porção tácita, apoiado em capital estrutural das rotinas organizacionais, combinando ambos ao capital presente nas relações com o cliente; e, sob a ótica da praticidade, é um conjunto de procedimentos voltados à administração da criação, da disseminação e da utilização do conhecimento para a execução dos objetivos da organização.

Concordando com a idéia de que a gestão de conhecimentos se pratica há 
tempos, SNOWDEN (2003:98-106) afirma que há uma nova gestão do conhecimento, derivada de uma antiga gestão, praticada exclusivamente sobre conteúdos e que só reconhecia o conhecimento que se apresentava por escrito e organizava a documentação. Esta nova gestão agrega, à de conteúdos, as de contexto (reconhece o que se sabe e sua pertinência e organiza sua acessibilidade) e de narrativa (entende que o que é dito faz parte do patrimônio intelectual e, mesmo que não transcrito, precisa ser absorvido). A mudança, segundo o autor, principia nas premissas de que: as pessoas apenas sabem que sabem quando precisam sabê-lo; sempre se sabe mais do que se diz saber; sempre se diz mais do que se consegue escrever e; só se recebe conhecimento de forma voluntária, não sendo próprio impô-lo. A gestão do conhecimento deve produzir estímulos para o conhecimento e sua recepção.

Uma outra definição dada ao termo vem de RUSSEL (2005), para quem o conhecimento (legado de informações, domínios sobre elas e capacidades de ação a partir delas, que as pessoas acumulam e aplicam em processos profissionais e organizacionais) junta-se à gestão (capacidade administrativa que conduz o profissional à gerenciabilidade de informações, atos e circunstâncias) para a formação de uma capacidade potencializada de administrar os legados próprios de informações, habilidades e competências, aplicáveis e replicáveis em processos de trabalho, cujas iniciativas explicam-se nas necessidades de negócio por competitividade, essencialidade da informação, dinamismo organizacional e evolução.

LOUREIRO (2003:11-15) apresenta a gestão do conhecimento como uma área no processo de construção do conhecimento; justamente a área organizacional e administrativa que o conhecimento, como recurso, exige. Na opinião do autor, já o vem exigindo desde há muito, sob aspectos pessoais e sociais, antes dos empresariais:

\footnotetext{
"as civilizações mais antigas sempre fizeram grandes esforços para preservar o conhecimento ganho através de experiências e reflexões ao longo do tempo. Esta necessidade de captação, armazenamento e distribuição de conhecimento conduziu ao desenvolvimento de novas tecnologias."
}

LOUREIRO (2003:11)

O autor traça uma cronologia do desenvolvimento de tal gestão, desde o período da pré-escrita, passando pelas revoluções representadas pelas invenções do texto, de máquinas de imprimir e de meios de comunicação a pontos distantes, até culminar nos 
períodos do processamento digital de informações em rede. Traça, ainda, um paralelo entre a moderna e a antiga gestões do conhecimento, apontando, como principais mudanças, o volume de informações envolvidas, a velocidade com que os conteúdos mudam e como se transformaram os espaços de trabalho.

A definição dada, enfim, por Loureiro, traduz a gestão do conhecimento, inicialmente, como uma abordagem sistemática cuja razão alicerça-se nos aumentos do valor e da acessibilidade ao capital do conhecimento da organização, com vistas a propagar a inovação constante e otimizar a eficácia de negócio e, finalmente, como uma prática emergente da aplicação de saberes pessoais na otimização da eficiência corporativa. No movimento das otimizações, da eficiência à eficácia, discorre sobre vários pontos, tais como: o envolvimento de ações de criação, captura, síntese e compartilhamento da inteligência coletiva e da experiência humana, na qual enraíza-se o conhecimento; a necessidade de atenção às pessoas, à cultura, à estrutura organizacional e à tecnologia contidas no processo, sem esquecer-se de que a gestão do conhecimento não se reduz à gerência da tecnologia e, sim, que abarca também os saberes e suas interseções com estratégias, organizações e processos relativos aos negócios; a interpretação do que é essencial nas influências das formações e experiências pessoais sobre o trabalho; e a consciência do tempo necessário para que projetos gestores deste gênero se concretizem e produzam consagrações de resultados.

Sobre esta consciência do tempo necessário, também discorrem ROSINI e PALMISANO (2003:104-107), para quem a questão de gerenciabilidade do conhecimento transcende a essencialidade e torna-se vital para a sobrevivência das empresas, à medida que representa uma abordagem no limiar do indispensável para a interseção entre a teoria da organização, a estratégia de negócio, a TI e a cultura administrativa: combinação que corrobora com postulados anteriores. Abordagem esta que exige a transponibilidade de obstáculos que não são poucos, nem triviais (opinião deles), em seu caminho para a implementação. Exige, também, significativos esforços e investimentos, inevitavelmente pensados a longo prazo. Em suas discussões, apoiam a idéia de inevitabilidade no que fora vivenciado durante o século XX (por eles e por outros autores, por eles citados): um processo contínuo de aumento e transformação no conhecimento disponível, que leva a obsolescências de conhecimentos a períodos cada vez menores e reclama por permanente atualização. Isso contribui com o afirmado por DAVIS e BOTKIN (1996:25-42), sobre a preocupação das empresas com a 
continuidade educacional, pois é necessário mais do que o aprendido em escolas para prover estratégias da gestão do conhecimento, cujo intuito agrega o entendimento, a organização, o controle e o lucro com o valor intangível deste ativo, ao qual denominam “cadeia alimentar da informação", em referência ao conceito evolucionário que leva dos dados ao conhecimento.

ROSINI e PALMISANO (2003:135) apresentam um ciclo do conhecimento que começa pela percepção da realidade (identificações do que é natural, sociocultural, emocional e contextual), a qual é filtrada, através dos ciclos culturais que cada pessoa, comunidade ou organização possui. Dependendo do resultado, a geração de conhecimento e cultura resultante pode levar a dois caminhos: à simples explicação que permite compreensão e manejo da situação a partir do próximo momento de realidade (o que impulsiona o próximo ciclo) e/ou a um processo mais longo e complexo que busca, através de processos de comunicação, identificar códigos e símbolos, tradutores da circunstância percebida como novidade, organizá-los em corpos de conhecimento que, expropriados, podem ser absorvidos e incorporados (institucionalizados, no caso da organização) e, através de sistemas formais ou não, serem novamente filtrados, fechando, assim, o ciclo que, segundo defendem os autores, precisa ser entendido, equacionado e definido, para permitir a ação da gestão.

TERRA (1999) define a gestão de conhecimento como sendo a organização de políticas, processos e ferramentas, gerenciais e tecnológicos, com a finalidade de melhor compreensão dos processos relativos à geração, à identificação, à validação, à disseminação, ao compartilhamento e ao uso de conhecimentos estratégicos de negócios, para gerar resultados para empresas e benefícios para seus colaboradores. Estabelece, inclusive, uma visão em sete dimensões para a realização de tal gestão, as quais aplicam-se: uma no nível da alta administração (nível administrativo estratégico da empresa: gestão de conhecimentos relativos a visão e estratégia de negócio); três nos níveis do gerenciamento, administrativo e executivo (nível administrativo tático da empresa: gestão de conhecimentos relativos a política de recursos humanos, cultura organizacional e estruturas organizacionais, estas avançando ao nível administrativo operacional); duas no limiar dos níveis do gerenciamento executivo e do processo (nível administrativo operacional da empresa: gestão de conhecimentos relativos a sistemas de informações ativos e mensurações de resultados, ambas avançando pelo processo de transformação operacional); e uma no ambiente externo (contexto externo da empresa: 
gestão de conhecimentos relativos às relações da organização com clientes, fornecedores, parceiros, concorrentes, e todos os envolvidos ou interessados no negócio). A figura 6.01 visa representar as dimensões propostas por Terra sobre a visão associada dos planos administrativo (organização $\leftarrow$ sistema de informações) e não administrativo (processo $\leftarrow$ sistema produtivo) do negócio.

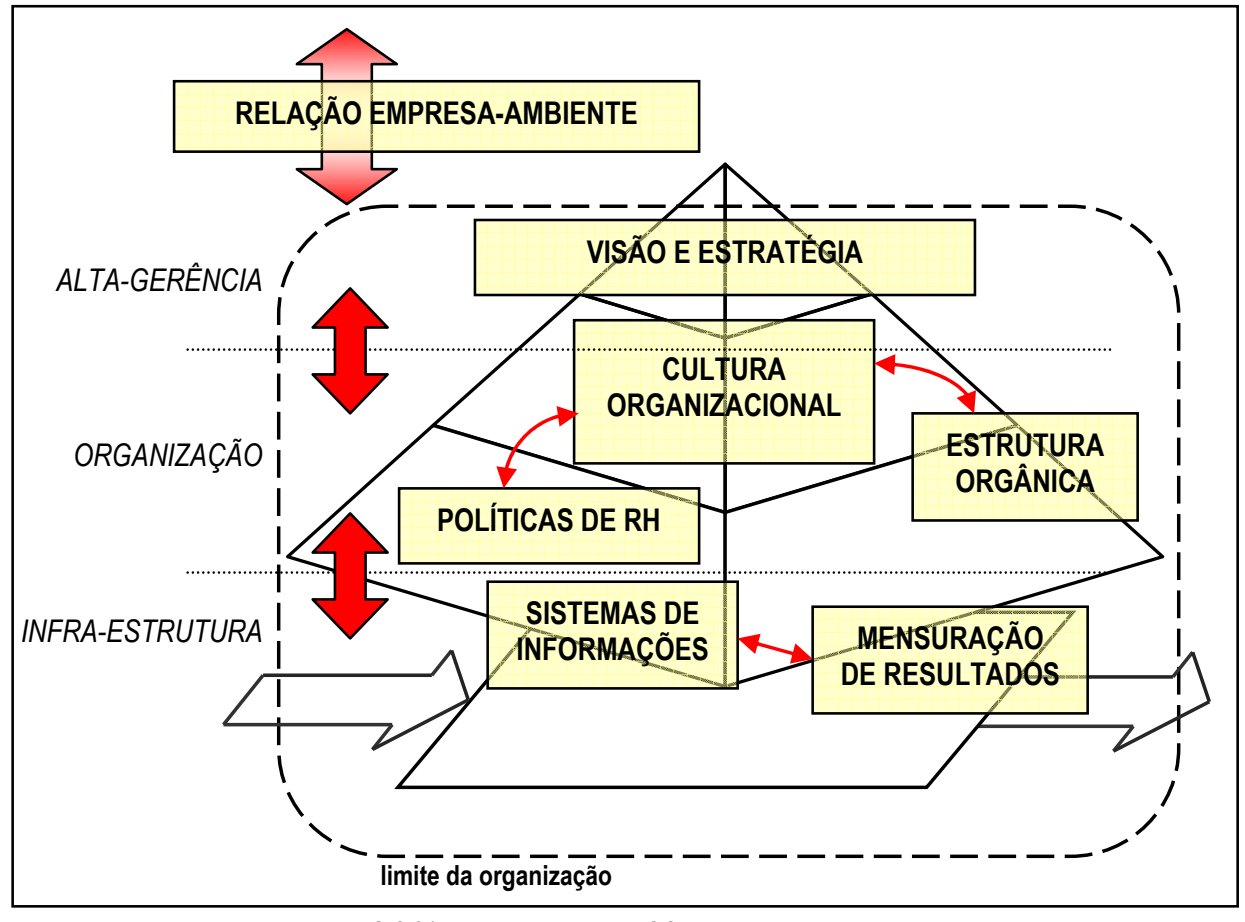

FIG 6.01 - As dimensões da GC e da administração. Adaptada de TERRA (1999).

$\mathrm{Na}$ característica inerente aos humanos de estender o aprendizado pessoal à coletividade, pela influenciação de grupos, o autor estabelece a relação conhecimento/empresa. Nesse sentido, o autor cita $\operatorname{Argyris}^{12}$ e sua teoria sobre o aprendizado organizacional, baseado em mudanças comportamentais e mapeamentos mentais, resultantes de laços de retroalimentação e de comprometimentos individuais com cooperação e compartilhamento com outros, para produzir o aprendizado organizacional e a sistematização de um processo de continuidade e expansão do conhecimento agregado à corporação.

Importante salientar que o autor coloca o SI como infra-estrutura olhando-o como ferramenta administrativa, e não como o conceito mais abrangente de todos os mecanismos de tratamento de informação que a organização possui em todos os seus níveis e dimensões.

\footnotetext{
${ }^{12}$ ARGYRIS, Chris; Double Loop Learning in Organizations; in: Harvard Business Review; EUA: Harvard University Graduate School of Business Administration, setembro e outubro de 1977.
} 
A gestão do conhecimento é fundamental para estabelecer as competências e a consciência que uma organização possui sobre elas, na opinião de TERRA (1999), além de determinar suas estratégias de competitividade, à medida que potencializa domínios: sobre ambientes organizacionais, seus bens, serviços e talentos humanos; sobre concorrências mercadológicas e; sobre relacionamentos com o mercado.

Este conceito, focado na questão da competência, lembra FLEURY e FLEURY (2001:18-33) e a figura 5.02, a qual apresenta o modelo de aprendizagem que leva a saberes que, a seu tempo, agregam o valor social e/ou econômico intitulado competência, e remete a ZARIFIAN (2001:40,52-74), cujo pensamento alinha-se a Fleury e Fleury, quando discorre sobre a nova realidade de crescimento indispensável do trabalhador, evoluindo de operário tradicional a profissional técnico, e sobre os elementos que geram um valor agregado relativo à capacidade que se pode desenvolver, nas corporações, de conhecerem a si próprias, pelo progresso de seus funcionários. $\mathrm{O}$ valor agregado é a competência que, em sua visão, é a capacidade de combinar fatores de forma cumulativa e auto-compartimentada, representada por um estado de evolução na característica executora, o qual delineia os perfis produtores de indivíduos e empresas. Tal evolução vai do comportamento ao conhecimento, dentro de um contexto definido, passando pela experiência e pelo saber-fazer.

A figura 6.02 traduz a competência idealizada por Zarifian, em cuja composição apresenta-se o conhecimento abrangente - social, técnico e organizacional - como fruto do saber-fazer, desenvolvido a partir dele e o contendo. Este saber-fazer, tecnológico e executivo, baseia-se na experiência, a partir dela soma elementos de aprendizagem e acumula-a, de forma a contê-la. A experiência, individual ou coletiva, por sua vez, que expressa a capacidade de aplicar tecnologia desenvolvida nos indivíduos - e, consequentemente, nas organizações, em conformidade com Terra -, advém do comportamento e o contém. Este comportamento, social e profissional, que as pessoas estruturam e aplicam em seus convívios em comunidade, representa aprendizado básico, humano, individual e coletivo, do uso de ferramentas diversas, naturais ou não.

O conhecimento é uma questão de produção de ciência e o que as organizações devem buscar é um desenvolvimento científico adequado de sua gestão, tornando-o replicável e possível de ser traduzido em método para a disseminação do saber-fazer que cada membro da organização precisa para otimizar e garantir seu processo de aproveitamento de experiências e refinar seu mecanismo comportamental. 


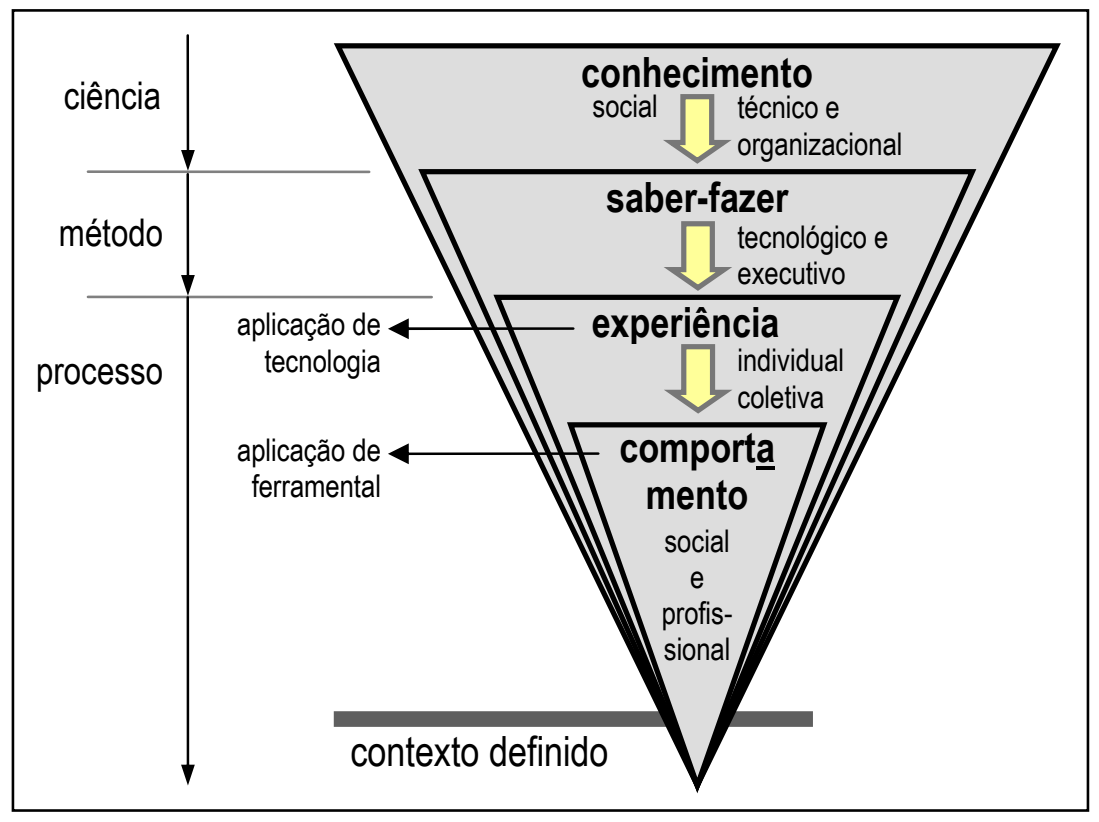

FIG 6.02: Visão evolutiva e compartimentada da competência.

Competência é, então, na opinião do autor, mais que obtenção e retenção de conhecimento. Traduz-se como todo potencial de aplicação, formalizada ou não (mas sempre com alguma disciplina), do mesmo. Onde o autor vê a competência, apoiada sobre o conhecimento abrangente (abrange o saber-fazer, que abrange a experiência, que abrange o comportamento), pode-se ver a própria gestão do conhecimento (que é uma questão de competência), como domínio sobre conhecimento e sua estrutura.

É possível afirmar que, considerando a evolutibilidade embutida no modelo de Zarifian, o crescimento pelo acúmulo dos elementos estabelece uma medida de nível de maturidade da organização em gerir seus conhecimentos e, portanto, suas competências. Nesse caso, o gerenciamento destes se dá por alguns questionamentos básicos, tais como: o que se pratica em termos de disponibilização e divulgação das experiências envolvidas com a organização? Apenas as que dizem respeito ao uso de ferramental ou ao mero cuidado com relações sociais externas? Procura-se difundir as relações dos técnicos com os processos? Há preocupação com a ampliação metodológica nas atividades técnicas e executivas? Há, de alguma forma, divulgação e conscientização da ciência envolvida com o negócio? Em todos os níveis, há difusão de conhecimentos e a organização sabe como ela se dá? Há gerenciamento de aprendizados e das aplicabilidades dos conhecimentos agregados? A organização sabe onde encontrar os não agregados? Que, ou quais, informações a empresa necessita e, destas, quais podem ser transformadas em conhecimento? 
Algumas destas preocupações são originárias da pesquisa parcialmente apresentada no início deste documento (capítulo primeiro), advindas do artigo de FARAH JÚNIOR e SILVA (2003:3-10). Assim como estas, outras perguntas poderiam ser feitas. A idéia dos questionamentos, mais que a estruturação das perguntas, é que define a questão de gerenciabilidade procurada por este trabalho e alicerça a necessidade de entender o mecanismo da gestão (ou a gestão como um mecanismo) do conhecimento.

O entendimento do que compõe a estrutura deste mecanismo, sob óticas diferenciadas, é a base para a definição e implantação da prática da gestão do conhecimento, conforme definem SMALL e TATALIAS (2000), quando buscam uma visão estrutural do mecanismo (figura 5.04) através de elementos provedores e influenciadores do mesmo: cultura, política, estratégia, conteúdo, volume, processo e tecnologia.

Estes elementos estruturais são corroborados por DIAZ et al. (2000:4-6) com alguma diversificação, pois apresentam estrutura, financiamento, tecnologia, medição, questões culturais e outras dimensões facilitadoras, como pontos de implementação, os quais permitem avaliação ou, no mínimo, delineamento de evidências sobre como empresas enfrentam as questões de viabilidade operacionais em projetos que visem a incorporação de Gestão do Conhecimento.

Quando referem-se à estrutura, os autores descrevem a questão de preparação organizacional necessária, sob responsabilidade da administração, que envolve o desenvolvimento de facilitações encorajadoras para que a comunidade profissional aplique e contribua com a gestão do conhecimento. O financiamento é uma questão de posicionamento de recursos para projetos do gênero, pois tal implementação alastra-se por duas vertentes da organização financeira: a de abordagens e a de projetos, além de ter abrangência tanto no nível dos sistemas de informações, quanto no das tecnologias da informação. Como tecnologia, preocupa a determinação do ferramental de organização e armazenamento do conhecimento e a percepção de como e quanto estas impactam sobre as gestões, do conhecimento e da organização. A medição diz respeito a determinação de indicadores que possibilitem a observação de volumes de descobertas no corpo produtivo e administrativo da organização, bem como a quantificação de acessos ao banco de dados de conhecimentos (melhores práticas, principalmente). Quanto às questões culturais e outras dimensões facilitadoras, o foco no impacto 
relativo a questões como ética e orgulho profissional (por exemplo: quando se busca uma cultura sustentada na gestão do conhecimento), bem como o foco em alguns aspectos facilitadores (como recompensas e apoios administrativos, para incentivar comportamentos compartilhados), expressam as preocupações de Diaz et al., na composição do mecanismo gestor.

Mecanismo leva a uma questão de processo.

\section{1 - O PROCESSO DO CONHECIMENTO:}

A referência ao processo do conhecimento foi feita na definição do conhecimento e no reconhecimento de seu caráter de ação, no capítulo quinto. Vários autores foram citados, os quais apresentam tal ação pelo processo de tratamento de dados e informações, entre eles NONAKA e TAKEUCHI (1997:65-83), preocupados em expressar o processo de criação pela transformação do que é tácito em explícito.

Evidente que os autores não descartam que o processo, além da transformação, executa outras tarefas não menos importantes, como reconhecimentos, classificações e organizações de conhecimentos que podem, inclusive, não serem modificados durante o processo, pois conhecimentos explícitos podem ser obtidos, classificados e, apenas, devidamente armazenados, assim como conhecimentos tácitos, cuja transformação não seja possível, podem gerar classificações e armazenamentos de informações a seus respeitos (meta-conhecimentos) ou, ainda, que conhecimentos tácitos sejam gerados no processo de transformação e tenham de ser adequadamente classificados e informados. Estas considerações, inclusive, permeiam o conceito de espiral do conhecimento, com o qual os autores defendem a criação de saberes e a transformação de uma condição inicial de conhecimento para uma condição de conquista de conhecimento, transformação esta com a qual concorda LE BOTERF (1994:16-21), para quem a competência é um processo dinâmico de sintetização da sabedoria.

A sabedoria, transcendência do conhecimento, conforme definem DAVIS e BOTKIN (1996:43-65), apresentada no capítulo 5, é o resultado deste processo de conquista, ou seja, a capacidade de influenciar o desempenho. Isto, nos negócios, sugere toda espécie de regras de negócios e suas administrações: o corpo de conhecimento e a habilidade para utilizá-lo em prol da evolução do negócio.

Entender os processos é importante para entender a gerenciablidade destes 
processos e o que eles envolvem, como, por exemplo, possibilidades de domínio sobre criação, utilização e disseminação do conhecimento, e sobre os requisitos da capacitação coletiva: indivíduo atuando em função de comunidades, empresariais ou não. É preciso entender a gestão do conhecimento como um processo organizado, envolvendo formação, armazenamento e transferência de habilidades e competências.

Este processo de gestão viabiliza a sustentabilidade e a qualidade competitiva esperada dos sistemas de informações, sobre os quais as diversas formas de organização se apoiam, e o faz envolvendo, formando e informando as pessoas, num processo de aprendizagem contínua. A figura 6.03 demonstra como a gestão de conhecimento, na forma de um processo, pode ser visualizada, apresentando-a como uma camada que, seqüencialmente, suplanta o sistema de informações que, também visto como uma camada, suplanta o processo sistêmico produtivo da empresa.

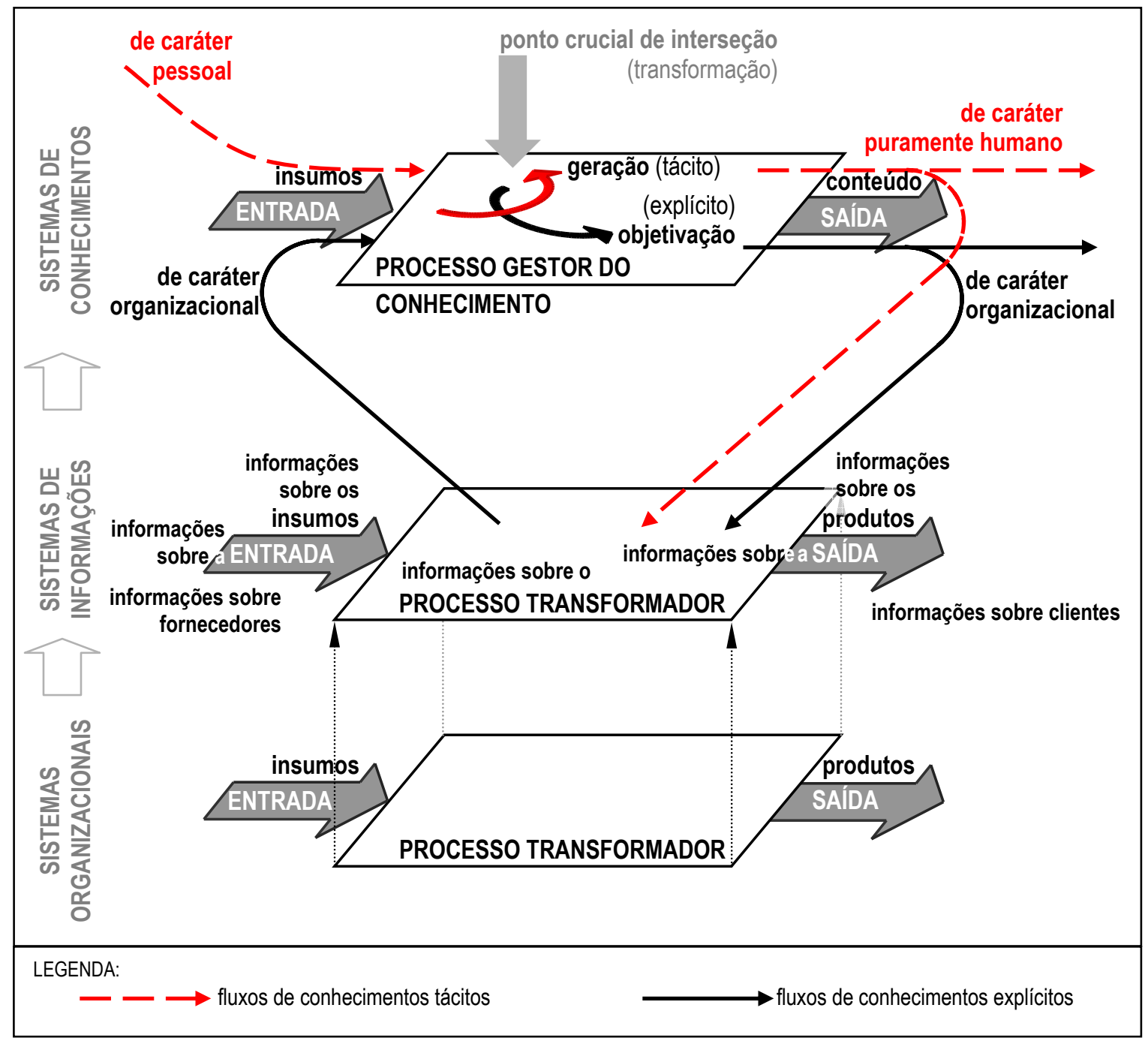

FIG 6.03: Visão, em camadas, dos processos sistêmicos: de transformação, de informações e de conhecimento. 
Pode-se, então, argumentar que, podendo ser toda e qualquer organização entendida como um processo de transformação, o sistema de informações é apenas uma de suas camadas; é o nível das informações sobre cada um dos elementos sistêmicos envolvidos. O sistema gestor de conhecimento é, assim, outra camada, superior à das informações, e representa o nível das habilidades, das competências, das capacidades de domínio, das inferências e das certitudes, provenientes de ensino e aprendizado, que regem o uso adequado de informações para a aplicação adequada de processos e contém o processo do conhecimento em si, como visto e comentado durante o capítulo anterior.

A gestão do conhecimento dá-se sobre o processo do conhecimento (nesta $3^{\underline{a}}$ camada), na capacidade de percepção de ocorrências de: insumos (informações e conhecimentos anteriores); geração e objetivação, internas ao processo; ponto de transformação do tácito para o explícito; conteúdo, como produto e; conteúdo, na forma de um meta-conhecimento. Os insumos e os produtos desse processo podem provir e destinar-se à organização ou à pessoa, podendo ser explícitos ou tácitos.

Este meta-conhecimento representa toda sorte de informação (e conhecimento) tratada que proporcione consciência de possuir o conhecimento e capacidades diversas de usá-lo para produzir mais conhecimento e para otimizar a gestão do negócio. A figura 6.04 serve à demonstração dele e do relacionamento de algumas das capacidades diversas citadas: de ter percepção, ciência e visão do conhecimento próprio e/ou apropriado; de solicitar (informações, profissionais específicos, mais conhecimento); de

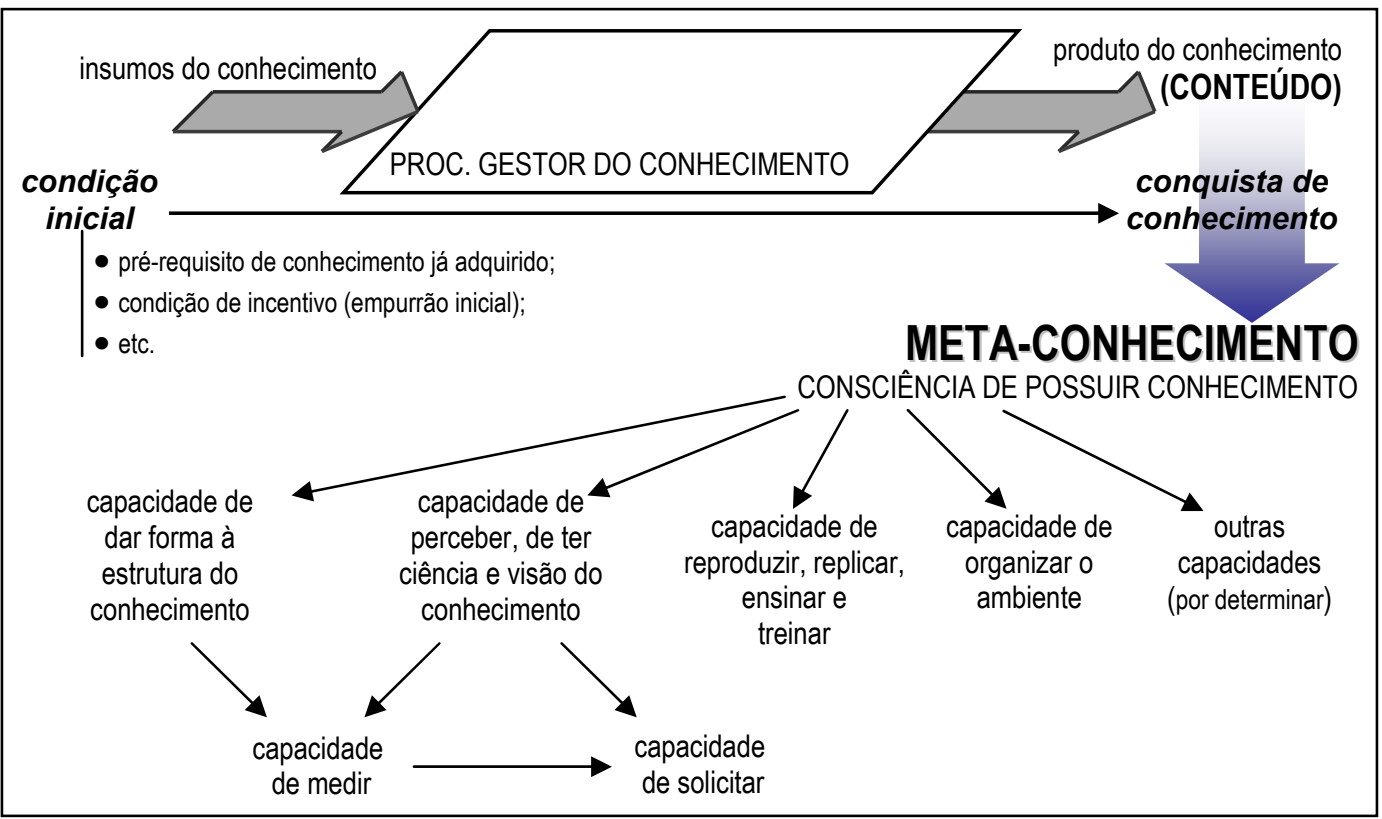

FIG 6.04: Meta-conhecimento, como fruto da conquista do conhecimento por sua gestão. 
replicar, ensinar e prover treinamento; de dar forma à sua estrutura; de organizar o ambiente e; de medir.

O meta-conhecimento como resultado da conquista do conhecimento é produto do processo de aprendizagem ${ }^{13}$ ou, como preferem chamar LEI et al. (2001:157-180), da "metaaprendizagem" que gera competências essenciais dinâmicas, conceito que vem alinhar-se com outros, já mencionados, propostos por FLEURY e FLEURY (2001) e CHATTERJEE (2002).

O contexto estratégico em que se dá esse processo pode ser expresso por meio das próprias palavras de LEI et al. (2001:164):

"Como os elementos exigidos para a aprendizagem de nível
mais elevado bem-sucedida podem transformar-se nos recursos
e ativos específicos da empresa que formam os ingredientes de
uma competência essencial."

e pela idéia de que o modelo de organização para o desenvolvimento de competências essenciais requer que as organizações sejam hábeis para processar, armazenar e recuperar informações, o que exige o desenvolvimento de uma memória organizacional que ajude o aperfeiçoamento da heurística de busca e solução.

Os autores atestam que o conhecimento tácito, geralmente, é capturado em metáforas que os não integrantes do negócio não conseguem decodificar e entender, daí suas afirmações de que a vantagem competitiva deriva justamente do conhecimento único que uma organização possa ter.

Estas metáforas produzem um vocabulário original (do negócio ou da corporação) e uma linguagem específica, que servirão à eficiência do armazenamento e de transferências de dados, informações e conhecimentos, e envolvem capacidades de: transferência e recuperação de informações; contribuição pela experimentação para a melhoria continua; produção de habilidades específicas; concretização da metaaprendizagem sistêmica; desenvolvimento e sustentação de competências essenciais (as dinâmicas); fornecimento de alternativas estratégicas de crescimento; redução de incertezas; e produção de um nível de especialização e domínio difícil de ser alcançado e imitado por outrem.

\footnotetext{
${ }^{13}$ Assunto do capítulo 7, deste trabalho.
} 
Enfim, estes autores defendem a idéia de que há vantagem intransferível no tácito relativo ao negócio, motivo pelo qual se investe em processos de externalização (transformação do tácito em explícito), pois estes fomentam as oportunidades de: planejamento e planejamento estratégico; solução de problemas; implantação de uma novidade (seja método, processo ou tecnologia); desenvolvimento de novo produto e; realização de benchmarking, todos elencados por RUAS (2001:242-267) como práticas que oportunizam aprendizagem, estimulam competências e resultam em natural ampliação e potencialização dos conhecimentos táticos aplicados, incorporados pela organização, através de um, alguns ou muitos de seus participantes. Não se pode esquecer que essa capacidade de aprender declarada amplia, também, o explícito.

Um exemplo de processo de raciocínio complexo para solução de problemas, que utiliza conhecimentos explícitos para análises de inferência e os amplia, na base de conhecimentos da organização, bem como cria novos tácitos, é dado por SILVA e SANTOS (2000:123-126). O exemplo resume um método de solução de problemas que, apesar de focado em uma situação bastante particularizada, de análise de rochas, consegue fornecer uma idéia genérica o suficiente de um modelo baseado em conhecimento e estruturado para seu desenvolvimento.

O processo que os autores propõem tanto pode utilizar-se exclusivamente de conhecimentos explícitos, dispostos em base, no caso de automações (situação mais difícil de concretizar-se), quanto mesclar estes com conhecimentos tácitos, pela participação de pessoas em seu desenvolvimento (situação mais comum). A proposição forma uma estrutura de caminhos possíveis do processo cognitivo de inferência, que vai da captura de um conjunto de estímulos sensórios, relativos ao objeto da análise, à geração das soluções combinadas na interpretação dos conhecimentos envolvidos. Este caminhamento passa por seleção e filtragem de conteúdo, análise do conteúdo legado e sua escolha (processo cognitivo, pela similaridade circunstancial) e disparo de raciocínio regressivo (seleção de um ou mais elementos associados, provocando iterações até que o número de possibilidades circunstanciais seja satisfatoriamente reduzido). Tal dinâmica caracteriza a capacidade de gerir o conhecimento aplicado em tomadas de decisão.

Também visualizando a dinâmica do processo do conhecimento como um processo gerenciável, MACEDO (2003:28-30,40-44) apresenta, em seu estudo sobre a memória corporativa estratégica (Strategic Corporate Memory), já apresentado no 
capítulo 5, um modelo do processo de negócio, como base para a implementação do banco de conhecimentos, denominado Organizational Baseline (terminologia que ele conservou de suas fontes), ao qual competem informações estratégicas, táticas e operacionais, importantes para o entendimento e a administração do negócio, formem elas conhecimentos tácitos ou explícitos, e, também, informações que traduzam experiências passadas. Daí a necessidade da gestão do conhecimento, tida, pelo autor, como processo de localização, elicitação, seleção, organização, armazenamento, proteção, compartilhamento, disseminação e apresentação do conhecimento, com vistas à melhoria e à compreensão: das capacidades de trabalho; das contribuições às soluções de problemas; do aprendizado organizacional dinâmico; do planejamento estratégico e; das tomadas de decisões. Um processo que vai além do uso do ativo do conhecimento, protegendo-o de sua deterioração natural. O autor afirma que:

"Em muitas empresas têm-se constatado que estas não sabem o que elas sabem. Essa situação pode conduzir à duplicação de esforços, consumindo tempo e dinheiro".

MACEDO (2003:42)

O contexto de tal proposta é representado pela figura 6.05, na qual se percebe uma perspectiva de processos associados a áreas funcionais. Com isso, o autor entende combinar atualizações de conhecimentos, tanto em tempo de execução (dos processos, nas diversas áreas, isolada ou conjuntamente) como em tempo de mudanças ambientais, pela retroalimentação (feedback dos resultados dos processos, gerando atualizações e, consequentemente, versionamento dos objetos de processo) das áreas.

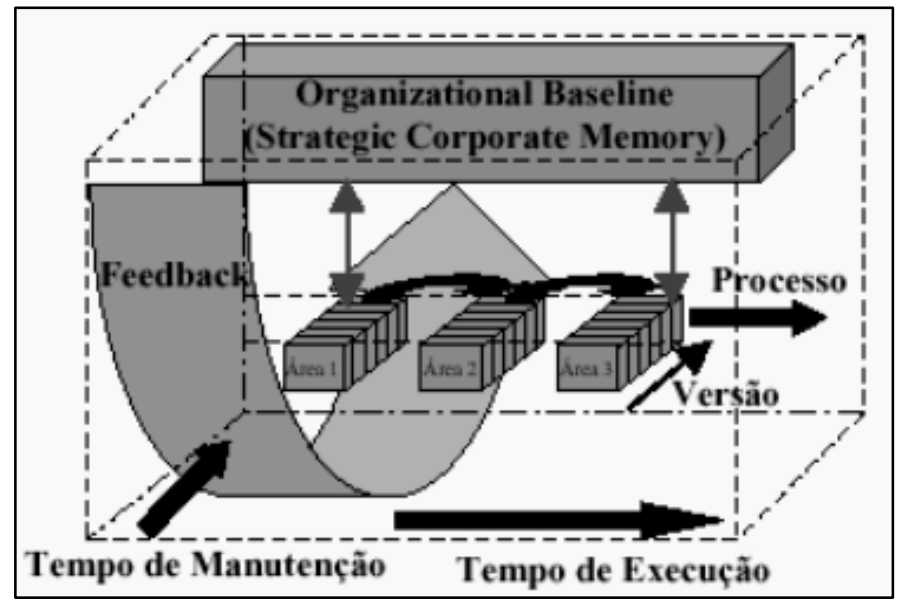

FIG 6.05: O contexto do Organizational Baseline. Extraída de MACEDO (2003:29)

O que Macedo pretende é a organização da memória estratégica dos negócios que, aqui, por ora, é vista por, apenas, um prisma: o do processo. Processo que, em sua 
visão, possui tridimensionalidade, pois ocorre em sentidos diversos e torna-se mais completo (e complexo) que o proposto pelas figuras 6.03 e 6.04 .

\section{2 - O MAPEAMENTO DO PROCESSO DO CONHECIMENTO:}

CHATTERJEE (2002:1-4) não só apresentou uma proposta de estruturação de um processo evolucionário - como outros autores mencionados, com ele, no item anterior, ou de forma independente dele, em itens e capítulos anteriores -, como também procurou harmonizar o agrupamento de conceitos diversos, ao pensar uma estrutura de trabalho focada na gestão dos elementos do processo, que leva à capacidade de administrar o ativo do conhecimento na empresa, em equipes de trabalho, em atividades pessoais e, eventualmente, as sociais também.

As diversas formas de combinar insumos e produtos do conhecimento, nesse processo, formam o que NONAKA e TAKEUCHI (1997:67-83) denominam espiral do conhecimento, o qual contém socialização, combinação, internalização e externalização.

A sociabilização se dá quando o processo usa de conhecimentos tácitos para produzir conhecimentos tácitos (ou apenas transferir os já existentes). Os autores chamam a esse fenômeno de mero compartilhamento de experiências e afirmam que um indivíduo pode adquirir saberes tácitos pela observação e imitação, sem utilização de qualquer linguagem que exija formalismo.

A combinação se dá quando o processo usa de conhecimentos explícitos para produzir conhecimentos explícitos. Aqui, também, pode ser um caso apenas de transferência, dado por linguagem e ferramental devidamente formalizados. Em não sendo apenas transferencia, configura-se num processo de sistematização de conceitos que envolvem combinações, classificações e acréscimos de conhecimentos explicitados por documentações, reuniões e sistemas computacionais. Os autores afirmam que este tipo de mecanismo é o mais comum de ocorrer em situações de negócios.

A internalização se dá quando o processo usa de conhecimentos explícitos para produzir conhecimentos tácitos, o que, geralmente, ocorre em situações em que se aprende fazendo e em processos de aprendizagem, segundo descrevem os autores, ao afirmarem que tais situações provocam internalizações dos conhecimentos obtidos nas bases tácitas dos indivíduos, sob formas de modelos mentais, concepções circunstanciais e saberes técnicos. 
A externalização se dá quando o processo usa de conhecimentos tácitos para produzir conhecimentos explícitos, através de processos de articulação de experiências e conhecimentos acumulados para a formulação de conceitos e novos conhecimentos formais e transferíveis. É considerado um processo de criação perfeito, à medida que transforma o tácito em explícito, formando metáforas, analogias, conceitos, hipóteses e/ou modelos, de acordo com NONAKA e TAKEUCHI (1997:67-83).

Gerir conhecimentos, portanto, é visualizar as circunstâncias em que estas abordagens do processo acontecem (ou podem acontecer) e, assim, conquistar domínio sobre a aplicação de legados de conhecimento. As condições, os parâmetros, os saberes sobre quais e como aplicar e, principalmente, a organização sobre o acumulado, o produto e as ações representam o meta-conhecimento anteriormente citado.

BUKOWITZ e WILLIAMS (2002:24-27) apresentam uma proposta de mapeamento da estrutura do processo de gestão do conhecimento que visa a utilização do ativo de conhecimento em situações diárias, as quais exigem respostas às demandas e oportunidades do mercado, e a combinação do capital intelectual da organização (envolvendo tácito e explícito) com as estratégias de negócio. A figura 6.06 representa a proposta das autoras, de uma massa de conhecimento permeada por ações relativas a sua geração, manutenção e aplicação. O ativo de conhecimento representa um inventário de todos os recursos relativos ao capital intelectual da organização, estejam eles em bases específicas ou nas cabeças de seus integrantes, o qual envolve depósito de conhecimento, relacionamentos, TIs envolvidas,

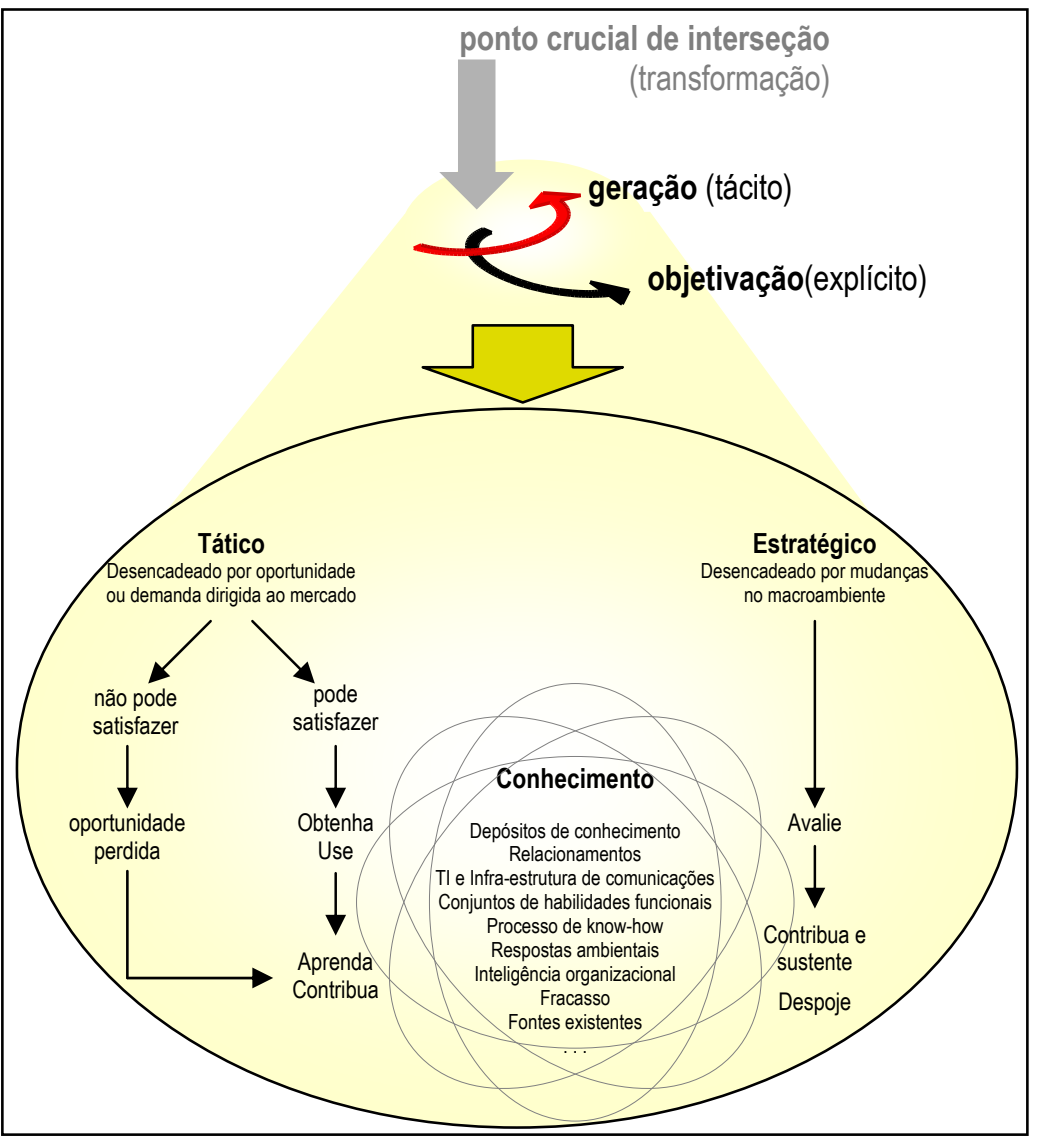

FIG 6.06: O mapeamento do núcleo do processo de conhecimento. Adaptada de BUKOWITZ e WILLIAMS (2002:24), a figura, no interior da elipse, adapta-se ao contexto de visualização para a gerenciabilidade. 
infra-estruturas, habilidades funcionais, saberes e domínios sobre o fazer, respostas ambientais e registros de sucessos e fracassos, entre outros possíveis elementos. Sobre este ativo, atua-se pela obtenção de dados, informações, conhecimentos ou capacidades de solução de problemas, o que é feito por seus usos e avaliações, por sua construção, contribuição e sustentação, pela aprendizagem e, até, pelo despojo de alguma parte de seu conteúdo, se necessário for.

O desenho no interior da elipse demarcada é reprodução fiel do modelo de Bukowitz e Williams, aplicado sobre um contexto maior, na intenção de mostrar que serve à representatividade e ao entendimento do processo do conhecimento, especial e primordialmente sobre o denominado "ponto de intersecção" do mesmo, conforme fora apresentado em oportunidades anteriores e demonstrado, pelas figuras 5.11, 6.03, $6.04 \mathrm{e}$ 6.05 , dedicadas à conceituação do processo como "caixa-preta", umas, e à intuição do possível mecanismo em seu interior, outras.

Os conceitos classificadores do que é estratégico e do que é tácito, propostos pelas autoras, condizem com os modelos de gestão de negócios discutidos no decorrer do capítulo terceiro, portanto, ao ampliar os detalhes de contribuição ao entendimento do modelo, estes se darão sobre o modelo hierarquizado de SI e, não, sobre o de processo (como propôs a figura 6.03), acompanhando a proposição da figura 3.03, que evoluiu para as figuras 3.06 (formas de classificar SI) e 3.07 (formas de estímulos de mudança que pressionam a organização e, consequentemente, sua administração). A figura 6.07 representa o contexto sobre o qual posiciona-se a gestão do conhecimento (GC), e sobre o qual se dará tal detalhamento, considerando-a como envolvente e integradora de todos os níveis organizacionais, permitindo customização e otimização da inteligência aplicada ao negócio (BI).

A dinâmica do conhecimento é motivada por vários fatores que, na maioria das vezes, decorrem de um principal: a constante mudança que ocorre no ambiente de maneira ininterrupta e, aparentemente, infinita, conforme expressam MINTZBERG e HUY (2003:18-23), e que provoca mudanças necessariamente assemelhadas, tanto na forma quanto na constância, nas organizações empresariais. O conhecimento é recurso constantemente utilizado (pertinentemente com a constância das mudanças) que precisa ser constantemente gerenciado, conforme afirmam vários autores, entre eles TERRA (1999), NONAKA e TAKEUCHI (1997) e FELIX (2003). 


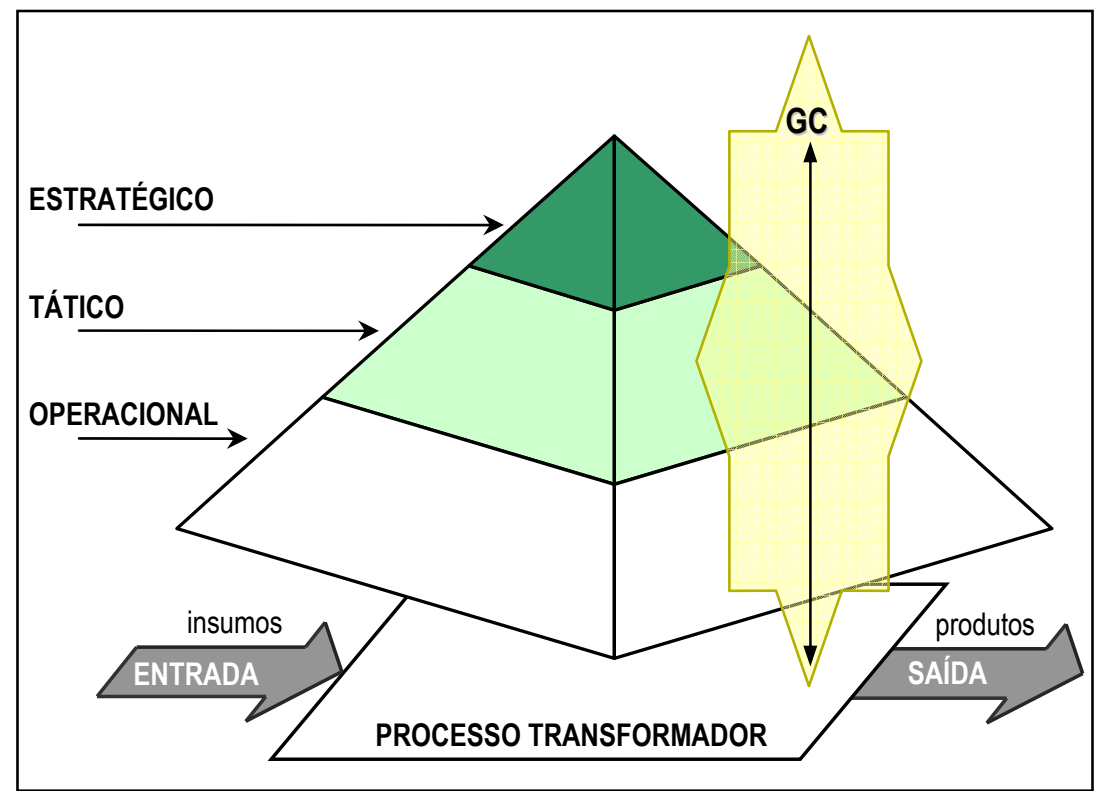

FIG 6.07: Contextualização da Gestão do Conhecimento

no ambiente da organização.

O modelo proposto por BUKOWITZ e WILLIAMS (2002:24-27,49-231) corrobora essa visão cíclica e evolutiva da constância do processo pela constância das mudanças e suas demandas por soluções. A todo instante, tanto no nível do processo transformador do sistema, quanto nos níveis da gerência apoiada em SI, conhecimentos são criados ou reutilizados, para atender as mais diversas situações possíveis de trabalho. Em alguns casos, a demanda é por uma contribuição que implemente ou sustenha o próprio sistema de conhecimento. Em todos os casos, o conhecimento (ou, mesmo, apenas informação ou dado) envolvido é avaliado e pode satisfazer ou não. Em caso negativo, pode ser rejeitado, perdido ou, até, descartado (no caso de conhecimento já incorporado). Em caso positivo, será obtido e aplicado (no caso de demanda por aplicação) ou construído para formar ou sustentar a GC (no caso de manutenção). Em todos esses casos, aprendizados devem ser contabilizados e contribuições devem ser agregadas, sejam tácitas ou explícitas. A figura 6.08 dá uma idéia dessa dinâmica.

As autoras definem duas dimensões, em seu modelo: a tática e a estratégica. Apesar de visualizar o modelo, de forma desmembrada, sobre a visão organizacional do sistema e do sistema de informações (este sob abordagem hierárquica), as dimensões descritas por elas não são exatamente os níveis (tático e estratégico) do SI. Tática, em suas opiniões, é a aplicação em si do conhecimento e como a gestão deste a vê. Estratégica representa a manutenibilidade da estrutura e da organização dos conhecimentos e de sua gerenciabilidade. 


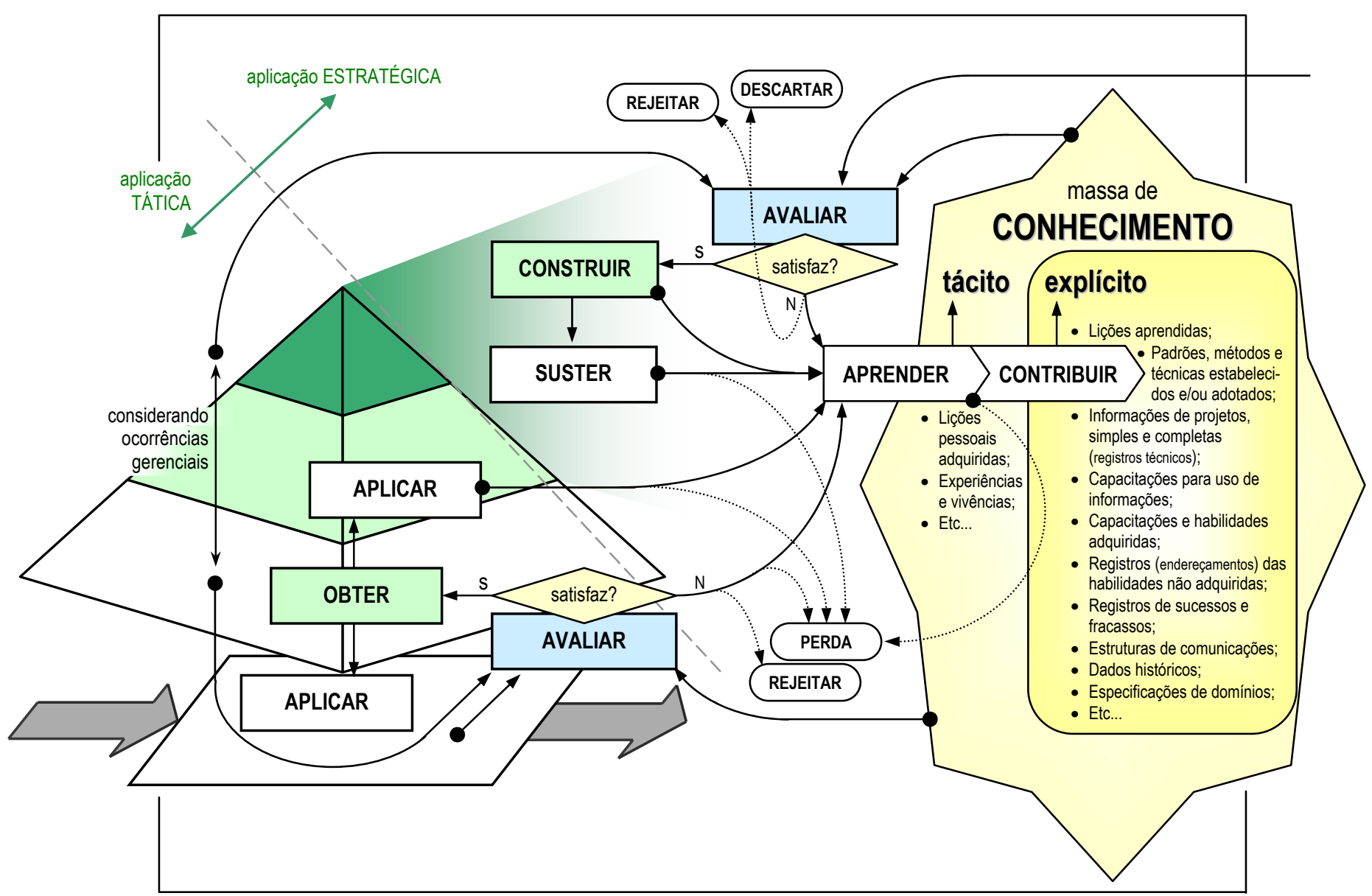

FIG 6.08: Mapeamento do processo do conhecimento organizacional. Desmembramento do modelo de BUKOWITZ e WILLIAMS (2002:24).

A massa de conhecimento (MC) representa a totalidade de todo o conjunto de conhecimentos e meta-conhecimentos relativos a determinada realidade (pessoal ou de negócio) que, por força do dinamismo do ambiente da organização e este, por sua vez, por força do dinamismo do mercado, precisa ser dinâmica, tanto em sua porção tácita, quanto em sua porção explícita e em sua estrutura.

Na dimensão tática, a aplicabilidade do modelo ocorre mais a curto e médio prazos, pois representa o uso do conhecimento de forma constante e diária, para atender demandas operacionais e oportunidades mercadológicas, conforme explicam as autoras. Existem duas sub-dimensões: a do uso e a da produção de componentes de conhecimento. O uso caracteriza-se por toda e qualquer situação que exija algum conhecimento para uma solução de problema ou tomada de decisão, sejam de cunho operacional ou gerencial (em todos os níveis - porém, devido ao caráter mais corriqueiro, tende, com maior freqüência, ao nível gerencial, administrativo e executivo); nesse caso, algum conhecimento já constante da massa de conhecimento, tácito ou explícito, será solicitado e, como pode haver mais de um elemento destes 
aplicáveis, uma avaliação é feita para verificar a satisfação ou não da situação. Caso nenhum conhecimento anteriormente apropriado sirva à situação, um novo conhecimento pode ser produzido. A produção caracteriza-se pela possibilidade da situação exigir algum conhecimento, ou seja, algum conteúdo novo, o qual possa encaixar-se na estrutura estabelecida de conhecimento; nesse caso, uma avaliação, além da já exposta, também é necessária, para determinar como o novo conteúdo pode agregar valor à estrutura estabelecida. A dimensão tática compõe-se, basicamente, de ações naturais, conforme a pessoa reuna informações e conhecimentos necessários a seu trabalho, por consulta à massa de conhecimentos já existente ou por observação, e inferência, dos acontecimentos à sua volta. $\mathrm{O}$ obtido é utilizado na agregação de valor ao negócio e torna-se um novo aprendizado que, incluído na massa de conhecimento, poderá ser compartilhado. Esta dimensão contém os sub-processos:

- Avaliar: ação destinada à filtragem de quantidades cada vez maiores de informações e conhecimentos, necessárias ao dia-a-dia da organização, buscando aumentar a eficiência na abstração. Um possível modelo de avaliação, a ser aplicado neste ato, é o apresentado por SILVA e SANTOS (2000:123-126), desde que adequadamente ajustado pela empresa a empregá-lo. A avaliação é tanto do conteúdo já agregado, quanto de novos conteúdos, resultantes de processos que empreguem o já existente ou, ainda, resultantes de situações fortuitas e inesperadas;

- Obter: ação natural, comum e cotidiana de apropriação de informações e conhecimentos próprios à resolução de problemas, à tomada de decisões ou à criação de novos produtos ou serviços. Com a ampliação dos volumes de informações, a disponibilização de novas tecnologias e de técnicas para suas aplicações torna-se essencial, principalmente no âmbito da organização, segundo expõem as autoras;

- Aplicar: ação de utilização do conhecimento, na operacionalização de processos ou nas tomadas de decisões. Novas formas de utilizar ou combinar estes elementos representam novos conhecimentos que, esperase, possam ser aprendidos, tanto sob o ponto de vista de ampliar a massa de conhecimento, quanto o de inovar na maneira de utilização (o que deve representar mais conhecimento);

- Aprender: ação de compreensão do significado da informação ou do 
conhecimento que acaba de ser aplicado ou desprezado por não satisfazer determinada situação. No nível organizacional, é preciso desenvolver, nas pessoas, consciência da importância do aprendizado, e na organização, consciência da importância de o provocar e estimular. O resultado deste ato é, em principio, um conhecimento tácito que possa ser aplicado em prol do negócio;

- Contribuir: ação de disseminação ou formalização do conhecimento adquirido, provocando o compartilhamento do resultado do aprendizado, ou pela divulgação, se tácito, ou pela formalização, se explicitável. O resultado deste ato é, em principio, a difusão do conhecimento tácito que, se transformado em explícito, passa a fazer parte do banco de conhecimentos da organização e, se não transformado, pode ser transmitido para outrem, colaborando para a formação de competências essenciais dinâmicas, apregoadas por LEI et al.(2001:157-180);

- Rejeitar: ação de desprezar o que foi pego na massa de conhecimento e não satisfez à situação, nem agregou qualquer novo valor e, ainda, não precisa retornar, pois não representa qualquer mudança;

- Perda: situação em que não se consegue agregar o conhecimento, ou mesmo o fato de sua rejeição, em seu próprio inventário ou ao de outras pessoas ou, ainda, ao da organização, de maneira formalizada ou não, mesmo que tenha havido algum aprendizado pessoal (não se pode esquecer que as autoras incluem, no rol dos tácitos, conhecimentos que as pessoas não sabem que sabem). Perda pode se dar, também, no momento da contribuição, logo após o aprendizado, tal que apenas parte do aprendido seja explicitado.

Na dimensão estratégica, o modelo aplica-se mais a longo prazo, pois representa a combinação do capital intelectual da organização com as exigências estratégicas do negócio. Como estas referenciam, naturalmente, questões e decisões de foro essencial nas relações da empresa com o mercado, refletem as possibilidades das mudanças radicais, apresentadas por MINTZBERG e HUY (2003:64-72) no capítulo 3, nas mudanças estruturais da massa de conhecimento da organização. Esta dimensão, segundo BUKOWITZ e WILLIAMS (2002:26-27,233-365), tem aplicabilidade em todos os níveis organizacionais, pois também pode, simplesmente, contribuir com 
conteúdos à estrutura vigente, mas sua maior incidência, ao menos o principal foco de suas preocupações, tende ao nível estratégico, pela importância das decisões que provoquem redefinição do modelo de conhecimento com o qual a organização passará a contar. As autoras afirmam que a gestão do conhecimento provoca "todo um novo modelo de trabalho"; daí suas inquietações. Esta dimensão compõe-se de atos mais afeitos à administração centrada em missões e objetivos organizacionais (sem deixar de prover necessidades decisórias de cunho gerencial, tanto administrativo quanto executivo). Atos que buscam alinhar, estrategicamente, CEO e $\mathrm{CKO}$, ou seja, os executivos gestores de negócio e de conhecimento, pela avaliação contínua do capital intelectual e das exigências visíveis impostas aos rumos futuros da gestão do negócio. $\mathrm{O}$ que se deve procurar, em suas opiniões, é a agregação de formas inovadoras para se aplicar o capital intelectual, por grupos de liderança e a garantia da eficiência gerencial, no que diz respeito à gestão tradicional, alicerçando ações com mais confiabilidade pelo teor de conhecimento agregado à cada ação. A agregação de formas diferenciadas é função de construção, enquanto que a garantia da eficiência é função de sustentação; funções estas contidas no rol de sub-processos que a dimensão engloba:

- Avaliar: ação destinada à filtragem de quantidades cada vez maiores de informações e conhecimentos vindos dos ambientes externo ou interno (organizacional decisório) e à apreciação de elementos presentes na massa de conhecimento, para determinar-lhes a valia de suas permanências, pois podem já ser descartáveis. Tal apreciação demanda capacidade de mapeamento do capital intelectual da organização, mais fixamente o já formulado, se bem que não se pode omitir possibilidades de fazê-lo também com o que permanece tácito, e de contrastação deste com as necessidades presumíveis de conhecimento, de acordo com o que se pode estimar pelo planejamento estratégico estabelecido pela missão traçada para a organização;

- Construir: ação destinada ao estabelecimento de relações entre os elementos intelectuais "patrimoniados" da organização, seus componentes de negócios (funcionários, executivos, clientes, fornecedores, parceiros, etc.) e a comunidade à qual integra-se (sociedade, mercado e interessados no negócio), visando a agregação do valor decorrente da união dos capitais que formam seu conhecimento 
(conforme demonstra a figura 6.09, na proposição de gerenciamento, definida pelas autoras) e a sustentabilidade do modelo e do processo de conhecimento em uso;

- Suster: ação de assegurar que o conhecimento (preferencialmente explícito, mas não exclusivamente, pois o foco deve ser abrangente ao capital intelectual como um todo, tanto quanto possível) mantenha a competitividade do negócio e a viabilidade mercadológica da organização, formando, a partir das relações estabelecidas no ato de construir, um alicerce de experiências e conhecimentos que solidifiquem a capacidade de gestão;

- Aprender: ação de compreensão do significado do conhecimento, a ponto de mudar a estrutura da massa, se preciso for. As autoras apontam, como desafio maior para as organizações, encontrar formas de integrar o aprendido e o processo de aprendizagem ao modo como as pessoas atuam em seus afazeres;

- Contribuir: o mesmo, anteriormente comentado;

- Rejeitar: ação de desprezar o que, em análise, não justifique inclusão (como já o foi explicado, no rejeite da dimensão tática), modificação de qualquer estrutura ou eventual ato de descarte;

- Descartar: ação de despojo de algum conhecimento que possa ser considerado definitivamente desnecessário para a organização, mesmo que já tenha sido de alta importância, pela medida de obsolescência do mesmo. Esta ação de dispensa deve atender a princípios de otimização de custos de oportunidade, necessários à gestão do capital intelectual, visando tanto tornar objetivas as questões de apego ao estoque criado de conhecimentos, quanto tornar perceptível alguma fonte alternativa de valor, disponibilizando o conhecimento além das fronteiras da organização. As autoras, nesse aspecto, ressaltam a importância e a gravidade do conceito e, consequentemente, a responsabilidade de decisão sobre a real existência de conhecimentos descartáveis;

- Perda: situação em que, além do descrito para a aplicação tática, pode ocorrer com uma mudança percebida que alteraria a estrutura da $\mathrm{MC}$, ou com parte dela. 


\section{3 - O GERENCIAMENTO DO PROCESSO DO CONHECIMENTO:}

O entendimento do processo, conforme definido por BUKOWITZ e WILLIAMS (2002:24,279-282) e detalhado pela figura 6.08, permite visualizar a dinâmica das atuações diversas no uso e na manutenção dos ativos de conhecimento da organização (ou da pessoa, já que o processo pode retratar, também, atividades de foro íntimo, no tratamento de informações, no acumulo de experiências e no desenvolvimento de saberes) e, assim, permite que tais ativos sejam gerenciados, bem como a própria dinâmica de percebê-los, armazená-los e aplicá-los.

Para as autoras, o resultado de tal dinâmica é, no âmbito das organizações, o capital intelectual: fruto do fluxo do conhecimento, ou seja, de uma triangulação de valores distintos (o humano, o organizacional - legado - e o do cliente) que agregam um valor resultante da multiplicidade e da diversidade de saberes, de habilidades e de competências, em prol do negócio. A figura 6.09 demonstra tal combinação, da qual pode-se comentar que o capital organizacional é o que, formulado, permanece na organização quando os membros portadores dos outros (humano e de cliente) se esvaem por perdas, descartes ou permutações, resultantes de mudanças diversas e naturais.

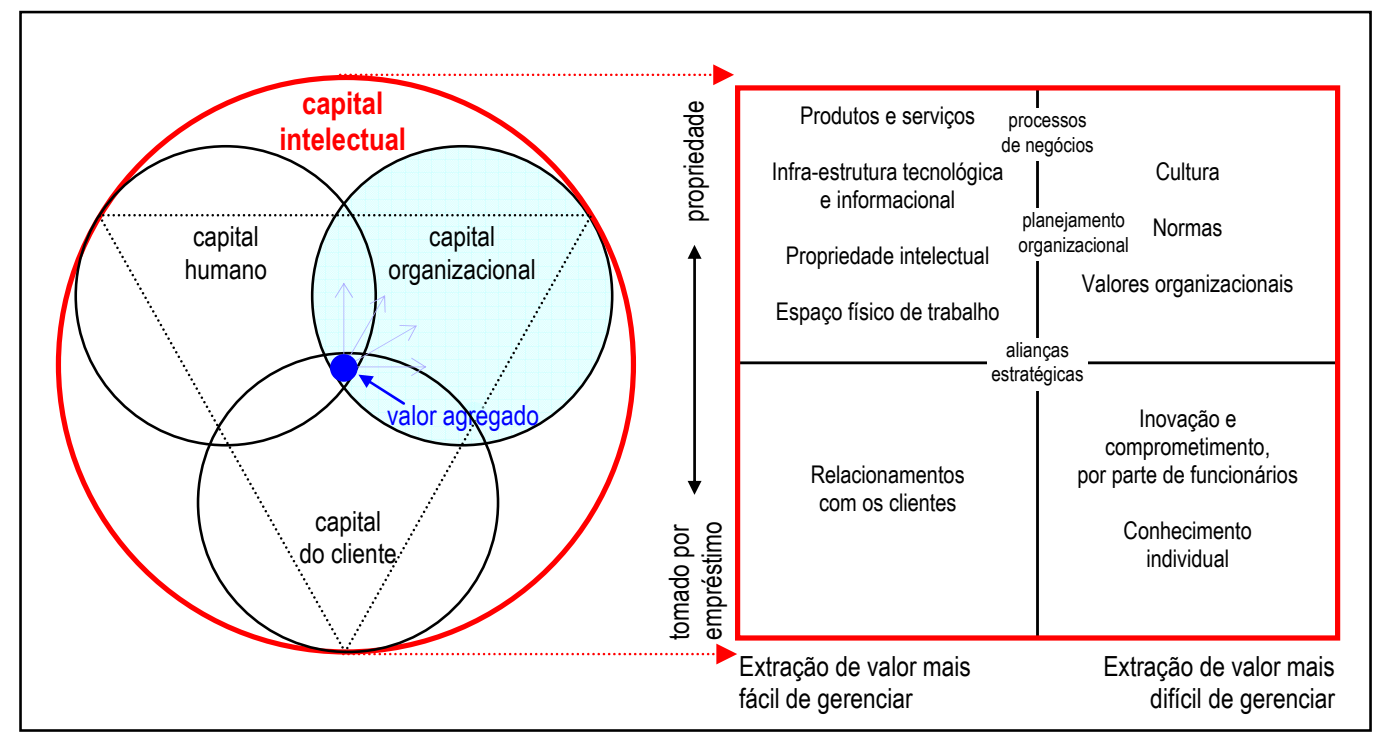

FIG 6.09: O modelo do capital intelectual, com sua matriz de gerenciamento. Adaptada de BUKOWITZ e WILLIAMS (2002:280,281).

Também com a finalidade de promover a gerenciabilidade, as autoras propõem uma visão deste capital intelectual na forma de uma matriz, onde é possível aperceberse do que mais se aproxima e o que mais se distancia do capital organizacional, propriedades da organização, por assim dizer, já que representam o que a organização possui de fato, em seu legado explícito. Os aspectos mais distantes desta capacidade de 
apropriação representam seu estoque tácito, ou seja, o conjunto de saberes e capacidades que a organização empresta de seus partícipes e clientes. Tantos estes como aqueles capitais, podem, ainda, ser pensados sob a égide do grau de facilidade com que podem ser geridos e vistos como fontes de valor.

Observando-se a matriz, pode-se perceber que produtos, serviços, infraestruturas, espaços físicos e propriedades intelectuais são considerados bens de plena propriedade, já que expressam os elementos de maior facilidade de entendimento, manipulação e gerenciamento. Permitindo-se utilizar os conceitos de composição do conceito maior de plena propriedade, vindos da física, pode-se estabelecer uma analogia que permite entender tais aspectos como de propriedade extensiva (que, sendo proporcional à massa do sistema...) e intensiva (...transcende à massa do sistema e torna-se independente dela, passando a caracterizar-lhe o estado) da organização. Nesse caso, pode-se entender que são parte de um conjunto de conhecimentos que caracterizam a objetividade funcional da organização e de seus negócios. A mesma matriz mostra, ainda, que o caráter inovador dos partícipes de negócio, bem como seus comprometimentos para com a empresa e seus conhecimentos individuais - em muito, tácitos - representam o que há de mais complexo no que diz respeito à gestão e extração de valores, principio no qual se baseia a afirmação das autoras de que sempre limitar-seão a elementos a serem tomados por empréstimos, enquanto durar o relacionamento das pessoas com as empresas, que não chegam a ser devidamente apropriados pela organização. Entre estes dois quadrantes, permeiam elementos que intermediam os extremos mencionados, uns bem definidos nos dois quadrantes restantes, outros transcendendo algum limite fronteiriço entre as divisões da matriz.

Lembrando CHATTERJEE (2002:1-4), apresentado no capítulo quinto: Há uma forma diferenciada e específica para a percepção e visualização da criação e da aplicação do conhecimento, gerando ou potencializando competências profissionais, que interessa à gerenciabilidade deste recurso. A proposta deste autor alinha-se à de Bukowitz e Williams, no que diz respeito à capacidade de gerenciamento que o conhecimento sobre cultura, valores intrínsecos da empresa, relacionamentos com clientes e capacidades informacional e inovadora, entre outros, pode proporcionar e, ainda mais, havendo alguma consciência que permita mensurar o que permanece como empréstimo e o que se consegue agregar como propriedade da organização e o que pode ser considerado fácil e difícil de gerenciar, no que tange aos saberes e habilidades. 
Alinha-se, também, a outras, como a de ZARIFIAN (2001:52-74), à medida que também define a competência como uma conjuntura resultante do acúmulo de fatores situacionais, práticos e teóricos, denominado conhecimento, o qual, por sua vez, é resultante de outros fatores acumulados; a diferença é que Chatterjee destaca as questões da inovação, intermediando a relação entre competência e conhecimento. Seus postulados alinham-se, também, com os de SETZER (2004) e de FLEURY e FLEURY (2001:18-33), para quem a competência é uma agregação de valores resultante de um processo que desenvolve saberes e habilidades. Alinha-se, ainda, com o que preconizam NONAKA e TAKEUCHI (1997:61-85), relativamente ao processo em si, tido como mecanismo de criação e objetivação dos conhecimentos, gerando ativos de domínio e gerenciabilidade. $\mathrm{O}$ autor harmoniza o agrupamento de tais preceitos ao pensar uma estrutura de trabalho focada na gestão dos elementos do processo.

O modelo criado por Chatterjee ressalta a importância de "pensar a gestão", pois considera as dificuldades para observar os conhecimentos em uso, principalmente os tácitos, sejam eles simples ou complexos, elementares ou sistêmicos. A proposta baseiase na coleta do conhecimento em atividades não apenas no momento em que ele está sendo requisitado para a ação, mas sim reconhecê-lo em seus resultados, tanto no momento da inovação, quanto no da formação da competência e no da efetivação desta, no aspecto global das competências. Os conhecimentos tácitos acarretam um ônus adicional em complexidade pelo caráter exclusivamente pessoal da consciência de seu alcance pleno e de seu potencial para criar valor econômico, quando incorporado às práticas organizacionais. A conversão do que é tácito em explícito, portanto, não é trivial, nem automática. Tem valor estratégico, o autor não tem dúvida disso, mas se pergunta: em não sendo mensurável ou tratável pelo organismo da empresa (ou por seus representantes maiores, gerentes e diretores), como pode ser valorado?

CHATERJEE (2002:1-4) defende a necessidade de empresas e profissionais serem multidisciplinares em suas aberturas à novidade, para que se tornem aptos a aplicar a informação e a intuição na reorganização das rotinas organizacionais, voltadas à inovação e à excelência sustentada, em seus ramos de negócio. Enquanto mecanismos informais de conversão da informação em conhecimento podem limitar a disseminação, os procedimentos formais, suportados por poderosas tecnologias da informação, oferecem aprendizado ilimitado (juízo do autor) e potencializam a eficiência do movimento informacional de "uma cabeça para outras"; conceito com o qual corrobora 
TAVARES (2004:36,39,90). À gestão do conhecimento cabe selecionar soluções, como o mapeamento tecnológico, a pesquisa por patentes, o projeto colaborativo, a aceleração do processo de negócio e a busca (mineração) de conteúdos bem estruturados. Tais preocupações levaram Chaterjee à proposta do modelo expresso pela figura 5.15, resultante de suas análises abrangentes sobre os desafios dos negócios na nova economia e sobre as áreas e os fatores chaves das pesquisas e das aplicações da gestão do conhecimento em organizações indianas de software.

Tal formalismo defendido por Cheterjee, bem como procedimentos do tipo mentoring, sugeridos por Tavares, relaciona a gestão do conhecimento com aprendizagens, fazendo desta, parte daquela, como forma de preservar o conhecimento.

\section{4 - EM SUMA...}

Este capítulo for dedicado à definição da gestão do conhecimento e de alguns aspectos da capacitação para o domínio da administrabilidade de um recurso que é, a um só tempo, dinâmico e complexo.

Sendo o conhecimento em si um processo e sendo sua gestão, também, um processo, o limite fronteiriço entre ambos apresenta-se de forma tênue. As questões de sua geração e aplicação (capítulo anterior), por exemplo, quase se confundem com seu processo e este, com seu processo gestor e seu mapeamento (neste capítulo). Apresentar um e outro, mesmo que sob formas tão próximas, foi considerado, pelo autor deste trabalho, fator de importância para distinguir o conhecimento do mapeamento necessário para entender sua colocação e seu comportamento na organização, a fim de promover a capacidade de entender seu gerenciamento.

Um dos fatores de interesse deste trabalho é a associação da gestão do conhecimento com processos que provoquem e viabilizem formas de aprendizagem, o que leva ao assunto sob foco no próximo capítulo. 


\section{ENSINAGEM E APRENDIZAGEM}

Abrir a "caixa-preta" apresentada por BOFF et al. (2001), conforme percebido na conceituação do conhecimento (capítulo 5), dado por diversos dos autores citados os quais o retratam como resultado de um processo de ensino (produto dinâmico) envolve conhecer os mecanismos de aprendizagem e ensinagem envolvidos.

Este capítulo visa estabelecer o conceito de ensinagem, associável à gestão do conhecimento e relacionado a uma das formas de abertura de tal "caixa preta" para, posteriormente, aplica-lo como base da preservação de conhecimento desejada.

PIMENTA e ANASTASIOU (2002:161-189) afirmam que o desenvolvimento profissional contempla o envolvimento de uma formação continuada, que garanta a valorização das identidades pessoal e profissional dos indivíduos. Tal identidade é epistemológica, pois reconhece a profissão, seja qual for, como um campo de conhecimentos específicos e configurados. O que as autoras propõem para a docência aplica-se às profissões em geral, dai perceber-se, atualmente, um aumento das preocupações quanto ao ensino e à aprendizagem, por parte das organizações, a ponto de DAVIS e BOTKIN (1996:25-42) defenderem teoria sobre a gradual transição do papel de formação, das escolas para as empresas. Estes autores discutem, com base em suas percepções sobre a relação escola-empresa, como esta relação tem mudado no decorrer do tempo, no que diz respeito à ensinagem, e para onde aponta esta tendência: as responsabilidades pela formação mais técnica e pela especialização sendo assumidas pela empresa, enquanto à escola caberia o estritamente básico.

De certa forma, CHAGAS (2001) concorda com eles, à medida que, focalizando a matemática, discute a forma equivocada como muitos docentes realizam seus exercícios de docência, sem estabelecer critérios de compartilhamento e comprometimento entre disciplina, docente e educando.

Este trabalho não pretende discutir o mérito ou a razão do que postulam Davis e Botkin ou Chagas, em referência a quaisquer inversões de papéis, apenas apoia-se em suas afirmações para pensar a questão do ensino, da aprendizagem, da necessidade do estabelecimento de uma ensinagem própria da empresa e da necessidade de 
gerenciabilidade para garantir domínio sobre os conhecimentos vitais à competitividade no mercado, para uma fábrica de software. Ainda sob este aspecto, e justamente por ele, não pretende aprofundar a discussão sobre ensino e educação, ou sobre ensinagem e aprendizagem, apenas sabê-los, mesmo que de forma superficial, para ancorar suas relações com a gestão do conhecimento. Faz-se necessário, então, tecer algumas definições básicas sobre os conceitos de ensino, ensinagem e aprendizagem.

\section{1 - ENSINO}

Tecnicamente, pode-se afirmar que o ensino é composto de conhecimentos e que sua finalidade é a transmissão destes conhecimentos, executada de forma sistêmica, visando progresso intelectual de quem quer que os receba.

GOLDBARG (1998:35-36), por exemplo, apresenta-o como instrumentalização indispensável a esse processo de transmissão, na composição de um processo maior: a educação. $\mathrm{O}$ autor estrutura suas deferências com foco no educando universitário, mas sem desconsiderar que seus conceitos, de processo transformador voltado a despertar aptidões e orientá-las, aplicam-se ao educando empresarial.

PIMENTA e ANASTASIOU (2002:203-205) entendem o ensino como um fenômeno situacional complexo, em cuja estrutura as implicações sociais práticas são elementos vitais e em cuja essencialidade os balanços críticos fazem-se necessariamente constantes no que diz respeito aos conhecimentos relativos ao conteúdo produzido e ao seu campo de ação. Ensino, segundo as autoras, é atividade social, com compromisso de assegurar que todos aprendam, contribuindo para a humanização e a redução das desigualdades sociais, composta de duas dimensões: a ensinagem e a aprendizagem; ambas de igual importância, no processo (e isso elas fazem questão de enfatizar), justificando-se na história da didática, pois houve época em que a importância do ensinar subjugava a do aprender e a ênfase no professor negligenciava métodos e recursos e, mais ainda, o despertar de motivação e comprometimento do aluno.

Conceitos estes, concordantes com os de SAWREY e TELFORD (1979:67-73), que discutem o assunto sob a ótica social, mesmo não fazendo uma distinção explícita entre o ensino e a educação. Realizam tal discussão como forma de visualizar o processo de transferência do conhecimento entre participantes de um contexto de aprendizagem e focalizando o participante receptor de tal contexto. Lembrando a 
filosofia dos antigos gregos, os autores identificam a virtude na sabedoria e o bom comportamento como inerente do conhecimento. Isto traduzido com olhos para a sociabilidade do ensino, eqüivale à convicção de que "aprender é, de si, uma coisa boa" à medida que um aumento de saber acarreta um aumento de virtude. Trabalhando esta linha de raciocínio, tratam a perspectiva da sociabilidade da educação no processo do ensino, visto, por eles, como um processo composto por transferência e aprendizagem.

CHAGAS (2001) explica o ensino como meio fundamental para o progresso intelectual, que envolve assimilação de conhecimentos, pela instrumentalização necessária à transmissão do mesmo. Essa forma de entender o ensino caracteriza a base do processo de educação. A autora afirma, ainda, que, segundo pesquisas, o ensino deve ser entendido como um processo compartilhado que depende, de forma profunda, do conhecimento do aprendiz (aluno) sobre a importância do assunto em discussão e sua capacidade de atender necessidades e expectativas impostas pelo processo e, ainda, de sua consciência sobre as alternativas envolvidas para a melhoria da qualidade de vida.

MARQUES FILHO (2002:1-7) discorre sobre o ensino, focando-o sob o ponto de vista empresarial, e pergunta-se o que as pessoas estão aprendendo no mundo do trabalho e como isso pode alterar suas percepções sobre seus papéis na sociedade. $\mathrm{O}$ autor crê vivermos em um mundo de capital intelectual, no qual o bem mais valioso é o cérebro das pessoas e sua energia. Dentro deste conceito que associa capital intelectual e conhecimento organizacional (se é que não se confundem em certos aspectos), o contexto empresarial divide-se em empresas que ensinam (teaching organizations) e que aprendem (learning organizations), posicionando as que ensinam a uma proximidade maior de liderança e sucesso do que as que aprendem. Porém, apesar de colocar a questão como uma evolução necessária à competitividade, o autor não escolhe as que ensinam, em detrimento das que aprendem. Ambas as orientações são importantes e complementares e evoluem para conceitos mais refinados: a aprendizagem organizacional, com semelhança ao termo aprendizagem, e o ensinamento organizacional, com proximidade ao termo ensinagem. Em sua opinião, empresas, assim como escolas, são organizações que devem primar pelo ensino. As que aprendem têm fim em si mesmas, pois a organização é o conjunto de pessoas que a forma; pessoas que aprendem para, elas mesmas, melhorarem a organização, num processo endógeno, que favorece acumulação e competição. Já as que ensinam possuem um processo exógeno, no qual o aprendizado é dirigido à comunidade que a integra e à 
qual se integra, formada por funcionário, clientes, fornecedores, parceiros, representantes, concorrentes e governo.

\section{2 - ENSINAGEM}

Tecnicamente, ensinagem é o ponto montante do ensino (se visto como um processo de transformação), o qual envolve a parte estimuladora do mecanismo, o agente de produção e todo insumo necessário.

PIMENTA e ANASTASIOU (2002:177-243) afirmam que a prática social do ensino, para ser bem feita, não pode ficar limitada ao momento da exposição do conteúdo a transmitir e, sim, exige a consideração de mais elementos essenciais na composição da intenção da aprendizagem, para transformá-la em ação efetiva de ensino. Mais que o domínio de conteúdos, exigência incontestável, é imprescindível a competência para a docência (as autoras cuidam para que não se confunda competência e dom, pois resumem a discussão a questões de capacitação e conquista de maturidade), a qual envolve o método dialético de ensinar, desenvolvido a partir de um pressuposto de utilização intencional de mecanismos de transmissão, motivação, envolvimento e comprometimento do educando. Este conjunto de conteúdos e métodos é a ensinagem: o processo como um todo, de ensino, sob a ótica de seu executor.

Ensinagem, então, pode ser entendida como a visualização da dinâmica do ensino por parte do agente estimulador (e, ao mesmo tempo, fornecedor e executor), cujos elementos de estruturação (o conteúdo, a estrutura metodológica, a organização interna e procedimental, a lógica e a contextualização) permeiam o papel condutor do executor, a quem cabe:

- organizar informações, conhecimentos e atividades;

- atender às características de conteúdo, curso e disciplina;

- entender características de processo, produto e aluno;

- mediatizar a apreensão da realidade contextual, pelo desafio;

- direcionar e orientar o aprendiz, a fim de promover sua percepção e assimilação;

- estabelecer técnica e tecnologia necessárias ao processo;

- dominar conteúdos e métodos.

BORGES NETO e SANTANA (2001:2-4) utilizam, também, o termo ensinagem 
para definir todo elemento relativo à docência na composição, junto com a aprendizagem, do ensino. São exemplos de elementos da docência: a formação docente, a prática do professor e o desenvolvimento de seqüências didáticas apropriadas ao que se pretenda ensinar, entre outros. $\mathrm{O}$ conceito de ensinagem fundamenta, segundo os autores, o entendimento do preceptorado - a interação de ambientes, materiais, idéias e pontos de vista, numa situação de ensino-aprendizagem - à medida que se refere ao desenvolvimento a partir dos modelos e experimentos docentes, mobilizando faculdades cognitivas discentes e envolvendo não só a transposição didática de conteúdos, mas também os contratos didáticos, explicito e implícito, contidos no processo de ensino.

SAWREY e TELFORD (1979:76-86,149-161,358-388) trazem, em suas considerações sobre o assunto, o conceito da transferência, duplamente segmentado, aplicando-se tanto sob a ótica docente, quanto discente: na docente, ajusta-se aos conceitos de ensinagem, anteriormente apresentados, e pode ser tomado como sinônimo destes; já sob a ótica discente, resume o uso que o aprendiz faz do conhecimento consumido, posteriormente ao aprendizado do mesmo, ou seja, a maneira como todos utilizam os produtos de seus aprendizados como pré-requisito - ou experiência acumulada - motivador e estimulador para os próximos eventos de aprendizagem, sugerindo a formação de um circulo virtuoso entre transferência e aprendizagem, que [eles] identificam como o processo dinâmico ao qual se dá o nome de ensino.

Segundo os autores, seus pontos de vista coincidem com o de Jean Piaget, para quem o processo se dá pela provocação de um desequilíbrio entre o novo (que se apresenta) e o legado (estabelecido pela estrutura cognitiva) do indivíduo. A discrepância desestabilizadora é motivadora e exige um processo de acomodação que se realiza na aprendizagem. Ainda com base em Piaget, comentam sobre a importância do agente de transferência (ensinagem) saber dimensionar os graus de discrepância e interesse contextual que o aprendiz possa ter sobre determinado assunto; isso depende do quanto seja seu conhecimento legado sobre o tema.

MARQUES FILHO (2002:4) utiliza o termo ensinamento organizacional para expressar a habilidade instalada de ser professor, treinador ou instrutor, no exercício profissional de identificação, estimulo e desenvolvimento das capacidades de aprender e de ensinar e empreender, entre o corpo técnico, operacional e gerencial da empresa. Seu conceito de ensinagem engloba a lógica do "quanto mais ensino [houver], mais pessoas adquirem a capacidade empreendedora de ensinar a outras". 


\section{3 - APRENDIZAGEM}

Tecnicamente, aprendizagem é o ponto jusante do ensino (se visto como um processo de transformação), o qual envolve a parte receptiva do mecanismo, o agente de consumo e o produto realizado pela produção.

A aprendizagem contrapõe e complementa o elemento ensinagem, na composição do fenômeno do ensino, segundo BORGES NETO e SANTANA (2001:1), à medida que define o processo sob a perspectiva discente, ou seja, a porção do preceptorado que envolve o aluno (ou aprendiz) no consumo do conhecimento e na absorção de resultados de uma experiência de ensinagem. Ao ensino, como processo, cabe o estudo de como otimizar o aprendizado, ou seja, a recepção dos conhecimentos.

Para MARQUES FILHO (2002:4-6) a aprendizagem é expressa pelo termo "aprendizagem organizacional", pois sua visão é a da empresa e está, mais especificamente, relacionada ao aprendiz e à sua capacidade de absorver, transformar, aplicar e compartilhar conhecimentos, segundo a lógica do "quanto mais aprendo melhor faço". Funcionários com conhecimentos agregados por um processo de aprendizagem vão interagir com clientes e fornecedores em níveis diferenciados, elevando, nas organizações, de forma rápida e eficaz, o "valor agregado do negócio", o que é observável pelas personagens ambientais envolvidas. Em seu pensar, o autor considera que o conceito de "rede" tende a envolver mais pessoas e sistemas em planejamentos, produções e distribuições de bens e que o uso intensivo de novas tecnologias deverá intensificar a substituição de estruturas e formas de trabalho, levando profissionais à obrigação de repensar participações e comprometimentos e aprender, intensa e continuadamente, para manterem-se ativas nos novos paradigmas sistêmicos.

SAWREY e TELFORD (1979:187-264,358-388), citando alguns teóricos do conhecimento, apresentam a aprendizagem como ampliação da estrutura cognitiva existente pela assimilação de informações ou experiências sensoriais e afirmam que o conhecimento que o aprendiz traz consigo, seu legado, é o mais importante fator de influência no processo de re-equilíbrio e acomodação, complementares da provocação da ensinagem, que a absorção de conhecimento realiza.

Para PIMENTA e ANASTASIOU (2002:208-214), aprendizagem é o processo como um todo, de ensino, sob a ótica de seu consumidor (educando ou aprendiz), 
absolutamente dependente da ensinagem, à medida que se complementam. É a visualização da dinâmica do ensino por parte do agente receptor (e, ao mesmo tempo, consumidor), a quem cabe:

- organizar-se para a participação e a recepção;

- preparar-se para adentrar ao processo e assumir compromisso com o mesmo;

- comprometer-se e participar do processo de superação de sua visão inicial, caótica e sincrética, sobre o objeto do conhecimento;

- mediatizar a apreensão da realidade contextual, pela reflexão;

- efetivar a construção do conhecimento.

As autoras explicam que o aprender não é passivo, exige esforçar-se, informar-se, exercitar-se e abstrair-se. A verdadeira ação da aprendizagem está associada ao desafio da síntese, da participação, da integração e do comprometimento.

DAVIS e BOTKIN (1996:43-62) trabalham a idéia do aprendizado, definindo, inclusive, detalhes de como ele pode ser construído (o que pode ser qualificado como ensinagem), tecendo considerações sobre como pode acontecer este processo de aprendizagem evolutiva que transcende o conhecimento para conquistar sabedoria: Passar do estágio (lembrando que esta é a designação dada pelos autores a cada uma das fases de desenvolvimento, conforme já o fora comentado no capítulo anterior) dos dados para o das informações representa o aprendizado de como reconhecer, nos dados, os elementos úteis para as informações e como executar a transformação, separando-os, armazenando-os e classificando-os para o uso na produção de informações estanques às fronteiras e restrições de cada assunto e/ou situação, sem grandes capacidades de associações. Atingir o estágio do conhecimento significa aprendizagem de como estabelecer conexões entre as mais diversas informações, estabelecendo uma rede de aplicabilidades com grande espectro de sofisticação e requintes de conveniência contextual, permitindo análises de circunstâncias, tomadas de decisões e armazenamento de experiências, que servirão como parâmetros em futuras circunstâncias (a qualquer momento e no momento seguinte). O próximo estágio de evolução representa o aprendizado de algo maior que o que começou como incremento de volume e grau de conhecimentos e estabelece gêneros de síntese para otimizar a quantidade incalculável de conhecimentos acumulados com o armazenar ininterrupto de experiências e aprendizados. Resultado: conhecimento tornado instrumento eficiente em 
prol da eficácia das decisões pessoais, sociais e profissionais, cotidianas ou não.

FLEURY e FLEURY (2001:21,31) podem ser relembrados aqui, visto que a agregação de valor, por eles defendida (e demonstrada na figura 5.02) resume o processo de aprendizagem, no qual o aprendiz conquista saberes, expresso em partes, tais como: um processo de memorização e disseminação de informações, a recepção do estimulo motivacional para a aprendizagem e a formação da competência sociabilizadora e realizadora desejável. Há de se observar, ainda, que o conhecimento destes elementos, como mecanismo de aprendizagem, e o aprofundamento em seus conhecimentos sobre como se deve dar um processo de ensino, do ponto de vista do estimulador, executor e agente agregador, viabiliza a definição da ensinagem necessária.

Outro autor, CARDOZA (2004:1-3), ao discorrer sobre processos de aprendizagem com processos de pesquisa e desenvolvimento, promovidos pela gestão de inovações, ilustra a dinâmica do conhecimento como uma escalada, que ele denominou "Escada de Aprendizado e Inovação", representada, conforme mostra a figura 7.01, por estágios que, a um só tempo, são evolutivos, recursivos e complementares; ou seja: evolutivos, pois não se pode escalar a um novo estágio sem a experiência no estágio anterior; recursivo, pois uma vez passado por um estágio, o

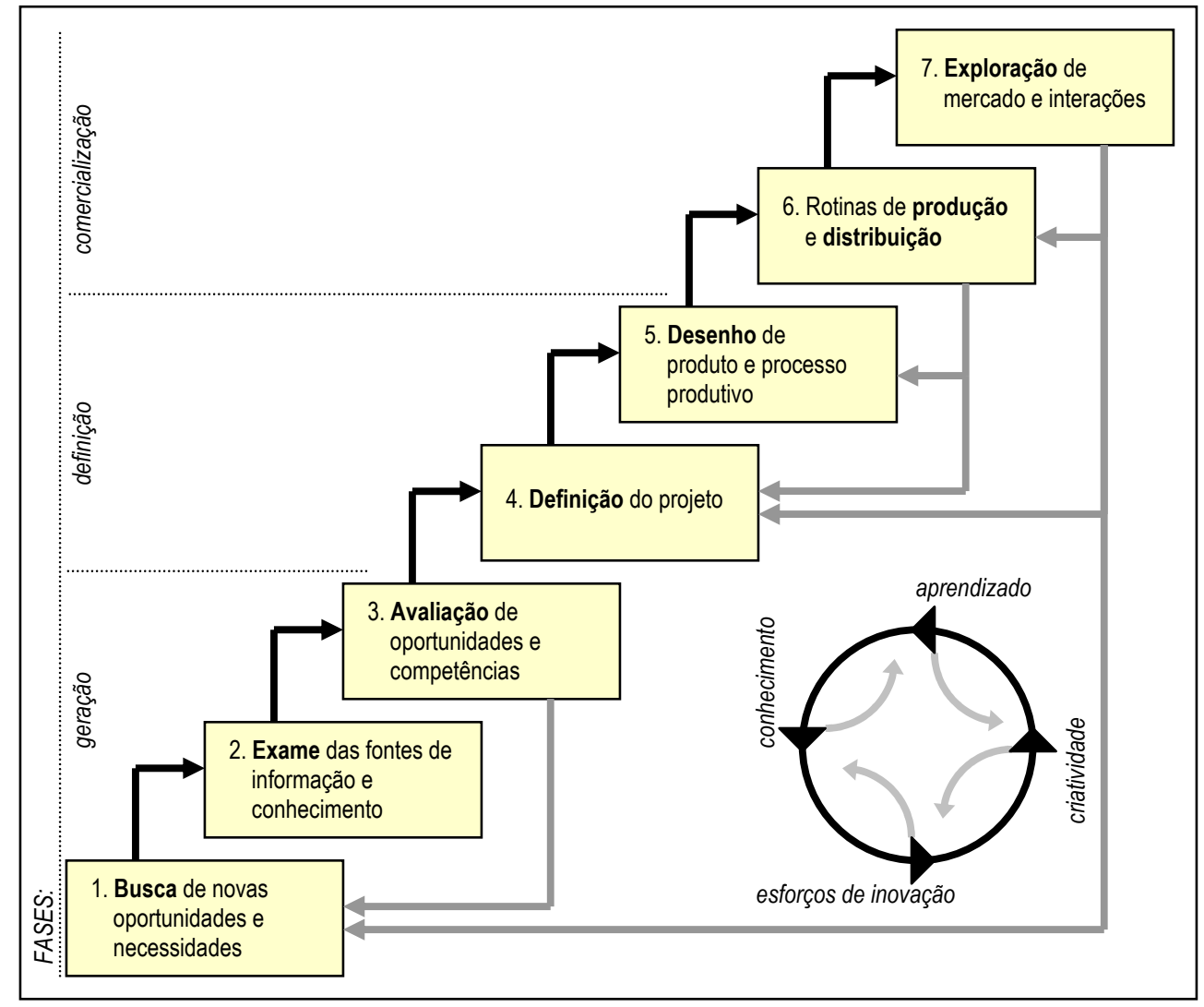

FIG 7.01: Escada de Aprendizagem e Inovação. Adaptada de CARDOZA (2004:3). 
mesmo não pode ser abandonado para a conquista do próximo, visto que os próximos sempre remeterão aos anteriores; complementares, pois, seguindo os conceitos de evolutibilidade e recursividade, não há vantagem em, apenas, conquistar o mais alto degrau da escada e, sim, dominar todos os seus degraus. A escalada proposta de sete degraus utiliza-se de conceitos comuns à administração e não pretende levar a um único ponto de gerenciabilidade do ambiente organizacional administrativo, por alto que seja, e, sim, ao domínio da gestão como um todo, permitindo um processo cíclico de uso, geração e aplicação do conhecimento.

Com base em um processo típico de desenvolvimento gerenciado de inovações produtivas, o autor propõe seu método de geração e aplicação de conhecimentos, cujos passos principais levam a:

1. aprender com o reconhecimento de necessidades de mercados e, ao entendê-las, com suas traduções em novos conceitos e oportunidades de negócios;

2. aprender com o exame das fontes de informações e conhecimentos já existentes, para avaliar, de forma adequada, mercado, produto e produtividade e permitir alinhamentos de estratégias corporativas;

3. aprender com a avaliação das competências necessárias aos projetos e dos custosbenefícios inerentes dos mesmos, trabalhando dimensões diferenciadas de informação, como: capacidades técnicas e organizacionais, habilidades necessárias e disponibilidades, entre outras, realizando prognósticos que apliquem conhecimentos acumulados de experiências;

4. aprender com a definição dos projetos e seus planejamentos de trabalho, como levantar os requisitos essenciais e como orçar a produção ideal;

5. aprender com o desenvolvimento do projeto técnico e com todas as situações de resolução de problemas e transposição de obstáculos estruturais e técnicos;

6. aprender com o processo em si de produção e com todas as situações que, no dia a dia, demandam iniciativas de criatividade e negociação;

7. aprender com a percepção do mercado e de como atua o produto da organização nesse mercado, principalmente no que tange à manutenibilidades e obsolescências de produtos e tecnologias.

Cardoza pensa no conhecimento como um processo que viabiliza outro processo. Um processo permeado de retro-alimentações que estabelece a capacidade do saber e sua aplicação em um processo cíclico e recursivo, no qual, basicamente, o 
conhecimento leva a esforços, que levam à criatividade, que leva ao aprendizado, que leva a mais conhecimento.

CERRI et al. (2003:1) apontam a aprendizagem como sendo um processo pessoal decorrente de experiências e de inter-relações com o meio, o qual envolve reaplicação de comportamentos pré-existentes em aspectos contextuais novos. O produto deste processo resume as respostas novas e as modificações de respostas já existentes, no conhecimento estocado do indivíduo. A aprendizagem é, portanto, um mecanismo dinâmico e de evolução gradual, caracterizado pelo estabelecimento de novas relações entre as atividades do aprendiz e o ambiente do qual faz parte e onde tais atividades sejam implementadas sobre comportamentos previamente estabelecidos. $\mathrm{O}$ conceito expresso pelas autoras aproxima-se, em muito, do processo de construção do conhecimento apresentado por MARÇULA (2001:15) e representado pela figura 5.01. Sendo um processo social, requer a participação e a interagência de dois ou mais sujeitos e realiza-se sob determinadas condições ambientais e relacionais observáveis, controláveis e alteráveis, o que o torna cientificamente administrável e, em decorrência, organizacionalmente gerenciável em sua produção de conhecimentos.

\section{4 - O BINÔMIO ENSINAGEM-APRENDIZAGEM}

Com base no exposto pelos diversos autores e, uma vez mais, baseando-se no que postulam PIMENTA e ANASTASIOU (2002:203-243), pode-se compreender o ensino como campo de aplicação de conhecimentos, composto pelas tarefas de traduzilos em um processo técnico, atribuição da ensinagem, e em transmiti-los aos aprendizes, para que o introjectem, atribuição da aprendizagem.

VICARI et al. (2005:1487-1491) discutem, sob a ótica do ensino à distância, a necessidade de ênfase no aprender remotamente gerenciável, o que, em certo aspecto, assemelha-se ao processo de ensinagem e aprendizagem conjugados, aplicáveis no ambiente organizacional; situação em que, mesmo com determinação e, eventualmente, presença de instrutor e orientador, exige comprometimento e abordagem por parte de quem projeta a forma de ensino e por parte de quem responsabiliza-se pela participação como aprendiz. A discussão é voltada para a engenharia, mas bem pode ser entendida de forma mais abrangente, ao menos no que diz respeito à instrução técnica-tecnológica e profissionalizante. Considerando as exigências de diversificação de competências e habilidades que o ambiente de trabalho e a competitividade contemporânea apresentam 
aos profissionais, os autores baseiam seus estudos na necessidade de desenvolvimento de inteligências múltiplas (conceito proposto por Howard Gardner) para a conquista de capacidade cognitiva e otimização do processo de conhecimento, tanto individual como corporativo, na medida em que distingue o grau de capacidade e a natureza das combinações de informações mais naturais para cada indivíduo e as ativa, para potencializar capacidades de trabalho, a partir da lingüística, da lógica matemática, da música, da cinestesia corporal, das visões espacial e naturalista e das relações intra e interpessoal. Tanto quem organiza como quem ensina e coordena, assim como quem aprende, precisam ter consciência de que o conhecimento das potencialidades individualizadas de cada personagem é parte do processo e, como tal, desempenha papel não desprezível sob qualquer ótica.

O ensino é um projeto coletivo, envolvente, bidimensional, que exige dois focos, dois pontos de vista, ao mesmo tempo distintos, interagentes e complementares: o binômio ensinagem-aprendizagem, explicitador de dois ângulos diferenciados de visão de um processo único de ensino, um processo que pretende determinar mecanismos para a disseminação de conhecimentos. A figura 7.02 apresenta este binômio.

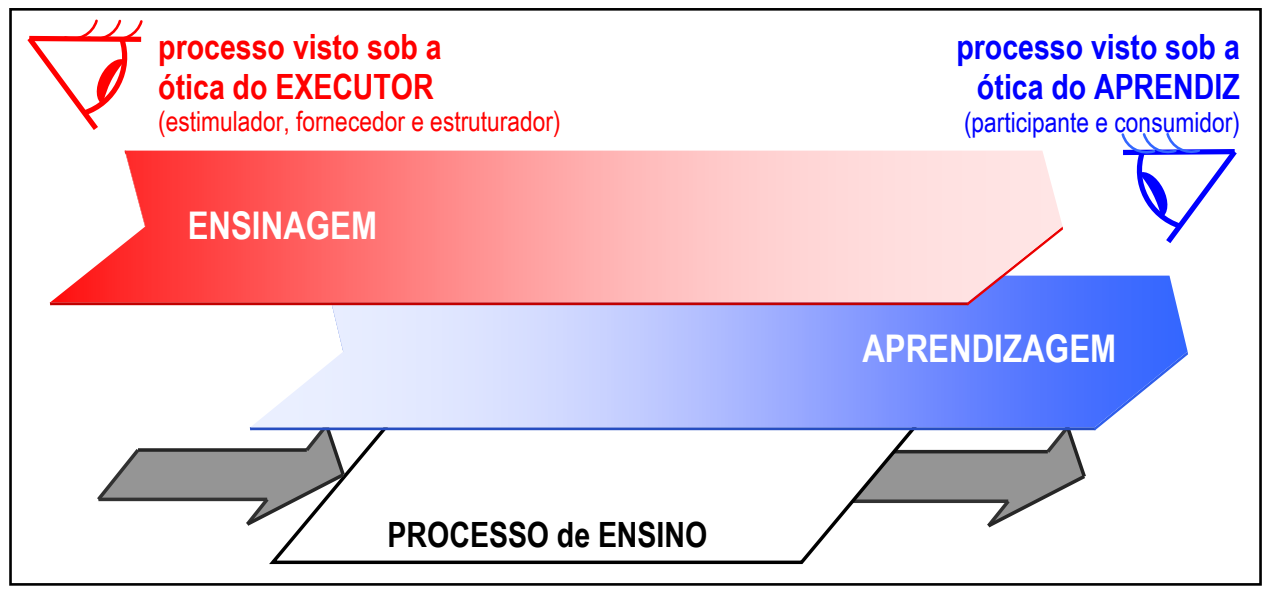

FIG 7.02: O binômio ensinagem-aprendizagem.

Mais que a visão de executor ou aprendiz, respectivamente fornecedor ou consumidor, que se deve ter sobre um processo, importa observar, aqui, a necessidade de tal visão para a gerenciabilidade de um processo de ampliação de conhecimentos dentro de uma organização. $O$ interesse pela designação do binômio ensinagemaprendizagem e por sua caracterização vem ao encontro da necessidade de uma gestão do conhecimento relativo aos processos possíveis de ensino e treinamento e aos conteúdos realizados por estes, dentro da estrutura, tanto tecnológica como dos recursos 
e talentos humanos, de uma empresa. O conhecimento, nas organizações, transcende questões culturais ou de modernização; promove cientificismo, metodologia, sistematização, integração e toda forma de evolução decorrente destes elementos potencializados.

Lembrando as perguntas formuladas no capítulo anterior (pág.128), decorrentes das considerações sobre o modelo advindo de Zarifian, algumas considerações podem ser feitas agora, associando os conceitos de ensinagem e aprendizagem, aqui tratados.

FERRIS (1999:1-3) traz algumas perspectivas norteadoras para a busca de respostas, ao apontar alguns aspectos do que deve ser esperado da gestão do conhecimento: inicialmente, o básico composto por captura e distribuição do conhecimento não documentado dos participantes do negócio, principalmente os internos; a isso, some-se a capacidade de tornar dados e documentos mais largamente disponíveis e úteis à "massa pensante" da organização; a capacidade de combinar os mais dessemelhantes dados e informações para prover cenários de desafios e oportunidades o mais holísticos possíveis; a capacidade de expandir e melhorar, constantemente, os treinamentos e os processos educacionais próprios; a capacidade de negociar com sobrecargas de informações, pela ampliação de capacitações de percepção, filtragem, recuperação e aplicação de conceitos estruturados sobre as coisas e; finalmente, a capacidade de direcionar interesses pela conquista da competência adquirida da cognição.

TAVARES (2004:93-96), através do estudo de diversos autores, elenca algumas recomendações pertinentes ao processo de transferência de conhecimento, os quais embasam o esforço de ensinagem que as organizações devem empreender, tais como treinamentos em metodologias e tecnologias e suas documentações e sessões de difusão na forma de overview e mentoring, entre outras.

\section{5 - EM SUMA...}

Este capítulo foi dedicado à definição do conceito de ensinagem, posicionando-o como componente de um processo de ensino. Muito da base conceitual aplicada nessa ilustração provém de literatura especifica da área de educação que, associada a algumas autorias preocupadas com a difusão corporativa do conhecimento (e não sendo de tal área, mas, sim, de áreas mais tecnológicas), define a ensinagem como a porção 
"fornecedor" do ensino.

Associar este conceito à fábrica de software e à gestão do conhecimento é o compromisso do próximo capítulo. Esse, por sua vez, encerra um conjunto de peças conceituais com as quais se pretende alicerçar a erudição necessária à pesquisa, escopo da terceira parte deste documento de tese. 


\section{PARIE 3}

\section{PESQUISA}

A função da pesquisa é contribuir com os debates sobre regras, fronteiras e métodos pelos quais realizam-se conquistas das mais diversas ordens. Esta parte da tese procura caracterizar e disciplinar a erudição e o estudo de caso, com os quais pretende-se desenvolver o arcabouço do estudo e testar as pressuposições aventadas. Para tanto, algumas conjecturas ainda precisam ser trabalhadas, através da análise bibliográfica e, nestas, os conceitos de base, apresentados, precisam ser agrupados, mesclados, comparados ou, quem sabe, associados para formar o alicerce sobre o qual apoiar-se-á o modelo desejado de ensinagem a ser posto em teste. Também nesta parte do documento, a descrição da pesquisa de campo, com as avaliações de resultados. 


\section{APLICAÇÃO DOS CONCEITOS}

Os conceitos básicos para o alicerçamento da pesquisa, desenvolvidos nos capítulos anteriores, necessitam de composição para que possam ser tratados como fusões ou complementações cujas sinergias provoquem conjugações outras que contribuam para o entendimento da pesquisa e seu posicionamento nos contextos origem: o do conhecimento e sua gerenciabilidade e o de fábricas de software, e no contexto alvo: o da preservação do conhecimento em ambientes de fabricação de software. Este capítulo dedica-se a discutir estas conjugações e composições.

Há, ainda, necessidade de posicionar as questões da promoção do conhecimento nestes ambientes, por meio de um processo de ensinagem e entender como eventos deste gênero podem acontecer com a necessária garantia de agregação de valor ao capital intelectual da organização.

Antes, porém, é preciso observar a quem interessa o conhecimento e que uso cada interessado pode fazer do mesmo, em uma organização. Sob este ponto de vista, PACHECO e KERN (2003:1) fazem um estudo focado nos atores do Sistema Nacional de Ciência, Tecnologia e Inovação, mais especificamente, nas conexões promovidas pela plataforma Lattes.

A análise realizada pelos autores tem como objetivo principal, demonstrar que nem só pesquisadores e fomentadores preocupam-se com este segmento de estudo e que outros atores diversos atuam com interesses variados na produção científica e tecnológica nacional.

De um lado, os autores perfilam pesquisadores, docentes, coordenadores, gestores (se visto como papel de alguém com interesse outro, além do fomento), egressos (tome-se por egresso, o recém-formado, ainda não investido de outros papéis mais à proximidade do mercado), estudantes, técnicos, funcionários, empresários e profissionais, como atores interessados no conhecimento.

De outro lado, os autores relacionam a aplicação de recursos de informação e conhecimento em (ou para) produção, multiplicação, gestão, buscas e apoio à geração (de mais conhecimento). 
A pesquisa, inicialmente, foca questões de produção de conhecimento em ambiente universitário ou de pesquisa e, nesse sentido, as apresenta conexões entre: Pesquisadores mostram interesse por produção (científica) e multiplicação (de resultados); Docentes mostram interesse por multiplicação (de conhecimentos); Gestores e coordenadores têm interesse comum pela gestão (das pesquisas e dos fomentos para estas); Estudantes, egressos, profissionais e empresários procuram conhecimento e informações pelo interesse direto pelas buscas e outros serviços (de pesquisa, aplicáveis a seus contextos). Os estudantes apresentam, ainda, interesse pela produção (do conhecimento), devido à condição de aprendizagem; e Técnicos e funcionários interessam-se devido ao papel de apoio à geração (de resultados conhecimentos) com que atuam.

Esta análise pode ter representatividade em contextos mais amplos, como o das organizações e, estendendo-se algumas visões sobre atores e interesses, serve à percepção da aplicação de informações e conhecimentos de maneira generalizada, em ambientes de empresas, para além dos limites das universidades e instituições de pesquisa. Nesse caso, há de se tecer algumas considerações:

O interesse pela produção passa a ser tanto de conhecimento quanto de produto e isso o torna abordável também por profissionais das mais diversas áreas administrativas ou técnicas. Esta reformulação de interesse por parte dos profissionais pela produção é fruto das questões de produtividade comercial, sua função natural, e, também, decorre de questões de aprendizagem de novos conhecimentos, por meio de treinamentos, cursos e exposições, entre outros meios.

O papel de gestor amplia-se do administrador de pesquisas para o executivo empresarial, ou seja, passa a uma abordagem executiva de administração e, com isso, abrange interesses de organização para mercado e de gerencia de conhecimento, abarcando papéis como $\mathrm{CEO}, \mathrm{CIO}$ e $\mathrm{CKO}$, por pensar as questões estratégicas e táticas envolvidas com o uso do recurso representado pelo conhecimento.

O papel de empresário passa a ter interesses outros, tanto na produção quanto na multiplicação e na gestão. Na produção por tratar-se de produtos, mesmo que isso não proíba que seu interesse estenda-se para tal por conta do conhecimento a produzir. $\mathrm{Na}$ multiplicação, assim como na gestão (mesmo que não primários, por isso a representação em linha tracejada, na figura 8.01), por assumir parte da função 
fomentadora, além de tornar-se, necessariamente, um estimulador destes interesses. Além das questões do conhecimento, funções abrangentes de questões de gerenciamento tático e operacional são atribuídas, aqui, ao empresário, como atividades que divide com o gestor.

Quanto aos demais atores percebe-se: pesquisadores podem estar tanto em instituições exclusivamente de pesquisa, como em empresas ou, ainda, mesmo que em instituições, realizando pesquisa de interesse particular de alguma organização. Docentes continuam seu papel multiplicador de conhecimentos, só que, agora, isso pode ser praticado em empresas (e isso vem ao encontro das pretensões desse trabalho). Coordenadores continuam atuando na gestão, porém, dentro da visão mais abrangente, executando administração operacional e coordenando produções de forma direta, além de coordenar aplicação de recursos. A figura 8.01 demonstra esta rede de interesses.

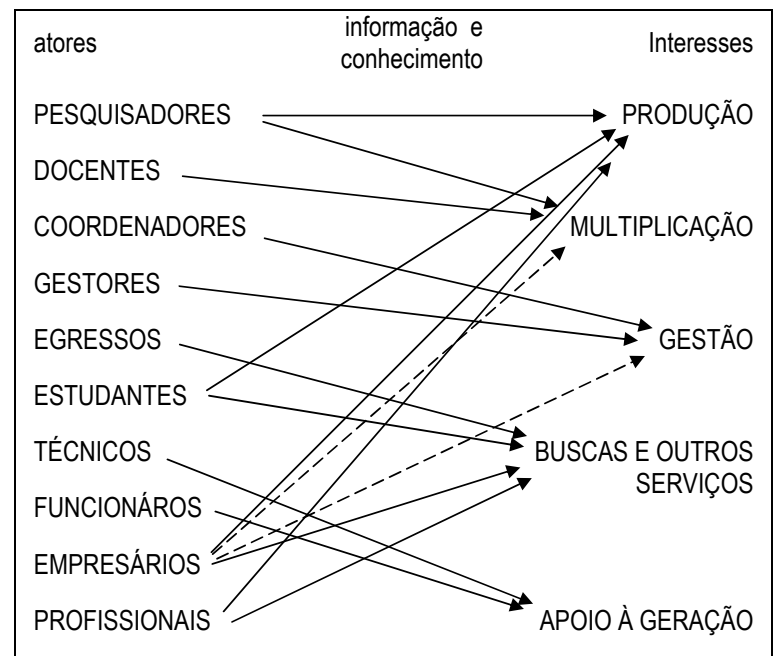

FIG 8.01: Informação e conhecimento: resultado da ação ampliada dos atores. Adaptada de PACHECO e KERN (2003).

Importante salientar, ainda, que estes papeis podem ser interpretados de forma cumulativa, ou seja, uma pessoa atuando em mais de um deles, em determinados momentos, sob determinadas circunstâncias.

A contribuição de PACHECO e KERN (2003) fornece uma visão - otimizável a cada situação a que se apliquem as questões centrais desta tese - das conexões estabelecidas por conta da informação e do conhecimento, o que leva à necessidade de gerenciamento de tais conexões, fluxos e interesses. Esta relação entre os interesses dos atores partícipes de situações empresariais e as estruturas de geração e utilização dos conhecimentos pode representar questões de aplicabilidade das competências, conforme 
proposição de ZARIFIAN (2001:40,52-74), comentadas no sexto capítulo. Toda a questão do conhecimento aplicado (fruto do saber-fazer que, por sua vez, vem da experiência e essa, do comportamento), representada pela figura 6.02, deve ser analisada sob duas abordagens: a das pessoas e a da organização, o que leva a pensar sobre o que e quais são as competências da corporação e do pessoal envolvido, o que pode ser internalizado na organização e o que não pode e, também, como os elementos do conhecimento convivem, tocam-se e interagem para a composição das competências, explícitas ou tácitas (chamadas essenciais dinâmicas).

Como forma de visualizar estas interposições e interagências, a figura 8.02, uma derivação, em perspectiva, da visão evolutiva e compartimentada criada a partir das proposições de Zarifian (e valendo-se do conceito multidimensional dos conteúdos concretos da competência, proposto por ele mesmo [págs.127 e 128], como apoio), expõe a perpendicularidade dos eixos pessoal e organizacional (por sua vez, perpendiculares ao conjunto aninhado de pirâmides de composição) a partir dos quais obtém-se uma das dimensões possíveis de gerenciamento, pois que, conhecidas as competências das pessoas que fazem parte da organização, capacita-se a corporação à gestão das competências internalizadas; por outro lado, conhecidas as características e

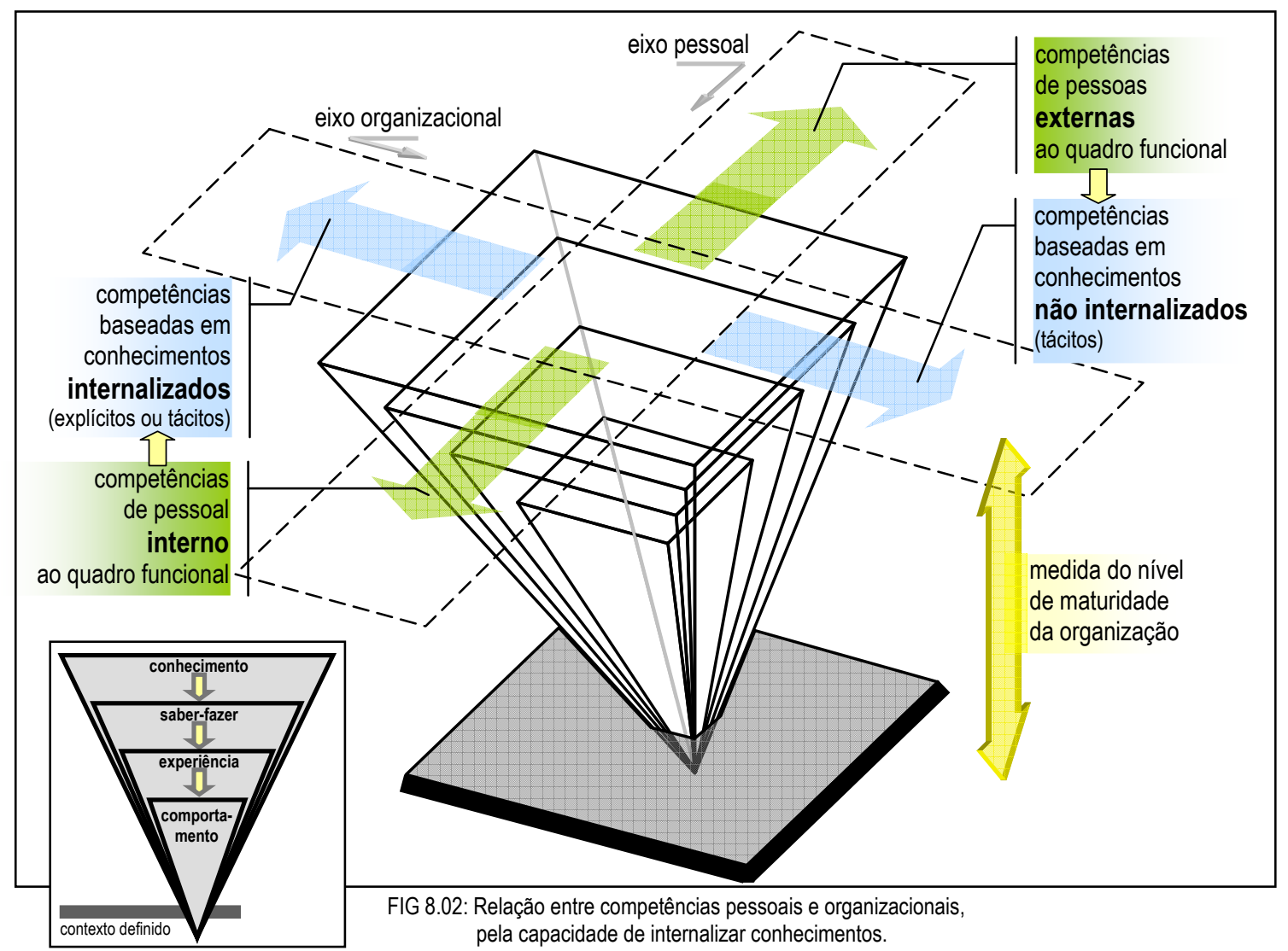


habilidades de pessoas de fora da corporação, possibilita-se domínio sobre as competências não internalizadas, mas necessárias em determinados projetos. Para cada elemento dessas competências, é possível medir o nível de comportamento, experiência, saber ou conhecimento que se tem à disposição e isso, essa capacidade de mensurar possibilidades, determina o nível de maturidade da organização.

Uma questão pertinente que pode surgir, a essa altura, é como isso se aplica a ambientes de manufatura de software e, mais ainda, a ambientes de fábrica experimental, como é o caso do eLabSoft, onde as figuras do docente e do estudante mesclam-se, com as de profissionais, empresários e gestores.

Pode-se entender que nos casos dos laboratórios de fábrica, assim como nos de fábricas de software comerciais, a aplicação está justamente apoiada na necessidade de perceber quais são as capacidades comportamentais (de participação), as experiências e os saberes de cada um. A partir de tal alicerce, a aplicação dá-se pelo estimulo da difusão destes (capacidades, experiências, saberes) através de processos de ensinagemaprendizagem, tal que o compartilhamento gere produtividade, mesmo em ambientes onde o fluxo de pessoas seja a regra da constância.

A questão é como realizar uma aplicação de preservação do conhecimento que seja motivadora, sob as óticas do processo e do projeto desse processo. BOFF et al. (2001), PAULA et al. (2004) e CHEWAR e McCRICKARD (2005) têm suas contribuições.

BOFF et al. (2001:2-17) contribuem abrindo a "caixa-preta" por eles mesmos mencionada (e citada nos capítulos 5 e 7) para visualizar o processo e suas capacidades de entender o ciclo funcional com que acontecem as fases de ações relativas à geração, codificação, disseminação e apropriação do conhecimento. Estes autores visualizam a aplicação do processo gestor do conhecimento (que é, por sua vez, um processo em si) como ciclos que podem ser circunscritos, conforme demonstra a figura 8.03, e que contribuem para a formação e a formulação de culturas organizacionais estratégicas de negócio, lideranças corporativas, infra-estrutura e mensurações de processos, tanto os voltados à produção quanto os direcionados à difusão do próprio conhecimento.

Boff e seus co-autores têm uma visão mais classificadora dos passos do processo e de como esses se aplicam, na operação de um sistema gestor implantado em uma organização. Segundo estes autores, a geração do conhecimento envolve a capacidade 
pessoal ou corporativa para sua criação, sua divulgação (por venda, publicação, exposição ou qualquer outro meio de externá-lo), sua identificação (percepção do que é e como pode servir aos interesses, se é que serve), sua aquisição (que pode ser, inclusive, por compra) e parte de sua coleta (a mais próxima da aquisição), já que esta é considerada de transição, entre a geração e a codificação. Tal espectro da geração estende-se da abordagem estratégica à de liderança, ou seja, pode-se dizer que a criação é uma questão estratégica e a aquisição/coleta, de liderança. Sob este aspecto, pode-se, ainda, afirmar que o transito, da criação à coleta, representa a dinâmica entre a estratégia corporativa e sua viabilidade de liderança de mercado.

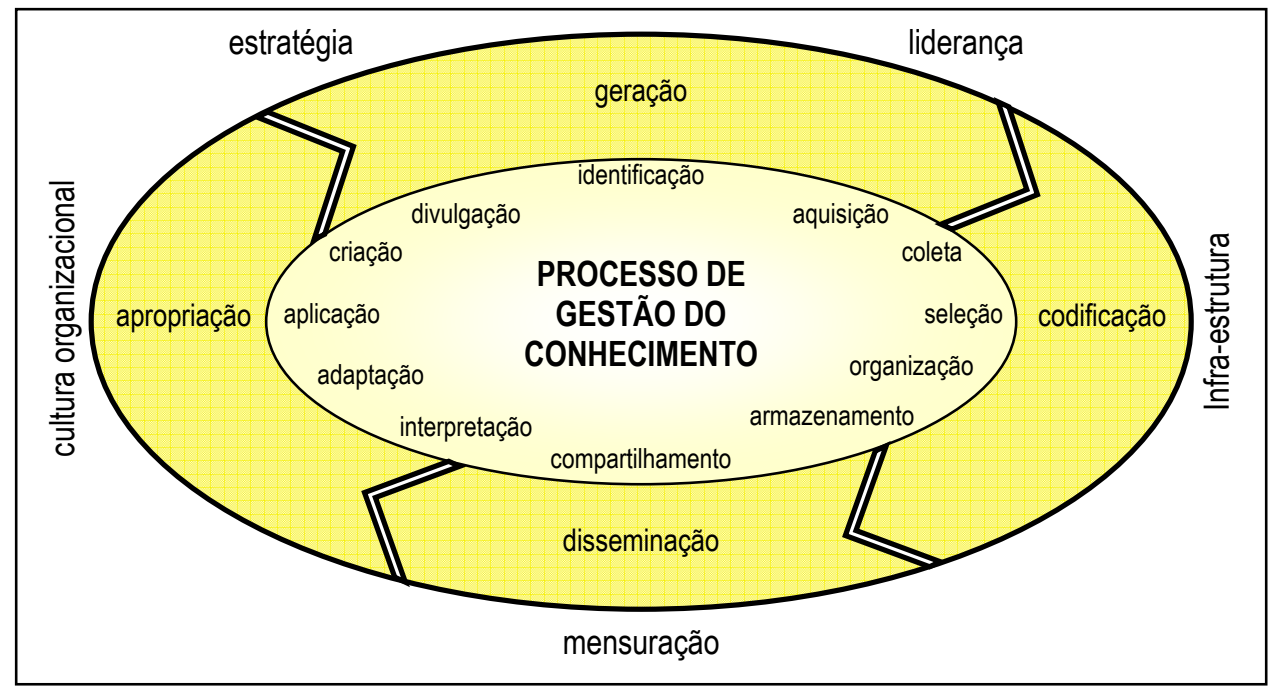

FIG 8.03: O processo de gestão do conhecimento e suas capacitações. Adaptada de BOFF et al. (2001:2,9).

A codificação do conhecimento começa com a porção estruturadora da coleta e envolve as capacidades de selecionar, organizar e estocar o conhecimento, ou seja, passos relativos à infra-estrutura do processo. Coleta e seleção envolvem conceitos de abstração, ou seja, de extração de conhecimentos de interesse de um universo de conhecimentos disponíveis em determinada realidade. Organização e armazenamento envolvem aplicações das ontologias nas modelagens e formações de bases. Esta abordagem representa a contribuição possível para com a efetivação da infra-estrutura necessária à gestão.

A disseminação do conhecimento é uma atividade interna à corporação que implica uma dinâmica de compartilhamento, que leva da percepção do conhecimento armazenado ao limiar da interpretação do mesmo. Tal disseminação tem uma abordagem de mensuração, pois que é necessário garantir o "valor essencial", tanto do 
conhecimento quanto de sua gestão para cada circunstância a que ele se aplique.

A apropriação do conhecimento envolve interpretação, adaptação (necessária para fazer da experiência passada uma lição nas decisões futuras) e aplicação propriamente dita, considerando que, uma vez aplicado, virou experiência e isso pode representar oportunidade de aprendizado. Toda aplicação é, portanto, uma potencialização para a criação de um novo conhecimento e isto tem parte da composição da cultura de organizações que aprendem e fazem, do aprendido, estímulo para novos aprendizados.

A contribuição de PAULA et al. (2004:5-11) corrobora a idéia de Boff et al., destinando a aplicação de tais ciclos processuais organizados em um processo de negociação, ou seja, mostra como aplicar conhecimentos e como gerir suas aplicações em procedimentos de negociação, de modo a satisfazer os requisitos fundamentais básicos para a gestão do conhecimento.

Para a consecução de tal satisfação, propõe uma discussão sobre onde alicerça-se a elaboração de um ambiente computacional que permita a gestão de todo conhecimento envolvido nas tomadas de decisão a realizarem-se durante uma negociação e, para isso, utiliza-se do que denomina a memória da negociação (um repositório de conhecimento específico), de procedimentos de gestão e de negociação (conjunto de atividades concernentes ao uso do conhecimento e à orientação da ação negociadora, respectivamente), da identificação de agentes específicos (pessoas e sistemas) e de elementos estruturais e determinísticos (a própria organização para o evento, a estratégia a aplicar e a tecnologia disponível para sua execução) que ofereçam suporte ao evento.

O processo aplicado de gestão do conhecimento configurado aproxima-se do modelo proposto por Boff et al. e é utilizado quando os agentes da negociação, pessoas em diversos papeis utilizando sistemas (pretensamente computacionais, mas não na totalidade do processo), ao progredirem pelas etapas da negociação, precisam de conhecimentos, estocados nas memórias (pessoal, organizacional e ambiental). As formas como serão utilizados os conhecimentos, explícitos ou tácitos, depende da estratégia de negociação a ser adotada, do ambiente organizacional e o que há de propício nele para as deliberações e da tecnologia disponível para processar as informações necessárias às tomadas de decisão.

Se a proposição de Paula et al. Explica-se na emergência de alicerçar projetos de 
TI, a de CHEWAR e McCRICKARD (2005:1-10) já é mais no sentido de garantir que projetos para a implementação de processos como o de Boff e seus co-autores, ou, ainda, o de Bukowitz e Williams, se concretizem e permitam que a TI torne-se ferramental adequado à gestão do conhecimento.

Chewar e McCrickard expõem os resultados de um estudo sobre como consagrar projetos de gestão do conhecimento pela promoção da consignação de organização e conteúdo do conhecimento, através de um meta-processo para desenvolvimento de empreendimentos que visem a produção ou a ampliação de repositórios de conhecimentos, com forte orientação ao reuso de experiências anteriormente vividas e que tenham contribuído, estrutural e conteudisticamente, com o repositório em foco. Consideram eles que meta-processo é a organização necessária para a definiç̧ão e implementação de processos de trabalho, aliada à ciência aplicada e a normalizações que provenham sua concretização e a concretização de sua qualidade.

Estes autores preocupam-se em discutir um mecanismo dinâmico de trabalho que permita a criação da memória do negócio (agora, já generalizando a idéia de negociação, de Paula et. al., para qualquer execução e gestão de negócio, inclusive em fábricas de software) e da dinãmica de gerenciamento dos conhecimentos inerentes ao negócio, além de permitir a manutenibilidade desse mecanismo, com ajustes, correções e evoluções que garantam seu sucesso.

\section{1 - GESTÃO DO CONHECIMENTO EM FÁBRICAS DE SOFTWARE:}

A discussão de CHEVAR e McCRICKARD (2005:1-10) pode vir a influenciar a elaboração de um projeto de aplicação da gestão de conhecimento em toda espécie de negócios, segundo os próprios autores, à medida que envolver a expressão de parâmetros críticos de tal projeto. Presta-se, portanto, à modelagem de tal aplicação em elaborações de repositórios de conhecimentos para fábricas de software, pela adequação de proposições observadas, por eles, em diversos estudos de caso. A citação destes autores se deve ao fato de que eles, coincidentemente com a orientação desta tese, preocupam-se com a preservação do conhecimento como forma de facilitar a absorção de novatos em sistemas já constituídos (no caso deles, projetistas novatos e, no caso da tese, todo e qualquer novo participante do desenvolvimento de software, de programadores a gestores). 
Importante lembrar e salientar que a preservação do conhecimento, sob a ótica deste trabalho, vai além de tal absorção, abrangendo aumento de capacidade produtiva de uma forma geral.

Tal abrangência, necessária à gestão sobre o processo de software, também é preocupação de FERNANDES e TEIXEIRA (2004:107-113, 196-205, 214-235) que a vêem sob a ótica dos indicadores de desempenho aplicados aos níveis administrativos do negócio de produção de software. Em concordância com a dinâmica do processo gestor sobre o processo fabril (apresentado no capítulo 4, figura 4.10), estes autores apontam responsabilidades essenciais, entre as quais:

- no nível estratégico:

o definir estratégias de melhoria contínua (fluxo descendente, na figura 4.10);

○ realizar análises comparativas entre os resultados do negócio e os parâmetros do mercado (fluxo ascendente);

- no nível tático:

○ realizar análise de tendências e definir os indicadores de negócio necessários à administração do conjunto de projetos (fluxo ascendente, na figura 4.10);

○ realizar análise de impactos dos resultados obtidos no desenvolvimento dos projetos (fluxo ascendente);

- no nível operacional:

○ especificar os parâmetros indicadores para gerenciar projetos ativos (fluxo descendente, na figura 4.10);

○ realizar análises sobre medições, produtiva e qualitativas, dos processos e dos produtos (fluxo ascendente).

A definição adequada destes pontos de gerenciabilidade permite a especificação de elementos incidentes sobre questões de domínio administrativo das fábricas de software, tanto as limitadas à produção de programas quanto as que abrangem projetos e soluções. Os autores listaram diversos componentes compartilháveis da administração cujas definições, aplicações e eficácias são diretamente dependentes da gestão aplicada do conhecimento. Alguns desses componentes são apresentados pela figura 8.04, a qual procura demonstrar seus posicionamentos nos níveis hierárquicos da organização.

Esta visão de estruturação de um negócio de fabricação de software, proposta por estes autores, concorda com as afirmações de outros, sobre a necessidade da gestão 
do conhecimento e gera conformidade entre os conceitos da aplicação do conhecimento (e sua gestão) e as necessidades de reconhecimento deste recurso para a administração da empresa fábrica de software.

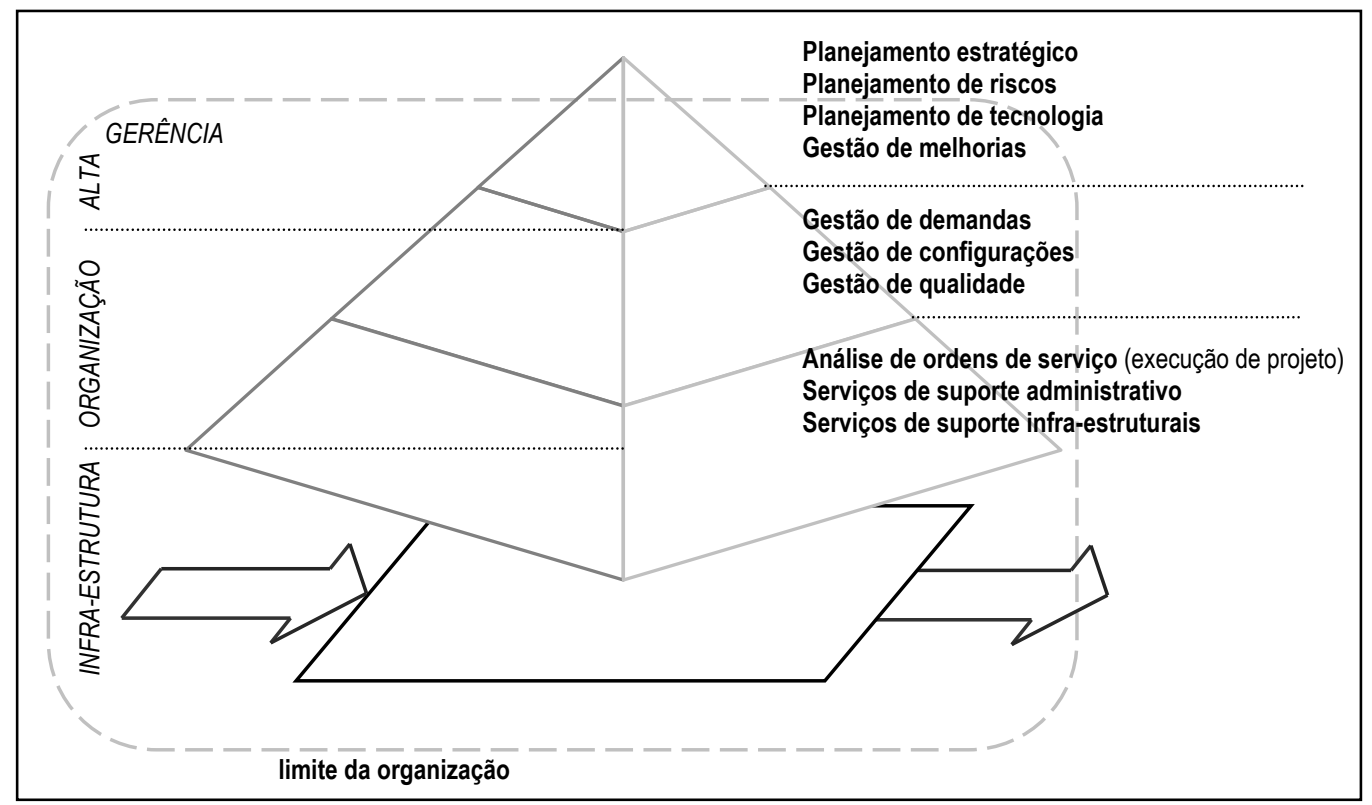

FIG 8.04 - Componentes de gestão influenciados pela GC, na visão de Fernandes e Teixeira.

Esta discussão, sobre a aplicação da gestão do conhecimento em ambientes de produção escalar de software, obriga o retorno aos postulados de Basili e sua fábrica de software, formada pela organização de projetos e pela fábrica de experiências, com a base apropriada, anteriormente comentada (capítulo 4, figura 4.05), e sua visão organizacional do ambiente de fabricação (também no capítulo 4).

BASILI et al. (1992b:370-381) traz uma proposta de organização de ambiente para a gestão dos conhecimentos relativos à fabricação do software, associada à gerenciabilidade dos outros componentes de tal manufatura, como a base de dados (históricos inclusive) e os modelos de processo praticáveis. Estes, além de representarem produtos (ferramentas de trabalho) também representam toda informação ativa que os caracteriza e que fornece a capacidade de domínio sobre o ambiente, através do conhecimento. Os autores pensaram e discutiram tal organização para possibilitar projeto e produção de um sistema automatizado para gestão de ambientes de produção de software, o qual, a partir da base de experiências (na qual estão contidos: os dados históricos, na base de dados do laboratório de engenharia de software; os diversos modelos de processo, para arquitetar, desenvolver e mensurar produção e; os conhecimentos, tais como lições aprendidas, projetos já desenvolvidos e aprendizagens 
institucionais), consiga prover a administração dos projetos em andamento (pela capacidade de planejar e acompanhar o planejamento, predizer dimensões e cronologias produtivas e assessorar a produção, entre outras).

BASILI et al. (1998:3-11) trazem uma proposta de organização do ambiente de trabalho, definindo estruturalmente várias abordagens, as quais também podem representar dimensões do negócio de produção de software, na forma de diagramas de estruturação modular (ou, diagramas de organização, também chamados organogramas). O conjunto destas estruturas representa uma forma de organizar ambiente que leva a uma organização da base de conhecimentos relativa a esse ambiente de produção. Forma esta que se aproxima das estruturas ontológicas, permitindo que não só armazene-se o conhecimento relativo à organização, seus procedimentos e formas de execução, como também conquiste-se a capacidade para acessar qualquer dos conhecimentos através de uma navegabilidade lógica pelas estruturas de arrumação dos elementos componentes.

BASILI et al. (2001:4-8) trazem uma proposta de organização de interface de trabalho para permitir a internalização (externalização também, mas para o interesse dessa tese, é a abordagem menos importante) dos conhecimentos, a capacitação administrativa e a organização estruturada, frutos da gerência do ambiente de produção. Esta interface, fruto da experiência realizada na Universidade de Maryland, intermedia os ambientes externo (front-end) e interno (back-end) da organização. Os termos front e back-end são típicos da área de software e os autores os utilizam, propositadamente, para estabelecer a referência entre todos os elementos da abordagem interna de desenvolvimento de um software e os da externa, próximos aos usuários do mesmo.

HOUDEK et al. (1998:443-447) concordam com estes postulados e acrescentam que o conceito de fábrica de experiências sistematiza o aprendizado e a melhoria contínua no desenvolvimento de software. É o que relatam, a partir da experiência que utilizam como caso, desenvolvida na empresa Daimler-Benz, onde o paradigma da melhoria constante de qualidade, uma vez implantado, inclusive no desenvolvimento do software, tanto os embarcáveis quanto os de suporte funcionais e administrativos, obrigou-os a destinar foco especial ao aprendizado com experiências. A capacitação para o gerenciamento do ativo do conhecimento baseado em experiências concretizouse com a aplicação dos conceitos desenvolvidos por Basili e seus co-autores. 
MACEDO (2003:65-69), cujas conceituações sobre a organização do conhecimento através de ontologias já foram expostas no capítulo 5 , discute-as quando aplicadas para organizar arquiteturas de software, sob a ótica do desenvolvedor dessa espécie de produto. A aplicabilidade dá-se, segundo sua defesa, pela complexidade inerente dos sistemas de software e o quanto isso pode gerar de problemas no desenho de sua arquitetura, baseado no fato de que tal atividade envolve abordagens com teores significativos de intangibilidade, tais como sua organização, sua estrutura de controle, sua comunicabilidade (acompanhada de protocolos e sincronizações), suas atribuições de funcionalidade, suas distribuições físicas (do produto e do processo de produção do mesmo) e seu escalonamento e desempenho, entre outras.

A arquitetura de um software é a soma de módulos, processos e dados não triviais, expõe o autor, e os empreendimentos relativos a este produto devem buscar fomentar sua longevidade, a estabilidade produtiva para minimizar retrabalhos, $\mathrm{o}$ suporte à mudança que o produto causará (inclusive sobre $\mathrm{o}$ ambiente de desenvolvimento), a lucratividade esperada com o projeto e o necessário favorecimento às limitações de escopo.

Considerando tais atributos e discorrendo, ainda, sobre o processo de criação da arquitetura, que passa pelos princípios e estilos arquiteturais, o autor conceitua a aplicabilidade dos princípios da ontologia (exemplificados na figura 5.07) na organização do conhecimento para sua gestão (e na aplicação desta gestão), em ambientes de produção de software.

\section{2 - TRIANGULAÇÃO:}

Este trabalho tem, como função, explorar uma parte de todo o processo gestor do conhecimento, relativo às práticas de disseminação do mesmo, envolvendo questões de ensinagem em um ambiente de fábrica de software. Para tanto, uma correlação faz-se necessária perceber, entre os elementos "conhecimento", “ensinagem" e "fábrica de software", e com que dinâmica interagem estes elementos. A figura 8.05 mostra tal triangulação, a qual dinamiza as relações entre conhecimento e fábrica de software, conhecimento e ensinagem e, por fim, ensinagem e fábrica de software. 


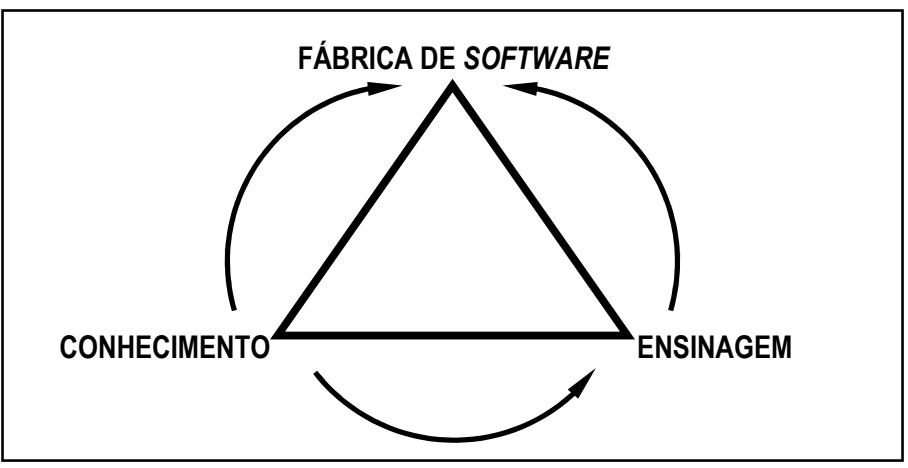

FIG 8.05 - Dinâmica da triangulação de desenvolvimento de relações.

\subsection{1 - CONHECIMENTO E FÁBRICA DE SOFTWARE:}

A relação entre o conhecimento e a fábrica de software é perceptível, conforme o que se desenvolveu, em matéria de conceitos e suas relações, até o item anterior.

KROGH et al (2005:1-10) afirmam que software é, notadamente, um conhecimento explícito identificável tanto por humanos quanto por computadores e sua produção, com escalabilidade, é uma questão de reuso de conhecimento, tanto explícitos quanto tácitos, na capacidade humana de reaplicar soluções.

Durante a produção de um software, diversos tipos de conhecimento (e suas decorrentes habilidades e competências) são reutilizados, tais como: descrição de problema; artefatos; propósitos de projetos; probabilidades dispostas; modelos de negócios; dicionários de dados; repositórios; glossários; prototipos; códigos fontes; e conhecimento tácito dos desenvolvedores.

Conhecimento é, portanto, recurso indispensável para o entendimento da fábrica em si, no que tange à sua organização (figura 4.03), de suas relações internas e externas (figuras 4.06 e 4.07), de seus processos executor (figuras 4.08 e 4.09 ) e gestor (figura 4.10), dos profissionais envolvidos (figuras 4.07, 4.09, 5.10 e 5.14), dos componentes, sendo alguns deles, elementos do próprio conhecimento (figuras 4.08 e 4.09) e, até mesmo, a de sua gestão aplicada (figuras 6.01 e 8.05).

O conhecimento é importante para entender como os elementos envolvidos com a manufatura e com a administração se relacionam, se coadunam e permeiam uns os outros na formação de uma malha de entendimentos que permite o assessoramento de idéias para a formação de pacotes de solução, não necessariamente no sentido de apresentar soluções prontas e formatadas, mas no sentido de apresentar processos que ajudem os profissionais a encontrar soluções. 
O conhecimento é importante para entender como funciona a organização. Neste caso, especificamente, uma organização de fábrica de software, em seus métodos e tecnologias aplicadas, que lhes promovem competências, em suas práticas de execução e administração, que lhes promovem o saber-fazer, em seus comportamentos circadianos, que lhes promovem o ferramental e as padronizações, e na união de todos estes saberes, que lhes promovem medida de maturidade (figura 8.02).

O conhecimento é importante para a promoção do ensino do próprio conhecimento e seus ciclos de continuidade e evolução constantes e é esse o foco principal desta tese, aplicado, naturalmente, em um ambiente de fábrica de software.

Dada a importância do conhecimento, ao qual FELIX (2003:24-25) denomina "ativo intangível", é preciso pensar modelos para sua transformação e, na opinião da autora, esta transformação gera competências, tecnologias e clima para ações estratégicas apropriadas ao negócio. A transformação é produto da aplicação do conhecimento e de seu aprendizado, tanto o que decorre diretamente da experiência pela aplicação, quanto o que se adquire através de processos próprios para o ensino ou o treinamento.

A autora, em sua erudição, afirma que as competências estratégicas abarcam conhecimentos estratégicos, essenciais ao reforço da estratégia de negócio, assim como as habilidades inerentes a eles. A ação direcionada à produção de tais competências resulta em tecnologias ditas estratégicas aos objetivos de negócio, designadas quanto a infra-estrutura necessária à gestão do conhecimento em transformação, bem como as aplicações que se façam dela. O desenvolvimento de clima organizacional para viabilizar ações estratégicas também é preocupação da autora e, neste sentido, reúne abordagens de conscientização, de alinhamento, de preparação e de motivação de pessoal. A figura 8.06 fornece uma idéia das preocupações que uma organização deve ter na estruturação de sistemas de auto-educação.

Estabelecer critérios de ensinagem, como contribuição à transformação dos ativos de conhecimento em fábricas de software é a direção que este trabalho pretende. Para o direcionamento da seqüência deste estudo, é necessário lembrar o contexto advindo da dinâmica ambiental de BASILI et al. (1992b, 1998 e 2001) e, principalmente, o mapeamento do processo do conhecimento organizacional, demonstrado pela figura 6.08, desenvolvido com base no modelo proposto por 
BUKOWITZ e WILLIAMS (2002:24).

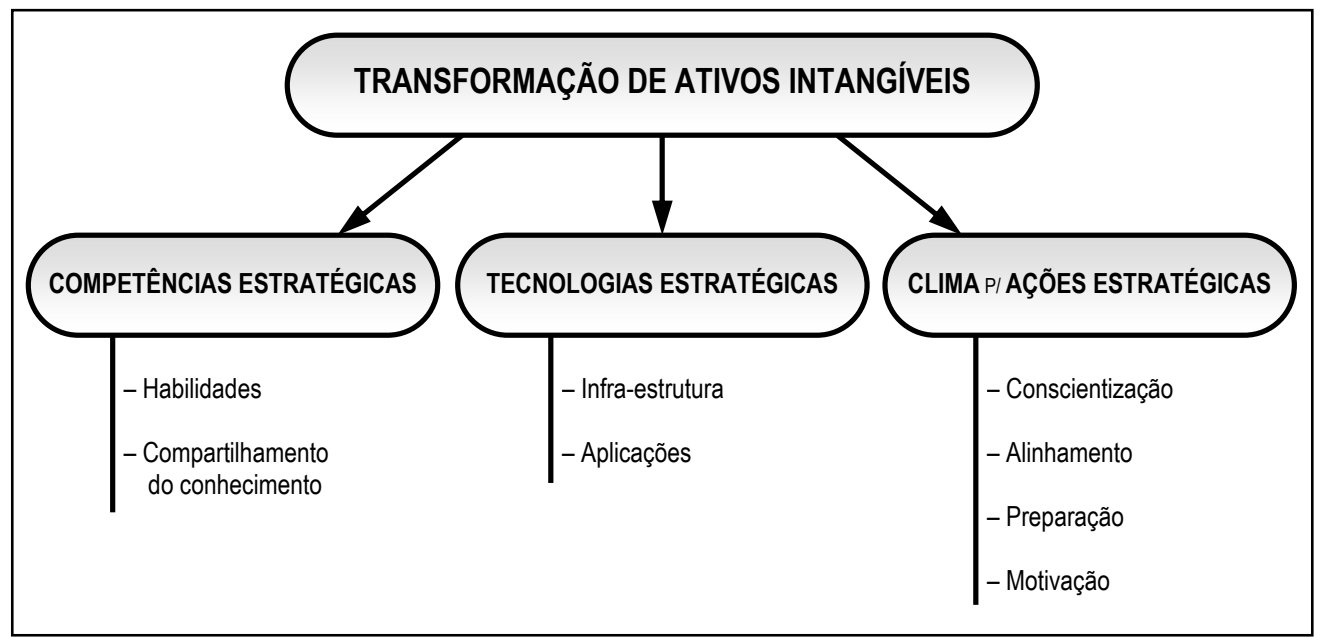

FIG 8.06: Transformação dos ativos intangíveis. Adaptada de FELIX (2003:57).

O foco da pesquisa, portanto, define-se sobre o meta-conhecimento, ou seja, o conhecimento sobre o conhecimento e como isso gera consciência sobre sua aplicabilidade e sobre a necessidade do aprendizado. A figura 8.07 o demonstra.

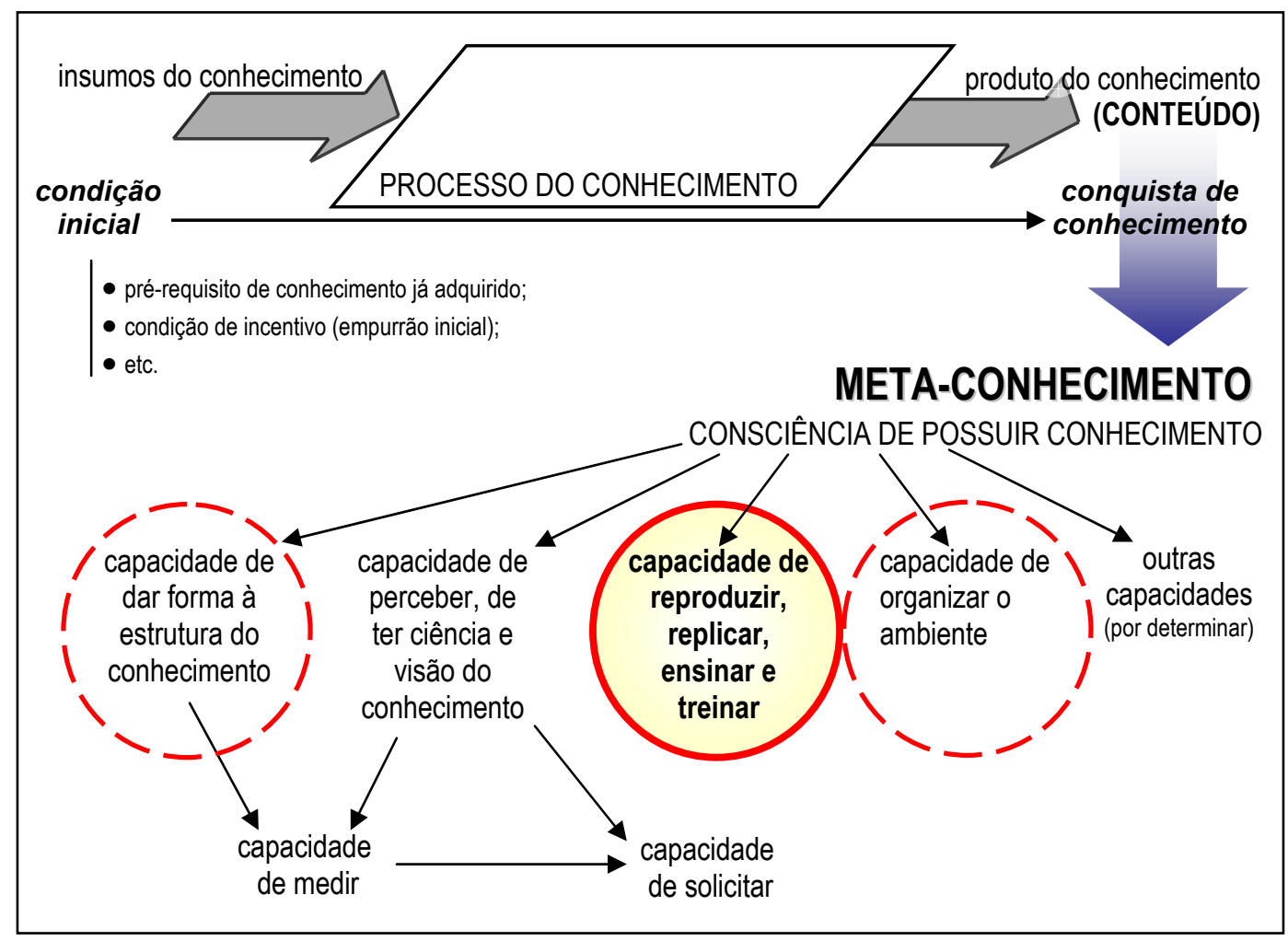

FIG 8.07: 0 foco da pesquisa, sobre o meta-conhecimento. Releitura sobre a figura 6.04.

A capacidade de reproduzir, replicar, ensinar e treinar representa a preocupação maior desta tese, principalmente as questões do ensinar e treinar, porém, parte-se, aqui, do princípio que estas ações não se dão sem replicação e reprodução. 
Esta capacidade de reprodução baseia-se em outras, para o exercício do ensino: a de dar forma à estrutura do conhecimento e à de organizar o ambiente de trabalho. Evidente que estas ocorrem antes e durante os processos de ensinagem e aprendizagem, porém toda questão de ensino envolvida só ocorre se houver uma estrutura de conhecimento especificada e uma organização estabelecida do ambiente. As duas capacidade aparecem, na figura, em círculos tracejados porque, apesar de essenciais, não são dependentes exclusivas de ensino e treinamento.

\subsection{2 - CONHECIMENTO E ENSINAGEM:}

O direcionamento para a questão do ensino internalizado na empresa toma, como base, as discussões de DAVIS e BOTKIN (1996:25-42), às quais somam-se as desenvolvidas por RUHE (1999:64-71), para quem a escola não supre a demanda por desenvolvedores de software com educação apropriada (no artigo, o autor clama por engenheiros de software, mas a amplitude com que ele próprio trata os elementos envolvidos na educação baseada em fábrica, leva à generalização).

Este autor atesta que há um forte aumento da demanda por engenharia nos negócios de software, mas, ao mesmo tempo, há uma dramática defasagem de engenharia qualificada de software, na figura de seus representantes (os juízos de valor são do autor). Sua reclamação, sendo por uma engenharia qualificada, e estando a engenharia presente em todo o ambiente de software, também explica a generalização mencionada no parágrafo anterior.

Com base em sua opinião, pode-se afirmar que os desenvolvedores mais antigos não apresentam qualificação atualizada, pois sua educação, contextualizada ao tema da engenharia de software, data de, no mínimo, uma década (estimativa do autor). Isto gera a defasagem: um "vazio" entre os estudos empíricos destes profissionais e os resultados que deveriam ser esperados, com base na engenharia de software. Esta é uma questão não resolvida pelo pouco conhecimento (formulado ou não, estudado ou vivido) proveniente de uso de inovações em matéria de métodos e tecnologias, as quais acabam sendo sub-utilizadas.

A relação entre o conhecimento e a ensinagem também serve de tema para DREYFUS e IYER (2005:1-5), os quais afirmam o investimento significativo das organizações no desenvolvimento do próprio conhecimento, apenas que dividindo esta iniciativa em duas dimensões: uma que trabalha as questões do ensino para agregar 
valor direto de produção, outra que pensa-o como meio voltado à formação de alicerce para suas capacidades de absorção que, com investimentos em busca e acessibilidade, permitam-lhes agregar conhecimentos externos, em um setor industrial que tem uma dinâmica inovadora muito acentuada: o de software.

Com tal visão, pode-se imaginar que o processo de ensinagem sirva à ampliação do conhecimento interno que amplia a competência de absorção de conhecimentos externos, os quais, por sua vez, incluídos no processo de ensinagem, potencializam e amplificam a capacidade para ampliar o conhecimento interno. $\mathrm{O}$ binômio ensinagemaprendizagem acaba circunscrito num ciclo virtuoso, no qual a retroalimentação expande a capacidade de produção.

Este círculo virtuoso, promovido por conceitos de desenvolvimento intelectual auto-estimulado e auto-promovido, em organizações, aplica-se nas dimensões propostas por DIAZ et al. (2000:4):

- transferência de conhecimento e melhores práticas, na qual o processo tem que responsabilizar-se pelo compartilhamento dos saberes, inclusive do que é tácito, para garantir a formação de competências essenciais dinâmicas, no negócio de software;

- conhecimento focado no consumidor, através da qual, pretende-se gerar aprendizado sobre como perceber o perfil do cliente da fábrica de software e como gerir o negócio, a partir das expectativas de consumo;

- responsabilidade pessoal pelo conhecimento, pela qual trabalha-se, diretamente, o progresso intelectual dos desenvolvedores de software, envolvidos com a fábrica;

- gestão do recurso intelectual, na qual o processo de desenvolvimento intelectual ensina, primeiro, como planejar o próprio processo de ensino e, depois, como gerir os saberes legados, estocados e potencializados;

- gestão do conhecimento como uma estratégia de negócios, pela qual desenvolvese competências para aplicação do conhecimento nas formulações do negócio, tais que este seja insumo para inovações e competências;

- inovação e criação de conhecimento, através da qual habilita-se, pela educação, tanto o corpo técnico (desenvolvedores de software) quanto o administrativo (gestores da fábrica), às práticas de criatividade que visam a geração da competitividade global, da organização, para com o mercado.

O relacionar destas dimensões, faz lembrar CHATTERJEE (2002:1-4) e 
imaginar como aplicar-se-á a ensinagem à dimensão do conhecimento da empresa. Uma forma de visualizar tal aplicação é pela ação direta do processo no elemento "conhecimento", apresentado pela dinâmica deste autor, na figura 5.15, fazendo reuso do próprio conhecimento para fomentar mais conhecimento e produzindo um novo elemento e um reciclo contínuo. O novo elemento é uma externação competitiva promovida pela capacidade potencializada de utilizar, externamente, o conhecimento em seu benefício, quando de sua participação no contexto ambiental em que compete, solidificando capacidades e habilidades e contribuindo para maior competitividade global. O reciclo contínuo representa uma otimização interna, recorrente, da capacidade de potencializar a expansão da massa de conhecimento e, evidentemente, uma vez ampliados os saberes, a ampliação da capacidade de inovação e assim por diante. A figura 8.08 demonstra esta influência sobre o processo de Chatterjee.

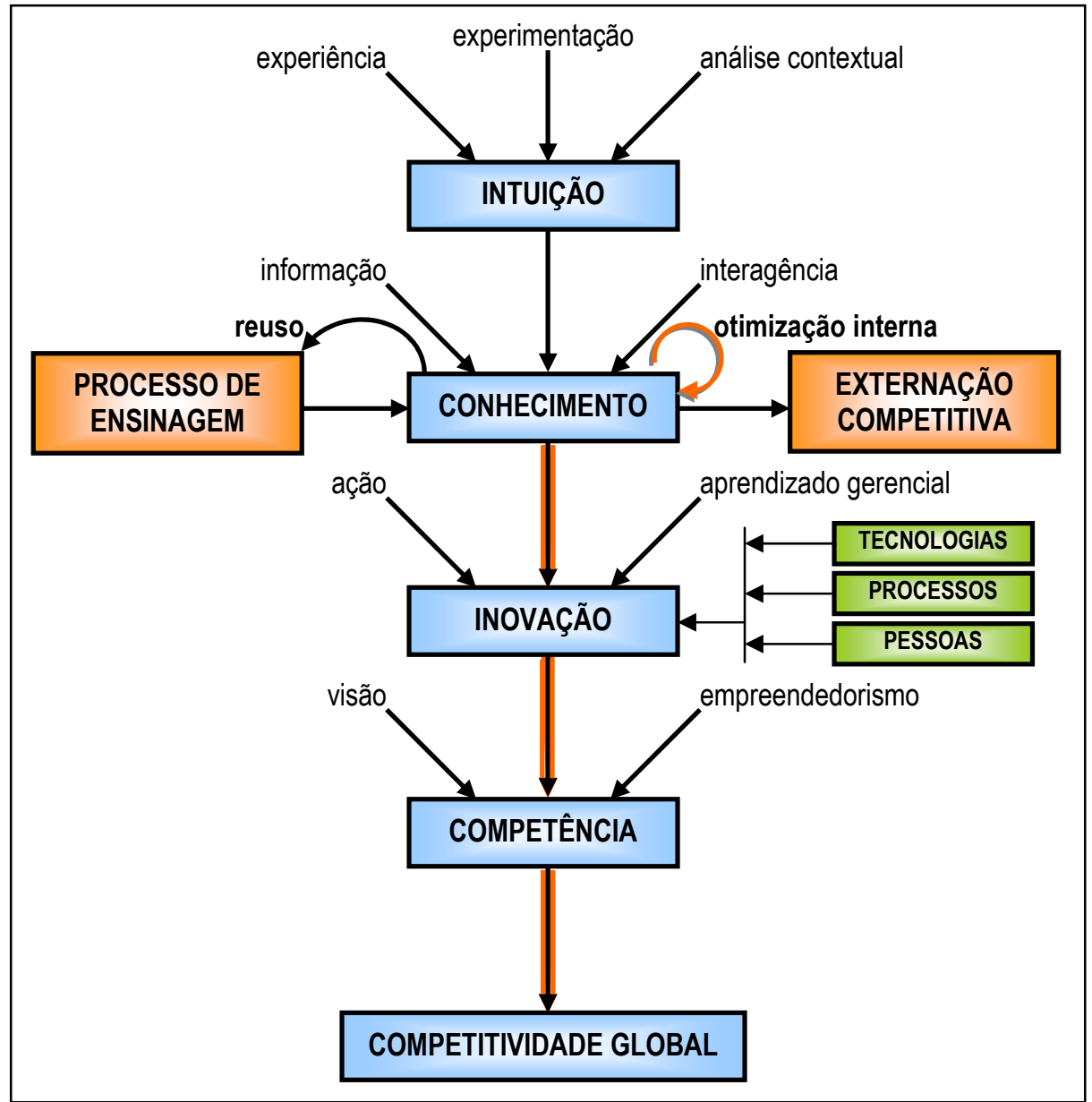

FIG 8.08: A relação da ensinagem com o conhecimento, no processo de condução à competitividade global. Releitura (e adaptação de conceito) da visão de CHATTERJEE (2002:4).

É exatamente sobre como se dá este processo de ensinagem e como isso atua sobre o processo do conhecimento desmembrado, desenvolvido a partir da proposição 
de BUKOWITZ e WILLIAMS (2002:24), representado na figura 6.08, que se estabelece o foco desta tese. A abordagem escolhida para o trabalho da pesquisa pretende tratar uma questão específica do binômio "aprender-contribuir", constante do processo detalhado no aludido desmembramento, apresentado no capítulo 6 .

A figura 8.09 mostra este foco, estabelecendo a fronteira da pesquisa e circunscrevendo os sub-processos "aprender" e "contribuir", o primeiro voltado à compreensão de significados e o segundo, à internalização e disseminação do conhecimento adquirido.

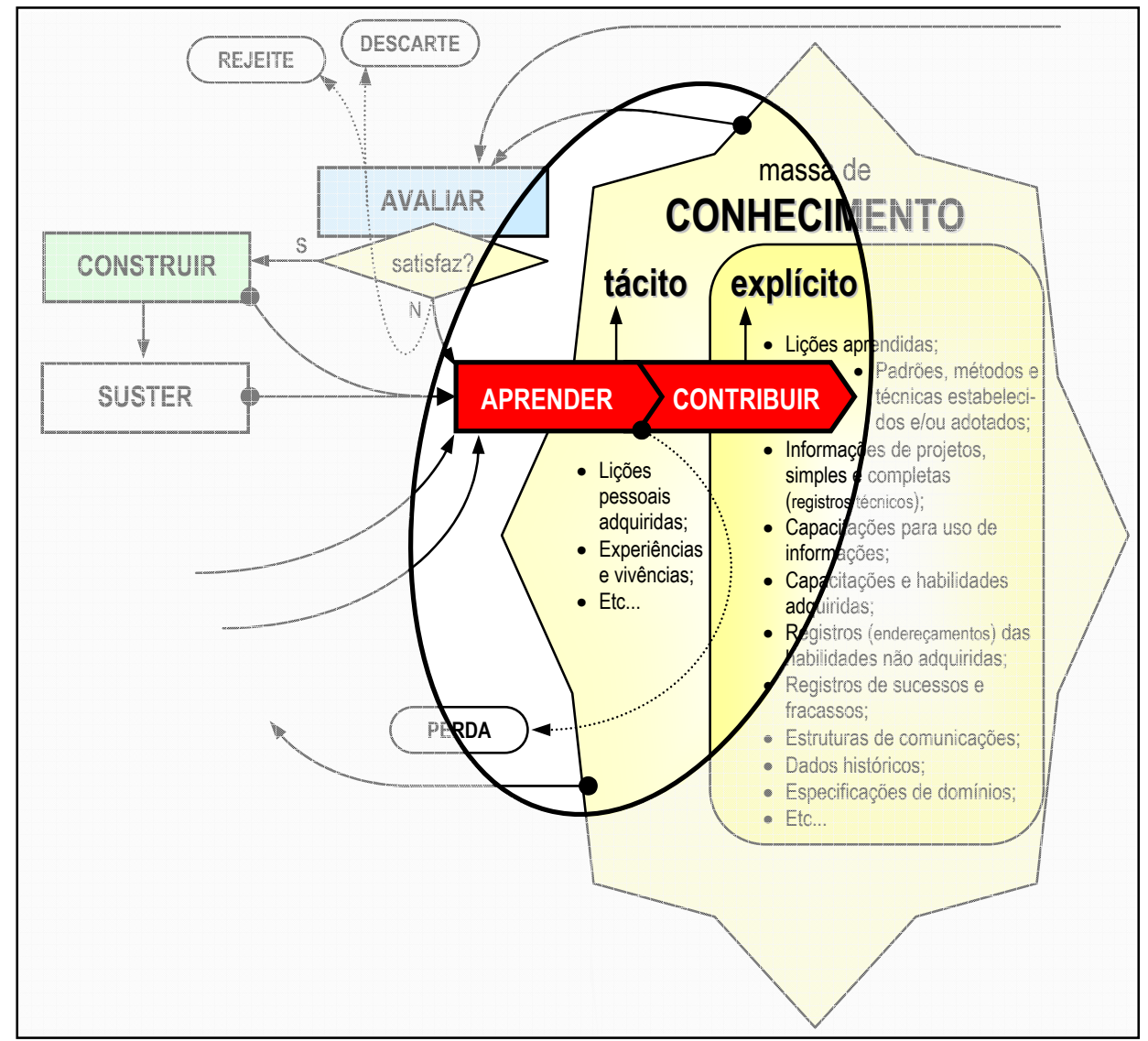

FIG 8.09 - Foco no binômio aprender-contribuir

Mais especificamente, o foco ajustar-se-á no processo de desenvolvimento intelectual do pessoal pertencente ao quadro funcional da fábrica de software, com atuação voltada ao ensino e à evolução de conhecimento que deve ser iniciada no momento em que um partícipe passar a integrar tal quadro, considerando que esta iniciativa contribua para a preservação do conhecimento sobre o negócio.

As questões pertinentes ao conteúdo da massa de conhecimento, no que se refere a organização e estruturação e processos primários de composição, são consideradas 
devidamente embasadas pelas prerrogativas lançadas por autores diversos, como MARÇULA (2001:8-16), comentando sobre a formação do conhecimento acumulado (cap.5, fig.5.01), como NEUBAUER (2004:52-57), definindo a composição da inteligência (cap.5, fig.5.03) e como OLIVEIRA et al. (2004:1-10), propondo organizações por ontologias, entre vários outros.

Há, entretanto, relacionados ao foco, dois outros pontos a discutir: como se realiza o binômio aprender-contribuir em uma fábrica de software e como procedem e embasam-se as interfaces deste binômio com a massa de conhecimento e dela com o ambiente organizacional. A forma e o modelo de aplicação do binômio desenvolver-se-á no decorrer dos próximos item e capítulo. Sobre as interfaces, apresentadas pela figura 8.10, algumas considerações precisam ser dissertadas ainda neste item.

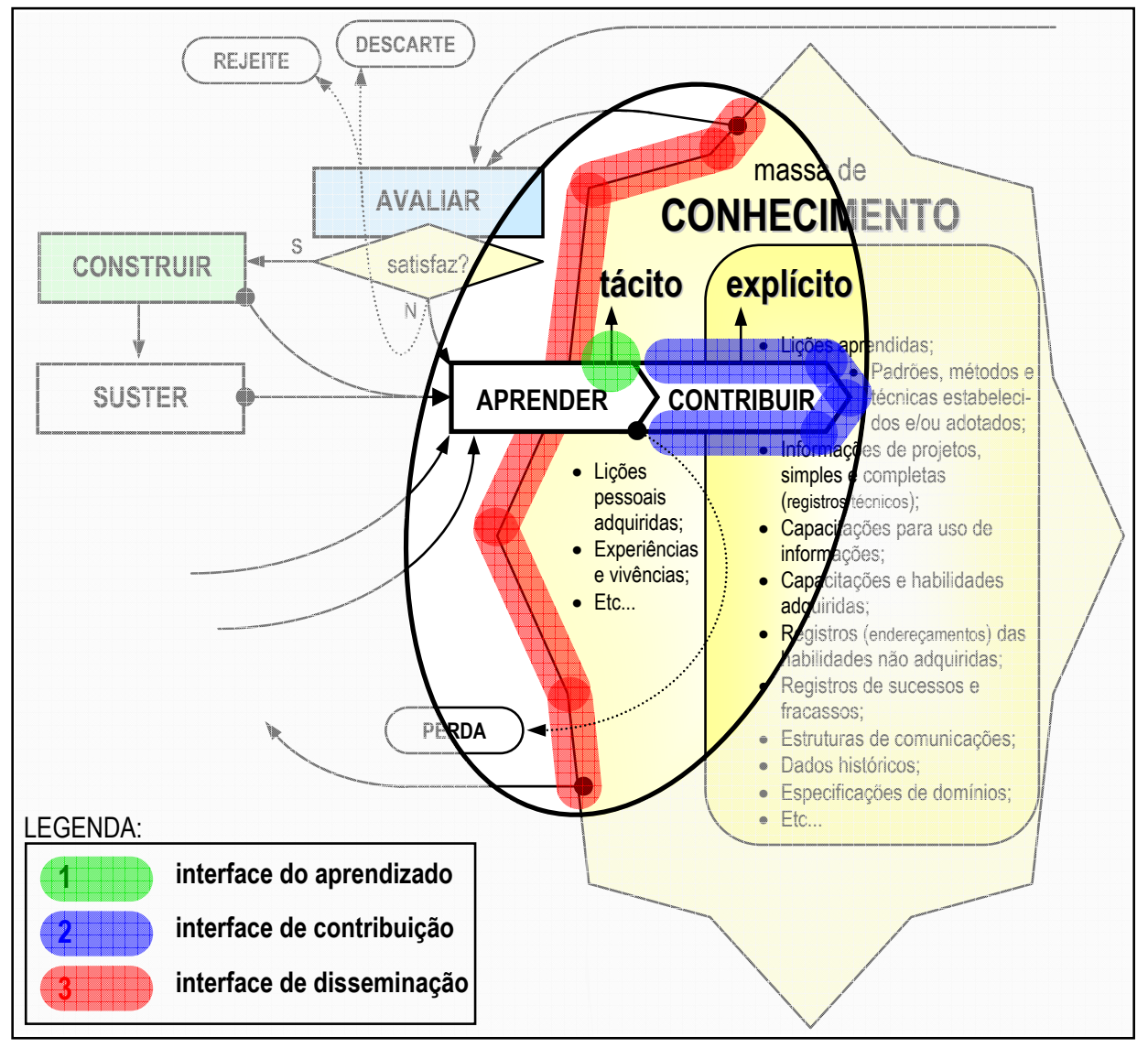

FIG 8.10 - As interfaces entre processo, conteúdo e ambiente.

A interface do aprendizado intermedia o processo "aprender" com a massa do conhecimento, introduzindo o que há de tático no resultado do processo. SMALL e TATÁLIAS (2000), quando discorrem sobre o assunto, apontam este relacionamento em três oportunidades: quando uma pessoa executa a captura de um novo 
conhecimento, transformando-o em ativo, mesmo antes de formaliza-lo (se é que poderá ser formalizado) fazendo, dele, uma competência essencial dinâmica, conforme definem LEI et al. (2001:157-180); o segundo momento é o do reuso, quando uma pessoa precisa de um conhecimento constante da massa, busca-o, utiliza-o e ganha uma nova experiência, o que pode mudar seu conceito e gerar variação no conhecimento agregado; o terceiro momento expressa ocorrências de trocas de conhecimentos entre pessoas, discutindo assuntos pertinentes ao problema relativos ao conhecimento ou participando de reuniões dos mais diversos tipos. Sob este aspecto, concorda TAVARES (2004:34-41), para quem a disseminação do conhecimento tem forte embasamento nas relações diretas entre as pessoas que participam de treinamentos, entrevistas, reuniões, eventos e processos de mentoring.

A interface de contribuição encarrega-se da formulação do conhecimento que possa ser explicitado e da definição de técnicas para isso. TAVARES (2004:40-41) percebe, nas técnicas de documentação, uma forma de realizar tal contribuição.

CHEWAR e McCRICKARD (2005:1-10) também acham importante criar técnicas de associação entre as características humanas de entendimento do conhecimento e as tecnologias para sua expressão (passando pelas ontologias, mas não se limitando a elas). Técnicas estas que eles denominam "sistemas de notificação", consideram emergentes como disciplinas de gestão do conhecimento e as definem como áreas das argüições, responsáveis por projetar formas de extrair e abstrair objetos de conhecimento das pessoas.

MACEDO (2003:100-107) discute este interfaceamento através dos "agentes de intermediação", dos quais relaciona alguns, na figura 5.08, como mecanismos de busca, incorporador de dados, mantenedor de visões e gestor de meta-conhecimentos.

BASILI et al. (2001:19-22) mostram ferramentas para a transposição da fronteira entre o front e o back-end, tais como portais, CHATs, e FAQs. Além do que, BASILI et al. (1992b:370-381) ainda discutem interfaces internas ao processo gestor, nas relações entre entendimento, assessoramento e empacotamento de conhecimentos.

A interface de disseminação expressa a capacidade organizada (ou não) de disseminar o conhecimento da massa e, neste caso, a concepção de comunicação entre front e back-end de BASILI et al. (2001:19-22), com as mesmas ferramentas mencionadas no parágrafo anterior, pode ser tomado como exemplo e orientação. 
FINNERAN (1999) também se utiliza de instrumentos como um portal, o que ele intitula "portal de conhecimento", baseado em uma rede, que pode ser inter, intra ou extranet, trabalhando a introdução dos objetos de conhecimento sob a abordagem documentativa, através de formulários de composição de informações como artefato principal, mas não único. Outros artefatos, em sua opinião, podem ser os registros de conversas pertinentes à relevância de negócio, realizadas por CHATs, e-Mails, etc. Além do portal, toda forma de documentação é válida, para o autor, tais como registros em áudio ou vídeo, diagramas, roteiros, gráficos e publicações diversas. Além das documentações, Finneran pensa na organização de comissários como encarregados específicos de organizar tais documentos e publicar os conhecimentos pertinentes a cada situação de projeto e/ou negócio.

\subsection{3 - ENSINAGEM E FÁBRICA DE SOFTWARE:}

Voltando a associar RUHE (1999:64-71) a DAVIS e BOTKIN (1996:25-42), entende-se que (e porquê) uma organização que trabalhe com forte embasamento em tecnologias (pois é produtora de tal) e em inovação (pois atua em ambientes, interno e externo, muito dinâmicos), como é o caso de fábricas de software, precise promover educação internalizada de seu pessoal, num grau acima do simples treinamento ou qualquer espécie de reunião informacional (estes recursos não são desprezados, apenas tornam-se insuficientes). A essa associação, poder-se-ia, ainda, conectar o pensamento de CHAGAS (2001:1), apresentada no sexto capítulo, de como a falta de comprometimento tem produzido perda no processo de ensino.

ZARIFIAN (2001:191-195) corrobora aspectos apoiadores da idéia de associação entre o ambiente de trabalho e o processo de ensino, ao afirmar que a qualificação profissional agrega representatividade social ao indivíduo, em seu trabalho e ao discutir como as relações sociais envolvem-se positivamente na produção.

Sobre a definição do conceito de ensinagem, aplicável ao ambiente profissional, vale-se, aqui, do proposto no capítulo 7, por autores como Pimenta, Anastasiou, Borges Neto, Santana e Marques Filho: é o ponto montante do ensino, a dinâmica deste por parte do agente estimulador e executor, que necessita alinhar-se ao conceito de aprendizagem para concretizar o ideal de ensino estabelecido por cada interessado em seus frutos. Neste caso, interessada é a organização produtora de software. Lembrando, uma vez mais, Marques Filho: uma organização, para promover em si um processo 
exógeno, precisa incorporar, efetivamente, o processo endógeno.

Antes, porém, de discutir o modelo do processo de ensinagem, é necessário pensar sobre como ele pode contribuir para o desenvolvimento da empresa.

BASILI et al. (1998:3-11), por exemplo, afirmam que a contribuição pode ser vista segundo duas possibilidades: primeiro, qualificando os participantes, se professor/ instrutor ou aluno/aprendiz, e como eles podem contribuir, cada qual com seu grau de conhecimento, para o aumento das eficiências tanto do ensino quanto do processo produtivo da empresa (este, inclusive, com o produto da aprendizagem) e; segundo, avaliando o grau de conhecimento de cada um a partir de suas experiências com a aplicação do saber adquirido, pela medição quantitativa de projetos dos quais tenham participado (atuando no contexto do conhecimento em evidência, é claro).

HOUDEK et al. (1998:443-447), por sua vez, concordam ao defender a idéia colaborativa que as pessoas precisam ter, como postura, para a formação de um ciclo de ensino realimentando o processo de ensino e para a permanência deste ciclo (necessária a aprendizado e melhoria contínuos) e, ainda, como devem usar seus conhecimentos para desenvolver outros conhecimentos, em pessoas e organizações.

As visões destes autores - Basili, Houdek e outros - sobre o ensino feito por partes, complementares, que se desenvolvem em iterações, num processo cíclico e evolutivo, não destoa do que se pratica no sistema de ensino convencional, para o qual pode-se conceber a idéia de uma escada de aprendizado, que leva alunos (ou aprendizes) à evolução conquistada degrau a degrau. Em suas opiniões, o que ocorre é, apenas, a busca por ajustes otimizados às necessidades de cada empresa, o que provoca uma necessidade de busca por mecanismos próprios que otimizem o comprometimento dos participantes e o compartilhamento dos conhecimentos agregados em cada um.

A idéia de escada, tal qual definida por CARDOZA (2004:1-3), mencionada no capítulo 7 (fig. 7.01), representa modularização de conhecimentos que se somam e interagem para a formação de um conhecimento ainda maior, de habilidades extensivas e de competências para o trabalho em exercícios cada vez mais complexos e completos. Segundo o autor, em cada degrau, o participante tem que estar imbuído de motivos (sua participação nos projetos da empresa, por exemplo) que o levem a esforços de inovação, os quais provocam sua criatividade, a qual estimula e provê seu aprendizado e o leva, consequentemente, a um novo conhecimento, o qual, associado a outros novos motivos 
(o próprio conhecimento caracteriza-se como motivador), leva-o a novos esforços de inovação, recomeçando o ciclo, agora em um degrau mais alto.

A figura 8.11 expressa o conceito de forma simplificada, na qual cada degrau representa um conhecimento (e, com ele, uma habilidade) a ser conquistado em processos de ensinagem que, com acúmulos e sinergias, agregam competências.

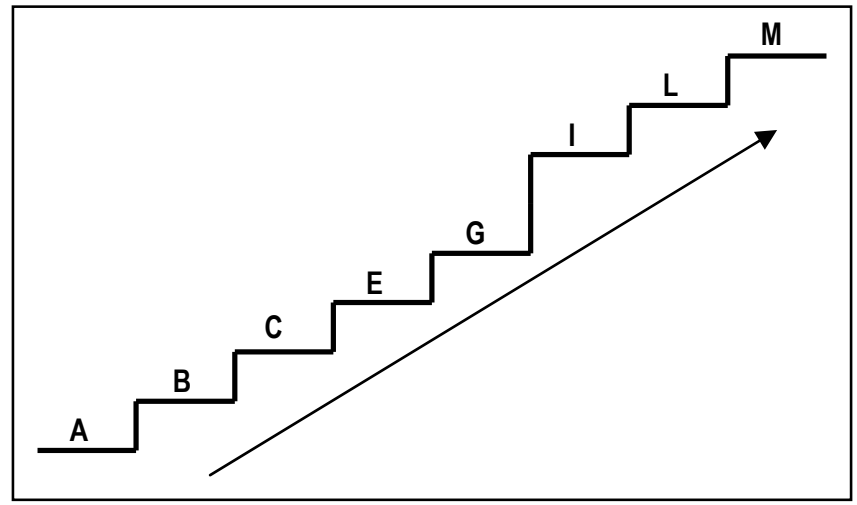

FIG 8.11 - A escada do aprendizado.

A figura não apresenta todos os degraus em simetria perfeita, pois os níveis de conhecimento auferidos por cada etapa não são necessariamente iguais. Não há, também, como pensar tal escada formando uma seqüência simples de ensinamentos encadeados. Haverá, certamente, de acordo com cada ambiente, cada política produtiva e cada conjunto de ferramentas, técnicas e métodos aplicáveis, um modelo diferenciado de combinações de saberes a serem desenvolvidos por processos contínuos e contíguos de ensinagem. A figura 8.12 exemplifica uma situação hipotética de combinações.

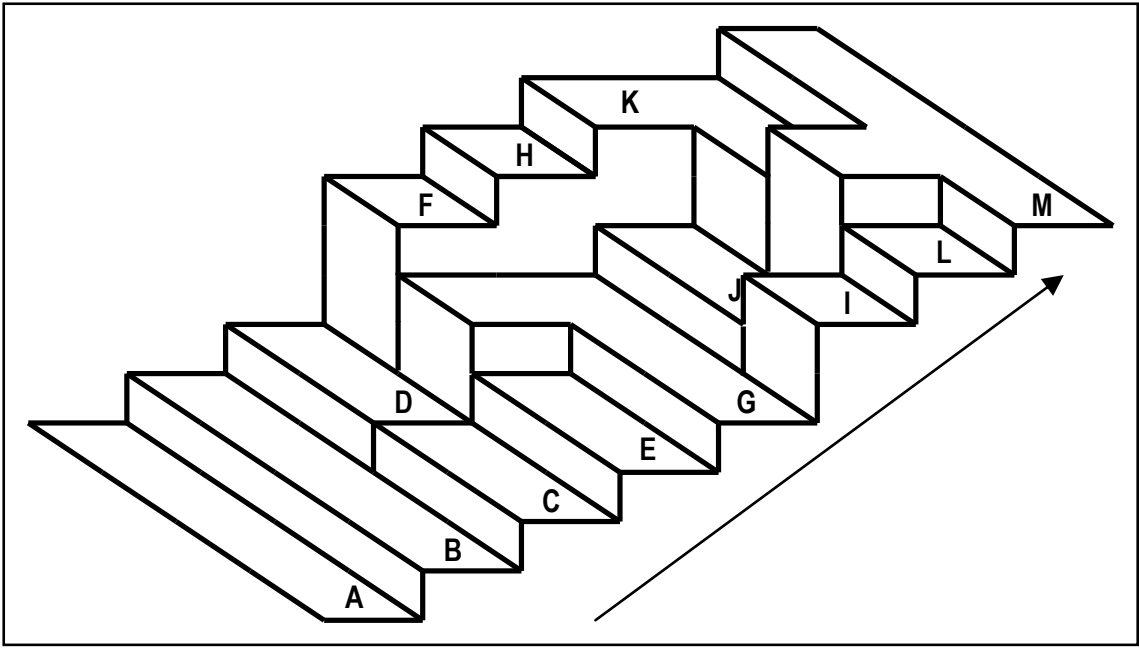

FIG 8.12 - A escada do aprendizado - vista em perspectiva.

Uma disciplina "A" serve de requisito para a realização de uma disciplina "B" que, uma vez realizada, permite opções de realização das disciplinas "C $C$ ” ou "D” ou 
ambas e assim por diante. A escada pode ter as mais diversas formas de combinação e as evoluções podem galgar degraus com diferentes tamanhos. Alguém que tenha concluído a disciplina “J”, por exemplo, pode seguir seu aprendizado optando por executar as disciplinas "I", "K" ou "M", ou combinações destas, dependendo de suas pretensões técnicas no contexto produtivo-administrativo da organização (ou as pretensões da organização quanto a ele). A decisão pela "altura" de um patamar depende do grau de importância que a organização do ambiente de ensinagem defina para cada conhecimento, dependendo, certamente, do tipo de conhecimento, do tipo de ambiente e, até mesmo, do tipo de projeto que a empresa esteja abraçando e que promova um conjunto de processos de treinamento, informação e formação profissional.

As possibilidades inumeráveis de combinações, pela vinculação que determinado conhecimento tenha que possuir com outros conhecimentos, fazem lembrar redes de precedência, para análise de caminhamentos de projetos. No aprofundamento da representatividade dos conhecimentos associados com determinada escada do aprendizado, cada degrau pode abrir-se em uma nova escada, ou seja, o olhar mais retido em determinado conhecimento pode mostrar que ele compõe-se de outros, menores, mais detalhistas, formando uma nova escada, em um nível mais conteudista.

Em se pensando em fábrica de software, um exemplo plausível de escada do aprendizado vem do imaginar que o degrau "A" pudesse representar um curso sobre algoritmos de programação, fundamental como conhecimento básico e exigível a todos os desenvolvedores de software. Todos os desenvolvedores seriam obrigados a realizar um curso sobre orientação a objetos (degrau “B”), matéria também considerada básica pela empresa hipotética com que trabalha o exemplo. Nesse ponto, há uma variação. São oferecidos dois cursos, considerados de igual importância para os propósitos da empresa fictícia: um sobre UML (Unified Modeling Language), voltado para aqueles que se direcionem aos projetos de software; outro, sobre JAVA (linguagem de programação), para aqueles que se direcionem à implementação de projetos de software. Seria possível, também, que alguém, do corpo funcional da empresa, realizasse ambos os cursos e todos e quaisquer outros que venham a constituir uma estrutura de evolução de conhecimentos pelos processos encadeados e combinados de ensinagem.

Mesmo escolhendo "caminhos" diferentes para realizar suas especializações, pessoas diferentes podem voltar a encontrarem-se em degraus acima, que voltem a 
combinar caminhos, ou seja, estas "rotas", uma vez separadas pelas combinações de opções, podem voltar a juntar-se a qualquer instante, em passos posteriores.

Os envolvidos, na categoria de aprendizes, do processo de desenvolvimento de conhecimentos intra-promovido não precisam todos iniciar seus desenvolvimentos pela mesma disciplina (ou degrau). Pessoas com conhecimentos diferenciados devem ingressar nesse processo de escada nos degraus que lhes convierem, baseados em suas competências legadas. A empresa deverá prover forma de avaliar o ingressante, para definir o pondo de entrada do mesmo no processo.

A definição dos degraus desta escada (os cursos que cada um deles representará, os graus de importância que os conhecimentos resultantes destes cursos possuem e as combinações de sequencialidade e "caminho" da escalada para a obtenção dos saberes), representa, em si, um outro processo, desta vez cíclico, conforme apresentam os postulados da CNSH (2001:40), visto na figura 8.13, na qual constam ponto inicial de análise, passos de desenvolvimento e ponto de contratação. A CNSH utiliza tal estratégia para determinar as necessidades de aplicação de cursos internos (voltados aos próprios funcionários), através de uma estrutura de e-Learning (ensino à distância).

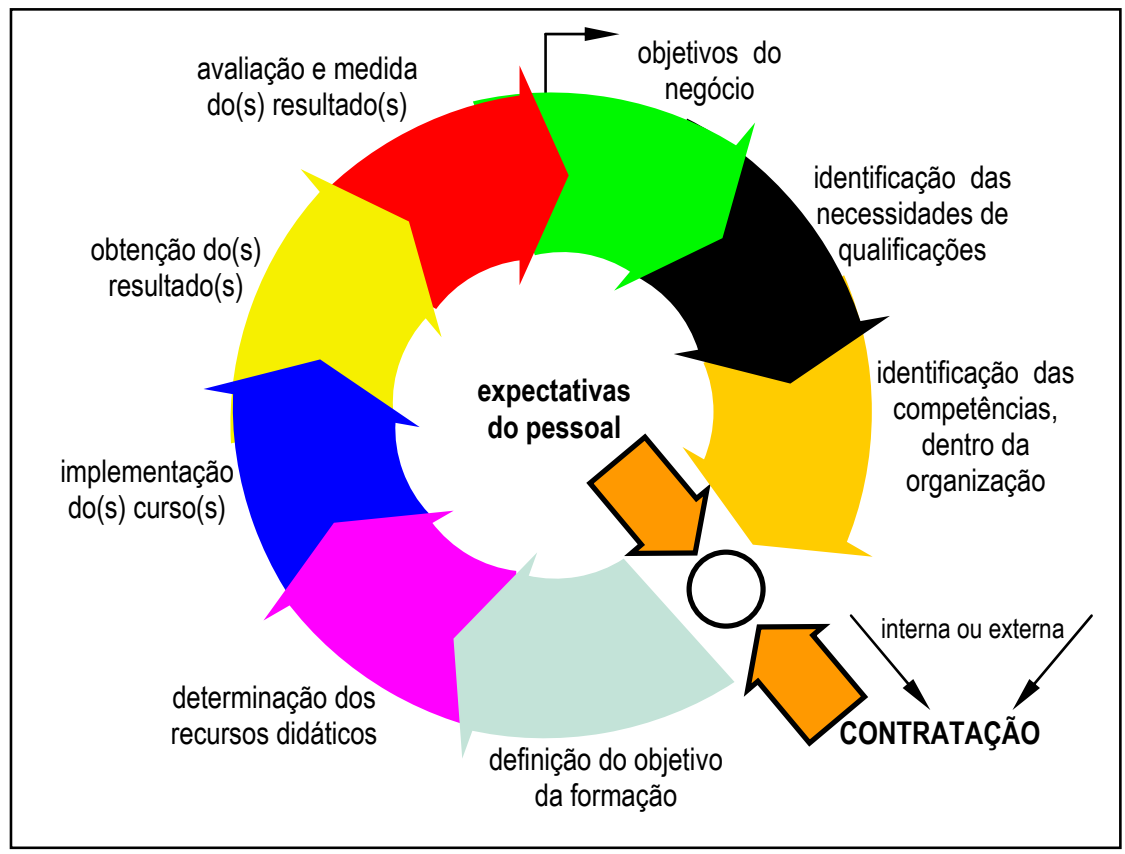

FIG 8.13 - 0 ciclo do desenvolvimento intelectual.

Adaptada do que CNSH (2001:40) denomina Feedback $360^{\circ}$

A dinâmica circular proposta tem seu ponto inicial na análise dos objetivos dos negócios que ora ocuparem as atenções dos gestores da empresa. Uma vez definidos, identifica-se as necessidades de qualificação que o negócio exige. Havendo alguma 
qualificação não atendida pelo corpo funcional (ligado ao projeto em análise) e sendo desejável incorporá-la, identifica-se competências necessárias para a ensinagem (termo não utilizado pela CNSH, incluído em prol do esforço da tese) e disponibilidade interna de profissional executor que possa realizá-la. A especialização é oferecida à organização e, havendo interesse, a contratação do agente executor é feita, aproveitando-se valores técnico-profissionais próprios ou buscando externamente quem os tenha. Inicia-se, então, o processo ensinagem-aprendizagem. Uma definição do objetivo da formação é realizada, pelo agente, em concordância com a organização, adequado aos interesses corporativos. Desígnio traçado, implementa-se o curso e obtêm-se, de forma organizada, os resultados de sua aplicação. Uma análise destes resultados deverá mostrar se os objetivos foram, ou não, atendidos e se há necessidade de novo ciclo. Além deste estudo, outro se realiza: se os objetivos, uma vez alcançados, provocam novo estímulo, levando a um objetivo maior que, por sua vez exigirá o início de outra dinâmica. Importante salientar que, além deste ciclo atuar com diversas iterações, para cada conhecimento considerado necessário ao negócio, várias destas iterações podem ocorrer ao mesmo tempo ou com qualquer grau de concomitância, tanto para um mesmo projeto quanto para projetos concorrentes.

\section{3 - EM SUMA...}

Este capitulo foi dedicado à aproximação dos conceitos propostos anteriormente, na segunda parte deste documento, discorrendo sobre como aplicam-se e arrazoando suas combinações para a formação da competência. Tal esforço, orientado à discussão do papel da gestão do conhecimento em fábricas de software, como instrumento de preservação, culminou em uma triangulação de conceitos (conhecimento - fábrica de software - ensinagem) de maneira a combiná-los e, através destas combinações, identificar o foco da pesquisa ora em curso.

O foco estabelece os critérios de desenvolvimento e suas necessidades, tal qual a de definir um modelo para investigação, do que trata o próximo capítulo. 


\section{MODELO CONCEITUAL PRELIMINAR}

Os conceitos que embasam o ciclo de desenvolvimento intelectual, conforme os propostos pela CNSH (2001:40), exigem um modelo metodológico, padronizado para a determinação dos recursos didáticos e implementação de cursos, além da definição de seu objetivo e a determinação de participantes, tanto na figura do executor quando na dos aprendizes. Este capítulo traduz um modelo que, uma vez proposto de maneira preliminar, sirva aos estudos de adequação entre teoria e prática.

RUHE (1999:63), concordando com a necessidade de implantação de educação profissional no local do exercício da profissão, sugere uma estratégia para a melhoria sistematizada da capacitação, como forma de potencializar aspectos relativos à qualidade, em contribuição à fábrica de experiências (Ruhe participou do mesmo projeto de Basili), Esta estratégia é conhecida por "Paradigma da Melhoria da Qualidade" e é composta de seis passos:

- Primeiro: caracterização do contexto do curso ou treinamento (aqui, doravante, será tratado, simplesmente, por "processo" ou "ensinagem", o que, mesmo não sendo original de Ruhe, interessa aos propósitos da tese), com a identificação de elementos e materiais relevantes reutilizáveis, de sessões anteriores. Isso exige caracterização da organização e a identificação de futuros desafios e necessidades contextuais que orientem iniciativas de difusão de conhecimentos e transferências de tecnologias;

- Segundo: definição das metas do evento em termos mensuráveis, com a relação de métricas e derivações possíveis. Isso exige a definição de metas de aprendizagem e melhoria, o que, por sua vez, exige boa definição dos requisitos do processo de ensinagem em evidência;

- Terceiro: escolha de mídia, casos, exemplos e ferramentas apropriadas à consecução das metas estabelecidas, que devem ser integradas através de um plano projetado. Isso exige identificação precisa de disciplinas, conteúdos e programas que garantam o desenvolvimento do grupo;

- Quarto: desenvolvimento do processo de acordo com planejado, coletando dados e provendo suporte (feedback) e munindo-se deles para conquistar o direcionamento desejável ao processo. Isso exige o desenvolvimento de uma organização da 
ensinagem, pelo sequenciamento de disciplinas;

- Quinto: análise da contribuição do processo, verificando o quanto agregou em conhecimento e experiência, pela análise de seu desenvolvimento, associada a sugestões de melhoria. Isso exige que os programas sejam analisados e criticados e que avaliações sejam feitas em nome de uma evolução positiva;

- Sexto: empacotamento (termo original do autor, com significado de introdução, embarque) de experiências no processo melhorado, para suas próximas sessões. Isso exige plano de incorporação de experiências agregadoras, visando o futuro do programa de melhorias.

É perceptível que a proposta da CNSH permeia a de Ruhe em vários pontos e que o quarto passo apresentado corrobora a idéia de que cada degrau de uma escada de aprendizado, ao ser detalhado, gera outra escada.

$\mathrm{O}$ que Ruhe e a CNSH apresentam não diverge de forma contundente ou extremada das orientações didáticas utilizadas pelo sistema educacional convencional. Apenas que alguns cuidados, agora, tomam corpo e aspecto diferenciado, como por exemplo: o direcionamento do estudo pretendido ser mais pontual, voltado a um interesse particularizado de uma empresa, ou ainda, de um projeto circunstancial de uma empresa; outro cuidado é com a forma como se desenvolve o processo, pois os resultados têm que levar a uma aplicação específica e imediata (ou próxima disso). A empresa CNSH tem uma preocupação especial com essa questão, visto que seu direcionamento para o tema é a prática de ensino à distância.

Esta também é a preocupação de VICARI et al. (2005:1487-1491): ensino à distância para especializar profissionais - com foco especialmente voltado a engenheiros - permeado por características gerenciais de inteligências múltiplas. $\mathrm{Na}$ opinião destes autores, quatro elementos básicos devem orientar as abordagens: da gestão pedagógica; da orientação do trabalho; da execução da instrução; e da gestão tecnológica. Abordagens estas relativas a um processo de educação não presencial (na opinião do autor desta tese, não há porquê não possam servir, também, à orientação para a organização e estruturação de eventos presenciais de ensino ou treinamento) e a figura 9.01 demonstra como elas compõem a coordenação de um programa do gênero. 


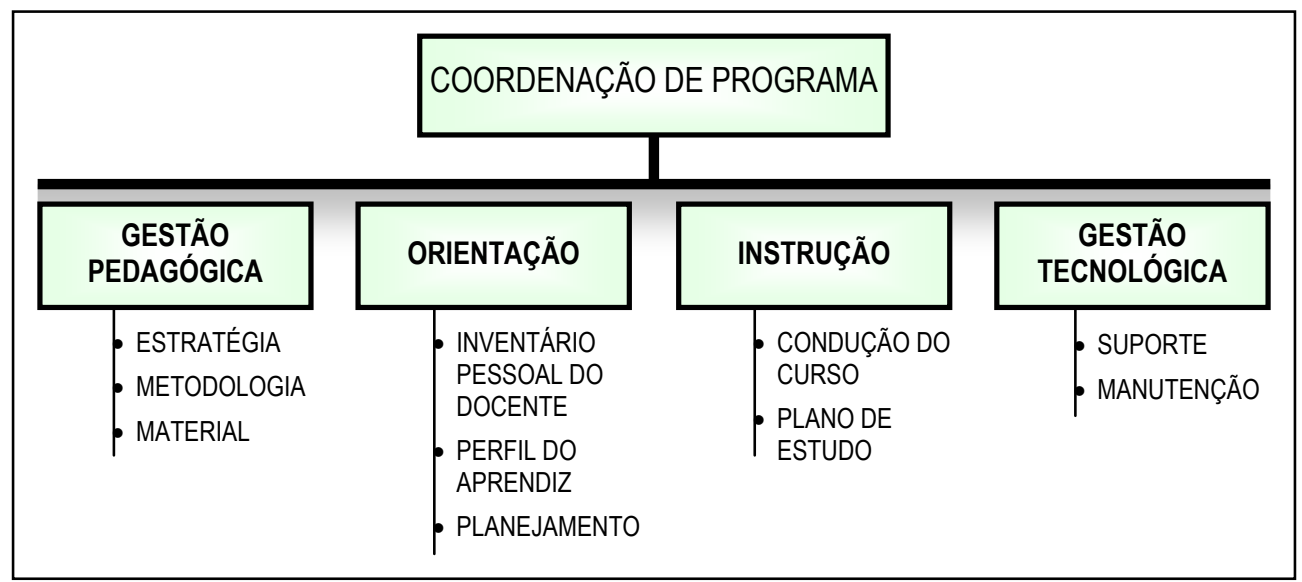

FIG 9.01: Modelo de ambiente de ensino à distância

Adaptada de VICARI et al. (2005:1490).

A figura, adaptada, não contém a referência ao estudo das inteligências múltiplas, representada, no original, ao lado da coordenação de programa. Ao considerar a figura, percebe-se o que compõe as preocupações expostas pelos autores: as questões de estratégia, metodologia e material para o ensino na abordagem pedagógica; as questões relativas ao inventário pessoal do docente (seus conhecimentos, habilidades, competências e experiências a influir na composição do processo), ao perfil do aprendiz e ao planejamento do curso, na abordagem da orientação das realizações durante o processo (e de seus resultados); as questões concernentes ao instrutor (executor do processo), no que diz respeito à condução do curso e ao plano de estudo e; as questões de suporte e manutenção, sob responsabilidade de um gerenciamento tecnológico necessários para a realização do empreendimento

$\mathrm{O}$ que estes autores sugerem complementa o que fora sugerido pela $\mathrm{CNSH}$, por Ruhe e, até, por Basili e seus co-autores; esses últimos, no entanto, de forma indireta, pois não se dedicaram a discutir processos de ensino, mas envolvem-se com questões de entendimento dos conhecimentos e suas representações e de como estes aplicam-se na produtividade de fábricas de software. Com o pensamento composto pelas contribuições destes autores todos, outros podem colaborar.

Um exemplo é PAULA et al. (2004:9-12), para quem a ensinagem do conhecimento aplicado em uma organização (e da gestão que lhe permite aplicação eficiente) precisam entender as diversas formas do conhecimento, formas estas dependentes de sua fonte, de características diversas de seu conteúdo e de sua estrutura. Lembrando: estes autores discutem o conhecimento na negociação e, ao analisarem o processo, identificaram, como inerente a ele, tanto os conhecimentos explícitos, 
contidos nos artefatos de negociação, quanto os tácitos, pertencentes aos negociadores. Isto lhes permitiu classificar tal conhecimento como pessoal, organizacional ou ambiental, conforme é demonstrado pela figura 9.02, e entender a extensibilidade deste ativo, cuja classificação concorda com a já apresentada por Bukowitz e Williams, ao findar do capítulo seis, apenas diferenciando em dois aspectos: quanto à nomenclatura, pois o que aqui é chamado "ambiental", lá é denominado "do cliente" e o que aqui é denominado "pessoal", lá é chamado "humano"; e quanto à abrangência, pois lá, a agregação do valor só é considerada na interseção dos três elementos e aqui, considerase que a agregação ocorra em todas as intersecções. Na central, apenas o conhecimento explícito e nas entre elementos, dois a dois, todo conhecimento que não seja explícito. A essência, entretanto, mantém-se, pois os princípios são os mesmos.

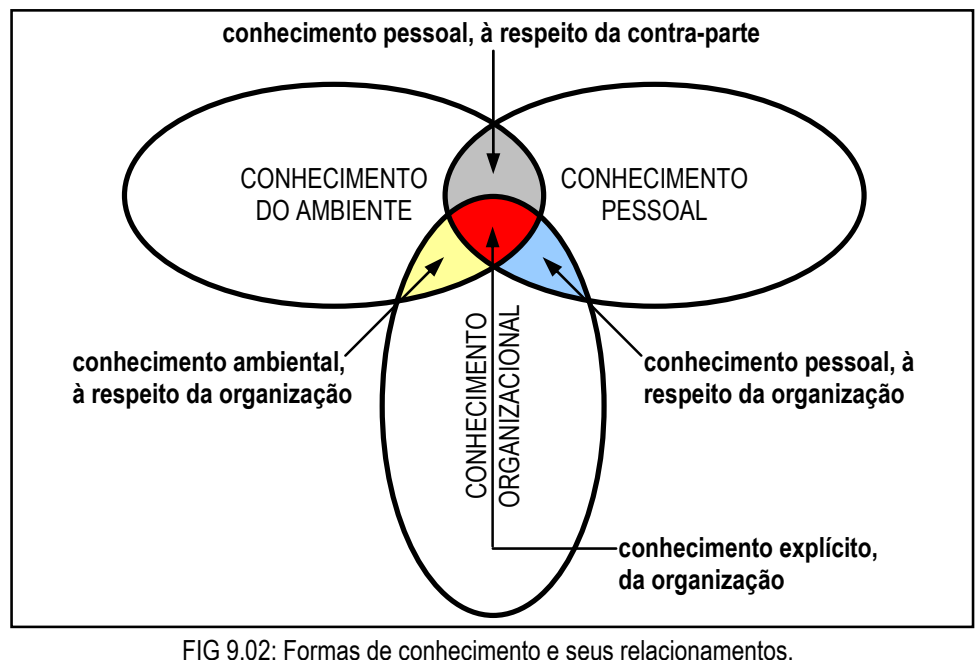

Adaptada de PAULA et al. (2004:9).

A contribuição dada por Paula et al. é a do entendimento das relações entre as formas do conhecimento e suas influências à medida que venham a permear o ciclo do desenvolvimento intelectual (fig. 8.13), e seus conteúdos e estruturas. Influências, por exemplo, nas decisões decorrentes das identificações de necessidades, sobre a realização, ou não, de cursos (se constatado que a necessidade é por qualificações) e/ou, ao definir objetivos para o processo de ensinagem a ser implantado, e/ou, ainda, na identificação das competências e, delas, na decisão sobre as contratações.

Por certo, as representatividades destas formas de conhecimento impactam o processo de ensinagem, pois dizem respeito ao tipo de informação, de habilidade, de conhecimento e de competência auferida aos partícipes e como isso os faz visualizar cada situação de relacionamento. O conhecimento pessoal, por exemplo, inclui 
experiência, cultura e estratégia dos negociadores e todos os valores que esses agentes aprenderam e desenvolveram ao longo da suas experiências pessoais e profissionais. À medida que estes elementos influenciem a maneira como um agente (executor de um processo de ensinagem, por exemplo) perceba e entenda o ambiente (o local de trabalho da empresa) e os aprendizes do processo, acabarão por influenciar o modelo, o método e a forma como a ensinagem possa ser desenvolvida. As relações da prática de comunicação durante o processo gerarão conhecimentos de uns sobre os outros e, parte deles, assim como parte do que se comunicou, tornar-se-á explícita, à medida que incorporada. Assim acontecerá com as outras relações também.

Esta prática de comunicação e como o agente executor de um processo de ensinagem deve atuar dependem, também, de como ele entenda o processo de aprendizagem, segundo afirma MORON (1998:54-58), para quem interessa saber quais elementos compõem o estilo de aprendizagem relacionado a perfis de pessoas (no caso do interesse direto desta tese: perfis de profissionais). A autora desenvolve um ciclo de aprendizagem, denominado "quadrifásico", que começa na experiência concreta do indivíduo e passa por sua capacidade de observar e pensar em conceitos que integrem suas observações em teorias lógicas e sólidas, até chegar à condição de fazer uso dessas teorias para suas tomadas de decisões e resoluções de problemas.

A preocupação da autora com a definição de estilos de aprendizagem relacionadas a personalidades pessoais, de certa forma, corrobora a preocupação de TOGNERI et al. (2003:3-4), os quais discutem a aprendizagem cooperativa e como as pessoas precisam comprometer-se com iniciativas educacionais introduzidas na organização. Esses autores baseiam suas discussões na pedagogia de projetos, com a qual promovem ensino orientado a objetos específicos de composição de negócios, em especial nos de software e, mais especificamente, no levantamento de requisitos.

As atenções observadas de Moron e Togneri e seus co-autores alinham-se às de Ruhe, da CNSH, Pimenta e Anastasiou e de Vicari e seus co-autores, os quais inquietam-se com a forma como se realiza um processo de ensino. Já o cuidado percebido em Paula e seus co-autores é com as possíveis influências sobre esta forma, conforme o tipo de conhecimento em evidência, com o que concordam Borges Neto, Santana, Sawrey e Telford, entre outros. Esta tese procura atender a ambas as perspectivas da ensinagem, considerando que um modelo para o processo precisa ser 
esboçado de acordo com os elementos que podem influenciá-lo.

O ponto de partida para esse modelo, conceitual e preliminar, é considerá-lo, antes de tudo, um processo, conforme sugerido pela figura 7.02, e, como processo, imaginá-lo uma caixa preta (processo transformador) com entrada (para insumos) e saída (para produtos), representação básica, consagrada por Bertalanffy (fig. 3.01) e adotada por diversos outros autores, desde então.

Porém, é desejável que sejam observados e especificados, de maneira detalhada, os insumos que alimentam, viabilizam e suportam o processo. Para tal, pode-se pensar em um modelo apresentado em 1972, segundo o Instituto Nacional de Padrões e Tecnologias dos Estados Unidos - NIST (1993:7-33), que apresenta a normalização do método $\mathrm{SADT}^{14}$ - Structured Analysis and Design Technique, do qual, a figura 9.03 demonstra o "atigrama", ou seja, um diagrama de atividade, através do qual modela-se a dinâmica funcional de um sistema (inclusive de informações), pelos movimentos de matéria-prima e outros objetos de consumo na produção (como mecanismos de trabalho e regras e controles), como alimentadores de um processo transformador (a atividade) capaz de produzir resultados planejados.

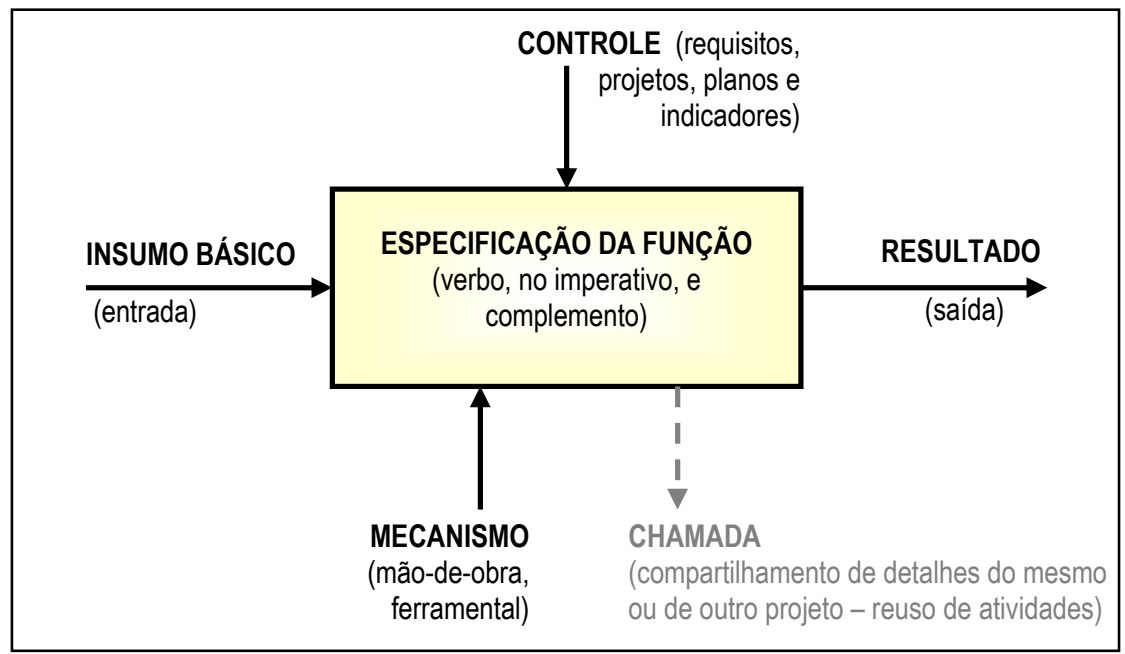

FIG 9.03: Diagrama de atividades do método SADT, na concepção de Douglas T Ross, seu autor. Adaptada de NIST (1993:11).

A vantagem deste modelo, sobre o de Bertalanffy, é demonstrar os elementos participantes de um processo transformador, como documentos de requisitos, projetos e

\footnotetext{
${ }^{14}$ O modelo criado por Douglas T. Ross foi normalizado pelo NIST por conta da necessidade de padronização que o governo dos Estados Unidos percebeu, para organizar os projetos de sistemas das forças armadas e, adotado em 1981, foi, primeiramente, aplicado por um projeto de manufatura auxiliada por computador, do laboratório aeronáutico Wright de computação integrada da força aérea (Air Force Wright Aeronautical Laboratories Integrated Computer - ICAM - Aided Manufacturing Architecture).
} 
planejamentos, além de modelos, regras e indicadores de desempenho, pelos quais se possa controlar e gerir o processo. Demonstra, ainda, as participações de pessoas, com suas atribuições, do ferramental (materiais de apoio, equipamentos, instrumentos, formulários, etc.) e de insumos (material de consumo). Um diagrama montado através do método SADT é composto de diversos atigramas encadeados.

Este modelo, assim como o de Bertalanffy, influenciou a criação dos diagramas de fluxo de dados, na forma de bolhas (representação dos processos por meio de um círculo, ao invés de retângulo) com múltiplos fluxos de entrada e saída (setas) de dados, propostos por McMENAMIM e PALMER (1991:15-33), para quem os fluxos contêm apenas dados em movimentos, em sistemas de informações. A figura 9.04 demonstra que os fluxos mostram apenas dados entrando ou saindo, vindo ou indo para componentes da base de dados (denominadas "depósitos de dados") ou para agentes externos (representantes do ambiente, que interagem com o sistema, podendo ser pessoa, empresa ou outro sistema). Os mecanismos e controles, fazendo parte do sistema em representação, ficam contidos no processo (bolha).

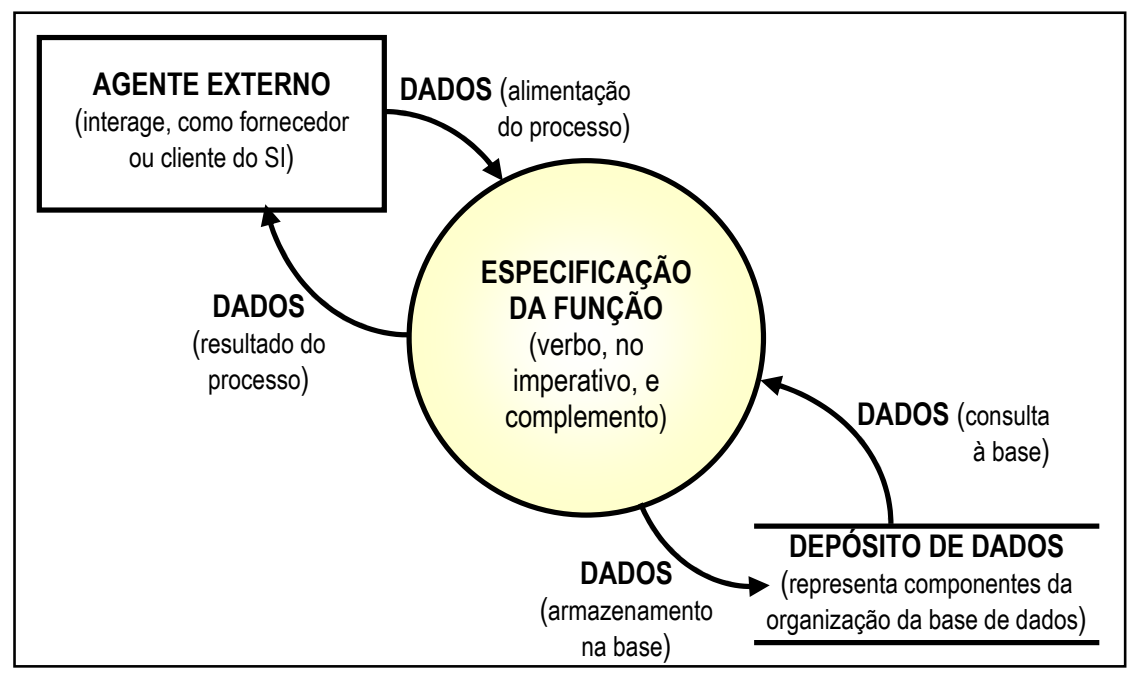

FIG 9.04: Diagrama de Fluxos de Dados, na concepção do método de análise estruturada essencial.

O modelo conceitual que aqui se busca deve conter elementos destes dois modelos: SADT e Essencial, e os combinar em nome da representação dinâmica dos elementos de composição (como mecanismos e controles) e das relações com bases (de dados, experiências e conhecimentos) e agentes (profissionais, internos ou externos à empresa), além de contar com liberdade para o posicionamento destes elementos e para a representatividade do dinamismo das relações.

Tal modelo, preliminarmente, deve considerar, ainda, a questão do pragmatismo 
de aplicação do produto do aprendizado que acaba de ser concretizado. A solução de representatividade pensada para esta demanda inclui um processo de produção, chamado, apenas, "produção", encadeado ao de ensinagem. Este elemento produtivo compõe-se de uma entrada (a força de trabalho gerada pela ensinagem) e várias saídas, pois, além da aplicação do aprendido em projetos da empresa (produção clássica), o profissional, no modelo sempre denominado "aprendiz" (a idéia de melhoria contínua leva ao ideal de que todo profissional é e sempre será um aprendiz) passa a contribuir com o conhecimento da corporação, seja pela formulação do que aprendeu, seja pela contribuição com documentos que promovam a evolução do conhecimento, e ainda, seja pela comunicação de saberes não explicitados a outros participantes da organização.

A figura 9.05 demonstra a proposta inicial de representação de um modelo que aplica-se de forma contínua, tal que uma ensinagem tenha tantos processos (etapas de aprendizagem) quantos necessário, segundo determinação particularizada de cada elemento de conhecimento que a organização deseje desenvolver em seus funcionários.

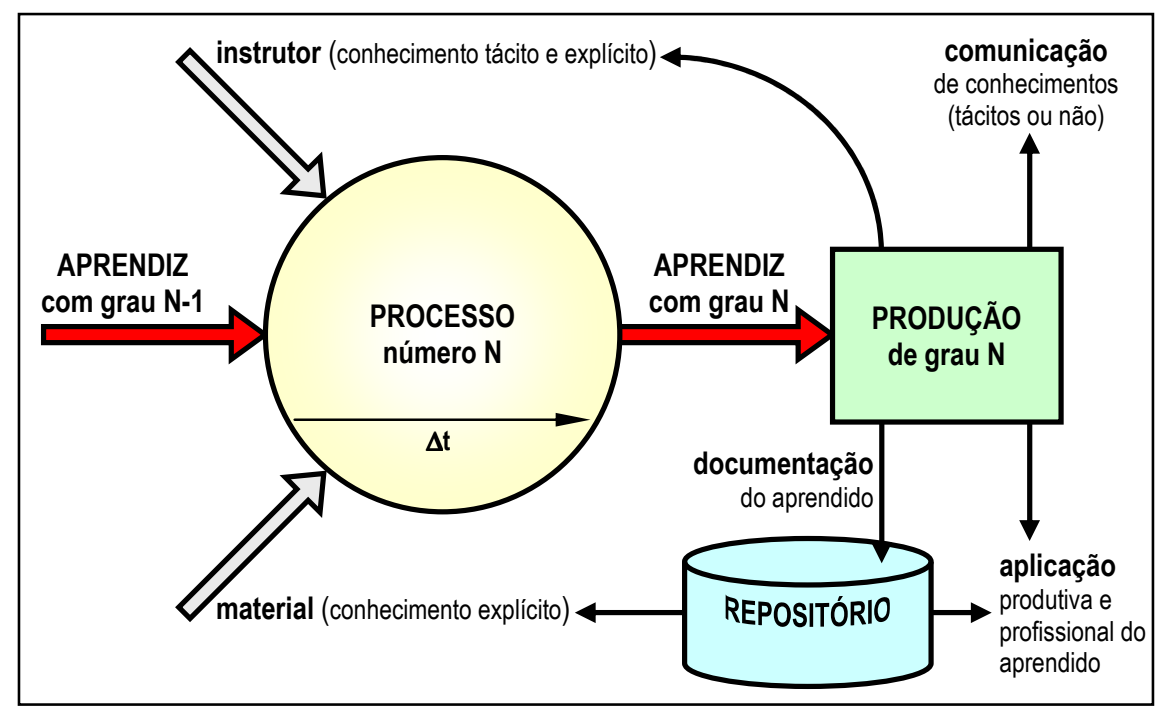

FIG 9.05: Modelo conceitual preliminar do processo de ensinagem.

Um processo de ensinagem, na realidade pode conter uma ou mais etapas de processo, tais como apresentado pela figura, a qual traz, como elementos:

- o processo em si, representando cada uma das etapas a ser aplicada e gerida;

- o aprendiz que, antes de realizar o processo, possui um grau "n-1" de conhecimento e, após sua realização, passaria a ter grau “n”, necessário para uma produção de igual grau de complexidade, dificuldade ou profundidade de saberes; 
- o instrutor, pessoa (ou grupo de) da empresa ou contratada externamente, detentor do conhecimento desejável de transmissão e disseminação. Pode haver casos, em processos mais desenvolvidos, onde o ensino torne-se totalmente remoto ou baseado em material didático, a ponto deste "cargo" ser reduzido a, no máximo, alguma ação de monitoramento de desenvolvimento de curso;

- o material de apoio, composto de contribuições diversas presentes no repositório da organização, como documentos, textos e páginas web, entre outros;

- o tempo de realização $(\Delta \mathbf{t})$, necessário para cada processo ou etapa, calibrável com o ganhar de experiência sobre cada prática de ensinagem realizada;

- a produção esperada do profíssional aprendiz, o qual acaba de conquistar grau "n" de determinado conhecimento. Tal produção pode ser expressa na forma como ele participa de futuros processos de ensinagem e na forma como ele contribui com o aparelhamento material para a difusão do conhecimento, além, é claro, de colocar sua capacidade de trabalho a serviço dos projetos da empresa, aplicando o fruto de sua aprendizagem;

- a produção por instrução ou auxílio ao instrutor é uma das formas de participação do aprendiz, podendo atuar em eventos futuros, nos processos de número, no máximo, "n";

- a produção com documentos é uma forma de contribuição. Realiza-se durante e após o processo, com inclusão de documentação que defina projetos ou registre experiências de suas produções ou, no mínimo, textos e artigos que contribuam com futuras ensinagens. Esta forma de produção limita-se a produção de conhecimentos explícitos;

- a produção por comunicação contribui com a massa de conhecimento da organização à medida em que sejam promovidas oportunidades para a troca e a discussão de idéias entre os partícipes da organização, com reuniões, workshops, tutorias, palestras e outras formas de disseminação de conhecimentos tácitos;

- a produção por aplicação do aprendido retrata o exercício do profissional no ambiente produtivo do qual faça parte, fazendo uso de conhecimentos tácitos (e competências essenciais dinâmicas) e explícitos, nestes, inclusive, valendo-se do conteúdo do repositório; 
- o repositório representa uma parte de todo o complexo de armazenagem de dados, informações, conhecimentos, experiências e outras formas de recursos explícitos agregados que a organização mantenha.

Interessante observar que o processo da ensinagem não dura apenas o tempo decorrido da(s) etapa(s) de instrução e, sim, prolonga-se tanto quanto necessário para que as produções, em suas diversas formas, apliquem-se. No caso das comunicações, por exemplo, devem constituir atividades periódicas com as quais todos se comprometam. No caso do aprendiz tornar-se monitor ou instrutor de um processo de grau já conquistado, a atividade pode alongar-se pelo período que dure a contratação da pessoa. O mesmo pode ser dito da aplicação e das contribuições diretas com o repositório: conhecimentos adquiridos serão disseminados e utilizados na prática profissional enquanto durar o praticante na organização.

A idéia de que um profissional portador de um grau " $n$ " de conhecimento dissemine-o, mesmo não sendo ele explícito, apoia-se em LEI et al. (2001:162-168), pois que estes autores exprimem a importância de tais saberes para a formação das competências essenciais dinâmicas, advindos de pessoas e transmitidos a pessoas, conforme discorre TAVARES (2004:94-96), baseando-se em diversos autores, principalmente Karhu ${ }^{15}$, através de instrumentos diretos, como entrevistas, práticas de mentoring, palestras e seminários (e ensinagens, pode-se somar), ou indiretos, como documentos depositados em bases apropriadas.

Quanto a profissionais tornarem-se instrutores, MARQUES FILHO (2002:123) defende que o empreendedorismo "pessoal” docente, incentivado por ampliação do conhecimento pela prática, através de um processo de ensino, gera estímulos profissionais que podem ser explorados estrategicamente pela empresa.

Quanto a oportunidades de comunicação, além de Tavares, Lei e outros, também as defende LE BOTERF (1994:99,249), apregoando a necessidade de promoção de eventos coletivos estruturados que permitam o emergir de argumentações, articulações e trocas de conhecimentos, em prol da difusão de competências individuais pois, segundo ele, é no aprendizado dor problemas (reconhecimento e classificação) que se aprende a aprender e desenvolve-se a habilidade de resolve-los (particular e extensivamente).

\footnotetext{
${ }^{15}$ KARHU, Katja; Expertise Cycle: an advanced method for sharing expertise; in: Journal of Intellectual Capital vol. 3, n- 4; Inglaterra: Emerald, 2002.
} 
SMALL e TATALIAS (2000) concordam, ao atribuir parte do processo de transmissão de conhecimentos à troca direta entre pessoas. Todos corroboram a idéia de que a diversificação de formas de tratamento e disseminação do conhecimento é importante para a competitividade do negócio.

A importância do tácito, inclusive, é defendida por outros autores, tais como CHATTERJEE (2002:1-4), que o mescla ao conceito da intuição, como elemento importante para a criação do conhecimento, e SNOWDEN (2003:98-206), para quem o que uma pessoa sabe e sabe que outras necessitam para a realização de um projeto é fator de estímulo para ela, ao seu comprometimento, e o autor defende que o processo de desenvolvimento deve ser estimulado e, não, imposto.

As quantificações do tempo de cada processo devem ser atribuições do executor do processo, pois é preciso partir do princípio de que este profissional tenha conhecimentos suficientes para inferir sobre o necessário ao seu trabalho, com o que concorda DAVENPORT (1996:1-5), autor que discute a internalização de processo de ensino em empresa e como ele deve ser estruturado. O caso publicado por ele não trata, especificamente, de um processo de ensinagem apenas, conforme já mencionado no inicio do sexto capítulo, mas, sim, de um processo do gênero como parte da estratégia da empresa para viabilizar a formação de uma rede de especialistas, num empreendimento maior, de implantação de gestão do conhecimento na organização.

Um serviço de gestão de tais elementos (o tempo e a definição de material de apoio) deve ser realizado em conjunto com o profissional, promovendo as calibrações (tempo) e quantificações (material) e ajustando tais informações com o decorrer de aplicações. A empresa, antes de iniciar um empreendimento de ensinagem, quando, ao estudar os objetivos do negócio, percebe uma necessidade de qualificação dos seus e faz a identificação das competências associadas (conforme propõe a figura 8.13), pode solicitar, se experiência anterior não houver, a especialistas (consultores externos, por exemplo, tomados da rede de especialistas sobre a qual a empresa deve manter informações em sua base de talentos, conforme proposição de Davenport), diretrizes que contribuam à mensuração de tempos e recursos que um executor desse ensino profissional possa vir a solicitar, quando de seu orçamento. Este conceito de rede é compartilhado por Marques Filho, principalmente quando tende ao envolvimento de recursos humanos internos ao negócio. Esse autor possui, ainda, uma máxima que 
ajusta-se à defesa da ensinagem e, principalemente, do fluxo de "aplicação", no modelo conceitual preliminar: Quanto mais aprende-se, melhor se faz! [pág.124]

\section{1 - A APLICAÇÃO DO MODELO:}

Decisões sobre necessidade, realização e composição de processos de ensinagem ocorrem simultaneamente a ciclos do desenvolvimento intelectual, tal qual proposto por CNSH (2001:40). Obviamente que não por mera coincidência, mas porque a estruturação de um depende da sistematização de um processo orientado por outro. Assim como na relação entre o processo operacional executivo de uma fábrica de software (fruto da organização de sua produção) e o processo gerencial da mesma (fruto de sua organização administrativa), pode-se afirmar que o ciclo do desenvolvimento intelectual expressa um processo que organiza e permite a administração da aplicação do modelo sugerido de processo de ensinagem.

Cada ocorrência desse modelo representa, em tese, um degrau de conhecimento na escada do aprendizado, a ser organizada pela empresa. A produção resultante de conhecimentos gerados em um degrau " $n-1$ " de tal escada (figuras 8.11 e 8.12) leva a avaliações constantes do negócio, desde seus objetivos, e isso, por sua vez, leva a uma significativa probabilidade de identificação de novas necessidades, a ponto de compensar a definição, organização e implementação de um novo degrau, com seu processo de ensinagem. Para isso, um estudo sobre as expectativas de pessoal e competências envolvidas leva à contratação de um instrutor, ou uma equipe, caso necessário. Define-se objetivos para o processo de ensinagem de grau " $n$ " a ser desenvolvido e estabelece-se os recursos necessários para sua realização. Entre estes recursos está o material de apoio e parte do conteúdo do repositório da organização, com documentos, relatos de experiências e outros artefatos disponíveis. Implementa-se o curso, levanta-se seus resultados e realiza-se a avaliação dos mesmos. Tais informações, assim como contribuições (novas) alimentam a base de conhecimentos e a avaliação dos frutos da produção, agora de grau "n”, estimula a continuidade do ciclo.

$\mathrm{Na}$ organização de um negócio, o corpo gestor precisa definir o conjunto de conhecimentos pertinentes aos seus processos produtivo e administrativo. Esta definição determina o primeiro nível da escada de aprendizado na qual a empresa deverá investir para a formação do quadro técnico-administrativo competente desejável. Este primeiro 
nível é o que se pode considerar "contextual", de caráter genérico ou "ambiental", como preferem denominar McMENAMIM e PALMER (1991:15-33), para quem o sistema, para ser entendido (para que se conquiste o domínio sobre ele), precisa ser visualizado em seus detalhes, precisa ser compreendido em seu caráter "comportamental". Isto apoia a idéia de que, em uma escada de aprendizado, cada degrau definido abre-se em uma nova escada, expondo conhecimentos cada vez mais granulares que detalham o conhecimento maior, aposto em um nível superior. Isso permite uma leitura "top-down" do sistema representado pelo conjunto de conhecimentos relativo ao negócio, assim como o entendimento de todas as outras abordagens sistêmicas desejáveis de compreensão, a respeito do negócio. Esta seqüência de aberturas de processos avança até que uma unidade autônoma de conhecimento seja encontrada e, sobre ela, se aberta, só disciplinas de composição sejam visíveis e, estas, comporão a estrutura do curso ou treinamento a ser realizado. Não se pretende discutir, aqui, a linha tênue que separa os conceitos de disciplina e conhecimento, pois esta depende de cada enfoque, cada situação, e muda para atender desejos circunstanciais de amplitude da modelagem.

A figura 9.06 exemplifica uma visão por nível destas escadas, aplicada ao exemplo de uma fábrica de software que possui, em seu nível mais genérico, as áreas organizacionais do negócio: administrativa, processual e tecnológica (o exemplo limitase a estas, nessa forma de divisão).

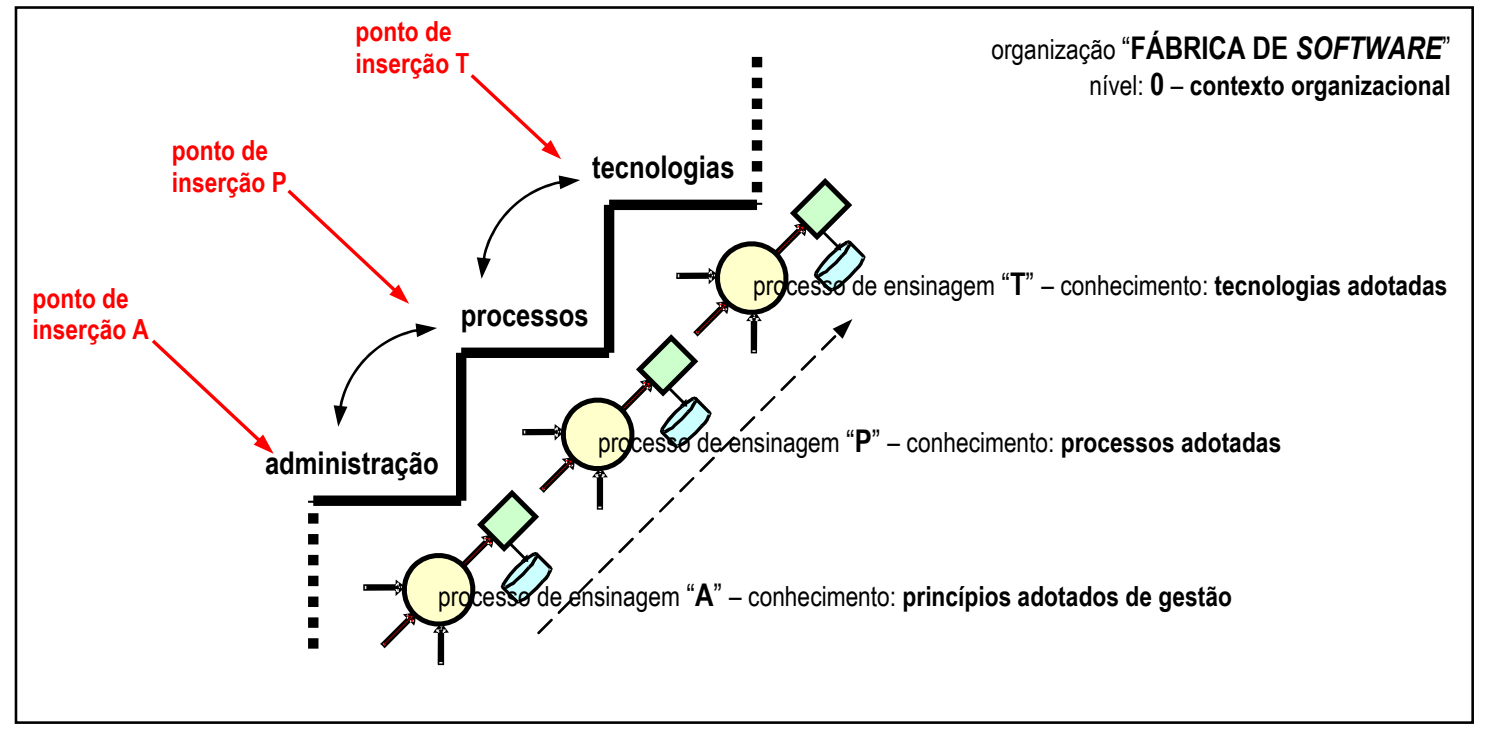

FIG 9.06: o modelo de processo de ensinagem e a escada do aprendizado.

A figura mostra que, a cada degrau de conhecimento, corresponde um processo de ensinagem. Como o exemplo demonstra um nível contextual, o mais genérico 
possível, é previsível que estes processos sejam complexos o bastante para conter, cada um, um número significativo de conhecimentos diversificados. A sequencialidade estabelecida pela imagem dá idéia de que o aprendizado iria das questões administrativas às tecnológicas, porém, isso não corresponde à realidade. O processo de aprendizado de alguém, em nível tão alto, seria o acumulo de aprendizados em qualquer dos degraus, dependendo de suas escolhas e posicionamento técnico dentro da organização. Nesse caso, poderia subir ou descer conforme lhe aprouvesse. Seja qual for o posicionamento que um profissional possa ter, o início de sua carreira corresponderá a um ponto de inserção no sistema de ensino corporativo. A figura mostra que cada segmento pode ser um ponto de entrada à escolha do profissional (ou da organização).

Uma vez introduzido o profissional no sistema, nos níveis comportamentais, de maior detalhe, para cada segmento de conhecimentos um ponto inicial (mais específico, mais especialista) será definido para cada profissional e, daí, a seqüência de processos segue o direcionamento indicado (carreira). Porém, conforme demonstra a figura 8.12, a configuração da escada pode exigir retornos para especializações complementares. A figura 9.07 trata a questão do detalhamento dos conhecimentos, apresentando, em apenas dois níveis de abertura, os detalhes de um curso Java, tomado como exemplo. Tal detalhamento, na evolução de visões, da mais genérica à mais detalhada, no entanto, pode ter mais níveis de desmembramento, caso necessário. Cada conhecimento aberto, pode gerar um número diferente de escadas de aprendizagem, conforme convier ao entendimento da estrutura a gerenciar

Na figura 9.07, o nível 1, representando a escada de aprendizagem do processo "tecnologia" de ensinagem, possui alguns degraus representados com linha pontilhada: são conhecimentos considerados pré-requisitos - nos degraus mais baixos - que o profissional precisa para poder participar do evento em foco (no exemplo, para que um profissional participe do contexto tecnológico da fábrica, é necessário que conheça algoritmos e, ao menos, uma linguagem de programação) ou são conhecimentos ainda não especificados para a escada - degrau mais alto. $\mathrm{O}$ mesmo acontece com a escada do nível 2 - programação Java - na qual os conceitos de "fábrica de software" e “orientação a objetos”, antes nos primeiros degraus de conhecimento a galgar, agora passam a ser pré-requisitos para o curso em questão. Esta preocupação com a determinação do "ponto de entrada" do aprendiz, na escada do aprendizado, representa 
um fator de importância para a gestão do processo, discutido e defendido por SAWREY e TELFORD (1979:358-388).

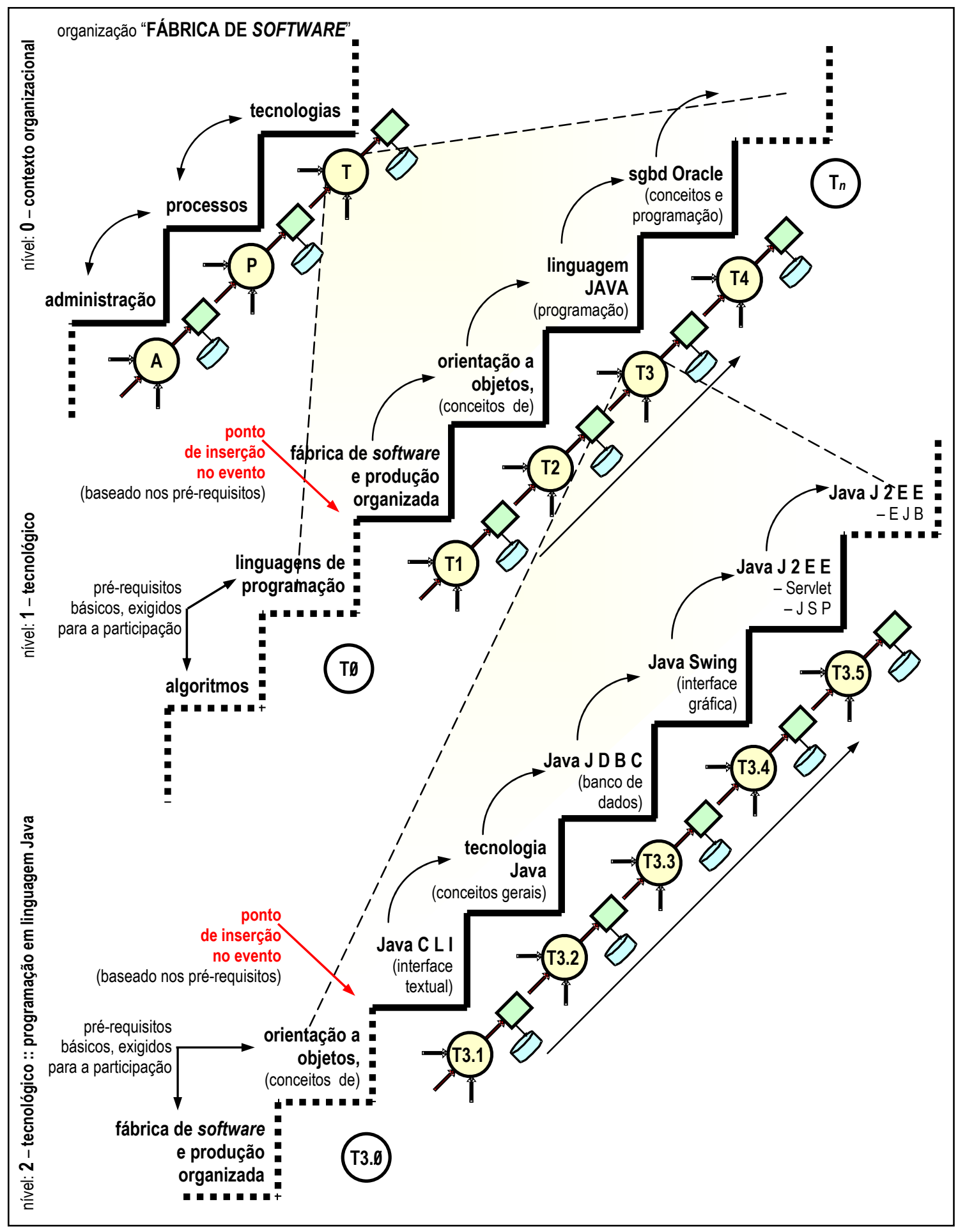

FIG 9.07: O detalhamento dos conhecimentos, nas escadas do aprendizado.

O curso de programação em linguagem Java, escolhido como exemplo, não pertence à área de domínio do autor desta tese. A escolha, porém, serve para demonstrar situações em que a organização, não tendo experiência anterior no assunto, nem 
possuindo competências internas para defini-lo, deve buscar auxílio externo. Nesse caso, seguindo as sugestões de DAVENPORT (1996:3), duas consultas foram realizadas, ao web site de uma empresa ${ }^{16}$ que oferece cursos sobre o tema (certificadora “Sun”, à época) e a um professor ${ }^{17}$ de Java da FEMA de Assis, estado de São Paulo.

A primeira consulta sugeriu que uma certificação básica na linguagem deve conter os seguintes cursos: Sintaxe da Linguagem Java (com duração de 12 h); Programação Orientada a Objetos com Java (28 h); Desenvolvimento de aplicações com Banco de dados (16 h) e; J2EE Web Applications (24 h).

A segunda consulta concordou que a especialização deve conter um degrau dedicado aos conceitos básicos e sintáticos da linguagem, mas sugeriu que sua ênfase seja na produção de interfaces textuais, denominando-o "Java CLI (Command Line Interface)", para o qual manteve-se a duração de 12 horas O segundo módulo, passaria a discutir as tecnologia Java e suas relações e aplicações, já que o exemplo em prática coloca conceitos de orientação a objetos como um pré-requisito para o curso, e a duração foi reduzida para 8 horas. O terceiro módulo manteve-se dedicado a bancos de dados, com tecnologias JDBC (Java DataBase Command), e com duração de 16 horas. Um módulo dedicado a produção de interfaces gráficas foi sugerido, antes de chegar ao J2EE (Java to Enterprise Edition); este módulo foi denominado "Java Swing" e, para ele, foi sugerida uma duração de 24 horas. Como o último módulo ficou limitado a aplicações voltadas à web, um módulo futuro de J2EE foi sugerido por L'Erário, contendo uma visão de EJB (Enterprise Java Beans) que abrange aspectos de composição do sistema institucional da organização. Este forneceria apenas uma noção desta abordagem, com cerca de 40 horas (valor não certo, que seria ajustado).

Como a discussão, na segunda consulta, resultou um projeto mais completo (no entender do autor desta tese), pois contém o que propõe a primeira consulta e estende e foca alguns pontos chave. Esta sugestão foi escolhida para compor o exemplo.

O próximo passo seria o detalhamento de cada um destes conhecimentos granulares representados pelos módulos da especialização (degraus da escada, em seu nível 2) e a formação de um mapeamento entre o conhecimento (ou seu módulo) e o

\footnotetext{
${ }^{16}$ GLOBALCODE; in: http://www.globalcode.com.br/index.jsp?pagina=IAJ (visitada em 08 de agosto de 2005)

${ }^{17}$ Alexandre L'ERÁRIO, em reunião realizada por grupo de pesquisa, nas dependências da FEMA, em 08 de agosto de 2005
} 
ferramental necessário à sua ensinagem. Uma tabela de distribuição de recursos, ou seja, uma estrutura que associa cada elemento com as ferramentas necessárias à sua consecução na formação do saber maior, deve ser construída. O conhecimento escolhido para exemplo foi o JDBC: desenvolvimento de aplicações com bancos de dados.

A figura 9.08 mostra que tal mapeamento origina-se no degrau “T3.3", e estabelece um conjunto de recursos aplicáveis a este estágio do processo de ensinagem. Tanto DAVENPORT (1996:1-5) quanto RUHE (1999:64-71) concordam com a necessidade de especificação e distribuição dos recursos, com o que concordam, também, TOGNERI et al. (2003:1-2) em sua discussão sobre a estruturação voltada à integração do indivíduo (que ora é denominado aprendiz) na aprendizagem cooperativa e como esta define os objetos de estudo focados em negócios específicos, para otimizar conteúdos representativos dos conhecimentos específicos, necessários à formação da

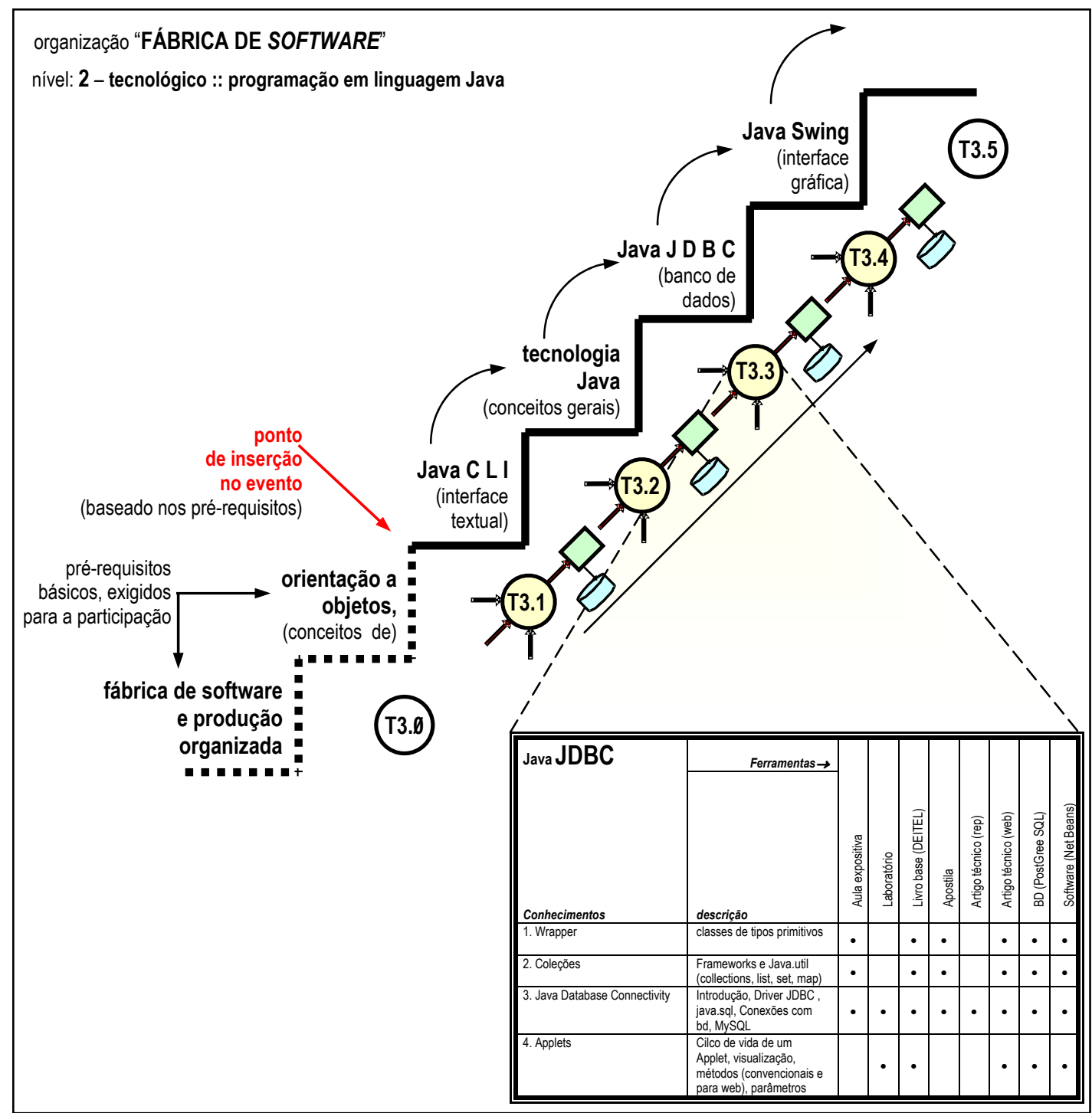

FIG 9.08: O mapeamento de conhecimentos e ferramentas, para cada curso da escada do aprendizado. 
competência (no caso desses autores, lembrar que o foco é a engenharia de requisitos).

A tabela 9.01, a seguir, amplia a exemplificação do mapeamento mostrado pela figura, de um dos cursos (o "T3.3”) constantes da escada do aprendizado, em seu nível 2 , relacionando os conhecimentos elencados com os recursos necessários e mapeando os que se encontram disponíveis, para a execução do evento de ensinagem.

\begin{tabular}{|c|c|c|c|c|c|c|c|c|c|}
\hline va $\mathrm{JBC}$ & Ferramentas $\rightarrow$ & & & & & & & & \\
\hline Conhecimentos & Descrição & 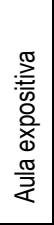 & 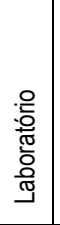 & 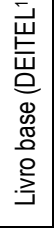 & $\begin{array}{l}\frac{0}{\bar{T}} \\
\frac{\mathrm{O}}{2} \\
\frac{0}{4}\end{array}$ & 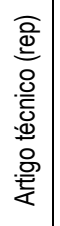 & 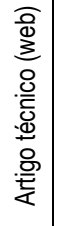 & 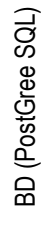 & 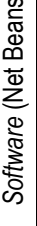 \\
\hline 1. Wrapper & classes de tipos primitivos & - & & - & - & & - & - & - \\
\hline 2. Coleções & $\begin{array}{l}\text { Frameworks e Java.util } \\
\text { (collections, list, set, map) }\end{array}$ & $\bullet$ & & $\bullet$ & $\bullet$ & & $\bullet$ & - & • \\
\hline 3. Java Database Connectivity & $\begin{array}{l}\text { Introdução, Driver JDBC, } \\
\text { java.sql, Conexões com bd, } \\
\text { MySQL }\end{array}$ & $\bullet$ & $\bullet$ & $\bullet$ & $\bullet$ & - & $\bullet$ & - & $\bullet$ \\
\hline 4. Applets & $\begin{array}{l}\text { Cilco de vida de um Applet, } \\
\text { visualização, métodos } \\
\text { (convencionais e para web), } \\
\text { parâmetros }\end{array}$ & & $\bullet$ & $\bullet$ & & & $\bullet$ & $\bullet$ & • \\
\hline
\end{tabular}

TAB 9.01: Exemplo de mapeamento de conhecimentos e ferramentas.

Enfim, o exemplo escolhido procurou demonstrar um caso de uso para o processo de ensinagem e sua representatividade no contexto do conhecimento de uma organização produtora de software. Eventos de ensinagem servem à preservação do conhecimento, a visão de cada evento permite sua gestão e a visão do conjunto deles, a gestão do conhecimento criado com sua realização. O exemplo serve de linha mestra para a aplicação da pesquisa.

\section{2 - EM SUMA...}

Este capítulo desenvolveu a idéia de um modelo conceitual preliminar de ensinagem e discutiu-o sob as luzes de conceitos e de sua aplicabilidade, como mecanismo perceptível em grupos estruturados de ensino institucionalizável, organizados, formando escadas do aprendizado. A seqüência do trabalho cuida de investigar o quanto este modelo preliminar alinha-se, ajusta-se e contribui para a melhoria organizacional, capacitando-a a tratar e conservar conhecimentos.

\footnotetext{
${ }^{18}$ DEITEL, Harvey M.; DEITEL, Paul J.; Java: como programar - $6^{\text {a }}$ edição; Brasil: Prentice-Hall, 2005.
} 
A pesquisa realizada para avaliar o modelo de ensinagem, preliminarmente definido no capítulo 9, foi, então, delineada como um estudo de casos múltiplos, segundo denota YIN (2005). Este capítulo traz a definição de como tal pesquisa foi estruturada, bem como informações sobre seu desenvolvimento, detalhando, item a item, os casos estudados.

Importante recordar que a exploração (em tempo presente) das realidades organizacionais envolvidas na análise da aplicabilidade do modelo esboçado tem, como fim primordial, validar um modelo teórico destinado à prática de ensino (cursos, treinamentos e difusões outras) que atenda ao problema central deste estudo: Como as fábricas de software preservam o conhecimento e como se realizam processos de transmissão do mesmo, no corpo funcional, com garantias de sucesso da aprendizagem.

\section{1 - DEFINIÇÃO DA PESQUISA:}

A atividade de campo configura-se sob o padrão de estudo de casos múltiplos, por representar investigação própria de condições contextuais empíricas, situacionais e circunstanciais, estabelecendo limites entre o fenômeno em estudo e seu contexto, de acordo com o que propõe YIN (2005:55-60). Alguns pontos relativos a tal proposição devem ser considerados:

- Em nome da validade do constructo, procurou-se estabelecer o devido encadeamento de evidências com os casos (apesar de não se ter explorado todos os seis tipos de evidência apresentados pelo autor, conforme será justificado). No que tange à composição, todas as informações relacionadas adiante, sobre todos os aspectos estudados em cada um dos casos, foram apresentadas, às organizações, na forma de relatórios, e contaram com a revisão da(s) pessoa(s)-chave(s) determinada(s) por cada empresa;

- À validade interna da pesquisa, procurou-se dar conotação à medida que as realidades percebidas nos casos levaram a adequações do modelo conceitual preliminar, isso devido à utilização do modelo lógico proposto, caso a caso, 
realizando análises concorrentes de suas dimensões, conforme arquitetadas e expostas no protocolo da pesquisa. Importante salientar que este tópico foi assim considerado pela necessidade de ampliação dos elementos de avaliação do modelo sob investigação, mesmo o estudo não tratando ou envolvendo quaisquer causalidades entre fenômenos internos ao processo da empresa, ou seja, qualquer tentativa determinística de eventos levando a outros eventos por implicação ou comprometimento interno de um terceiro elemento, tal qual um fator;

- Quanto à validade externa, este estudo busca identificar possível generalidade de conceitos (ou descobertas) pela utilização lógica da replicação em estudos de casos múltiplos, pela padronização de tema, foco e questões, através da definição de um protocolo de procedimentos, com o qual se pretende ajustar a análise a condições de qualidade que permitam inferências sobre determinado universo de interesse;

- A confiabilidade da pesquisa conta com a utilização do mencionado protocolo, para a determinação do teor das discussões (presenciais ou não), enviado às empresas com antecedência, dando ciência do conteúdo a ser discutido. O protocolo contém 49 pontos de análise, os quais foram largamente discutidos através de roteiro de pesquisa, utilizados por ocasião das visitas e das entrevistas.

A composição do estudo replicável, inclusive de seu protocolo, utilizado nos eventos de pesquisa, junto às empresas, foi realizada segundo estrutura apresentada por YIN (2005:101) e representa o movimento sobre os quadrantes que associam características do projeto com as das fontes de coleta de dados. A figura 10.01 expressa as trajetórias realizadas, relativas a esta relação estrutural, resultantes da

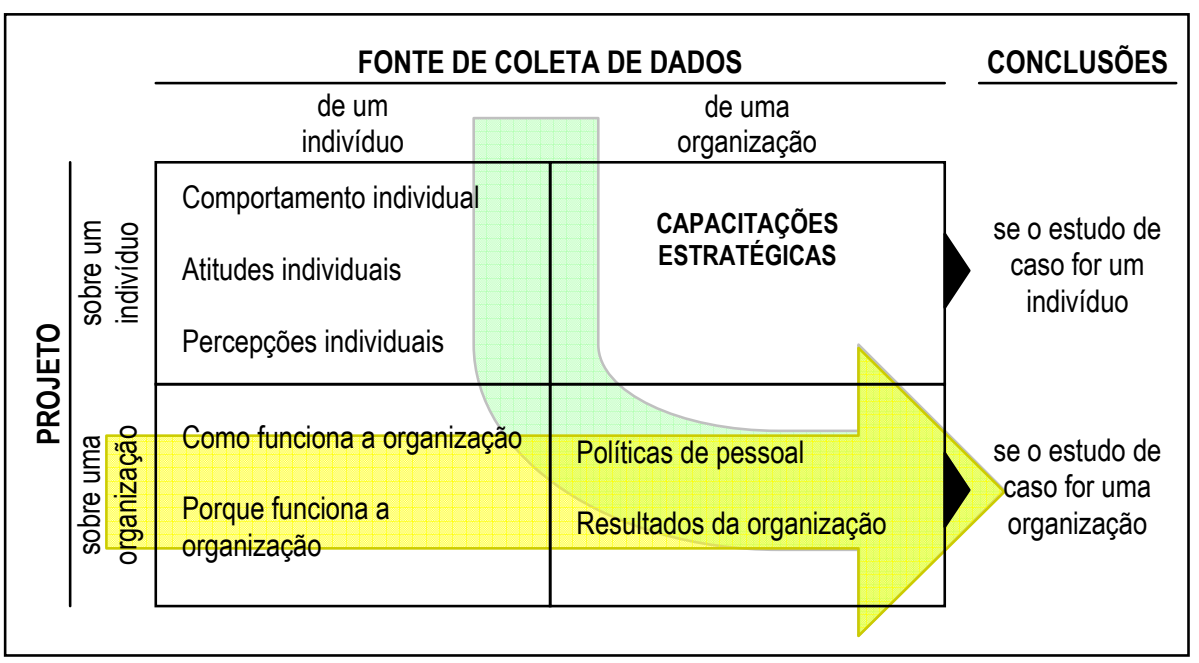

FIG 10.01: A relação estrutural entre o projeto e as fontes de pesquisa. Adaptada de YIN (2005:101) 
disponibilização de fontes de evidências.

A trajetória assinalada em amarelo demonstra ser, este estudo, uma análise sobre organizações que leva a conclusões específicas para estudos de casos focados em organizações. A trajetória em verde, o uso de fonte mista de coleta de dados (originários tanto da estrutura organizacional quanto de indivíduos) para levar às mesmas especificidades de foco nas conclusões do estudo.

Essencialmente, a figura mostra que o projeto desenvolveu-se sobre organizações, utilizando, como fonte de dados, tanto indivíduos, quanto as próprias estruturas organizacionais das empresas.

Dos seis tipos diferentes de tais fontes, denominadas "de evidência" e listados por YIN (2005:111-124), apenas três foram utilizados nesses casos, estabelecendo uma triangulação entre entrevistas pessoais, levantamentos documentais e observações ambientais. A pesquisa direta em registros arquivados, com artefatos físicos e por observação participante não foi realizada. Tais possibilidades, de acesso a arquivos, de acesso a participações que extrapolassem a observação e de acesso a artefatos, não foram abertas, por parte das empresas. Das fontes utilizadas, temos:

- Entrevista: o ponto forte nas análises junto às empresas, tendo, como pessoaschaves, funcionários de cargos executivos de tecnologia, algumas, e de recursos humanos, outras. A cada empresa apresentada adiante, tais cargos ou perfis o serão também, assim como os tempos relativos às entrevistas;

- Documentação: baseada em informações expostas em documentações institucionais e em páginas web (não necessariamente ambas em todos os casos) das empresas, além de material de apresentação (marketing) fornecido por mais de um dos representantes, por ocasião de uma palestra (em uma das visitas) e de uma reunião do gênero (em outra das visitas), apresentadas à época das visitas;

- Observações diretas: apenas de composição, estruturação e disposição dos ambientes de trabalho das unidades visitadas.

\section{2 - PROTOCOLO DE PESQUISA}

O desenvolvimento desta pesquisa contou com algumas etapas, tal como a definição inicial de um protocolo de pesquisa para informar, às organizações, a intenção e o conteúdo do que se esperava discutir em reuniões. Este passo é o primeiro quando se 
considera a aplicação da pesquisa, mas não quando se considere seu contexto. Nesse caso, o que explicita este item já é o segundo passo, realizado paralelamente a outro (seleção de casos), pois a definição de um modelo para estudo já ocorreu em momento anterior, conforme planejamento que a figura 1.04 demonstrou.

O protocolo é uma estrutura operacional (framework) através da qual se pode desenvolver um roteiro de procedimentos que traduza, de forma específica, um padrão de análise em movimento, replicável em mais de um caso. A padronização visa garantir tipificação e especificação das informações que se deseja colher, para a devida ação comparativa. O protocolo é expresso em segmentos, denominados blocos, decorrentes da necessidade de explorar todas as dimensões do modelo em estudo.

O primeiro dos blocos foi dedicado à identificação das empresas pesquisadas. Os demais, ao foco sobre conhecimento e ensinagem, cujas dimensões, demonstradas pela figura 10.02 (que as posicionadas sobre o modelo em experimentação), demandam informações sobre: culturas; conhecimentos e seus compartilhamentos; organizações ambientais para a ensinagem; os processos em si; contribuições para as produções inerentes ao negócio das empresas; contribuições para os repositórios; contribuições para os corpos funcionais; e organizações de eventos de ensino e difusão.

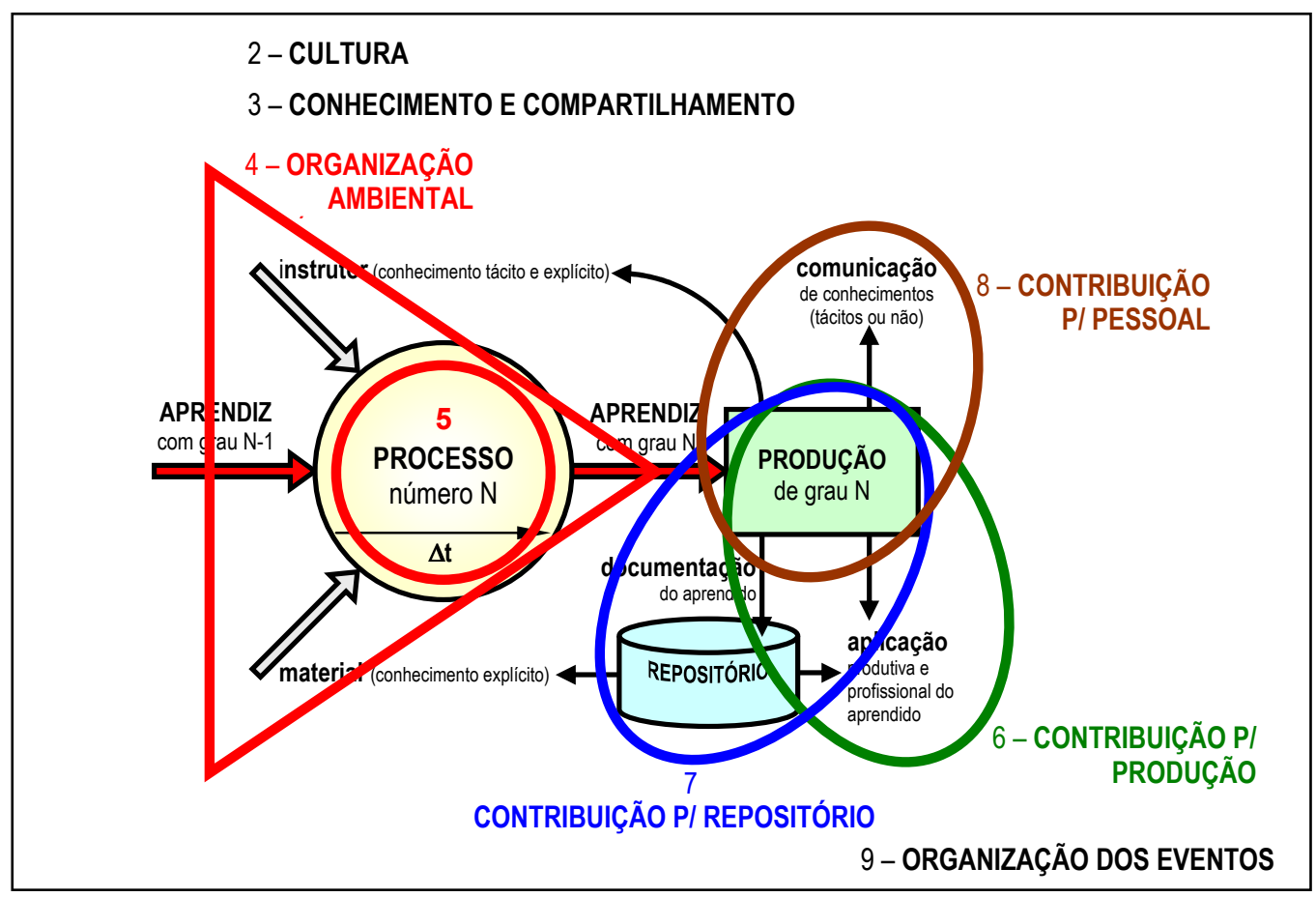

FIG 10.02: Os tópicos do protocolo posicionados sobre o modelo conceitual preliminar.

As dimensões consideradas são demonstradas pela tabela 10.01: 


\begin{tabular}{|l|l|l|}
\hline BLOCo & O QUE DETECTAR & BASE TEÓRICA \\
\hline $\begin{array}{l}\text { Identificação da } \\
\text { organização }\end{array}$ & $\begin{array}{l}\text { Concepção organizacional da } \\
\text { empresa }\end{array}$ & Nenhuma em especial \\
\begin{tabular}{|l|l|} 
1. identificação da empresa; \\
2. identificação do contato primário (pessoa(s)-chave(s)); \\
3. missão da empresa; \\
4. principal atividade de negócio; \\
5. atividades secundárias de negócio; \\
6. organograma (destaque para a área que envolva o processo de ensino).
\end{tabular} \\
\hline
\end{tabular}

2 Cultura da organização

Concepção cultural da
empresa, relativa ao
conhecimento

\begin{tabular}{|l|} 
BASILI et al. (2001) \\
DAVENPORT (1996) \\
TOGNERI et al. (2003)
\end{tabular}

7. filosofia relativa ao conhecimento e seu compartilhamento;

8. consideração da reflexão sobre lições aprendidas como filosofia de trabalho (sucessos e fracasso);

9. processos externos de aprendizagem e experiência.

3 Conhecimento e compartilhamento

\begin{tabular}{|l|l|}
\hline $\begin{array}{l}\text { Grau de estruturação do } \\
\text { conhecimento e da organização } \\
\text { para o conhecimento }\end{array}$ & BUKOWITZ e WILLIAMS (2002) \\
& DAVENPORT (1996) \\
MARQUES FILHO (2002) \\
MORON (1998) \\
TAVARES (2004)
\end{tabular}

10. identificação do conhecimento relativo ao seu core business;

11. identificação dos agentes:

- gestor do conhecimento;

- coordenador do conhecimento;

- guardião do conhecimento;

12. relação entre aprendizado e mensuração de desempenho;

13. mapeamento das tendências (pessoais e coletivas) de compartilhamento;

14. análise do nível de retorno de investimento no tema.

\begin{tabular}{|l|l|l|}
\hline $\begin{array}{l}\text { Organização } \\
\text { ambiental para a } \\
\text { ensinagem }\end{array}$ & $\begin{array}{l}\text { Aculturamento ambiental para } \\
\text { o exercício da ensinagem }\end{array}$ & $\begin{array}{l}\text { CARDOZA (2004) } \\
\text { DAVENPORT (1996) } \\
\text { HOUDEK et al. (1998) } \\
\text { MORON (1998) }\end{array}$ \\
\hline
\end{tabular}

15. análise de elementos de aprendizagem (inovações, sucessos e fracassos);

16. abrangência de estilos de aprendizagem;

17. planejamento do espaço próprio de ensinagem;

18. planejamento do espaço de trabalho, voltado à promoção da dinâmica de disseminação do conhecimento pelo ensino;

19. identificação das áreas de transferência de conhecimentos;

20. freqüência da avaliação do capital intelectual;

21. motivadores da decisão de disseminação do conhecimento pelo processo de ensinagem;

22. composição dos elementos do conhecimento, formando uma escada do aprendizado.

5 Processo de $\quad$ Estruturação de um processo ensinagem da ensinagem

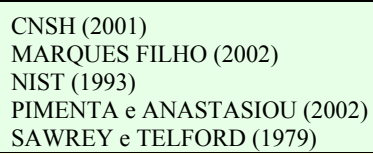

23. definição do processo;

24. identificação de seu posicionamento, na escada do aprendizado;

25. definição de instrutor - contratação interna ou externa;

26. definição de material - uso (ou reuso) de conhecimento em repositório, na atividade específica;

27. facilitação dos processos de busca de conhecimentos no repositório.

\begin{tabular}{|c|c|c|}
\hline $\begin{array}{l}6 \text { Contribuição ao } \\
\text { ambiente } \\
\text { produtivo }\end{array}$ & $\begin{array}{l}\text { Uso do produto da ensinagem, } \\
\text { na produção }\end{array}$ & $\begin{array}{l}\text { BUKOWITZ e WILLIAMS (2002) } \\
\text { CHATTERJEE (2002) } \\
\text { FABRI et al. (2004) } \\
\text { MARQUES FILHO (2002) } \\
\text { SMALL e TATALIAS }(2000)\end{array}$ \\
\hline
\end{tabular}

28. identificação, por parte dos agentes especialistas de conhecimentos especificos necessários a cada situação ou projeto;

29. prática (consciente e sob controle organizacional) de reuso constante de conhecimentos;

30. facilitação dos processos de busca de conhecimentos no repositório;

31. constância de ajustes dos instrumentos de busca e agregação de conhecimentos, junto ao repositório;

32. processos integrados, apropriados, que tornem natural o ato da contribuição com conhecimentos gerados na produção. 
7 Contribuição ao repositório do conhecimento

\section{Agregação de conhecimentos explícitos ao repositório}

BASILI et al. (2001)

FABRI et al. (2004)

FINNERAN (1999)

33. filosofia de difusão de lições aprendidas;

34. ferramental (verificar se próprio) de documentação de informações, experiências e conhecimentos;

35. fornecimento de artefatos (artigos técnico-científicos, resumos, resenhas, comentários, etc.)

36. cálculos de freqüência com que se contribuí com o repositório.

8 Contribuição ao ambiente do conhecimento

\section{Agregação interpessoal de} conhecimentos tácitos

\section{CHATTERJEE (2002) \\ LEI et al. (2001) SNOWDEN (2003) TAVARES (2004)}

37. filosofia de difusão de lições aprendidas;

38. estudos sobre melhores práticas de difusão;

39. discussões sobre experiências (erros e acertos) e melhorias;

40. mecanismos de estímulo à prática da reflexão conjunta;

41. eventos de interação que promovam transmissão do tácito.

9 Organização de eventos de Realização de processos e seus resultados ensinagem SNOWDEN (2003) TOGNERI et al. (2003)

42. freqüência de realização de processos de ensino (cursos, treinamentos, etc.); 43. quantificações relativas:

- de horas/ano investidas em processos de ensinagem;

- de horas/ano por funcionário;

- de tempo dedicado, pelas pessoas, a estudos e coleta de material;

44. nível de retorno do investimento em ensinagem;

45. correlações entre lições aprendidas e as experiências de trabalho (na ensinagem, lições que extrapolem o conteúdo "didático");

46. organização de grupos para as práticas de reflexão sobre experiências e lições aprendidas;

47. planejamento da interagência de diferentes formas de conhecimento para a criação de valor de aprendizagem;

48. mapeamento dos fluxos de conhecimento;

49. incentivos ao comprometimento com o compartilhamento de conhecimentos.

\section{TAB 10.01: A composição do PROTOCOLO de pesquisa}

A identificação dos agentes de que trata o ponto de análise de número 11 considerou o que definem BUKOWITZ e WILLIAMS (2002:73-84), à respeito das responsabilidades inerentes aos papéis dos agentes gestor, coordenador e guardião do conhecimento, tratado no capítulo 5 (figura 5.10). A formação da escada do aprendizado de que trata o ponto de análise 22 considerou o que define CARDOZA (2004:3), à respeito da modularização do conhecimento em elementos interagentes, de aprendizagem cumulativa, para a formação de um conhecimento maior, e aplicada no capítulo 8 (figuras 8.11 e 8.12 ).

O protocolo não foi estruturado na forma de perguntas, mas, sim, de pontos abertos de análise. Isso para fornecer, à empresa, liberdade para discutir os pontos, sem amarrem-se, as pessoas-chave, a perguntas fechadas. YIN (2005:98-101) salienta que as perguntas devem ser produzidas para o pesquisador, não para a organização em estudo. Podem ser repassadas ou não ao entrevistado-chave. Como houve, por parte de empresas consultadas, preocupação quanto ao teor da informação a divulgar, esta 
estratégia foi a escolhida para permitir-lhes a escolha sobre tais conteúdos.

\section{3 - ESCOLHA DOS CASOS}

Definir parâmetros que ajustem os critérios de escolha das empresas a serem estudadas atende ao terceiro dos componentes expostos por YIN (2005:42-46), tidos como importantes a um projeto de pesquisa: a definição das unidades de análise.

O principal fator de escolha das empresas partícipes foi a necessidade de visualização de proximidade e familiaridade com o uso intensivo do conhecimento (e consciência de seu uso) como recurso estratético e competitivo, bem como de tendências à valorização de meios que estabeleçam processos de ensino e treinamento. Alguns critérios de seleção foram necessários:

- Serem todas de uma mesma indústria, a do software, e terem estrutura e conceito de fábrica definindo seus esforços de produção;

- Serem todas atuantes como fornecedoras de tecnologia da informação;

- Serem todas conscientes da necessidade de qualidade na produção de software e, em decorrência disto, apresentarem preocupações com certificações que exijam, de alguma forma, níveis de organização, difusão e preservação do conhecimento, entre outras formas, através de iniciativas de ensino corporativo;

- Haver uma certa dispersão entre níveis de amadurecimento (certificações, se possível) que possam oferecer parâmetros diferenciados de comparação ante as alternativas possiveis e perceptíveis da gestão do conhecimento e da adoção de estratégias de ensino do mesmo como forma de garantir a produção;

Com base na maior ou menor satisfação de tais critérios, mas garantindo atendimento de todos, foram selecionadas 4 empresas, cada qual representando um caso, para a composição do estudo:

- EMPRESA "A": Fábrica de software nacional, produtora de tecnologias da informação, direcionada ao fornecimento de soluções integradas de TI, com a missão bem orientada ao provimento de integração gerencial pela inovação tecnológica;

- EMPRESA "B": Fábrica de software nacional, produtora de soluções em sistemas e tecnologias da informação, com missão focada em desenvolvimento de software e novas tecnologias, consultoria, suporte técnico e alocação de recursos humanos especializados em SI e TI; 
- EMPRESA “C": Fábrica de software nacional, produtora de soluções competitivas em tecnologias da informação para seus clientes, com missão focada em desenvolvimento de software e novas tecnologias, consultoria e serviços, promovendo satisfação, a clientes, parceiros, funcionários e sócios, pela melhoria contínua dos processos e da gestão;

- EMPRESA "D": Fábrica de software multinacional, produtora de sistemas e tecnologias da informação, direcionada ao fornecimento globalizado de soluções de SI e TI, com a missão bem orientada à melhoria e crescimento das capacidades de negócios de seus clientes;

A não identificação das empresas é uma questão de respeito ao anonimato e ao sigilo com o qual o autor desta tese comprometeu-se. Mesmo havendo caso de empresa que tenha liberado a apresentação de seu nome, resolveu-se por não externar nenhum deles, para que se mantenha a unidade da informação.

\section{4 - RELATÓRIO DOS CASOS}

Os relatos de informações colhidas nas pesquisas realizadas junto às empresas serão descritos, a seguir, divididos em tópicos relativos às dimensões componentes do protocolo apresentado e, não, caso a caso. Neste ponto (e dele até o próximo capítulo deste trabalho), começam a ser trabalhados os quarto e quinto componentes expostos por YIN (2005:47-49) e tidos como importantes a um projeto de pesquisa: a definição das unidades de análise.

Neste capítulo, apenas as descrições e narrativas, organizadas tópico a tópico, empresa a empresa, serão expostas. Comentários e comparações de cada item, com seus sub-itens, com maior ou menor detalhe e aprofundamento, dependendo do grau de influência deles para o modelo conceitual sob investigação, serão desenvolvidos no decorrer do próximo capítulo.

As classificações das empresas, como fábricas "de programas”, “de projetos físicos", "de projetos de software" ou "ampliada de projetos" será sempre em conformidade ao que postulam FERNANDES e TEIXEIRA (2004:118).

Os número apresentados são todos arredondados pelas próprias empresas. 


\subsection{1 - IDENTIFICAÇÃO DAS ORGANIZAÇÕES}

\subsubsection{1 - EMPRESA “A"}

Empresa nacional com área restrita de atuação e foco bem definido na produção de software (com uma linha específica), possui projeção em diversos estados brasileiros e, como portfolio, 30 funcionários e uma clientela na casa das centenas de empresas. Classifica-se como uma "fábrica de projetos de software".

Nesta empresa, duas pessoas participaram da entrevista, a qual teve duração de cerca de quatro horas. Foram elas: um executivo de prospecção (de clientes) e uma executiva de produção. $\mathrm{O}$ executivo é co-proprietário da empresa.

Sua unidade de desenvolvimento de aplicações funciona com a filosofia de fábricas de software dedicada ao desenvolvimento de sistemas computacionais focados em uma solução integrada (ERP), sendo detentora de certificação NBR ISO 9001:2000 à época da pesquisa.

Sua organização conta com um front-end totalmente focado no cliente, responsável pela promoção de vendas de soluções denominadas satélites (nome dado pela própria empresa às soluções dos clientes), personalizadas, sobre o produto ERP. Este front-end é composto de: prospecção de clientes, encarregado das percepções de mercado, segundo os interesses da organização cliente, com base em um mapa de negócios (domínios e competências); relacionamento direto com clientes, encarregado da manutenção das contas e da avaliação de mercado, no que diz respeito à perceptividade e aceitabilidade de produto; e gestão externa de produtos, encarregado de conferir o grau de atendimento das necessidades dos clientes e promover as garantias necessárias, referentes ao mesmo.

Complementa-se a organização com um back-end focado em produto, produção e suporte, responsável pela promoção da estrutura de fábrica e sua manutenção, composto de: gestão interna de produção, encarregado de garantir que a produção funcione adequadamente, tanto no versionamento evolutivo do núcleo do produto ERP quanto na manufatura de satélites negociados, garantindo a conformidade produtiva, segundo especificações ISO; padronização de soluções, encarregado de orientar a produção pela definição de métodos, validar o produto e criar documentação, técnica e de usuários (os métodos citados referem-se aos produtivos e os da qualidade), dentro de parâmetros criteriosos; e atendimento e treinamento de clientes, encarregado do 
atendimento direto a clientes, com solução de dúvidas ou percepção de alterações/correções necessárias e treinamentos em uso do produto.

A interface desta frente de negócio com o interior produtivo da organização é categorizada por três segmentos filtrantes, definidores dos tipos de ações a serem executadas, concomitantemente ou não, para que os serviços sejam concretizados em soluções. O primeiro destes segmentos é o de sistema, voltado às questões de atendimento direto dos requisitos (arquitetura) de clientes, análise de adequação de soluções às suas necessidades de negócio em todos os níveis (estratégico, tático e operacional), ao planejamento produtivo, à pesquisa (P\&D) e à manufatura do produto (núcleo ou satélite contratado). O segundo, é o de produto, voltado à validação do produto (cumprimento do requisitado) e a sua documentação, além da determinação dos padrões de qualidade e de produção exigíveis para o negócio. O terceiro, é o de suporte, voltado ao atendimento informativo e corretivo de clientes, bem como de seus treinamentos, necessários a suas preparações para uso do produto. Produto e suporte recebem influência direta dos resultados da $\mathrm{P} \& \mathrm{D}$, praticada pelo segmento de sistema. A figura 10.03 demonstra esta organização.

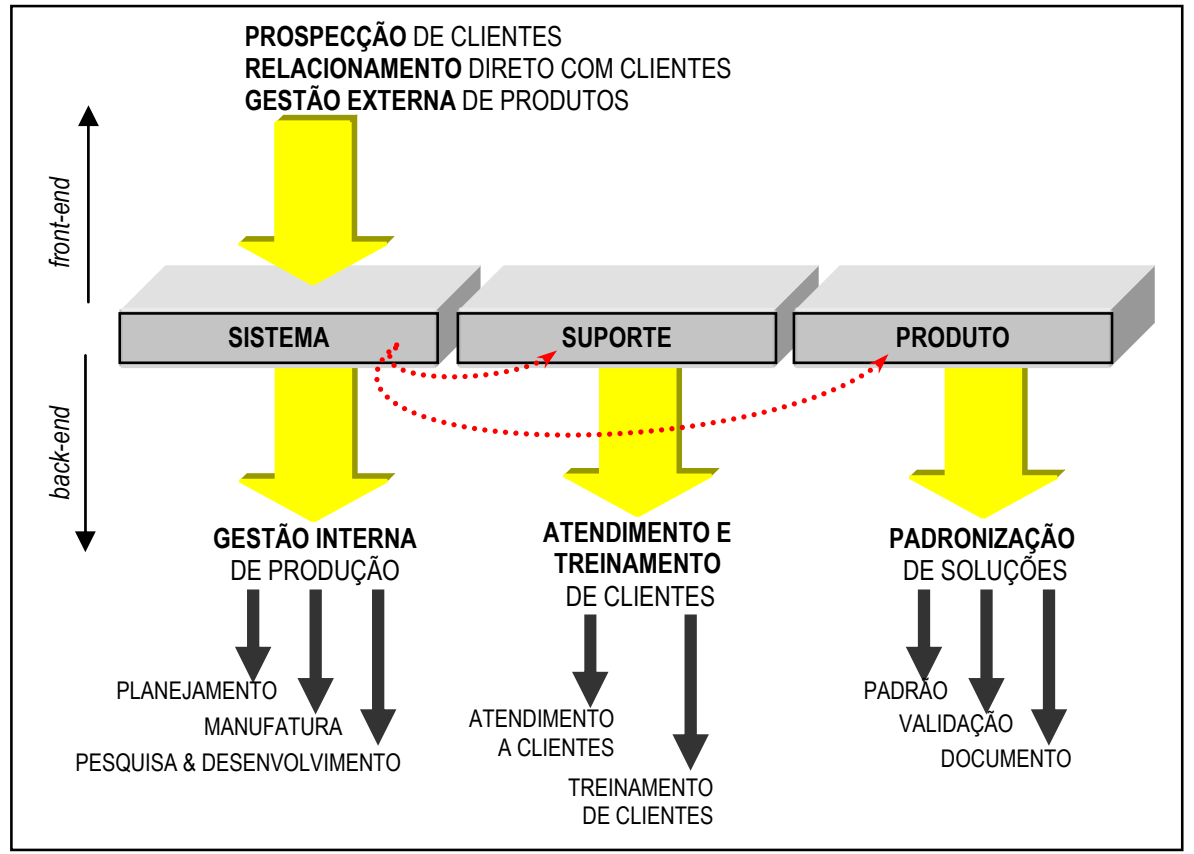

FIG 10.03 - A organização da empresa "A".

\subsubsection{2 - EMPRESA "B"}

Empresa nacional com projeção em diversos estados brasileiros, voltada ao desenvolvimento de aplicações sob a filosofia de fábrica de software qualificável de "fábrica de projetos de software" (unidade visitada) a "fábrica de projetos físico". 
Dedica-se ao desenvolvimento de sistemas computacionais focados (trabalham com segmentos bem definidos de mercado).

Possui um portfolio de dezenas de clientes de grande e médio portes, de pontos diversos do território nacional, e 600 funcionários em três unidades próprias e algumas unidades instaladas junto a clientes, com uma nova unidade em fase de criação, à época do estudo, e planos de constituir um quadro de 200 funcionários, a serem somados ao corpo da organização até o término de 2006. Certificada CMMI nível 2, com auditoria para certificação em nível 3 já agendada, à época da pesquisa.

Nesta empresa, duas pessoas participaram das entrevistas que, juntas, somaram duração aproximada de cinco horas. Foram elas: a gerente da divisão de tecnologias e o coordenador de SLM (Service Level Management).

A organização possui uma estrutura organizacional que mantém, sob a diretoria de negócios, diversos grupos de trabalho, dos quais se destacam (segundo o interesse deste estudo): produto e tecnologia.

A divisão de produto encarrega-se de analisar e parametrizar as soluções comercializadas, definindo viabilidades e especificidades necessárias à sua produção. Ecarrega-se, também, de analisar mercados e tendências em relação a produtos (utilizase de resultados de prospecção realizada pela divisão comercial), a fim de determinar estratégias (ou administrar as já implantadas) de rastreamentos de aceitabilidades e replicabilidades de produtos, fomentando a escalabilidade comercial e produtiva.

A divisão de tecnologia encarrega-se de providenciar condições para a produtividade e o atendimento das contratações e das tendências percebidas de mercado, pesquisando novos paradigmas em tecnologias, ferramentas e comunicabilidade, providenciando cursos e treinamentos, estruturando e mantendo a fabricação do software e garantindo-lhe padrões de qualidade. O foco da pesquisa centrou-se mais sobre esta divisão, que possui assistência direta do grupo de melhoria contínua (que agrega a gerência do conhecimento) e estruturação com um nível de gerenciaa de projetos suportado por vários grupos de trabalho: consultoria, projeto, fábrica, qualidade, administração de rede e cursos técnicos.

A consultoria encarrega-se da pesquisa necessária em tecnologias e ferramentas, para o desenvolvimento de novas soluções e novas arquiteturas e atua nas discussões sobre melhoria contínua e domínio sobre o conhecimento. O grupo de projetos 
incumbe-se da arte necessária ao desenvolvimento de interfaces para os produtos a construir, além da responsabilidade para com toda a estrutura de comunicação, via TI, da empresa (interfaceamento homem-máquina, como função específica de projeto na divisão de tecnologia; na divisão de produto há, também, projeto, aí voltado para desenho técnico e especificações detalhadas de produtos. Como fábrica, a empresa denomina a produção de código com seu detalhamento, ou seja, a implementação propriamente dita, envolvendo codificação e testes unitários. O grupo de qualidade encarrega-se de definir métodos e critérios para medir e garantir a qualidade do produto, analisando especificidades e conformidades entre requisitos e componentes produzidos. O grupo de teste define a tecnologia necessária e planeja a prática deste tipo de atividade, para experimentar o que se produz em matéria de componentes, definindo planos e baterias, além de aplica-los nas integrações e no produto final. O grupo administrador da rede incumbe-se em disponibilizar toda a tecnologia necessária aos outros grupos, tornando funcional o complexo tecnológico: equipamentos, sistemas operacionais, estruturas de comunicação, redes físicas, aplicativos e artefatos diversos. O grupo de cursos técnicos encarrega-se de gerir talentos e carreiras, fomentando oportunidades de disseminação de conhecimento através de eventos como cursos, treinamentos e workshops, entre outros. É nesse grupo que a pesquisa concentra o foco, pois envolve, diretamente, os exercícios de ensinagem e preservação de conhecimento. A figura 10.04 representa a estrutura da organização.

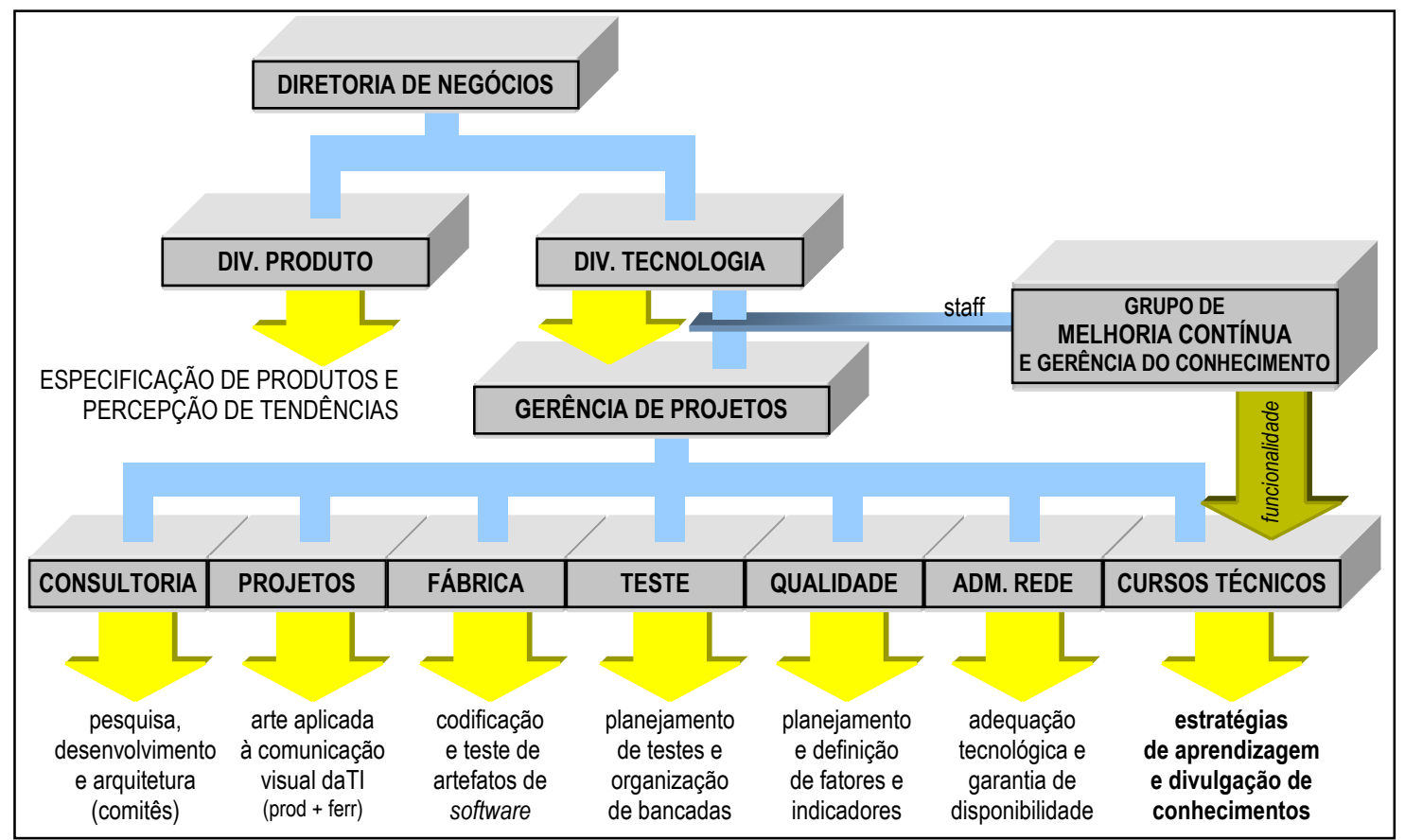

FIG 10.04 - A organização da empresa "B". 
O grupo de melhoria contínua tem um envolvimento nítido, de alto grau de comprometimento, com as questões relativas ao conhecimento e tem, por conta disso, uma ascendência processual direta ante o grupo de cursos técnicos.

O que a figura 10.04 procura mostrar é mais que uma estrutura organizacional hierárquica (em azul), é importante a percepção da relação funcional (processo - em amarelo) da divisão de tecnologia, a qual conta com: no nível da gerência de projetos, decisões quanto à organização de projetos contratados, alocação de recursos e definição de papéis profissionais para cada um deles; e, no nível da execução de produtos, etapas e serviços de implementação pela aplicação dos recursos e alocação de profissionais.

\subsubsection{3 - EMPRESA “C"}

Empresa nacional com 5 unidades, cada qual em um estado brasileiro, e clientes em todo território nacional. Possui um portfolio de dezenas de clientes de grande porte (tem, como estratégia de negócio, foco em grandes corporações) e cerca de 1500 funcionários. Trabalha focada em domínio de conhecimentos, centrada em projetos e com produção estruturada em células.

Nesta empresa, uma pessoa, gerente de qualidade de software, participou de entrevista indireta (dados colhidos de outro pesquisador), a qual teve duração aproximada de quatro horas. Esta mesma pessoa e uma outra, a diretora de recursos e serviços, participaram de tres entrevistas via telefone (uma com a diretora e duas com a gerente), a quais somaram um periodo de tempo aproximado ao declarado como direto.

A pesquisa deu-se na unidade matriz, detentora de certificação CMMI nível 3, à época do desenvolvimento. Esta unidade conta com 100 a 300 funcionários, conforme a época. Esse número varia constantemente, de acordo com a necessidade de reorganização anteriormente mencionada. À época das entrevistas, considerado período de produção mais distribuída, havia pouco mais de 100 profissionais, em sua maioria, dedicados a projetos e prospecções.

As unidades instaladas da empresa podem trabalhar com filosofias que vão desde "fábrica de projetos de software" até "fábricas de programas". A empresa possui uma capacidade significativa e interessante de reorganização, montando ou desmontando células de produção e reposicionando pessoal, conforme as demandas, o que lhes permite trabalhar de formas diferentes para diferentes clientes ou, ainda, mudar suas relações de pessoal por tecnologia ou por solução, conforme oportunidade, 
reorganizando, inclusive, disposições físicas de pessoas. Esta característica está totalmente alicerçada, segundo a entrevistada, em conhecimento, tanto os que definem domínio do negócio quanto os que permitem domínio sobre o ambiente do negócio.

A organização dos serviços de TI possui um nível de contratação focado no cliente, cujas funções envolvem a prospecção de mercado, consolidação e aceitação de demandas (novos produtos ou alterações solicitadas) classificáveis nos domínios de conhecimento, nos quais a empresa atua.

No nível de operação, a empresa conta com uma organização logicamente segmentada em consultoria, gestão, desenvolvimento e integração. A consultoria encarrega-se de prover governança, alinhamento e gestão de TI necessários à estruturação de clientes, além de cuidar dos projetos de arquitetura. A gestão encarregase de garantir o grau de atendimento de necessidades dos clientes e a produtividade da empresa, gerindo o sistema e a infra-estrutura e estabelecendo o conceito de escritório de projetos, para configurar a solução software a ser desenvolvida. O desenvolvimento encarrega-se da produção em si (produtos e componentes) e do gerenciamento de customizações que produto e processo exijam. O segmento da Integração encarrega-se dos relacionamentos de terceirização, para atender casos em que clientes estejam contratando serviços e não produtos, fornecendo, além do serviço contratado, projeto de infra-estrutura necessário ao cliente. A figura 10.05 demonstra esta composição.

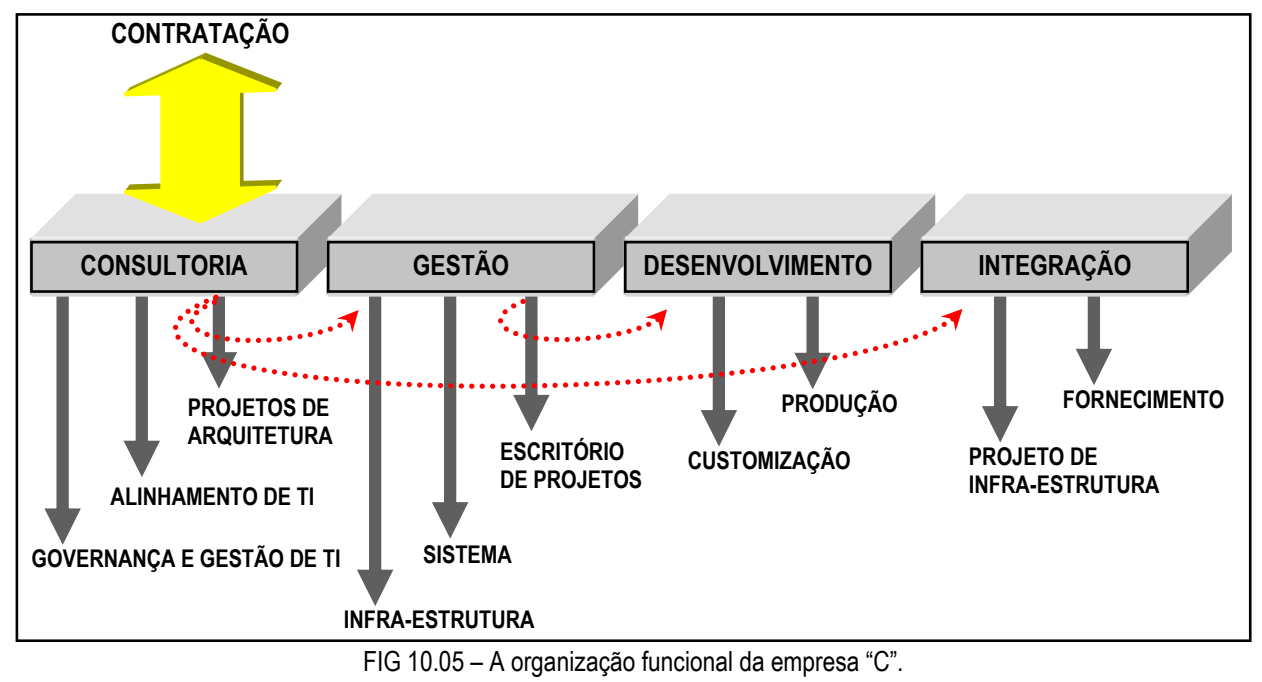

Fisicamente, a organização é composta por níveis de hierarquização que se integram para explorar a estrutura funcional mostrada na figura 10.05. O organograma resultante desta composição possui várias diretorias e gerências, das quais, apenas algumas interessaram a esta pesquisa: diretorias de Operações, de Marketing e de 
Conhecimentos e Inovações e algumas de suas gerências. Além delas, um grupo em especial é representado, por seu envolvimento com as questões do conhecimento, sua preservação e ensinagem necessária, identificado como grupo de melhoria contínua. A diretoria de Operações apresenta outras diretorias sob seu encargo, entre elas, a de Recursos e Serviços. A figura 10.06 demonstra.

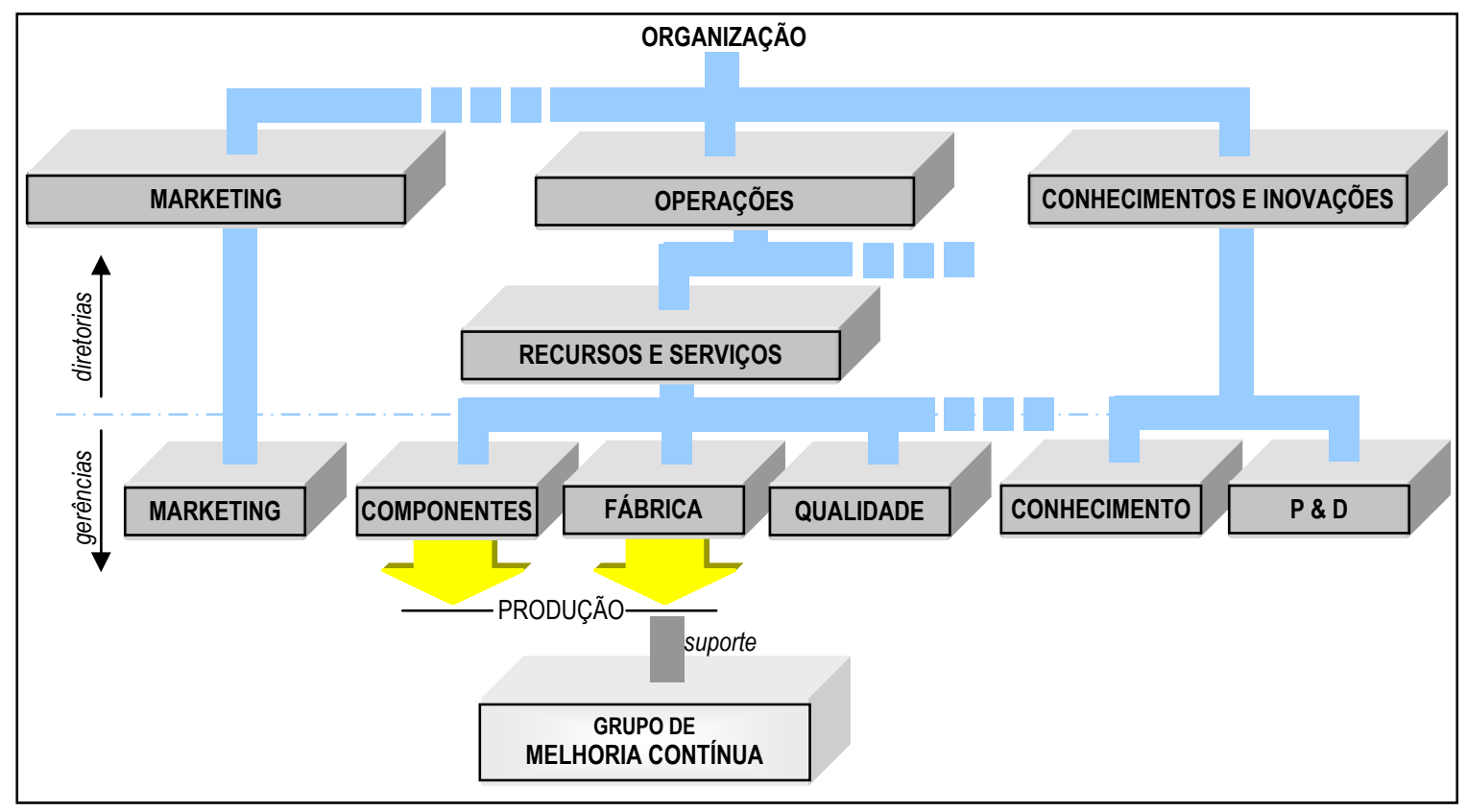

FIG 10.06 - A organização administrativa da empresa "C".

Sob a égide da diretoria de Recursos e Serviços (e esta, sob a de Operações), as gerências denominadas Fábrica e Componentes representam unidades de produção, uma de partes de composição e outra de composição de produto, estruturadas como células, que se encarregam da codificação e testes e montagem do produto software. Estas gerências possuem capacidade para atender requisitos de clientes, que podem ser tanto externos quanto internos, pois a empresa trabalha com conceito de desenvolvimento distribuído, onde uma unidade pode ser contratada por outra, para realizar partes de projetos. A gerência da Qualidade encarrega-se de garantir que processo e produto realizem seus papéis com eficiência, para afiançar a eficácia da organização como produtora de software. Outras gerências pertencem à estrutura de Operações, mas não foram incluídas nesse estudo. Além da gerência de Qualidade, aqui destacada e identificada como sendo de software, há um grupo de qualidade atendendo à gerência de Conhecimento, encarregada da qualidade corporativa, definindo normas e modelos para a empresa como um todo.

A diretoria de Conhecimentos e Inovações traz, sob sua tutela, duas gerências: a 
de Conhecimentos, encarregada de definir o ativo do conhecimento e estabelecer sua importância como recurso crucial para a capacidade produtiva da empresa; e a de Pesquisa e Desenvolvimento (P\&D), encarregada da busca por métodos, tecnologias e padrões outros que possam representar novos paradigmas de produtividade e qualidade.

A gerência de Marketing, sob a diretoria de mesmo nome, também participa deste conjunto pelo papel de disseminadora de casos de sucesso e de boas práticas que realiza, caracterizando-se como colaboradora para o aprendizado e a preservação de conhecimentos, criando consciência corporativa e estimulando envolvimento dos profissionais com a organização.

Apoiando a gerência de Fábrica, no que tange a questões de conhecimento, sua preservação e a capacidade corporativa de gerá-los e às competências que deles advêm, está um grupo, denominado "Grupo de Melhoria Contínua”. Este grupo é formado por membros da produção, por gerentes de fábricas, pelos próprios diretores de Operações e de Recursos e Serviços, contando com apoio de gerentes de Conhecimento e de Qualidade, além de lideres de equipe. A esse grupo compete, deliberar sobre estratégias, táticas, operações e tecnologias relacionadas ao exercício da gestão do conhecimento relativo à fabricação, além de apoiar a produção.

\subsubsection{4 - EMPRESA “D”}

Multinacional com área diversificada de atuação, possui unidades de desenvolvimento atuantes sob filosofia de fábricas de software, contando com subsidiárias configuradas desde "fábricas de programas" até "fábricas ampliadas de projetos" (espectro completo de classificações).

Presente em cerca de 60 países, atua nos 5 continentes e possui dezenas de milhares de clientes e mais de 30.000 funcionários dedicados, exclusivamente, ao desenvolvimento de sistemas computacionais. No Brasil, conta com três unidades, cada uma em um estado diferente da União, uma conta com mais de 500 funcionários (alvo deste estudo), sendo detentora de certificação CMMI nível 5, à época da pesquisa.

Nesta empresa, uma pessoa, o executivo de tecnologias para a América Latina, concedeu entrevista por um dia completo, totalizando aproximadamente oito horas.

A organização dos serviços de TI possui um front-end totalmente focado no mercado, formado por quatro segmentos relativos às relações com clientes, cujas 
definições são diretamente relacionadas aos perfis dos executivos que deles participam, responsáveis pela promoção global de vendas de soluções, pelas garantia de entrega de serviços e todas as garantias que delas decorrem e, ainda, pela gestão da carteira de clientes e projetos. Os segmentos são: o de prospecção de clientes, encarregado das percepções de mercado e das vendas; o de desenvolvimento de soluções aos clientes, encarregado de arquitetar modelos sistêmicos e/ou tecnológicos que atendam às suas necessidades, determinando escopos e fronteiras de domínio de aplicação; o de gestão de entregas de produtos, encarregado de conferir o grau de atendimento das necessidades dos clientes, garantir que a organização funcione adequadamente para a produção do produto negociado e promover garantias; e o de relacionamento direto com clientes, encarregado da manutenção das contas.

Deste corpo de executivos, os de prospecção, relacionamento e desenvolvimento formam os grupos estratégicos de oferta de soluções aos clientes e os de gestão formam grupos organizados por domínio de conhecimento, localização geográfica ou administração de contas, estabelecendo e administrando os relacionamentos do frontend com as unidades de modelagem de negócios e, destas, com as de desenvolvimento.

A interface desta frente de negócio com o interior produtivo da organização é composta por quatro segmentos filtrantes, definidores dos tipos de ações a serem executadas, concomitantemente ou não, para que os serviços sejam concretizados em soluções. O primeiro deles é o de consultoria, voltado às questões de atendimento direto dos clientes e análise de soluções às suas necessidades de negócio em todos os níveis (estratégico, tático e operacional); outro dos segmentos é o de infra-estrutura, voltado à análise de soluções de suporte necessárias aos clientes, como configurações de redes, de servidores e de equipamentos de comunicação, entre outros, essenciais à implantação do sistema computacional em desenvolvimento; o terceiro é o de aplicação (no qual centrou-se o estudo de caso), voltado às definições produtivas da organização, imprescindíveis ao desenvolvimento e manutenção de produtos, além da modernização de plataformas. O último dos segmentos é o de terceirização de processos, voltado a atender clientes com o fornecimento de serviços que não sejam de seus core-business e para os quais eles não desejem desenvolver aplicações, apenas contratar serviços.

Em todos estes segmentos, percebe-se, nitidamente, filosofia alicerçada nos princípios de melhoria contínua, tanto do conhecimento necessário à efetividade mercadológica da organização e à sua produtividade, quanto da modernização de 
métodos e técnicas, seja para aplicação adequada da engenharia de software, seja pela evolução de plataformas internas de trabalho, seja pelo princípio da atualização de aplicações externas, decorrente de sua visão sobre a necessidade, de seus clientes, de migrar suas plataformas de aplicação, orientando e conduzindo-os de modelos engessados e proprietários, de insuficiente conectividade entre aplicações, para modelos ágeis, baseados em preceitos mais modernos e abertos de tecnologia.

O corpo produtivo, denominado back-office, possui uma estruturação bidimensional: em uma dimensão estão as divisões de regionalização e, em outra, as unidades de suporte de negócios, com seus níveis de extensibilidade de ação (fábricas de níveis de atuação). No que diz respeito às regionalizações, a organização é composta de grandes divisões continentais. A das Américas, possui uma subdivisão da América Latina na qual, por sua vez, há uma regionalização dedicada ao Brasil. Quanto à extensibilidade, as unidades de desenvolvimento de aplicações organizam-se por competência regionalizada e/ou por capacitação técnica-tecnológica. A figura 10.07 expressa a organização descrita.

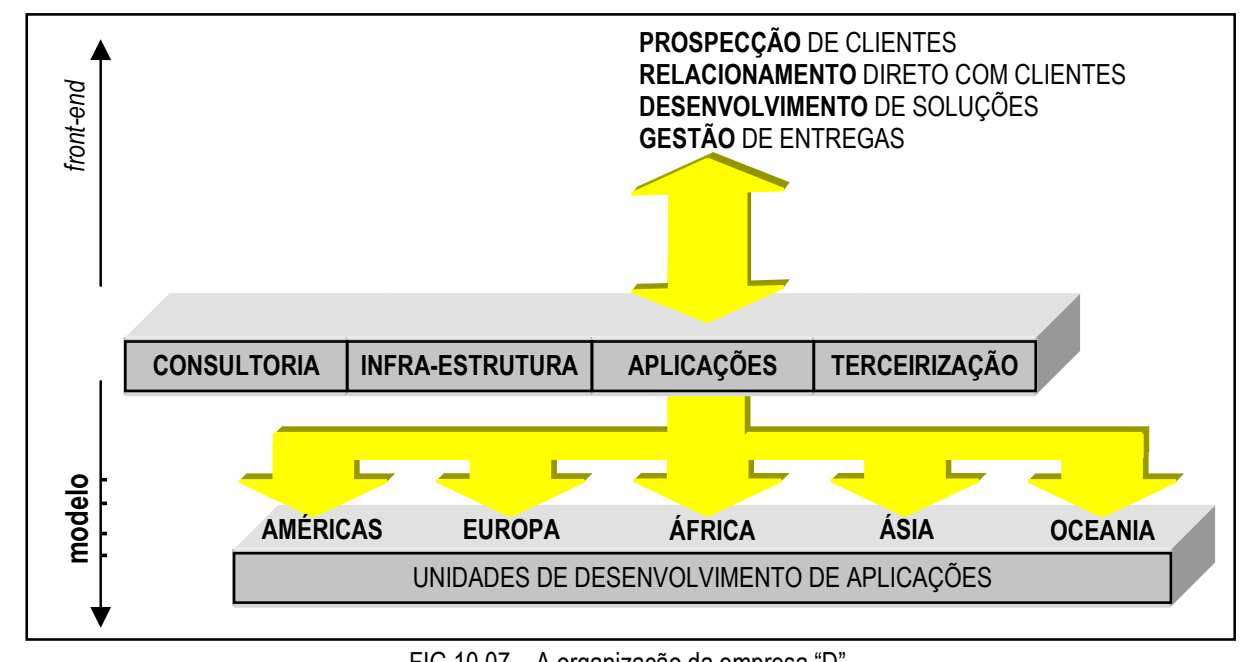

FIG 10.07 - A organização da empresa "D".

\subsection{2 - CULTURA DAS ORGANIZAÇÕES}

Neste tópico, a condução das entrevistas procurou discutir os pontos sob dois aspectos: a cultura institucionalizada e o que as pessoas entendem sobre as questões relativas ao conhecimento e sua influência. Importante salientar que cultura, aqui, é tomada como termo representativo do desenvolvimento de grupos profissionais, relativo ao contexto da produção de software, e, não, como todo o complexo dos padrões de comportamentos, crenças e valores institucionais coletivos. 


\subsubsection{1 - EMPRESA “A”}

A concepção cultural relativa ao conhecimento, apresentada pela empresa "A" é essencial à uma estrutura de produção focada em produto único e que, com um quadro relativamente pequeno, mantém um negócio que atende centenas de clientes, com base em gestão avançada de projetos, em prospecção mercadológica por domínios de negócios (mapas de negócios), e em conceito institucionalizado de padronização de procedimentos e disseminações (de conhecimentos).

O conhecimento institucionalizado, apesar de não ser padronizante, apenas padronizado, permite unificação de processos e uniformização de comportamentos individuais na execução de serviços e na qualidade do produto (núcleo) e seus satélites (componentes personalizados), o que proporciona capacidade de produção organizada e com equalização de requisitos entre as partes em constante dinâmica do sistema (bem como o próprio núcleo, que, segundo relatado, nunca entra em total estado de inércia).

O conhecimento individual integrado estipula conhecimentos desejados nos participantes do quadro funcional da organização, em função de seu papel e nível hierárquico. A organização possui alguma preocupação com a administrabilidade possível e o gerenciamento de talentos, habilidades e saberes, bem como das lições representadas pelas experiências pessoais. Internaliza alguns dos processos de ensino, mas vale-se mais de eventos externos, desde que estes atendam a necessidades de circunstâncias de projetos ou plataformas.

Sua cultura de gestão do conhecimento envolve visão e controle de talentos, promovendo avaliações periódicas em níveis definidos, principalmente nos estágios iniciais de uma situação de integração de novos funcionários ao quadro e em situações de agregação de novos domínios, seja por evolução de produto, seja por evolução de plataforma. Talentos são administrados, ainda, para manter um banco de clientes possíveis para envolvimento em beta-testes, com estrutura que lhes permita avaliá-los, qualificá-los e relacioná-los a cada situação de desenvolvimento. A organização mantém, também, um banco de idéias organizado, para formalizar e armazenar, padronizadamente, toda e qualquer contribuição que funcionários, consultores e clientes possam trazer para a corporação.

\subsubsection{2 - EMPRESA "B"}

Quanto à concepção cultural relativa ao conhecimento da empresa "B", uma 
constante pode ser percebida na pesquisa, com relação aos segmentos organizacionais da divisão de tecnologia (e, aparentemente, das outras também): O conhecimento é parte consciente e fortemente valorizada da essencia organizacional e sobre sua gestão e aprendizagem a estrutura, a funcionalidade e a gestão empresarial se sustentam.

$\mathrm{Na}$ institucionalização do ativo de conhecimento, define-se critérios para estabelecer estrutura e base de conhecimentos que padronizam produtos e produção, além de otimizar suas evoluções pelo aumento da eficiência de interpretações mercadológicas, concepções de produtos e planejamentos da produção. Os padrões estabelecidos permitem a prática do compartilhamento, tanto do que é técnico quanto do que é comportamental, potencializando o capital intelectual da empresa Em experiências de replicação de unidades de trabalho (por enquanto, duas com estrutura totalmente proprietária e algumas com estrutura de posicionamento remoto, em clientes) os sucessos conquistados são frutos desta capacidade de institucionalização.

$\mathrm{Na}$ integração do conhecimento individual viabiliza-se domínio sobre capacidades, habilidades e competências em níveis não institucionalizáveis, de pessoas internas e externas ao quadro funcional. Tal domínio permite saberes importantes para a gestão de projetos, no que diz respeito ao relacionamento possível e articulável de funcionários, talentos e disponibilidades funcionais no momento de alocar recursos. A organização apresentou preocupação com a gerenciabilidade destes bens e das lições aprendidas a partir de experiências pessoais. Internaliza processos de ensino em sua grande maioria, mas vale-se também de eventos externos, desde que se alinhem a interesses administrativos e a necessidades de projetos ou plataformas.

Sua cultura de gestão do conhecimento envolve, além da gestão de talentos, gestão de carreiras, promovendo agregação de novos domínios, seja por evolução de capacitações internas (de seu quadro funcional), seja por melhoria das capacidades de detectar valores externos ao quadro.

\subsubsection{3 - EMPRESA “C"}

A concepção cultural relativa ao conhecimento, sustentada pela empresa, fundamenta a idéia de que o conhecimento é um ativo considerado crucial para a produtividade da empresa, o que a faz investir significativamente, em capacitação do corpo funcional e em infra-estrutura que lhe permita explorar os benefícios de tal ativo. Com base nisso, verifica-se iniciativas como as criações de uma gerência específica 
para tratar o assunto e da universidade corporativa e a consecução de convênios com universidade (externa) para fornecimento de especializações e titulações. A organização trabalha com base em domínios de conhecimentos.

No que diz respeito às dimensões corporativa e pessoal, pode afirmar que:

O conhecimento corporativo apóia a organização em sua capacidade de produção e nas replicações de tecnologia (e conhecimento) na abertura de novas unidades produtivas (10 projetos de expansão aguardando execução, à época da pesquisa) com garantia de padronização de serviços e produtos.

$\mathrm{O}$ conhecimento individual, alinhando-se à missão $\mathrm{e}$ às prerrogativas organizacionais, possibilita o desenvolvimento da atividade fim da organização, além de sua gestão. É perceptível o quanto a empresa preocupa-se com o desenvolvimento intelectual (técnico-administrativo-comportamental) de seus funcionários e o quanto organiza-se para que se somem, na formação do capital intelectual da empresa.

Um exemplo de como a empresa considera o conhecimento um ativo estratégico e como acultura-se para otimizar sua gestão e uso, pode ser traduzido pela filosofia de compartilhamento institucionalizada através da iniciativa piloto de um portal do conhecimento. Esta iniciativa resultou em dinâmica sistematizada que preserva e dissemina conhecimentos em diversos níveis, de forma explícita (através de lições aprendidas, melhores documentos, taxonomias, reuso), bem como implícita (através da criação dos repositórios dos projetos). Associado à iniciativa do portal, desenvolveu-se um trabalho de conscientização do quadro funcional sobre a importância de alimentar e utilizar a base de conhecimentos (repositório). Outros exemplos podem ser percebidos nos programas de desenvolvimento e integração de gerentes, encarregados do desenvolvimento de carreiras, na composição de uma universidade corporativa e no convênio com universidade local (lembrando que a matriz possui o papel de formadora), para criar estímulos e incentivos à evolução intelectual de seus profissionais.

\subsubsection{4 - EMPRESA "D"}

A concepção cultural relativa ao conhecimento, sustentada pela empresa " $D$ " (e sustentando-a), é parte fundamental de sua estrutura de organização por domínios de conhecimento e viabiliza o conceito institucionalizado de padronização dos processos produtivos espalhados pelo mundo. A qualidade dos produtos é de vital importância para sua estratégia de mercado. 
O conhecimento institucionalizado é padronizante e permite que a organização replique unidades ampliadas de projetos, ou menores, ao redor do mundo, com garantia de padronização de serviços e equidade da qualidade de seus produtos. Além do que, proporciona a capacidade de produção distribuída pelas garantias de equalização de requisitos entre as unidades ativas.

O conhecimento individual é alinhado e define quais conhecimentos cada pessoa, participante do quadro funcional da organização, deve possuir, em função de seu nível hierárquico, da competência geograficamente localizada pela distribuição institucional dos domínios do conhecimento (os quais determinam as competências das unidades de desenvolvimento) e da capacidade técnica de produção absorvida. A organização preocupa-se com a administrabilidade possível e o gerenciamento efetivo de talentos, habilidades e saberes, bem como das lições representadas pelas experiências pessoais. Investe na internalização dos processos de ensino, sem descartar eventos externos, desde que estes atendam ao alinhamento estratégico de cada unidade.

Sua cultura de gestão do conhecimento envolve a gestão de carreiras e talentos, promovendo avaliações periódicas em níveis diversos, tanto das unidades de relacionamento (front-end) e desenvolvimento (back-office) quanto de funcionários.

\subsection{3 - CONHECIMENTO E COMPARTILHAMENTO}

\subsubsection{1 - EMPRESA “A"}

O core-business desta organização é alicerçado no desenvolvimento de aplicativos computacionais, com modelo de produção centralizada, dentro dos limites de um conjunto de produtos integrados a um núcleo de ERP, principal produto da empresa, cuja manutenção exige estrutura organizacional voltada à gestão do conhecimento.

Pelo que se pode observar na empresa visitada, os conhecimentos relativos ao produto (e seus componentes de interfaceamento) e à produção têm um tratamento aprofundado, no que diz respeito ao compartilhamento, este bem organizado e aparelhado tecnologicamente, por meio de software específico aliado a procedimento sistêmicos bem definidos. Somente na prospecção e relacionamento direto com clientes é que houve narrativa de dificuldades a esse respeito.

Quanto aos agentes do conhecimento, não houve uma identificação precisa, no corpo organizacional da empresa, do gestor (ou gestores), porém, por tratar-se de 
empresa de pequeno porte, os profissionais-chaves de cada setor (prospecção de mercado, produção, produto e relacionamento direto) apresentam características estratégicas de contextualização dos saberes. O papel de coordenador do conhecimento pode ser percebido, também, sob responsabilidade de três profissionais-chaves: de forma extensiva nas gestões externa e interna, o executivo de produção e, de forma pontual, os executivos de produto (para viabilizar manufatura e suporte) e o de recursos humanos (para dar suporte e viabilizar tanto a dimensão de sistema como a de produto). O papel de guardião do conhecimento, segundo a característica de integração e comprometimento de todos com a documentação percebida, é extensivo aos grupos de trabalho de produção, de produto e de recursos humanos. A figura 10.08 procura posicionar os agentes e mostra os gestores em linhas tracejadas pelo caráter de indefinição anteriormente mencionado.

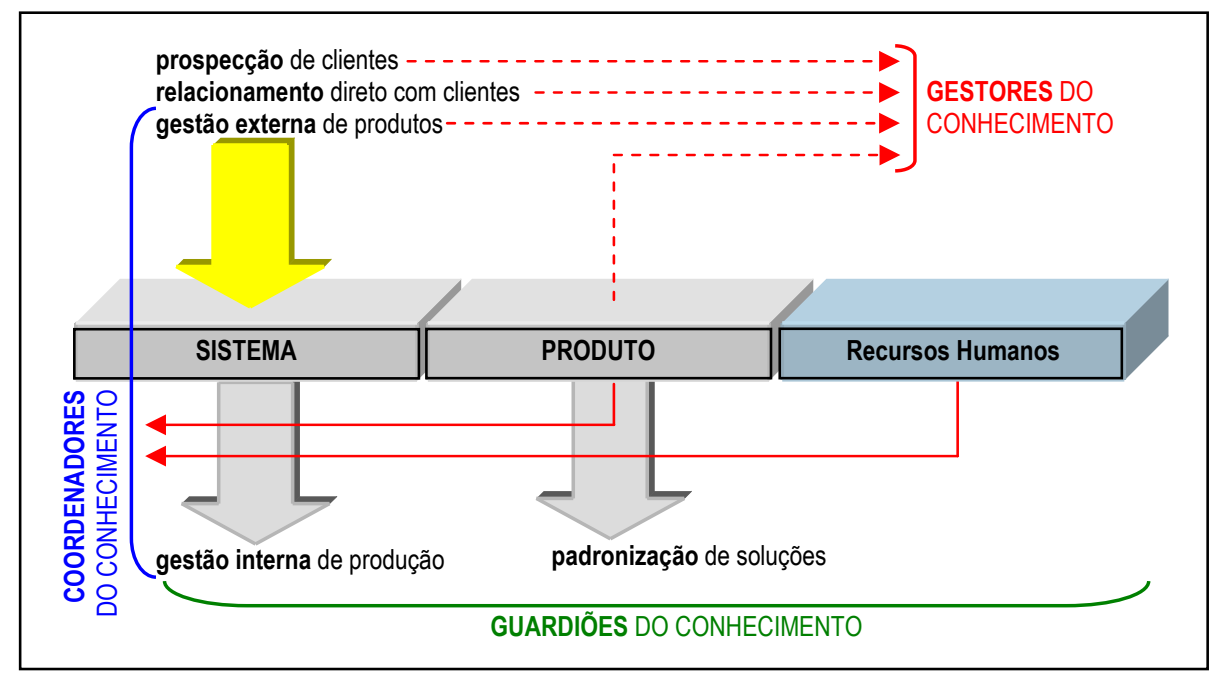

FIG 10.08 - Os agentes do conhecimento na empresa "A".

Compartilhamento e aplicabilidade do conhecimento fazem parte do negócio, formando a base para solidificar um negócio organizado, capaz de manter produtividade e fornecer atendimento com qualidade a um número de clientes na casa das centenas com um quadro funcional na casa das dezenas.

\subsubsection{2 - EMPRESA “B”}

A empresa define seu core-business no desenvolvimento de aplicativos com modelo de produção localizada (com local definido para cada projeto), sem produção distribuída (ao menos, até o desenvolvimento da pesquisa, já que a nova unidade servirá ao desenvolvimento conjunto de projetos de outros locais). Possui um catalogo de produtos focado em quatro principais domínios de negócio, cuja manutenção exige 
estrutura organizacional voltada à gestão do conhecimento.

Percebe-se consciência de que um conhecimento relativo ao core-business não deve ser propriedade de uma única pessoa. Pelo que se pode observar, os conhecimentos relativos a produtos, qualidade, tecnologias, engenharia e gerência, entre outros tantos, técnicos-administrativos, são compartilhados sob a responsabilidade de agentes do conhecimento facilmente identificados em grupos e pessoas (gerentes e executivos).

As funções de gestão do conhecimento foram detectadas nos grupos de gerenciamento de projetos e de melhoria contínua (este, inclusive, com exercício interdivisões ou, ainda, inter-diretorias). As funções do coordenador foram identificadas como prerrogativas do grupo de cursos técnicos, pelo seu papel de difusor e organizador da disseminação deste recurso pelos outros grupos. As funções do guardião do conhecimento foram identificadas como prerrogativas do grupo de administração da rede, pelo papel de mantenedor das tecnologias que este grupo representa. Por esta última função, no entanto, acaba havendo uma responsabilidade compartilhada entre todos os outros grupos técnicos da empresa. A figura 10.09 o demonstra.

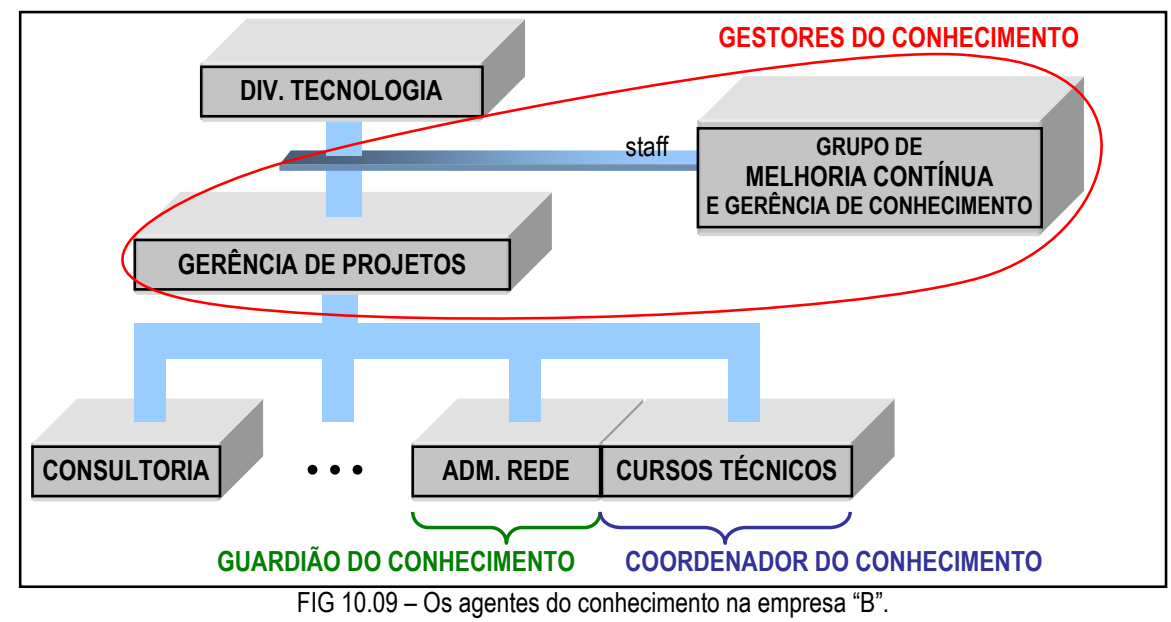

O compartilhamento do conhecimento, assim como sua acessibilidade e aplicabilidade, é parte do negócio e formam base sobre a qual é solidificado um negócio organizado, capaz de manter produtividade e fornecer atendimento com qualidade a um número considerável de clientes, conforme o que se pode perceber pelas entrevistas.

\subsubsection{3 - EMPRESA “C"}

A empresa pesquisada possui seu core-business no desenvolvimento de soluções em tecnologia de informação para otimizar o processo produtivo das organizações, agregando prestação de serviços em consultoria, suporte e planejamento e atendendo às 
necessidades dos clientes de forma customizada.

A empresa demonstra (até pelo que já foi relatado) consciência da importância do compartilhamento, principalmente do conhecimento diretamente relativo ao corebusiness. Mostrou ciência, também, da importância de não permitir que um conhecimento destes seja propriedade de uma única pessoa, apresentando uma estrutura de disseminação gerida por agentes bem definidos.

A gestão do conhecimento, por exemplo, é prerrogativa da gerência do Conhecimento, apoiando diretamente o grupo de melhoria contínua (sobre estruturação e decisões relativas ao conhecimento, à preservação e à capacitação) em seu suporte à fábrica. A coordenação é prerrogativa da gerência da Qualidade de software e esta também apóia, diretamente, o grupo de melhoria contínua. A guarda é prerrogativa da coordenação da produção (grupo de engenharia de processo, ligado às gerências de Fábrica e de Componentes). A figura 10.10 representa suas participações.

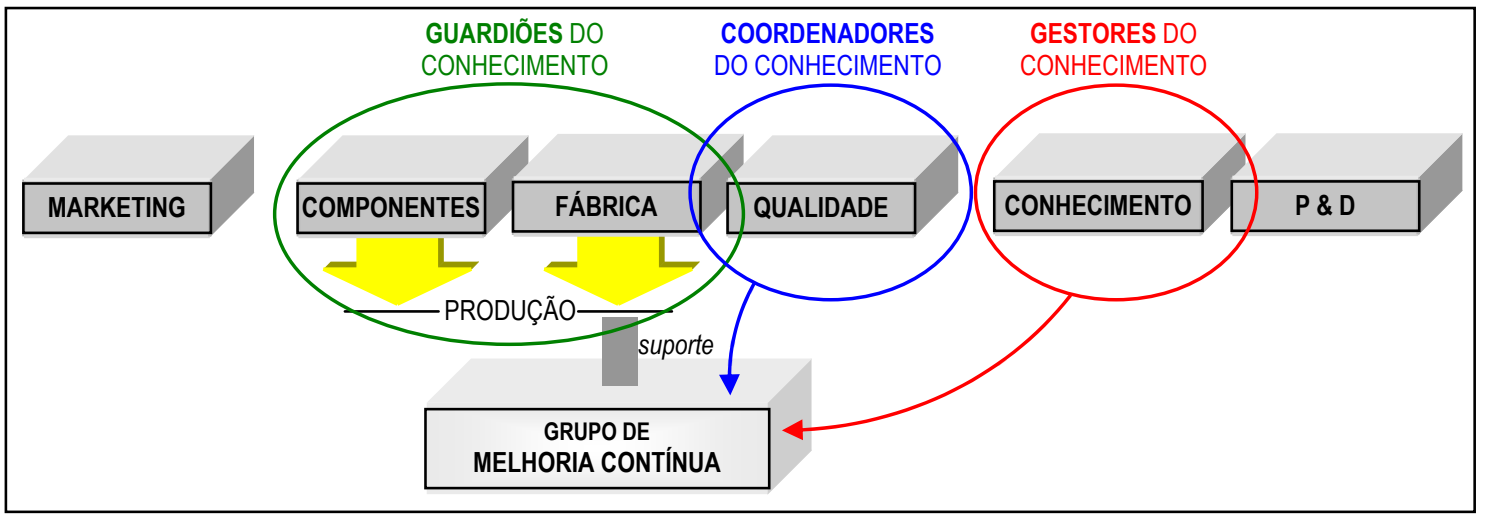

FIG 10.10 - Os agentes do conhecimento na empresa "C".

O compartilhamento do conhecimento, assim como sua aplicabilidade, faz parte da base estratégica de negócio e conta, na estruturação do repositório, com configuração formulada para armazenamento de projetos, contendo: registros de negociações, problemas e soluções, especificações, códigos; e as lições aprendidas, técnicas (melhores práticas, padrões, base de problemas técnicos, códigos para reuso), gerenciais (base de riscos, base de decisões formais, taxonomia de riscos) e operacionais (melhores documentos, orientações de uso de ferramentas).

Os profissionais da empresa são constantemente avaliados e o grau de seu aprendizado é constantemente comparado ao desempenho apresentado nas funções de produção. Uma avaliação comparativa direta dos valores agregados ao quadro funcional com as práticas da ensinagem, não pode ser apresentada pela empresa. 


\subsubsection{4 - EMPRESA “D”}

A unidade visitada da empresa possui seu core-business no desenvolvimento de aplicativos computacionais, utilizando um modelo distribuído de produção, dentro dos limites de um catálogo de produtos cuja manutenção exige estrutura organizacional voltada à gestão do conhecimento.

Consciente de que um conhecimento relativo ao core-business não deve ser propriedade de uma única pessoa, a identificação de agentes do conhecimento foram relativas a grupos de trabalho.

Nas unidades de modelagem de negócios, a gestão estratégica do conhecimento fica por conta de dois grupos, um que define estratégias globais de vendas e encarregase da oferta de soluções aos clientes e outro, que encarrega-se do desenvolvimento do catálogo de serviços e produtos contextualizados no core-business. Estes dois grupos atuam diretamente sobre um centro de conhecimentos baseado em um repositório dinâmico. A coordenação tática do conhecimento fica por conta de um grupo encarregado de definir as entregas e, com isso, organizar e comprometer a estrutura regional da organização. A guarda operacional do conhecimento não possui, nesse nível de front-end, uma definição de agente específico; talvez, segundo o entrevistado, seja o mesmo que o das unidades de desenvolvimento de aplicações.

Nas unidades de desenvolvimento de aplicações, a gestão estratégica do conhecimento fica por conta, também, de dois grupos, um que gerencia as capacitações estratégicas, encarregando-se de identificar geograficamente as competências regionais, e outro que cuida dos compartilhamentos de serviços, cuja missão é garantir replicações de modelos funcionais e metodologias. A coordenação tática do conhecimento é uma responsabilidade da estrutura regional da organização (cada região possui seus próprios executivos), alicerçada nas atividades de grupos que garantem os compatilhamentos de serviços, principalmente por suas características de "fiadores" já mencionadas, para garantir a capacidade de compartilhar projetos da organização. A guarda operacional do conhecimento fica a cargo do grupo que garante a melhoria contínua dos processos da engenharia de software e que precisa efetivar a padronização dos conhecimentos necessários à gerenciabilidade do negócio. Este grupo de melhoria contínua também atua na coordenação tática. A figura 10.11 dá uma visão de participação destes agentes.

O compartilhamento do conhecimento, assim como sua aplicabilidade, faz parte, 
como base estratégica, de um negócio no qual as unidades de composição, física e geograficamente distantes, compartilham do mesmo modelo funcional, por meio do qual viabiliza-se o compartilhamento de metodologias, tecnologias, ferramentas e projetos, desenvolvidos de forma compartilhada.

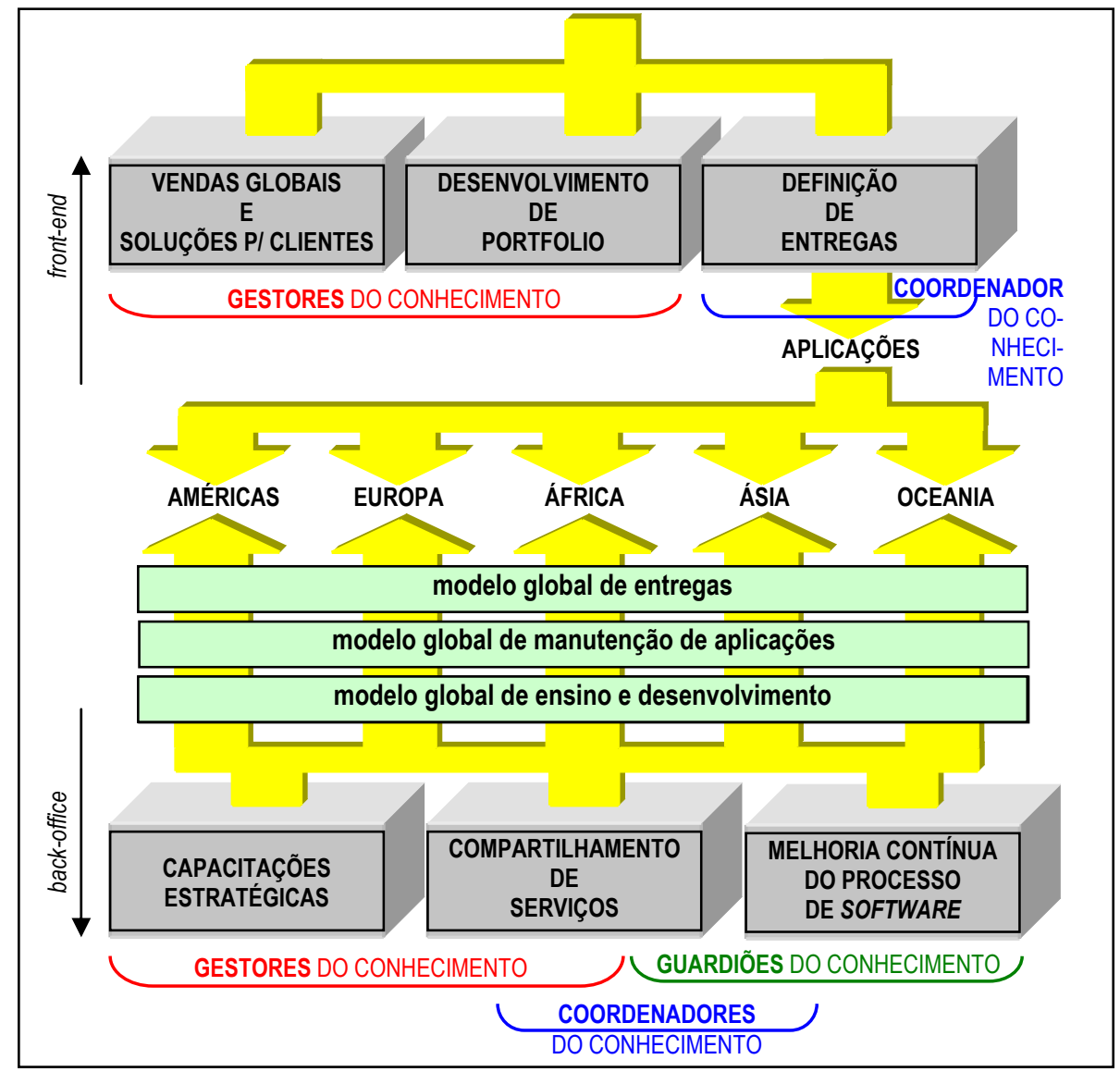

FIG 10.11 - Os agentes do conhecimento na empresa " $D$ ".

Tanto o grupo de capacitações estratégicas, quanto os de compartilhamento de serviços e de melhoria contínua posicionam-se paralelamente aos níveis de gerenciamento das unidades, sendo independente destes para definir suas prerrogativas organizacionais, expressas na forma de modelos, conforme demonstra a figura 10.12.

Na figura, detalha-se apenas a função do grupo de capacitações estratégicas, por ser uma questão de organização dos compartilhamentos. $\mathrm{O}$ detalhamento dos modelos dos outros dois grupos, virão adiante.

As unidades de desenvolvimento possuem uma estrutura administrativa composta por uma diretoria e por duas camadas de gerenciamento: uma de programa (um programa é um tipo de desenvolvimento de competência da unidade - um domínio de conhecimento) e outra de projeto (cada gerente de programa controla diversos 


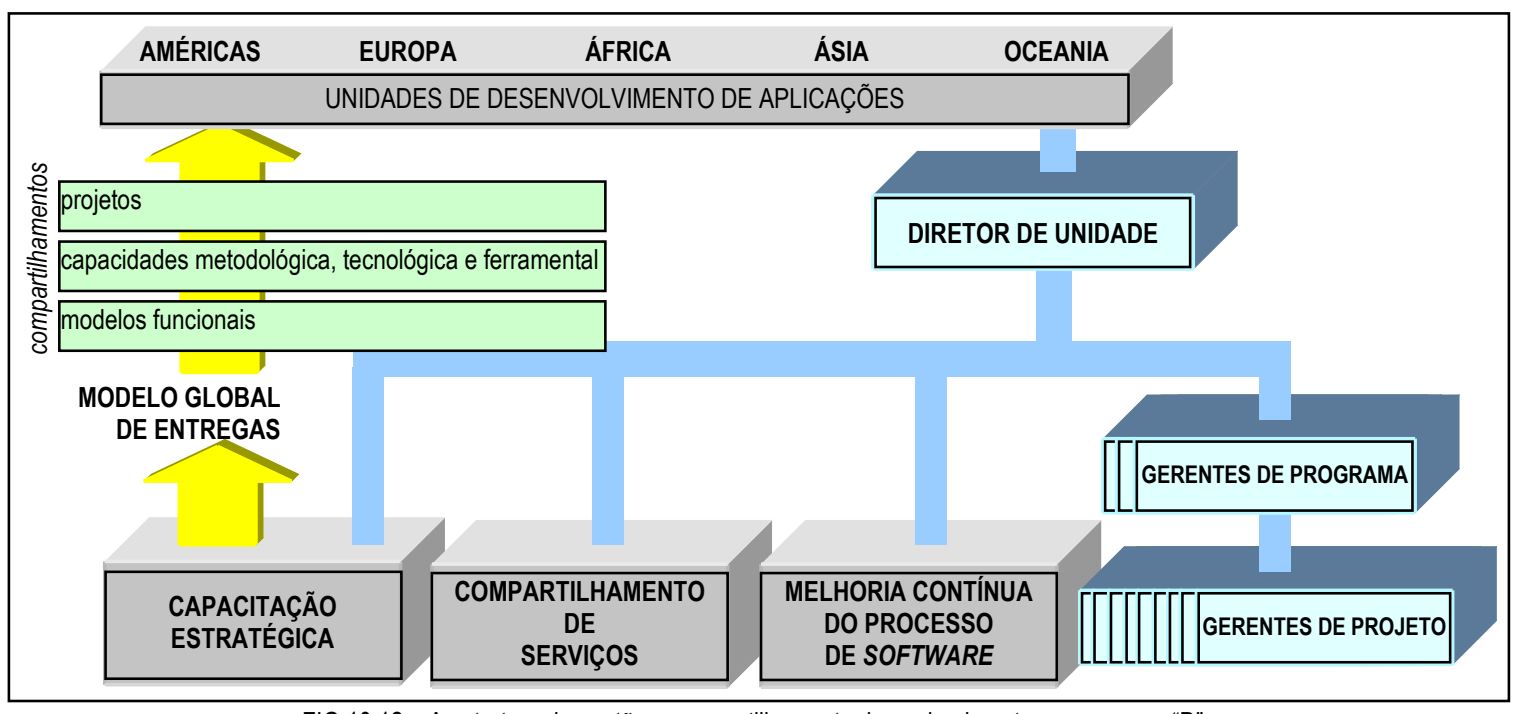

FIG 10.12 - A estrutura de gestão e compartilhamento do conhecimento, na empresa "D".

projetos e é a ele que seus gerentes reportam-se). Tal organização da estrutura empresarial baseia-se na necessidade de compartilhamento para a transferência. Ao grupo de capacitações estratégicas cabe, como função principal, definir o modelo global de entregas (orientação para formação das unidades de desenvolvimento e promoção do padrão organizacional de compartilhamentos), determinando, com base nas tendências regionais, quais conhecimentos deverão ser transferidos à unidade para que possa integrar-se ao todo e permitir o compartilhamento, inclusive, de projetos.

Este modelo global de entregas define a estrutura organizacional necessária à administração de capacidades, segundo competências, locais e regionais, de domínio do conhecimento e, identificadas tendências locais (regionais), determinam as capacidades técnicas que centros de desenvolvimento e unidades de produção devem possuir, visando desenvolvimentos padronizados, entregas garantidas e qualidade assegurada.

Tal explicação, dada pela pessoa entrevistada, embasa o nível de dependência que a organização tem de uma boa gestão do conhecimento e o quanto é estratégica sua preservação, levando a uma relação interessante entre aprendizado e desempenho.

\subsection{4 - ORGANIZAÇÃO AMBIENTAL PARA A ENSINAGEM}

\subsubsection{1 - EMPRESA “A"}

A ensinagem como prática organizada (apesar de não reconhecida por essa nomenclatura, pela empresa) pode ser percebida de forma bem específica e pontual na:

- integração de novos funcionários ao quadro, com a necessária informação sobre a empresa e suas características técnicas e procedimentais; 
- conscientização do novo integrante quanto ao produto;

- conscientização deste integrante quanto às ferramentas que compõem a plataforma de trabalho da empresa, tanto a de produção quanto a de gestão (nesse caso, inclusive definindo, para o profissional, a forma como ele será gerido pela organização).

Cada um destes pontos pode ser visto como um processo de ensinagem específico obrigatório a todos os profissionais, de quaisquer níveis técnico ou administrativo, que venham a integrar a empresa. Do último deles derivam novas ocasiões de aprendizagem (novos processos), conforme seja percebida a necessidade por novas tecnologias ou novos domínios de negócio, ocasiões estas a serem desenvolvidas internamente (em menor número de vezes) ou externamente (na maioria das vezes e, em geral, aproveitando-se da oportunidade de eventos específicos sobre os assuntos de interesse). A figura 10.13 demonstra a cronologia de tais circunstâncias.

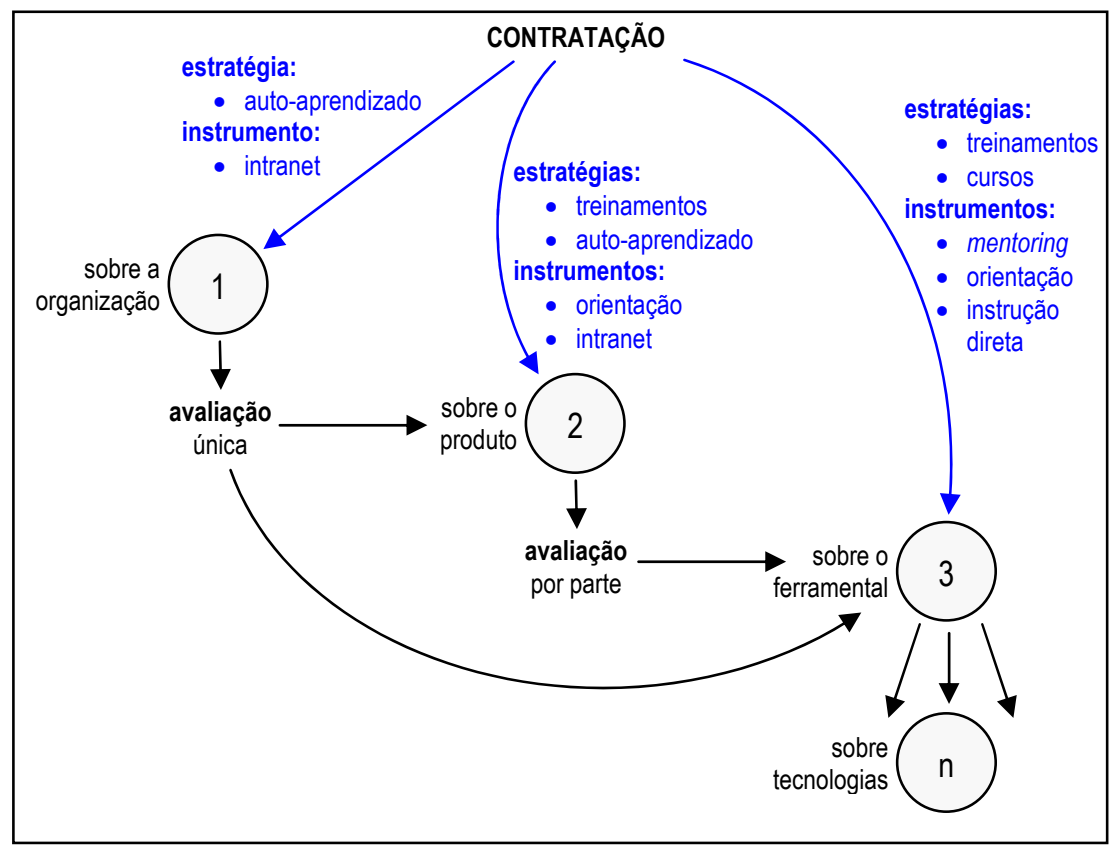

FIG 10.13 - A seqüência inicial de aprendizagens prevista pela empresa "A".

A primeira destas circunstâncias é baseada em auto-aprendizagem, através de consulta a material extenso, liberado em intranet. O profissional só pode passar à segunda fase após avaliação realizada em uma única fase. Na segunda fase, a atividade baseia-se em treinamentos (atividades internas de ensinagem) e auto-aprendizado pela consulta de material disponível em repositório; os treinamentos são realizados por gerentes internos (cursos sobre como montar treinamentos foram e costumam ser realizados com certa periodicidade) que agem como orientadores de estudos. Diversas avaliações são realizadas nesta fase, uma para cada ponto, abordagem ou domínio de 
conhecimento do ERP. A terceira fase é baseada em treinamentos (geralmente internos) e cursos (geralmente externos) decididos sob planejamento gerencial, em exercícios de mentoring e realizados com orientação, quando treinamentos, e com instrução direta, quando cursos (alguns treinamentos também). Nesta fase, procura-se disseminar conhecimento sobre as ferramentas utilizadas pela empresa, tanto para a produção (o que ele vai utilizar) quanto para a gestão (com o que seu trabalho será gerido).

A fase denotada como " $n$ " corresponde aos diversos cursos que o profissional poderá realizar, a partir dessa tomada de consciência sobre ambiente, política e estrutura da organização. A definição das tecnologias a serem absorvidas, então, é uma questão de estratégia empresarial somada a necessidade percebida de cada profissional, pois todos os integrantes do quadro funcional da empresa podem, a qualquer momento, solicitar algum conhecimento que percebam seja necessário adquirir para realizar ou melhorar a capacidade de realização de seu trabalho.

Cada uma das circunstâncias apresentadas corresponde a um (ou mais) processo de ensinagem, representável através do modelo conceitual preliminar, sob investigação. Afirmação baseada no fato de terem sido identificados, na organização ambiental, elementos condizentes com cada um dos elementos do modelo. Considera-se, também, que o conjunto dos pontos circunstanciais apresentados pela figura 10.13, bem como a dinâmica relacional entre eles, é condizente com a organização de conhecimentos e seus elementos, associados e encadeados, expressa dinamicamente através das escadas do aprendizado. Exemplos de capacitações técnicas aplicáveis a esta forma de organização são as tecnologias adotadas pela empresa, que lhe formam a plataforma de trabalho: .NET, ASP, SQL, VB-6 e aplicativos específicos para gerenciamento de projetos pelo gerenciamento de ordens de serviço.

É definido, no ambiente, o planejamento de espaço para o processo de ensino, tanto na forma de aulas e treinamentos, quanto na forma de reuniões e palestras. Pode-se observar, nos dois pavimentos que alojam a empresa, uma estrutura de ambientação organizada que conta com salas dedicadas a aulas e treinamentos e equipamentos móveis de apresentação para levar orientações, práticas de mentoring e, até mesmo, treinamentos ao laboratório de desenvolvimento ou à sala de reuniões.

\subsubsection{2 - EMPRESA “B”}

A ensinagem é perceptível como processo costumeiro, sobre o qual cercam-se 
muitas atenções, pela consciência de sua importância para as estratégias da empresa. Um grupo específico para cuidar da definição e das estratégias de aplicação de procedimentos de ensino foi formado, identificado como "grupo de cursos técnicos" (figuras 10.04 e 10.09). Este grupo cuida de todo processo relacionado à aprendizagem e preservação de conhecimento, sob orientação e apoio do grupo de melhoria contínua.

Uma das análises que tal grupo realiza é para decidir o que é e o que não é necessário internalizar, em matéria de cursos, treinamentos e outros eventos que sirvam à preparação de seu pessoal, norteado pelo princípio de que internaliza-se conhecimento e procedimento que fizer parte do core business, ou seja, o que é estratégico e financeiramente viável para o negócio. Agenda-se e realiza-se através de eventos externos tudo o que não fizer parte dessa categoria.

A prática da ensinagem possui papel significativo para a empresa, para integração e evolução de seu corpo funcional (e para preparação técnica de seus clientes também), o que leva à constatação de que a empresa possui cultura estabelecida de ensino corporativo. Perceptível também é a filosofia de aprendizado constante na organização, pela essência do negócio.

Várias formas de aprendizado foram relacionadas, quando do estudo. Entre elas: cursos, treinamentos, workshops, reuniões de discussão, difusão constante de resultados e discussões de erros e acertos. Apesar desta constatação, de que a organização de eventos traduz dinâmica relacional condizente com a organização das escadas do aprendizado, não foi possível detalhar a formação deste aspecto da organização.

A empresa apresenta uma boa definição de ambiente para eventos dessa linha, com planejamento de espaço para o processo de ensino, tanto na forma de aulas e treinamentos, quanto na forma de reuniões e palestras. Pode-se observar, no pavimento que aloja a parte visitada da empresa (são 3, mas apenas um ligado ao teor da pesquisa), uma estrutura de ambientação organizada que conta com salas e auditório na forma seguinte: 1 sala dedicada a aulas e treinamentos, com 12 máquinas instaladas; 1 sala de reuniões grande (15 a 20 lugares) e 8 menores (4 a 8 lugares); e 1 auditório com capacidade para acomodar 40 pessoas. Auditório e sala maior de reuniões equipados com equipamentos multi-mídia.

\subsubsection{3 - EMPRESA “C"}

Apesar de não se utilizar do termo, o conceito da ensinagem aplica-se de forma 
intensa na organização, visto que define uma diretoria própria para tratar de conhecimentos em sua estrutura organizacional (e, sob ela, uma gerência específica) e mantém uma estrutura de universidade corporativa para gerir os caminhos do aprendizado pelo quadro funcional e um convênio com universidade para prover conhecimentos mais abrangentes aos seus, tal qual MBAs, mestrados, doutorados.

Considerando a existência de 5 unidades instaladas e o planejamento de outras, pode-se afirmar que a empresa preocupa-se em disseminar conhecimentos que permitam as transferências de tecnologias e padrões (de produto e de produção) quando uma nova unidade é implantada e isso demanda organização dedicada ao exercício do ensino corporativo. Pelo teor das respostas fornecidas, percebe-se filosofia de aprendizado constante na organização, voltado à melhoria continua de competências e habilidades. Programas específicos de capacitação técnica, de integração e de desenvolvimento gestor mostram que não somente o aprendizado tem estímulo e incentivo, mas também as discussões de análises de sucessos e de fracassos levam ao aprender.

A observação de ambiente planejado como espaço próprio para o processo de disseminação e difusão de conhecimento reforça tal filosofia. Uma estrutura composta de 1 sala específica e aparelhada para treinamento (capacidade para 20 pessoas), 2 salas grandes de reuniões, sendo uma delas reversível para treinamento e 3 salas pequenas de reuniões (onde se praticam encontros de trabalho ao estilo de mesas redondas) perfazem o relatado físico. Há, ainda, o portal que, mesmo sendo um espaço virtual, é considerado e utilizado como ambiente de ensinagem e disseminação de conhecimentos. Além do que, o próprio ambiente da fábrica é planejado com base em proximidade e integração pessoal, tal que possa incentivar, pela disposição de mobiliário e equipamento, dinamismo e comunicabilidade, gerando ganho considerável em troca de conhecimento (tanto tácito quanto expícito) entre o pessoal.

Através de um sistema de avaliações profissionais próprio, faz-se controle semestral de desempenho de pessoal e os resultados determinam o planejamento de carreiras (gestão, a ser tratada adiante).

O modelo, preliminarmente composto demonstra ser adequado à forma como a filosofia da organização entende tanto o processo de ensino quanto a organização de conhecimentos. Escadas de aprendizado, não puderam ser averiguadas, mesmo sendo considerado que planejamento e programação acontecem por influências da gerência de 
conhecimentos e da universidade corporativa.

A unidade estudada, por exemplo, mantém células de produção funcionando sobre plataformas J2EE e MS, o que leva a pensar a organização de capacitações relativas a estas plataformas. Além do que, foi declarada obrigatoriedade de que todo profissional contratado, ao ingressar, realize treinamentos (capacitações) em, no mínimo, três pontos de conhecimento considerados básicos para toda e qualquer atividade técnica futura dele na fábrica: O-O (capacidade de trabalhar com visão orientada a objetos), UML (produzir e/ou interpretar com uso de ferramentas de projeto orientado a objetos) e CMM (trabalhar sob padronizações conscientes, para garantir qualidade). Além do quê, existe um processo de treinamento organizacional independente, pelo qual as necessidades estratégicas são identificadas e determinadas pela Diretoria de Recursos e Serviços, em consenso com Recursos Humanos, através de discussões realizadas em reuniões mensais. Por esse processo define-se um plano semestral, cujas necessidades operacionais são determinadas pela gerência da Fábrica.

\subsubsection{4 - EMPRESA “D”}

A idéia da ensinagem aplica-se de forma interessante na organização para a preservação do conhecimento. Há uma preocupação constante com o acondicionamento e a comparticipação necessários à estruturação de novas unidades, distantes que sejam, e com a transferência de técnicas, tecnologias e metodologias; ou seja, quando a estrutura organizacional da empresa é estimulada à expansão (uma nova unidade de modelagem ou de desenvolvimento), trabalha com replicação e transferência de conhecimento e tecnologia, acondicionando (colocando nos moldes da necessidade local em implantação) e comparticipando (compartilhando de tal forma a estabelecer o necessário compromisso entre os integrantes) as técnicas, as habilidades e os saberes já desenvolvidos na inteligência central de negócio e nas unidades veteranas.

A ensinagem tem um papel de significativa importância nestes processos de implantação, tal que se pode afirmar, com significativo grau de certeza, a existência de um aculturamento ambiental para o exercício do ensino corporativo (filosofia do aprendizado constante), decorrente do aspecto incessantemente inovador que permeia 0 negócio de uma empresa deste gênero e que, pela própria essência do negócio, depende muito do auto-aprendizado (empresa que aprende - melhoria contínua), onde faz-se necessário analisar os porquês de sucessos e de fracassos e, com eles, aprender. 
Aprende-se, então, com teorias inovadoras, com replicações de teorias já consagradas na organização, com discussões sobre erros e acertos, com reuniões de exposição de fatos, técnicas e conhecimentos adquiridos e com o desenvolvimento da memorização das melhores práticas, estabelecendo uma boa abrangência de estilos.

Os grupos de compartilhamento de serviços e de melhoria contínua do processo de software agregam preocupações relativas ao aprendizado. Inicialmente, pode-se considerar as do grupo de compartilhamento de serviços, sob quem encontram-se os grupos de liderança técnica-tecnológica e de organização de treinamentos, os quais, associados ao grupo de melhoria de processos (especificamente este, sob o da melhoria contínua), formam corpo e força de fomento ao conhecimento que, além de pensar e organizar cursos e treinamentos, estimulam e organizam as trocas de experiências e os aprendizados por análise de sucessos e fracassos. A figura 10.14 demonstra como é organizada a estrutura geradora do modelo de manutenção de soluções.

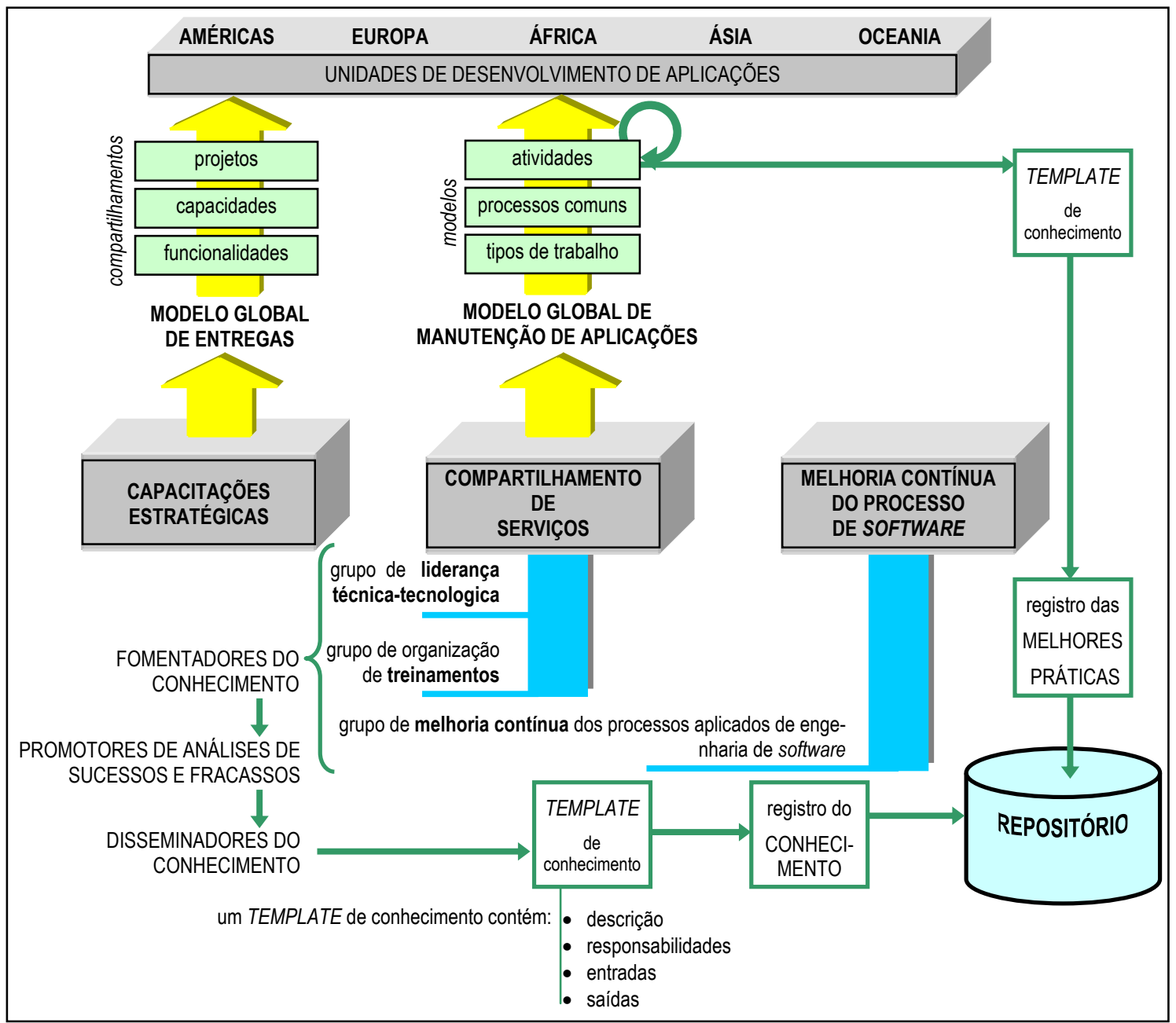

FIG 10.14 - A dinâmica de aprendizagem e compartilhamento de conhecimento na empresa "D" 
A estrutura informacional que organiza o compartilhamento de serviços tem, como função principal, a definição do modelo global de manutenção de aplicações, o qual determina os padrões que permitem especificar os tipos de trabalho a serem implantados na unidade (os processos comuns entre unidades) e as atividades produtivas e de ensino que estas pratiquem.

Entre os grupos de compartilhamento de serviços estão: o de liderança tecnológica (provimento da tecnologia e suas técnicas) e o de treinamentos (provimento do ensino internalizado), os quais, junto com o grupo de melhoria contínua, fomentam e disseminam o conhecimento, além de promoverem as necessárias análises de sucessos e fracassos. Assim forma-se a consciência dos conjuntos de informações vitais ao negócio e das atividades que constituem-se nas melhores práticas relativas à negociação, produção e administração do mesmo. Tanto os conteúdos quanto as melhores práticas precisam ser registrados e, para tanto, formulários próprios e padrões adequados, denominados templates, são definidos para que o conhecimento seja depositado no repositório (nesse caso, só o que se consegue formular).

Há, nos planos estratégicos, intenção de evolução do modelo global de manutenção de aplicações para um modelo global de gestão de soluções, tornando mais abrangente o papel dos grupos associados pela implantação de estruturas gerenciais que permitam maior visão e domínio sobre prerrogativas de negócios e suas proposições.

É bem definido, no ambiente da unidade visitada, o planejamento de espaço próprio para o processo de ensino, tanto na forma de aulas e treinamentos, quanto na forma de reuniões e palestras. Pode-se observar, nos dois pavimentos que alojam a unidade, uma estrutura de ambientação organizada que conta com 2 salas dedicadas a aulas e treinamentos e 7 para outras formas de reunião, com um aproximado de 60 equipamentos especialmente instalados para estes fins. Todas as unidades dedicadas a desenvolvimento e manutenção de aplicações, já instaladas na empresa, possuem área específica para tais atividades.

Através de alguns aplicativos apropriados, há controle e gestão intensivos do capital intelectual da organização, através de métricas focadas e capacidade de tratamento de dados relativos à produção de conhecimento, associada a uma estratégia de gestão de carreiras (a ser tratado adiante).

A unidade estudada da empresa "D", caracterizada como uma fábrica de 
programas, possui, como especialidades estabelecidas, .NET, Java, Z/OS e Gerenciamento de Projetos. A escala das capacidades técnicas determinadas e seqüenciadas é bem representada. Há uma gestão estruturada de carreiras e eventos de ensinagem, formando a realidade estratégica e gerencial da organização, na ação de grupos dedicados a estabelecer o modelo de progressão de conhecimentos, denominado "modelo global de ensino e desenvolvimento".

\subsection{5 - PROCESSO DE ENSINAGEM}

Esse item e os adiante, de 10.4.5 a 10.4.9, têm uma proximidade maior do modelo conceitual preliminar que os anteriores, mais próximos da organização e caracterização das empresas. As questòes tratadas a partir deste ponto, então, possuem poder maior de influência sobre a estruturação do modelo, diferente das anteriores, que procuraram mostrar a aplicabilidade do mesmo pela composição organizacional das empresas estudadas. Os itens que passam a ser descritos neste capítulo, por conta do exposto, não trarão detalhes maiores representados em figuras (exceto se ainda forem representativas de questões de organização e aplicação), pois estas ficam reservadas ao desenvolvimento do próximo capítulo, que tem, como função, apresentar as influências da realidade levantada no estudo sobre o modelo conceitual.

\subsubsection{1 - EMPRESA “A”}

Como já fora mencionado anteriormente (item 10.4.4.1), novas ocasiões de aprendizagem representam novos processos de ensinagem e esta empresa, apesar de desenvolvê-los internamente no menor número das vezes, mantém uma política específica para suas definições, bem como seus posicionamentos nas escadas do aprendizado, como parte da cultura de desenvolvimento contínuo.

Os cursos ou treinamentos são frutos das determinidades estabelecidas pelo modelo estratégico adotado pela empresa, visando a qualidade desejável do produto e a produtividade necessária da equipe de desenvolvimento.

A definição do instrutor possui dois momentos a pensar (figura 10.13):

- Primeiro, quando das atividades básicas obrigatórias aos novos funcionários. No primeiro degrau (conscientização sobre a organização), utiliza-se apenas de material padronizado e disponibilizado no repositório da empresa, através de ambiente navegável por uma intranet. Os degraus seguintes já começam a aplicar serviços de instrutor, fazendo orientação ou mentoring, com intensidade maior conforme avança 
o desenvolvimento e aprofunda-se o conhecimento.

- Segundo, quando de atividades mais específicas, direcionadas a todo o corpo funcional. Percebe-se que, quanto maior o aprofundamento, maior é a tendência de proporcionalidade na aplicação de instrutor (e menor a de material), até porque a empresa não mantém seus próprios instrutores e, na maioria das vezes, quando realiza a ensinagem internamente, contrata instrutores no mercado.

Estes itens delineiam, então, a dinâmica da relação instrutor-material $(\Delta d)$. Esta relação determina tempos e métodos (entre aulas e pesquisas, por exemplo) e orçamentos, na implantação de eventos, da usabilidade de materiais e da necessidade de instrutores, para cada oportunidade de aplicação de cada processo. $\mathrm{O}$ amadurecimento de determinado tema pode transformar seu curso ou treinamento de total ou parcialmente assistido a totalmente auto-suficiente, alicerçado exclusivamente sobre material didático. Apesar de conhecida a importância das questões de tempo dos processos, nada foi discutido nesse sentido.

\subsubsection{2 - EMPRESA "B"}

As definições dos processos de ensinagem, bem como seus posicionamentos e agendamentos, são determinações resultantes do trabalho encadeado dos grupos de cursos técnicos e de melhoria contínua. A evolução dos processos é resultante, diretamente, da evolução educacional e cultural empreendidas na empresa pelas ações destes grupos, apoiadas pelo consenso de instancias superiores em prol do constante aprendizado como forma de progresso técnico e mercadológico.

Assim como fora percebido na empresa anterior, os eventos são frutos das determinidades estabelecidas pelo modelo estratégico adotado pela empresa, visando qualidade tanto de produto quanto de produção.

A definição do instrutor, preferencialmente, atém-se ao próprio quadro de funcionários, fazendo uso de um banco de talentos mantido pela empresa (tratado adiante). Nas ocasiões em que não houver possibilidade de encontrar tal competência internamente, e sendo vital a execução interna do processo, contrata-se externamente, para evento(s) especifico(s) - pode ser para a execução de um curso completo sobre determinado conhecimento ou parte dele. Em casos em que a execução internalizada não seja vital, contratam-se eventos externos (cursos, congressos, etc.) e agenda-se a disponibilização dos funcionários para sua realização. 
Percebe-se a preocupação com a produção de material e sua relação estrutural $(\Delta \mathrm{d}-$ evento a evento) com o instrutor. Apesar das discussões não terem sido aprofundadas sobre o tema, nota-se o cuidado com o quão necessária é a exposição direta do instrutor (presencialmente ou não, já que a empresa conta com estruturas de voz sobre IP e vídeo-conferência) e o quanto se pode realizar com o auto-aprendizado, através de material especificamente desenvolvido para tal. $\mathrm{O}$ formato dos processos de ensinagem, relativos a conteúdos, tempos e relações entre instrutores e materiais muda com constância, de acordo com o amadurecimento do sistema.

\subsubsection{3 - EMPRESA “C"}

As definições dos processos de ensinagem se dão por trabalho encadeado do Grupo de Melhoria do Contínua, gerência de Conhecimento e diretoria de Recursos e Serviços. Estes componentes organizacionais contam com influência da universidade corporativa, que estrutura os processos de ensinagem necessários.

$\mathrm{Na}$ definição do instrutor, a empresa tem, por princípio, sempre prestigiar aqueles, dentro de seu quadro, capazes de executar um processo de ensinagem. Primeiramente, verifica-se a existência de recursos internos para atuar em tal atividade, que possam atender à demanda de eventos. Caso positivo, este instrutor será treinado no processo; caso negativo, busca-se alternativa externa. Considerando a definição da Universidade corporativa, sua influência recai tanto sobre o evento quanto a contratação externa de instrutores. A organização preocupa-se com a qualidade da capacitação (consequentemente, do processo de ensinagem que a gera) oferecida aos funcionários e, por conta desta preocupação com padrões, fornece, ela própria, o treinamento. necessário a quem venha a executar um processo (instrutor). Uma característica de personalidade da empresa é investir no desenvolvimento de capacidades mais de orientadores (e de mentores) que de professores, para seus instrutores.

Pela mesma preocupação percebida, outras influências determinam o material didático a ser utilizado a cada evento e a relação instrutor-material que o evento apresentará. Estas determinações são realizadas por instrutores consultores, responsáveis por elaborar ou adquirir o material didático. Sobre o tempo planejado para processos, informou-se que são dinâmicos e ajustados pelas avaliações de eficiência (diretas, por aprendizes e instrutores) e eficácia (indireta, pela aplicação do aprendizado esperado). 


\subsubsection{4 - EMPRESA "D"}

As definições dos processos de ensinagem, bem como seus posicionamentos nas escadas de aprendizado, pensados e propostos para a composição estratégica do capital intelectual de seus funcionários, são resultados do trabalho encadeado dos grupos de gerência das capacitações estratégicas e de melhoria do processo de software, considerando-se que a evolução dos processos são resultados diretos da evolução educacional e cultural que se possa empreender na empresa.

O planejamento desenvolvido por tais grupos (de forma direta o de melhoria do processo de software, atendendo a prerrogativas estratégicas do de gerência das capacitações estratégicas) é apresentado, pela a figura 10.15, na forma de um modelo, denominado "modelo global de ensino e desenvolvimento", que traz, em seu arcabouço, um catálogo de treinamentos e cursos disponibilizáveis, assim como a definição das ferramentas necessárias a suas realizações.

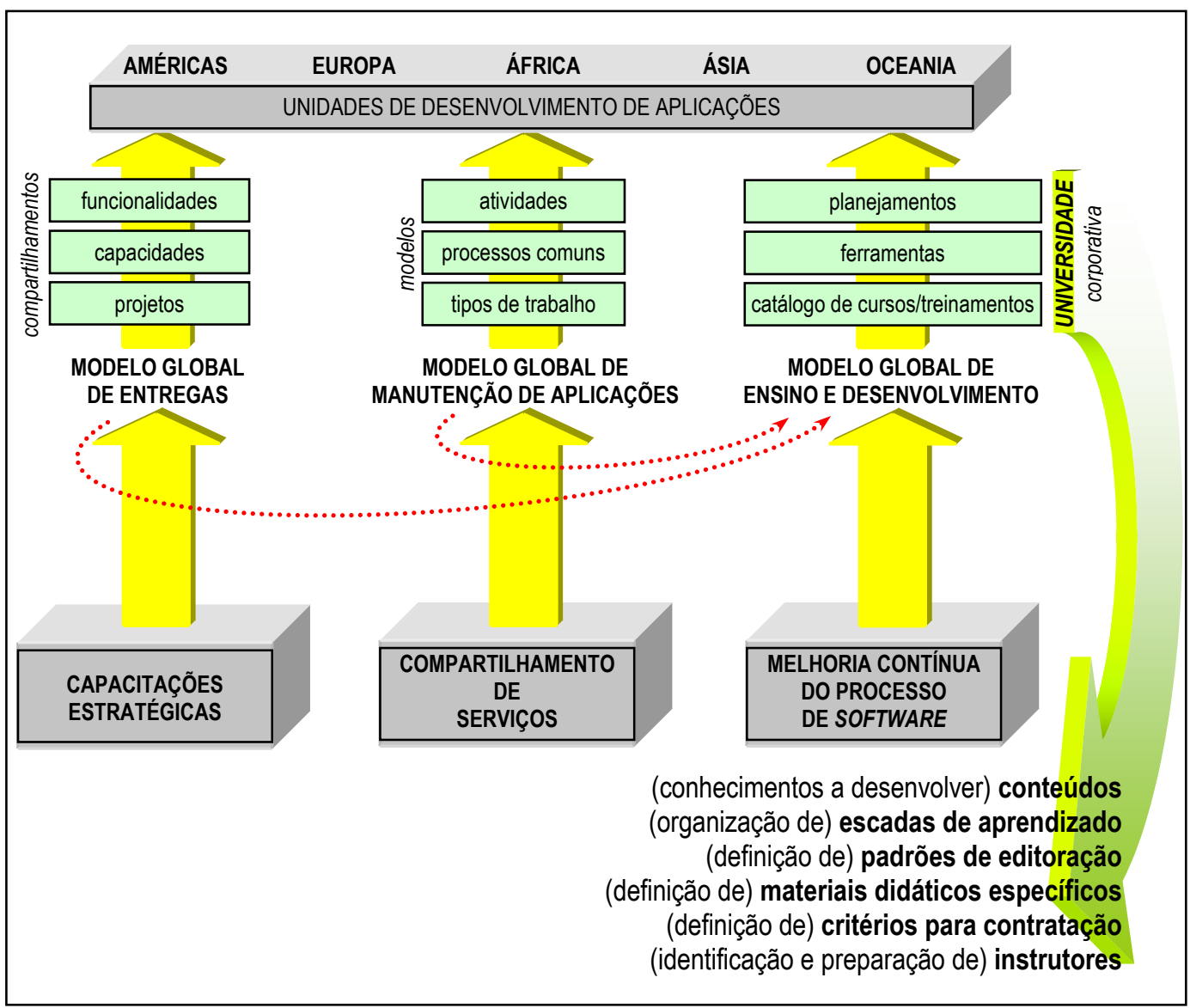

FIG 10.15 - O modelo de gestão do ensino institucionalizado da empresa "D".

Os cursos ou treinamentos são fruto, primeiro, das determinidades estabelecidas pelos modelos globais de gestão de soluções e de entregas, pois estes determinam os 
níveis de distribuição e compartilhamento entre as unidades da organização, e, segundo, dos indícios demonstrados pelas apurações estatísticas sobre os dados e conhecimentos armazenados em uma base própria, os quais orientam as decisões globais, regionais e locais, sobre táticas e estratégicas de ensino interiorizado na organização.

O modelo global de ensino e desenvolvimento leva à formação de uma organização maior das prerrogativas e dos conteúdos de conhecimento, de interesse da fábrica de software, formando uma estrutura universitária internalizada na instituição da empresa, um catálogo de conhecimentos necessários às demandas de capacitação e competência técnicas que cada unidade da empresa precisa a cada instante.

A estrutura denominada Universidade Corporativa traz as diretrizes, as orientações e os conteúdos dos processos, assim como disponibiliza o material didático necessário ao seu desenvolvimento, além de apresentar os padrões estabelecidos para a produção ou evolução de tal material. Padroniza, também, toda e qualquer contribuição que possa alterar ou integrar o conteúdo do material.

$\mathrm{Na}$ definição do instrutor, a empresa tem, por princípio, sempre prestigiar aqueles, dentro de seu quadro, capazes de executar um processo de ensinagem, tendo passado por um processo de aprendizagem, tendo adquirido domínio sobre o conhecimento em evidência circunstancial e sendo reconhecidamente competente para o evento. $\mathrm{O}$ reconhecimento vem de uma certificação interna que a pessoa precisa conquistar, num processo da própria universidade corporativa que o capacita a ministrar aulas ou treinamentos sobre assuntos específicos. Esta preocupação com a certificação, no ato deste tipo de contratação com critérios bastante rígidos, decorre da necessidade de garantir a qualidade dos cursos e treinamentos que oferece. Ainda nesta linha de garantias de qualidade, esta empresa sugere que, cada instrutor em fase de qualificação, antes de certificar-se, deve proceder um exercício prático de ensinagem assistido e avaliado por seu instrutor.

\subsection{6 - CONTRIBUIÇÃO AO AMBIENTE PRODUTIVO}

\subsubsection{1 - EMPRESA “A”}

A organização conta com um software de gestão que sustenta o conceito de PCP (planejamento e controle da produção) com o qual trabalha e sobre o qual executa a administração de projetos e desenvolvimentos. Esta ferramenta (helpdesk) permite que, tanto no âmbito do planejamento, quanto do controle, haja domínios sobre as fases de 
projetos, de produções e de testes, além de servir ao registro de toda experiência em eventos produtivos (até mesmo uma reunião).

Discutir, compor e expor conhecimentos que possam auxiliar nas análises de sucessos e fracasso e, consequentemente, nas tomadas de decisões é um princípio dominante na busca pela eliminação de possibilidades de fracassos futuros, pela possibilidade de acesso ao conhecimento aprendido através da experiência.

Importante entender que a idéia de lições aprendidas não fica circunscrita à fronteira do repositório da empresa. Engloba informações de especialistas com quem a empresa venha a ter contato. A empresa visitada estende esta rede ao conhecimento sobre as capacidades de realização de testes "beta" de seus clientes.

Um farto apontamento de toda e qualquer ocorrência de produção, de correções (visão evolutiva) e de retrabalhos (visão corretiva), aliado a uma boa métrica, garante nível de maturidade gerencial à organização. Tais providências baseiam-se nas exigências da ISO 9001.

A empresa experimenta, atualmente (época da pesquisa), formas de conquistar a plena identificação de tipos de conhecimentos associáveis a situações específicas de projetos, tanto para auxiliar nas tomadas de decisões quanto para orçar prazos, utilização de recursos e custos.

\subsubsection{2 - EMPRESA "B"}

O uso do conhecimento legado como parâmetro de comparação com situações presentes, pela análise de semelhanças circunstanciais é prática apoiada por software de gestão, o qual suporta o princípio da busca de eliminação de possibilidades de fracassos futuros e o faz promovendo acesso ao conhecimento depositado em repositório. Esta aplicação caracteriza-se, ainda, pela potencialidade em compor e expor conhecimentos de forma que tornem-se recursos disponíveis às análises e estímulos dispostos para inovações nas decisões.

As lições aprendidas são documentadas através de apontamentos que se organizam num banco de contatos externos (especialistas e seus talentos) e clientes (principalmente estes), dos quais se procura registrar informações de cunho técnico e comportamental, sobre projetos e experiências com estes, que permitam análises posteriores de situações de interesse. O próximo capítulo apresenta detalhes sobre a 
presença de especialistas e clientes, no âmbito do modelo.

Essas análises apresentam uma tendência nítida: cruzar informações por “especialista/cliente x projetos" e por "especialista/cliente x tecnologia". O padrão de tal realização ainda está em desenvolvimento pela divisão de tecnologia da empresa.

\subsubsection{3 - EMPRESA “C"}

Os coordenadores de produção desempenham um papel de identificação de informações e conhecimentos importantes a cada situação vivenciada em projetos, para que isso possa ser difundido e, se explícito, armazenado em repositório. Isto contribui para a política de reuso constante de conhecimentos, a qual conta com acesso irrestrito para consultas, por parte do pessoal da empresa, e com um procedimento organizado para realizar as documentações necessárias. O acesso ao repositório, para consultar ou contribuir é permitido e gerenciado por uma ferramenta que atua sobre estruturação de taxonomia. O aprimoramento deste ferramental é feito, constantemente, pelo pessoal que atende à gerência de Conhecimento.

Ainda como característica desta aplicação, há de se informar que tem todo um conceito de interfaceamento para facilitar a verificação de código para reuso e para coletar lições aprendidas. Pode-se entender que a idéia de lições aprendidas englobe informações sobre especialistas internos e, também, externos, com quem a empresa venha a ter contato.

A organização funcional adotada pela empresa proporciona integração entre conhecimentos (o repositório) e ambiente (os usuários), inclusive por uma política que leva níveis de governança a atuar em conjunto com o Grupos de Melhoria Contínua, na discussão periódica de casos de negócio.

\subsubsection{4 - EMPRESA "D"}

A organização possui um software que permite analisar situações e, por semelhanças de casos, compor e expor conhecimentos que podem auxiliar nas análises de sucessos e fracasso e, consequentemente, nas tomadas de decisões. A idéia é, em princípio, buscar a eliminação de possibilidades de fracassos futuros, pela possibilidade de acesso à informação registrada acerca de lições aprendidas através da experiência.

Uma outra face desta aplicação, mesmo por decorrência de tal capacidade crítica provida, é a potencialidade intrínseca para compor e expor um nível de conhecimento 
tal que capacite iniciativas de melhoria em modelos, técnicas e ferramentas de trabalho, servido como importante elemento de estímulo à inovação.

Ainda como outra face desta aplicação, pode-se entender que a idéia de lições aprendidas englobe informações sobre especialistas com quem a empresa, por conta da experiência de trabalho junto ao mercado, venha a ter contato. Manter tais conhecimentos atende ao postulado por alguns autores, tal qual Davenport, sobre a necessidade de formar uma rede de especialistas aos quais se possa consultar e com os quais se possa contar em oportunidades eventuais.

Através da gerenciabilidade obtida por esta ferramenta, aliada à organização de uso e reuso de conhecimentos depositados em repositório, há plena identificação de quais tipos de conhecimentos associam-se a quais tipos de projetos e, para cada projeto específico, quais conhecimentos podem ser elencados.

A documentação do aprendido, que no modelo preliminar é decorrência direta do ato da ensinagem, pode, também, ser gerada pelas aplicações, gerando novos conhecimentos. Percebeu-se, neste caso, uma importância impar legada a estes novos conhecimentos, pela influência que têm sobre sua governança nas decisões sobre atitudes inovadoras a implantar, sejam voltadas à produção, sejam à administração.

\subsection{7 - CONTRIBUIÇÃO AO REPOSITÓRIO DO CONHECIMENTO}

\subsubsection{1 - EMPRESA “A"}

A idéia de difusão de lições aprendidas nesta empresa, anteriormente mencionada, assemelha-se à realidade operacional dos resultados diretos da produção, ou seja, registrar o que se aprende no decorrer das experiências da produção é tão importante quanto registrar o ganho de saber que acaba de ser promovido por um processo de ensinagem. Da mesma forma, registrar as especialidades profissionais de pessoas externas ao quadro funcional da empresa é tão importante quanto o registro de habilidades e competências adquiridas pelos membros da empresa em todo tipo de evento, tanto interno quanto externo.

As contribuições ao repositório do conhecimento ocorrem pela documentação de fatos (acontecimentos, experiências) e artefatos (artigos, resumos, comentários, resenhas) que possam ser formulados e grafados de maneira a serem armazenados em um meio não natural, eletrônico ou não (no caso desta empresa, há intenso uso de meio 
eletrônico). Este ato de preservação de conhecimento conta com uma estrutura baseada em ferramenta, cujo uso associa-se a análises (por parte dos coordenadores do conhecimento) da informação endereçada ao repositório. O que for aprovado gerará registros. Exemplos: o que se aprende com sucessos e fracassos; as historiações de ocorrências (problemas detectados, solução encontrada, desenvolvimento da solução); as negociações e discussões do front-end (junto a clientes) e do back-end (internamente, entre níveis de solução e entre pares); entre outros. Estes registros devem ocorrer a cada projeto desenvolvido. Cálculos de freqüência de contribuição, ou uso, do repositório não foram relatados pela empresa.

\subsubsection{2 - EMPRESA “B”}

Esta empresa não difere muito da anterior, no que diz respeito ao uso do repositório para difusão de lições aprendidas, apenas organiza de forma um pouco diferente os conhecimentos armazenados, qualificando-os sob a ótica dos talentos (internos e externos, estes envolvendo clientes), mantendo, sobre os clientes, informações que visam orientar negociações e discussões sobre projetos, ao invés de vêlos como testadores de nível beta. Registros de experiências e enunciados formam a base para a formação de um ativo estratégico de competitividade e contribuição direta de e para processos de ensinagem.

Em relação à documentação, é importante dizer que esta empresa procura definir padrões de formulação e tipificação de documentos, especialmente voltados à alimentação da base de dados e conhecimentos, com intenso uso de meio eletrônico. A empresa demonstrou utilizar-se desta forma para viabilizar a preparação de seu conjunto de conhecimentos e garantir, pela preservação do conhecimento, a sobrevivência de suas áreas funcionais (divisões, domínios, etc.), tornando-as independentes das pessoas, tanto quanto possível for. São exemplos do que se aprova para registros: o que se aprende com sucessos e fracassos; ocorrências e seus resultados; progressos pessoais em eventos de ensinagem, internos ou não; e novos materiais de consulta resultantes da prática de produção, entre outros. Outros itens, anteriormente mencionados, sobre clientes e especialistas externos também são exemplos, mesmo não repetidos aqui.

Não houve informação sobre métricas para determinação de freqüências destas contribuições ou com as quais permita-se gerir impactos e influências dos registros. 


\subsubsection{3 - EMPRESA “C"}

A filosofia de difusão de lições aprendidas via repositório é fortemente incentivada na empresa e o portal é uma interface poderosa, com seu módulo de registro de comunicações. As contribuições são gerenciadas pela quantidade de lições incorporadas e geram "conhecimentos explícitos aprendidos", ou seja, todo registro de progressos pessoais, registros de ocorrências, novos materiais de consulta e novos conhecimentos de conteúdos. Inclui-se aí lições aprendidas e melhores práticas.

A organização incentiva (e cobra) a pesquisa continua por conhecimentos que representem a extensão daquilo que a ocasião da aprendizagem (curso ou treinamento) propiciou. A capacidade de inclusão de tais contribuições, executadas por instrutores, profissionais em aprendizagem e seus líderes e gerentes, é garantida por um sistema de registros de comunicações (modelo de padrões e regras) e um aplicativo, associados ao portal do conhecimento.

\subsubsection{4 - EMPRESA "D"}

Tão importante quando a difusão das lições aprendidas e seus armazenamentos devidos, são os resultados diretos da produção imediata que cada processo de ensinagem promove, pois não se pode relegar ou ocultar a importância dos registros possíveis dos conhecimentos que acabam de ser adquiridos, gerando informação sobre conhecimentos e competências profissionais que traduzam nova condição de trabalho para cada pessoa que participe do quadro funcional da empresa, bem como de pessoas externas a tal quadro, desde que seus conhecimentos possam vir a ser úteis em consultorias ou contratações futuras.

Tal prática de contribuição não só promove um banco de informações sobre profissionais, com o qual, aplicadas algumas métricas, estimula-se a gerencia de talentos, como também promove um banco de dados sobre conteúdos associados a temas diversos, inerentes do negócio da empresa. A organização utiliza-se de um aplicativo próprio para promover e organizar o trabalho com as métricas, necessárias a cálculos, por exemplo, da freqüência com que se contribui com o repositório. Com tais métricas, líderes podem gerir as contribuições advindas de aplicações de conhecimentos em projetos específicos, gerentes podem gerir tanto a produção direta de documentação, quanto, em um nível superior, a produtividade de locais e regiões quanto aos processos de ensino e seus reflexos no aumento da capacitação pessoal. 
A capacidade de inclusão de tais contribuições; executadas por instrutores, profissionais em aprendizagem e seus líderes e gerentes, é garantida por dois aplicativos de software, cuja integração já encontra-se planejada porém, até o fechamento deste estudo, ainda não fora iniciada.

\subsection{8 - CONTRIBUIÇÃO AO AMBIENTE DO CONHECIMENTO}

\subsubsection{1 - EMPRESA "A"}

A prática de difusão de lições aprendidas, já mencionada, é complementada pela prática de comunicação dos conhecimentos tácitos, relativos a ela, incentivada pela organização, que se ocupa em organizar formas de realizar e registrar as realizações, já que os conhecimentos em si não podem ser armazenados em repositório.

Na organização percebida, a empresa busca, em tais oportunidades, que sejam discutidas as experiências, tanto erros quanto acertos, as melhorias possíveis e os conteúdos anexados ao repositório (análise dos conhecimentos explícitos, para embasar as argumentações sobre o tácito), o que culmina em discussão e definição de melhores práticas de produção. Em tais discussões, um tema importante, dentro do escopo da empresa, é a satisfação de clientes e a capacidade de atendimento de suas chamadas.

Uma análise do teor de chamadas que o cliente realize (suporte) é constantemente efetuada para detectar:

- se o pessoal de suporte não está precisando ser envolvido em novos cursos ou treinamentos para corrigir deficiências de conhecimento;

- se o cliente não está precisando envolver seus funcionários em treinamentos, caso o número de chamadas (que cause preocupações) seja causado por desinformação deste e caso qualquer produto da análise deste item e do anterior não seja suficiente para minimizar chamadas;

- se o produto implantado no cliente não está precisando de evolução, o que pode significar evolução de núcleo ou de satélites (há uma política estabelecida de não deixar nenhum cliente com mais que duas gerações atrasadas, em relação à evolução do núcleo do ERP).

O mais comum dos mecanismos utilizados por esta empresa, para o exercício da comunicação de conhecimentos é a reunião formal, com agendamentos periódicos, sem impedir chamadas eventuais, geralmente em casos de crise de produção ou questões de problemas de software fora de padrão. A empresa já utilizou o workshop como recurso 
para este tipo de comunicação, porém informou não o praticar há algum tempo e, ainda, que pensam em retornar à sua prática.

\subsubsection{2 - EMPRESA "B"}

A ocupação com o providenciar da comunicação dos conhecimentos tácitos é nítida, também nesta empresa, que se utiliza de diversos tipos de eventos como oportunidades nas quais sejam discutidas as experiências e as melhorias possíveis, com o que se conquistam melhores práticas.

Na empresa "B", assim como na "A", o principal mecanismo desta atividade é a reunião, formal, com agenda e local específicos. O local, neste caso, pode ser uma das salas de reunião descritas anteriormente ou distribuída por locais diversos, fazendo-se uso de estrutura de vídeo-conferência. As periodicidades destas reuniões fazem parte de um planejamento gestor-estratégico (até como base para a certificação CMMI por ser auditorada) e definem-se, como base prioritária, pelo teor de dinamismo que cada tipo de conhecimento apresenta, podendo ser:

- Semanais: - Reuniões para discussão de processos e ocorrências com claras influências sobre os procedimentos mais imediatos, promovidas e realizadas pelo grupo de melhoria contínua;

- Reuniões para encontros entre projetos, promovida pela gerencia de divisão e realizada por esta, com os gerentes de recursos (gerencia direta, projeto a projeto), para discutir acontecimentos e suas lições;

- Mensais: - Reuniões para encontros entre gerentes de divisão, para discussão dos negócios diversos e como estes envolvem produto, produção, recursos financeiros, etc.;

- Reunião para encontros entre comitês de produtos, os quais envolvem os gerentes de divisão com diretores encarregados da superintendência dos negócios, nas quais são discutidas novas realidades e/ou tendências em matéria de tecnologias, ferramentas e oportunidades;

- Eventuais: - Reuniões para encontros entre envolvidos de um projeto específico, quando este é encerrado (ocorre nos encerramentos de todos os projetos), para discussão sobre suas características diferenciadoras das experiências anteriores com projetos, lições, dificuldades, 
soluções, etc.

Outro mecanismo de contribuição é representado por eventos de workshop, através dos quais a empresa preocupa-se em discutir e exemplificar "vivências" (termo interno). A idéia é abordar mais que a transmissão de conhecimentos técnicos, é discutir comportamentos profissionais e humanos sociabilizantes, além de experiências, que possam influenciar a ambientação ao trabalho de forma benéfica.

\subsubsection{3 - EMPRESA “C"}

É perceptível, como filosofia de difusão de lições, a prática da comunicação dos conhecimentos tácitos, incentivada já há algum tempo, segundo narrativa da entrevistada, e que contou com premiações, como forma inicial de incentivo, até a conquista da consciência necessária do ganho de produtividade que o compartilhamento pode alavancar, por parte do corpo funcional.

O mecanismo de tal atividade é a reunião de pessoal, realizada com freqüência, no decorrer dos projetos. Reuniões trimestrais nos programas de integração e desenvolvimento de gerentes também são considerados eventos de difusão, sem limitarse à reunião, mas estendendo esta prática a outras, como visitas de integralização pessoal, palestras e outras alternativas voltadas à criação de atitudes de comprometimento entre aprendizes de gestão. O papel da gerência de Marketing também é classificado como evento de difusão, além de aprendizagem e disseminação, pois que utiliza-se de mídias para discutir o tema do conhecimento e toda informação inerente a ele. $\mathrm{O}$ uso do portal é outra estratégia para tal fim.

\subsubsection{4 - EMPRESA “D”}

Nesta organização, a contribuição para pessoal - o fluxo de comunicação da produção ao ambiente (no modelo conceitual preliminar) - é representado pela comunicabilidade dos conhecimentos tácitos relativos tanto à empresa e sua regimentação quanto aos negócios e seus projetos. O estudo demonstrou preocupação e ocupaçào da empresa " $D$ " em organizar formas de realizar e registrar as realizações, já que os conhecimentos em si não podem ser armazenados em repositório, nos casos particulares de não serem explicitáveis.

O que se pode perceber é a busca pela discusão de experiências, de erros e acertos e de como estimular melhorias e consciência de melhores práticas de produção. 
O mecanismo de tal atividade é a reunião, formal, agendada, com local específico (físico ou não, pois algumas realizam-se via internet), cuja periodicidade depende do modelo (local ou remota) e do tipo de assunto a tratar, por exemplo:

- líderes de projeto, reuniões mensais;

- comitês de análise de inovações, quinzenais;

- executivos de tecnologia, semanais ou quinzenais.

Tais variações da agenda são uma função, primariamente, do escopo de cada reunião, caracterizável como operacional, tática ou estratégica. Uma reunião com equipes de desenvolvimento é, geralmente, mais focada em compartilhar o conhecimento imediato, resolver problemas do dia a dia e distribuir informações para o uso no momento. Já reuniões de cunho mais tático/estratégico têm foco menos imediato, olhando, mais adiante, horizontes de meses ou anos. A empresa "D" utiliza, para estas ocasiões, reuniões simples (troca de informações), locais ou remotas, e reuniões expositivas, como workshops ou palestras.

Em tais discussões, um tema importante, dentro do escopo desta empresa, é a satisfação de clientes e funcionários. A dos funcionários, tanto com o ambiente de trabalho e incentivos à carreira, quanto com as oportunidades de aprendizagem promovidas. A dos clientes, deve ser vista sob dois aspectos: a dos clientes externos, realizada pelo front-end, e a dos clientes internos (outras unidades de desenvolvimento para as quais uma unidade específica realiza trabalho, lembrando, principalmente, da representatividade disso em uma organização que trabalha com o paradigma da produção distribuída), realizada pelo back-office.

\subsection{9 - ORGANIZAÇÃO DE EVENTOS DE ENSINAGEM}

\subsubsection{1 - EMPRESA “A”}

A organização de eventos de ensinagem, nesta empresa, mostrou-se imprescindível e é praticada em formas diversas: auto-aprendizados, orientações e mentorings, treinamentos e/ou cursos. Em sua maioria, auto-aprendizados e orientações são realizações internas, enquanto cursos são externas. Não há especificação de tempo dedicado (por funcionário-ano ou por horas-ano) para tal finalidade, apesar do interesse demonstrado em constituir métrica condizente.

É consciência formada na empresa que o investimento em ensino gera retorno favorável, haja visto o nível de ajuste que a organização conseguiu em produtividade, o 
que os entrevistados reputam como benefício do conhecimento agregado.

A organização de processos de ensinagem é baseada em dois fatores principais: a demanda desencadeada da expansão de conhecimentos relativos a ferramentaria e tecnologia (e, por vezes, às tendências do produto) e a demanda desencadeada pelo mercado, o que leva a diversificações de tendência do produto. Em resumo, pode-se afirmar que é o interesse pela produção associado ao interesse por talentos agregáveis.

A gestão de carreiras envolve os resultados do planejamento de ensino, internalizado ou não, e a rede de especialistas, internos e externos. O planejamento, realizado por cada executivo ou gerente da empresa, reflete a possibilidade de programações de evolução de aprendizagem de seus funcionários, segundo necessidades de projetos (ou de desenvolvimento de satélites ou de evolução do núcleo de produtos) e competências localizadas, de forma a buscar um alinhamento entre o conhecimento especificado e a carreira almejada. A rede de especialistas apresenta as opções de instrutores possíveis para cada novo processo de ensino organizado.

\subsubsection{2 - EMPRESA "B"}

Processos de ensino, preocupados com ensinagem (também com aprendizagem), mostraram-se importantes para a organização estratégica desta empresa, internalizados ou não, dependendo de cada trajetória traçada de negócio. Não houve, no entanto, uma especificação do tempo dedicado (por funcionário ou horas - ano) para tal finalidade.

Percebe-se, na empresa, uma consciência formada sobre o benefício do investimento em ensino, treinamento e disseminação de conhecimentos, pois que implicam diretamente em aumento de produtividade e da capacidade de produzir mais eventos de ensinagem, sem dizer da amplificação do capital intelectual da organização e da preservação de conhecimentos. O retorno é favorável à medida que potencializa capacidades e competências e estabelece um dinamismo próprio às soluções de problemas e à produtividade conseqüente (mensuração dele, não houve).

A gestão de carreiras (talentos inclusos) envolve os resultados do planejamento da aprendizagem e a rede de especialistas, internos e externos. O planejamento, realizado por cada executivo ou gerente da empresa, reflete a possibilidade de programações de evolução de aprendizagem de seus funcionários, segundo necessidades de projetos e competências localizadas, devidamente alinhadas. O alinhamento, estratégico, busca também aderência entre o conhecimento especificado e a carreira 
almejada. A rede de especialistas apresenta, ainda, as opções de instrutores possíveis para cada novo processo de ensino organizado.

\subsubsection{3 - EMPRESA “C”}

A observaçào deste caso revelou que a maturidade na fundamentação do negócio está na capacidade de organizar e realizar processos de ensino, visto a característica de ambasamento que a organização tem, sobre o conhecimento.

Apesar de não haver apuração declarada pela empresa quanto a quantificações de horas, por funcionário, por ano, dedicadas a ensinagens, alguns indicadores foram apresentados, como forma de se garantir eficiência do processo educacional e capacitador que a empresa utiliza. Entre eles, quantificação pura de treinamentos realizados e quantificações relativas (percentuais) de treinamentos entregues, quantificação de horas oferecidas ao desenvolvimento de eventos (geral) e medidas de efetividade dos eventos. Foram relatados indicadores, mas não os índices.

Não há mensurações dos níveis de retorno do investimento com agregação de valores produtivos. A empresa reconhece a importância do papel dos processos de ensino institucionalizados, haja visto o quanto investe em treinamentos e educação, mantendo universidade corporativa e convênios para especializações e titulações, mas não implantou métrica que ofereça tal informação (há pretensões de fazê-lo).

A organização de processos de ensinagem é baseada na demanda desencadeada da expansão de conhecimentos relativos a projeto e tecnologia de trabalho, adotadas para cada unidade. Percebe-se que há um controle sobre carreiras dos profissionais partícipes do quadro funcional, principalmente pela abordagem planejadora dos grupos gestores do conhecimento, em parceria com a universidade corporativa, o que leva a determinidades da organização de eventos de ensinagem.

\subsubsection{4 - EMPRESA "D"}

Este caso demonstrou a necessidade com que processos de ensino (cursos ou treinamentos) devam ser realizados pela organização e o quanto eles representam em maturidade na fundamentação de negócios. Mais especificamente, a empresa promove cerca de sete dias-ano por funcionário, em ensino institucionalizado, o que leva a uma totalização de cerca de 30.000 horas-ano localmente (exclusivas da unidade estudada) e aproximadamente dois milhões de horas-ano globalmente. 
A organização e a distribuição destas horas pelos processos de ensinagem elencados pela organização são baseadas em dois fatores principais: primeiro, a demanda desencadeada da expansão de conhecimentos relativos à ferramentaria, à tecnologia e à metodologia de trabalho adotadas para cada unidade ou região; segundo, a estratégia, adotada por cada local (ou região), seguindo diretrizes globais, de desenvolvimento profissional de seu pessoal, dentro dos padrões de capacitação e melhoria continuadas.

Não há qualquer dúvida, por parte da empresa, segundo seu representante, dos benefícios que a organização e realização dos processos de ensinagem, determinados e estruturados pela universidade corporativa, trazem à empresa como um todo, unidade a unidade. Apesar de não haver uma metrificação do nível de retorno, há consciência (deles) de que o valor agregado à competitividade e produtividade são significativos.

Este esforço todo resulta no gerenciamento das carreiras do corpo funcional, permitindo, à organização, capacidade de planejar futuros eventos de negócios com base no planejamento de conquistas de competências. Este gerenciamento é realizado pelos usos dos aplicativos de métricas e de administração anteriormente mencionados.

\section{5 - EM SUMA...}

Este capitulo foi dedicado à expressão de informações levantadas no estudo de casos múltiplos, realizado junto a 4 empresas do setor de fabricação de software. As constatações da pesquisa foram relatadas, item a item (segundo as dimensões do modelo conceitual preliminar, definidas por protocolo) e empresa a empresa, procurando uma estruturação que permita a facilitação de comparações entre as realidades percebidas.

Com o objetivo de melhorar a visualização do cenário representado pelas empresas envolvidas na pesquisa, a tabela 10.02 resume-as a partir de um conjunto de características julgadas principais pelo autor do trabalho: 


\begin{tabular}{|c|c|c|c|c|}
\hline$\frac{\text { empresas: }}{\text { características: }}$ & A & B & & D \\
\hline ORIGEM & Nacional & Nacional & Nacional & Estrangeira \\
\hline TIPO & Local & Inter-municipal & Inter-estadual & Multinacional \\
\hline DIVERSIFIC. DE NEGÓCIOS & Não & Não & Não & Sim \\
\hline FUNCIONÁRIOS DEDICADOS & 30 & $600 \rightarrow 800$ & 1.500 & 30.000 \\
\hline UNIDADES NO BRASIL & 1 & $3(+1)$ & 5 & 3 \\
\hline FUNCIONÁRIOS NO BRASIL & 30 & $600 \rightarrow 800$ & 1.500 & 1.500 \\
\hline FUNC. NA UNIDADE VISITADA & 30 & 300 & $100 \leftrightarrow 300$ & 500 \\
\hline $\begin{array}{l}\text { CERTIFICAÇÃO UNID. } \\
\text { VISITADA }\end{array}$ & ISO 9001:2000 & CMMI-2 & CMMI-3 & CMMI-5 \\
\hline \multirow[t]{3}{*}{ CULTURA DE CONHECIMENTO } & Focada em produto & Focada em projetos & $\begin{array}{c}\text { Focada em projetos, } \\
\text { com transferência de } \\
\text { tecnologia }\end{array}$ & $\begin{array}{c}\text { Focada em projetos, } \\
\text { com transferência de } \\
\text { tecnologia }\end{array}$ \\
\hline & Padronizada & Padronizante & $\begin{array}{c}\text { Fortemente } \\
\text { padronizante }\end{array}$ & $\begin{array}{c}\text { Fortemente } \\
\text { padronizante }\end{array}$ \\
\hline & $\begin{array}{l}\text { Consciência e forte } \\
\text { envolvimento }\end{array}$ & $\begin{array}{l}\text { Forte envolvimento e } \\
\text { comprometimento }\end{array}$ & $\begin{array}{c}\text { Forte } \\
\text { comprometimento }\end{array}$ & $\begin{array}{c}\text { Forte } \\
\text { comprometimento }\end{array}$ \\
\hline $\begin{array}{l}\text { CONHECIMENTOE } \\
\text { COMPARTILHAMENTO }\end{array}$ & $\begin{array}{c}\text { "Core" = produto SW } \\
\text { Agentes definidos } \\
\text { com reservas } \\
\text { Compartilhamento } \\
\text { natural }\end{array}$ & $\begin{array}{c}\text { "Core" = soluções TI } \\
\text { Agentes bem } \\
\text { definidos } \\
\text { Compartilhamento } \\
\text { solidificado }\end{array}$ & $\begin{array}{c}\text { "Core" = soluções TI } \\
\text { Agentes bem } \\
\text { definidos } \\
\text { Compartilhamento } \\
\text { planejado }\end{array}$ & $\begin{array}{c}\text { "Core" = soluções } \\
\text { SI e TI } \\
\text { Agentes bem } \\
\text { definidos } \\
\text { Compartilhamento } \\
\text { planejado }\end{array}$ \\
\hline $\begin{array}{l}\text { ORGANIZAÇÃO AMBIENTAL } \\
\text { PARA A ENSINAGEM }\end{array}$ & $\begin{array}{c}\text { Integração e } \\
\text { conscientização } \\
\text { (produto e produção) } \\
\text { de novatos } \\
\text { Organização com } \\
\text { poucos processos, bem } \\
\text { organizados } \\
\text { (escadas) } \\
\text { - Sala aula/treinam (1) } \\
\text { - Sala reunião (1) }\end{array}$ & $\begin{array}{c}\text { Diversificação de } \\
\text { aplicações orientadas à } \\
\text { ensinagem } \\
\text { Organização com } \\
\text { diversos processos, } \\
\text { bem odefinidos e } \\
\text { planejados (escadas) } \\
\text { - Sala aula/treinam (2) } \\
\text { - Sala reunião } \\
\text { (1 grande, várias } \\
\text { menores) } \\
\text { - Auditório (1) }\end{array}$ & $\begin{array}{c}\text { Diversificação de } \\
\text { aplicações orientadas à } \\
\text { ensinagem } \\
\text { Organização com } \\
\text { diversos processos, } \\
\text { planejamento existente } \\
\text { mas não percebido } \\
\text { - Sala aula/treinam } \\
\text { (1 grande) } \\
\text { - Sala reunião } \\
\text { (2 grandes e } \\
3 \text { pequenas) }\end{array}$ & $\begin{array}{c}\text { Diversificação de } \\
\text { aplicações orientadas à } \\
\text { ensinagem } \\
\text { Organização com } \\
\text { diversos processos, } \\
\text { bem odefinidos, com } \\
\text { planejamento } \\
\text { complexo (escadas) } \\
\text { - Sala aula/treinam } \\
\text { (2 grandes) } \\
\text { - Sala reunião (7) }\end{array}$ \\
\hline PROCESSO DE ENSINAGEM & $\begin{array}{c}\text { Raros internos, } \\
\text { muitos externos } \\
\text { instrutores externos } \\
\text { material: manuais e } \\
\text { tutoriais gerados } \\
\text { internamente }\end{array}$ & $\begin{array}{c}\text { Muitos internos, } \\
\text { poucos externos } \\
\text { instrutores internos ou } \\
\text { externos } \\
\text { material: manuais e } \\
\text { tutoriais gerados por } \\
\text { empresa e/ou } \\
\text { instrutores }\end{array}$ & 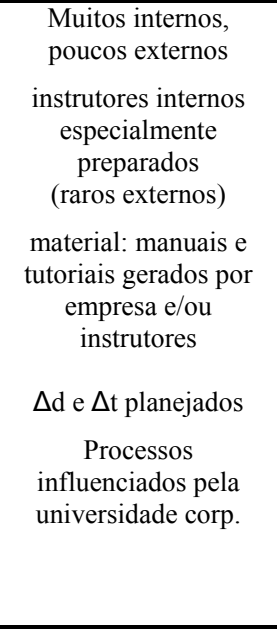 & $\begin{array}{c}\text { Muitos internos, } \\
\text { raros externos } \\
\text { instrutores internos e } \\
\text { certificados } \\
\text { (raros externos) } \\
\text { Definição de escada } \\
\text { do aprendizado para } \\
\text { certificação de } \\
\text { instrutor } \\
\text { material: diversos } \\
\text { gerados por instrutores } \\
\text { e fornecidos por } \\
\text { funcionários } \\
\Delta \text { d e } \Delta \text { t planejado } \\
\text { Processos definidos } \\
\text { por catálogo, pela } \\
\text { universidade corp. }\end{array}$ \\
\hline CONTRIBUIÇÃO À PRODUÇÃO & $\begin{array}{l}\text { Gerenciada, por SW e } \\
\text { PCP } \\
\text { Participação parcial de } \\
\text { agentes do conhecim/ } \\
\text { bom reuso de } \\
\text { conhecim/ } \\
\text { Busca por capacidade } \\
\text { de associação de tipos } \\
\text { de conhecimento a } \\
\text { situações de projetos }\end{array}$ & $\begin{array}{l}\text { Gerenciada, por SW } \\
\text { Focada em bancos de } \\
\text { contatos externos } \\
\text { Boa participação de } \\
\text { agentes do conhecim/ } \\
\text { bom reuso de } \\
\text { conhecim/ } \\
\text { Busca por capacidade } \\
\text { de explorar } \\
\text { associações entre } \\
\text { clientes, projetos e } \\
\text { situações }\end{array}$ & $\begin{array}{l}\text { Gerenciada, por SW } \\
\text { Focada em bancos de } \\
\text { especialistas } \\
\text { Boa participação de } \\
\text { agentes do conhecim/ } \\
\text { bom reuso de } \\
\text { conhecim/ }\end{array}$ & $\begin{array}{c}\text { Gerenciada, por SW, } \\
\text { com capacidade de } \\
\text { análise de semelhanças } \\
\text { de casos } \\
\text { Participação total de } \\
\text { agentes do conhecim/ } \\
\text { bom reuso de } \\
\text { conhecim/ }\end{array}$ \\
\hline
\end{tabular}




\begin{tabular}{|c|c|c|c|c|}
\hline $\begin{array}{l}\text { CONTRIBUIÇÃO AO } \\
\text { REPOSITÓRIO }\end{array}$ & $\begin{array}{c}\text { Registros consistentes } \\
\text { de projetos e } \\
\text { ocorrências } \\
\text { Banco de clientes } \\
\text { (testes) } \\
\text { Banco de consultores e } \\
\text { instrutores } \\
\text { Documentação } \\
\text { abrangente }\end{array}$ & $\begin{array}{l}\text { Registros consistentes } \\
\text { de projetos e } \\
\text { ocorrências } \\
\text { Banco de talentos } \\
\text { (internos e externos) } \\
\text { Banco de clientes } \\
\text { (projetos) } \\
\text { Documentação } \\
\text { abrangente }\end{array}$ & $\begin{array}{c}\text { Registros consistentes } \\
\text { de projetos e } \\
\text { ocorrências } \\
\text { Banco de talentos } \\
\text { (rede completa) } \\
\text { Documentação } \\
\text { abrangente }\end{array}$ & $\begin{array}{c}\text { Registros consistentes } \\
\text { de projetos e } \\
\text { ocorrências } \\
\text { Banco de talentos } \\
\text { (rede completa) } \\
\text { Banco de conteúdos } \\
\text { associados por temas } \\
\text { Documentação } \\
\text { abrangente e } \\
\text { diversificada }\end{array}$ \\
\hline CONTRIBUIÇÃO AO AMBIENTE & $\begin{array}{c}\text { Reuniões formais } \\
\text { Discussões sobre } \\
\text { projetos e ferramental }\end{array}$ & $\begin{array}{c}\text { Reuniões formais, com } \\
\text { agendamento } \\
\text { planejado, presenciais } \\
\text { ou remotas } \\
\text { Workshops } \\
\text { Discussões sobre } \\
\text { projetos, tecnologias e } \\
\text { ferramental }\end{array}$ & $\begin{array}{l}\text { Reuniões formais em } \\
\text { mesas redondas, com } \\
\text { equipes de projetos } \\
\text { Reuniões formais, com } \\
\text { agendamento } \\
\text { planejado } \\
\text { Workshops } \\
\text { palestras (etc) } \\
\text { Discussões sobre } \\
\text { projetos e tecnologias } \\
\text { Estratégia de uso do } \\
\text { conteúdo do } \\
\text { repositório para } \\
\text { formular e embasar } \\
\text { discussões }\end{array}$ & $\begin{array}{c}\text { Reuniões formais, com } \\
\text { agendamento } \\
\text { planejado, presenciais } \\
\text { ou remotas } \\
\text { Workshops } \\
\text { overviews } \\
\text { palestras (etc) } \\
\text { Discussões sobre } \\
\text { projetos, } \\
\text { metodologias, } \\
\text { tecnologias e } \\
\text { ferramental } \\
\text { Estratégia de uso do } \\
\text { conteúdo do } \\
\text { repositório para } \\
\text { formular e embasar } \\
\text { discussões }\end{array}$ \\
\hline ORGANIZAÇÃO DE EVENTOS & $\begin{array}{c}\text { Constante e planejada, } \\
\text { baseada em demandas } \\
\text { por expansão (do } \\
\text { conhecm/) e de } \\
\text { mercado } \\
\text { Consciência sobre } \\
\text { retorno do \$ mas sem } \\
\text { mensuração } \\
\text { Gestão de carreiras } \\
\text { Sem especificação de } \\
\text { tempo de dedicação à } \\
\text { aprendizagem }\end{array}$ & $\begin{array}{c}\text { Constante e planejada, } \\
\text { baseada em demandas } \\
\text { por expansão (do } \\
\text { conhecm/) e de } \\
\text { mercado } \\
\text { Consciência sobre } \\
\text { retorno do \$ mas sem } \\
\text { mensuração } \\
\text { Gestão de carreiras } \\
\text { Gestão de talentos } \\
\text { Sem especificação de } \\
\text { tempo de dedicação à } \\
\text { aprendizagem }\end{array}$ & $\begin{array}{c}\text { Constante e planejada, } \\
\text { baseada em demandas } \\
\text { por expansão } \\
\text { (reconfiguração da } \\
\text { empresa) e de mercado } \\
\text { Consciência sobre } \\
\text { retorno do \$ mas sem } \\
\text { mensuração } \\
\text { Gestão de talentos } \\
\text { Gestão de carreiras } \\
\text { Sem especificação de } \\
\text { tempo de dedicação à } \\
\text { aprendizagem }\end{array}$ & $\begin{array}{c}\text { Constante e planejada, } \\
\text { baseada em demandas } \\
\text { por expansão (da } \\
\text { empresa ou do } \\
\text { conhecm/) e de } \\
\text { mercado } \\
\text { Consciência sobre } \\
\text { retorno do \$ mas sem } \\
\text { mensuração } \\
\text { Gestão de talentos } \\
\text { Gestão de carreiras } \\
\text { Com especificação de } \\
\text { tempo de dedicação à } \\
\text { aprendizagem }\end{array}$ \\
\hline
\end{tabular}

TAB 10.02: Características das empresas envolvidas no estudo de casos 


\section{MODELO DE ENSINAGEM}

As principais contribuições do estudo de casos múltiplos, para este trabalho, são a perspectiva positiva do uso intensivo do conhecimento como recurso competitivo e estratégico e a visão de como o modelo conceitual preliminar corrobora com as prerrogativas do envolvimento da ensinagem com a preservação do conhecimento nas empresas investigadas.

Evidentemente, a análise mais apurada das realidades contemporâneas explicitadas pelos casos influenciou o modelo e este capítulo tem, como objetivo, discutir tais influências e evoluir o modelo preliminar para um modelo adequado ao cenário levantado pelo estudo.

As primeiras 4 dimensões do protocolo (identificação, cultura, conhecimento e compartilhamento e organização ambiental) revelaram o aculturamento e a consciência da importância do conhecimento e sua gestão para as empresas, demonstrando, inclusive, suas preocupações reais com a preservação do mesmo. Pouco influenciaram, no entanto, o modelo conceitual preliminar. Não o desqualificaram. Um resumo rápido destas dimensões será desenvolvido antes das 5 dimensões finais.

As dimensões finais, no entanto, exercem influências sobre o modelo, tal a aproximação dele com as práticas vigentes nas organizações, tornando-o mais próximo de um modelo generalizável de produção, preservação e difusão de conhecimentos. Como já foi dito no capítulo anterior (item 10.4.5), esta parte do desenvolvimento deste capítulo será divido em tópicos relativos às 5 dimensões, à partir da quinta, e trará análise e expressão gráfica (figuras) mais detalhadas sobre tais influências.

\section{1 - AS DIMENSÕES RELATIVAS AOS AMBIENTES ESTUDADOS:}

- Sobre as organizações: Uma faixa extensa foi atingida, no que diz respeito à dimensão das empresas envolvidas no estudo, bem como se pretendia que fosse. A idéia de serem todas preocupadas com qualificações foi, também, plenamente atingida, já que todas são portadoras de alguma certificação. Independente do 
tamanho, trazem estilos estruturais e organizacionais com proximidades que não eram esperados de se encontrar. O mesmo se pode dizer do empenho de todas para as questões do conhecimento.

- Sobre as culturas relativas ao conhecimento: Percebe-se, claramente, que as empresas possuem cultura arraigada sobre o conhecimento e sua necessidade de gestão. Mesmo a menor delas, preocupa-se com tais questões e com sua capacidade de preservar e ensinar. Percebe-se consciência formada sobre a importância do conhecimento como recurso para a competitividade e a organização alicerçada neste ativo, guardadas as devidas proporções, em todas, com semelhanças consideráveis. À pergunta sobre o porquê de tal proximidade, todos foram unânimes ao apoiar-se na necessidade de padronização para a produção, um entrevistado, porém, complementou com a obrigatoriedade decorrente da certificação.

- Sobre o conhecimento e o compartilhamento: A consciência sobre as importâncias do conhecimento, de sua preservação e gestão e de sua ensinagem institucionalizada percebida fazem com que todas as empresas visitadas desenvolvam suas estruturas apropriadas (cada qual a seu tamanho) para trabalhar com o ativo do conhecimento e estabelecer critérios e incentivos de compartilhamento. No intuito de sua difusão e distribuição, definem, com mais ou menos propriedade, os papéis profissionais do gestor, do coordenador e do guardião do conhecimento. As empresas com maior estruturação não apresentaram dificuldade para identificar estes agentes em sua corporação e o fizeram sempre apontando grupos de trabalho. A menor das empresas apresentou alguma dificuldade para tal identificação e, dos agentes, os gestores (atuação estratégica) não puderam ser precisamente identificados. Além do que, nesse caso, as delegações de papéis, nesse sentido, foram pessoais, feitas a executivos da empresa (mesmo que tenha se formado um grupo, os papéis foram atribuídos a profissionais, sem uma identificação clara de interagência entre eles). As empresas de maior porte conseguem identificar, claramente, retorno para o investimento feito com compartilhamento; nenhuma definiu medidas a respeito.

- Sobre a organização ambiental para a ensinagem: Desde uma estruturação simples, baseada em uma seqüência de 3 adventos de ensino, acompanhados de uma proliferação de circunstâncias de aprendizagem, até estruturação complexa, com envolvimento de diversos grupos na composição de uma universidade corporativa, 
em todas as empresas percebe-se alguma forma de organização voltada à ensinagem. Interessante observar, na diversidade comentada, a diversidade de soluções apresentadas para a questão da difusão do conhecimento pelo ensino nas empresas e como soluções simples apresentam-se tão competentes quanto outras para empresas de dimensões reduzidas. Diversidade à parte, o modelo, preliminarmente composto, com o qual trabalha a tese, e o qual está em avaliação, apresentado pela figura 11.01, demonstra ser adequado à forma como as filosofias das organizações entendem tanto o processo de ensino com aplicação imediata de seu produto, quanto a organização de conhecimentos e seus elementos, associados e encadeados, em

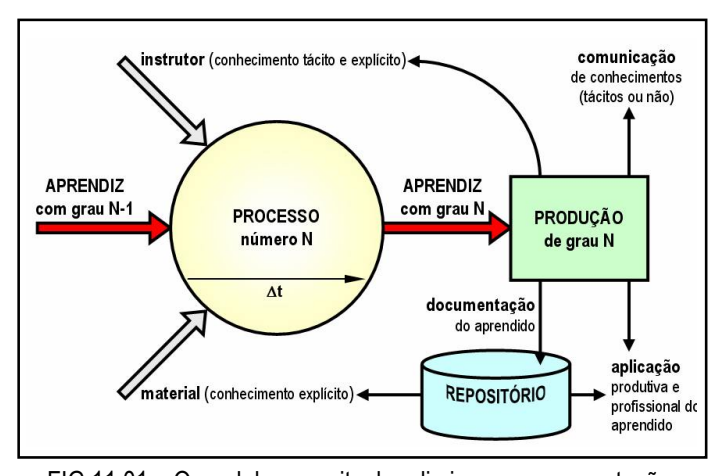

FIG 11.01 - O modelo conceitual preliminar - reapresentação. escadas do aprendizado. Apesar da escada não pode ser identificada em duas das empresa (uma por não haver o tipo de organização investigado e outra por não haver oportunidade de observação, apesar de reconhecer a existência), ainda assim houve percepção da organização do conjunto de conhecimentos para a aprendizagem dos seus. O modelo mostrou-se aplicável em todos os ambientes estudados. Que a aplicação do modelo conceitual, preliminarmente composto, seja viável a pequenas empresas, então, é uma consideração plausível. Esta conjectura, assim como outras, não pode, no entanto, ser generalizada. Serve, apenas, para o conjunto de empresas estudadas e, em eventual caso, a empresas cuja abordagem, tipologia e estrutura sejam compatíveis com estas.

\section{2 - AS DIMENSÕES RELATIVAS AO MODELO CONCEITUAL:}

\subsection{1 - A DIMENSÃO DO PROCESSO DE ENSINAGEM}

Percebe-se, pela análise dos processos de ensinagem aplicados, a importância da definição do instrutor, a ponto de sugerir que o modelo conceitual precisa agregar a preocupação com este pormenor, pois dele advém as garantias de domínio que o profissional tenha do tema a instruir. A empresa "A", devido à sua estrutura, contrata-os externamente para aturarem internamente (quando não para atuar externamente mesmo - a maioria dos casos) e o faz realizando um processo que se ajusta ao proposto pela 
CNSH (fig. 8.13), tomando cuidados relativos a tais garantias. As empresas "B", "C" e "D" preferem trabalhar com pessoal do próprio quadro funcional. As empresas " $\mathrm{C}$ " e "D”, inclusive, posicionam os próprios funcionários em tal função mais intensamente que a "B", e utilizam, como estratégia para a qualidade, treinamentos especiais ("C") e certificações (“D”) e/ou critérios rígidos de contratação. A figura 11.02 demonstra como tal preocupação influencia a preparação para o ensino.

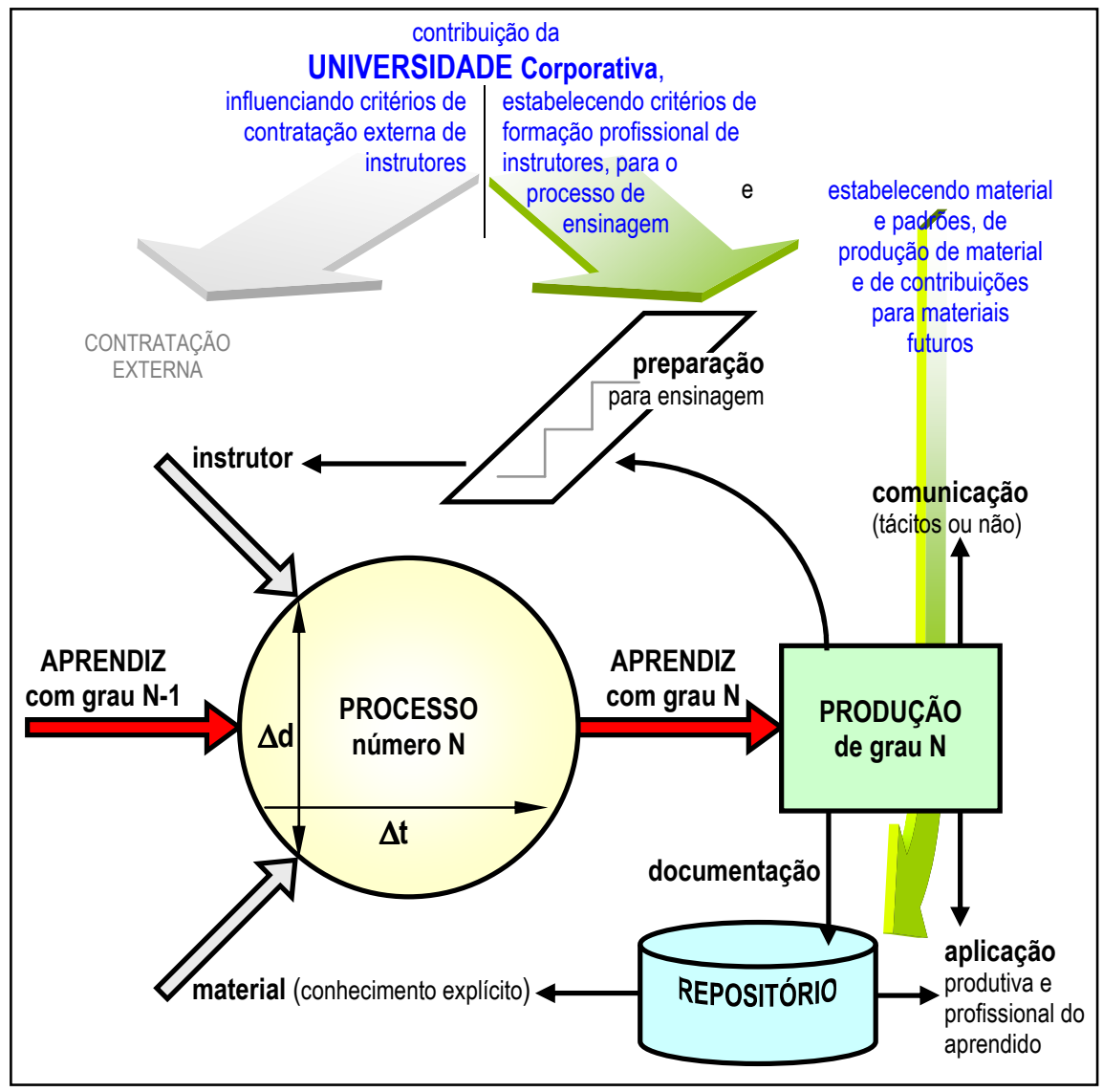

FIG 11.02 - A definição de regras de contratação e preparação de instrutores e materiais.

É perceptível a preferência que as empresas "C" e "D" demonstram em, elas próprias, fornecerem preparação a seus instrutores. Utilizar pessoal externo para tal cargo é, no caso de "B”, realizado na minoria das vezes, por questão estratégica, e, no caso de "C" e "D", quase uma exceção rara, por questão cultural.

Outras influências determinadas pelas prerrogativas de estratégia, também apresentadas pela figura 11.02, versam sobre o tempo de cada processo $(\Delta t)$, ou seja, de ocorrência de cada unidade do conhecimento que se pretende fornecer, e sobre a relação instrutor-material $(\Delta \mathrm{d})$.

O tempo nem foi discutido com a empresa "A", mas as outras o consideram 
importante por afetar toda a programação necessária de pessoal (as três) e a composição de catálogos de cursos e treinamentos ("D”), bem como as relações de contratação de instrutores e, em sendo eles funcionários das organizações, suas relações de disponibilidade entre os eventos de ensino e seus outros afazeres nas empresas. Para a empresa "C", este tempo varia de acordo com avaliações de eficiência e eficácia dos eventos. A de eficiência, pelo levantamento e avaliação diretos de instrutores (por aprendizes) e de aprendizes (por instrutores e gerentes); a de eficácia, pela aplicação dos resultados na produção (por gerentes).

Já as relações entre instrutores e materiais podem determinar desde uma questão de tempos e métodos (entre aulas e pesquisas, por exemplo) até as questões de variação, nas implantações de eventos, variando do estritamente presencial ao totalmente remoto. Para cada oportunidade de aplicação de cada processo, por influência inclusive do local onde ele se dará, deve ser determinada uma relação apropriada e um mesmo curso pode ter variação desta relação entre cada aplicação, principalmente pela evolução do material disponibilizado. $\mathrm{O}$ amadurecimento de determinado curso pode transformá-lo de total ou parcialmente presencial a totalmente remoto. Uma outra diretriz foi apresentada pela empresa "C", a qual configura o $\Delta \mathrm{d}$ considerando que processos de ensinagem relativos a conhecimentos mais técnicos e operacionais têm uma tendência mais para basearem-se em material que em profissional de instrução, enquanto que cursos de cunho mais gerencial baseiam-se mais na figura do instrutor que em material.

Os padrões de contribuição e definição de materiais, também dispostos pelas institucionalizações dos processos de ensinagem, visam, além da organização do repositório para a inclusão de objetos, uma organização que propicie a pesquisa sobre tal base, quando os processos de ensino estiverem ativos. Isso é comum a todas.

A empresa "D" apresentou uma organização interessante da escada do aprendizado para a capacitação para a ensinagem (a certificação interna), fazendo dela própria, um corpo de conhecimento, composto, exposto aqui como importante contribuição ao modelo e demonstrado pela figura 11.03, a qual possui, em cada degrau, um processo de conhecimento relativo à formação profissional dos instrutores.

A composição desta escada possui três partes: uma, inicial, que prepara os profissionais para exercícios de ensino ou treinamento, desenvolvendo, neles, os conceitos necessários de ensinagem adotados pelas empresas; outra, que prepara um 
corpo específico de conhecimento sobre um dos assuntos específicos, desejáveis de disseminação, determinando seu conteúdo informacional e o material didático necessário para sua efetivação; e uma terceira, de uma única fase, que experimenta os profissionais, assistindo seus primeiros processos de ensino prático, como forma de realizar avaliação final para as certificações.

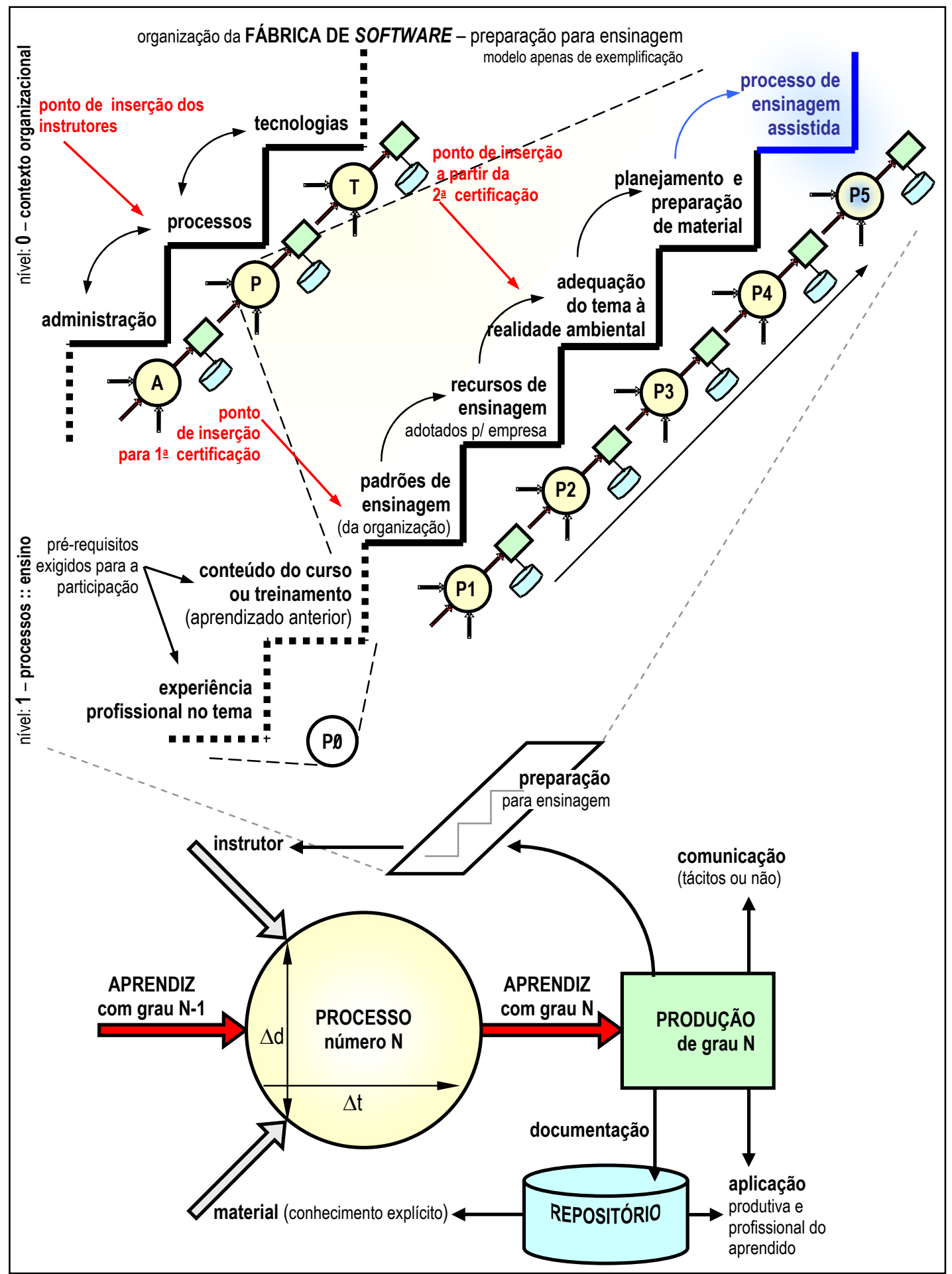

FIG 11.03 - A preparação de instrutores 
A escada especifica da preparação para ensinagem deve possuir, então, dois pontos possíveis de inserção: o primeiro para aqueles que realizam, pela primeira vez, uma preparação para instrutor e; outro, para aqueles que, já sendo instrutores de algum assunto, apenas preparam-se para assunto ou disciplina diferente. Quando a estrutura básica da ensinagem adotada muda, todos repassam algum dos degraus anteriores ao segundo ponto de inserção.

A última fase, denominada de "ensinagem assistida", configura, na realidade, o primeiro processo já em execução sob a condução de um instrutor que esteja certificando-se, o qual o conduz sob a observação de um outro instrutor de maior grau, que o avalia e garante o corretismo tanto de postura quanto de mensagem.

\subsection{2 - A DIMENSÃO DA CONTRIBUIÇÃO AO AMBIENTE PRODUTIVO}

Em todas as empresas visitadas, a documentação do aprendido é realidade e as formas são mais complexas quanto mais complexa seja a estrutura do conhecimento que a empresa utiliza. Simples ou complexa, a preocupação conteudista do repositório, advinda do registro de ocorrências e fatos, é fator importante para a aplicação do conhecimento gerado na ensinagem, à medida que tal conteúdo sirva como referência ao profissional que precisa aplicar tecnologias e tomar decisões.

A gestão, recuperação e difusão do conhecimento assistido por tecnologia também é ponto de consenso em todas as organizações visitadas. A empresa "A", por exemplo, utiliza o próprio software que produz (ERP) associado a um aplicativo de helpdesk para gerir o planejamento e o controle da produção. A empresa "B" dedica-se a modelar o resgate do conhecimento legado e sua aplicação comparativa para promover associações circunstanciais que eleve o grau de acertos nas tomadas de decisão. As empesas "C" e "D", por sua vez, praticam a análise de erros e acertos em produção para rever conceitos e planejar projetos. Todas iniciativas baseadas em uso de software.

Iniciativas estas que usam registro ostensivo de dados sobre todo fato e toda ocorrência (na empresa "A" até mesmo uma reunião é uma ocorrência digna de registro através de uma ordem de serviço, que só pode ser fechada depois que todas as providências solicitas no evento sejam cumpridas). Das anotações que se produz, muitas fomentam conhecimentos sobre lições aprendidas que serão largamente reutilizadas em momentos futuros. Todas as organizações analisadas preocupam-se com o resgate desses dados e conhecimentos, bem como com formas de ajustar as relações entre 
hardware, software e repositório. Algumas apresentaram projetos voltados a esse aspecto, em andamento.

Com tais políticas, percebeu-se, em todas as ocasiões de estudo, o empenho em difundir tais importâncias ao quadro funcional e inciativas de envolvimento e comprometimento dos profissionais, tanto com a alimentação adequada do repositório quanto com a utilização otimizada de seu conteúdo.

\subsection{3 - A DIMENSÃO DA CONTRIBUIÇÃO AO REPOSITÓRIO DO CONHECIMENTO}

A filosofia de difusão de lições aprendidas, mencionada no item anterior, é similar ao que acontece com os resultados diretos da produção imediata de cada processo de ensinagem executado. Registrar o que se aprende no decorrer das experiências da produção é tão importante e necessário quanto registrar os conhecimentos que acabam de ser adquiridos em todo e qualquer estágio de aprendizagem. Se por um lado é necessário registrar as especialidades profissionais de pessoas externas ao quadro funcional da empresa, pois seus conhecimentos podem vir a serem úteis em consultorias ou contratações futuras (até mesmo para ministrar algum processo de ensinagem), por outro, é necessário prover de conhecimentos sobre os progressos pessoais diretos, resultantes de todo e qualquer processo de aprendizagem, relativos aos profissionais partícipes do quadro funcional da organização.

Como "conhecimentos explícitos aprendidos" deve-se, então, considerar os registros de progressos pessoais, atualizados a cada graduação ou certificação profissional conquistada por um processo de ensinagem, novos conhecimentos de conteúdos do ensino específico que acaba de ser adquirido, efetivado pela experiência de produção, e novos materiais de consulta resultantes da prática de produção, oportunidade em que a organização incentiva (e cobra) a continuidade da pesquisa por conhecimentos que representem a extensão daquilo que a ocasião da aprendizagem (curso ou treinamento) propiciou (materiais com grande probabilidade de uso em processos futuros de ensinagem). Alimenta-se, com isso, um conjunto de informações encadeadas denominado rede de especialistas internos.

O que se pode perceber pela pesquisa, e o modelo preliminar não previa, é que a contribuição para com o repositório sofre influência direta das aplicações das teorias (acompanhadas ou não de práticas) adquiridas em processos de ensino. Um processo, 
portanto, gera novos conhecimentos que aplicados, fomentam experiências que geram novos conhecimentos, relativos às lições aprendidas, e que também devem ser preservados, pois serão utilizados, em oportunidades vindouras, na análise de situações de projetos, para o entendimento de cenários de decisão.

Sob este aspecto, formas diversificadas de registro das experiências, bem como de agentes (especialistas, clientes) que formam a rede de contatos das empresas foram encontradas, tais como: a formação de um banco de consultores e clientes para betatestes e a organização de registros históricos de negociações e discussões, de aprendizado (sucessos e fracassos) e do envolvidos com os fatos, na empresa "A"; a formação de um banco de consultores e instrutores potenciais, identificando talentos internos e externos, um banco de clientes para identificação de detalhes de projetos e a inclusão de detalhes sobre projetos aos outros detalhes (tal qual a empresa anterior registros históricos desses projetos, negociações e discussòes acerca de projetos e profissionais envolvidos), na empresa "B"; e a formação da rede de especialistas e registros sobre projetos, tais quais os anteriores, nas empresas "C $\mathrm{C}$ " e "D" (estas não utilizam o cadastro de clientes com o mesmo sentido de banco de conhecimentos que as outras empresas apontaram). A empresa " $D$ " mantém uma outra categoria de registros de conhecimentos, envolvendo conteúdos associados a temas diversos, inerentes ao negócio, o que permite uma gestão ampliada de contribuições advindas de projetos e de aplicações dos conteúdos do repositório (na opiniào do pesquisador, a maior demonstração de maturidade no uso do conhecimento revelada entre as pesquisadas).

A figura 11.04 propõe a forma como este fluxo, do conhecimento conseqüente da experiência, seja considerado no modelo.

A documentação de lições aprendidas é grafada de forma pontilhada por não ser fruto direto da ensinagem e, sim, indireto. Importante incluí-la neste contexto, pois as lições representam conhecimentos significativos a serem utilizados como material docente em processos futuros de ensinagem. Tal importância é devida, também, à necessária constância da inovação dos catalogos de cursos e treinamentos e/ou das (re)composições de futuros processos de determinado conhecimento; isso sem esquecer sua essencialidade para decisões futuras sobre projetos. Em resumo, mesmo não sendo função direta de um processo de ensino, influencia significativamente processos futuros. 


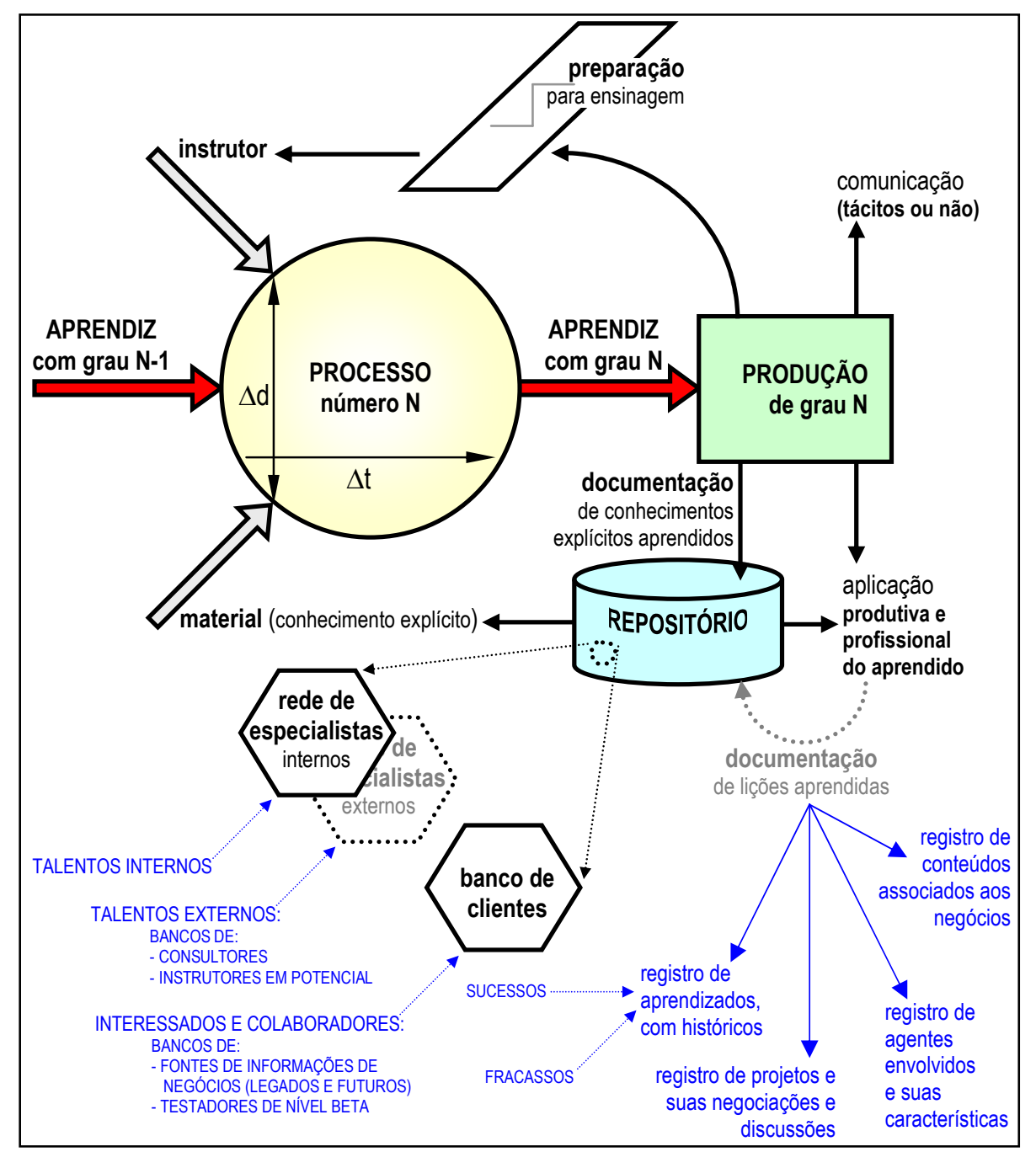

FIG 11.04 - A contribuição da aprendizagem e a formação de redes.

A organização operacional adotada pelas empresas acaba por proporcionar integração significativa entre os conhecimentos (o repositório) e o ambiente (os usuários), inclusive por políticas que levam os níveis de governança a atuarem em conjunto com grupos de melhoria contínua (comum nas empresas estudadas portadoras do CMMI, mas não presente, como grupo instituído na empresa "A", apesar desta contar com os preceitos de envolvimento e funcionalidade, nas pessoas de seus executivos) e de gestão de inovações (não presente em todos os casos), em discussões periódicas de casos de negócio, avaliando-os e determinando justificativas quando estes apontam direcionamentos inovadores nos modelos políticos, de negociações e de produções das empresas como um todo.

Nenhuma das empresas estudadas apresentou cálculos de freqüência sobre ocorrências destas contribuições. Apenas a empresa " $\mathrm{D}$ ” comentou tê-los planejados, mas sem defini-los, apenas informando a proximidade de suas implantações. 


\subsection{4 - A DIMENSÃO DA CONTRIBUIÇÃO AO AMBIENTE DO CONHECIMENTO}

A filosofia de difusão de lições aprendidas, mencionada nos itens anteriores, é complementada neste item com a capacidade de comunicar conhecimentos tácitos (explícitos também, mas o foco é sobre os tácitos) que a empresa consiga implantar entre seus servidores. Um ponto com o qual todas as empresas estudadas demonstraram preocupação e que as levou a ocuparem-se de organizar formas de realizar eventos,com os devidos registros de acontecimentos). A prática mais comum é a reunião formal.

A empresa "A" faz, destas reuniões, mecanismo tão essencial para esta espécie de comunicação que formaliza seu conteúdo, sua composição (pessoas) e o evento em si, por meio de uma ordem de serviço (OS). Na empresa, as reuniões são consideradas eventos de produção, tanto quanto qualquer procedimento de análise, desenvolvimento, atendimento ou correção de produto e, em seu agendamento, uma OS é aberta, na qual registrar-se-á todo o acontecimento e seus resultados, e um planejamento é realizado para envolvimento de pessoas e agendamento de horários. A importância de tais reuniões está nas discussões que elas promovem, nos encontros entre desenvolvedores. Todos os procedimentos da empresa (reuniões inclusas) são percebidos, pela organização, como ações pensadas sobre o planejamento e o controle produtivo utilizados, e tratados de maneira a respeitá-lo. A empresa "C" utiliza-se de tal recurso, mas sem gerar registros de OS, apenas registrando ocorrências, no repositório. As empresas "B" e " $D$ " têm, também, seus formalismos e utilizam-se de recursos tecnológicos para realizar reuniões à distância, tais como internet, voz sobre IP e vídeoconferências.

As reuniões, enfim, apresentaram-se, nos casos estudados, como um mecanismo de significativa importância a essa comunicação, que deve ser realizada formalmente, com agenda definida, cujo teor e duração devem depender de circunstâncias, da importância do tema a ser discutido e de níveis de estruturação gerencial (reunião de cunho operacional, tático ou estratégico).

As reuniões podem ser de diversos tipos, como, por exemplo, reuniões locais para troca de informações, verificada em todos os casos, remotas, via internet ou audio/vídeo-conferência (dois casos), sob a forma de workshop (dois casos) ou, ainda, sob as formas de palestras, overviews, representações, etc. (um caso). Sobre a forma de 
workshop, inclusive, a empresa "B" reportou realizá-las com uma característica própria: a preocupação com discussões que abordem comportamentos, humanos e sociais, em conjunto com assuntos técnicos, além das experiências, é claro.

Destas discussões frutificam boa parte dos entendimentos sobre lições (aprendizados práticos), cujas formulações realizadas em grupo permitem expressões explícitas das mesmas e, portanto, seus registros no repositório. Pode-se imaginar, então, que elas, no mínimo, influenciam a documentação de lições aprendidas, conforme apresentada pela figura 11.04, mas, há relatos de conquistas maiores que este mínimo, relatos de influências sobre a massa de conhecimento do grupo, devido à promoção de comunicações de entendimentos cujas formulações só se realizam tacitamente e, uma vez fomentada a discussão pelo fato da reunião, permitem sua comunicação mesmo sem formulação definida.

\subsection{5 - A DIMENSÃO DA ORGANIZAÇÃO DE EVENTOS DE ENSINAGEM}

O investimento em ensino possui retorno extremamente favorável, segundo a pesquisa, pois estimula a capacidade produtiva para além dos conteúdos de conhecimento envolvidos na composição didática de cada evento, estabelecendo um dinamismo próprio às soluções de problemas e à produtividade conseqüente. A resposta fornecida ao questionamento sobre a relação entre o processo de ensinagem e a preservação de conhecimento foi positiva em todos os casos.

Sob o aspecto da melhoria do capital intelectual, o modelo conceitual deve contar, segundo o que se pode observar pelo estudo dos casos, com uma constante análise de registros e perfis funcionais, analisando talentos e carreiras, observando funcionários e prestadores de serviços (redes interna e externa) e, pela qualificação de pessoal que tais aplicações promovem, organizar agendas (todas), contratar instrutores (todas, mas no caso das empresas "C" e " $\mathrm{D}$ ", dificilmente externos), organizar eventos (cursos e treinamentos), e posicionar compromissos de funcionários com eles. Esta característica pode ser observada, mais especificamente, no caso da empresa " $D$ ", que promove uma gestão bem estruturada de carreiras e talentos, mas não deixou de ser observada nas outras, mesmo que com menor aprofundamento técnico-administrativo.

A figura 11.05 demonstra esta contribuição ao modelo, a qual deve ser realizada a partir dos conhecimentos constantes do repositório e, a partir da qual, deve ser produzido um planejamento resultante, desenvolvido por líderes de projetos e gerentes 
executivos, além dos procedimentos de contrato de talentos externos.

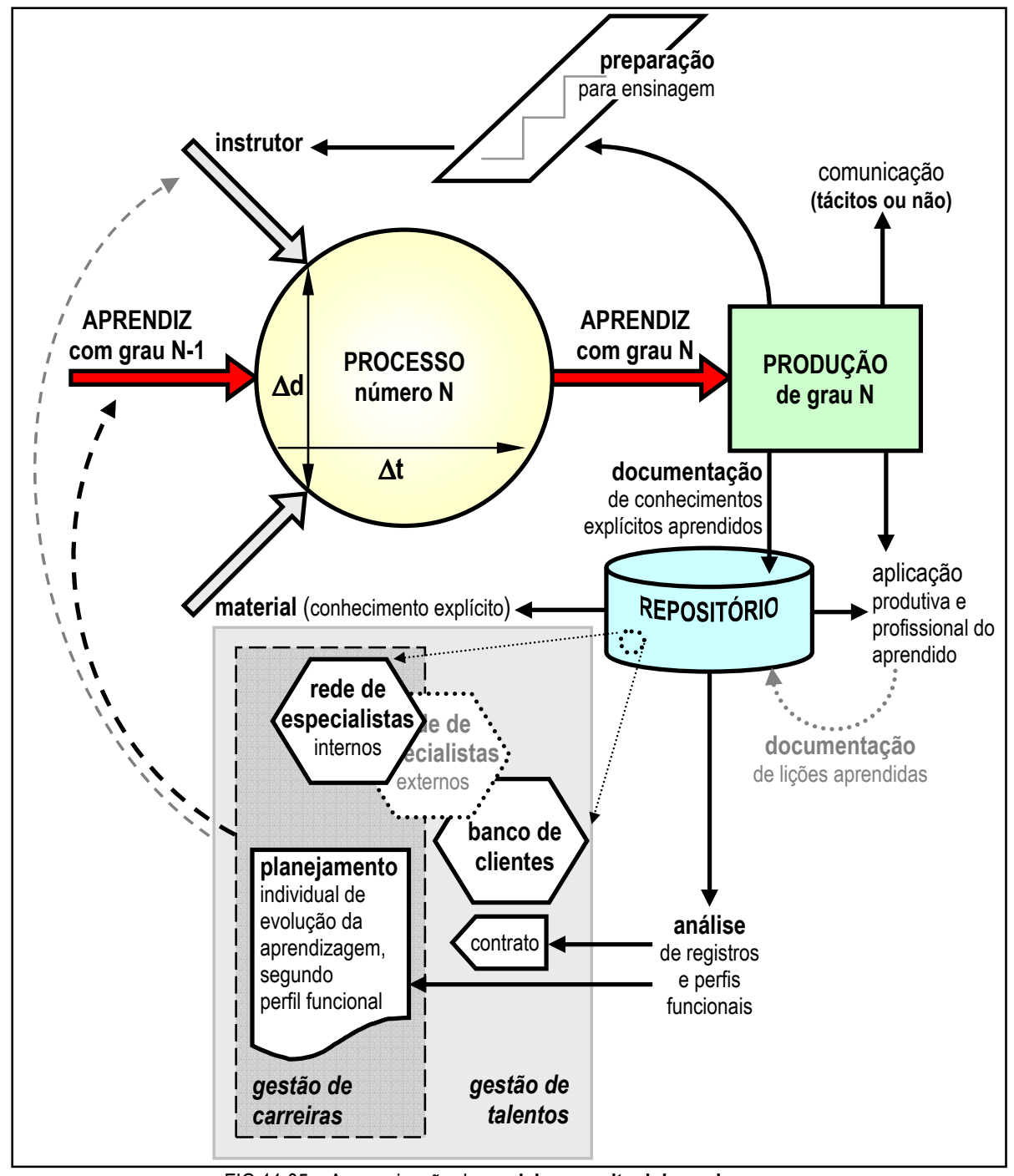

FIG 11.05 - A organização do modelo conceitual de ensinagem

A gestão de carreiras envolve os resultados do planejamento de aprendizagem e a rede de especialistas, internos e externos. O planejamento, realizado por cada líder ou gerente, deve refletir programações de evolução de aprendizagem de seus funcionários, segundo necessidades de projetos, competências e alinhamentos estratégicos entre o conhecimento especificado e a carreira almejada. A rede de especialistas deve apresentar as opções de instrutor possíveis para cada novo processo de ensino organizado, considerando que é especialista para tal quem, do quadro, tiver adquirido a competencia (certificada ou não, depende da empresa) resultante da preparação para ensinagem ou quem, não sendo do quadro, apresentar qualificações específicas para a disseminação do conhecimento desejado.

A figura 11.05 agrega o conjunto de contribuições apresentadas, também, pelos 
itens anteriores e pode, portanto, representar o modelo conceitual de ensinagem.

\section{3 - EM SUMA...}

Este capítulo dedicou-se a discutir os resultados dos levantamentos realizados nos estudos de casos, sob a ótica de contribuições ao modelo conceitual preliminar. Item a item, mostrou, de forma comparativa e consensual, informações sobre como as empresas estudadas atuam em cada uma das dimensões protocoladas do modelo.

O resultado dessa análise foi a proposição do modelo de ensinagem, resultante e condizente com a prática das empresas estudadas, reepresentado pela figura 11.05.

Este capítulo encerra a terceira parte da tese, dedicada à pesquisa. $\mathrm{O}$ próximo, dedicar-se-á às conclusões. 


\section{PARIE 4}

\section{DISPOSIÇÕES FINAIS}

A parte final deste trabalho encarrega-se de fechar as discussões sobre a contribuição apresentada pela tese à ciência, relativa ao modelo conceituado e ajustado, a pesquisa que levou à sua adequação e o referencial bibliográfico que serviu como base de erudição a seu autor. As conclusões, além de levarem às considerações finais sobre a pesquisa e o modelo, fecham questão sobre suas contribuições, assim como as da tese como um todo, levando a reflexões sobre uma das maneiras possíveis de alicerçamento do conhecimento em empresas, pela internalização do duo-processo ensinagemaprendizagem. Reflexões que se estendem às possibilidades de continuidade de trabalhos de cunho científico, a partir do ponto onde este se encerra. 


\section{CONSIDERAÇÕES FINAIS}

Este capítulo é dedicado às discussões finais sobre a pesquisa e o modelo e como eles contribuíram para a percepção de uma realidade de produção, tanto sob aspecto de sua organização quanto da estruturação para uso de um recurso tão importante como o ativo do conhecimento. Comenta-se, aqui, também, como tal realidade percebida contribuiu para o amadurecimento do modelo preliminar e o levou ao detalhamento apresentado pelo capítulo anterior.

\section{1 - A PESQUISA:}

O desenvolvimento da pesquisa conseguiu cumprir com o pretendido: atenter à organização disposta por YIN (2005:41-49), quanto projeta um fluxo "logístico" para seu desenvolvimento, composto pelos cinco componentes considerados, por ele, de especial importância:

1. as questões do estudo: definidas logo no capítulo 2 ;

2. suas proposições: também estabelecidas no segundo capítulo;

3. sua(s) unidade(s) de análise: definidas no capítulo 10, com a identificação do tipo de empresa a ser envolvida no estudo de caso e, logo a seguir, com a identificação das quatro empresas selecionadas, por atenderem aos quesitos propostos;

4. a lógica que une dados às proposições: começou a ser delineado com o décimo capítulo, ao se fazer análise dos dados colhidos em empresas e ao serem iniciadas as comparações entre elas, estendeu-se pelo capítulo 11, para discutir as influências sobre o modelo proposto e fecha-se neste capítulo, com as discussões conclusivas;

5. os critérios para interpretar as constatações: Adotou-se, como critério, que as interpretações seriam realizadas sobre os pontos de discussão que as empresas se dispusessem a discutir, pois, como fora apontado no início do capítulo 10 (item 10.2), o formato de protocolo de pontos abertos (sem perguntas pré-definidas) procurou atender às preocupações que empresas poderiam demonstrar ( $\begin{aligned} & \mathrm{e} \\ & \mathrm{o}\end{aligned}$ demonstraram) com o teor da informação a ser divulgada.

As empresas selecionadas cumpriram, todas, com as prerrogativas determinadas: 
todas fábricas de software (com qualificações diferenciadas, segundo seus core business): uma desenvolvedora de software, outra de tecnologias de informação (visão mais abrangente que apenas software) e as outras, mais abrangentes ainda, desenvolvedoras de sistemas e tecnologias da informação; todas fornecedoras de aplicativos (software) de TI; e serem todas envolvidas e comprometidas com as questões da qualidade (certificadas - apesar de que a certificação não seria uma exigência, desde que se pudesse constatar, pela pesquisa, tal envolvimento).

Uma outra prerrogativa proposta era a de certa dispersão entre níveis de amadurecimento (perceptível pelo envolvimento e comprometimento com qualidade) e esta também foi atendida, já que uma empresa apresentou certificação ISO 9001, outra apresentou CMMI nível 2, uma terceira, CMMI nível 3 e a última, CMMI nível 5.

O relatório dos casos mostra, inicialmente, como as empresas estruturam-se, mas com a preocupação de perceber, apenas, questões de uso, preservação e ensino do conhecimento envolvido com a fabricação de software, não detalhando estruturações administrativas em sua completude. Em seqüência, mostra, tópico a tópico (dimensões de estudo, relativas a um modelo preliminar) as visões da empresa (sobre o assunto em tese) e do pesquisador (sobre assunto e empresas).

Nos quatro casos estudados, pode-se perceber a proximidade das empresas, de portes diversificados, com as questões relativas ao conhecimento e como são suas abordagens quanto à sua gestão e a necessária estruturação de processos de ensinagem, voltados à solidificação de um capital intelectual produtivo, que induza à competitividade. Evidente que tais abordagens apresentam-se umas mais complexas que outras, o que é natural diante da diversidade de estruturas organizacionais, porém, guardadas as devidas proporções, o autor deste trabalho considera excelentes as relações percebidas em todas, com as questões da preservação do conhecimento.

A pesquisa, em sua totalidade (erudição e campo) mostrou que a maturidade é razão direta da consciência e do envolvimento da corporação com as questões de competência (conforme propõe a representação da figura 8.02) e que indagações relativas à disponibilidade e divulgação de experiências e relações técnicas e sociais (internas e externas), ampliações metodológicas e tecnológicas, percepção, aquisição e difusão de conhecimentos e métodos de implantação e gerenciamento de aprendizados (página 128) podem ser respondidas positivamente. 
Isto leva às questões e proposições, definidas e identificadas no capítulo 2.

Com o que se colheu de informações sobre as relações das empresas com as questões do conhecimento, é possível confirmar as proposições:

P1 - Conhecimento é mesmo recurso tornado organizacional, que as empresas estudadas utilizam plenamente no desenvolver de suas estratégias funcionais e estruturais, a fim de garantir-lhes domínio sobre o negócio e competitividade.

P2 - Os processos organizacionais tornam-se otimizados com modelagem e tecnologia, como resultados da organização do conhecimento corporativo.

P3 - Essa organização, do conhecimento corporativo, mostrou-se, realmente, abrangente com suficiência para permitir e otimizar o uso de conhecimentos. Este uso, também de forma abrangente, alcança conhecimentos que as empresas estudadas não possuem (mesmo a mais estruturada delas), mas sabem necessários a seus propósitos.

P4 - A viabilidade da P3 é garantida, nas empresas analisadas, pela manutenção de base de dados com informações pertinentes a conhecimentos não próprios da organização, tal que possam ser absorvidos, e realmente o são, através de contratações junto à rede de especialistas (e clientes, em alguns casos) configurada.

P5 - A consciência da necessidade de internalização do conhecimento primordial ao core business da empresa ou do negócio é realidade e sua concretização também. As empresas demonstraram que, sem esse pressuposto, perde-se capacidade estratégica e de competitividade. Todas buscam maximizar esta premissa. No segmento de fábrica de software, então, pode-se, também, concordar com TAVARES (2004:4-6), sobre a importância da identificação do que é e o que não é “core” para o negócio.

P6 - As empresas preocupam-se com modelos de ensino que se encarreguem de incorporar o conhecimento à organização, pela ampliação do capital intelectual (soma de saberes individuais, agrupados ao explícito armazenado) e demonstram ciência sobre a decisão do que internalizar (relativa ao core business).

P7 - A absorção do conhecimento é uma realidade percebida pela pesquisa, nas empresas visitadas, tanto os saberes de aplicação direta aos negócios de fabricação de software quanto os saberes sobre saberes necessários, mas não apropriáveis, através das redes de especialistas, que armazenam o conhecimento sobre quem possui o recurso.

P8 - Investimentos em estratégias e tecnologias para a conscientização de 
pessoal e disseminação do conhecimento entre os participantes do quadro funcional são, também, realidades nas empresas (cada qual com seu volume, condizente com a dimensão organizacional). A pesquisa ratifica o pressuposto de que tais investimentos viabilizam gestão de conhecimento que otimiza difusão desse recurso de trabalho.

P9 - A ensinagem está presente nos ambientes estudados e seu modelo, apesar de não totalmente definido em todas as organizações, pode ser reconhecido pelo pesquisador como sendo aderente ao modelo conceitual preliminar. Esta prática gera importantes contribuições para com o volume de conhecimentos armazenáveis (viabilidade de melhoria do próprio processo de ensinagem para ciclos vindouros), para com o ensino de saberes incorporados e armazenados de experiências anteriores (viabilidade de otimização e inovação de processos produtivos) e para com os saberes que, apesar de não armazenáveis em bancos corporativos, são importantes para os processos de negócio (viabilidade de incorporação de novos padrões de projetos).

Diversos pontos no desenvolvimento do levantamento conceitual, em capítulos anteriores, corroboram com estas afirmações. Portanto, a pesquisa mostrou que todas as proposições chamadas "de alicerce" puderam ser confirmadas com as análises bibliográfica e ambiental, esta realizada nas empresas selecionadas, bem como com a aderência do modelo preliminar aos seus processos de capacitação profisssional internalizada. Vistas em blocos, estas proposições validam outras, denominadas "de estrutura", também apresentadas no capítulo 2. Confirma-se, então, que:

H1 - Conhecimento é recurso armazenável, transferível e reutilizável (P1 a P3);

H2 - É possível pensar um processo definido para reger a internalização do ativo de conhecimento na base corporativa, o que demanda organização do conhecimento e, consequentemente, domínio sobre conhecimentos sobre o conhecimento (P4 e P5); e

H3 - É possível criar um modelo de ensinagem que sirva à internalização de novos conhecimentos e à disseminação otimizada do conhecimento já apropriado, como forma de preservá-lo (P6 a P9).

A parte de levantamento de conceitos teóricos da pesquisa, associada à experiência docente do pesquisador, levou à concepção de um modelo que, preliminarmente definido, procurou atender à proposição H3 e pode, no campo, ser testado em organizações que se dispuseram a participar do estudo de casos. 


\section{2 - O MODELO CONCEITUAL DE ENSINAGEM:}

A pesquisa de campo conseguiu demonstrar que o modelo preliminarmente proposto atende às prerrogativas de ensino, treinamento e disseminação de conhecimentos, pois em todos os casos as dimensões que ele sugere puderam ser percebidas nos ambientes estudados.

Percebe-lo aderente à realidade, ativamente participante das estratégias de empresas representativas do setor produtor de software, permite considera-lo como um modelo válido e aplicável como exemplo de como se realizam os processos de transmissão do conhecimento, no corpo funcional. É evidente que o autor desta pesquisa não pretende tornar tal afirmação genérica a ponto de abranger toda a indústria de software. $\mathrm{O}$ que se pode afirmar aqui é que o modelo correspondeu às expectativas de investigação para um fragmento de tal setor.

É interessante observar, ainda, que nos ambientes de maior padronização constituída, ou seja, de maior certificação (e há de se pensar o quanto isso significa em matéria de amadurecimento gestor-produtivo), o modelo mostrou-se mais aderente, o que revela sua proximidade com padronizações estabelecidas pela engenharia (de produto e de produção).

A percepção de retorno produtivo decorrente de sua aplicação (mesmo que as empresas ainda não consigam traduzi-lo em números) e o nível de preocupação das organizações com sua consecução permitem considerar a ensinagem um processo constituído, partícipe (sempre conjugada com a aprendizagem) de eventos como cursos e treinamentos e garantido pelo modelo conceitual apresentado e desenvolvido. Estas considerações respondem à questão de embasamento, apresentada no capítulo 2 .

As empresas, provavelmente por conta das padronizações necessárias às suas certificações, utilizam-se de expedientes com abordagens muito próximas sobre o assunto e isto faz com que o modelo possa ser percebido em aplicação plena. Mais que isso, a pesquisa mostrou pontos que o modelo preliminar não observava. Portanto, os casos estudados acabaram por oferecer contribuição ao modelo, como, por exemplo, a necessária preparação de instrutores (caso em que se pretenda utilizar de pessoal próprio para esta função) e as disposições diferenciadas sobre o repositório e sobre as gestões de talentos e de carreiras (visão evolucionária sobre o princípio das redes de especialistas). 
Como resultado da análise destes pontos de contribuição, delineou-se o modelo conceitual de ensinagem, o qual, mais completo, é representado pela figura 11.05 que concebe a intimidade com que o processo de ensinagem deve ser relacionado às gestões de talentos e carreiras, pois que atua diretamente sobre a composição destas e recebe influencia direta delas.

Olhar a dinâmica que tal figura representa e perceber o quanto ela permeia preocupações sobre o processo da gestão do conhecimento (tal qual o apresentado pela figura 6.08) e sobre o foco definido deste estudo (aprender e contribuir, com suas interfaces - figuras 8.07, 8.09 e 8.10), permitem considerar o modelo como resposta à questão primordial da pesquisa: "Como fábricas de software preservam conhecimento?"

Uma vez mais, é importante lembrar que o autor não faz tal afirmação de maneira generalizante. $\mathrm{O}$ que se pode perceber é que as empresas analisadas utilizam tal dinâmica como resposta à questão. Há de se considerar a representatividade que tais empresas empenham.

Há de se considerar, ainda, que o modelo conceitual de ensinagem, tido como exemplo possível, contribui com a ciência inerente ao negócio de fabricação de software na medida em que possa servir de orientação às organizações interessadas em estabelecer e implantar um modelo de preservação de conhecimento.

\section{3 - EM SUMA...}

Este capítulo foi dedicado ao fechamento das considerações sobre a pesquisa, e como ela atendeu às proposições, e o modelo de ensinagem, e como ele serviu de resposta à questão da pesquisa. O teor de encerramento que este capítulo traduz é preparatório para a conclusão, presente no próximo. 


\section{Conclusão}

A complexidade do recurso do conhecimento, pela subjetividade em si que ele representa, como processo dinâmico, associa-se à complexidade do processo de sua gestão e leva corpos administrativos a conjecturas sobre como conquistar o domínio de um ativo tão importante quanto intricado. Conjecturas sobre como conquistá-lo, guardálo e difundi-lo. Sobre como disseminá-lo, ensiná-lo aos seus e reutilizá-lo. Conjecturas sobre como preservá-lo.

Este trabalho foi dedicado a conjecturar sobre um fragmento do universo da gestão do conhecimento, justamente o de sua preservação, mas mesmo esse representa universo considerável de variáveis e vertentes. De maneira mais específica, a direção tomada pela pesquisa aqui composta foi a do ensino como parte da estratégia de preservação e como instrumento para a análise sobre como as fábricas de software preservam seus conhecimentos.

Vivência e convivência foram fatores decisivos para a escolha da vertente e a definição da direção. A vivência do pesquisador com a docência, por mais de duas décadas, fê-lo perceber a vertente do ensino. A convivência com um laboratório de fábrica de software, por quase uma década, fê-lo direcionar para a preservação. Afinal, foi exatamente no laboratório de fábrica de software do Departamento de Engenharia da Produção (Politécnica - USP), denominado eLabSoft, que a questão primordial desta pesquisa foi trazida, pela primeira vez, à presença do pesquisador.

Nesta linha, propôs-se conhecer o conhecimento e sua relação com o conceito de negócio (e os conceitos que o permeiam), a gestão do conhecimento como elemento de domínio dessa relação, o negócio de fabricação de software, sua estrutura e ambientação e a ensinagem, como parte executora do processo de ensino, que se complementa com a aprendizagem. Perceber como se pode dar a preservação do conhecimento é uma questão de entender conceitos e associações envolvidas.

Nesta busca pelo conhecimento, adotou-se levantamentos bibliográfico e de campo como estratégias de desenvolvimento da pesquisa. O bibliográfico pela intenção 
de levantar teoria que embasasse os conceitos desejados e, como resultado desse trabalho, percebeu-se a necessidade de um modelo que representasse a realidade da(s) prática(s) de preservação vigente(s). A teorização levou a esse modelo, conceitual, definido de maneira preliminar, para a investigação. O levantamento de campo foi adotado como estratégia para experimentar o modelo em situações reais de trabalho, pela seleção de alguns ambientes fabris dedicados ao produto software.

$\mathrm{O}$ resultado da pesquisa mostrou que o modelo preliminar, baseado em teoria, tem aderência às situações reais de trabalho e, portanto, foi capaz de representar, em sua plenitude, os pontos relevantes da questão formulada sobre a preservação do conhecimento em um ambiente específico. Plenitude de si, mas não do ambiente levaram à percepção de contribuições ambientais ao modelo preliminar, as quais complementaram a idéia inicial e a tornaram mais aplicável a situações de semelhança funcional e administrativa.

Interessante observar, uma vez mais, que o modelo conceitual proposto mostrouse mais aderente aos ambientes com maior certificação, ou seja, sua contigüidade com estruturas mais amadurecidas e padronizadas pode ser utilizada como uma constatação favorável à sua replicabilidade. Em outras palavras, pode-se afirmar que as práticas reveladas pela pesquisa, tendo sido percebidas em conformidade com as postulações da engenharia (padronização para otimizar produção) e das certificações (padronização para otimizar qualidade) apresentadas pelas empresas estudadas, mostram proximidade entre modelo e padronizações aplicadas. Esta proximidade denota sua adequabilidade de conceitos e lhe permite servir como referência a empresas ainda sem estruturação orientada ao conhecimento e sua preservação, mas que venham a perceber-se preocupadas com o tema.

O autor deste trabalho vê, nessa afirmação, uma contribuição desta tese, ao menos no que disser respeito às preocupações relativas a preservação do conhecimento e internalização do ensino necessário à conscientização corporativa de fabricantes de software sobre este ativo. É preciso considerar, por exemplo, que o trabalho, na decorrência de seu desenvolvimento, mostra, nos capítulos 9 e 11 (este, principalmente), sugestões sobre pontos a perceber na implantação de estratégias de preservação e ensinagem, além de apresentar, no capítulo 10, informações sobre como algumas empresas, criteriosas e certificadas, realizam suas práticas. 
Também podem ser tomados como contribuições, a sugestão e o estímulo prováveis que a revelação de um modelo plausível possa causar em organizações ainda não preocupadas com tais questões (ou já preocupadas, mas ainda não encorajadas), principalmente se considerar que o modelo não apresenta mudança estrutural tão complexa que não o torne viável a organizações de todos os portes. Esse modelo contribui na medida em que dissemina um conjunto de informações necessárias à formação de uma massa de conhecimento sobre o conhecimento, o que pode ser tomado como motivador para a adoção do formalismo necessário à sua preservação.

Há de se pensar, ainda, que alguns pontos do modelo, periféricos ao processo que constitui seu núcleo, também podem ser tomados como recomendações para evolução no tratamento do conhecimento organizacional, mesmo para quem não pretenda internalizar processo de ensinagem. Aspectos como melhoria na integração entre profissionais (tanto no âmbito interno quanto externo ao quadro funcional) e incentivo à transferência do conhecimento, por exemplo, podem resultar da implantação apenas da dimensão da comunicação (contribuição ao ambiente produtivo). Aspectos como melhoria da capacidade de formalização técnica e disseminação do conhecimento adquirido podem, por sua vez, resultar da implantação apenas da dimensão da documentação (contribuição ao repositório).

Evidente que o assunto não se esgota com este trabalho, tanto por sua amplitude e dinamismo quanto pela limitação da amostra estudada. A fim de instigar sua continuidade, algumas propostas são relacionadas a seguir, como sugestões de estudo:

- Ainda sobre a aplicação do modelo de ensinagem proposto:

1. A replicação desta pesquisa em um número maior de empresas fabricantes de software, envolvendo, inclusive, não certificadas, para uma visão mais abrangente de replicabilidade do que este estudo pode fornecer;

2. A replicação desta pesquisa em empresas de outros ramos, para averiguar se há aderência mais genérica do modelo proposto às circunstâncias relativas à preservação e ensinagem, independentemente do foco de aplicação;

3. A aplicação do modelo em situações de implantação de práticas de gestão do conhecimento (focadas em preservação e ensino) em pesquisa que utilize estratégia de experimento ou pesquisa-ação, para analisar sua aplicabilidade como modelo orientador de formação de quadro funcional ou, ainda, de formação de 
consciência sobre a importância do ativo do conhecimento;

4. Um estudo mais detalhado sobre métricas que permitam mensurar o retorno fornecido por investimentos em preservação e ensinagem, como, por exemplo, no que disser respeito a agregação de valor produtivo gerado pela ensinagem (este é um dos pontos que nenhuma das empresas pode responder);

- Sobre uma visão mais abrangente, envolvendo conceitos que contextualizam a ensinagem (vistos na teorização apresentada por este trabalho), tanto da preservação quanto da gestão do conhecimento:

5. A associação deste estudo com estudos sobre a aprendizagem e seus estilos baseados em perfis comportamentais e de assimilação que os profissionais possam apresentar, para melhorar a capacidade de composição dos processos de ensinagem a partir de referências culturais ou organizacionais;

6. A associação deste estudo com estudos sobre organização de repositórios (ontologias) e interfaces de transferência (alimentação e difusão) de conhecimentos pode produzir teoria importante para facilitar a implementação do modelo no que diz respeito às ações de documentar conhecimentos (explícitos) e recuperá-los para aplicação;

7. Do mapeamento do processo do conhecimento organizacional apresentado na figura 6.08, apenas os elementos "aprender" e "contribuir" foram abordados por esta pesquisa. Os outros elementos (“obter", “construir", "suster”, “aplicar”, "avaliar" e "descartar") podem gerar estudos de interesse para o entendimento da gestão do conhecimento. Destes, "suster" e "avaliar" podem ser usados em estudos sobre a preservação do conhecimento. Uma análise mais profunda e detalhada sobre como "descartar" conhecimentos também pode gerar uma pesquisa significativa.

8. O meta-conhecimento foi apontado como base para alguns dos conceitos que permeiam o foco desta tese. Um estudo sobre sua importância para a gestão do conhecimento pode ser a linha mestra de uma pesquisa interessada no entendimento dos conhecimentos sobre os conhecimentos, que embasem seus domínio e preservação. 


\section{4}

ANDRADE, Maria M.; Introdução à Metodologia do Trabalho Científico - $3^{\mathrm{a}}$ edição; Brasil: Atlas, 1998.

ANSOFF, Igor; MCDONNEL, Edward; Implantando a Administração Estratégica; Brasil: Atlas, 1993.

ANTHONY, Robert N.; Planning and Control Systems: a framework for analysis; EUA: Harvard University Graduate School of Business Administration, 1965.

ARBAGE, Alessandro P.; Administração Científica e a Escola Clássica; in: http://gestor.adm.ufrgs.br/adp/taylorfayol_adpo14_2000_1.html (visitada em 20 de setembro de 2005); Brasil: UFRGS, 11 de abril de 2000.

BARBARÁ, Antonio C.; EAI - Enterprise Application Integration, integrando seus negócios (workshop); in: http://www.sucesues.org.br/eventos/agenda_passada.asp (visitada em 1 de setembro de 2005); Brasil: Consist, 2002.

BASILI, Victor R.; CALDIERA, Gianluigi; CANTONE, Giovanni; $\boldsymbol{A}$ Reference Architecture for the Component Factory; in: ACM Transactions on Software Engineering and Methodology - vol.1, n⿳ำ 1; EUA: ACM Press, janeiro de 1992.

BASILI, Victor R.; CALDIERA, Gianluigi; McGARRY, Frank; PAJERSKI, Rose; PAGE, Gerald; WALIGORA, Sharon; The Software Engineering Laboratory: an operational software experience factory; in: ACM Proceedings of the $14^{\text {th }}$ international conference on Software engineering; Austrália: ACM Press, 1992.

BASILI, Victor R.; SHULI, Forrest; LANUBILE, Filippo; Using Experiments to Build a Body of Knowledge; in: Proceedings of the NASA Twenty-Third Annual Software Engineering Workshop; EUA: University of Maryland, 1998.

BASILI, Victor R.; LINDVALL, Mikael; COSTA, Patrícia; Implementing the Experience Factory Comcepts as a Set of Experience Bases; in: Proceedings of the SEKE'01 - the $13^{\text {th }}$ International Conference on Software Engineering and Knowledge Engineering; Argentina: IJSEKE/KSI/ACM, junho de 2001.

BEMER, Robert. W.; Position Papers For Panel Discussion: the economics of program production; in: Information Processing $-\mathrm{n}^{-0}$ 68, vol. II; Holanda: NorthHolland Publ.Co., 1969.

BERTALlANFFY, Ludwig V.; Teoria Geral de Sistemas - 2ª edição; Brasil: Vozes, 1975.

BOFF, Luiz H.; ABEL, Mara; LIEBOWITZ, Jay; MONTANO, Bonnie; BUCHWALTER, Judah; Knowledge Management: a comparative look at a brasilian and an american organization; in: Portal de pesquisa em Bancos de Dados Inteligentes, da UFRGS - 
http://www.inf.ufrgs.br/gpesquisa/bdi/publicacoes/lista_public_port.php?id=7 (visitada em 23 de agosto de 2005) e Anais do ISKM/DM'2001 - International Symposium in Knowledge Management and Document Management; Brasil: CITS, agosto de 2001. BORGES NETO, Hermínio; SANTANA, José R.; Fundamentos Epistemológicos da Teoria de Fedathi no Ensino de Matemática; in: Projeto Multimeios Virtual da Faculdade de Educação da Universidade Federal do Ceará http://www.multimeios.ufc.br/producao_cientifica/fedathi.php (visitada em 25 de julho de 2005) e Anais do XV EPENN - Encontro de Pesquisa Educacional do Nordeste: Educação, Desenvolvimento Humano e Cidadania; Brasil: UFC, junho de 2001.

BRETZKE, Miriam; CRM: Conceitos e aplicabilidade em empresas BtoB (workshop); in: http://www.sucesues.org.br/eventos/agenda_passada.asp (visitada em 1 de setembro de 2005); Brasil: Sucesu-ES, setembro de 2002.

BUKOWITZ, Wendi R.; WILLIAMS, Ruth L.; Manual de Gestão do Conhecimento: ferramentas e técnicas que criam valor para a empresa; Brasil: BookmanPriceWaterhouseCoopers, 2002.

CANTONE, Giovanni.; Software Factory: Modeling the Improvement; in: Proceedings of the $3^{\text {rd }}$ International Conference on Factory 2000; Inglaterra: IEEE, 1992.

CARDOZA, Guilherme; A Escada de Aprendizado e Inovação; in: HSM Management Update $-\mathrm{n}^{\mathrm{o}}$ 15; Brasil: HSM Group, novembro e dezembro de 2004.

CASSARO, Antônio C.; Sistemas de Informações para Tomadas de Decisões - $2^{\text {a }}$ edição; Brasil: Pioneira, 1994.

CERRI, Adriana M.; MARCOS, Guaciara F.; OLIVEIRA, Maria H.M.A.; GARGANTINI, Marisa B.M.; Estratégias de Aprendizagem Aplicadas à Fonoaudiologia; in: Anais do VIII Encontro de Iniciação Científica (Semana Científica, Tecnológica e Artística) da PUC Campinas; Brasil: PUC, setembro de 2003.

CHAGAS, Elza M.P.F.; Educação Matemática na Sala de Aula: Problemáticas e possíveis soluções; in: Revista Partes - ano II, $\mathrm{n}^{\mathrm{o}} \mathrm{XV}$ - http://www.partes.com.br (visitada em 24 de julho de 2005); Brasil: Gilberto da Silva, 2001.

CHATTERJEE, Jayanta; Knowledge Management - theories, issues and challenges; in: http://ewh.ieee.org/r10/kerala/paper/KM_theories.PDF (visitada em 29 de janeiro de 2005); EUA: IEEE, agosto de 2002.

CHERUBINI NETO, Reinaldo; O Que é Conhecimento? Sintetizando epistemologia, metodologia e teoria de sistemas em uma nova proposição; in: REAd Revista Eletrônica de Administração - vol. 8, no 1 (edição 25) - http://read.adm.ufrgs.br (visitada em 20 de julho de 2005); Brasil: UFRGS, janeiro e fevereiro de 2002.

CHEWAR, Christa M.; McCRICKARD, Donald S.; Links for a Human-Centered Science of Design: Integrated design knowledge environments for a software development process; in: Proceedings of the $38^{\text {th }}$ Hawaii International Conference on System Sciences (University of Hawaii); Havaí: IEEE, janeiro de 2005. 
CHIAVENATO, Idalberto; Administração nos Novos Tempos; Brasil: Makron Books, 1999.

CÍCERO, Antônio; O Mundo Desde o Fim; Brasil: Francisco Alves, 1995.

CNSH Hipermédia; B2E: Business to Employee - Estratégias para uma solução integrada de comunicação empresa / coloaboradores (white paper); Portugal: $\mathrm{CNSH}$, maio de 2001.

CUSUMANO, Michael A.; Software Factory: a historical interpretation; in: IEEE Software $-\mathrm{n}^{\mathrm{o}}$ 2, vol. 6; EUA: IEEE, março/abril de 1989.

DAVENPORT, Thomas H.; Knowledge Management Case Study at Hewlett-Packard, Early 1996; in: University of Texas at Austin web site http://www.mccombs.utexas.edu/kman/hpcase.htm (visitada em 18 de agosto de 2005); EUA: Utexas, 1996.

DAVIS, Stanley M.; BOTKIN, Jim; O Monstro Embaixo da Cama: o modo mais eficaz das empresas venderem conhecimentos; Brasil: Futura, 1996.

DIAZ, Álvaro; BARBOSA, Cristiano C.; CARCERERI, Daniela L.; MORRO, Jarbas N.; TOMELIN, Letícia B.; AZEVEDO, Luiz A.de; KUNZ, Marcelo; SILVA, Terezinha M.P.da; ZAPELINI, Wilson; Aplicação da Gestão Estratégica do Conhecimento em Setores Diversos; in: http://www.eps.ufsc.br/ergon/textoson.htm (visitada em 18 de abril de 2005); Brasil: UFSC, 2000.

DREYFUS, David; IYER, Bala; Knowledge Sharing and Value Flow in the Software Industry: searching the patent citation network; in: Proceedings of the $38^{\text {th }}$ Hawaii International Conference on System Sciences (University of Hawaii); Havaí: IEEE, janeiro de 2005.

ERBUG, Hakki; Act from the basis of knowledge ; in: Information Systems for Business, BI portal - http://www.isa.co.uk/bi_portal.htm (visitada em 5 de setembro de 2005) ; Reino Unido: Information Systems, 2005.

FABRI, José A.; TRINDADE, André L. P.; L’ERÁRIO, Alexandre; BEGOSSO, Luiz R.; PESSÔA, Marcelo S. P.; SPINOLA, Mauro M.; Desenvolvimento e Replicação de uma Fábrica de Software; in: Anais da 4ª Jornada Ibero-Americana de Engenharia de Software e Engenharia de Conhecimento; Espanha: Universidade Politécnica de Madri, 2004.

FABRI, José A.; TRINDADE, André L. P.; L'ERÁRIO, Alexandre; PESSÔA, Marcelo S. P.; SPINOLA, Mauro M.; Desenvolvimento e Replicação de uma Fábrica de Software - tutorial; in: Anais do VI SIMPROS - Simpósio Internacional de Melhoria de Processos de Software; Brasil: SENAC/CenPRA, novembro de 2004.

FARAH JÚNIOR, Moisés F.; SILVA, Christian L.; Gestão do Conhecimento na Cadeia Produtiva da Indústria Automobilística na Região Metropolitana de Curitiba; in: X SIMPEP - Simpósio de Engenharia de Produção de Bauru / SP; Brasil: UNESP, novembro de 2003. 
FELICIANO NETO, Acácio; SHIMIZU, Tamio; Sistemas Flexíveis de Informações; Brasil: Makron books, 1996.

FELIX, Patrícia P.; Análise Situacional da Gestão do Conhecimento em uma Instituição de Ensino Superior por meio da Espiral do Conhecimento; dissertação de mestrado apresentada à faculdade de engenharia da produção da Universidade Federal de Santa Catarina; Brasil: UFSC, julho de 2003.

FERNANDES, Aguinaldo A.; TEIXEIRA, Descartes S.; Fábrica de Software: implantação e gestão de operaç̃̃es; Brasil: Atlas, 2004.

FERRIS, Nancy; Knowledge is Power. Really; in: http://www.govexec.com/tech/articles/0699mantech.htm (visitada em 4 de março de 2005) EUA: National Journal Group Inc, junho de 1999.

FINNERAN, Tom; A Component-Based Knowledge Management System; in: TDAN The Data Administration Newsletter - no 9 - http://www.tdan.com/i009hy04.htm (visitada em 5 de fevereiro de 2005) EUA: Robert S. Seiner, junho de 1999.

FLEURY, Afonso C.C.; Rotinização do Trabalho: o caso das indústrias mecânicas; in: FLEURY, Afonso C.C.; VARGAS, Nilton; Organização do Trabalho; Brasil: Atlas, 1994.

FLEURY, Afonso C.C.; FLEURY, Maria T.L.; Estratégias Empresariais e Formação de Competências; Brasil: Atlas, 2001.

FLEURY, Afonso C.C.; VARGAS, Nilton; Organização do Trabalho; Brasil: Atlas, 1994.

GIANNETTI, Eduardo; Auto-Engano; Brasil: Companhia das Letras, 1997.

GOLDBARG, Marco C.; Educação e Qualidade: repensando conceitos; in: Revista Brasileira de Estudos Pedagógicos - vol. 79, n 193; Brasil: INEP, setembro a dezembro de 1998.

GRABNER-KRAEUTER, Sonja; Alternative Approaches Toward Measuring CRM Performance; in: Proceedings of the $6^{\text {th }}$ International Research Conference on Relationship Marketing and Customer Relationship Management; EUA: - , junho de 2002.

GREENBERG, Paul; CRM: na velocidade da luz; Brasil: Campus, 2001.

HABERKORN, Ernesto; Teoria do ERP - 2ª edição; Brasil: Makron books, 1999.

HAMPTON, David R.; Administração: comportamento organizacional; Brasil:

McGraw-Hill, 1990.

HOUDEK, Frank; SCHNEIDER, Kurt; WIESER, Eva; Establishing Experience Factories at Daimler-Benz: an experience report; in: Proceedings of the $20^{\text {th }}$ International Conference on Software Engineering; Japão: IEEE , abril de 1998.

HUMPHREY, Watts S.; Software and the Factory Paradigm; in: Software Engineering Journal; EUA: IEEE, setembro de 1991. 
IEEE; SwEBoK: Guide to the Engineering Body of Knowledge-a project of the software engineering coordinating committee; EUA: IEEE, 2002.

JACOBSON, Ivar; BOOCH, Grady; RUMBAUGH, James; The Unified Software Development Process; EUA: Addison-Wesley, 1998.

KROGH, Georg von; SPAETH, Sebastian; HAEFLIGER, Stefan; Knowledge Reuse in Open Source Software: an exploratory study of 15 open source projects; in: Proceedings of the $38^{\text {th }}$ Hawaii International Conference on System Sciences (University of Hawaii); Havaí: IEEE, janeiro de 2005.

KWASNICKA, Eunice L.; Teoria Geral da Administração: uma síntese - 2ª edição; Brasil: Atlas, 1989.

KWASNICKA, Eunice L.; Introdução à Administração - 5ª edição; Brasil: Atlas, 1995.

LAUDON, Kenneth C.; LAUDON, Jane P.; Sistemas de Informação; Brasil: LTC, 1999.

LAURINDO, Fernando J.B.; Tecnologia da Informação: eficácia nas organizações; Brasil: Futura, 2002.

LE BOTERF, Guy; De La Compétence: essai sur um attracteur étrange; França: Éditions d'Organisation, 1994.

LEI, David; HITT, Michael A.; BETTIS, Richard; Competências Essenciais Dinâmicas Mediante a Metaaprendizagem e o Contexto Estratégico; in: FLEURY, Maria T.L.; OLIVEIRA JÚNIOR, Moacir M.; Gestão Estratégica do Conhecimento, integrando aprendizagem, conhecimento e competências; Brasil: Atlas, 2001.

LÉVY, Pierre; As Tecnologias da Inteligência: o futuro do pensamento na era da informática; Brasil: Editora 34, 1993.

LI, Chao; LI, Huaizhang; LI, Mingshu; A Software Factory Model Based on ISO9000 and CMM for Chinese Small Organization; in: Proceedings of the $2^{\text {nd }}$ Asia-Pacific Conference on Quality Software; China: IEEE, 2001.

LOUREIRO, Joaquim L.; Gestão do Conhecimento; Portugal: Centro Atlântico, 2003.

LUCHETTI, Carlos A.; PESSÔA, Marcelo S.P.; Software: obra de arte ou produto manufaturado?; in: Boletim Conectivo - $\mathrm{n}^{\mathrm{o}}$ 48; Brasil: FCAV, outubro de 2001.

MACEDO, Néstor A.M.; Criando uma Arquitetura de Memória Corporativa Baseada em um Modelo de Negócio; tese de doutoramento apresentada à Pontifícia Universidade Católica do Rio de Janeiro; Brasil: PUC, julho de 2003.

MARCONI, Marina A.; LAKATOS, Eva M.; Técnicas de Pesquisa - 3ª edição; Brasil: Atlas, 1996..

MARQUES FILHO, Alberto; Ensino x Aprendizagem: os desafios da formação de uma cultura empreendedora no trabalho; in: Portal do Desenvolvimento http://www.desenvolvimento.gov.br/arquivo/sti/publicacoes/futAmaDilOportunidades/r 
ev20020325_02.pdf(visitada em 27 de julho de 2005); Brasil: Ministério do Desenvolvimento, Indústria e Comércio Exterior, março de 2002..

MARÇULA, Marcelo; Metodologia para a Gestão do Conhecimento em Pequenas e Médias Empresas, Apoiada pela Tecnologia da Informação; dissertação de mestrado apresentada à Universidade Paulista; Brasil: UNIP, 2001.

McMENAMIM, Stephen M.; PALMER, John F.; Análise Essencial de Sistemas; Brasil: McGraw-Hill, 1991.

MELO, Ivo S.; Administração de Sistemas de Informação; Brasil: Pioneira, 1999.

MINTZBERG, Henry; HUY, Quy N.; Reforma, Revolução e Rejuvenescimento; in: HSM Management - n⿳⺈ 41; Brasil: HSM Group, novembro e dezembro de 2003.

MIRANDA, Roberto C.R.; O Uso da Informação na Formulação de Aç̃̃es

Estratégicas pelas Empresas; in: CI - revista da Ciência da Informação - vol. 28, $\mathrm{n}^{0}$ 3; Brasil: IBICT, setembro a dezembro de 1999.

MORON, Marie A.M.; Concepção, Desenvolvimento e Validação de Instrumentos de Coleta de Dados para Estudar a Percepção do Processo Decisório e as Diferenças Culturais; dissertação de mestrado apresentada à Universidade do Rio Grande do Sul; Brasil: UFRGS, 1998.

NATSUI, Érica; Inteligência Competitiva; trabalho de conclusão de curso apresentado à Faculdade de Economia, Administração e Contabilidade da USP; Brasil: FEA-USP, 2002.

NEBEL, Jean-Francois; BLATTBERG, Robert C.; Brand Relationship Management: A new approach for the third millennium - white paper; in: SoftCoin, BRM portal http://corp.softcoin.com/brm/brm_more.html (visitada em 5 de setembro de 2005); EUA: SoftCoin Inc., 2005.

NEUBAUER, Aljoscha C.; A Arte de Compreender o Desconhecido; in: Viver - Mente \& Cérebro - nº 142; Brasil: Duetto Editorial, novembro de 2004.

NIST, National Institute of Standards and Technology; Integration Definition For Function Modeling (IDEF0): A draft federal information processing standards publication; EUA: NIST, dezembro de 1993.

NONAKA, Ikujiro; TAKEUCHI, Hirotaka; Criação de Conhecimento na Empresa: como as empresas japonesas geram a dinâmica da inovação - $8^{\text {a }}$ edição; Brasil: Campus, 1997.

OAKS, Susan; MARKHAM, Bill; MEHLTRETTER, Steve; Os Segredos da Supply Chain; in: HSM Management - $\mathrm{n}^{\mathrm{o}} 46$; Brasil: HSM Group, setembro e outubro de 2004.

OLIVEIRA, Ismênia R.; SOUZA NETO, Rafael; GIRARDI, Rosário; Uma Ontologia para a Especificação de Sistemas de Padrões; in: Anais da 4- Conferência LatinoAmericana de Linguagens de Padrões para Programação; Brasil: Universidade Federal do Ceará, Agosto de 2004. 
OLIVEIRA JÚNIOR, Moacir M.; Competências Essenciais e Conhecimento na Empresa; in: FLEURY, Maria T.L.; OLIVEIRA JÚNIOR, Moacir M.; Gestão Estratégica do Conhecimento, integrando aprendizagem, conhecimento e competências; Brasil: Atlas, 2001.

PACHECO, Roberto; KERN, Vinícius; Arquitetura Conceitual e Resultados da Integração de Sistemas de Informação e Gestão da Ciência e Tecnologia; in: DataGramaZero - Revista de Ciência da Informação - vol. 4, n⿳0 2 - disponível em http://www.dgz.org.br/abr03 (visitada em 08 de outubro de 2005); Brasil: IASI, abril de 2003.

PÁDUA, Elisabete M. M.; Metodologia da Pesquisa: abordagem teórico-prática; Brasil: Papirus, 2005.

PAULA, Melise M.V.; OLIVEIRA, Jonice; SOUZA Jano M.; Um Modelo de Gestão do Conhecimento na Negociação; in: Anais do IV Simpósio de Desenvolvimento e Manutenção de Software da Marinha; Brasil: EGN/SBC, novembro e dezembro de 2004.

PFLEEGER, Shari L.; Albert Einstein and Empirical Software Engineering; in: IEEE Computer - vol. 32, n⿳丷 10; EUA: IEEE, outubro de 1999.

PIMENTA, Selma G.; ANASTASIOU, Léa G.C.; Docência no Ensino Superior; Brasil: Cortez, 2002.

POLLONI, Enrico G.F.; Administrando Sistemas de Informação: estudo de viabilidade; Brasil: Futura, 2000.

RAMASUBRAMANIAN, Shivram; JAGADEESAN, Gokulakrishnan; Knowledge Management at Infosys; in: IEEE Software; EUA: IEEE, maio-junho de 2002.

ROCKWELL, Robert; GERA, Michael H.; The Eureka Software Factory CoRe: a conceptual reference model for software factories; in: Proceedings of the Software Engineering Environments Conference; Inglaterra: IEEE, 1993.

ROSINI, Alessandro M.; PALMISANO, Angelo; Administração de Sistemas de Informação e a Gestão do Conhecimento; Brasil: Pioneira Thomson Learning, 2003.

RUAS, Roberto; Desenvolvimento de Competências Gerenciais e Contribuição da Aprendizagem Organizacional; in: FLEURY, Maria T.L.; OLIVEIRA JÚNIOR, Moacir M.; Gestão Estratégica do Conhecimento, integrando aprendizagem, conhecimento e competências; Brasil: Atlas, 2001.

RUHE, Giinther; Experience Factory-Based Professional Education and Training; in: Proceedings of the $12^{\text {th }}$ Conference on Software Engineering Education and Training; Alemanha: IEEE, 1999.

RUSSEL, Karen G.; What Is Knowledge Management?; in: EE - Evaluation Engineering (http://www.evaluationengineering.com/archive/articles/1102manag.htm); EUA: Nelson Publishing Inc., visitada em 19 de maio de 2005. 
Lagoas - Revista da Faculdade de Ciências Gerenciais, da Fundação Educacional Monsenhor Messias - n⿳ํㅡㄹ 2 Brasil: FEMM, novembro de 2004.

SAWREY, James M.; TELFORD, Charles W.; Psicologia Educacional - 2ª edição; Brasil: LTC, 1979.

SCHULTZ, Majken; HATCH, Mary J.; Como a Lego Reposicionou sua Marca; in: HSM Management - n⿳⺈ 45; Brasil: HSM Group, julho e agosto de 2004.

SETZER, Valdemar W.; Dado, Informação, Conhecimento e Competência; in: http://www.ime.usp.br/ vwsetzer/dado-info-Folha.html (visitada em 27 de janeiro de 2005); Brasil: USP, 2004.

(também publicado na Folha Educação, nํ 27 - mesmo ano)

SILVA, Luís A.L.; SANTOS, Clésio S.; Modelagem de Perícia como uma Solução de Conhecimento e Dados; in: anais da V Semana Acadêmica do Programa de PósGraduação em Computação da Universidade Federal do Rio Grande do Sul; Brasil: UFRGS, julho de 2000.

SLACK, Nigel; CHAMBERS, Stuart; JOHNSTON, Robert; Administração da Produção - 2ª edição; Brasil: Atlas, 2002.

SMALL, Cynthia T.; TATALIAS, Jean; Knowledge Management Model Guides KM Process; in: The Edge - vol.4, $\mathrm{n}^{\mathrm{o}} 1-$

http://www.mitre.org/news/the_edge/april_00/index.html (visitada em 17 de dezembro de 2004); EUA: Mitre Corporation, abril de 2000.

SOMMERVILLE, Ian; Software Engineering $-7^{\text {th }}$ Edition; EUA: Pearson Education, 2004.

SNOWDEN, Dave; A Nova Forma de Ser Simples; in: HSM Management - no 39 ; Brasil: HSM Group, julho e agosto de 2003.

SOUZA, Maria Carolina S.; Desenvolvimento e Recuperação do Conhecimento em Sistemas de Ensino à Distância; in: Anais do IV Encontro Nacional de Ciência da Informação; Brasil: Unifacs, 2003.

STEWART, Thomas A.; Capital Intelectual: a nova vantagem competitiva das empresas; Brasil: Campus, 1998.

TAVARES, Edval S.; Uma Contribuição para os Processos da Gerência de Projetos Através da Gerência do Conhecimento; tese de doutoramento apresentada ao Departamento de Engenharia da Produção da Escola Politécnica da USP; Brasil: PoliUSP, 2004.

TERRA, José C.C.; Gestão de Conhecimento: aspectos conceituais e estudo exploratório sobre as práticas de empresas brasileiras; tese de doutoramento apresentada ao Departamento de Engenharia da Produção da Escola Politécnica da USP; disponível em http://www.terraforum.com.br/sites/terraforum/paginas/teses/teses.aspx (visitada em 30 de junho de 2004); Brasil: PoliUSP/TerraForum, 1999.

THIOLLENT, Michel; Metodologia da Pesquisa-ação - $6^{\mathrm{a}}$ edição; Brasil: Cortez, 1994. 
THORESON, Sharilyn A.; The Automated software Development Project at McDonnell Aircraft Company (the software factory); in: Proceedings of the National Aerospace and Electronics Conference; EUA: IEEE, 1989.

TOGNERI, Denise F.; BRITO, Silvana R.; FALBO, Ricardo A.; TAVARES, Orivaldo L.; MENEZES, Crediné S.; Um Ambiente para Aprendizagem Cooperativa de Engenharia de Requisitos Orientado a Projetos; in: Anais da Conferência Internacional sobre Engenharia e Educação Computacionais de 2003; Brasil: ICECE, março de 2003.

TRINDADE, André L.P.; Métricas para Orçamento e Planejamento da Produção de Software; Dissertação de mestrado apresentada ao Departamento de Engenharia da Produção, da Escola Politécnica, da Universidade de São Paulo; Brasil: PoliUSP, 1999.

VERRALL, Malcom S.; ESF: The software bus; in: Colloquium on Architectures for Distributed Development Support Environments; Inglaterra: IEEE, 1991.

VICARI, Luci M.; SUMENSARI, Edson L.; PESSÔA, Marcelo S.P.; As Inteligência Multiplas Apoiando o Ensino à Distância em Engenharia; in: Proceedings of the Global Congress on Engineering and Technology Education 2005; Brasil: COPEC, março de 2005.

YIN, Robert K.; Estudo de Caso: planejamento e métodos - $3^{\mathrm{a}}$ edição; Brasil: Bookman, 2005.

ZARIFIAN, Phillipe; Objetivo Competência: por uma nova lógica; Brasil: Atlas, 2001. 